\section{Pacific Northwest} National Laboratory

Operated by Battelle for the U.S. Department of Energy

\title{
Hanford Site Environmental Report for Calendar Year 2004
}

\author{
Editors \\ T. M. Poston \\ R. W. Hanf \\ R. L. Dirkes
}

September 2005

Prepared for the U.S. Department of Energy under Contract DE-AC05-76RL01830 


\title{
DISCLAIMER
}

This report was prepared as an account of work sponsored by an agency of the United States Government. Reference herein to any specific commercial product, process, or service by trade name, trademark, manufacturer, or otherwise does not necessarily constitute or imply its endorsement, recommendation, or favoring by the United States Government or any agency thereof, or Battelle Memorial Institute. This report is a summary of major or significant activities occurring at the Hanford Site only, and is not a full disclosure of all details associated with Hanford-related activities, nor a substitute for legally required information subject to reporting requirements regarding releases, violations, etc.

\author{
PACIFIC NORTHWEST NATIONAL LABORATORY \\ operated by \\ BATTELLE \\ for the \\ UNITED STATES DEPARTMENT OF ENERGY \\ under Contract DE-AC05-76RL01830
}

Printed in the United States of America

May be available to DOE and DOE contractors from the

Office of Scientific and Technical Information,

P.O. Box 62, Oak Ridge, TN 37831-0062;

ph: (865) $576-8401$

fax: (865) 576-5728

email: reports@adonis.osti.gov

The cover photo (84-E-065-74cn) of Rattlesnake Mountain is from Lockheed Martin Information Technology, Richland, Washington. The cover design is by SB Neely, Pacific Northwest National Laboratory, Richland, Washington. 


\section{HANFORD SITE ENVIRONMENTAL REPORT FOR CALENDAR YEAR 2004}

(INCLUDING SOME EARLY 2005 INFORMATION)

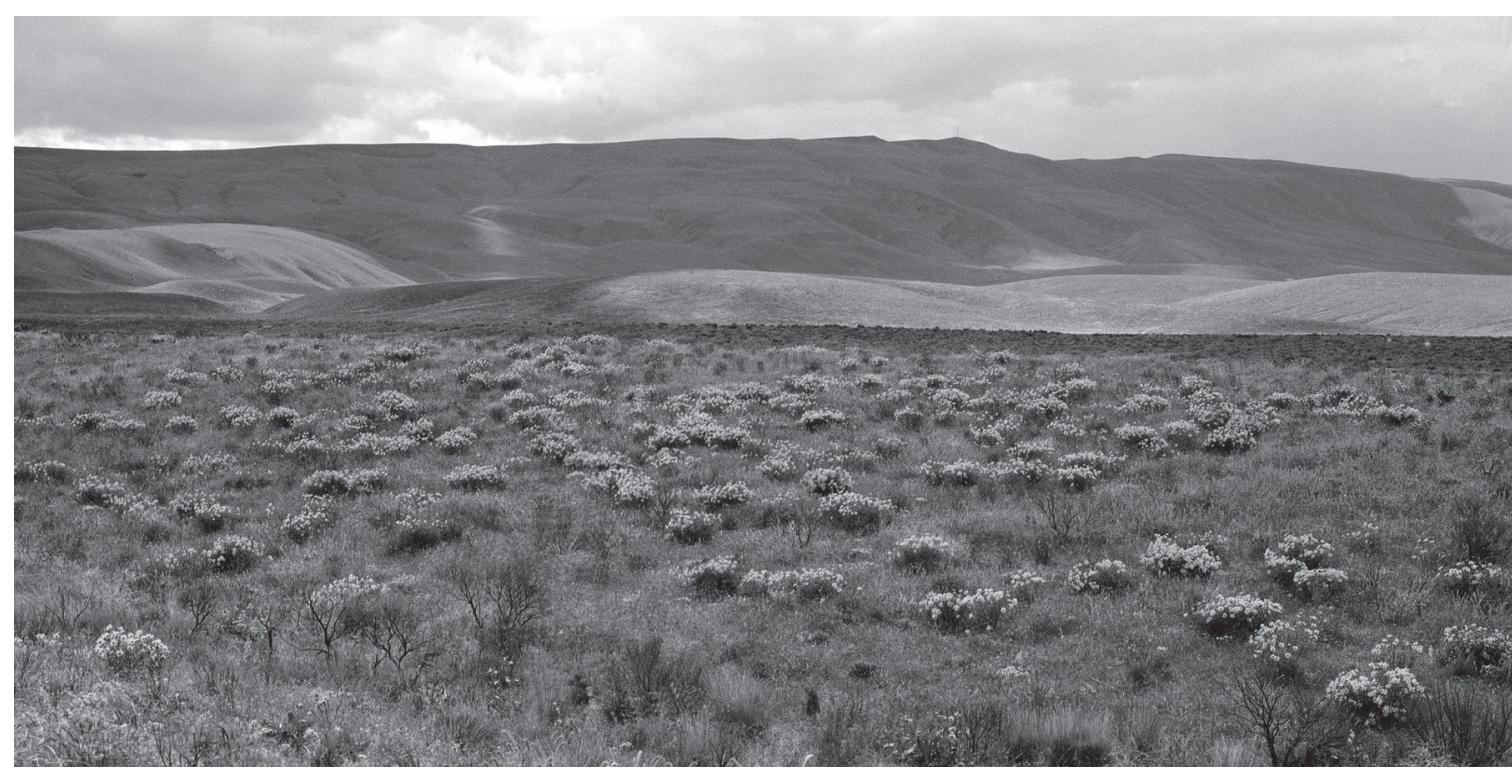

EDITORS

T. M. POSTON

R. W. HANF

R. L. DIRKES

SEPTEMBER 2005

Prepared for the U.S. Department of Energy by staff from the Pacific Northwest National Laboratory under contract DE-AC05-76RL01830, with contributions from Bechtel Hanford Inc. and its subcontractors; Bechtel National, Inc.; CH2M HILL Hanford Group, Inc.; and Fluor Hanford, Inc. and its subcontractors 


\section{Preface}

The Hanford Site environmental report is prepared annually for the U.S. Department of Energy (DOE) in accordance with the requirements in DOE Manual 231.1-1A, Environment, Safety, and Health Reporting Manual, and DOE Order 231.1A, Environment, Safety, and Health Reporting. The report provides an overview of activities at the site; demonstrates the status of the site's compliance with applicable federal, state, and local environmental laws and regulations, executive orders, and DOE policies and directives; and summarizes environmental data that characterize Hanford Site environmental management performance. The report also highlights significant environmental and public protection programs and efforts. Some historical and early 2005 information is included where appropriate. More detailed environmental compliance, monitoring, and surveillance information may be found in additional reports referenced in the text.

Although this report was primarily written to meet DOE reporting requirements and guidelines, it also provides useful summary information to members of the public, Indian tribes, public officials, regulatory agencies, Hanford Site contractors, and elected representatives. Appendix A of this report lists scientific notation, units of measure, unit conversion information, and nomenclature that may help readers understand the report. Appendix B is a glossary of terms.

The Pacific Northwest National Laboratory's Public Safety and Resource Protection Project produced this report for the DOE Richland Operations Office. Battelle Memorial Institute (Battelle) operates the Pacific Northwest National Laboratory for DOE. Battelle is a non-profit, independent, contract research institute. Personnel from the Pacific Northwest National Laboratory and Fluor Hanford, Inc. and its subcontractors wrote major portions of the report. Bechtel Hanford, Inc. and its subcontractors; Bechtel National, Inc.; and CH2M HILL Hanford Group, Inc. also prepared or provided significant input to selected sections.

Inquiries regarding this report should be directed to D. C. (Dana) Ward, DOE Richland Operations Office, P.O. Box 550, MS A2-17, Richland, Washington 99352 (dana_c_ward@rl.gov) or to T. M. (Ted) Poston, Pacific Northwest National Laboratory, P.O. Box 999, MS K6-75, Richland, Washington 99352 (ted.poston@pnl.gov).

\section{Report Availability}

This report was produced in both paper and electronic formats. The paper formats include this technical report, two supplemental data appendixes, and a less detailed summary report (PNNL-15222-SUM). Electronically, the report is available in portable document format (PDF) on compact disk (CD), and on the Internet at http://hanfordsite.pnl.gov/envreport. Copies of the report are also available at libraries in communities around the Hanford Site, at several university libraries in Washington and Oregon, and at the DOE's Public Reading Room located at the Consolidated Information Center in Richland, Washington. All versions of the report can be obtained from R. W. (Bill) Hanf, Pacific Northwest National Laboratory, P.O. Box 999, MS K6-75, Richland, Washington 99352 (bill.hanf@pnl.gov) while supplies last. 


\section{Summary}

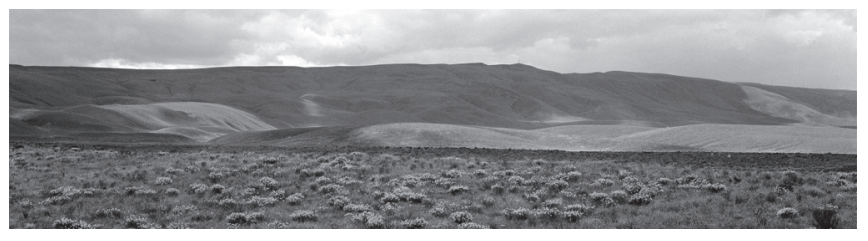

L. F. Morasch

Each year, the U.S. Department of Energy (DOE) publishes this integrated environmental report about the Hanford Site. Individual sections of the report are designed to:

- Describe the Hanford Site and its mission.

- Summarize the status of compliance with environmental regulations.

- Discuss the status and results of Hanford Site cleanup and remediation activities.

- Describe the environmental and groundwater monitoring programs at the Hanford Site.

- Summarize and discuss monitoring information.

- Discuss the estimated radiation exposure to the public from 2004 Hanford Site activities.

- Discuss activities conducted to assure data quality.

The current mission of DOE at the Hanford Site includes cleaning up the site and reducing its size. It is the policy of the DOE that all its activities be carried out to comply with applicable federal, state, and local laws and regulations, DOE Orders, Secretary of Energy Notices, and directives, policies, and guidelines from DOE Headquarters and site operations.

\section{Compliance with Environmental Regulations in 2004}

The site's compliance with federal acts in 2004 is summarized in Table S.1 and discussed in detail in Chapters 3 and 5 of this report.

A key element in Hanford's compliance program is the Hanford Federal Facility Agreement and Consent Order (Tri-Party Agreement). The Tri-Party Agreement is an agreement among the Washington State Department of Ecology, U.S. Environmental Protection Agency (EPA), and the DOE to achieve compliance with the remedial action provisions of the Comprehensive Environmental Response, Compensation, and Liability Act (CERCLA) and with treatment, storage, and disposal unit regulation and corrective action provisions of the Resource Conservation and Recovery Act (RCRA). During 2004, there were 49 specific Tri-Party Agreement cleanup milestones scheduled for completion: 48 were completed on or before their required due dates, and 1 was completed beyond its established due date.

Cleanup activities on the Hanford Site generate radioactive, mixed, and hazardous waste (Chapters 5, 6, and 8). Mixed waste has both radioactive and hazardous nonradioactive substances. Hazardous waste contains either dangerous waste or extremely hazardous waste or both. This waste is handled and prepared for safe storage on the site or shipped to offsite facilities for treatment and disposal. A summary of waste stored or generated on the site or received from off the site in 2004 is provided in Table S.2.

In addition to newly generated waste, significant quantities of legacy waste remain from years of nuclear material production and waste management activities. Most legacy waste from past operations at the Hanford Site resides in RCRA-compliant waste sites or is stored in places awaiting cleanup and ultimate safe storage or disposal. Examples include high-level radioactive waste stored in single-shell and double-shell underground waste storage tanks and transuranic waste stored in vaults and on storage pads (see Sections 6.3 and 6.4 for details).

\section{Environmental Occurrences}

Environmental releases of radioactive and regulated materials from the Hanford Site are reported to the DOE and other federal and state agencies as required by law. The specific agencies notified depend on the type, amount, and location of the individual occurrence. The Hanford Site Occurrence Notification Center maintains both a 
Table S.1. Compliance with Federal Acts at the Hanford Site in 2004

\section{Regulation}

American Indian Religious Freedom Act, Antiquities Act, Archaeological and Historic Preservation Act, Archaeological Resources Protection Act, Historic Sites, Buildings, and Antiquities Act, National Historic Preservation Act, and Native American Graves Protection and Repatriation Act

Clean Air Act

Clean Water Act

Comprehensive Environmental Response, Compensation, and Liability Act (CERCLA)

Emergency Planning and Community Right-to-Know Act

Endangered Species Act

Federal Insecticide, Fungicide, and Rodenticide Act

Migratory Bird Treaty Act

National Environmental Policy Act Recovery Act (RCRA)

Safe Drinking Water Act

Toxic Substances Control Act

\section{What it Covers}

2004 Status

Cultural resources.

One hundred sixty-six cultural resource reviews were conducted on the Hanford Site.
Air quality, including emissions from facilities and from unmonitored sources.

Discharges to U.S. waters.

Sites already contaminated by hazardous materials.

The public's right to information about hazardous materials in the community and establishes emergency planning procedures.

Rare species of plants and animals.

Storage and use of pesticides.

Migratory birds or their feathers, eggs, or nests.

Environmental impact statements for federal projects.

Tracking hazardous waste from generator to treatment, storage, or disposal.

Drinking water systems operated by DOE at Hanford.

Primarily regulation of chemicals called polychlorinated biphenyls (PCBs).
Washington State Department of Health issued four noncompliance documents regarding emissions at T Plant, B Plant, and the 209 E Criticality Laboratory and concerns about the Central Waste Complex Permacon Unit.

The Hanford Site had one National Pollutant Discharge Elimination System Permit, one storm water permit, and ten State Wastewater Discharge Permits. There were no permit violations in 2004.

Remediation work on these sites followed CERCLA requirements and met the schedules established by the Tri-Party Agreement.

The Hanford Site met the reporting requirements contained in this act.

Hanford activities followed the requirements of this act. The Hanford Site has eleven plant species, three fish species, and five bird species on the federal or state lists of threatened or endangered species.

At the Hanford Site, pesticides are applied by commercial pesticide operators licensed by the state.

Hanford activities used the ecological review process as needed to minimize any adverse effects to migratory birds. There are over 100 species of birds that occur on the Hanford Site that are protected by this act.

Environmental impact statements and environmental assessments were prepared or conducted as needed. In 2004, DOE issued two environmental impact statements, one record of decision, and a supplemental analysis for the Hanford Site.

The Washington State Department of Ecology identified five non-compliance issues during 2004: (1) concerns about no wear plates installed beneath pulse-jet mixers at the Waste Treatment Plant; (2) concerns about corrosion allowances in piping design at the Waste Treatment Plant; (3 and 4) concerns related to receipt and management of sample residue from offsite; and (5) concerns about waste transfer lines that did not meet minimum slope requirements.

There were nine public water systems on the Hanford Site. The systems were monitored for radiological contaminants and all contaminant concentrations in 2004 met the requirements of the Washington State Department of Health.

Non-radioactive waste and radioactive PCB waste in certain categories were disposed of in accordance with 40 CFR 761 or remained in storage onsite pending the development of adequate treatment and disposal technologies. 
Table S.2. Hanford Site Waste Summary, 2004

Activity

Waste generated during onsite cleanup activities

Waste received at Hanford from off the site

Waste shipped off the Hanford Site

Waste volume pumped from underground single-shell waste storage tanks

Waste volume evaporated at the 242-A evaporator

Waste generated at Hanford and added to underground doubleshell waste storage tanks

Waste volume in underground double-shell waste storage tanks at the end of 2004

\section{Waste Type}

Solid mixed waste

Radioactive waste

Solid mixed waste

Radioactive waste

Hazardous waste

Liquid waste

Liquid waste
Amount

318,594 pounds

1.9 million pounds

563,699 pounds

1.1 million pounds

352,547 pounds

734,000 gallons

$-194,000$ gallons

876,000 gallons

25.16 million gallons computer database and a hardcopy file of event descriptions and corrective actions. The significance categories are operational emergency, recurring, 1 (significant impact), 2 (moderate impact), 3 (minor impact), and 4 (some impact).

In 2004, there were no occurrences ranked as operational emergency, recurring, or category 1 on the Hanford Site (see Section 5.2.3). There was one category 2 (moderate impact) occurrence when small radiologically contaminated paint chips were discovered near the 233-S facility. The chips were collected, bagged, and disposed of. There was one category 3 (minor impact) event when a subcontractor employee's personal lapel air monitor showed a high level for uranium during work on the 300 Area Remediation Project. The elevated result was from airborne radioactivity in the area. Technicians underwent in vivo chest counts and bioassays, which revealed no detectable intake.

There were four category 4 (some impact) events during 2004: (1) Radioactive wasps nests were discovered during cleanup at the $100-\mathrm{N}$ Area; the nests were removed and disposed of following appropriate guidelines. (2) Beta emitting contaminants were discovered in the 200-East Area in two ant mounds. Biological control personnel applied a pesticide to the affected area. (3) Grass fires in the 600 Area were extinguished within 2 hours of being reported. Although the fires were not in contaminated areas, any fire on the Hanford Site is treated as though it has the potential to spread to areas that could be contaminated. (4) Contaminated tumbleweeds were discovered during surveys of contaminated areas. The deep tap root of the tumbleweed allows uptake of subsurface contamination into the plants. In most cases, the contaminated tumbleweeds were removed and disposed of; in some instances, the contamination area boundary was extended to encompass the tumbleweed growth.

\section{Pollution Prevention and Waste Minimization}

This program (Section 5.10) is an organized and continuing effort to reduce the quantity and toxicity of hazardous, radioactive, mixed, and sanitary waste produced at Hanford. The program fosters the conservation of resources and energy, reduction in the use of hazardous substances, and prevention or minimization of pollutant releases to all environmental media from all operations and site cleanup activities. Affirmative procurement (the purchase of environmentally preferable products containing recycled material) at the Hanford Site achieved 100\% of the 2004 goal.

The Hanford Site met the fiscal year 2004 Secretarial Goals (as defined in a DOE memorandum) for low-level waste, mixed low-level waste, hazardous and sanitary routine waste generation, and recycling (including paper, plastic, cardboard, glass, etc.). In 2004, the program reported recycling of 2,504 metric tons (2,760 tons) of sanitary and hazardous waste. This recycled waste included 309 metric tons (341 tons) of office and mixed paper, 385 metric tons (424 tons) of iron/steel, 103 metric tons (114 tons) of non-ferrous metal, and 107 metric tons (118 tons) of appliances and furniture.

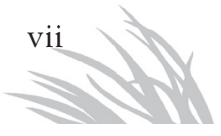


The Hanford Site generated 27,546 cubic meters (36,000 cubic yards) of cleanup/stabilization waste (i.e., low-level waste, mixed low-level waste, and hazardous waste), and did not meet the $10 \%$ cleanup stabilization goal of 24,547 cubic meters (32,100 cubic yards). Not meeting this goal could be a reflection of additional cleanup/waste stabilization activities that were not anticipated in the fiscal year 2004 waste forecast.

One notable achievement in 2004 was the Mortar Lining Project for Water Distribution receiving the DOE Office of Environmental Management Pollution Prevention Best in Class Award for Innovative Technology. Mortar lining, an innovative, commercially available technology, is being used to refurbish 53 kilometers $(28.62$ miles) of degraded water lines, ensuring fire protection and a supply of drinking water during site closure activities. For the same cost, mortar lining restores twice as much pipeline as replacement pipe, stopping leaks, and protecting groundwater from soil contaminants. Pipelines are restored in place using minimal excavation, which reduces worker risk by decreasing exposure to possibly contaminated soil. Over the 10-year life of the project, cost avoidance of more than $\$ 19$ million is anticipated, along with waste avoidance of 6,134 metric tons (6,760 tons) of replacement pipe.

\section{Cleanup Operations}

Since cleanup activities began at Hanford in 1996, the primary focus has been on liquid effluent waste sites. After nearly 8 years of work, the number of liquid effluent waste sites requiring remediation has been reduced and cleanup activities now are turning to remediation of waste burial grounds. The volume of contamination in waste burial grounds is less than in liquid effluent waste sites; however, the burial grounds may contain unknown materials and additional time may be required to characterize the waste and dispose of it properly.

100 Areas Waste Sites. Full-scale remediation of waste sites began in the 100 Areas in 1996 and continued in 2004 at the $100-\mathrm{B} / \mathrm{C}, 100-\mathrm{K}, 100-\mathrm{N}$, and 100-F Areas (Section 6.1.3.2). A total of 470,060 metric tons (518,006 tons) of contaminated soil from 100 Areas remediation activities were disposed at the Environmental Restoration Disposal Facility (near the 200-West Area) during 2004. Pump-and-treat systems operated to help remove contamination from groundwater (Table S.3; Section 8.7.4).
K Basins Closure Activities. From February 1994 through 2004, work has continued to clean out the K Basins (Section 6.1.3.1). The $\mathrm{K}$ Basins contained 2,100 metric tons (2,300 tons) of Hanford N Reactor spent fuel and a small quantity of irradiated single-pass reactor fuel (fuel from older Hanford reactors). In mid-2004, responsibility for $\mathrm{K}$ Basins cleanout passed to the new K Basins Closure Project, and the Spent Nuclear Fuel Project was phased out. During 2004, the Spent Nuclear Fuel Project, later the K Basins Closure Project, made the following progress in cleaning out the $\mathrm{K}$ Basins:

- Completed all shipments (370 shipments) of fuel from the K-East Basin to the K-West Basin.

- Removed and dried the last 93 multi-canister overpacks of fuel from the K-West Basin, completing a total of 386 shipments to achieve $100 \%$ completion, satisfying a major Tri-Party Agreement milestone (i.e., the removal of all spent fuel from the $\mathrm{K}$ Basins was completed in 2004). Over 1.8 million kilograms (4 million pounds) of fuel, containing over 50 million curies $(1,850$ million gigabecquerels) of radioactivity, were removed from the K-West Basin.

- Welded 170 multi-canister overpacks with permanent, N-Stamped closure welds for a total of 290 multicanister overpacks welded by year's end. This welding effort remained consistently ahead of schedule.

- Continued the washing and load-out of aged fuel canisters from the $\mathrm{K}$ Basins for disposal as low-level nuclear waste. By the end of 2004, 5,830 cans (78\% of the total) had been washed and disposed. Also 100\% of the contaminated, long-handled pole tools from the $\mathrm{K}$-West Basin (212 tools) were removed, washed, and packaged as waste.

- Began pumping sludge from two locations in the K-East Basin, with two pumping systems, in June and October 2004 . By the year's end, nearly $25 \%$ of the total sludge volume in the K-East Basin had been transferred to containers.

- Sealed the discharge chute of the K-East Basin permanently closed by filling it with special cement called grout. Putting grout in the discharge chute resolved some key environmental issues because it sealed the construction joint between the K-East Basin and the K-East Reactor structure, a joint that had leaked contaminated water to the environment in the past. Also, placing grout in the discharge chute permanently 
Table S.3. Summary of Groundwater Pump-and-Treat Systems and a Vadose Zone Soil-Vapor Extraction System

\begin{tabular}{|c|c|c|c|c|}
\hline Location & $\begin{array}{l}\text { Startup } \\
\text { Date }\end{array}$ & Contaminant & $\begin{array}{l}\text { Mass Removed } \\
\underline{\underline{2004}}\end{array}$ & $\begin{array}{l}\text { Mass Removed - } \\
\text { Since Startup }\end{array}$ \\
\hline \multicolumn{5}{|c|}{ Groundwater Pump-and-Treat Systems } \\
\hline 100-D Area & 1997 & Chromium & $\begin{array}{l}30.1 \text { kilograms } \\
\text { (66.4 pounds) }\end{array}$ & $\begin{array}{l}199 \text { kilograms } \\
\text { (438.8 pounds) }\end{array}$ \\
\hline 100-H Area & 1997 & Chromium & $\begin{array}{l}3.5 \text { kilograms } \\
\text { (7.7 pounds) }\end{array}$ & $\begin{array}{l}38.6 \text { kilograms } \\
\text { (85.1 pounds) }\end{array}$ \\
\hline 100-K Area & 1997 & Chromium & $\begin{array}{l}29.6 \text { kilograms } \\
\text { (65.3 pounds) }\end{array}$ & $\begin{array}{l}257.6 \text { kilograms } \\
\text { (568 pounds) }\end{array}$ \\
\hline 100-N Area & 1995 & Strontium-90 & 1.63 curies & $\begin{array}{c}0.15 \text { curies removed; } \\
\sim 12 \text { curies decayed naturally }\end{array}$ \\
\hline $\begin{array}{l}\text { 200-West Area (200-ZP-1) } \\
\text { Operable Unit }\end{array}$ & 1994 & Carbon tetrachloride & $\begin{array}{l}898.3 \text { kilograms } \\
(1,969.7 \text { pounds })\end{array}$ & $\begin{array}{l}\text { 8,764.4 kilograms } \\
\text { (19,325.5 pounds) }\end{array}$ \\
\hline \multirow[t]{4}{*}{$\begin{array}{l}\text { 200-West Area (200-UP-1) } \\
\text { Operable Unit }\end{array}$} & 1994 & Carbon tetrachloride & $\begin{array}{l}6.67 \text { kilograms } \\
\text { (14.7 pounds) }\end{array}$ & $\begin{array}{l}32.71 \text { kilograms } \\
\text { (72.1 pounds) }\end{array}$ \\
\hline & 1994 & Nitrate & $\begin{array}{l}5,401 \text { kilograms } \\
\text { (11,909 pounds) }\end{array}$ & $\begin{array}{l}32,744 \text { kilograms } \\
\text { (72,191 pounds) }\end{array}$ \\
\hline & 1994 & Technetium-99 & $\begin{array}{c}12.8 \text { grams } \\
\text { (0.41 ounces) }\end{array}$ & $\begin{array}{c}116.1 \text { grams } \\
\text { (3.73 ounces) }\end{array}$ \\
\hline & 1994 & Uranium & $\begin{array}{l}25 \text { kilograms } \\
\text { (55.1 pounds) }\end{array}$ & $\begin{array}{l}206.8 \text { kilograms } \\
\text { (456 pounds) }\end{array}$ \\
\hline $\begin{array}{l}\text { Waste Management Area } \\
\text { S-SX }\end{array}$ & 2003 & Technetium-99 & $\begin{array}{l}0.033 \text { grams } \\
\text { (0.001 ounce) }\end{array}$ & $\begin{array}{l}0.00211 \text { curies } \\
(78.07 \mathrm{MBq})\end{array}$ \\
\hline \multicolumn{5}{|c|}{ Soil-Vapor Extraction } \\
\hline 200-West Area & 1991 & Carbon tetrachloride & $\begin{array}{l}256 \text { kilograms } \\
\text { (564.5 pounds) }\end{array}$ & $\begin{array}{l}78,300 \text { kilograms } \\
(172,651.5 \text { pounds })\end{array}$ \\
\hline
\end{tabular}

removed approximately 397,000 liters (105,000 gallons) of contaminated water from the K-East Basin (about $10 \%$ of the total water volume).

- Successfully demonstrated an underwater technique that will remove and clean the contaminated outermost surface of the $\mathrm{K}$ Basins walls and floor. By the end of 2004, the K Basins Closure Project was actively procuring full-scale hydrolasing equipment, in preparation for beginning to hydrolase the K-East Basin walls in mid-2005.

200 Areas Waste Sites. Remedial investigations or feasibility studies continued on various facilities in the 200 Areas in preparation for cleanup and closure (Section 6.1.2).

300 Area Waste Sites. Remediation continued at the 300-FF-2 Operable Unit. In 2004, 21,640 metric tons (23,800 tons) of contaminated soil from 300 Area remediation were removed and disposed of at the Environmental Restoration Disposal Facility (Section 6.1.4). The
300-FF-1 Operable Unit was replanted with various species of grasses; to help prevent erosion, the site was covered with straw mulch.

\section{Facility Decommissioning}

100 Areas Facilities. Decontamination and decommissioning activities continued during 2004 in the 100-D, $100-\mathrm{H}$, and $100-\mathrm{N}$ Areas. The interim safe storage of the D Reactor was completed in 2004, while work on the $\mathrm{H}$ Reactor will continue through 2005. These activities are conducted as non-time-critical removal actions under CERCLA.

Facility demolition was conducted at the 100-N Area in 2004. Facilities and structures demolished included the 1304-N emergency dump tank, 1300-N emergency dump basin, 11-N, 13-N, 1714-N, 1714-NA, and 1714-NB facilities. During 2004, work began on the demolition of the 190-DR pump house. 
200 Areas Facilities. Transition and decommissioning activities continued in the 200 Areas during 2004. Demolition began in June 2004 and was completed in September 2004 at the B Plant construction lay-down yard (Section 6.2.1.2). It was conducted as a non-time-critical removal action under CERCLA and involved the safe demolition, waste packaging, and disposal of 23 contaminated structures, including mobile trailers and storage units, in the B Plant construction lay-down yard.

233-S Plutonium Concentration Facility. Decontamination and demolition activities were completed in 2004 at the 233-S Plutonium Concentration Facility (233-S facility) located in the 200-West Area adjacent to the Reduction-Oxidation (REDOX) Plant. The 233-S facility and associated process equipment were used to concentrate plutonium produced at the REDOX Plant from 1955 to 1967. The activities were conducted as a non-timecritical removal action under CERCLA and involved the safe demolition, waste packaging, and disposal of the 233-S facility (Section 6.2.1.3).

221-U Chemical Processing Facility. Removal of ancillary facilities at the 221-U Chemical Processing Facility began in November 2004 and demolition of at least 11 of the structures began in January 2005 (Section 6.2.1.4). Demolition of the 224-U and 224-UA Buildings is expected to be deferred to coincide to the remedial action for the 221-U Canyon Facility.

Plutonium Finishing Plant. Workers at the Plutonium Finishing Plant complex (Section 6.2.1.5) stabilized, immobilized, re-packaged, and/or properly disposed of nearly 18 metric tons (19.8 tons) of plutonium-bearing materials in the plant by February 2004. The workers then started decontaminating and deactivating the processing facilities while still providing for the safe and secure storage of nuclear materials until final disposition.

224-B Plutonium Concentration Facility. This facility was part of the B Plant complex. Past operations have resulted in contamination throughout some of the structures. The 224-B Facility Decommissioning Project was conducted as a non-time-critical removal action under CERCLA and involved the safe demolition, waste packaging, and disposal of 23 contaminated structures. Demolition began in June 2004 and was completed in September 2004.
Using the 200 Areas Chemical Separations Plants for Waste Disposal. The Canyon Disposition Initiative (Section 6.2.1.7) was created to investigate the potential for using the five canyon buildings (B Plant, T Plant, U Plant, PUREX Plant, and REDOX Plant) at the Hanford Site as disposal facilities for Hanford Site remediation waste, rather than demolishing the structures. In December 2004, a feasibility study and proposed plan were released for public review. These documents examine five alternatives for the remediation of the 221- $\mathrm{U}$ facility; however, the 'close in place - collapsed structure' alternative is the preferred alternative. Under this alternative, equipment already in the U Plant would be consolidated into the below-ground U Plant process cells, the cells would be backfilled with grout, the exterior walls and roof would be collapsed in place, and the site would be covered with a barrier. The final disposition path for the U Plant will be selected during the record of decision process.

300 Area Facilities. Decommissioning of the 324 and 327 Buildings continued during 2004. Preparations are underway for removal of the remaining waste items, and the buildings are being maintained in surveillance and maintenance mode in compliance with safety and regulatory requirements.

The 313 and 314 Buildings have been in surveillance and maintenance mode in recent years. These two facilities were turned over to Bechtel Hanford, Inc. in October 2004 to prepare for facility decommissioning.

The 309 Plutonium Recycle Test Reactor was shut down in 1969. The facility is being maintained in a surveillance and maintenance mode to comply with safety and regulatory requirements.

400 Area Facilities - Fast Flux Test Facility. Deactivation activities continued at the Fast Flux Test Facility (Section 6.2.3) in 2004. Liquid sodium was drained from the primary heat transport system loops and auxiliary systems, as well as the upper portion of the reactor vessel to sodium storage tanks, where approximately 567,812 liters (150,000 gallons) of liquid sodium metal are now stored, pending future conversion to sodium hydroxide for use by the Waste Treatment Plant. The sodium-potassium alloy systems containing approximately 3,407 liters (900 gallons) of sodium-potassium alloy were drained or flushed into associated sodium systems for disposition with the 
sodium. Eighty-four fueled components were washed and packaged into 12 interim storage casks. These interim storage casks and 22 filled interim storage casks previously stored in the 400 Area Interim Storage Area were transferred to the 200 Areas Interim Storage Area.

TransNuclear, Inc. began fabricating the remainder of the interim storage casks and the first nine were delivered. Work continued on design and fabrication of the reactor vessel drain pump. Three polychlorinated biphenyl (PCB) cooled transformers were removed from service and shipped offsite for disposal; this leaves 10 of the original 19 PCB transformers in service. Additionally, selected process systems were deactivated that are no longer required since the secondary heat transport system sodium has been drained.

\section{Waste Management}

Solid Waste Management. Waste management at the Hanford Site in 2004 included the treatment, storage, and disposal of solid waste at many Hanford locations (Section 6.3.2). Onsite solid waste facilities include the Central Waste Complex, Waste Receiving and Processing Facility, T Plant Complex and Radioactive Mixed Waste Disposal Facility. Radioactive waste stored or disposed of on the Hanford Site in 2004 included 28,500 curies of low-level waste, 28,500 curies of mixed low-level waste, and 15,200 curies of transuranic waste.

Two defueled reactor compartments from the U.S. Navy (Section 6.3.1.5) were received and disposed of in a trench in the 200-East Area in 2004; this brings the total number of Navy reactor compartments received to 114 .

Waste destined for the Waste Receiving and Processing Facility includes stored waste as well as newly generated waste from current site cleanup activities. The waste consists primarily of contaminated cloth, paper, rubber, metal, and plastic. This facility, which began operating in 1997, dispositioned and shipped 154 cubic meters (5,440 cubic feet) of waste during 2004.

Throughout 2004, approximately 566,733 metric tons $(624,719$ tons) of remediation waste were disposed at the Environmental Restoration Disposal Facility. A total of approximately 4.8 million metric tons (5.2 million tons) of remediation waste have been placed in the Environmental
Restoration Disposal Facility from initial operations start-up in July 1996 through 2004. The total available expansion area of the facility site was authorized in the 1995 record of decision to cover as much as 4.1 square kilometers (1.6 square miles).

The Radioactive Mixed Waste Disposal Facility consists of two trenches in the 200-West Area (Section 6.3.1.8). Disposal to the first trench began in September 1999 and the first layer of waste packages has been completed and covered with sand and gravel. The second waste layer has been started. There are currently approximately 3,020 cubic meters ( 106,600 cubic feet) of waste disposed in the first trench. There are approximately 80 cubic meters $(2,825$ cubic feet $)$ of waste stored in the second trench, which was opened for operations in July 2004.

During 2004, there were 2,272 cubic meters ( 2,972 cubic yards) of mixed low-level waste treated or disposed of at the Mixed Low-Level Waste Treatment and Disposal Facility (Section 6.3.1.4).

Liquid Waste Management. Liquid effluent is managed in facilities that comply with RCRA and state regulations (Section 6.3.4).

The 242-A evaporator (Section 6.3.4.5) in the 200-East Area concentrates dilute liquid tank waste by evaporation. This reduces the volume of liquid waste sent to the doubleshell tanks for storage and reduces the potential need for more double-shell tanks. The 242-A evaporator completed one campaign during 2004. The volume of waste treated was 3.69 million liters ( 974,000 gallons), reducing the waste volume by 619,000 liters $(164,000$ gallons), or approximately $17 \%$ of the total volume. The volume of process condensate transferred to the Liquid Effluent Retention Facility for subsequent treatment in the Effluent Treatment Facility was 1.36 million liters (360,000 gallons).

The Effluent Treatment Facility (Section 6.3.4.2) in the 200-East Area treats liquid effluent to remove toxic metals, radionuclides, and ammonia, and destroy organic compounds. The treated effluent is stored in tanks, sampled and analyzed, and discharged to the State-Approved Land Disposal Site (also known as the 616-A crib). The volume of wastewater treated and disposed of in 2004 was approximately 106.9 million liters (28.25 million gallons). 
Approximately 46.84 million liters (12.38 million gallons) of liquid waste were stored at the Liquid Effluent Retention Facility at the end of 2004 (Section 6.3.4.1). The volume of wastewater received for interim storage during 2004 was approximately 107.5 million liters (28.4 million gallons).

The 200 Area Treated Effluent Disposal Facility received 540.9 million liters (142.9 million gallons) of unregulated effluent for disposal in 2004. The major source of this effluent was uncontaminated cooling water and steam condensate from the 242-A evaporator.

Industrial wastewater generated throughout the Hanford Site is collected and treated in the 300 Area Treated Effluent Disposal Facility (Section 6.3.4.4). The wastewater consists of once-through cooling water, steam condensate, and other industrial wastewater. The volume of industrial wastewater treated and disposed of during 2004 was 136.8 million liters (33.13 million gallons).

Underground Waste Storage Tanks. The Office of River Protection manages the DOE's River Protection Project, which is responsible for storage, retrieval, treatment, and disposal of high-level tank waste and the closure of tank farms on the Hanford Site (Section 6.4). During the year, 605,800 liters $(160,100$ gallons) of waste were pumped from single-shell tanks into the double-shell tank system. At the end of 2004, there were 95.27 million liters (25.17 million gallons) of waste in the double-shell tanks.

Hanford Waste Treatment and Immobilization Plant (Waste Treatment Plant). The Waste Treatment Plant is being built on 26 hectares (65 acres) located on the Central Plateau outside of 200-East Area to treat radioactive and hazardous waste currently stored in 177 underground waste storage tanks (Section 6.5). At the end of 2004, engineering designs were $77 \%$ complete and construction was $37 \%$ complete for the pretreatment, high-level waste vitrification, and low-activity waste vitrification facilities. Site excavation for the Waste Treatment Plant analytical laboratory was completed and construction was approximately $10 \%$ complete at the end of 2004. A notable Waste Treatment Plant achievement in 2004 was installation of the pretreatment 4-pack waste receipt vessels. Each 1.42-million-liter (375,000-gallon) stainless steel tank was fabricated onsite, then lifted over walls and set in place. During 2004, workers at the Waste Treatment Plant installed more than 39,624 meters
(130,000 feet) of piping and 20,865 metric tons (23,000 tons) of rebar, and poured over 12,000 truckloads of concrete.

DOE has completed the final review of the report on revised seismic data for the design of the Waste Treatment Plant (Section 5.8.2.1). As a result of the analysis, the seismic design specifications for the Waste Treatment Plant Pretreatment Building and High-Level Waste Building will be modified to withstand larger ground motions. The design changes do not impact other large facility structures within the Waste Treatment Plant complex. The principal impact of the revised specifications is additional expense for design re-analysis and probable project delays from equipment procurement and redesign of piping hangers. The design re-analysis is expected to take approximately 6 months, while the effects of the redesign on the construction schedule are still being determined. Preliminary analyses indicate that most of the existing construction has sufficient design margin to preclude physical modifications to the existing construction. DOE is performing an analysis of overall project costs and schedule impacts.

Throughout 2004, DOE and its contractor have worked closely with the Defense Nuclear Facilities Safety Board to resolve concerns about the presence of potentially flammable concentrations of hydrogen in the Waste Treatment Plant (Section 5.8.2.2). The Waste Treatment Plant waste will generate hydrogen in quantities and at rates that may require controls in some of the pretreatment facility vessels and high-level radioactive waste vessels. Work has been done to systematically identify and evaluate locations throughout the Waste Treatment Plant beyond the primary process vessels (in pipes and ancillary vessels) where hydrogen could accumulate. A design guide to evaluate the potential of hydrogen buildup and apply preferred preventive and mitigative engineering controls has been proposed. Identification of areas where additional controls are needed has been completed, and recommended design solutions are currently being finalized. The final report is scheduled to be completed in April 2005.

\section{Effluent Monitoring Program}

Effluent monitoring at Hanford has two elements: (1) liquid effluent and airborne emissions monitoring at 
site facilities and operations and (2) environmental monitoring near facilities and operations that have the potential to discharge, or have discharged, stored, or disposed of radioactive and hazardous materials.

Liquid Effluent and Airborne Emissions. Liquid effluent and airborne emissions that may contain radioactive or hazardous constituents are continually monitored when released to the environment at the Hanford Site. Facility operators perform the monitoring mainly through analyzing samples collected at points of release into the environment. Monitoring data are evaluated to determine the degree of regulatory compliance for each facility and/or the entire site. The evaluations are also useful to assess the effectiveness of effluent treatment and pollutionmanagement practices.

In 2004, only facilities in the 200 Areas discharged radioactive liquid effluent to the ground, which went to the State-Approved Land Disposal Site (Section 8.3). Nonradioactive hazardous materials in liquid effluent were discharged to both the State-Approved Land Disposal Site and to the Columbia River at designated (permitted) discharge points. Monitoring indicated that no known releases of hazardous substances exceeding reportable quantities occurred at these discharge points in 2004 (Section 5.4.1).

Radioactive air emissions usually come from a building stack or vent. In 2004, radioactive emission discharge points were located in the $100,200,300,400$, and 600 Areas. Table 8.1.1 of this document provides a summary of radionuclides discharged to the atmosphere at the Hanford Site in 2004. Non-radioactive air pollutants from such things as diesel-powered electrical generating plants were also monitored. Table 8.1.2 summarizes the non-radioactive discharges to the air on the Hanford Site during 2004.

\section{Site Closure Activities}

The principal requirements for the control and release of property at Hanford containing residual radioactivity are given in DOE Order 5400.5, Radiation Protection of the Public and the Environment. These requirements are designed to be certain that property is evaluated; radiologically characterized; and decontaminated before release; the level of residual radioactivity in property to be released is as near background levels as is reasonably practicable and meets DOE authorized limits; and all property releases are appropriately certified, verified, documented, and reported. No property with detectable residual radioactivity was released from the Hanford Site in 2004 (Chapter 7).

Emergency Decontamination Facility. The Emergency Decontamination Facility (Section 7.0.1.1) maintained next to Kadlec Medical Center in Richland is no longer needed because other decontamination facilities have been constructed. During 2004, DOE and Kadlec Medical Center continued to work on closing the facility.

Hanford Reach National Monument. The Hanford Reach National Monument lies within the boundaries of the Hanford Site. Although DOE maintains administrative control over the land within the monument, the U.S. Fish and Wildlife Service manages about $84 \%$ of the land (Section 7.0.1.2). In 2001, the DOE Office of Inspector General concluded that 57,900 hectares (143,000 acres) of land within the monument could be transferred to the U.S. Department of Interior without adversely affecting DOE operations on the Hanford Site. Subsequently, the DOE Richland Operations Office entered into negotiations with the U.S. Department of Interior regarding release and transfer of selected portions of the monument from DOE control to the jurisdiction of the U.S. Fish and Wildlife Service. The necessary processes and assessments to make that happen are currently underway.

Columbia River Corridor. Activities continued during 2004 to clean up the Columbia River Corridor (Section 7.0.2). Although risk assessments are usually done prior to cleanup activities, the regulatory agencies have granted interim records of decision to initiate cleanup first and postpone conducting risk assessments until a later date. The River Corridor Baseline Risk Assessment Project has begun a pilot risk assessment in the 100-B/C Area that may be adapted for use at all 100 Areas and the 300 Area. The project has created a website to provide information about project activities. The site includes the dates of public involvement opportunities, documents available for review and comment, administrative information, and links to related projects. The website can be found at http://www.bhierc.com/Projects/risk/risk.htm. 


\section{Environmental Monitoring}

The early identification of, and appropriate response to, potentially adverse environmental and resource effects associated with DOE operations are assured by routinely conducting pre-operational environmental characterization and assessment activities; monitoring effluent and emissions; performing environmental monitoring and surveillance; monitoring cultural resources; performing periodic sampling of Hanford Site drinking water; and monitoring and controlling contaminated and undesirable biota.

The primary environmental and resource monitoring program and projects at Hanford include the Effluent Monitoring Program, conducted by Fluor Hanford, Inc.; the Public Safety and Resource Protection Project, managed by the Pacific Northwest National Laboratory; and the Groundwater Performance Assessment Project, also managed by Pacific Northwest National Laboratory. Pacific Northwest National Laboratory personnel through a contract with Fluor Hanford, Inc. monitor radiological contaminants in Hanford Site drinking water. The Biological Control Program manages activities on the Hanford Site to prevent, limit, and clean up contaminated or undesirable plants or animals and to remediate their impact to the environment and human health and safety. This program is managed for DOE by Fluor Hanford, Inc. The overall objectives of these monitoring and surveillance programs are to demonstrate compliance with applicable federal, state, and local regulations; confirm adherence to DOE environmental, public health, and worker protection policies; and support environmental and waste management decisions.

Table S.4. Hanford Site Monitoring Results for 2004

What was Monitored?

Air

Columbia River Water

Columbia River Shoreline Springs

Groundwater

Drinking Water
Air particles and gases were analyzed for radioactive materials. Air was sampled at 23 site-wide locations on Hanford, 11 perimeter locations, 8 community locations, and in 2 distant communities In addition, near-facility monitoring collected air samples at 85 locations near Hanford facilities.

Columbia River water was collected from multiple Hanford Reach sampling points throughout the year. Water samples were analyzed for radioactive and chemical materials. Water in the Columbia River continues to be designated Class A (Excellent) by the state of Washington. This designation means that the water is usable for substantially all needs.

Includes groundwater discharges to the Columbia River via surface and subsurface springs. Discharges above the water level of the river are identified as riverbank springs. Samples of spring water were collected at locations along the Columbia River shoreline.

Groundwater samples were collected from 727 wells and 154 shoreline aquifer tubes to monitor contaminant concentrations. Water levels were measured in several hundred wells on the site to map groundwater movement.

The quality of the drinking water supplied by nine DOE-owned systems on the Hanford Site was monitored.

\section{The Bottom Line}

All measurements of radioactive materials in air were below recommended guidelines. In general, radionuclide concentrations near facilities were at or near Hanford Site background levels, which are much less than DOE derived concentration guides but greater than concentrations measured off the site. The data also show that concentrations of certain radionuclides were higher and widely variable within different onsite operational areas.

As in past years, small amounts of radioactive materials were detected downriver from Hanford. However, the amounts were far below federal and state limits. During 2004 , there was no indication of any deterioration of Columbia River water quality resulting from operations at Hanford.

Samples collected at the springs contained some contaminants at levels above those observed in nearshore river water but similar to local groundwater. However, concentrations in river water downstream of the shoreline springs remained far below federal and state limits.

Samples showed that groundwater contaminant plumes are continuing to move from beneath former waste sites to the Columbia River. The total area of radiological and chemical contaminant plumes with contaminant concentrations exceeding drinking water standards was estimated to be approximately 66 square miles during 2004. This area occupies $11.2 \%$ of the total area of the Hanford Site. The tritium and iodine-129 plumes have the largest areas with concentrations exceeding drinking water standards.

All DOE-owned drinking water systems on the Hanford Site met Washington State and EPA standards. 
Environmental monitoring and surveillance results for 2004 are summarized in Table S.4. For detailed discussions of results, refer to the appropriate sections of this report.

Climate and Meteorology. Meteorological measurements are taken to support Hanford Site emergency preparedness, site operations, and atmospheric dispersion calculations (Section 8.16). Support includes weather forecasting and maintenance and distribution of climatological data. A complete listing of climatological data for calendar year 2004 is contained in Hanford Site Climatological Data Summary 2004 with Historical Data.

Calendar year 2004 was slightly warmer than normal and precipitation was above normal. The average temperature for 2004 was $12.6^{\circ} \mathrm{C}\left(54.6^{\circ} \mathrm{F}\right)$, which was $0.6^{\circ} \mathrm{C}\left(1.0^{\circ} \mathrm{F}\right)$ above normal $\left(12.0^{\circ} \mathrm{C}\left[53.6^{\circ} \mathrm{F}\right]\right)$. Seven months during 2004 were warmer than normal; five months were cooler than normal. December had the greatest positive departure, $2.3^{\circ} \mathrm{C}\left(4.2^{\circ} \mathrm{F}\right)$; January, at $1.4^{\circ} \mathrm{C}\left(2.6^{\circ} \mathrm{F}\right)$ below normal, had the greatest negative departure.
Precipitation during 2004 totaled 20.2 centimeters ( 7.96 inches), which is $114 \%$ of normal ( 17.7 centimeters [6.98 inches]). Snowfall for 2004 totaled 58.2 centimeters (22.9 inches), compared to an annual normal snowfall of 39.1 centimeters ( 15.4 inches).

The average wind speed during 2004 was 3.1 meters per second (7.0 miles per hour), which was 0.3 meter per second ( 0.6 mile per hour) below normal. The peak gust for the year was 28.2 meters per second (63 miles per hour) on January 30.

No dust storms were recorded at the Hanford Meteorology Station during 2004. There has been an average of five dust storms per year at the Hanford Meteorology Station during the entire period of record (1945-2004).

Cultural Resources. The DOE is responsible for managing and protecting the Hanford Site's cultural and historic resources (Section 8.15). The Hanford Cultural and Historic Resources Program, which is maintained by DOE, assures that cultural and historic resources entrusted

Table S.4. (contd)

What was Monitored?

$\begin{array}{ll}\text { Food and Farm Products } & \begin{array}{l}\text { Samples of asparagus, grapes, leafy vegetables, } \\ \text { milk, potatoes, tomatoes, and wine were collected } \\ \text { from locations upwind and downwind of the Hanford } \\ \text { Site. }\end{array} \\ \text { Fish and Wildlife } & \begin{array}{l}\text { Game animals on the site and along the Hanford } \\ \text { Reach and fish from the Columbia River were mon- } \\ \text { tored at } 85 \text { onsite locations and } 6 \text { reference location } \\ \text { Carcass, bone, and muscle samples were analyzed } \\ \text { to evaluate radionuclide levels. }\end{array} \\ \text { Effluent and Emissions } & \begin{array}{l}\text { Airborne emissions and liquid effluent that may } \\ \text { contain radioactive or hazardous constituents are } \\ \text { continually monitored on the Hanford Site. }\end{array} \\ \text { Soil } & \begin{array}{l}\text { Soil samples were collected at } 83 \text { locations near } \\ \text { facilities and at 42 site-wide and offsite locations; } \\ 19 \text { investigative samples were also collected. }\end{array}\end{array}$

Vegetation
Vegetation samples were collected near Hanford Site facilities and at 14 site-wide and offsite locations.

\section{The Bottom Line}

Radionuclide concentrations in samples of food and farm products were at normal environmental levels.

Samples of carp, sculpin, quail, pheasant, clams, deer, and elk were collected and analyzed. Radionuclide levels in wildlife samples were well below levels that are estimated to cause adverse health effects to animals or to the people who may consume them.

Compliance with all applicable effluent and emissions monitoring requirements was achieved in 2004.

In general, radionuclide concentrations in soil samples collected from or adjacent to waste disposal facilities in 2004 were higher than the concentrations in samples collected farther away and were significantly higher than concentrations than concentrations measured offsite. The data also show, as expected, that concentrations of certain radionuclides in 2004 were higher within different operational areas when compared to concentrations measured in distant communities. There were 19 instances of radiological contamination in investigative soil samples. Of the 19 locations, 16 were cleaned up. At the remaining locations, the contamination levels did not exceed the radiological control limits for the sites and the soil was left in place.

Concentrations of radionuclides were elevated near facilities when compared to distant communities. Some radionuclides were detected at low concentrations in site-wide samples. Concentrations is offsite samples were generally below detection limits. 
to DOE are managed responsibly and in accordance with applicable regulatory requirements.

Cultural resources reviews must be conducted before a federally funded, federally assisted, or federally licensed ground disturbance or building alteration/demolition project can take place. As such, cultural resource reviews are required at Hanford to identify properties within the proposed project area that may be eligible for, or listed in, the National Register of Historic Places and evaluate the project's potential to affect any such property. During 2004, 166 cultural resource reviews were requested and conducted.

During 2004, sites were also monitored to gather data about the characteristics of each site, processes adversely affecting the site, and changes at the site. Of the findings recorded at these monitored places, most were related to natural causes.

Places with cemeteries or known human remains include locations that are sacred to the Wanapum Band, Yakama Nation, Confederated Tribes of the Umatilla Indian Reservation, and the Nez Perce Tribe. Overall, places with human remains were found to be stable during 2004. No violations were noted.

The historic First Bank of White bluffs building continues to deteriorate. Stabilization and planning for the rehabilitation of the bank building continued in 2004. Of the current walls, $50 \%$ to $60 \%$ will need to be reconstructed.

Identification and evaluation activities are performed to comply with National Historic Preservation Act Section 106 and Section 110. In 2004, approximately 1,335 hectares (3,300 acres) were surveyed. Twenty-one historic period archaeological sites and 32 isolated finds, 25 of which date to the prehistoric period, were recorded in 2004 .

Evaluation efforts in 2004 focused on generating information about the Hanford Site's pre-1943 agricultural landscape and White Bluffs town site in order for DOE to make its determination on the eligibility of these resources for listing in the National Register. DOE will make a final determination on their eligibility in 2005.

The application of the curation strategy for artifacts and records associated with the Hanford Site Manhattan Project and Cold War Era Historic District continued during 2004. Twenty assessments were conducted during
2004, in four buildings in the 300 Area, seven buildings in the 200 Areas, two facilities in the 700 Area (downtown Richland), and seven buildings in the 100-N Area.

\section{Potential Radiological Doses from 2004 Hanford Operations}

During 2004, the potential radiological dose to the public from Hanford operations was evaluated to determine compliance with pertinent regulations and limits (Section 8.14). The methods used to calculate the potential doses are presented in Appendix E. The potential dose to the offsite maximally exposed individual in 2004 was $0.014 \mathrm{mrem}(0.14 \mu \mathrm{Sv})$ per year. The national average dose from background sources, according to the National Council on Radiation Protection, is approximately $300 \mathrm{mrem} / \mathrm{yr}(3 \mathrm{mSv} / \mathrm{yr})$, and the current DOE radiological dose limit for a member of the public is $100 \mathrm{mrem} / \mathrm{yr}$ $(1 \mathrm{mSv} / \mathrm{yr})$.

\section{Quality Assurance}

Comprehensive quality assurance programs, which include various quality control practices and methods to verify data, are maintained by monitoring and surveillance projects to assure data quality. The programs are implemented through quality assurance plans designed to meet requirements of the American National Standards Institute/ American Society of Mechanical Engineers and DOE Orders. Quality assurance plans are maintained for all activities, and auditors verify conformance. Quality control methods used in 2004 included replicate sampling and analysis, analysis of field blanks and blind reference standards, participation in interlaboratory crosscheck studies, and splitting samples with other laboratories.

In 2004, sample collection and laboratory analyses were conducted using documented and approved procedures. When sample results were received, they were screened for anomalous values by comparing them to recent results and historical data. Analytical laboratory performance on the submitted double blind samples, the EPA Laboratory Intercomparison Studies Program, and the national DOE Quality Assessment Program indicated that laboratory performance was adequate overall, was excellent in some areas, and needed improvement in others. 


\section{Acknowledgments}

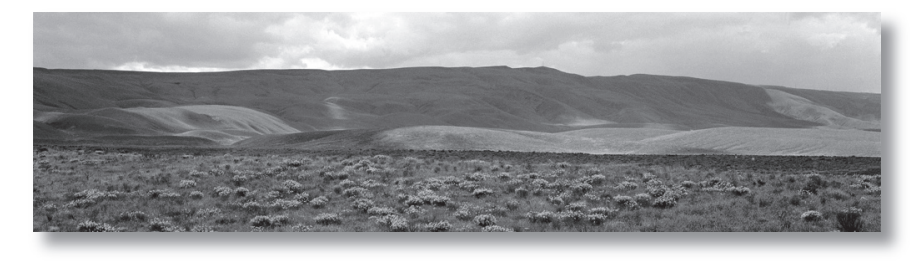

The production of this report was managed by the Pacific Northwest National Laboratory's Public Safety and Resource Protection Project under the direction of Roger L. Dirkes.

The authors appreciate the comprehensive reviews of the draft report by William H. Rickard, Larry L. Cadwell, Bruce A. Napier, and Keith R. Price (Pacific Northwest National Laboratory).

The report was prepared by Pacific Northwest National Laboratory staff: Loel E. Kathmann, Cornelia P. Brim, and Launa F. Morasch, text editors, and Kathy R. Neiderhiser, text processor. Graphics were prepared by Deborah L. Liddell (Lockheed Martin Services, Inc.), Chris A. Newbill, JoAnn T. Rieger, and Rhett K. Zufelt (Pacific Northwest National Laboratory). Shannon B. Neely (Pacific Northwest National Laboratory) designed the report cover and layout. Duplicating and printing arrangements were managed by Stanley J. Kophs, who was supported by Olivia P. Valadez and Maria I. Barrera. This report was produced using Adobe ${ }^{\circledR}$ InDesign and formatted for the Internet by Debora A. Schulz and others in Pacific Northwest National Laboratory's Scientific and Technical Information Department.

Community-operated environmental surveillance stations were managed by local teachers who were responsible for collecting the samples and maintaining the stations. The managers and alternate managers for each station included the following:

Leslie Groves Park, Richland: Chuck A. Wagner, Manager, and Dale R. Johns, Alternate Manager

Basin City Elementary School, Basin City: Cliff L. Stevenson, Manager, and Kathy McEachen, Alternate Manager

Edwin Markham Elementary School, North Franklin County: Mitch P. Madison, Manager, and Karen A. Thomas, Alternate Manager

Heritage College, Toppenish: Ryan A. Landvoy, Manager, and Holly Ferguson, Alternate Manager. 


\section{Contents}

Preface

Summary

Acknowledgments

xvii

1.0 Introduction.

1.0.1 Current Site Mission .....

1.0.2 Overview of the Hanford Site

1.0.3 Site Management

2.0 Public Involvement at Hanford....

2.0.1 The Role of Indian Tribes

2.0.2 Consultations and Meetings with Tribes, Interested Parties, and the State Historic

Preservation Office

2.0.3 Hanford Natural Resource Trustee Council

2.0.4 Public Participation in Hanford Site Decisions

2.0.5 Hanford Advisory Board.

3.0 Regulatory Oversight at Hanford

3.0.1 Hanford Federal Facility Agreement and Consent Order .............................................................

3.0.2 Status of Tri-Party Agreement Milestones ......................................................................................

3.0.3 Approved Modifications to the Tri-Party Agreement.................................................................

3.0.4 Washington State Department of Health ...................................................................................

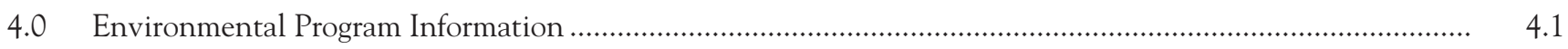

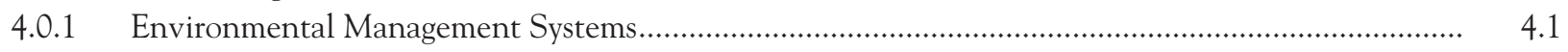

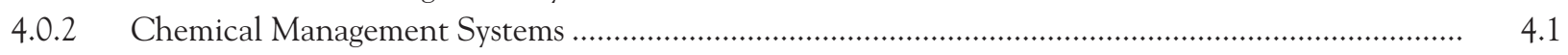

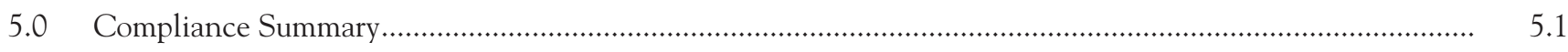

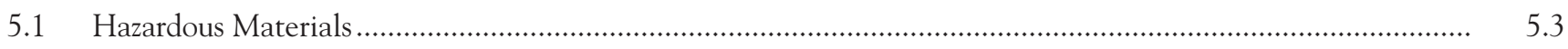

5.1.1 Emergency Planning and Community Right-To-Know Act......................................................... 5.3

5.1.2 Resource Conservation and Recovery Act .................................................................................

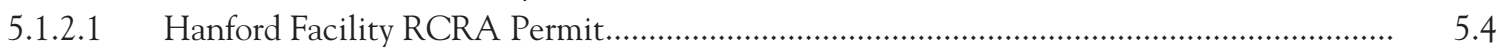

5.1.2.2 RCRA/Dangerous Waste Permit Applications and Closure Plans ..................................... 5.4

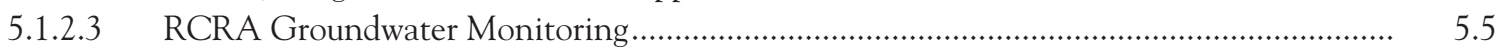

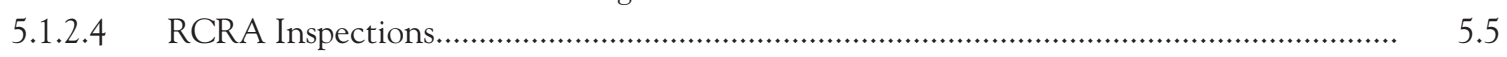

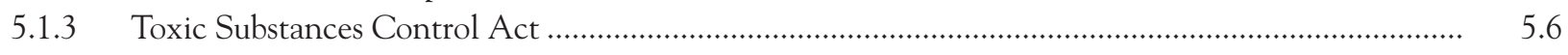

5.1.4 Federal Insecticide, Fungicide, and Rodenticide Act .............................................................. 5.7

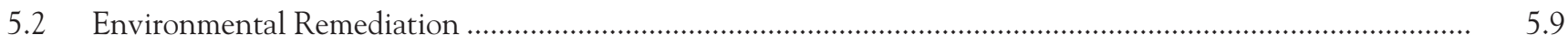

5.2.1 Comprehensive Environmental Response, Compensation, and Liability Act................................. 5.9

5.2.2 Hanford Site Institutional Controls Plan..................................................................................... 5.9 
5.2.3 CERCLA and Washington Administrative Code Reportable Releases to the Environment............. $\quad$ 5.10

5.2.4 Washington Administrative Code Groundwater Monitoring ............................................................... 5.10

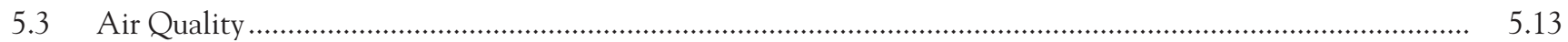

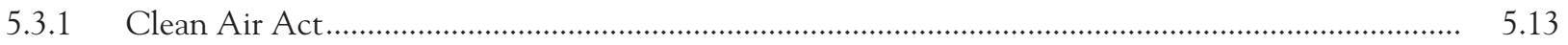

5.3.2 Clean Air Act Enforcement Inspections ....................................................................................... 5.13

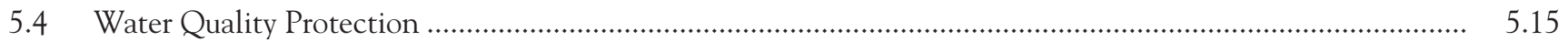

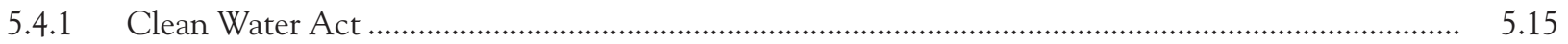

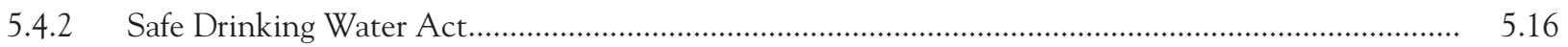

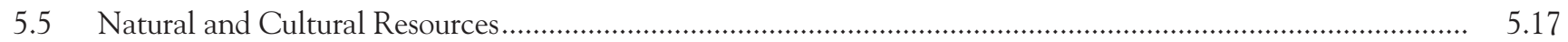

5.5.1 Ecological Compliance ........................................................................................................... 5.17

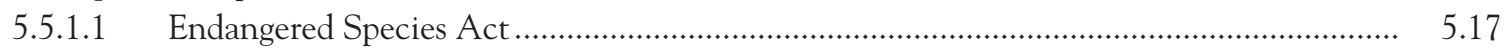

5.5.1.2 Migratory Bird Treaty Act ..................................................................................... 5.17

5.5.2 Cultural Resources...................................................................................................

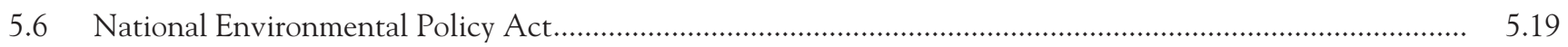

5.6.1 Recently Issued Environmental Impact Statements .......................................................................... 5.19

5.6.2 Recent Environmental Assessments ................................................................................................. 5.20

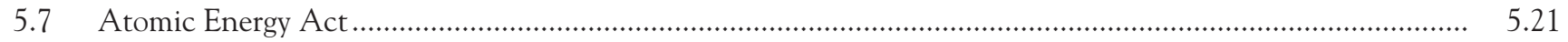

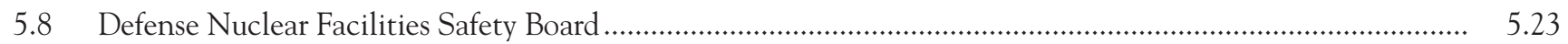

5.8.1 Defense Nuclear Facilities Safety Board Related Accomplishments, DOE Richland

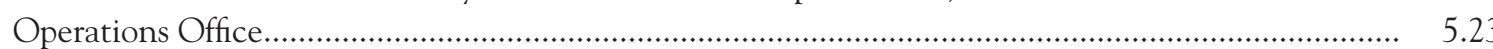

5.8.2 Defense Nuclear Facilities Safety Board Related Accomplishments, DOE Office of

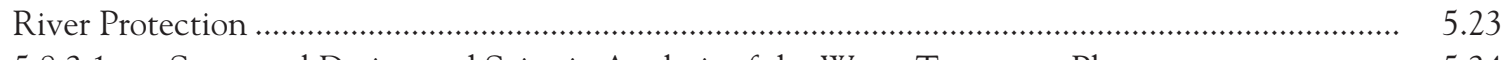

5.8.2.1 Structural Design and Seismic Analysis of the Waste Treatment Plant............................ 5.24

5.8.2.2 Concerns about Hydrogen Generated at the Waste Treatment Plant............................... 5.24

5.8.2.3 Assessment of Waste Treatment Plant Design and Analysis Computer Software ............ 5.25

5.8.2.4 Assessment of Instrument and Control System Computer Software for Tank Farms ........ 5.25

5.8.2.5 Integrated Safety Management System in the Tank Farms ............................................. 5.25

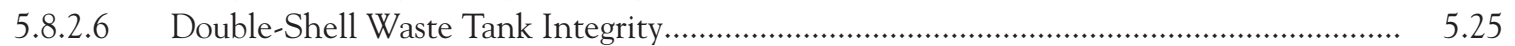

5.8.3 Status of DOE Order 435.1, Radioactive Waste Management ............................................................... 5.25

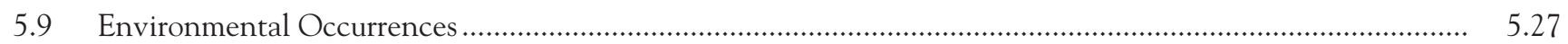

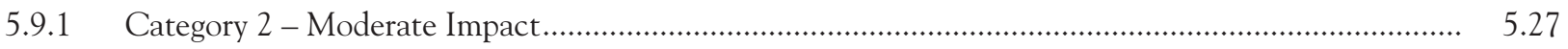

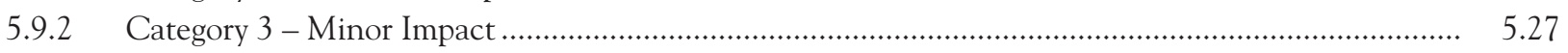

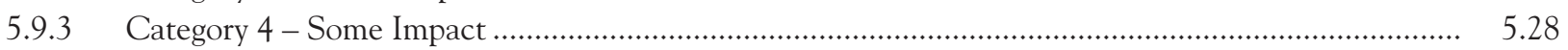

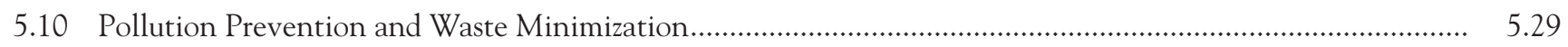

5.10.1 Pollution Prevention Program............................................................................................. 5.29

5.10.2 Washington State Initiative 297, The Cleanup Priority Act …………………..................................... 5.30

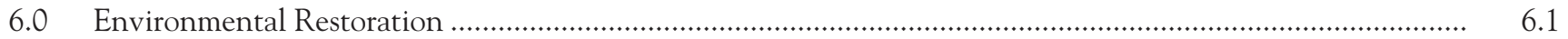

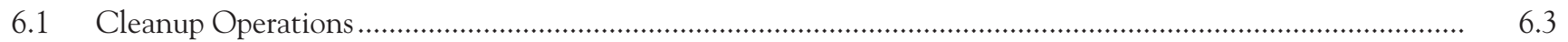

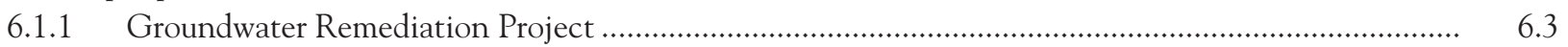

6.1.2 Waste Site Investigations and Remediation Activities in the 200 Areas .......................................... 6.3 


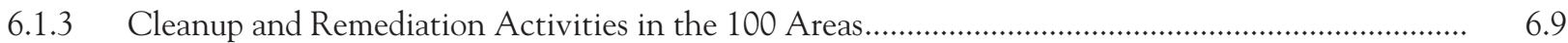

6.1.3.1 K Basins Closure Activities .................................................................................................... 6.9

6.1.3.2 Remediation of Waste Sites in the 100 Areas................................................................. 6.10

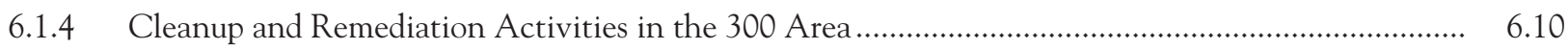

6.1.5 Cleanup and Remediation Activities in the 600 Area ..................................................................... 6.11

6.2 Facility Decommissioning Activities ........................................................................................................

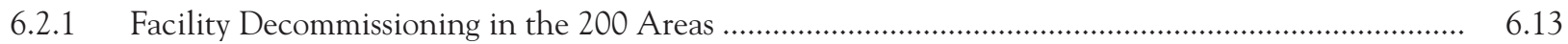

6.2.1.1 Decommissioning of the 224-T Plutonium Concentration Facility ................................... 6.13

6.2.1.2 Decommissioning of the 224-B Plutonium Concentration Facility .................................. 6.13

6.2.1.3 Decommissioning of the 233-S Plutonium Concentration Facility ................................... 6.14

6.2.1.4 Removal of Ancillary Facilities at the 221-U Chemical Processing Facility .................... 6.14

6.2.1.5 Decommissioning of the Plutonium Finishing Plant ........................................................ 6.15

6.2.1.6 Surveillance, Maintenance, and Deactivation Activities in the 200 Areas and on the Fitzner/Eberhardt Arid Lands Ecology Reserve Unit................................................... 6.16

6.2.1.7 Investigating the Potential for Using the 200 Areas Chemical Separations Plants

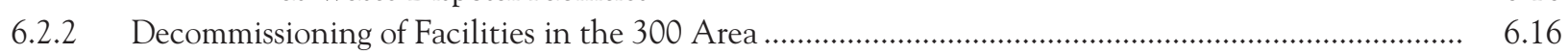

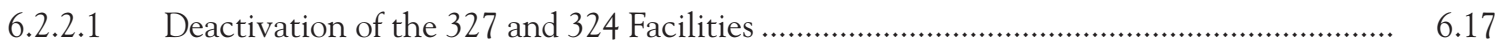

6.2.2.2 Status of the 309 Plutonium Recycle Test Reactor Facility ............................................... 6.17

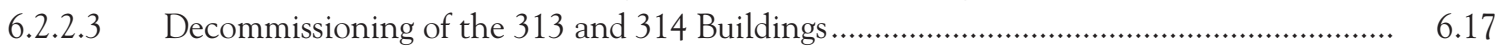

6.2.3 Decommissioning of Facilities in the 400 Area ............................................................................. 6.17

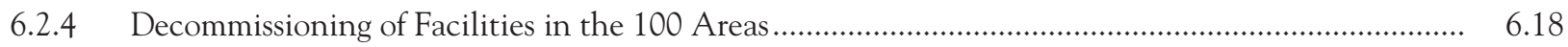

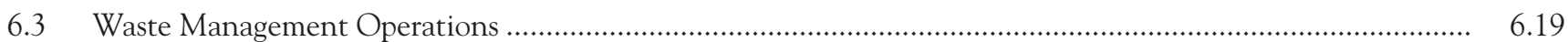

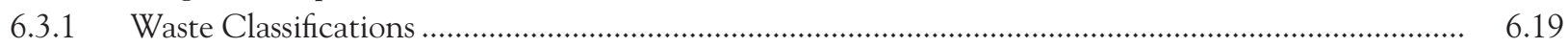

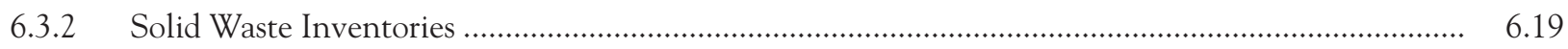

6.3.3 Solid Waste Management...................................................................................................... 6.20

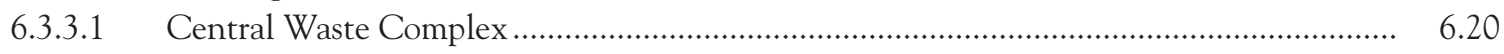

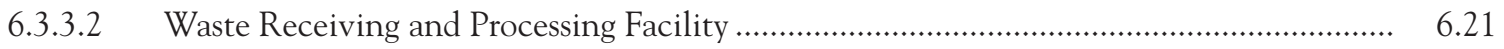

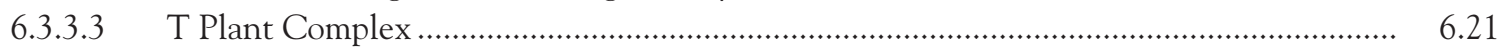

6.3.3.4 Mixed Low-Level Waste Treatment and Disposal ............................................................ 6.23

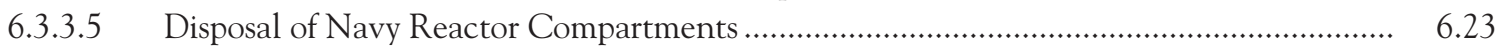

6.3.3.6 Environmental Restoration Disposal Facility .................................................................... 6.23

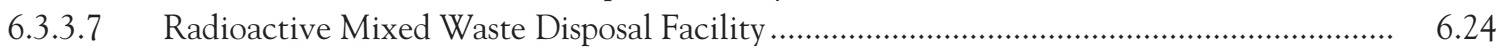

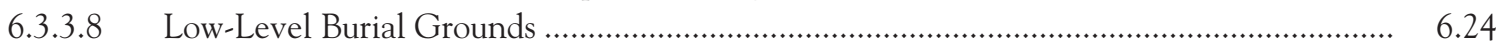

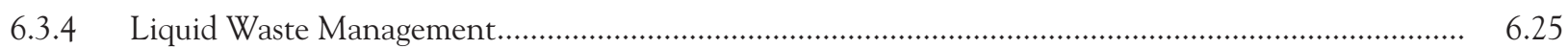

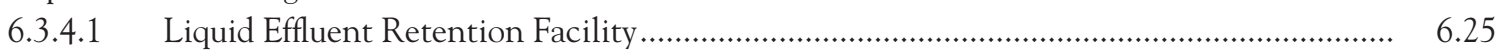

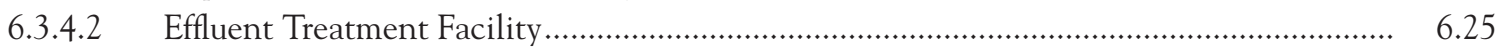

6.3.4.3 200 Area Treated Effluent Disposal Facility ............................................................... 6.26

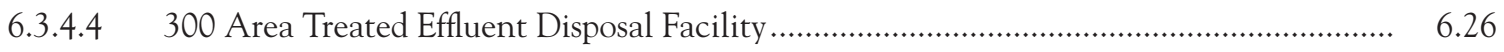

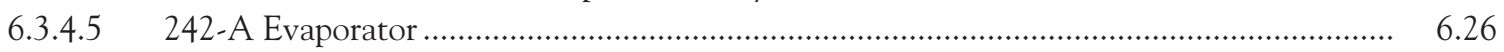

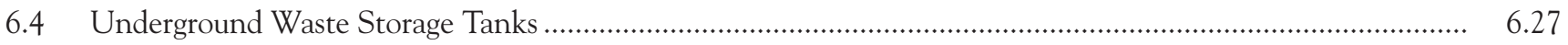

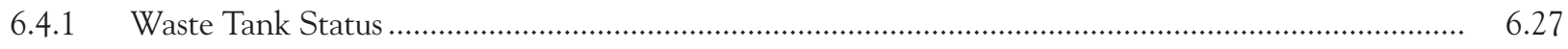

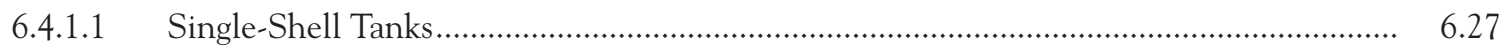

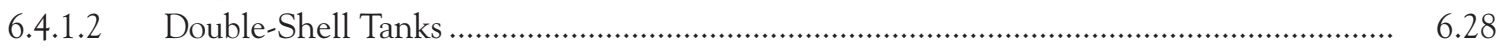

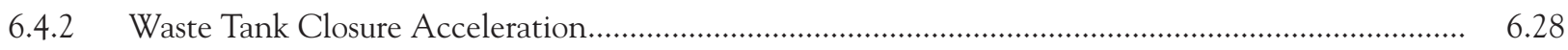

6.5 Hanford Waste Treatment and Immobilization Plant ................................................................................... 
7.0 Site Closure Activities................

7.0.1 Radiological Release of Property from Hanford ..................................................................................

7.0.1.1 Radiological Clearance for Release of Selected Hanford Reach National Monument Lands.

7.0.1.2 Assessment of Fitzner/Eberhardt Arid Lands Ecology Reserve Unit Soil for Residual Radioactive Contamination ............................................................................................. 7.4

7.0.1.3 Emergency Decontamination Facility ........................................................................

7.0.2 Columbia River Corridor Risk Assessment......................................................................................

8.0 Environmental and Resource Protection Programs.............................................................................

8.0.1 Effluent Monitoring Program .......................................................................................... 8.2

8.0.1.1 Liquid Effluent and Airborne Emissions Monitoring ........................................................ 8.2

8.0.1.2 Near-Facility Environmental Monitoring ..................................................................... 8.2

8.0.2 Public Safety and Resource Protection Project............................................................................

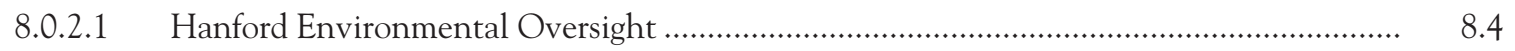

8.0.2.2 Meteorological and Climatological Services Project ......................................................... 8.4

8.0.2.3 Surface Environmental Surveillance Project ................................................................... 8.5

8.0.2.4 Ecological Monitoring and Compliance Project................................................................ 8.6

8.0.2.5 Cultural Resources Project ......................................................................................... 8.7

8.0.3 Groundwater Performance Assessment Project ..................................................................................... 8.7

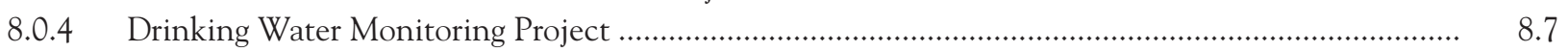

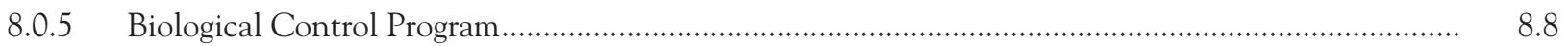

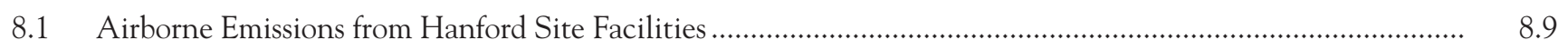

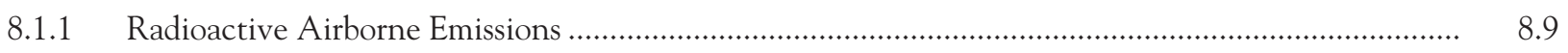

8.1.2 Non-Radioactive Airborne Emissions..................................................................................... 8.10

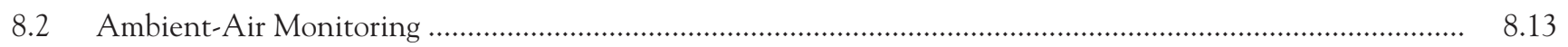

8.2.1 Ambient-Air Monitoring Near Facilities and Operations........................................................... 8.13

8.2.2 Site-Wide and Offsite Ambient-Air Monitoring............................................................................. 8.18

8.2.2.1 Collection of Site-Wide and Offsite Ambient-Air Samples and Analytes Tested............. 8.18

8.2.2.2 Ambient-Air Monitoring Results for Site-Wide and Offsite Samples ................................ 8.22

8.2.2.3 Monitoring of Airborne Particulate Matter on the Hanford Site ........................................ 8.27

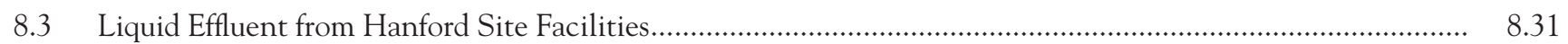

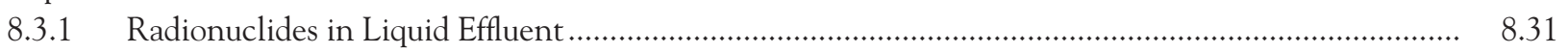

8.3.2 Non-Radioactive Hazardous Materials in Liquid Effluent ............................................................. 8.31

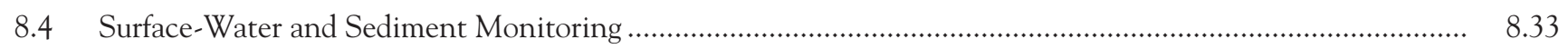

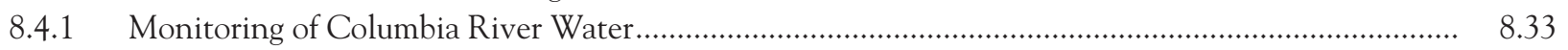

8.4.1.1 Collection of Columbia River Water Samples and Analytes of Interest............................ 8.37

8.4.1.2 Radiological Results for Columbia River Water Sample Analyses...................................... 8.38

8.4.1.3 Chemical and Physical Water Quality Results for Columbia River Water Samples.......... 8.43

8.4.2 Monitoring of Columbia River Sediment ....................................................................................... 8.44

8.4.2.1 Collection of Columbia River Sediment Samples and Analytes of Interest ...................... 8.46

8.4.2.2 Radiological Results for Columbia River Sediment Sample Analyses .............................. 8.46

8.4.2.3 Chemical Results for Columbia River Sediment Sample Analyses...................................... 8.48 
8.4.3 Monitoring of Onsite Pond Water and Sediment........................................................................

8.4.3.1 Collection of Pond Water and Sediment Samples and Analytes of Interest...................... 8.49

8.4.3.2 Radiological Results for Pond Water and Sediment Sample Analyses............................... 8.49

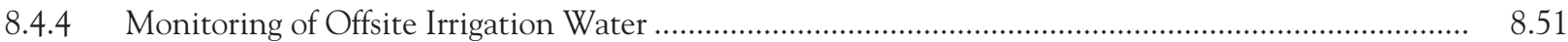

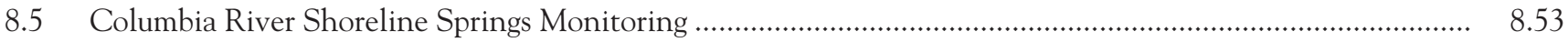

8.5.1 Water Monitoring at Columbia River Shoreline Springs................................................................... 8.53

8.5.1.1 Collection of Water Samples from Columbia River Shoreline Springs and Analytes

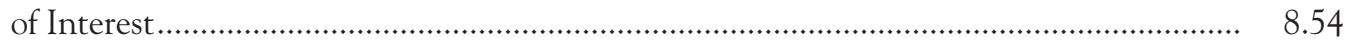

8.5.1.2 Radiological Results for Water Samples from Columbia River Shoreline Springs............. 8.55

8.5.1.3 Chemical Results for Water Samples from Columbia River Shoreline Springs ................. 8.57

8.5.2 Monitoring Columbia River Shoreline Springs Sediment ........................................................... 8.58

8.5.3 Radiological Monitoring of Columbia River Shoreline Spring Water in Seep Wells in the

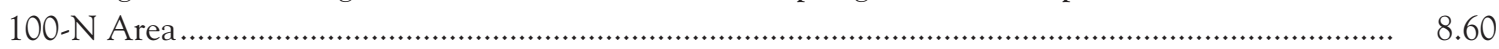

8.6 Radiological Monitoring of Hanford Site Drinking Water ....................................................................

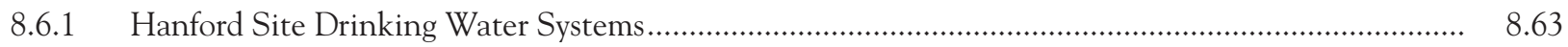

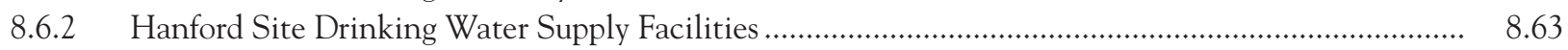

8.6.3 Collection of Drinking Water Samples and Analytes of Interest ........................................................ 8.64

8.6.4 Radiological Results for Hanford Site Drinking Water Samples .......................................................... 8.65

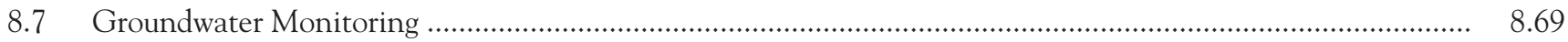

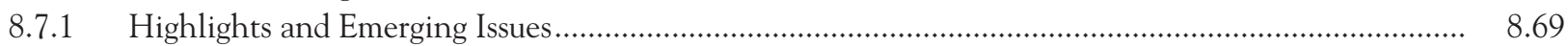

8.7.1.1 Groundwater Monitoring Highlights ............................................................................... 8.69

8.7.1.2 Groundwater Monitoring at Operable Units ..................................................................... 8.71

8.7.1.3 Groundwater Monitoring at Waste Facilities................................................................... 8.71

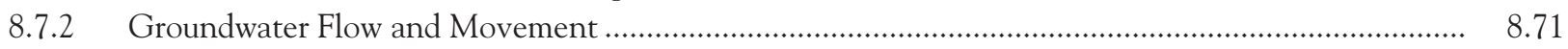

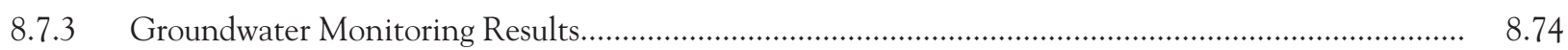

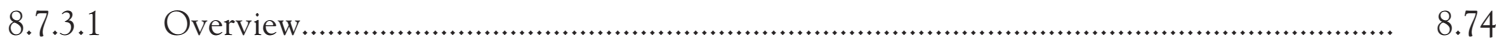

8.7.3.2 Groundwater Monitoring Results for the 100-BC-5 Operable Unit ................................. 8.79

8.7.3.3 Groundwater Monitoring Results for the 100-KR-4 Operable Unit .................................. 8.79

8.7.3.4 Groundwater Monitoring Results for the 100-NR-2 Operable Unit................................... 8.81

8.7.3.5 Groundwater Monitoring Results for the 100-HR-3-D Operable Unit ............................ 8.81

8.7.3.6 Groundwater Monitoring Results for the 100-HR-3-H Operable Unit .............................. 8.81

8.7.3.7 Groundwater Monitoring Results for the 100-FR-3 Operable Unit................................... 8.82

8.7.3.8 Groundwater Monitoring Results for the 200-ZP-1 Operable Unit .................................... 8.83

8.7.3.9 Groundwater Monitoring Results for the 200-UP-1 Operable Unit .................................. 8.84

8.7.3.10 Groundwater Monitoring Results for the 200-BP-5 Operable Unit................................. 8.84

8.7.3.11 Groundwater Monitoring Results for the 200-PO-1 Operable Unit .................................. 8.85

8.7.3.12 Groundwater Monitoring Results for the 300-FF-5 Operable Unit .................................. 8.87

8.7.3.13 Groundwater Monitoring Results for the 1100-EM-1 Operable Unit................................ 8.88

8.7.3.14 Groundwater Monitoring Results for the Confined Aquifers .......................................... 8.88

8.7.4 Groundwater and Vadose Zone Remediation ............................................................................ 8.88

8.7.4.1 Groundwater Remediation Using Pump-and-Treat Systems and In Situ Redox

Manipulation Technology ................................................................................... 8.89

8.7.4.2 Vadose Zone Remediation Using Soil-Vapor Extraction Systems..................................... 8.96

8.7.5 Well Installation, Maintenance, and Decommissioning ............................................................. 8.97

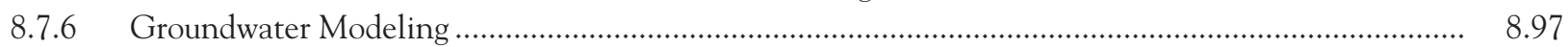

8.7.6.1 An Assessment Tool for Estimating the Impact of Groundwater Contaminants ............... 8.97

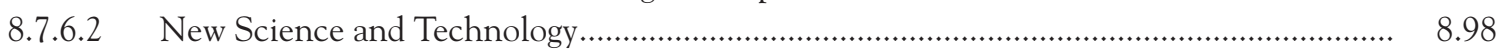

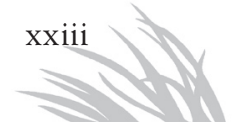


8.7.7 Groundwater Remediation Project: Strategic Planning, Public Involvement, and Database

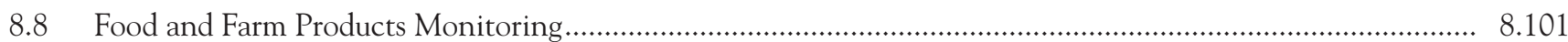

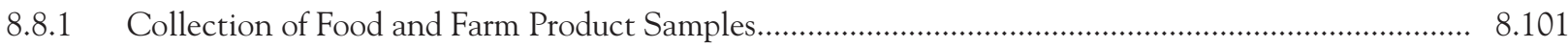

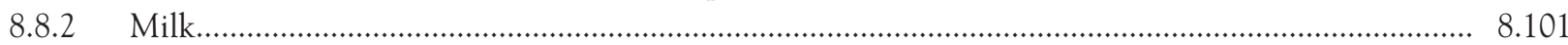

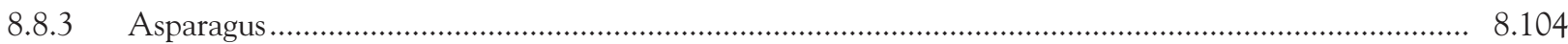

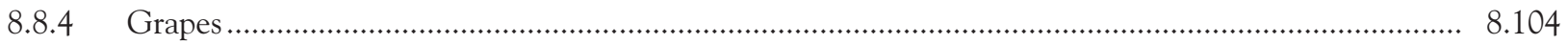

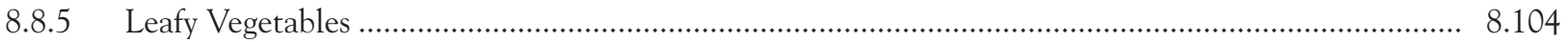

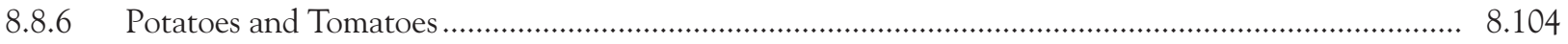

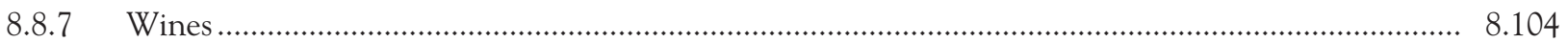

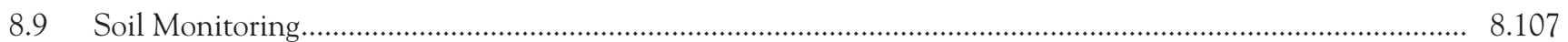

8.9.1 Soil Monitoring Near Hanford Site Facilities and Operations......................................................... 8.107

8.9.1.1 Soil Sampling Near Hanford Site Facilities and Operations .......................................... 8.107

8.9.1.2 Analytical Results for Soil Samples Collected Near Hanford Site Facilities

8.9.1.3 Investigations of Radioactive Contamination in Soil Near Hanford Site Facilities
and Operations .......................................................................................................... 8.111

8.9.2 Soil Monitoring at Site-Wide and Offsite Locations ............................................................................ 8.113

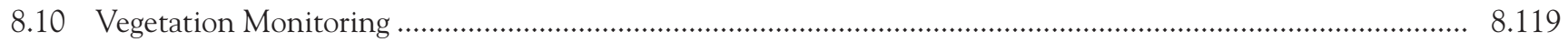

8.10.1 Plant Communities and Population Surveys on the Hanford Site ................................................... 8. 8.119

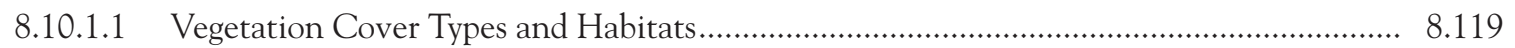

8.10.1.2 Rare Plant Monitoring ........................................................................................... 8.120

8.10.2 Vegetation Monitoring Near Hanford Site Facilities and Operations............................................... 8.120

8.10.2.1 Vegetation Sampling Near Hanford Site Facilities and Operations .................................. 8.121

8.10.2.2 Analytical Results for Vegetation Samples Collected Near Hanford Site Facilities

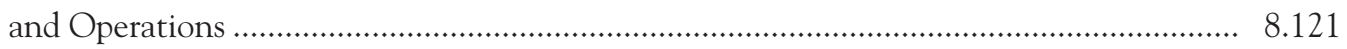

8.10.2.3 Investigations of Radioactive Contamination in Vegetation Near Hanford Site
Facilities and Operations ........................................................................................ 8.125

8.10.3 Vegetation Monitoring at Site-Wide and Offsite Locations............................................................. 8.125

8.10.3.1 Vegetation Sampling at Site-Wide and Offsite Locations ................................................ 8.125

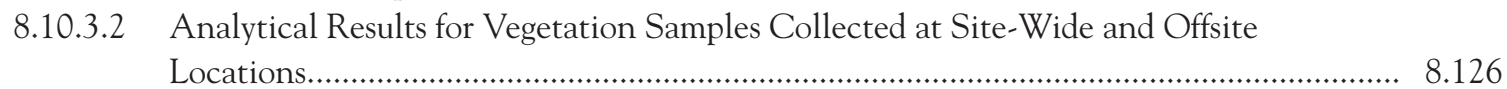

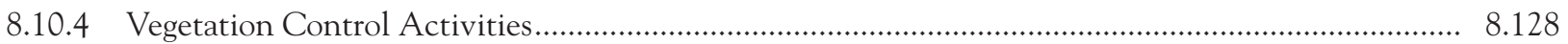

8.10.4.1 Control of Contaminated or Potentially Contaminated Vegetation in 2004 …............... 8.128

8.10.4.2 Revegetation Activities in 2004 to Control Blowing Weeds and Dust............................... 8.130

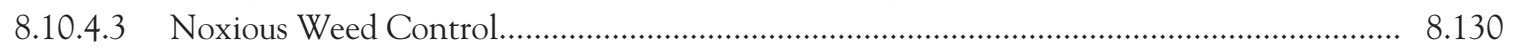

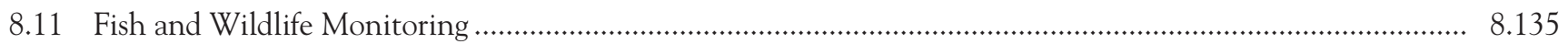

8.11.1 Ecological Monitoring of Hanford Site Wildlife Populations.............................................................. 8.135

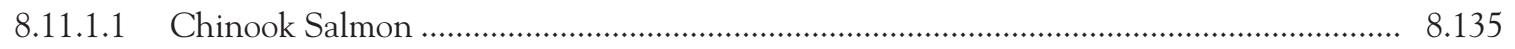

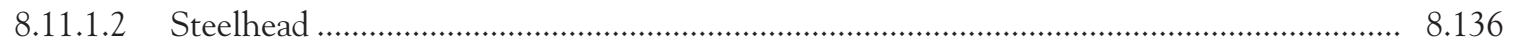

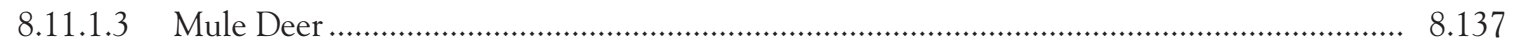

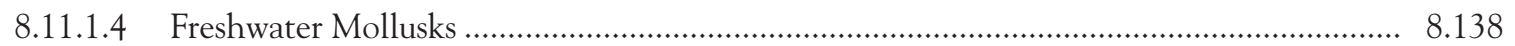

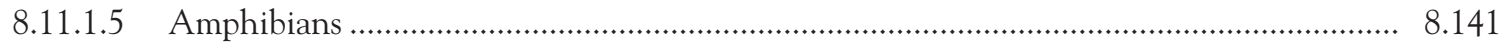

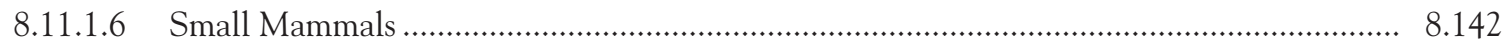

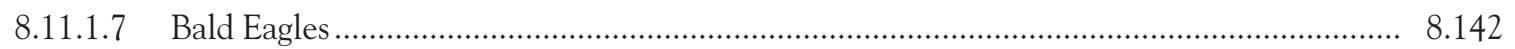

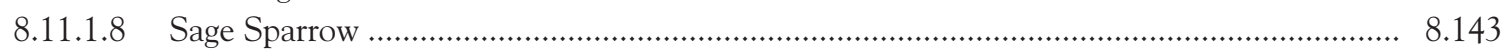


8.11.2 Monitoring of Fish and Wildlife for Hanford-Produced Contaminants ............................................. 8.143

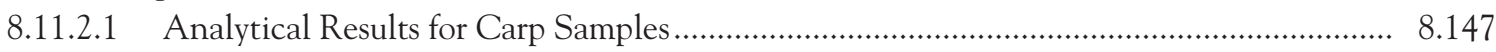

8.11.2.2 Analytical Results for Upland Game Samples............................................................. 8.150

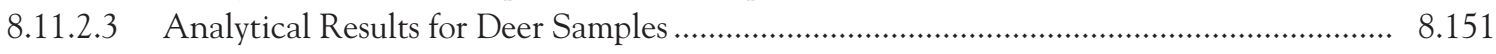

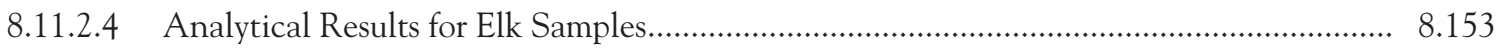

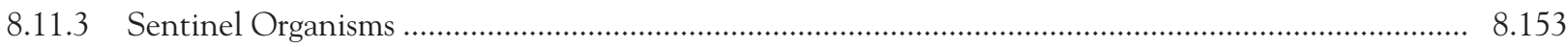

8.11.3.1 Asiatic Clam Sample Results and Analytes of Interest …............................................... 8.153

8.11.3.2 Sculpin Sample Results and Analytes of Interest ............................................................... 8.157

8.11.4 Investigations of Radioactive Contamination in Wildlife and Wildlife-Related Materials

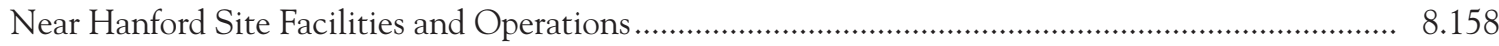

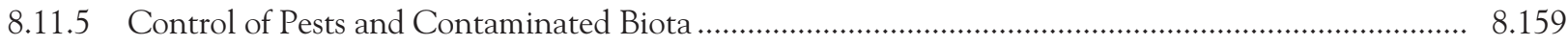

8.12 Threatened and Endangered Species at Hanford …................................................................................ 8.161

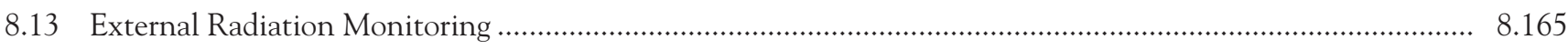

8.13.1 External Radiation Monitoring Onsite Near Facilities and Operations............................................ 8.166

8.13.1.1 External Radiation Measurements Onsite Near Facilities and Operations .......................... 8.166

8.13.1.2 Radiological Surveys at Active and Inactive Waste Disposal Sites.................................... 8.169

8.13.2 External Radiation Monitoring at Site-Wide and Offsite Locations................................................ 8.170

8.13.2.1 External Radiation Measurements at Site-Wide Locations................................................. 8.174

8.13.2.2 External Radiation Measurements at Perimeter and Offsite Locations.............................. 8.174

8.13.2.3 External Radiation Measurements at Columbia River Shoreline Locations....................... 8.175

8.13.2.4 Columbia River Shoreline Radiological Survey Results................................................. 8.176

8.13.2.5 Pressurized Ionization Chamber Results at Four Offsite Locations...................................... 8.176

8.14 Potential Radiological Doses from 2004 Hanford Site Operations................................................................ 8.179

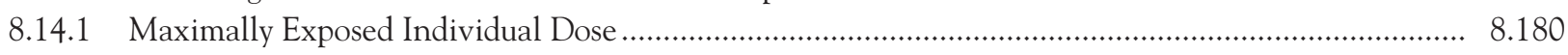

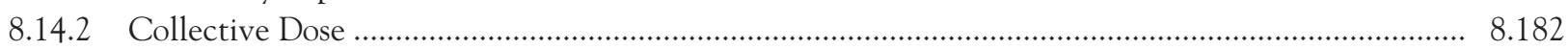

8.14.3 Compliance with Clean Air Act Standards................................................................................... 8.184

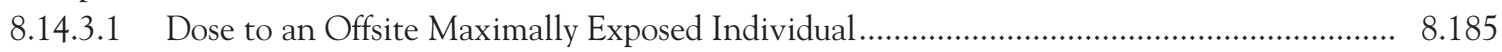

8.14.3.2 Maximum Dose to Non-DOE Workers on the Site .................................................... 8.185

8.14.3.3 Dose from Diffuse and Fugitive Radionuclide Emissions ................................................... 8.185

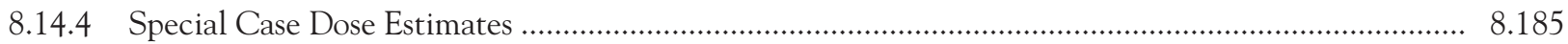

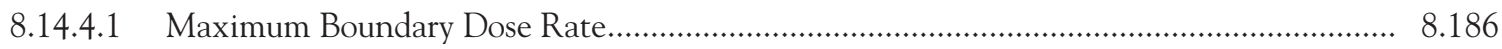

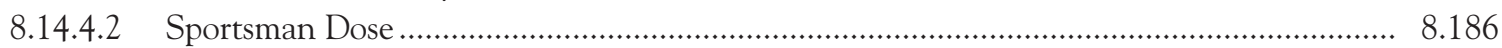

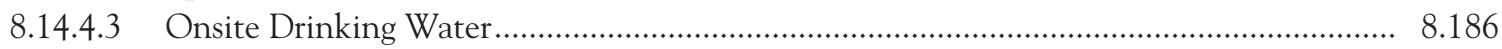

8.14.4.4 Inhalation Doses for Entire Year ............................................................................ 8.187

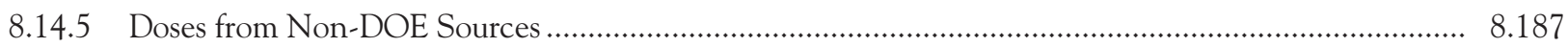

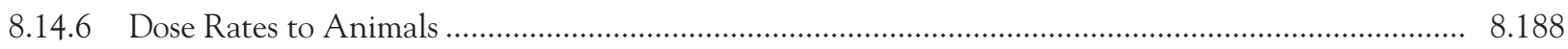

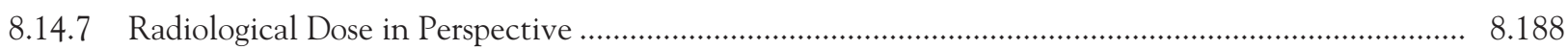

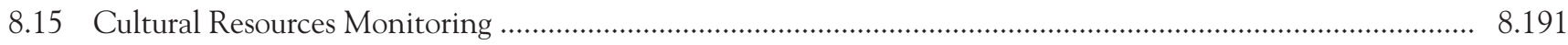

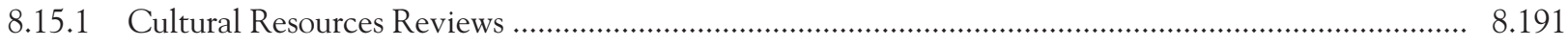

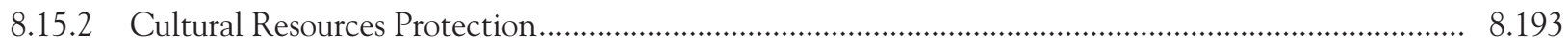

8.15.2.1 Monitoring Cultural Sites for Natural and Visitor Impact ............................................... 8.194

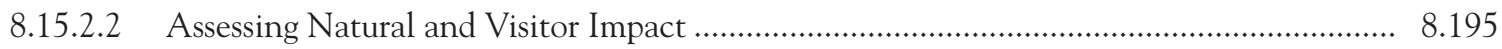

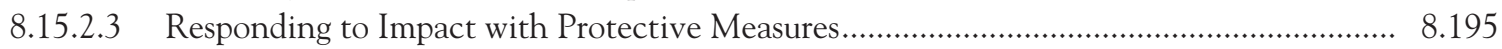

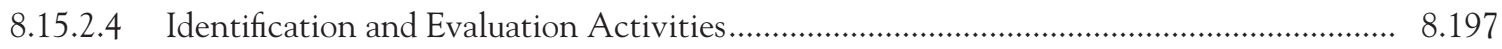

8.15.2.5 Management of Artifact and Data Collections................................................................ 8.197

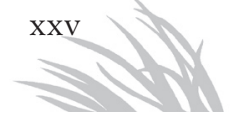


8.16 Climate and Meteorology

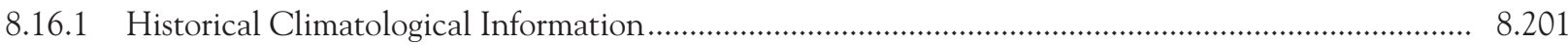

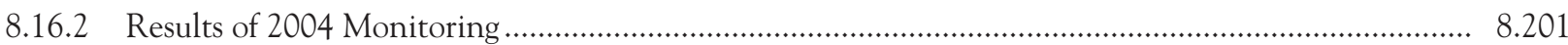

8.17 Community Involvement in Environmental Surveillance …….................................................................... 8.203

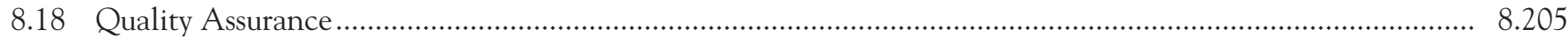

8.18.1 Site-Wide and Offsite Environmental Monitoring and Groundwater Monitoring............................. 8.205

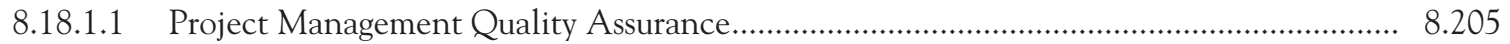

8.18.1.2 Sample Collection Quality Assurance and Quality Control ........................................... 8.205

8.18.1.3 Analytical Results Quality Assurance and Quality Control................................................ 8.206

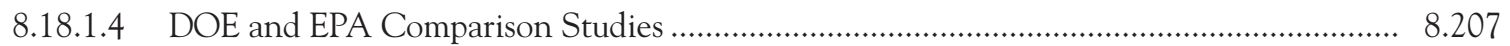

8.18.1.5 Pacific Northwest National Laboratory Evaluations............................................................ 8.208

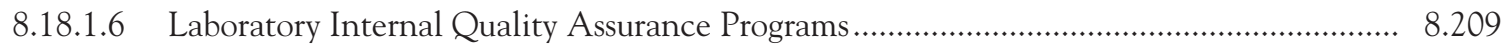

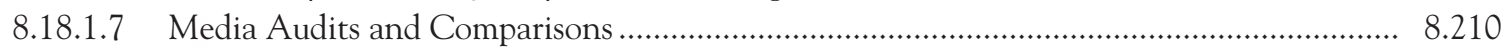

8.18.2 Effluent Monitoring and Environmental Monitoring Near Facilities and Operations ....................... 8.211

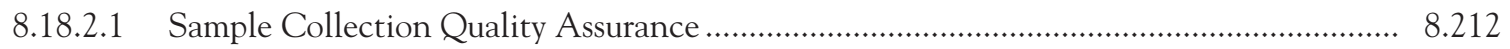

8.18.2.2 Analytical Results Quality Assurance......................................................................... 8.212

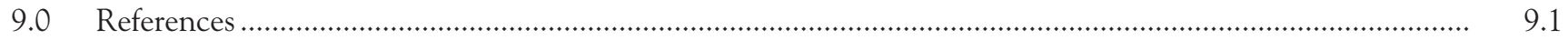

Appendix A - Helpful Information

Appendix B - Glossary

Appendix C - Additional Monitoring Results for 2004

Appendix D - Standards and Permits

Appendix E - Dose Calculations

Appendix F - Radionuclides Measured by Gamma Spectroscopy

\section{Figures}

1.0.1 The Hanford Site and Surrounding Area.......................................................................................

1.0.2 Management Units on the Hanford Reach National Monument .............................................................

7.0.1 Median and Maximum Measured Soil Concentrations and Authorized Release Limits for Radionuclides Detected in Soil Samples Collected on the Fitzner/Eberhardt Arid Lands Ecology Reserve Unit of the Hanford Reach National Monument in 2004.

8.1.1 Airborne Releases of Selected Radionuclides from the Hanford Site, 1994 through 2004......................... 8.9

8.2.1 Average Concentrations of Selected Radionuclides in Ambient-Air Samples Collected on the Hanford Site Near Facilities and Operations Compared to Those Collected in Distant Communities, 1999 through 2004

8.2.2 Hanford Site-Wide and Offsite Ambient-Air Sampling Locations During 2004 ....................................... 8.19

8.2.3 Gross Alpha Concentrations in Airborne Particulate Samples Collected at Hanford Site-Wide and Distant Locations During 2004 
8.2.4 Gross Beta Concentrations in Airborne Particulate Samples for all Hanford Site-Wide and Offsite Sampling Locations in 2004 and Average Wind Speed over the Sampling Period.

8.2.5 Gross Beta Concentrations Measured in Airborne Particulate Samples for Hanford Site-Wide and Offsite Sampling Locations in 2004 Versus the Average Wind Speed over the Sampling Period

8.2.6 Iodine-129 Concentrations in Hanford Site-Wide and Offsite Ambient-Air Samples, 1999 through 2004.

8.2.7 Daily Average $\mathrm{PM}_{10}$ Particle Concentrations at the Hanford Meteorology Station, 2004

8.2.8 Daily Average $\mathrm{PM}_{2.5}$ Concentrations at the Hanford Meteorology Station, 2004

8.3.1 Liquid Releases of Selected Radionuclides from the Hanford Site, 1994 through 2004

8.4.1 Surface-Water and Sediment Sampling Locations On and Around the Hanford Site, 2004

8.4.2 Mean, Maximum, and Minimum Columbia River Flow Rates at Priest Rapids Dam,

Washington, 2004

8.4.3 Annual Average Gross Alpha Concentrations in Columbia River Water Upstream and Downstream of the Hanford Site, 1999 through 2004.

8.4.4 Annual Average Gross Beta Concentrations in Columbia River Water Upstream and Downstream of the Hanford Site, 1999 through 2004

8.4.5 Annual Average Tritium Concentrations in Columbia River Water Upstream and Downstream of the Hanford Site, 1999 through 2004

8.4.6 Annual Average Strontium-90 Concentrations in Columbia River Water Upstream and Downstream of the Hanford Site, 1999 through 2004 ......

8.4.7 Annual Average Total Uranium Concentrations in Columbia River Water Upstream and Downstream of the Hanford Site, 1999 through 2004

8.4.8 Annual Average Iodine-129 Concentrations in Columbia River Water Upstream and Downstream of the Hanford Site, 1999 through 2004

8.4.9 Tritium Concentrations in Cross-River Transect Water Samples from the Hanford Reach of the Columbia River, September 2004

8.4.10 Tritium Concentrations in Columbia River Water Collected at the Hanford Site Shoreline, 2004......

8.4.11 U.S. Geological Survey Water Quality Measurements for the Columbia River Upstream and Downstream of the Hanford Site, 1999 through 2004

8.4.12 Median, Maximum, and Minimum Concentrations of Selected Radionuclides Measured in Columbia River and Snake River Sediment, 1999 through 2004

8.4.13 Median, Maximum, and Minimum Concentrations of Selected Metals Measured in Columbia River Sediment, 2004

8.4.14 Average Acid Volatile Sulfide/Simultaneously Extracted Zinc and Sum of Simultaneously Extracted Cadmium, Copper, Lead, Nickel, and Mercury in Columbia River Sediment, 1997 through 2003 
8.4.15 Median, Maximum, and Minimum Gross Beta and Tritium Concentrations in Water Samples from the Fast Flux Test Facility Pond on the Hanford Site, 1999 through 2004

8.4.16 Median, Maximum, and Minimum Concentrations of Tritium in Water Samples from West Lake on the Hanford Site, 1999 through 2004

8.5.1 Concentrations of Selected Radionuclides in Water from Columbia River Shoreline Springs Near the Hanford Site's 300 Area, 1999 through 2004

8.5.2 Concentrations of Selected Radionuclides in Columbia River Shoreline Springs Water at the Hanford Town Site, 1999 through 2004

8.6.1 Hanford Site Drinking Water Distribution Facilities and Sampling Locations, 2004.....

8.6.2 Tritium Concentrations in Drinking Water from Three Wells in the Hanford Site's 400 Area, 1985 through 2004 .

8.7.1 Groundwater Interest Areas on the Hanford Site in 2004

8.7.2 Locations of the Regulated Waste Management Units on the Hanford Site During 2004

8.7.3 Water-Table Elevations and Inferred Flow Direction for the Unconfined Aquifer at the Hanford Site, March 2004

8.7.4 Distribution of Major Radionuclides in Hanford Site Groundwater at Concentrations Above Drinking Water Standards During 2004.....

8.7.5 Distribution of Major Hazardous Chemicals in Hanford Site Groundwater at Concentrations Above Drinking Water Standards During 2004

8.7.6 Influence of Pump-and-Treat Remediation and Natural Processes on Chromium Concentrations in Groundwater Beneath the Hanford Site's 100-H Area, 1994 Compared to 2004

8.7.7 Tritium Concentrations in Hanford Site Groundwater, 1980 Compared to 2004

8.7.8 Pump-and-Treat, In Situ Remediation, and Soil-Gas Extraction Systems Operating on the Hanford Site in 2004

8.7.9 The Effect of Pump-and-Treat System on Groundwater Chromium Concentrations in the Hanford Site's 100-K Area, 1994 Compared to 2004

8.7.10 Chromium Concentrations in Hanford Site's Central 100-D Area Groundwater, 1999 Compared to 2004

8.7.11 Strontium-90 Concentrations in the Hanford Site's 100-N Area Groundwater, 1990 Compared to 2004

8.7.12 Influence of a Pump-and-Treat System on Carbon Tetrachloride Concentrations Beneath the Hanford Site's 200-West Area, 1990 Compared to 2004

8.7.13 Influence of a Pump-and-Treat System at the Hanford Site's 200-UP-1 Operable Unit on Uranium Concentrations in Groundwater, 1995 Compared to 2004

8.7.14 Impact of a Pump-and-Treat System at the Hanford Site's 200-UP-1 Operable Unit on Technetium-99 Concentrations in Groundwater, 1995 Compared to 2004 
8.9.1 Average Concentrations of Selected Radionuclides in Soil Samples Collected on the Hanford Site Near Facilities and Operations Compared to Those Collected in Distant Communities, 1999 through 2004 ......

8.9.2 Hanford Site-Wide and Offsite Soil Sampling Locations, 2004

8.9.3 Average Concentrations of Cesium-137 and Plutonium-239/240 in Hanford Site-Wide and Offsite Soil Samples, 1993 through 2004

8.10.1 Average Concentrations of Selected Radionuclides in Vegetation Samples Collected Near Hanford Site Facilities and Operations Compared to Those Collected in Distant Communities, 1999 through 2004.

8.10.2 Hanford Site-Wide and Offsite Vegetation Sampling Locations, 2004.

8.10.3 Plutonium-239/240 Concentrations in Hanford Site-Wide and Offsite Vegetation Samples Collected in 2004

8.10.4 Major Populations of Noxious Weeds on the Hanford Site, 2004

8.11.1 Number of Salmon Redds in the Hanford Reach of the Columbia River.....

8.11.2 Major Fall Chinook Salmon Spawning Areas in the Hanford Reach of the Columbia River.

8.11.3 Estimates of the Number of Fawns per 100 Does in the Post-Hunting Period on the Hanford Site from 1994 through 2004

8.11.4 Percent of Male Mule Deer on the Hanford Site from 1994 through 2004 Showing Signs of Abnormal Antler Growth

8.11.5 Mean Sagebrush Cover, Territory Size, and Sagebrush Patchiness for Burned Versus Unburned Sage Sparrow Territories on the Hanford Site in 2003 and 2004

8.11.6 Fish and Wildlife Sampling Locations On and Around the Hanford Site, 2004 ......

8.11.7 Median, Maximum, and Minimum Strontium-90 Concentrations in Columbia River Carp Carcasses at the Hanford Site, 2004 Compared to Previous Years......

8.11.8 Median, Maximum, and Minimum Strontium-90 Concentrations in Hanford Site and Background Upland Game Bird Bone Samples, 2004 Compared to Previous Years

8.11.9 Median, Maximum, and Minimum Strontium-90 Concentrations in Hanford Site and Background Deer Bone Samples, 2004 Compared to Previous Years.....

8.11.10 Comparison of Median and Maximum Concentrations of Strontium-90 in Elk Bone, 2004 Compared to Previous Years and Reference Locations

8.11.11 Chromium Levels in Soft Tissues of Asiatic Clams Collected Near the Vernita Bridge and the 100-B/C, 100-K, 100-N, and 100-D Areas at the Low-Water Line and 2 Meters Below the Low-Water Line, 2004 
8.13.2 Surface Environmental Surveillance Project Thermoluminescent Dosimeter Locations on the Hanford Site, 2004.

8.13.3 Community, Distant, and Perimeter Thermoluminescent Dosimeter Locations Around the Hanford Site, 2004 ......

8.13.4 Hanford Site Surface Environmental Surveillance Project Thermoluminescent Dosimeter Locations Along the Columbia River, 2004

8.13.5 Annual Average Dose Rates at Site-Wide, Perimeter, and Distant Locations of the Hanford Site, 1999 through 2004

8.13.6 Maximum and Average External Dose Rates Measured Along the Columbia River at 100-N Area Shoreline Locations on the Hanford Site, 1999 through 2004.

8.14.1 Locations Important to Dose Calculations at the Hanford Site, 2004 .......

8.14.2 Calculated Dose to the Hypothetical, Maximally Exposed Individual Near the Hanford Site, 2000 through 2004

8.14.3 Collective Dose to the Population within 80 Kilometers of the Hanford Site, 2000 through 2004........... 8.183

8.14.4 National Annual Average Radiological Doses from Various Sources......................................................... 8.184

8.15.1 Cultural Resources Review Requests for Hanford Site Operational Areas Received in 2004 .................. 8.192

8.15.2 Percentage of Impact by Type at Cultural Sites at Hanford from 1989 through 2004 ............................. 8.194

8.15.3 Bank Loss at Locke Island Erosion Transects from 1996 through 2004 .................................................. 8.195

8.15.4 Percentage of Monitored Sites at Hanford Affected by Collector Digging by Year ................................... 8.196

8.15.5 Percentage of Monitored Sites at Hanford with Public Recreation Impact by Year ................................. 8.196

8.16.1 Hanford Meteorological Monitoring Network Wind Roses, 2004 ......................................................... 8.200

8.17.1 Community Members See Environmental Surveillance in Action at a Community-Operated Environmental Surveillance Station in Richland, Washington

A.1 A Graphical Representation of Maximum, Median, and Minimum Values

A.2 Data Plotted Using a Linear Scale

A.3 Data Plotted Using a Logarithmic Scale

A.4 Data with Error Bars Plotted Using a Linear Scale

\section{Tables}

S.1 Compliance with Federal Acts at the Hanford Site in 2004 
S.3 Summary of Groundwater Pump-and-Treat Systems and a Vadose Zone Soil-Vapor Extraction System

S.4 Hanford Site Monitoring Results for 2004

5.1.1 Emergency Planning and Community Right-to-Know Act Compliance Reporting at the Hanford Site, 2004

5.1.2 Average Quantity of Ten Hazardous Chemicals Stored on the Hanford Site, 2004

6.3.1 Quantities of Solid Waste Generated on the Hanford Site, 1999 through 2004

6.3.2 Quantities of Solid Waste Received on the Hanford Site from Offsite Sources, 1999 through 2004.........

6.3.3 Quantities of Dangerous Waste Shipped Off the Hanford Site, 1999 through 2004

6.3.4 Radioactive Solid Waste Stored or Disposed of on the Hanford Site, 2004...

6.4.1 Quantities of Liquid Waste Generated and Stored Within the Tank Farm System on the Hanford Site During 2004 and During Each of the Previous 5 Years.

7.0.1 Maximum Levels of Radionuclides Allowed in Soil on the Hanford Reach National Monument.......

8.0.1 Routine Environmental Monitoring Samples and Locations Near Hanford Site Facilities and Operations, 2004.

8.0.2 Routine Hanford Site Environmental Surveillance Samples and Locations at Site-Wide and Offsite Locations, 2004

8.1.1 Radionuclides Discharged to the Atmosphere at the Hanford Site, 2004.

8.1.2 Non-Radioactive Constituents Discharged to the Atmosphere at the Hanford Site, 2004.

8.2.1 Monitoring Locations and Analyses for Ambient-Air Monitoring Samples Collected Near

Hanford Site Facilities and Operations, 2004

8.2.2 Annual Average and Maximum Concentrations of Selected Radionuclides in Ambient-Air Samples

Collected Near Facilities and Operations on the Hanford Site, 2004.

8.2.3 Site-Wide and Offsite Ambient-Air Sampling Locations, Sample Composite Groups, and Analytes, 2004 .

8.2.4 Airborne Radionuclide Concentrations in the Environs of the Hanford Site, 2004 Compared to

Previous Years

8.3.1 Radionuclides in 200 Areas Liquid Effluent Discharged to the State-Approved Land Disposal Site at the Hanford Site, 2004 .....

8.3.2 Radionuclides in Liquid Effluent from the 100 Areas Discharged to the Columbia River, 2004.....

8.4.1 Surface-Water Surveillance On and Near the Hanford Site, 2004

8.4.2 Columbia and Snake River Sediment Surveillance, 2004

8.5.1 Shoreline Springs Water Monitoring at the Hanford Site, 2004.

8.5.2 Hanford Reach Shoreline Springs Sediment Monitoring, 2004. 
8.5.3 Concentration Ranges for Selected Chemicals in Water Monitoring Samples from Columbia

River Shoreline Springs at the Hanford Site, 1999 through 2004.

8.5.4 Radionuclide Concentrations in Samples Collected from Wells Along the Columbia River

Shoreline in the 100-N Area, 2004.

8.6.1 Concentrations of Selected Radiological Constituents in Hanford Site Drinking Water, 2004 ................ 8.65

8.6.2 Tritium Concentrations in Hanford Site 400 Area Drinking Water Wells, 2004 ................................... 8.66

8.7.1 Summary of Hanford Site Groundwater Performance Assessment Project by Groundwater Interest

Area, 2004.

8.7.2 Summary of Hanford Site Groundwater Performance Assessment Project by Monitoring Purpose, 2004.

8.7.3 Regulated Units Requiring Groundwater Monitoring on the Hanford Site, 2004

8.7.4 Areas of Contaminant Plumes on the Hanford Site at Levels Above Drinking Water

Standards, 2004

8.7.5 Summary of Maximum Contaminant Concentrations in Hanford Site Groundwater by Groundwater Interest Area, 2004

8.7.6 Summary of Maximum Contaminant Concentrations in Hanford Site Groundwater by Monitoring Purpose, 2004

8.7.7 Summary of Groundwater Remediation Activities at the Hanford Site, 2004

8.7.8 Radioactive Contaminants Investigated in the Composite Analysis and Hazardous Chemical Contaminants Chosen for Future Evaluations

8.8.1 Sampling Locations, Frequencies, and Analyses Performed for Food and Farm Products Sampled Around the Hanford Site, 2004.

8.9.1 Number and Locations of Soil Samples Collected Near Hanford Site Facilities and Operations, 2004.

8.9.2 Average Radionuclide Concentrations in Surface Soil Samples Collected on the Hanford Site in the 100-N Area, 1999 through 2004.

8.9.3 Average Radionuclide Concentrations in Surface Soil Samples Collected on the Hanford Site in the 100-N Area in 2004, Compared to Distant Communities and Accessible Soil Concentration Limits......

8.9.4 Average Radionuclide Concentrations in Surface Soil Samples Collected Near Hanford Site Facilities and Operations in the 200 and 600 Areas, 1999 through 2004

8.9.5 Radionuclide Concentrations in Surface Soil Samples Collected Near Hanford Site Facilities and Operations in the 200 and 600 Areas in 2004, Compared to Distant Communities and Accessible Soil Concentration Limits

8.9.6 Average Radionuclide Concentrations in Surface Soil Samples Collected Near Hanford Site Facilities and Operations in the 300 and 400 Areas, 1999 through 2004 
8.9.7 Radionuclide Concentrations in Surface Soil Samples Collected Near Hanford Site Facilities and Operations in the 300 and 400 Areas in 2004, Compared to Distant Communities and Accessible Soil Concentration Limits.

8.9.8 Radionuclide Concentrations in Soil Samples Collected on the Hanford Site for Environmental Restoration Contractor Projects, $2004 \ldots$

8.9.9 Number and Location of Soil Contamination Incidents Investigated Near Hanford Site Facilities and Operations, 2004.

8.9.10 Annual Number of Soil Contamination Incidents Investigated Near Hanford Site Facilities and Operations, 1994 through 2004

8.9.11 Sampling Information for Hanford Site-Wide and Offsite Soil Samples Collected and Analyzed, 2004

8.9.12 Concentrations of Selected Radionuclides in Hanford Site Soil Samples Collected Site-Wide and Offsite, 2004 Compared to Previous Years .....

8.10.1 Number and Locations of Vegetation Samples Collected Near Hanford Site Facilities and Operations in 2004

8.10.2 Concentrations of Selected Radionuclides in Vegetation Samples Collected on the Hanford Site in the 100-N Area, 2004

8.10.3 Average Radionuclide Concentrations Detected in Vegetation Samples Collected on the Hanford Site in the 100-N Area, 1999 through 2004.

8.10.4 Average Radionuclide Concentrations Detected in Vegetation Samples Collected Near Hanford Site Facilities and Operations in the 200 and 600 Areas, 1999 through 2004

8.10.5 Concentrations of Selected Radionuclides in Vegetation Samples Collected Near Hanford Site Facilities and Operations in the 200 and 600 Areas, 2004

8.10.6 Average Radionuclide Concentrations Detected in Vegetation Samples Collected Near Hanford Site Facilities and Operations in the 300 and 400 Areas, 1999 through 2004.

8.10.7 Concentrations of Selected Radionuclides in Vegetation Samples Collected Near Hanford Site Facilities and Operations in the 300 and 400 Areas, 2004

8.10.8 Number of Vegetation Contamination Incidents Investigated Near Hanford Site Facilities and Operations, 2004 .

8.10.9 Annual Number of Vegetation Contamination Incidents Investigated Near Hanford Site Facilities and Operations, 1994 through 2004

8.10.10 Hanford Site-Wide and Offsite Vegetation Samples Collected and Analyzed, 2004

8.10.11 Concentrations of Selected Radionuclides in Hanford Site-Wide and Offsite Vegetation Samples, 2004 Compared to Previous Years

8.11.1 Total Number of Bucks and Number of Bucks Showing Signs of Antler Abnormality Observed in Roadside Surveys from 1994 through 2004

8.11.2 Mussels and Freshwater Snails Observed in the Hanford Reach of the Columbia River in 2003 and 2004. 
8.11.3 Amphibian Species Observed in Pools Along the Shoreline of the Hanford Reach of the Columbia River in 2004

8.11.4 Capture Ratios for Small Mammals by Season and Community Type

8.11.5 Site-Wide and Offsite Fish, Wildlife, and Aquatic Sentinel Sampling Locations and Analyses, 2004.......

8.11.6 Trace Metals and Radionuclides in Asiatic Clams, Hanford Reach Samples Compared to Reference Area Samples Collected Upstream of the Vernita Bridge, 2004.

8.11.7 Comparison of Chromium Levels in Clam Tissue, Spring Water, and Riverbank Spring Sediment Samples Collected Along the Benton County Shoreline of the Hanford Reach.....

8.11.8 Number of Wildlife or Wildlife-Related Contamination Incidents Investigated Near Hanford Site Facilities and Operations, 2004

8.11.9 Annual Number of Wildlife or Wildlife-Related Contamination Incidents Investigated Near Hanford Site Facilities and Operations, 1994 through 2004.

8.12.1 Federal or Washington State Threatened and Endangered Species that Occur or Potentially Occur on the Hanford Site

8.12.2 Washington State Candidate and Sensitive Animal Species Occurring or Potentially Occurring on the Hanford Site

8.12.3 Washington State Plant Species of Concern on the Hanford Site.....

8.13.1 Thermoluminescent Dosimeter Results Near Hanford Site Operations in 2003 and 2004 and Comparative Offsite Location Results for 1999 through 2004

8.13.2 Status of Outdoor Contamination Areas at Hanford, 2004

8.13.3 Change in Status of Outdoor Contamination Areas at Hanford, 2004

8.13.4 Dose Rates Measured by Thermoluminescent Dosimeters at Site-Wide Locations on the Hanford Site, 2004 Compared to Previous 5 Years

8.13.5 Dose Rates Measured by Thermoluminescent Dosimeters at Perimeter and Offsite Locations Around the Hanford Site, 2004 Compared to Previous 5 Years.

8.13.6 Dose Rates Measured by Thermoluminescent Dosimeters Along the Shoreline of the Hanford Reach of the Columbia River, 2004 Compared to Previous 5 Years.....

8.13.7 Exposure Rates Measured by Pressurized Ionization Chambers at Four Locations Around the Hanford Site, 2004.

8.13.8 Quarterly Average Exposure Rates Measured by Thermoluminescent Dosimeters at Four Locations Around the Hanford Site, 2004.

8.14.1 Dose to the Hypothetical, Maximally Exposed Individual Residing at Sagemoor from 2004 Hanford Site Operations

8.14.2 Collective Dose to the Population from 2004 Hanford Site Operations

8.14.3 Comparison of 2004 Doses to the Public from Hanford Site Effluent and Emissions to Federal Standards and Natural Background Levels. 
8.14.5 Results of Using the RESRAD-BIOTA Computer Code to Estimate Radiological Doses to Biota On and Around the Hanford Site, 2004 ......

8.14.6 Estimated Risk from Various Activities and Exposure

8.14.7 Activities Comparable in Risk to the 0.014-mrem Dose Calculated for the Hanford Site's 2004 Maximally Exposed Individual.....

8.15.1 Major Cultural Resources Reviews Conducted by Pacific Northwest National Laboratory in 2004 ......

8.16.1 Monthly and Annual Climatological Data for 2004 from the Hanford Meteorology Station

8.18.1 Summary of Field Replicate Results for the Surface Environmental Surveillance Project at Hanford, $2004 \ldots$

8.18.2 Summary of Laboratory Performance on NSI Laboratory Proficiency Test Program Samples, 2004

8.18.3 Summary of Laboratory Performance on Hanford Site Surface Environmental Surveillance Project Samples by the DOE Quality Assessment Program, 2004

8.18.4 Summary of Laboratory Performance on Hanford Site Surface Environmental Surveillance Project Samples by the Environmental Resource Associates Proficiency Testing Program, 2004.

8.18.5 Summary of Hanford Site Surface Environmental Surveillance Project Blind Spiked Determinations, 2004.

8.18.6 Comparison of Co-Sampling Results for Samples Collected Near the Hanford Site, 2004.

8.18.7 Comparison of Pacific Northwest National Laboratory Thermoluminescent Dosimeter Results with

Known Exposure, 2004

8.18.8 Hanford Site Laboratories Used by Site Contractors and Types of Effluent Monitoring and Near-Facility Monitoring Samples Analyzed, 2004

8.18.9 The Hanford Site's Waste Sampling and Characterization Facility Performance on DOE Quality Assessment Program Samples and on DOE Mixed Analyte Performance Evaluation Program Samples, 2004 ......

8.18.10 The Hanford Site's 222-S Analytical Laboratory Performance on DOE Quality Assessment Program Samples, 2004

8.18.11 The Hanford Site's 222-S Analytical Laboratory Performance on EPA Laboratory Water Pollution Inorganic and Organic Studies, 2004.

A.1 Names and Symbols for Units of Measure.

A.2 Conversion Table

A.3 Names and Symbols for Units of Radioactivity

A.4 Conversions for Radioactivity Units

A.5 Conversions for Radiological Dose Units.

A.6 Names and Symbols for Units of Radiation Dose or Exposure 
A.8 Elemental and Chemical Constituent Nomenclature

C.1 Radionuclide Concentrations in Columbia River Water Samples Collected at Priest Rapids Dam, Washington, 2004 Compared to Previous 5 Years

C.2 Radionuclide Concentrations in Columbia River Water Samples Collected at Richland,

Washington, 2004 Compared to Previous 5 Years

C.3 Radionuclide Concentrations Measured in Columbia River Water Samples Collected Along Transects of the Hanford Reach, 2004

C.4 Radionuclide Concentrations Measured in Columbia River Water Samples Collected at Near-Shore Locations in the Hanford Reach, 2004

C.5 Concentrations of Dissolved Metals in Columbia River Transect and Near-Shore Water Samples Collected Near the Hanford Site, 2004

C.6 Selected U.S. Geological Survey Columbia River Water Quality Data for Vernita and Richland, Washington, 2004

C.7 Radionuclide Concentrations in Sediment from the Columbia River Near the Hanford Site and from Columbia River Riverbank Springs Along the Hanford Site, 2004 Compared to Previous 5 Years...........

C.8 Median Metal Concentrations in Sediment Samples Collected from the Columbia River Near the Hanford Site, 2004.

C.9 Radionuclide Concentrations Measured in Columbia River Water Samples Collected from Riverbank Springs Along the Hanford Site, 2004 Compared to Previous 5 Years.

C.10 Annual Average Dose Rates Measured at Site-Wide and Offsite Locations in $2004 \ldots$

C.11 Concentrations of Metals in Livers from Carp Collected from the Hanford Reach of the Columbia River in 2004 and at a Columbia River Reference Location Near Desert Aire, Washington, in 2002 ......

C.12 Concentrations of Metals in Livers from Quail Collected on the Hanford Site and at a Reference Location Near Grandview, Washington, in 2004

C.13 Concentrations of Metals in Livers from Deer Collected on the Hanford Site in 2004 and at Reference Locations Near Olympia, Washington, in 2004 and Boardman, Oregon, in 1994

C.14 Concentrations of Metals in Livers from Sculpin Collected from the Columbia River Near Hanford Site Reactor Areas in 2004 and Near the Vernita Bridge in 2003 and 2004

D.1 Washington State Water Quality Criteria for the Hanford Reach of the Columbia River.

D.4 Radiation Standards for Protection of the Public from all Routine DOE Concentrations 
E.1 Food Pathway Parameters Used in Hanford Site Dose Calculations, 2004 ….......................................... E.5

E.2 Dietary Parameters Used in Hanford Site Dose Calculations, 2004 ………............................................... E.6

E.3 Residency Parameters Used in Hanford Site Dose Calculations, 2004 ..................................................... E.6

E.4 Columbia River Recreational Parameters Used in Hanford Site Dose Calculations, 2004 ........................ E.6

E.5 Technical Details of Airborne Release Dose Calculations for the 100-K Area of the Hanford Site, 2004 ......

E.6 Technical Details of Liquid Release Dose Calculations for the 100-N Area of the Hanford Site, 2004

E.7 Technical Details of Airborne Release Dose Calculations for the 200 Areas of the Hanford Site, 2004 .......

E.8 Technical Details of Liquid Release Dose Calculations for the 200 Areas of the Hanford Site Calculated as Difference in Upstream and Downstream Concentrations, 2004

E.9 Technical Details of Airborne Release Dose Calculations for the 300 Area of the Hanford Site, 2004

E.10 Technical Details of Airborne Release Dose Calculations for the 400 Area of the Hanford Site, 2004.

E.11 Annual Dose to Workers in the 100-K Area on the Hanford Site from Ingestion of Drinking Water Obtained from the Columbia River and to Workers in the 400 Area from Ingestion of Drinking Water Obtained from Groundwater Wells, 2004 


\subsection{Introduction}

R. W. Hanf

This report, published annually since 1958, includes information and summary analytical data that (1) provide an overview of U.S. Department of Energy (DOE) activities at the Hanford Site during calendar year 2004; (2) demonstrate the site's compliance with applicable federal, state, and local environmental laws and regulations, executive orders, and DOE policies and directives; (3) characterize Hanford Site environmental management performance; and (4) highlight significant environmental, public, and worker protection programs.

Specifically, this report provides a short introduction to the Hanford Site, discusses the site mission, and briefly highlights the site's various environmental-related programs. Included are sections discussing site compliance with local, state, and federal environmental laws and regulations; site operations including environmental restoration efforts and cleanup and closure activities; environmental occurrences; effluent and emissions from site facilities; the results of onsite and offsite environmental and groundwater monitoring efforts; and cultural and biological resource assessments.

Readers interested in more detail than that provided in this report should consult the technical documents cited in the text and listed in Section 9.0. Descriptions of specific analytical and sampling methods used in the monitoring efforts are contained in the Environmental Monitoring Plan, United States Department of Energy Richland Operations Office (DOE/RL-91-50).

\subsubsection{Current Site Mission}

The missions of DOE at Hanford are to safely clean up and manage the site's legacy waste, and to develop and deploy technology. The Hanford Site's primary mission is accelerating the completion of waste cleanup. The report Performance Management Plan for the Accelerated Cleanup of the Hanford Site (DOE/RL-2002-47) states that the cleanup mission includes six strategies:

1. Restoring the Columbia River corridor by accelerating cleanup of Hanford Site sources of radiological and chemical contamination that threaten the air, groundwater, or Columbia River. It is expected that most river corridor projects will be completed by 2012.

2. Ending the tank waste program by 2033 by accelerating waste retrieval, increasing the capacity of the Waste Treatment Plant (currently under construction), and starting the process of closing the underground waste storage tanks.

3. Accelerating the cleanup of other Hanford facilities that are considered urgent risks.

4. Accelerating treatment and disposal of mixed low-level waste, and the retrieval of transuranic waste and its shipment off the site.

5. Accelerating cleanup of excess facilities on the Central Plateau.

6. Accelerating cleanup and protection of groundwater beneath the Hanford Site.

The goal of these strategies is to accelerate the completion of site cleanup, excluding underground waste storage tanks, from 2070 to 2035, and possibly as soon as 2025, and to do so in a cost-effective manner that protects public and worker health and safety and the environment.

\subsubsection{Overview of the Hanford Site}

The Hanford Site lies within the semi-arid Pasco Basin of the Columbia Plateau in southeastern Washington State (Figure 1.0.1). The site occupies an area of approximately 1,517 square kilometers (586 square miles) located north 


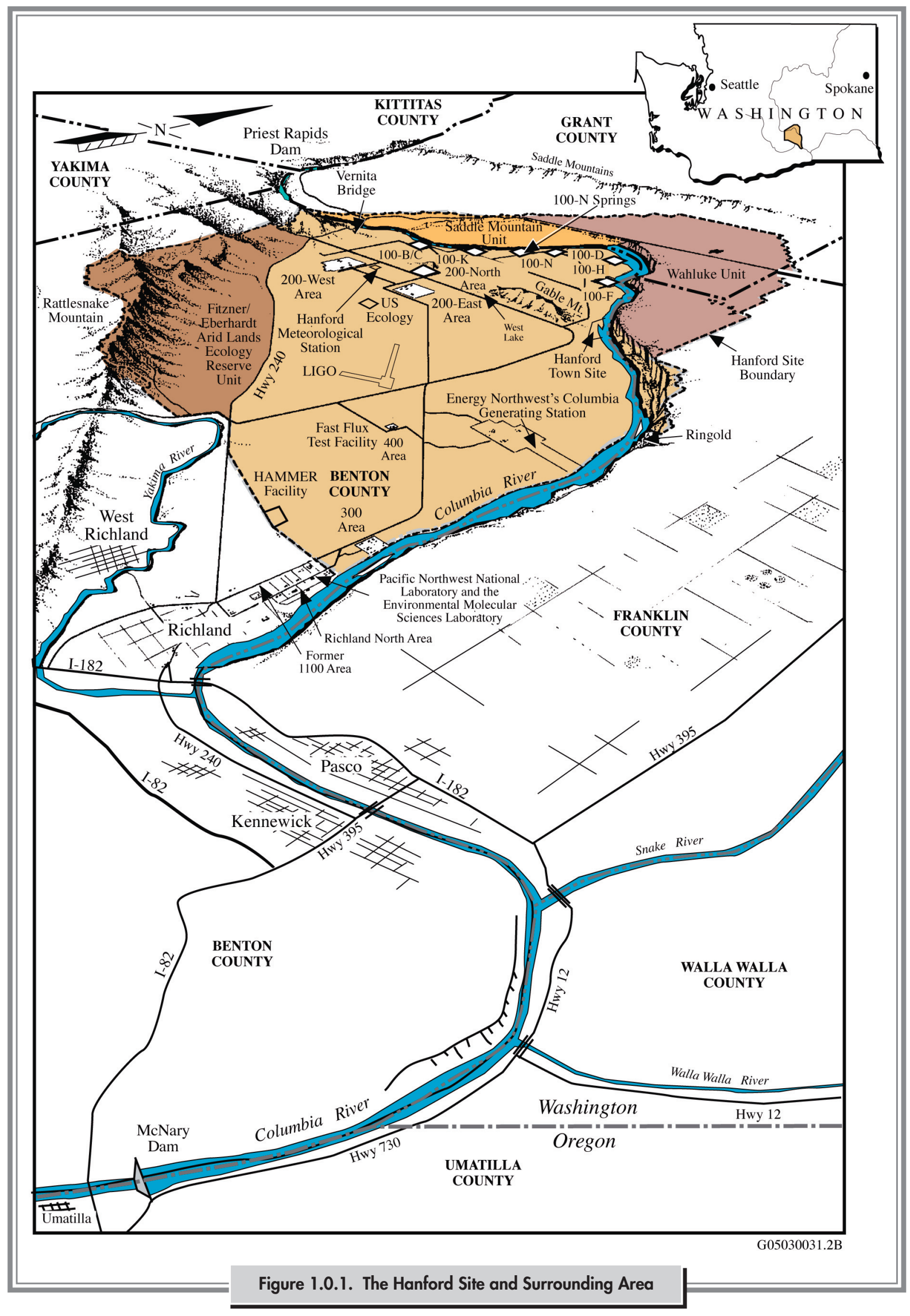


of the city of Richland (DOE/EIS-0222-F). This area has restricted public access and provides a buffer for areas on the site that were used for production of nuclear materials, waste storage, and waste disposal. The Columbia River flows eastward through the northern part of the site and then turns south, forming part of the eastern site boundary.

The major DOE operational, administrative, and research areas on and around the Hanford Site (Figure 1.0.1) include the following locations:

- 100 Areas - located along the south and west shores of the Columbia River. These are the sites of nine retired plutonium production reactors. The 100 Areas occupy a total of approximately 11 square kilometers (4 square miles).

- 200-West and 200-East Areas - centrally located on a plateau. These areas are approximately 8 and 11 kilometers ( 5 and 7 miles), respectively, south and west of the Columbia River. These areas contain underground waste storage tanks and house facilities that received and dissolved irradiated fuel and then separated out the plutonium. The facilities were called "separations plants." The 200-East and 200-West Areas cover a total of approximately 16 square kilometers (6 square miles).

- 300 Area-located just north of Richland, Washington. From the early 1940s until the advent of the cleanup mission, most research and development activities at the Hanford Site were carried out in the 300 Area. The 300 Area was also the location of nuclear fuel fabrication. This area covers approximately 1.5 square kilometers (0.6 square mile).

- 400 Area - located northwest of the 300 Area. The 400 Area is the location of the Fast Flux Test Facility, which was being deactivated and decommissioned during 2004. This nuclear reactor was designed to test various types of nuclear fuel. The 400 Area covers approximately 0.61 square kilometer $(0.23$ square mile).

- 600 Area - includes all of the Hanford Site not occupied by the 100, 200, 300, and 400 Areas. This area includes most of the Hanford Reach National Monument. The portion of the Hanford Reach National Monument administered by the DOE Richland Operations Office included the McGee Ranch/Riverlands Unit (north and west of State Highway 24 and south of the
Columbia River), and the Columbia River Corridor Unit, including the Hanford Reach islands in Benton County and a 0.4-kilometer- (0.25-mile-) wide strip of land along the Benton County side of the Hanford Reach shoreline from the Vernita Bridge to just north of the 300 Area. This unit also includes the Hanford dunes area north of Energy Northwest (Figure 1.0.2).

- Former 1100 Area - located between the 300 Area and the city of Richland covering an area of 311 hectares (768 acres). On October 1, 1998, this area was transferred to the Port of Benton as a part of DOE's Richland Operations Office economic diversification efforts and is no longer part of the Hanford Site. However, DOE contractors continue to lease facilities in this area.

- Richland North Area (off the site) - includes the Environmental Molecular Sciences Laboratory, the Pacific Northwest National Laboratory, and other DOE and contractor facilities, mostly office buildings, generally located in the northern part of the city of Richland.

- 700 Area (off the site) - an area of DOE administrative buildings in central Richland.

- Volpentest Hazardous Materials Management and Emergency Response Training and Education Center (also called HAMMER) - a worker safetytraining facility located on the site near the city of Richland. It consists of a 32-hectare (80-acre) main site and a 4,000-hectare (10,000-acre) law enforcement and security training site. The facility is owned by DOE, managed by Fluor Hanford, Inc., and is used by site contractors, federal and state agencies, tribal governments, and private industry.

Other site-related facilities (office buildings) are located within Richland, Pasco, and Kennewick (the Tri-Cities).

The 78,900-hectare (195,000-acre) Hanford Reach National Monument (Figure 1.0.2) was established on the Hanford Site by a Presidential Proclamation in June 2000 (65 FR 114) to protect the nation's only non-impounded stretch of the Columbia River upstream of Bonneville Dam in the United States, and a remnant of the shrubsteppe ecosystem that once blanketed the Columbia River Basin.

Non-DOE operations and activities on Hanford Site leased land include commercial power production by 


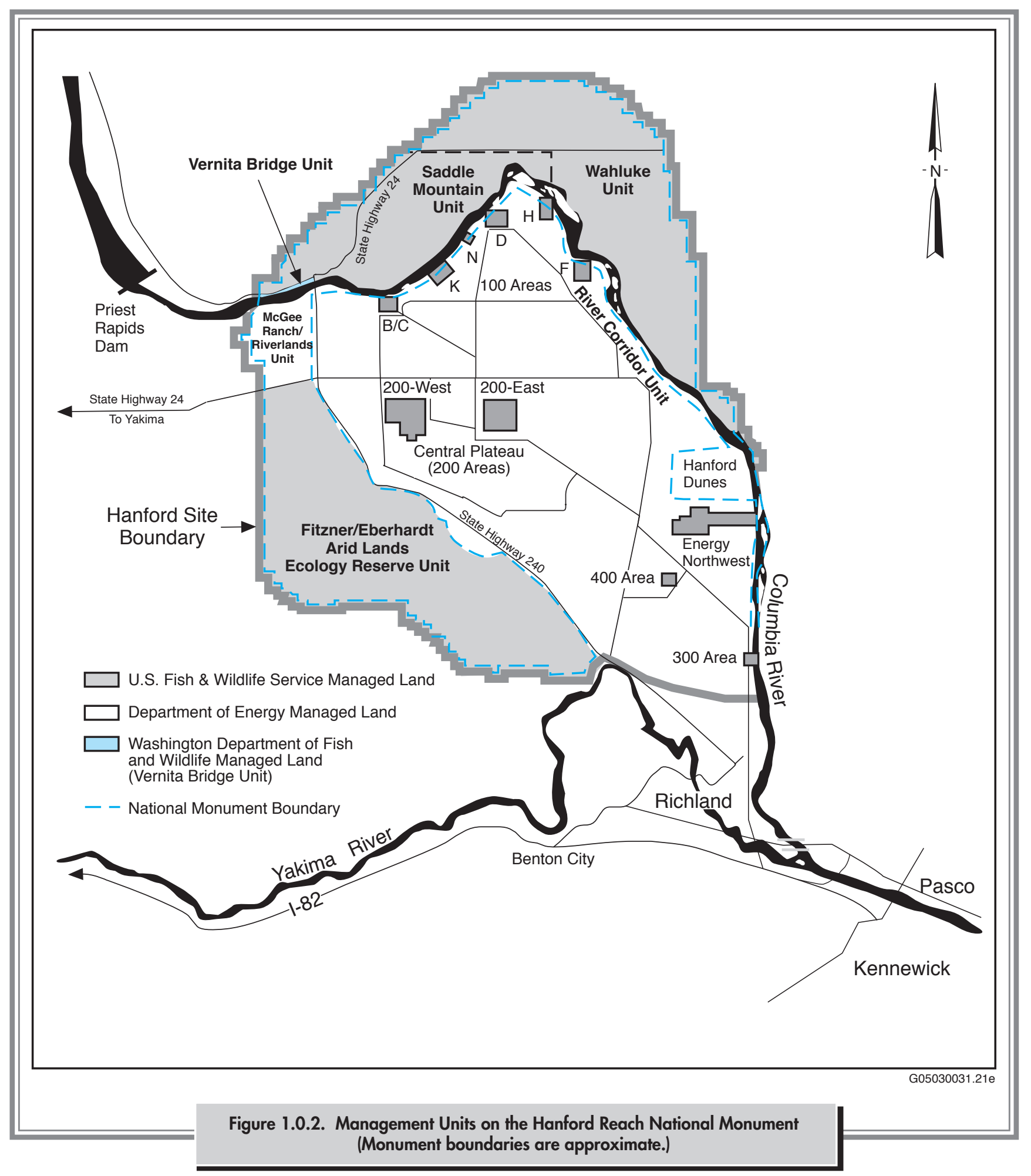


Energy Northwest at the Columbia Generating Station (4.4 square kilometers [1.6 square miles]) and operation of a commercial low-level radioactive waste burial site by US Ecology, Inc. (0.4 square kilometer [0.2 square mile]). The Laser Interferometer Gravitational Wave Observatory (LIGO) was constructed between 1994 and 1999 and is operated jointly by the California and Massachusetts Institutes of Technology and sponsored by the National Science Foundation.

Near the city of Richland, immediately adjacent to the southern boundary of the Hanford Site, AREVA operates a commercial nuclear fuel fabrication facility, and Pacific EcoSolutions operates a low-level radioactive waste decontamination, super compaction, and packaging facility.

\subsubsection{Site Management}

DOE's Richland Operations Office and Office of River Protection jointly manage the Hanford Site through several contractors and their subcontractors. Each contractor is responsible for safe, environmentally sound, maintenance and management of its activities or facilities; for waste management; and for monitoring any potential effluent to assure environmental regulatory compliance. DOE, the U.S. Fish and Wildlife Service, and the Washington Department of Fish and Wildlife each manage portions of the Hanford Reach National Monument.

The DOE Office of Science. The Pacific Northwest Site Office of the DOE Office of Science oversees Pacific Northwest National Laboratory to support DOE's Science and Technology programs, goals, and objectives. Pacific Northwest National Laboratory is a DOE facility operated by Battelle Memorial Institute for DOE's national security and energy missions. The core mission is to deliver environmental science and technology in the service of the nation and humanity.

The DOE Richland Operations Office. The DOE Richland Operations Office serves as landlord of the Hanford Site and manages legacy cleanup, research, and other programs. During 2004, the principal contractors for the DOE Richland Operations Office, and their respective responsibilities, included the following:

- Bechtel Hanford, Inc. was the environmental restoration contractor for the Hanford Site during 2004.
Bechtel Hanford, Inc., a subsidiary of Bechtel National, Inc., planned, managed, and executed activities for the cleanup of contaminated soil and inactive nuclear facilities, with a major focus of protecting the Columbia River. Bechtel Hanford, Inc.'s subcontractors in 2004 were CH2M HILL Hanford, Inc. and Eberline Services Hanford, Inc. Washington Closure Company, LLC, was awarded the River Corridor Closure Contract in April 2003. This team of companies consisting of Washington Group International, Inc.; Fluor Federal Services; and Earth Tech, LLC, would have replaced Bechtel Hanford, Inc. and the personnel from Fluor Hanford, Inc. doing 300 Area decontamination and decommissioning work. A protest over the contract award was filed by Bechtel National, Inc. in May 2003, and this halted the transition of work to the Washington Closure Company. The protest was successful and in March 2005, Washington Closure (a limited liability corporation owned by Washington Group International [the lead contractor]; Bechtel National, Inc.; and CH2M HILL Hanford Group, Inc.) was chosen as the new River Corridor Closure contractor. Principal subcontractors will be Eberline Services and Integrated Logistics Services. This contractor selection was immediately protested by Fluor Hanford, Inc., but the protest was withdrawn in late May 2005. Work on the 7-year, \$1.9-billion contract began in early June 2005.

- Fluor Hanford, Inc. is the primary management contractor for Project Hanford. It manages and integrates work to support cleanup of former DOE nuclear production facilities at the site. In 2004, Fluor Hanford, Inc.'s principal subcontractors were Framatome ANP DE\&S, Inc.; Duratek Federal Services of Hanford, Inc.; Numatec Hanford Corporation; and Westinghouse Safety Management Solutions. Other subcontractors to Fluor Hanford, Inc. included Day \& Zimmerman Protection Technology Hanford, Lockheed Martin Information Technology, and Fluor Government Group.

- AdvanceMed Hanford was the occupational health contractor on the site in 2004. The company provided occupational medicine and nursing; medical surveillance and evaluations; ergonomics assessment; exercise physiology; case management; psychology counseling and evaluations; fitness-for-duty evaluations; 
health education; infection control; immediate health care; industrial hygiene; and health, safety, and risk assessment.

The DOE Office of River Protection. The DOE Office of River Protection was established by Congress in 1998 as a field office to manage Hanford tank-waste retrieval, treatment, and disposal. The principal contractors for the DOE Office of River Protection in 2004 and their respective responsibilities included the following:

- Bechtel National, Inc. - Bechtel National, Inc.'s contract mission is to design and build facilities (the Waste Treatment Plant) on a 26.3-hectare (65-acre) site on the Central Plateau of Hanford to convert liquid radioactive waste into a stable glass form (vitrification). The 10-year contract for this work was awarded in December 2000.

- Washington Group International - A subcontractor to Bechtel National, Inc., Washington Group International is a participant in the mission to design and construct the Waste Treatment Plant.

- CH2M HILl Hanford Group, Inc. - This contractor has the responsibility to retrieve and store for treatment about 201 million liters (53 million gallons) of radioactive and chemically hazardous waste stored in 177 underground tanks at Hanford. The company's role also includes storing the treated waste until permanent disposal facilities are available. The contract for CH2M HILL Hanford Group, Inc. runs through fiscal year 2006.
U.S. Fish and Wildlife Service. During 2004, the U.S. Fish and Wildlife Service administered three major management units of the Hanford Reach National Monument totaling about 668 square kilometers (258 square miles). These included (1) the Fitzner/Eberhardt Arid Lands Ecology Reserve Unit, a 312-square-kilometer (120-squaremile) tract of land with no public access in the southwestern portion of the Hanford Site; (2) the Saddle Mountain Unit, a 130-square-kilometer (50-square-mile) tract of land with no public access located north-northwest of the Columbia River and generally south and east of State Highway 24; and (3) the Wahluke Unit, a 225-squarekilometer (87-square-mile) tract of land located north and east of both the Columbia River and the Saddle Mountain Unit (Figure 1.0.2). All of these lands have served as a safety and security buffer zone for Hanford Site operations since 1943, resulting in an ecosystem that has been relatively untouched for nearly 60 years.

Washington Department of Fish and Wildlife - The Washington Department of Fish and Wildlife managed the Vernita Bridge Unit of the Hanford Reach National Monument, approximately 162 hectares (400 acres) along the north side of the Columbia River, west of the Vernita Bridge, and south of State Highway 243.

Additional information about Hanford Site management and contractors can be found on the Internet at http://www. hanford.gov/?page $=78 \&$ parent $=15$. 


\subsection{Public}

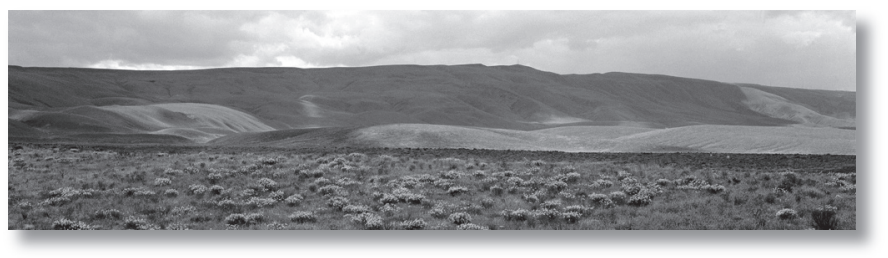

Involvement at Hanford

J. P. Duncan

A number of federal, state, and local governmental agencies; tribal governments; advisory boards; activist groups; and individuals exercise various roles with respect to the U.S. Department of Energy's (DOE's) mission of waste cleanup and management, development and deployment of new technologies, and protection of public health and safety at the Hanford Site. For example, federal and state agencies exercise a regulatory role over contaminant releases and concentrations of contaminants in various media, and several tribes assure, through a governmentto-government relationship with DOE, that treaty rights and other values important to Native Americans are taken into account. The roles of the regulatory agencies, organizations, and the public are addressed in the following sections.

\subsubsection{The Role of Indian Tribes}

\section{K. V. Clarke}

The Hanford Site is located on land ceded to the United States government by the Yakama Nation and the Confederated Tribes of the Umatilla Indian Reservation in the Treaties of 1855. These tribes, as well as the $\mathrm{Nez}$ Perce Tribe, have treaty fishing rights on portions of the Columbia River. These tribes reserved the right to fish at all usual and accustomed places and the privilege to hunt, gather roots and berries, and pasture horses and cattle on open and unclaimed land. The Wanapum are not a federally recognized tribe; however, they have historic ties to the Hanford Site as do the Confederated Tribes of the Colville Reservation, whose members are descendants of people who used the area known as the Hanford Site.

The Hanford Site environment supports a number of Native American foods and medicines and contains sacred places important to tribal cultures. The tribes hope to safely use these resources in the future and want to assure themselves that the Hanford environment is clean and healthy.

American Indian tribal governments have a special and unique legal and political relationship with the government of the United States defined by history, treaties, statutes, court decisions, and the U.S. Constitution. In recognition of this relationship, DOE and each tribe interact and consult directly. Tribal government representatives from the Yakama Nation, Confederated Tribes of the Umatilla Indian Reservation, and Nez Perce Tribe participate in DOE-supported groups such as the State and Tribal Government Working Group, the Hanford Natural Resources Trustee Council, the Hanford Cultural Resources Program, and provide review and comments on draft documents. Both the Wanapum and the Confederated Tribes of the Colville Reservation also are provided an opportunity to comment on documents and participate in cultural resource management activities.

The DOE American Indian and Alaska Native Tribal Government Policy (DOE 2000, revised in November 2000) guides DOE's interaction with tribes for Hanford plans and activities. The policy states, among other things, "The Department will consult with any American Indian or Alaska Native tribal government with regard to any property to which that tribe attaches religious or cultural importance which might be affected by a DOE action." In addition to the DOE American Indian and Alaska Native Tribal Government Policy, laws such as the American Indian Religious Freedom Act, the Archaeological Resources Protection Act, the National Historic Preservation Act, and the Native American Graves Protection and Repatriation Act require consultation with tribal governments. The combination of the Treaties of 1855 , federal policy, executive orders, laws, regulations, and the federal trust responsibility 
provide the basis for tribal participation in Hanford Site plans and activities. DOE provides financial assistance through cooperative agreements with the Yakama Nation, Confederated Tribes of the Umatilla Indian Reservation, and $\mathrm{Nez}$ Perce Tribe to support their involvement in environmental management activities of the Hanford Site.

\subsubsection{Consultations and Meetings with Tribes, Interested Parties, and the State Historic Preservation Office}

\section{W. Harvey}

DOE conducts formal consultations with the Washington State Historic Preservation Office, tribes, and interested parties for cultural resource reviews in order to comply with National Historic Preservation Act Section 106 and the National Environmental Policy Act. In 2004, DOE consulted with the Washington State Historic Preservation Office on four cultural reviews, and with tribes on four cultural reviews. Two consultations occurred with interested parties.

The Hanford Cultural and Historic Resources Program also holds meetings with tribal cultural resource representatives to discuss cultural resource reviews and issues that concern the protection of cultural resources on the Hanford Site; six meetings were held in 2004. A main issue discussed focused on the development of a programmatic agreement for DOE's planned transfer of the Hanford Reach National Monument to the U.S. Fish and Wildlife Service.

There were no public meetings with interested parties in 2004.

\subsubsection{Hanford Natural Resource Trustee Council}

\section{C. Ward}

The President of the United States, by Executive Order 12580, Superfund Implementation (52 FR 2923), has appointed the heads of some federal departments to act on behalf of the public as trustees for natural resources when natural resources may be injured, destroyed, lost, or threatened as a result of a release of hazardous substances. For example, the President appointed the Secretary of Energy as the primary trustee for all natural resources located on, over, or under land administered by DOE, including the Hanford Site. Other designated federal trustees for Hanford natural resources include the U.S. Department of the Interior represented by the U.S. Fish and Wildlife Service and the Bureau of Land Management and the U.S. Department of Commerce represented by the National Oceanic and Atmospheric Administration. The Comprehensive Environmental Response, Compensation, and Liability Act (CERCLA) authorizes state governors to designate a state trustee to coordinate all state trustee responsibilities. CERCLA further states that chairmen (or heads of governing bodies) of Indian tribes have essentially the same trusteeship over natural resources belonging to or held in trust for the tribe as state trustees. In that regard, Indian tribes and state organizations have been designated as natural resource trustees for certain natural resources at or near the Hanford Site by the National Oil and Hazardous Substances Pollution Contingency Plan (55 FR 8666) and Executive Order 12580 (52 FR 2923). Indian tribes include the Yakama Nation, the Confederated Tribes of the Umatilla Indian Reservation, and the Nez Perce Tribe. State organizations include the Washington State Department of Ecology, Washington Department of Fish and Wildlife, and Oregon Department of Energy.

DOE cooperates and coordinates with trustees' assessments, investigations, and planning and with devising and implementing restoration plans. The Hanford trustees signed a Memorandum of Agreement in 1996 establishing the Hanford Natural Resource Trustee Council. The primary purpose of the council is to facilitate the coordination and cooperation of the trustees in their efforts to mitigate the effects to natural resources that result from either hazardous substance releases on the Hanford Site or remediation of those releases. The council has adopted bylaws to direct the process of arriving at consensus agreements. During 2004, the trustees met as a formal council four times to discuss cleanup issues concerning the Central Plateau and Columbia River corridor. Information about the council, including its history and projects, can be found at http://www.hanford.gov/public/boards/nrtc. 
The council worked on the development of a three-point agreement during the latter part of 2004. The agreement was initially developed as a high-level agreement among the trustees. It has been undergoing modification since its inception and has not received full approval by the council. The three points of the agreement are:

- focus on ecological risk assessments

- focus on incorporating potential injury assessment data into the ecological risk assessments in order to support remedial action decisions or as the collection of injury assessment data makes sense

- focus on injury assessment data that exclusively support natural resource damage assessments, at a later date.

\subsubsection{Public Participation in Hanford Site Decisions}

\section{S. E. Chalk}

Individuals may influence Hanford Site cleanup decisions through public participation activities. The public is provided opportunities to contribute their input and influence decisions through many forums including, but not limited to, Hanford Advisory Board meetings, Hanford Federal Facility Agreement and Consent Order (also known as the Tri-Party Agreement, Ecology et al. 1989) activities, National Environmental Policy Act public meetings on various environmental impact statements, and other involvement activities. DOE's Office of River Protection has an Office of Communications and DOE's Richland Operations Office has an Office of Organizational Effectiveness and Communication; these two offices coordinate the planning and scheduling of public participation activities for the Hanford Site.

During 2004, the Tri-Party Agreement agencies met with a broad representation of public interests to discuss the vision for Hanford Site surface water, soil, and groundwater following completion of cleanup - Hanford's "end state" vision. Three workshops focused on the 100, 200, and 300 Areas. Information on these workshops can be found at http://www.hanford.gov/docs/rbes (select TPA End State Vision, Public Workshop Outcomes).

The Hanford Site Tri-Party Agreement Public Involvement Community Relations Plan (Tri-Party Agreement Agencies
2002) outlines how public information and involvement activities are conducted for Tri-Party Agreement decisions (Section 3.0.1). The Washington State Department of Ecology, DOE, and U.S. Environmental Protection Agency (EPA) developed and revised the plan with input from the public. The plan was approved in 1990 and is updated on an as-needed basis; the most recent revision occurred during January 2002. The plan can be found on the Internet at http://www.hanford.gov/crp/toc.htm.

A mailing list of about 3,300 individuals who have indicated an interest in participating in Hanford Site decisions is maintained. The mailing list also is used to send topicspecific information to those people who have requested it. Information is provided on upcoming decisions to elected officials, community leaders, special interest groups, and the news media.

To inform the public of upcoming opportunities for public participation, a newsletter titled The Hanford Update, a synopsis of all ongoing and upcoming Tri-Party Agreement public involvement activities, is published approximately bimonthly and distributed to the entire mailing list. To allow Hanford stakeholders and others to access up-to-date information, documents from the Tri-Party Agreement's Administrative Record and Public Information Repository are available at http://www2.hanford.gov/arpir.

The public can obtain information about cleanup activities from the Washington State Department of Ecology's Hanford Cleanup Line at (800) 321-2008. The public can request information about public participation activities and receive a response by contacting the Office of Organizational Effectiveness and Communications (DOE Richland Operations Office) at (509) 376-7501. Also, a calendar of public involvement opportunities can be found at http://www.hanford.gov/public/calendar/.

\subsubsection{Hanford Advisory Board}

\section{S. E. Chalk}

The Hanford Advisory Board was chartered during January 1994 under the Federal Advisory Committee Act to advise DOE, EPA, and Washington State Department of Ecology on major Hanford Site cleanup policy issues. 
The Hanford Advisory Board was the first of many such advisory groups created by DOE at sites across the nation involved in weapons production cleanup. The board consists of 31 members who represent environmentalists, local governments, public health organizations, businesses, tribal governments, and the public. Each board member has at least one alternate. Todd Martin, a member of Citizens for a Clean Eastern Washington, is the current chairman.

The board held five 2-day meetings during 2004. Members were engaged in discussions with representatives from the
Tri-Party Agreement agencies on major cleanup issues; plans to treat tank waste and the role of supplemental technologies; storage, treatment, and/or disposal of waste; and budget priorities. The board issued 14 pieces of consensus advice, engaged in a series of meetings, participated in several workshops, and engaged in informational exchanges with each other and representatives from the Tri-Party Agreement agencies. Information about the Hanford Advisory Board, including copies of its advice and responses can be found at http://www.hanford.gov/ public/boards/hab/. 


\subsection{Regulatory Oversight at Hanford}

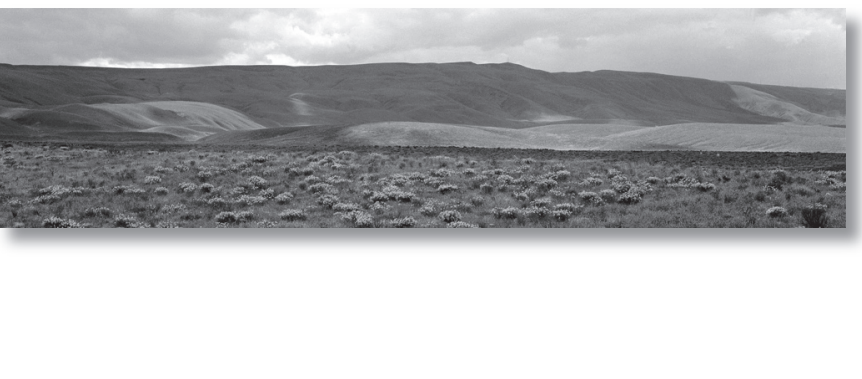

K. A. Peterson

Several federal, state, and local regulatory agencies are responsible for monitoring and enforcing compliance with applicable environmental regulations at the Hanford Site. The agencies include the U.S. Environmental Protection Agency (EPA), Washington State Department of Ecology, Washington State Department of Health, and Benton Clean Air Authority. EPA is the primary federal regulatory agency that develops, promulgates, and enforces environmental regulations and standards as directed in statutes enacted by Congress. In some instances, EPA has delegated authority to the state or authorized the state program to operate in lieu of the federal program when the state's program meets or exceeds the EPA's requirements. In other activities, the state program is assigned direct environmental oversight of the U.S. Department of Energy (DOE), as provided by federal law. Where federal regulatory authority is not delegated or only partially authorized to the state, the EPA Region 10 office is responsible for reviewing and enforcing compliance with EPA regulations as they pertain to the Hanford Site. EPA periodically reviews state environmental programs and may directly enforce federal environmental regulations. Although Oregon does not have regulatory authority at the Hanford Site, DOE recognizes its interest in Hanford Site cleanup because of the site's location along the Columbia River, upriver from where the river serves as a border between Washington and Oregon. Oregon has seats on the Hanford Advisory Board and participates in the State and Tribal Government Working Group for the Hanford Site, which reviews the site's cleanup plans, and participates in the Hanford Natural Resource Trustee Council.

\subsubsection{Hanford Federal Facility Agreement and Consent Order (Tri-Party Agreement)}

\section{R. D. Morrison}

The Hanford Federal Facility Agreement and Consent Order (also known as the Tri-Party Agreement; Ecology et al. 1989) is an agreement among the Washington State Department of Ecology, EPA, and DOE to achieve environmental compliance at the Hanford Site with the Comprehensive Environmental Response, Compensation, and Liability Act (CERCLA), including the Superfund Amendments and Reauthorization Act remedial action provisions, and with the Resource Conservation and Recovery Act (RCRA) treatment, storage, and disposal unit regulations and corrective action provisions. The Tri-Party Agreement (1) defines RCRA and CERCLA cleanup commitments, (2) establishes responsibilities, (3) provides a basis for budgeting, and (4) reflects a concerted goal to achieve regulatory compliance and remediation with enforceable milestones. A companion document to the Tri-Party Agreement is the Hanford Site Tri-Party Agreement Public Involvement Community Relations Plan (Tri-Party Agreement Agencies 2002). This plan describes how public information and involvement activities are conducted for Tri-Party Agreement decisions.

The Tri-Party Agreement has evolved as cleanup of the Hanford Site has progressed. Significant changes to the agreement have been negotiated to meet the changing conditions and needs of cleanup. All significant changes undergo a process of public involvement that enhances communication and addresses the public's concerns prior 
to final approvals. Copies of the agreement are publicly available at DOE's Public Reading Room located in the Consolidated Information Center in Richland, Washington, and at information repositories in Seattle and Spokane, Washington, and Portland, Oregon. The Tri-Party Agreement can be viewed on the Internet at http://www. hanford.gov/tpa/tpahome.htm. To be placed on the mailing list to obtain Tri-Party Agreement information, contact EPA or DOE directly, or call the Washington State Department of Ecology at (800) 321-2008. Requests can be sent to:

Hanford Mailing List

P.O. Box 1000

$\mathrm{M} / \mathrm{S} \mathrm{B} 3-30$

Richland, WA 99352

\subsubsection{Status of Tri-Party Agreement Milestones}

\section{R. D. Morrison}

The Tri-Party Agreement (Ecology et al. 1989) commits DOE to achieve compliance with the remedial action provisions of CERCLA and with the treatment, storage, and disposal unit regulations and corrective action provisions of RCRA, including the state's implementing regulations. From 1989 through 2004, a total of 876 milestones were completed and 289 target dates were met. During 2004, there were 49 specific cleanup milestones scheduled for completion; 48 were completed on or before their required due dates and one was completed beyond its established due date.

\subsubsection{Approved Modifications to the Tri-Party Agreement}

\author{
R. D. Morrison
}

During 2004, 29 negotiated change requests to the Tri-Party Agreement were approved. These approved change requests may be viewed in their entirety in the Tri-Party Agreement Administrative Record at http:// www2.hanford.gov/arpir/.

\subsubsection{Washington State Department of Health}

\section{J. A. Bates}

The Washington State Department of Health's Office of Radiation Protection has regulatory oversight of all sources of ionizing radiation in the state. The oversight includes a permit program requiring state review and approval for construction of all planned new or modified sources of airborne emissions, issuance and enforcement of emissions licenses, and inspection of sources which may emit airborne radioactive material. The state enforces an as low as reasonably achievable approach to minimize airborne emissions for protection of public health. Section 5.3.2 provides information about Washington State Department of Health inspections and enforcement activities on the Hanford Site in 2004. 


\subsection{Environmental Program Information}

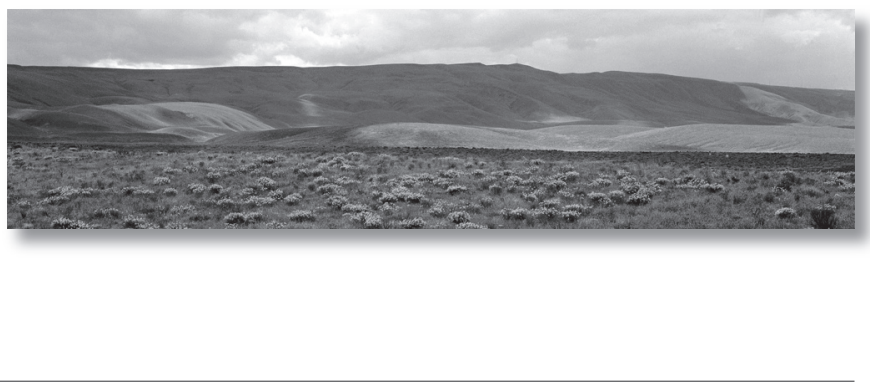

This section provides information on the environmental and chemical management systems on the Hanford Site.

\subsubsection{Environmental Management Systems}

\author{
H. T. Tilden II, G. D. Cummins, J. D. Doughty, \\ and D. M. Yasek
}

Contractors at the Hanford Site have established integrated environment, safety, and health management systems as mandated by their contracts with the U.S. Department of Energy (DOE). These systems are intended to protect workers, the public, and the environment by integrating environment, safety, and health considerations into the way work is planned, performed, and improved. The international voluntary consensus standard ISO 14001, Environmental Management Systems Specifications with Guidance for Use, and DOE Order 450.1, Environmental Protection Program, were considered during the development of these systems. Basic elements of these management systems include environmental policy, planning, implementation, checking and corrective action, and management review.

Prior to 2004, DOE verified the following Hanford contractors, and the Pacific Northwest National Laboratory, as having adequately implemented an integrated environmental, safety, and health system in accordance with DOE P 450.4, Safety Management System Policy: Bechtel Hanford, Inc. (May 2000), CH2M HILL Hanford Group,
Inc. (May 2000), Fluor Hanford, Inc. (August 2000), and the Pacific Northwest National Laboratory (1998). The Pacific Northwest National Laboratory obtained ISO 14001 third-party registration of its Environmental Management System in 2002. Bechtel Hanford, Inc. maintains an Environmental Management System that is integrated with the company's Integrated Environment, Safety, and Health Management System. Fluor Hanford, Inc. and CH2M HILL Hanford Group, Inc. are prepared to achieve the implementation date of December 31, 2005, as outlined in DOE Order 450.1. Efforts continued in 2004 to implement and improve these environmental, safety, and health programs.

\subsubsection{Chemical Management Systems}

\section{T. Jansky}

Hanford Site contractors developed and documented formal systems for the management of chemicals during 1997 that are still in use today. These management systems are applicable to the acquisition, use, storage, transportation, and final disposition of chemicals including hazardous chemicals as defined in the Occupational Safety and Health Administration's Hazard Communication Standard (29 CFR 1910, Subpart Z, Appendices A and B). The chemical management systems have been reviewed periodically and improved as needed. Details on the chemical inventories stored at the Hanford Site may be found in Section 5.1.1. 


\subsection{Compliance Summary}

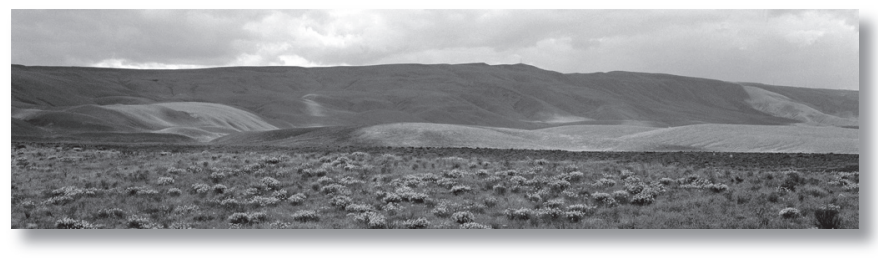

J. P. Duncan

It is the policy of the U.S. Department of Energy (DOE) that all DOE activities at Hanford are carried out in compliance with applicable federal, state, and local environmental laws and regulations, DOE Orders, Secretary of Energy Notices, DOE Headquarters and site operations office directives, policies, and guidance. This includes those specific requirements, actions, plans, and schedules identified in the Hanford Federal Facility Agreement and Consent Order (also known as the Tri-Party Agreement, Ecology et al. 1989) and other compliance or consent agreements.
This section summarizes the status of Hanford Site activities with regard to federal environmental protection statutes and associated state and local environmental regulations. Permits required under specific environmental protection regulations are also discussed.

Both the DOE Richland Operations Office and the DOE Office of River Protection recognize the importance of maintaining a proactive program of self-assessment and regulatory reporting to assure that environmental compliance is achieved and maintained at the Hanford Site. 


\subsection{Hazardous Materials}

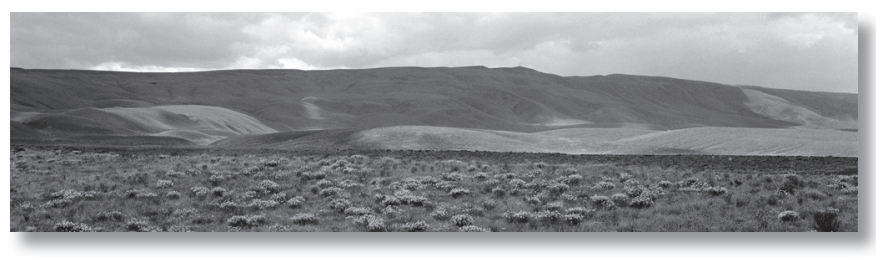

This section provides information about federal statutes related to the regulation of hazardous materials.

\subsubsection{Emergency Planning and Community Right-To- Know Act}

\section{E. Zaloudek}

The Emergency Planning and Community Right-to-Know Act requires states to establish a state emergency response commission and local emergency planning committees and to develop a process to distribute information on hazardous chemicals present in facilities. These organizations gather information and develop emergency plans for local planning districts. Facilities that produce, use, or store extremely hazardous substances in quantities above threshold planning quantities must identify themselves to the state emergency response commission and local emergency planning committee and periodically provide information to support the emergency planning process. Facilities must also notify the state emergency response commission and local emergency planning committee immediately after an accidental release of an extremely hazardous substance (40 CFR 355, Appendices A and B) over the reportable quantity. Two annual reports are required by the Emergency Planning and Community RightTo-Know Act. The Tier Two Emergency and Hazardous Chemical Inventory contains information about hazardous chemicals stored at the facility in amounts exceeding minimum threshold levels. The Toxic Chemical Release Inventory contains information about total annual releases of certain toxic chemicals and associated waste management activities.

In early 2005, the Hanford Site issued the 2004 Hanford Site Tier Two Emergency and Hazardous Chemical Inventory
(DOE/RL-2005-11) to the Washington State Department of Ecology's Community Right-To-Know Unit; local emergency planning committees for Benton, Franklin, and Grant Counties; and to both the Richland and Hanford Site fire departments. The 2004 Hanford Site Toxic Chemical Release Inventory report (DOE/RL-2005-12), which included releases and waste management activities involving the metal lead and the chemical propylene, was provided to the U.S. Environmental Protection Agency (EPA) and the Washington State Department of Ecology. Table 5.1.1 provides an overview of 2004 reporting under the Emergency Planning and Community Right-To-Know Act.

Types, quantities, and locations of hazardous chemicals are tracked through prime-contractor-specific chemical management system requirements (Section 4.0.2). Table 5.1.2 summarizes the information reported, listing the average quantity of ten hazardous chemicals stored in greatest quantity on the Hanford Site in 2004.

\subsubsection{Resource Conservation and Recovery Act}

\section{J. Hartman}

The Resource Conservation and Recovery Act (RCRA) was enacted during 1976 with the objective of protecting human health and the environment. During 1984, the Hazardous and Solid Waste Amendments re-authorized RCRA and imposed new requirements on the management of hazardous waste. The most important aspect of RCRA is its establishment of cradle-to-grave management to track hazardous waste from generator to treatment, storage, and disposal. The Washington State Department of Ecology has the authority to enforce RCRA requirements in the state under Washington 
Table 5.1.1. Emergency Planning and Community Right-to-Know Act Compliance Reporting at the Hanford Site, 2004

\section{Sections of the Act}

302-303: Planning notification

304: Extremely hazardous substances release notification

311-312: Material safety data sheet/chemical inventory

313: Toxic chemical release inventory reporting

$\begin{array}{lll}{\underline{\text { Yes }^{(a)}}}_{X^{(b)}}^{\text {No }^{(a)}} & \underline{\text { Not Required }}^{(a)} \\ X & X \\ X & \end{array}$

(a) "Yes" indicates that notifications were provided and/or reports were issued under the applicable provisions. "No" indicates that notifications or reports should have been provided but were not. "Not Required" indicates that no actions were required under the applicable provisions, either because releases were too small to require action or no releases occurred.

(b) These notifications apply to the Hanford Site but were completed prior to 2004.

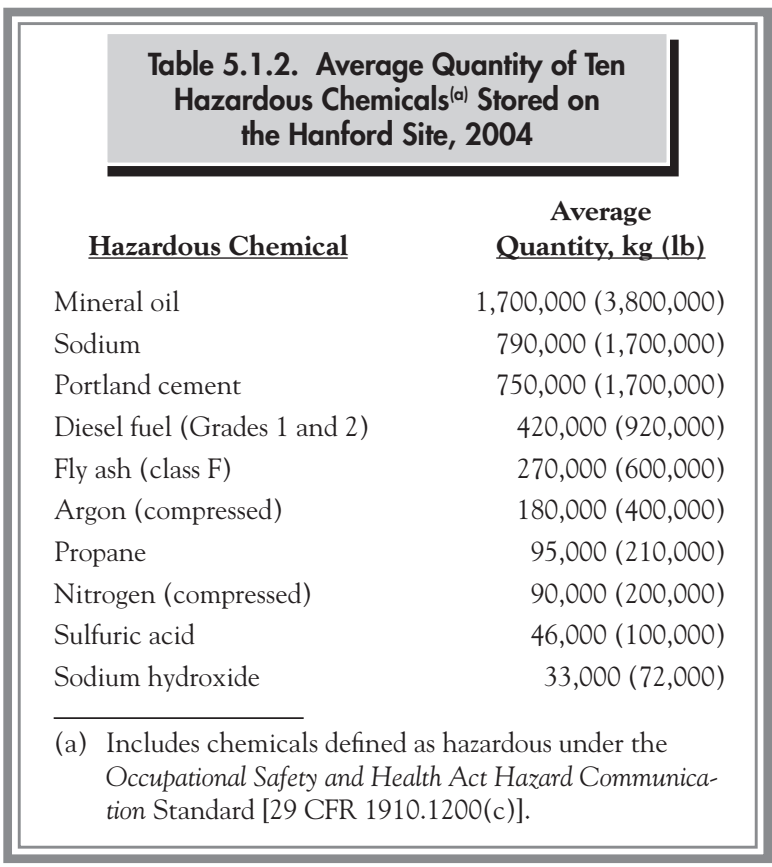

Administrative Code (WAC) 173-303, Dangerous Waste Regulations. At Hanford, RCRA applies to approximately 70 hazardous waste treatment, storage, or disposal units that have received waste since implementation of the act.

\subsubsection{Hanford Facility RCRA Permit}

\section{S. A. Thompson}

The Washington State Department of Ecology issued the Hanford Facility RCRA Permit on September 27, 1994 (Ecology 1994). The permit is the foundation for RCRA permitting on the Hanford Site in accordance with provisions set forth in the Tri-Party Agreement (Ecology et al. 1989). The permit is issued to seven permittees: the DOE Richland Operations Office and the DOE Office of River Protection as the owners/operators and to five of their contractors as co-operators. The Hanford Facility RCRA Permit expired on September 27, 2004, and on September 1, 2004, DOE submitted, in accordance with WAC 173-303-806(6), Final Facility Permits, re-applications and relevant documentation for renewal of the permit. The Washington State Department of Ecology determined the documentation was sufficiently complete according to WAC 173-303-840(1)(b), Procedures for Decision Making, for them to begin preparing a draft permit. DOE continues to operate under the old permit, until a new permit is in effect.

\subsubsection{RCRA/Dangerous Waste Permit Applications and Closure Plans}

\section{S. A. Thompson}

The Hanford Site is considered a single facility for purposes of RCRA and WAC 173-303. The facility encompasses approximately 70 treatment, storage, and disposal units. The Tri-Party Agreement recognized that not all of the units could be issued dangerous waste permits simultaneously, and a schedule was established to submit unit-specific permit applications and closure plans to the Washington State Department of Ecology. 
During 2004, ten revisions to the Part A RCRA Permit were submitted to the Washington State Department of Ecology for review and approval. These revisions to the Part A forms included modifications to information for the 183-H evaporation basins, 300 Area process trenches, 325 hazardous waste treatment units, 1301-N liquid waste disposal facility, 1324-N surface impoundment, 1324-NA percolation pond, $1325-\mathrm{N}$ liquid waste disposal facility, $1706-\mathrm{KE}$ waste treatment system, hexone storage and treatment facility, and T Plant complex.

In 2004, two Part B permit applications were submitted to the Washington State Department of Ecology. The submittals included the Hanford Facility Dangerous Waste Permit Application, General Information Portion (DOE/RL91-28), and Hanford Facility Dangerous Waste Permit Application, Integrated Disposal Facility (DOE/RL-2003-12).

\subsubsection{RCRA Groundwater Monitoring}

\section{J. Hartman}

RCRA groundwater monitoring is part of the Hanford Site Groundwater Performance Assessment Project (Section 8.7).

In 2004, DOE, the Washington State Department of Ecology, and EPA agreed to revise Tri-Party Agreement Milestone M-24 to allow prioritization of groundwater drilling for Comprehensive Environmental Response, Compensation, and Liability Act (CERCLA) and Atomic Energy Act wells along with RCRA wells. During 2004, drillers completed seven RCRA monitoring wells, nine CERCLA monitoring wells, and two wells for research on chromate bioremediation.

At the end of 2004, 15 RCRA sites were monitored to detect whether they were contaminating groundwater with hazardous constituents. Seven sites were monitored to assess the extent of known contaminants, and two were monitored to determine the progress of groundwater contamination cleanup activities. Twelve of the sites monitored under RCRA are scheduled for closure under the Hanford Site Part B RCRA Permit. The Liquid Effluent Retention Facility, low-level burial grounds (Waste Management Areas 1 to 4), and planned Inte- grated Disposal Facility, will receive permits as operating facilities.

A summary of groundwater monitoring activities for these sites during 2004 is provided in Section 8.7 and more detailed information is available in the Hanford Site Groundwater Monitoring Report for Fiscal Year 2004 (PNNL-15070).

\subsubsection{RCRA Inspections}

\section{R. C. Bowman}

Hanford Site contractors and DOE worked to resolve notices of violation and warning letters of non-compliance that were received from the Washington State Department of Ecology during 2004. These documents identified conditions that were alleged to be non-compliant with RCRA requirements. The following items summarize RCRA non-compliance documents that were received in 2004:

- Notice of Non-Compliance in Process Tanks with Pulse Jet Mixers at the Waste Treatment Plant On July 1, 2004, the Washington State Department of Ecology issued a Notice of Non-Compliance letter to the DOE Office of River Protection and Bechtel National, Inc. The letter stated that during an inspection of the nearly completed waste feed receipt vessel at the Waste Treatment Plant (now under construction), it was noticed that wear plates were not installed beneath each pulse jet mixer. The Washington State Department of Ecology claims that Bechtel National, Inc. approved design changes that deleted the wear plates. It further alleges that these design changes should have been submitted as permit modification requests since the plates are included in the approved equipment assembly drawings that are incorporated in the Waste Treatment Plant Dangerous Waste Permit. Resolution is still under discussion with the Washington State Department of Ecology.

- Failure to Consider Corrosion Allowances in Piping Design - On July 2, 2004, the Washington State Department of Ecology issued a Notice of Non-Compliance letter to the DOE Office of River Protection and Bechtel National, Inc. This letter documented their concerns regarding compliance with Waste Treatment Plant RCRA Permit conditions. 
A meeting was held between the Washington State Department of Ecology and Bechtel National, Inc. on June 25, 2004, to discuss how corrosion allowances had been factored into the design of the Waste Feed Evaporation Process System concentrate recycle line at the Waste Treatment Plant. The Washington State Department of Ecology's letter alleged that Bechtel National, Inc. failed to include corrosion allowance and its effect on piping in its design. This violated design requirements that Bechtel National, Inc. had committed to follow in the permit and could potentially compromise the structural integrity of Waste Treatment Plant tank systems. All requested information was provided to the Washington State Department of Ecology.

- Notice of Penalty Incurred - Violation of Washington Administrative Code - On September 21, 2004, the Washington State Department of Ecology issued a Notice of Penalty for alleged violations of WAC 173-303 related to receipt and management of sample residues from the Savannah River Technical Center. The Notice of Penalty levied a penalty of $\$ 270,000$ against the DOE Richland Operations Office and DOE Office of River Protection; Fluor Hanford, Inc.; and Duratek Federal Services of Hanford, Inc. This matter is under appeal.

- Notice of Administrative Order - Violation of Washington Administrative Code - On September 21, 2004, the Washington State Department of Ecology issued Notice of Administrative Order No. 1671 for alleged violations of WAC 173-303 related to receipt and management of sample residues from the Savannah River Technical Center. This Administrative Order was written against the DOE Richland Operations Office and DOE Office of River Protection; Fluor Hanford, Inc.; and Duratek Federal Services of Hanford, Inc. This matter is under appeal.

- Notice of Concerns for Waste Transfer Line Inspections and Slope - On October 22, 2004, the Washington State Department of Ecology issued a Notice of Concerns letter to the DOE Office of River Protection and Bechtel National, Inc. This letter documented their concerns regarding compliance with specified Waste Treatment Plant permit conditions. During an inspection conducted by the Washington State Department of Ecology on June 22, 2004, it was determined that the recently backfilled waste transfer lines from the Low-Activity Waste Building and Laboratory Building to the Pretreatment Building did not meet the Waste Treatment Plant permit conditions for the required minimum slope of $0.5 \%$ or evidence of required inspections by a qualified professional engineer or an independent installation inspector to ensure that design requirements were met. The Notice of Concerns was closed by the Washington State Department of Ecology on February 11, 2005, following the receipt of requested information.

\subsubsection{Toxic Substances Control Act}

\author{
Hanford Site PCB Technical Team \\ (POC - A. L. Prignano)
}

Requirements in the Toxic Substances Control Act that apply to the Hanford Site primarily involve regulation of polychlorinated biphenyls (PCBs). Federal regulations for use, storage, and disposal of PCBs are found in 40 CFR 761, Polychlorinated Biphenyls (PCBs) Manufacturing, Processing, Distribution in Commerce, and Use Prohibitions. (Washington State also regulates certain classes of non-Toxic Substances Control Act-regulated PCBs through WAC 173-303.) Non-radioactive and certain categories of radioactive PCB waste are stored and disposed in accordance with 40 CFR 761. Other radioactive PCB waste remains in storage onsite pending the development of adequate treatment and disposal technologies and capacities. Electrical equipment that might contain PCBs is maintained and serviced in accordance with 40 CFR 761.

To encourage consistent interpretation and implementation of the Toxic Substances Control Act PCB regulations throughout the Hanford Site, a Polychlorinated Biphenyl Hanford Site Users Guide was drafted in 2001 (DOE 2002). In 2003, this guide was revised to add additional sections on management of PCBs and PCB waste. During 2004, Hanford submitted both the 2003 PCB annual document $\log$ (DOE/RL-2004-51) and a 2003 PCB annual report (DOE/RL-2004-52) to EPA as required by 40 CFR 761.180. The reports describe the management and disposal activities taking place for PCB waste at the Hanford Site. The "Framework Agreement for Management of Polychlorinated Biphenyls in Hanford Tank Waste," signed on 
August 31, 2000 (http://yosemite.epa.gov/R10/OWCM. $\mathrm{NSF} /$ permits/hanfordframework), resulted in EPA, the Washington State Department of Ecology, and DOE and its Hanford Site contractors working together to resolve the regulatory issues associated with managing PCB waste at the Waste Treatment Plant (now under construction), in the waste tank farms, and at affected units upstream and downstream of the waste tank farms. The flexibility of the 1998 PCB disposal amendments in 40 CFR 761 is used at the Hanford Site to allow necessary storage and to expedite disposal of Toxic Substances Control Act-regulated PCB waste.

During 2004, the Pacific Northwest National Laboratory completed studies, under 40 CFR 761.60(j), Disposal Requirements, for disposal of 4 liters (1.1 gallons) of PCB remediation waste from the North Load-Out Pit located in the East K Basin. The PCB remediation waste included sludge consisting of sand, dust, and water and corrosion products from the corrosion of the spent fuel that was stored in the basin. The purpose of the studies was to optimize the process to solidify the sludge for transportation to, and disposal at, the Waste Isolation Pilot Plant in Carlsbad, New Mexico.

In January 2002, DOE submitted a Risk-Based Disposal Approval to EPA Region 10 for the management of PCB waste brought into and managed in the double-shell waste storage tank system. This Risk-Based Disposal Approval has not been approved. In June 2004, EPA approved a Risk-Based Disposal Approval for management of certain aqueous PCBs at the 200 Areas Liquid Waste Processing Facility. EPA found that treatment of the aqueous PCB waste would result in effluents and secondary waste that do not pose an unreasonable risk of injury to human health or the environment. The approval allows for the 242-A evaporator to process waste feed with a PCB concentration up to $600 \mu \mathrm{g} / \mathrm{L}$ without individual campaign approvals from EPA. Also in June, DOE submitted to EPA a chemical waste landfill application to allow disposal of certain PCB-containing waste in lined onsite land disposal trenches. The chemical waste landfill application has not been approved, but there have been discussions among DOE and the regulatory agencies. In October 2004, EPA approved an application for alternative PCB decontamination of spent nuclear fuel from $\mathrm{K}$ Basin. This activity is being performed as part of the cleanout of the Hanford K Basins.

In November 2004, DOE submitted a Risk-Based Disposal Approval for retrieval of waste from single-shell waste storage tanks using double-shell waste storage tank supernatant, a Toxic Substances Control Act-regulated PCB remediation waste. The approval for this application is still under review by EPA and approval is expected in summer 2005.

\subsubsection{Federal Insecticide, Fungicide, and Rodenticide Act}

\section{J. M. Rodriguez}

The Federal Insecticide, Fungicide, and Rodenticide Act is administered by EPA. The standards administered by the Washington State Department of Agriculture to regulate implementation of the act in Washington State include the Washington Pesticide Control Act (Revised Code of Washington [RCW] 15.58), Washington Pesticide Application Act (RCW 17.21), and rules relating to general pesticide use codified in WAC 16-228, Pesticide Regulations. At the Hanford Site, pesticides are applied by commercial pesticide operators, who are listed on one of two commercial pesticide applicator licenses, and by a private commercial applicator. 


\subsection{Environmental Remediation}

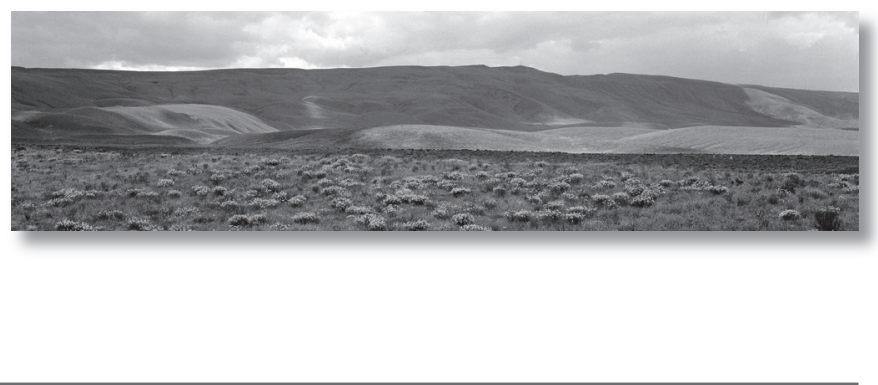

This section provides information about federal statutes and regulations related to environmental remediation.

\subsubsection{Comprehensive Environmental Response, Compensation, and Liability Act}

\section{B. L. Vedder}

During 1980, CERCLA was enacted to address response, compensation, and liability for past releases or potential releases of hazardous substances, pollutants, and contaminants to the environment. During 1986, CERCLA was extensively amended by the Superfund Amendments and Reauthorization Act, which made federal facilities subject to the provisions of CERCLA. EPA is the lead regulatory agency responsible for oversight of the DOE's implementation of CERCLA. There is significant overlap between the state RCRA corrective action program (Section 5.1.2) and the CERCLA program. Many waste management units at Hanford are subject to remediation under both programs. The CERCLA program is implemented via 40 CFR 300, National Oil and Hazardous Substances Pollution Contingency Plan, which establishes procedures for characterization, evaluation, and remediation. The Tri-Party Agreement (Ecology et al. 1989) addresses CERCLA implementation at the Hanford Site and is generally consistent with the national contingency plan process. There are several remediation activities under way at the Hanford Site that are accomplished using the CERCLA process (e.g., remedial investigation in the 200 Areas, and cleanup in the 100 and 300 Areas).

\subsubsection{Hanford Site Institutional Controls Plan}

\section{A. E. Teimouri}

Section 4.2 of the Sitewide Institutional Controls Plan for Hanford CERCLA Response Actions (DOE/RL-2001-41) requires the DOE Richland Operations Office to conduct an annual assessment regarding the performance of the institutional controls described in the plan. The plan calls for a focused and periodic self-assessment and reporting of institutional controls to (1) assess the performance of institutional controls to ensure their effectiveness and (2) identify the need to make any adjustments to the institutional controls based on performance findings. Initially, the plan required an assessment be conducted on an annual basis within 12 months of its issuance and a report be submitted to EPA and the Washington State Department of Ecology as a primary Tri-Party Agreement document as described in Section 9.2.1 of the Tri-Party Agreement (Ecology et al. 1989). This institutional controls assessment addresses objectives outlined in the assessment plan by conducting a performance-based review of selected areas of institutional controls located within the four National Priorities List sites at the Hanford Site. An assessment team primarily comprising DOE staff is usually designated and the assessment team reviews any prior institutional controls self-assessments and performance reviews and the contractor's oversight program as it pertains to this activity.

The Site Wide Institutional Controls Annual Assessment Report for Hanford CERCLA Response Actions (DOE/RL2004-56), issued in 2004, identified inconsistent use of institutional control language and/or terms used in Hanford Site decision and supporting documentation 
for CERCLA response actions. An institutional control dictionary and language was developed to standardize the institutional control language and/or terms used at the Hanford Site. The language and/or terms used in the guidance document are not intended as legal or environmental regulatory requirements, nor are they intended to be inconsistent with them. They are meant to be used only as language and/or terms for purposes of identifying and/or addressing institutional controls. Institutional control language and/or terms used in Hanford Site decision and supporting documentation for CERCLA response actions may be found in, but are not limited to: CERCLA records of decisions, remedial design and remedial action work plans, cleanup verification packages, waste site reclassification forms, and waste identification data system listings. This guidance document is intended for "post-remediation" actions, as defined under CERCLA. Where appropriate, however, institutional controls may also be used during remediation as applicable under CERCLA.

The 2004 institutional controls assessment report (DOE/RL-2004-56) also identified the need to evaluate the effectiveness of the surveillance and maintenance program for facilities in the 300 Area. The surveillance and maintenance activities for 300 Area facilities are performed by multiple contractors (e.g., Bechtel Hanford, Inc., and Fluor Hanford, Inc.) and the Pacific Northwest National Laboratory. Currently, Fluor Hanford, Inc. is responsible for the majority of the facilities located in the 300 Area; however, in October 2004, Fluor Hanford, Inc. transitioned 16 facilities to Bechtel Hanford, Inc. In response to the report, the DOE Richland Operations Office evaluated the effectiveness of the 300 Area surveillance and maintenance program. The primary reasons DOE conducted this evaluation were because: the 300 Area is located very close to a populated area, potential hazards exist, and area entry controls could potentially be breached. The evaluation indicated that the existing 300 Area surveillance and maintenance program is sufficiently protective of human health and the environment such that imposing formal institutional controls is unnecessary. Virtually no systematic concerns or major physical problems, such as broken fences and gates, or damaged signs, were observed with existing access controls. New safety portals (under design) and new construction in the 300 Area will provide additional entry controls above and beyond current warning devices such as signs and fences.

\subsubsection{CERCLA and Washington Administrative Code Reportable Releases to the Environment}

\section{P. Diediker}

Releases that are reportable to the state and/or EPA include spills or discharges of hazardous substances or dangerous waste to the environment, other than releases permitted under state or federal law. Releases of hazardous substances that are continuous and stable in quantity and rate but exceed specified limits must be reported as required by CERCLA Section 103(f)(2).

Reporting of spills or non-permitted discharges of dangerous waste or hazardous substances to the environment is required (WAC 173-303-145). That requirement applies to spills or discharges onto the ground, into groundwater, the surface water (e.g., Columbia River), or into the air such that human health or the environment are threatened, regardless of the quantity of dangerous waste or hazardous substance.

One reportable release occurred on the Hanford Site during 2004, which was a mercury spill in the 100-B/C Area. The spill occurred on September 11, 2004, and involved approximately 51 kilograms (113 pounds) of mercury. During CERCLA remediation of a waste burial ground, a 25.4-centimeter- (10-inch-) diameter by 1.22-meter(4-foot-) long metal cylinder was discovered that was leaking mercury. After a determination was made that the spill exceeded the reportable quantities listed in 40 CFR 302, Designation, Reportable Quantities and Notification, it was reported to DOE, EPA, and the National Response Center. The spilled material was cleaned up without incident in accordance with established procedures.

\subsubsection{Washington Administrative Code Groundwater Monitoring}

\section{J. Hartman}

Groundwater monitoring was required for three regulated, non-RCRA waste facilities in 2004. The 200 Area Treated 
Effluent Disposal Facility and the State-Approved Land Disposal Site are monitored under state discharge permits (WAC 173-216). The Solid Waste Landfill is monitored for the requirements of WAC 173-304, Minimum
Functional Standards for Solid Waste Handling. Wells near these facilities were monitored in 2004 for waste constituents specified in the facility permits.

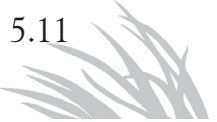




\subsection{Air Quality}

This section provides information about federal statutes and assessments related to air quality.

\subsubsection{Clean Air Act}

\section{K. A. Peterson}

The Clean Air Act, the basis for federal air quality regulations, was passed in 1967 and had comprehensive amendments in 1970, 1977, and 1990. In accordance with Section 112 of the Clean Air Act, EPA established the National Emissions Standards for Hazardous Air Pollutants (40 CFR 61). DOE and EPA signed the Federal Facility Compliance Agreement for Radionuclides NESHAP (EPA 1994). The agreement provides a plan and schedule that are being followed to bring the Hanford Site into compliance with Clean Air Act requirements under 40 CFR 61, Subpart $\mathrm{H}$, for continuous measurement of emissions from applicable airborne emission sources. Scheduled milestones of the agreement were met during 2004, and Hanford Site radiological air emissions remained well below the levels that approach the EPA offsite emission standard of 10 mrem $(100 \mu \mathrm{Sv})$ per year (40 CFR 61.92) (see Section 8.1). The requirements for flow and emissions measurements, quality assurance, and sampling documentation have been implemented at Hanford Site emission sources and/or are monitored for milestone progress in accordance with a schedule approved by EPA and monitored by the Washington State Department of Health. Data for the sources are documented annually in the Radionuclide Air Emissions Report for the Hanford Site, Calendar Year 2004 (e.g., DOE/RL-2005-06).

The Washington State Department of Health's Division of Radiation Protection regulates radioactive air emissions statewide through Washington State legislative authority. The Hanford Site operates under state license FF-01 for air emissions. Conditions specified in the license were incorporated into the Hanford Site air operating permit issued by the Washington State Department of Ecology in July 2001. The permit provides a compilation of applicable Clean Air Act requirements both for radioactive and nonradioactive emissions. The permit requires the DOE Richland Operations Office to submit periodic reports (e.g., DOE/RL-2002-38) and an annual compliance certifcation to the Washington State Department of Ecology.

The Washington State Department of Ecology's Nuclear Waste Program regulates air toxic and criteria pollutant emissions from the Hanford Site. The Department enforces state regulatory controls for air contaminants as allowed under the Washington Clean Air Act (RCW 70.94). The EPA regulates other potential air emission sources under the Clean Air Act at the Hanford Site.

At the local level, EPA designated the Benton Clean Air Authority as the agency to establish a local oversight and compliance program for asbestos renovation and/or demolitions. Benton Clean Air Authority imposes additional requirements on sources within the local agency's jurisdiction and incorporates the EPA's regulation by reference (i.e., the National Emission Standards for Asbestos [40 CFR 61, Subpart M]). In addition, the Benton Clean Air Authority regulates open-air burning as an extension of the Washington State Department of Ecology's open-air burning requirements (WAC 173-425).

\subsubsection{Clean Air Act Enforcement Inspections}

\section{R. C. Bowman}

Hanford Site contractors and DOE have worked to resolve notices of violation and warning letters of non-compliance that were received from the Washington State Department of Health and Washington State Department of Ecology during 2004. These documents identify conditions that are alleged to be non-compliant with Clean Air Act 
requirements. The following paragraphs summarize the four Clean Air Act non-compliance documents that were received in 2004.

On March 2, 2004, the Washington State Department of Health issued a Notice of Correction against the 291-T-1 emission unit associated with T Plant. The Washington State Department of Health wrote the Notice of Correction based on their review of the T Plant air permit description and operations found to be outside that scope. As a result of the five findings identified, an update of the T Plant air permit application was pursued. On April 26, 2005, the Consolidated T Plant Operations Notice of Construction (i.e., air permit) was approved by the Washington State Department of Health addressing all current and planned activities at the plant.

On March 4, 2004, the Washington State Department of Health issued a Notice of Correction against the 296-B-2 emission unit associated with B Plant. The Washington State Department of Health wrote the Notice of Correction based on findings from an inspection to determine if capping the 296-B-2 passive vent was in compliance with WAC 246-247, Radiation Protection-Air Emissions, standards. As a result of the review, seven findings were identified. On April 30, 2004, DOE provided the Washington State Department of Health with a response to the Notice of Correction findings. The Washington State Department of Health reviewed the response and indicated their desire to meet with the DOE Richland Operations Office to discuss the response.

On July 12, 2004, the Washington State Department of Health issued a Notice of Correction against the 296-P-31 emission unit associated with the 209 E Criticality Laboratory. The Washington State Department of Health wrote the Notice of Correction based on a review of document maintenance practices associated with the emission unit. The Washington State Department of
Health alleged that the licensee was out of compliance because of a failure to retain and provide documents to them as is required by WAC 246-247-080(8) and (10), Inspections, Reporting, and Recordkeeping. As a result of the review, one finding was identified. On October 26, 2004, the DOE Richland Operations Office provided an initial response to the Notice of Correction addressing its records retention and provision failure in the case of the 209-E facility. The response addressed two of the three actions specified in the Notice of Correction. The records failure was found to be an isolated incident based on the DOE Richland Operations Office investigation and survey of Hanford prime contractor records practices. On February 11, 2005, the DOE Richland Operations Office provided an ALARA Control Technology assessment of the 209-E facility, demonstrating the associated stack provides minor potential for emissions. Provision of the assessment completed the third and final action specified in the Notice of Correction. As of August 16, 2005, the Washington State Department of Health is reviewing the assessment and is expected to close the Notice of Correction in the near future.

On September 9, 2004, the Washington State Department of Health issued a Notice of Correction against the Central Waste Complex Permacon Unit. The Washington State Department of Health wrote the Notice of Correction based on findings resulting from an inspection they performed on August 11, 2004, to determine compliance of the Central Waste Complex Permacon Unit with WAC 246-247 standards. As a result of their review, six findings were identified. In two separate letters, dated September 23 and October 21, 2004, the DOE Richland Operations Office provided responses to complete actions called for in the six findings. As of August 16, 2005, the Washington State Department of Health has not closed the Notice of Correction. 


\subsection{Water Quality Protection}

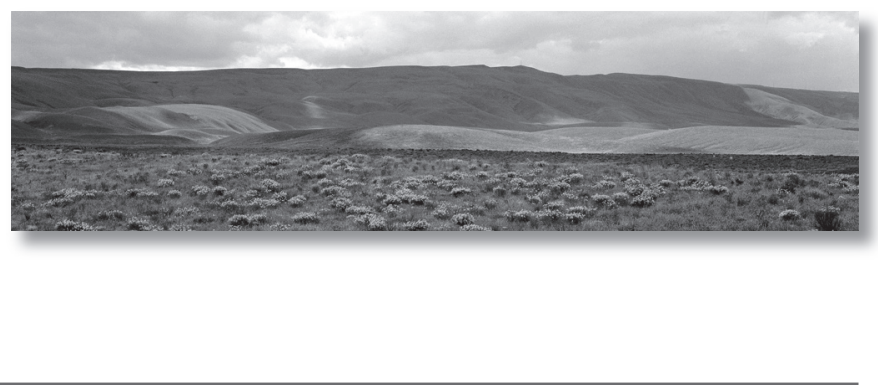

This section provides information about federal statutes and assessments related to water quality.

\subsubsection{Clean Water Act}

\section{R. Ranade}

The Clean Water Act applies to point source discharges to surface waters of the United States. At the Hanford Site, the regulations are applied through the EPA Administered Permit Programs: The National Pollutant Discharge Elimination System (40 CFR 122) permits that govern effluent discharges to the Columbia River. There is one National Pollutant Discharge Elimination System permit, WA-002591-7, issued by EPA for the Hanford Site. The permit covers three active outfalls: outfall 001 for the 300 Area Treated Effluent Disposal Facility and outfalls 003 and 004 in the 100-K Area. Fluor Hanford, Inc. is the holder of this permit.

The Hanford Site was covered by one storm water permit during 2004. EPA's National Pollutant Discharge Elimination System Storm Water Multi-Sector General Permit WAR05A57F establishes the terms and conditions under which storm water discharges associated with industrial activity are authorized. This permit was issued on May 30, 2001, and supersedes all other National Pollutant Discharge Elimination System storm water permits previously in effect at the site. Fluor Hanford, Inc. is the holder of this permit.

Wastewater from the William R. Wiley Environmental Molecular Sciences Laboratory, located in the Richland North Area, is discharged to the city of Richland's wastewater treatment facility under pretreatment permit CR-IU005. This permit, formerly issued by the city to the DOE Richland Operations Office, was re-issued by the city of Richland to Pacific Northwest National Laboratory on October 1, 2001.
There are numerous sanitary waste discharges to the ground throughout the site. Sanitary wastewater from the 400 Area is discharged to a treatment facility of Energy Northwest's Columbia Generating Station (Figure 1.0.1). Sanitary wastewater from the 300 Area, the former 1100 Area, and other facilities north of and in Richland is discharged to the city of Richland's treatment facility. Sanitary wastewater in the 200 Areas is primarily treated in a series of onsite sewage systems. The placement of these systems is based on population centers and facility locations. In recent years, extensive efforts have been made to regionalize the onsite sewage systems. Many of the small onsite sewage systems have been replaced with larger systems. These larger systems (with design capacities of 13,248 to 54,883 liters [3,500 to 14,500 gallons] per day) operate under permits issued by the Washington State Department of Health and treat wastewater from several facilities rather than a single facility.

The Washington State Department of Ecology has a State Wastewater Discharge Permit Program that regulates the discharge or disposal of wastewater to groundwater. DOE is complying with this program at the Hanford Site and is currently holding several state wastewater discharge permits. During 2004, the Hanford Site had ten state waste discharge permits issued by the Washington State Department of Ecology (ST-4500, ST-4501, ST-4502, ST-4507, ST-4508, ST-4509, ST-4510, EPA NPDES Permit WA-002591-7, EPA Stormwater Permit WAR05A57F, and Permit CR-IU005 for wastewater discharges from Pacific Northwest National Laboratory's William R. Wiley Environmental Molecular Sciences Laboratory to the city of Richland's wastewater treatment facility).

There were no permit violations during 2004. 


\subsubsection{Safe Drinking Water Act}

\section{M. Kelly}

In 1974, Congress passed the Safe Drinking Water Act. The act set up a cooperative program among local, state, and federal agencies to establish drinking water regulations applicable for all public water systems in the United States. States were granted primary responsibility for administering and enforcing the Safe Drinking Water Act, known as primacy. To obtain primacy, states had to meet certain criteria, including adoption of regulations equal to or more stringent than EPA's regulations.

The state of Washington was awarded primacy in 1978. The state Board of Health and the Washington State Department of Health became partners in developing and enforcing state drinking water regulations. The water systems on the Hanford Site were designated as public water systems in 1986, and became formally registered as public systems under the jurisdiction of the Washington State Department of Health in 1987.

The Safe Drinking Water Act was amended in 1986 to strengthen the act (Safe Drinking Water Act Amendments), and amended again in 1996. More standards are being established and some existing standards are becoming more stringent. The applicable state drinking water administrative codes have been revised consistent with the major regulatory changes. The latest revision of WAC 246-290, Public Water Supplies, was issued on July 3, 2004.
For the nine public water systems at Hanford, the administrative burden increased considerably in 2004 to ensure compliance with the new progressively complex regulations. A review of the revised regulations and associated guidance documents was performed during 2002 to 2004 to determine the impact on Hanford water systems. New monitoring plans and procedures were developed and implemented, and water treatment plants and processes were assessed to ascertain if hardware or process changes would be necessary to comply with the new and upcoming regulations. To disclose the information, training was provided to managers, engineers, and operators responsible for providing safe drinking water to Hanford consumers. Monitoring, reporting, and recordkeeping activities increased commensurate with the implementation of the new laws.

On August 10, 2004, the Washington State Department of Health conducted Sanitary Surveys for the Group A Hanford water systems supplied from the Columbia River. A Sanitary Survey evaluates the ability of a water system to reliably produce and distribute safe drinking water. No issues or deficiencies were noted in the final Sanitary Survey reports.

Hanford water systems were monitored during 2004 for the required microbiological, chemical, physical, and radiological constituents to ensure that all existing and new standards were being met. There were no microbiological detections and all chemical concentrations were well below the maximum contaminant levels set by the EPA. All analytical results for 2004 radiological monitoring are summarized in Section 8.6. 


\subsection{Natural and Cultural Resources}

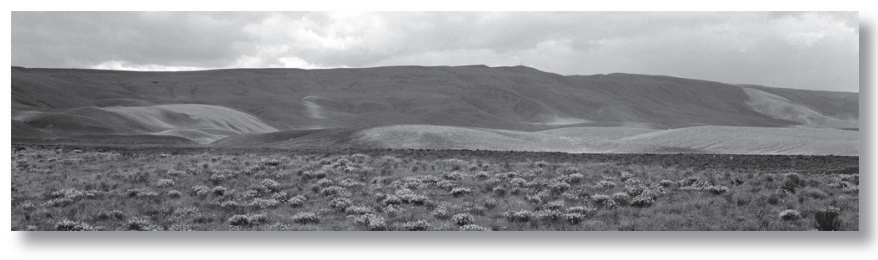

This section provides information about federal statutes and assessments related to ecological compliance and cultural resources.

\subsubsection{Ecological Compliance}

\author{
M. R. Sackschewsky, R. E. Durham, and \\ R. P. Mueller
}

DOE policies require that all projects having the potential to adversely affect biological resources have an ecological compliance review performed prior to initiation of the project. This review determines if the project will comply with the Endangered Species Act and the Migratory Bird Treaty Act. It also re-examines whether other significant resources such as Washington State listed species of concern, wetlands, and native shrub-steppe habitats are adequately considered during the project planning process. Where effects are identified, mitigation action is prescribed. Mitigation actions can include avoidance, minimization, rectification, or compensation.

Because many projects occur during periods of the year when plants are not growing and are difficult to identify or evaluate, each of the operational areas (200-East and 200-West Areas, $100-\mathrm{N}$ and 100-K Areas, and the 300 Area) are surveyed each spring. All habitat areas within these areas are surveyed and each building is inspected for the nests of migratory birds. These baseline visual surveys provide information about habitat types, and species inventories and abundance, which can be used throughout the rest of the year to assess the potential impact. These data are also used to support ecological inventory and data requirements for ecological risk evaluations. Examples of the baseline survey maps are available at http://www.pnl.gov/ecomon/Compliance/comp.html.
There were 225 reviews preformed during 2004 including 174 ecological compliance reviews in support of general Hanford Site activities and 51 reviews performed in support of environmental restoration activities.

\subsubsection{Endangered Species Act}

\section{R. Sackschewsky}

Several protected species of plants and animals exist on the Hanford Site and along the Hanford Reach of the Columbia River. The bald eagle (Haliaeetus leucocephalus), steelhead trout (Oncorhynchus mykiss), and spring-run Chinook salmon (Oncorhynchus tshawytscha) are listed by the U.S. Fish and Wildlife Service as either threatened or endangered (50 CFR 17, Subpart B) and occur onsite. Other species at Hanford are listed by the Washington Department of Fish and Wildlife as endangered, threatened, or sensitive (see Section 8.12).

\subsubsection{Migratory Bird Treaty Act}

\section{R. Sackschewsky}

The Migratory Bird Treaty Act prohibits taking or disturbing specified migratory birds or their feathers, eggs, or nests. Over 100 species of birds that regularly occur on the Hanford Site are protected by the Migratory Bird Treaty Act.

All Hanford Site projects with a potential to affect federally or state listed species of concern complied with the requirements of this act by using the ecological compliance review process (see Section 5.5.1) as described in the Hanford Site Biological Resources Management Plan (DOE/RL-96-32). When applicable, the ecological reviews produced recommendations to minimize adverse impact to migratory birds, such as performing work outside of the nesting season and minimizing the loss of habitat. 


\subsubsection{Cultural Resources}

\section{W. Harvey}

DOE's policy is to comply with all cultural resourcerelated laws and regulations. Cultural resources on the Hanford Site are subject to the provisions of the following seven acts, two executive orders, and one Presidential Proclamation: American Indian Religious Freedom Act; Antiquities Act; Archaeological and Historic Preservation Act; Archaeological Resources Protection Act; Executive
Order 11593, Protection and Enhancement of the Cultural Environment (36 FR 8921); Historic Sites, Buildings, and Antiquities Act; National Historic Preservation Act; Native American Graves Protection and Repatriation Act; Proclamation 7319 of June 9, 2000, Establishment of the Hanford Reach National Monument (65 FR 37253); and Executive Order 13287 of March 3, 2003, Preserve America (68 FR 10635).

See Section 8.15 for details regarding the cultural resources programs on the Hanford Site. 


\subsection{National Environmental Policy Act}

M. T. Jansky

The National Environmental Policy Act (NEPA) requires preparation of an environmental impact statement for major federal actions with the potential to significantly affect the quality of the human environment. An environmental assessment is prepared when it is uncertain if a proposed action would require the preparation of an environmental impact statement. A supplement analysis is prepared to consider new information developed since issuance of an environmental impact statement and record of decision. The supplement analysis would determine if the federal action is still bounded by the original environmental impact statement and record of decision or if a supplemental environmental impact statement is required.

Additionally, certain types of actions may fall into typical classes that have already been analyzed by DOE and have been determined to not normally result in a significant environmental impact. These actions are called categorical exclusions, and, if eligibility criteria are met, they are exempt from NEPA environmental assessment or environmental impact statement requirements. Typically, the DOE Richland Operations Office documents more than 20 specific categorical exclusions annually, involving a variety of actions by multiple Hanford Site contractors. In addition, site-wide categorical exclusions are applied to routine, typical actions conducted daily on the Hanford Site. In 2004, there were 20 site-wide categorical exclusions.

NEPA documents for the Hanford Site are prepared and approved in accordance with the Council on Environmental Quality National Environmental Policy Regulations for Implementing the Procedural Provisions of the National Environmental Policy Act (40 CFR 1500-1508), DOE NEPA implementation procedures (10 CFR 1021), and DOE Order 451.1B Change 1, National Environmental Policy Act Compliance Program - Change 1. In accordance with the Order, DOE documents prepared for CERCLA projects incorporate NEPA values such as analysis of cumulative, offsite, ecological, and socioeconomic impact to the extent practicable in lieu of preparing separate NEPA documentation.

\subsubsection{Recently Issued Environmental Impact Statements}

\section{T. Jansky}

The Final Hanford Site Solid (Radioactive and Hazardous) Waste Program Environmental Impact Statement, Richland, Washington, was issued in January 2004 (DOE/EIS-0286F). The final statement analyzed alternatives for (1) disposing of immobilized low-activity radioactive waste from Hanford underground waste storage tanks, other low-level waste, and mixed low-level waste; (2) treating mixed lowlevel waste; and (3) processing and certifying transuranic waste prior to its shipment to the Waste Isolation Pilot Plant in New Mexico for disposal. A record of decision was issued on June 30, 2004 (69 FR 39449) stating that DOE will limit the volumes of low-level waste and mixed low-level waste received at Hanford from other sites for disposal to 62,000 cubic meters $(81,100$ cubic yards) of low-level waste and 20,000 cubic meters (26,200 cubic yards) of mixed low-level waste. Also, effective immediately, DOE will dispose of low-level waste by placing it in lined disposal facilities, a practice already used for mixed low-level waste. In addition, DOE will construct and operate a lined, combined-use disposal facility in Hanford's 200-East Area to dispose of low-level waste and mixed low-level waste and will further limit the receipt of offsite waste until the facility is constructed. Low-level waste and mixed low-level waste requiring treatment will 
be treated either at offsite facilities or existing or modified onsite facilities, as appropriate. Storage, processing, and certification of transuranic waste for subsequent shipment to the Waste Isolation Pilot Plant will occur at existing and modified onsite facilities.

DOE issued the Supplement Analysis. Waste Retrieval from the 218-W-4C, 218-E-12B, 218-W-3A, and 218-W-4B Low-Level Burial Grounds, 200 Areas, Richland, Washington (DOE/EIS-0113-SA4) on March 25, 2004. The supplement analysis provided current information concerning the proposed full retrieval and disposition of retrievably stored and newly generated transuranic waste, mixed low-level waste, suspect mixed low-level waste, and lowlevel waste in the 218-W-4C, 218-E-12B, 218-W-3A, and 218-W-4B low-level burial grounds in the 200 Areas of the Hanford Site. The supplement analysis updated process knowledge and data since the record of decision based on the Final Environmental Impact Statement, Disposal of Hanford Defense High-Level, Transuranic and Tank Wastes, Hanford Site, Richland, Washington (DOE/EIS-0113). The supplement analysis provided the basis for a determination that no additional NEPA review was required to support the action.

US Ecology operates a commercial low-level radioactive waste disposal site near the 200 Areas on land leased from the federal government by the state of Washington. The Washington State Department of Health and Washington State Department of Ecology distributed a draft environmental impact statement for the facility for comment in August 2000. This Washington State Environmental Policy Act (RCW 43.21C) impact statement considers the renewal of US Ecology's license to operate the waste site, an increase to the upper limit for disposal of naturally occurring radioactive materials, and an approval of the site stabilization and closure plan.
The Final Environmental Impact Statement was issued on June 30, 2004 (DOH 320-031).

A draft comprehensive conservation plan and environmental impact statement for the Hanford Reach National Monument/Saddle Mountain National Wildlife Refuge is being prepared by the U.S. Fish and Wildlife Service to evaluate management alternatives for the monument and national wildlife refuge. As co-manager of the monument, the DOE Richland Operations Office is a cooperating agency. Projected issuance of the draft environmental impact statement is summer 2005.

A draft environmental impact statement is being prepared about retrieval, treatment, and disposal of waste from underground waste storage tanks and closure of 149 singleshell underground waste storage tanks. The Washington State Department of Ecology is a cooperating agency in the preparation of this environmental impact statement. The draft statement is scheduled to be issued for public comment in 2006.

A draft environmental impact statement is being prepared to consider reasonable alternatives for decommissioning the deactivated Fast Flux Test Facility. Initial input from the public was solicited in September 2004. The draft statement is scheduled to be issued for additional public comment in 2006.

\subsubsection{Recent Environmental Assessments}

\section{T. Jansky}

No environmental assessments were prepared during 2004. 


\subsection{Atomic Energy Act}

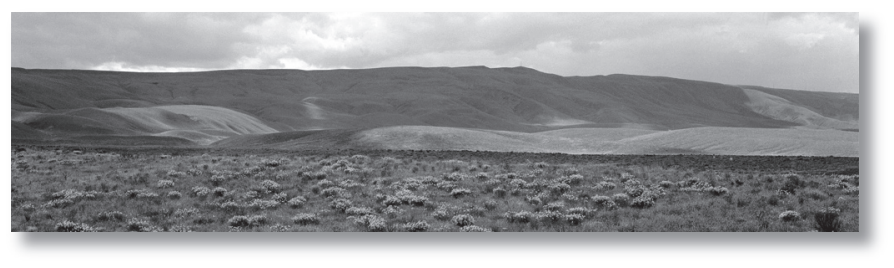

W. M. Glines

The Atomic Energy Act was promulgated to assure the proper management of radioactive materials. The act and its amendments have delegated the roles and responsibilities for the control of radioactive materials and nuclear energy primarily to DOE, the Nuclear Regulatory Commission, and EPA.

Under the act, DOE regulates the control of radioactive materials under its authority including the treatment, storage, and disposal of low-level radioactive waste from its operations. Sections of the act authorize DOE to set radiation protection standards for itself and its contractors.
Accordingly, DOE promulgated a series of regulations (e.g., 10 CFR 820, 10 CFR 830, and 10 CFR 835) and Orders (e.g., DOE Order 435.1, and DOE Order 5400.5) to protect public health and the environment from potential risks associated with radioactive materials. Operations at the Hanford Site are subject to the requirements in these regulations and Orders. There were no significant revisions to these regulations or Orders affecting operations at the Hanford Site in 2004. 


\subsection{Defense Nuclear Facilities Safety Board}

S. M. Hahn

The Defense Nuclear Facilities Safety Board is an independent federal agency established by Congress in 1988. The board's mandate under the Atomic Energy Act is to provide safety oversight of the nuclear weapons complex operated by DOE. The nuclear weapons program remains a complex and hazardous operation. DOE must maintain readiness of the nuclear arsenal, dismantle surplus weapons, dispose of excess radioactive materials, clean up surplus facilities, and construct new facilities for many purposes. It is the board's responsibility to help ensure that all of these activities are carried out by DOE in a manner that provides adequate protection for the public, workers, and the environment.

\subsubsection{Defense Nuclear Facilities Safety Board Related Accomplishments, DOE Richland Operations Office}

\section{S. M. Hahn}

In 2004, the DOE Richland Operations Office accomplished the following tasks related to Defense Nuclear Facilities Safety Board recommendations:

- Completed stabilization and packaging of all plutonium metal, oxide, polycube, and alloy items (approximately 11 tonnes [12.1 tons]) at the Plutonium Finishing Plant into standardized 3013 cans, suitable for long-term storage.

- Completed removal of all spent fuel (2,106 tonnes [2,321.5 tons]) from the $\mathrm{K}$ Basins into safe, dry, compliant storage at Hanford's Canister Storage Building about 14.5 kilometers (9 miles) from the Columbia River. The spent fuel is now awaiting eventual shipment to a national repository.
- Initiated the second phase of $\mathrm{K}$ Basins cleanup by removing about 50 cubic meters (65 cubic yards) of radioactive sludge. Sludge from the K Basin's North Load Out Pit is being pumped into largediameter canisters and will be mixed with grout in a treatment facility for disposal offsite as contacthandled transuranic waste. The remainder of the $\mathrm{K}$ Basin sludge, containing higher concentrations of cesium and uranium, is being transferred to containers in preparation for onsite treatment. The treatment method for K-West sludge has been selected.

- Began retrieval of transuranic waste from trenches in Hanford's 200-West Area burial grounds. The Tri-Party Agreement milestone for removal of 6,000 drums was met 4 months early. The DOE Richland Operations Office continues to provide the Defense Nuclear Facilities Safety Board with the status on plans to safely retrieve and disposition drums containing plutonium.

- Completed several commitments related to software quality assurance including the qualification of software quality assurance personnel, completion of software quality assurance related assessments, and an update of the Richland Functions, Responsibilities, and Authorities Manual (RL/RIM-2002-01).

\subsubsection{Defense Nuclear Facilities Safety Board Related Accomplishments, DOE Office of River Protection}

\section{M. Fetto}

The DOE Office of River Protection worked closely with the Defense Nuclear Facilities Safety Board during 2004 to 
address safety questions related to the design and construction of the Hanford Waste Treatment and Immobilization Plant (Waste Treatment Plant) and operations of the tank farms. Significant progress was made designing and constructing the Waste Treatment Plant in 2004 with $74.1 \%$ completion of the engineering design and 28\% completion of construction. Primary areas of interest to the Defense Nuclear Facilities Safety Board are discussed below.

\subsubsection{Structural Design and Seismic Analysis of the Waste Treatment Plant}

DOE has completed the final review of the Site Specific Seismic Site Response Model for the Waste Treatment Plant, Hanford, Washington (PNNL-15089). The report, issued March 1, 2005, provides revised seismic data for the design of the Waste Treatment Plant following analysis by expert seismologists from industry and the Pacific Northwest National Laboratory. As a result of the analysis, the seismic design specifications for the Waste Treatment Plant Pretreatment Building and High-Level Waste Building will be modified to withstand larger ground motions. The design changes do not affect other large facility structures within the Waste Treatment Plant complex. The previous seismic design basis, derived from a seismic hazard analysis in 1993-1994 by Geomatrix (WHC-SD-W236A-TI-002) was questioned by the Defense Nuclear Facilities Safety Board in 2002, and most questions regarding the adequacy of the design basis were resolved. The 2005 report (PNNL15089 ) is expected to resolve the final questions.

The principal impact of the revised specifications is additional expense for design re-analysis and probable project delays from equipment procurement and redesign of piping hangers. The design re-analysis is expected to take approximately 6 months, while the effects of the redesign on the construction schedule are still being determined. Preliminary analyses indicate that most of the existing construction has sufficient design margin to preclude physical modifications to the existing construction. DOE is performing an analysis of overall project costs and schedule impact.

\subsubsection{Concerns about Hydrogen Generated at the Waste Treatment Plant}

Throughout 2004, DOE and its contractor have worked closely with the Defense Nuclear Facilities Safety Board to resolve their concerns about the presence of potentially flammable concentrations of hydrogen in the Waste Treatment Plant. The Waste Treatment Plant waste will generate hydrogen in quantities and at rates that may require controls in some of the pretreatment facility vessels and high-level radioactive waste vessels. The normal control strategy to prevent accumulation in the vessel headspace is to maintain a continuous air purge to dilute the hydrogen released from the waste and vent it through the vessel ventilation system. In addition to ventilation, a key component of the control strategy is to keep the waste mixed so that hydrogen will not accumulate in the solids and release in large amounts all at once.

Mixing will be accomplished with pulse jet mixers and air spargers. A number of tests have been completed which demonstrate the pulse jet mixers and air spargers are effective in releasing hydrogen that may be retained in solids in Waste Treatment Plant vessels. In cases where pulse jet mixers are inoperable for periods of time, spargers alone have been confirmed to be adequate for agitating settled solids in Waste Treatment Plant tanks facilitating hydrogen release and preventing potential gas buildup.

Work has also been done to systematically identify and evaluate locations throughout the Waste Treatment Plant beyond the primary process vessels (in pipes and ancillary vessels) where hydrogen could accumulate. A design guide for evaluating the potential of hydrogen buildup and applying preferred preventive and mitigative engineering controls has been proposed. Identification of areas where additional controls are needed has been completed, and recommended design solutions are currently being finalized. The final report was scheduled to be completed in April 2005.

DOE and the Defense Nuclear Facilities Safety Board have been working to refine and finalize the hydrogen generation calculation, which is the technical basis for the rate and amount of hydrogen to be generated in the Waste Treatment Plant. One of the last tasks to be performed 
in support of the hydrogen generation calculation is to confirm that an anti-foam reagent will contribute minimal amounts of hydrogen during operations. Bechtel National, Inc. Engineering and Research and Technology selected an appropriate simulant to perform the hydrogen generation rate studies on the anti-foam reagent and worked with Savannah River National Laboratory to accelerate work to provide early data to support the hydrogen generation calculation activity. Savannah River National Laboratory will provide test results for discussion by April 2005 and issue a letter report to the Waste Treatment Plant Project by May 2005 .

\subsubsection{Assessment of Waste Treatment Plant Design and Analysis Computer Software}

The DOE Office of River Protection assessed the design and analysis computer software being used at the Waste Treatment Plant. The assessment was an action included in the DOE response to the Defense Nuclear Facilities Safety Board Recommendation 2002-1, Quality Assurance for Safety Software at Department of Energy Defense Nuclear Facilities. The assessment team concluded that the overall software control program was effective.

\subsubsection{Assessment of Instrument and Control System Computer Software for Tank Farms}

The DOE Office of River Protection assessed tank farm instrument and control system computer software in response to the Defense Nuclear Facilities Safety Board Recommendation 2002-1. The DOE Office of River Protection evaluated five Hanford tank farm instrument and control systems and found them to be acceptable. The Defense Nuclear Facilities Safety Board is evaluating the DOE Office of River Protection's assessment and will continue to follow this topic.

\subsubsection{Integrated Safety Management System in the Tank} Farms

The Defense Nuclear Facilities Safety Board requested a report identifying weaknesses in the Integrated Safety Management System for the tank farms, with particular focus on work planning, conduct of operations, feedback and improvement programs at the activity level, and corrective action plans and schedules. DOE provided a response to the Defense Nuclear Facilities Safety Board describing its path forward. The Defense Nuclear Facilities Safety Board staff will continue to follow this topic.

\subsubsection{Double-Shell Waste Tank Integrity}

A Chemical Optimization Expert Panel recommended stress corrosion cracking testing be conducted on doubleshell waste tanks to better define double-shell tank chemistry control limits. In response to this recommendation, the DOE Office of River Protection and tank farms contractor are developing a test design matrix to perform laboratory studies of the effects of stress-related corrosion on crack formation in the walls of waste storage tanks. The first test phase is to validate previous slow strain rate test results. A subset of the test design matrix will include conducting similar tests with waste simulant on tank 241-AN-107 to be finalized by the end of 2005. Additional testing of simulants for other tank waste types is planned for 2006 and beyond.

The tank farms contractor proposed increasing operating waste levels in double-shell tanks. Structural analysis of the tanks indicated that waste levels could be increased to new operating levels by decreasing the specific gravity of the tank waste. The AP Tank Farm was selected for wastelevel testing after review of construction and structural records. An expert panel was formed and a workshop was held in 2004 to review the analysis. The expert panel agreed with a recommendation to increase waste levels in AP Tank Farm tanks. Proposed authorization basis amendments, which could modify the nuclear safety basis, are being discussed by the DOE Office of River Protection and the tank farms contractor.

\subsubsection{Status of DOE Order 435.1, Radioactive Waste Management}

\section{S. D. Stubblebine}

DOE Order 5820.2A, Radioactive Waste Management, was issued in 1988. During September 1994, the Defense 
Nuclear Facilities Safety Board issued Recommendation 94-2, Conformance with Safety Standards at DOE Low-Level Nuclear Waste and Disposal Sites, addressing problems with DOE's radioactive waste management. In July 1999, DOE issued a revised directive on managing radioactive waste, DOE Order 435.1, Radioactive Waste Management, with its associated manual and guidance documents, reflecting advances in radioactive waste management practices. DOE Order 435.1 included a compliance date of July 12, 2000.

The U.S. District Court for the District of Idaho ruled on July 3, 2003, that a key provision of DOE Order 435.1 was invalid. The ruling applied to that portion of the order that allows radioactive waste that is incidental to reprocessing to be managed as low-level radioactive waste. Such determination is viewed by DOE as important to speeding the treatment and reducing associated disposal costs of radioactive liquid wastes generated by DOE's prior reprocessing of spent nuclear fuel. Under the Order, waste incidental to reprocessing that remains in Hanford waste storage tanks could be disposed of in place as low-level waste rather than being disposed of in a repository as highlevel waste. The Natural Resources Defense Council, along with others, challenged the provision as inconsistent with the Nuclear Waste Policy Act. The court agreed that part of DOE Order 435.1 was inconsistent with the Nuclear Waste Policy Act and held that portion invalid.

DOE appealed this decision to the 9th Circuit Court of Appeals. The Court of Appeals issued a unanimous decision on November 5, 2004, determining that the case was not ripe for decision and reversed and remanded it to the District Court with instruction to dismiss. In other words, the 9th Circuit Court of Appeals concluded that since the case did not involve actual application of DOE Order 435.1, there were no facts upon which to determine how DOE would apply the rule, and that, therefore, the plaintiffs had filed their action prematurely. Plaintiffs filed requests with the three-judge panel that decided the case and the full bench of the entire 9th Circuit Court of Appeals to grant a re-hearing but these petitions were denied. The case is currently with the District Court, awaiting the Court's entry of dismissal. 


\subsection{Environmental Occurrences}

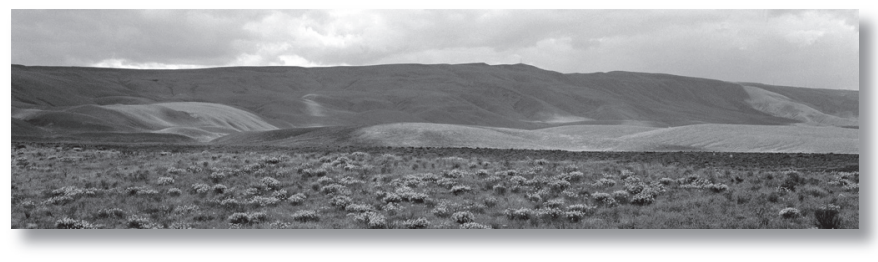

B. G. Fritz

Releases of radioactive and regulated materials to the environment are reported to DOE and other federal and state agencies as required by law. The specific agencies notified depend on the type, amount, and location of each event. All occurrences at the Hanford Site are reported to the Occurrence Notification Center. The following sections summarize the occurrences that took place during 2004 that could have had an impact on the Hanford environment. The occurrences are arranged according to significance category. Significance categories are assigned based on the nature and severity of the occurrence. The categories include operational emergency, recurring, category 1 (significant impact), category 2 (moderate impact), category 3 (minor impact), and category 4 (some impact). In 2004, there were no occurrences ranked as level operational emergency, recurring, or category 1 on the Hanford Site.

\subsubsection{Category 2 - Moderate Impact}

Category 2 occurrences are defined as having a moderate impact on safe facility operations, worker or public safety and health, regulatory compliance, or public and business interests. One Category 2 occurrence with potential environmental implications occurred on the Hanford Site in 2004.

Small Contaminated Paint Chips Discovered Near
the 233-S Facility Radiological Control Boundary
(RL-PHMC-CENTPLAT-2004-0003). On Friday, January 29, 2004, demolition work at the 233-S facility was secured because of wind conditions exceeding 5.4 meters per second (12 miles per hour). High winds were expected to persist through the weekend, so actions were taken to secure the demolition site, including application of soil cement and removal of waste. On Saturday, January 30, winds exceeded 26.8 meters per second (60 miles per hour). On the following Monday, three contaminated paint chips were discovered by radiological control personnel during a precautionary survey outside of the Radiological Control Boundary and downwind of the 233-S facility. Surveys of the chips showed alpha contamination levels of $63,000 \mathrm{dpm} / 100 \mathrm{~cm}^{2}$. The chips were collected, bagged, and disposed of. The paint chips were assumed to have originated in the High Contamination Area where other contaminated paint chips were discovered. The high winds blew the High Contamination Area doors open, allowing the contaminated paint chips to be blown out of the area.

\subsubsection{Category 3 - Minor Impact}

Category 3 occurrences are defined as having a minor impact on safe facility operations, worker or public safety and health, regulatory compliance, or public and business interests. One Category 3 occurrence with potential environmental implications occurred on the Hanford Site in 2004.

Exposure to Airborne Radiation at the 300 Area Remediation Project (RL-BHI-REMACT-2004-0018). On Monday, December 13, 2004, a subcontractor employee's personal lapel air monitor showed a result of 27 derived air concentration hours, or 2.7 derived air concentration hours corrected for uranium. The employee was working in the 618-2 burial ground of the 300 Area, which was being excavated as part of a remediation effort. Because of the elevated result, two radiological control technicians attempted to identify the exposure source. Smear samples were collected at locations identified by portable survey instrumentation. The lapel air samplers worn by the radiological control technicians during the investigative sampling showed 3,400 and 1,400 derived air concentration hours, respectively. In response to the high 
concentrations on the lapel air sample filters, soil fixative was applied to the area, and the area was posted as an airborne radioactivity area. The radiological control technicians underwent in vivo chest counts and bioassays. The chest counts revealed no detectable intake. The bioassay results were not yet available at the time of this report. The radiological control technicians were restricted from entering radiological areas until the results of the bioassay were in.

\subsubsection{Category 4 - Some Impact}

Category 4 occurrences are defined as having some impact on safe facility operations, worker or public safety and health, regulatory compliance, or public and business interests. Four Category 4 occurrences with potential environmental implications occurred on the Hanford Site in 2004. They are separated here according to the general type of occurrence.

- Spread of Contamination by Mud Daubers (RL-BHI-DND-2004-0010 and RL-BHI-DND. 2004-0011). Cleanup activities in the 100-N Area involved the demolition of a number of abandoned buildings. In two of these buildings (1712-N and 13-N), contaminated mud dauber nests were found during demolition activities. At $1712-\mathrm{N}$, a nest with 140,000 dpm beta/gamma direct reading (no removable contamination) was found attached to demolished sheetrock. At building 13-N, a nest with $167,000 \mathrm{dpm}$ beta/gamma direct reading and 7,000 dpm beta/gamma smearable was found under the sub-floor of the building. Neither of the nests had any detectable alpha contamination. In both cases, the areas were controlled and the nests were removed and disposed of.

- Spread of Contamination by Ants (RL-PHMC. CENTPLAT-2004-0011). During a survey of the 218-E-2 burial ground, located in the 200-East Area, health physics technicians discovered two red ant mounds. The mounds were in an area approximately 3 by 3 meters ( 10 by 10 feet) square. The area is posted as a soil contamination area. Maximum contamination levels found were $150,000 \mathrm{dpm} / 100 \mathrm{~cm}^{2}$ beta/gamma, with no removable contamination. There was no alpha contamination detected. Biological control personnel applied a pesticide to the affected area.
- Grass Fires in the 600 Area (RL-PHMC-FSS. 2004-0003, RL-PHMC-FSS-2004-0005, and RL-PHMC-FSS-2004-0007). During 2004, there were five grass fires that burned in the 600 Area of the Hanford Site. The 600 Area is the portion of the Hanford Site not included in the operational areas and consists of essentially natural vegetation. While the fires were not on contaminated sites, any grass fire on the Hanford Site has the potential to spread out of control and onto contamination areas. One of the fires occurred east of the 100-N Area and was determined to have been caused by an electrical fault that resulted in a spark at a weak point in the grounding system. The spark ignited nearby ground cover. This fire was extinguished in 5 hours and burned 6 hectares (15 acres). The other four fires were all caused by lightning strikes. One lightning storm in June resulted in two fires. These fires were located at the base of Rattlesnake Mountain and north of the 200-West Area. In total, these two fires burned approximately 32.4 hectares ( 80 acres). Both were controlled and extinguished within 2 hours of being reported. Another lightning storm in August ignited two separate fires near the Hanford town site. The fires were declared contained within 7 hours of being reported. These two fires combined to burn approximately 253 hectares (625 acres). There was no damage to any facilities or government equipment as a result of these fires.

- Contaminated Tumbleweeds (Reports RL-PHMC. SOLIDWASTE-2004-0002, -0010, -0012, -0012, $-0014,-0015$, and RL-PHMC-CENTPLAT-20040007, -0008, -0010, -0014, -0015, -0016, -0017, $.0018,-0019,-0020,-0021,-0022)$. During 2004, many contaminated tumbleweeds were discovered during surveys of contamination areas. The deep tap root of the tumbleweed allows uptake of contamination into the plant matrix. This is well known, and consequently tumbleweeds are checked by radiological control personnel during surveys of contamination areas. The maximum levels of contamination found in tumbleweeds in 2004 varied from 72,000 to $540,000 \mathrm{dpm} / 100 \mathrm{~cm}^{2}$ beta/gamma. None of the contaminated tumbleweeds had any removable contamination or alpha contamination. In most cases, the contaminated tumbleweeds were removed for appropriate disposal. In some instances, the contamination area boundary was extended to encompass the area of contaminated tumbleweed growth. 


\subsection{Pollution Prevention and Waste Minimization}

This section provides information about Hanford Site policies regarding pollution prevention and waste minimization. Initiative 297, a ruling enacted by Washington State voters in November 2004, is also discussed.

\subsubsection{Pollution Prevention Program}

\section{J. G. Coenenberg}

The Hanford Site Pollution Prevention and Waste Minimization Program Plan (DOE/RL-2004-57) provides guidance for Hanford Site contractors to prevent pollution from entering the environment, to conserve resources and energy, and to reduce the quantity and toxicity of hazardous, radioactive, mixed, and sanitary waste releases to the environment at the Hanford Site. The program plan reflects the national and local waste minimization and pollution prevention goals and policies and represents an ongoing effort to ensure that pollution prevention and waste minimization is part of the Hanford Site operating philosophy. The program plan is designed to satisfy DOE Orders 435.1 and 450.1, executive orders, and federal and state regulations and requirements. In accordance with sound environmental management, the first priority is to prevent pollution through source reduction. When source reduction is not possible or practical, waste treatment to reduce quantity, toxicity, or mobility is considered. The second priority is environmentally safe recycling, and the third priority is approved disposal at permitted sites. The DOE Richland Operations Office is responsible for the Hanford Site pollution prevention program. The office provides program guidance for Hanford Site contractors, which integrated through Fluor Hanford, Inc.

The Hanford Site met the fiscal year 2004 Secretarial Goals (as defined in a DOE memorandum) for low-level waste, mixed low-level waste, hazardous and sanitary routine waste generation, and recycling (including paper, plastic, cardboard, and glass). In 2004, the program reported recycling 2,504 metric tons (2,760 tons) of sanitary and hazardous waste. This recycled waste included 309 metric tons (341 tons) of office and mixed paper, 385 metric tons (424 tons) of iron and steel, 103 metric tons (114 tons) of non-ferrous metal, and 107 metric tons (118 tons) of appliances and furniture. Affirmative procurement (the purchase of environmentally preferable products containing recycled material) at the Hanford Site achieved 100\% of the 2004 goal. The Hanford Site generated 27,546 cubic meters $(36,000$ cubic yards) of cleanup and stabilization goal waste (i.e., low-level waste, mixed low-level waste, and hazardous waste), and did not meet the $10 \%$ cleanup stabilization goal of 24,547 cubic meters (32,100 cubic yards). Not meeting this goal could be a reflection of additional cleanup and waste stabilization activities that were not anticipated in the fiscal year 2004 waste forecast.

One notable achievement in 2004 was the Mortar Lining Project for Water Distribution receiving the DOE Office of Environmental Management Pollution Prevention Best in Class Award for Innovative Technology. Mortar lining, an innovative, commercially available technology, is being used to refurbish 53 kilometers (28.62 miles) of degraded waterline, ensuring that water for fire protection and drinking is available during site closure activities. For the same cost, mortar lining restores twice as much pipeline as replacement pipe, stopping leaks and protecting groundwater from soil contaminants. Pipelines are restored in place using minimal excavation, which reduces worker risk by decreasing exposure to possibly contaminated soil. Over the 10-year life of the project, cost avoidance of more than $\$ 19$ million is anticipated, along with waste avoidance of 6,134 metric tons (6,760 tons) of replacement pipe. 


\subsubsection{Washington State Initiative 297, The Cleanup Priority Act}

\section{K. Marvin}

Initiative 297, known as the Cleanup Priority Act and included in Mixed Radioactive and Hazardous Waste (RCW 70.105E), was passed by Washington State voters in November 2004. The provisions of the Cleanup Priority Act could affect a variety of operations at Hanford, depending on how the law is interpreted. Among other things, the act could restrict the importation of offsite waste to Hanford, circumscribe available disposal methods, set cleanup standards for radioactive releases, and require DOE to pay a new mixed-waste surcharge. In December 2004, the
U.S. Department of Justice sought and received a temporary restraining order from the U.S. District Court that enjoined application or enforcement of the act at Hanford or Pacific Northwest National Laboratory, except to the extent it prohibited import of mixed waste to Hanford. The U.S. Department of Justice filed a motion for summary judgment arguing the Cleanup Priority Act is preempted by federal law, violates the principle of sovereign immunity, and burdens the flow of interstate commerce in violation of the U.S. Constitution. In February 2005, the state of Washington asked the federal court to certify five issues for interpretation by the Washington State Supreme Court. The federal court agreed and then prohibited application of the entire initiative, including waste importation prohibitions, until all claims are resolved in both federal and state courts. 


\subsection{Environmental Restoration}

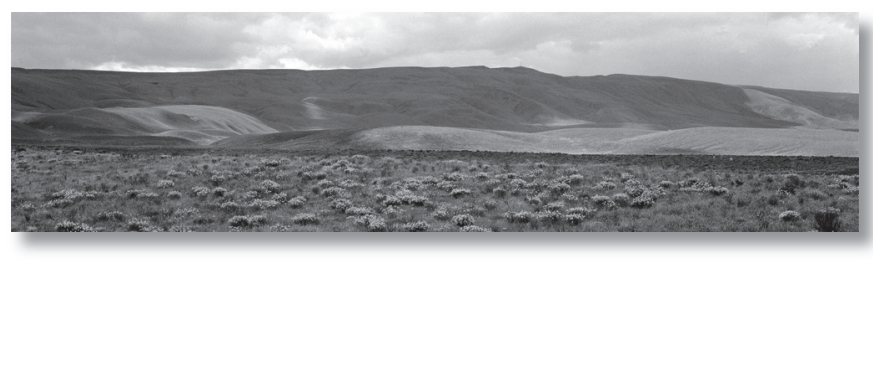

J. P. Duncan

This section describes continuing Hanford Site environmental cleanup and decommissioning activities. Included are discussions of project compliance activities, waste management, liquid effluent treatment, revegetation and mitigation, environmental restoration, groundwater protection, and waste storage tank research. Activities, accomplishments, and relevant issues are presented and discussed openly with the regulatory agencies and with the public to assure resolution. 


\subsection{Cleanup Operations}

This section describes ongoing cleanup and remediation activities on the Hanford Site.

\subsubsection{Groundwater Remediation Project}

\section{B. H. Ford}

The U.S. Department of Energy (DOE) established the Groundwater/Vadose Zone Integration Project in 1997. On July 1, 2002, the project was transferred from the environmental restoration contractor, Bechtel Hanford, Inc., to Fluor Hanford, Inc. and designated as the Groundwater Remediation Project. The Groundwater Remediation Project team includes staff from Fluor Hanford, Inc.; CH2M HILL Hanford Group, Inc.; and Pacific Northwest National Laboratory, as well as support from other national laboratories and universities. The purpose of the Groundwater Remediation Project is to coordinate all projects at the Hanford Site involved in characterization, monitoring, and remediation of groundwater and vadose zone contamination, with the overall objective of protecting the Columbia River.

The 200 Area's Waste Site Remedial Actions group within the Groundwater Remediation Project was transferred to the Central Plateau Remediation Project during 2004, and is now designated as the Decontamination and Decommissioning Project. Information on groundwater and vadose zone remediation systems in use in 2004 is summarized in Section 8.7.

\subsubsection{Waste Site Investigations and Remediation Activities in the 200 Areas}

\section{C. Hulstrom}

Remedial investigation/feasibility study activities continued during 2004 at soil waste sites in the 200 Areas. Work was performed within the characterization and regulatory framework defined in the 200 Areas Remedial Investigation/Feasibility Study Implementation Plan Environmental Restoration Program (DOE/RL-98-28). Work was performed at a number of operable units, which were at various stages of the Comprehensive Environmental Response, Compensation, and Liability Act (CERCLA) remedial investigation/feasibility study process. The following summary provides descriptions of activities that were performed during 2004.

200-CW-1 Operable Unit. The 200-CW-1 Operable Unit consists of former ponds and ditches located within the 200-East Area and north and east of the 200-East Area. These sites received cooling water from facilities such as the Plutonium-Uranium Extraction (PUREX) and B Plants. Preparation of a feasibility study for the operable unit was completed in 2003. The feasibility study refines remedial action objectives and remedial technologies originally identified in DOE/RL-98-28 and develops and evaluates remedial alternatives for the representative sites in the 200-CW-1 Operable Unit. The results of the remedial alternative evaluations of the representative sites are applied to the analogous sites in the operable unit as defined in DOE/RL-98-28. The feasibility study includes ecological screening level and baseline risk assessments. In addition to the 200-CW-1 Operable Unit waste sites, 
the 200-CW-3 Operable Unit and several other 200-North Area waste sites are included in the feasibility study based on negotiations with state and federal regulatory agencies on the Central Plateau Hanford Federal Facility Agreement and Consent Order (Tri-Party Agreement, Ecology et al. 1989) milestones. Under Tri-Party Agreement Milestone M-015-38A, the feasibility study and proposed plan were submitted to the state and federal regulatory agencies on March 31, 2003. Comments from the regulatory agencies have been incorporated. In addition, ecological sampling was conducted on two of the 200-CW-1 waste sites in the fall of 2003. Additional ecological sampling was conducted in the spring of 2004. The feasibility study is undergoing revision to incorporate the data from these sampling events and to support the public review of the proposed plan. The feasibility study report is made available during the public review of the proposed plan as supporting information since it contains much more detail than what is presented in the proposed plan.

200-CS-1 Operable Unit. The 200-CS-1 Operable Unit consists of waste sites that received sewer wastewater containing chemicals from major plant facilities in both the 200-West and 200-East Areas. A remedial investigation/feasibility study work plan (DOE/RL-99-44) was approved during 2000 that defines planned remedial investigation activities at four representative waste sites of the operable unit: the 216-S-10 pond, 216-S-10 ditch, 216-B-63 trench, and 216-A-29 ditch. A borehole at the 216-S-10 pond was installed during 1999 and completed as a Resource Conservation and Recovery Act (RCRA) groundwater monitoring well. Test pit characterization work was completed in 2002 at the 216-A-29 ditch and partially completed at the 216-B-63 trench. The final remedial investigation activities were performed in 2003 and included characterization work at the 216-B-63 trench, 216-S-10 pond, and 216-S-10 ditch. In addition, three boreholes (one at each waste site) were installed at the 216-A-29 ditch, 216-B-63 trench, and 216-S-10 ditch. The borehole at the 216-S-10 ditch was completed as a RCRA groundwater monitoring well. During 2004, the remedial investigation report (DOE/RL-2004-17), was submitted to the regulatory agencies, fulfilling Tri-Party Agreement Milestone M-015-39B. Upcoming activities for 2005 include developing a feasibility study and proposed plan, plus a closure plan for this operable unit.
200-CW-2, 200-CW-4, 200-CW-5, and 200-SC-1 Operable Units. The 200-CW-2, 200-CW-4, 200-CW-5, and 200-SC-1 consolidated operable unit group consists of waste sites that received cooling water, steam condensate, and chemical sewer waste from facilities in the 200-West Area, including the U Plant, powerhouse and laundry facilities, 242-S evaporator, Plutonium Finishing Plant and associated facilities, Reduction-Oxidation (REDOX) Plant, T Plant, Plutonium-Uranium Extraction (PUREX) Plant, and Waste Encapsulation and Storage Facility. The 200-CW-5 remedial investigation/feasibility study work plan (DOE/RL-99-66) was approved in 2000 and defined planned remedial investigation activities at one representative waste site, the 216-Z-11 ditch. This work plan directed field characterization using driven soil probes and geophysical logging to locate the area with the highest levels of transuranic contamination for subsequent borehole sampling. A revision of the work plan was issued in March 2004.

Data from the field work described in the 2000 work plan were compiled into a remedial investigation report (DOE/RL-2003-11), which was provided to the regulatory agencies for review during May 2003 in fulfillment of Tri-Party Agreement Milestone M-015-40B. Review comments were incorporated and conditional approval of the remedial investigation report was received from the U.S. Environmental Protection Agency (EPA), pending resolution of two issues. The first issue was resolved with EPA in June 2004. The requested information for the second issue was transmitted to EPA for review and approval in early 2005.

In 2003, a feasibility study was initiated to evaluate the remedial alternatives that could be applied to the waste sites in the 200-CW-2, 200-CW-4, 200-CW-5, and 200-SC-1 Operable Units. This feasibility study (DOE/RL-2004-24), was submitted to the state and federal regulatory agencies for review, fulfilling the Tri-Party Agreement Milestone M-15-40C. Work in 2005 will concentrate on finalizing the document and preparing a proposed plan for public review.

200-LW-1 and 200-LW-2 Operable Units. The waste sites in the 200-LW-1 and 200-LW-2 Operable Units received two types of waste: liquid waste resulting from 300 Area process laboratory operations that supported radiochemistry metallurgical experiments and liquid 
waste resulting mainly from laboratory operations in the 200 Areas that supported the major chemical processing facilities and equipment decontamination at T Plant. A work plan (DOE/RL-2001-66), was approved in 2002 that requires remedial investigation activities at four representative waste sites (216-T-28 crib, 216-B-58 trench, 216-S-20 crib, and 216-Z-7 crib) in the 200-LW-1 and 200-LW-2 Operable Units and includes borehole drilling, soil sampling, and geophysical logging. During late 2003, two 30.4-meter- (100-foot-) deep boreholes were drilled in the 216-B-58 trench in anticipation of the transfer of four 200-LW-1 Operable Unit waste sites in the BC cribs and trenches area into the 200-TW-1 Operable Unit. In May 2004, the transfer of these sites was completed. Field activities at the 216-T-28 and 216-S-20 cribs were completed in the fall of 2004. Activities at the 216-Z-7 crib were scheduled to occur in the spring of 2005.

200-MW-1 Operable Unit. The waste sites in the 200-MW-1 Operable Unit consist mainly of cribs, French drains, and trenches that received moderate to low volume equipment decontamination waste and ventilation system waste plus small volume waste streams commonly disposed to French drains. A work plan (DOE/RL2001-65) was approved during 2002, which requires remedial investigation activities at five representative waste sites (216-A-4 crib, 216-T-33 crib, 216-T-13 trench, 216-U-3 French drain, and 200-E-4 French drain) in the 200-MW-1 Operable Unit. The investigative work includes installing vadose zone boreholes and test pits to collect soil samples and do geophysical logging. In 2004, pre-job planning activities were completed and a borehole was begun at the 216-A-4 crib. Work on this borehole was temporarily halted because of unexpected high levels of radioactive contamination. A re-assessment of the plan for this borehole is being conducted. In parallel with this activity in late 2004, a borehole at the 216-U-3 French drain was initiated and completed in January 2005. A borehole at the 216-T-33 crib is planned during 2005, followed by completion of a test pit at the 216-T-13 trench and an auger hole at the 200-E-4 French drain.

200-PW-2 and 200-PW-4 Operable Units. Waste sites in the 200-PW-2 Operable Unit received uranium-rich condensate and process waste, primarily from waste streams generated at the U Plant, Reduction-Oxidation (REDOX) Plant, Plutonium-Uranium Extraction (PUREX) Plant, B Plant, and semi-works facilities. Waste sites in the
200-PW-4 Operable Unit received mostly process drainage, process distillate discharge, and miscellaneous condensates from the same facilities including condensates from S and A Tank Farms and the 242-A evaporator. The original draft work plan (DOE/RL-2000-60) was prepared and submitted to the regulatory agencies for review in December 2000. The revised work plan, which received regulatory agency approval in February 2003 to proceed with field work, proposed remedial investigation activities at six representative waste sites (216-A-19 trench, 216-B-12 crib, 216-A-10 crib, 216-A-36B crib, 216-A-37-1 crib, and 207-A south retention basin) and consolidated the 200-PW-4 Operable Unit into the work scope associated with the 200-PW-2 Operable Unit. Field work was completed in October 2003 and included installing vadose zone boreholes to collect soil samples and conducting geophysical logging. In addition, five drive casings (steel tubes driven into the ground) were installed and geophysically logged at the 216-A-10 crib to determine the optimum location for the characterization borehole that was installed in 2003. Evaluation of the data was initiated in conjunction with preparation of the remedial investigation report for these operable units. This report (DOE/RL2004-25) was provided to the regulatory agencies in June 2004 for review, fulfilling Tri-Party Agreement Milestone $\mathrm{M}-15-43 \mathrm{~B}$. Investigation of an additional waste site, the 216-S-7 crib, was added to the scope of this operable unit in early 2004 and included in Revision 1 of the work plan, which was approved in July 2004. Field work at this site took place in late 2004 following completion of pre-job planning activities. Results of the investigation of this site will be included in the feasibility study scheduled to be prepared during 2005.

\section{0-TW-1, 200-TW-2, and 200-PW-5 Operable Units.}

The 200-TW-1 Operable Unit consists of waste sites, mostly cribs and trenches, which received waste associated with uranium recovery activities at $\mathrm{U}$ Plant. The 200-TW-2 Operable Unit consists of waste sites, mostly cribs and trenches, which received waste from the decontamination processes at B Plant and T Plant. The 200-PW-5 Operable Unit consists of cribs, French drains, and locations of unplanned releases that received similar types of wastes and quantities of effluents as the 200-TW-2 Operable Unit. The work plan for the operable unit (DOE/RL-2000-38) prescribed remedial investigation at three representative waste sites (216-T-26 crib in the 
200-TW-1 Operable Unit, and the 216-B-7A crib and 216-B-38 trench in the 200-TW-2 Operable Unit). The field efforts for these operable units were completed in 2001 and consisted of installing three vadose zone boreholes (one each at the 216-T-26 crib, the 216-B-38 trench, and the 216-B-7A crib), collecting soil samples, and geophysical logging. Data from the laboratory analyses were compiled into a remedial investigation report (DOE/RL-2002-42), which was submitted to state and federal regulatory agencies in 2003 under Tri-Party Agreement Milestone M-015-41B. The remedial investigation report included a human health risk assessment and a screening of ecological impacts. In late 2003, following preparation and approval of a sampling and analysis plan, a borehole was drilled in the 216-B-26 trench. (The 216-B-26 trench is located within the BC cribs and trenches area. Because of the waste stream it received, the 216-B-26 trench was designated as a site assigned to the 200-TW-1 Operable Unit.) A feasibility study (DOE/RL2003-64) and proposed plan (DOE/RL-2004-10) to evaluate remedial alternatives to address the contamination at the waste sites in the combined 200-TW-1, 200-TW-2, and 200-PW-5 Operable Units were submitted in April 2004. Submittal of these documents satisfied the requirements for Tri-Party Agreement Milestone M-15-41C. Comments from the regulatory agencies included a request to separate the documents into smaller segments, with the initial focus on the $\mathrm{BC}$ cribs and trenches area waste sites. Work began on a focused feasibility study and associated proposed plan for the $\mathrm{BC}$ cribs and trenches area wastes sites in mid2004.

BC Cribs and Trenches Area. The BC cribs and trenches area was identified for accelerated closure during 2003. Two trenches were identified for further characterization to facilitate an eventual decision regarding remedial action. The 216-B-58 trench, previously selected as a representative site for the 200-LW-1 Operable Unit, was the focus of two boreholes in 2003. The first borehole was located at the point of apparent highest concentration. The second borehole was drilled following the unexpected discovery of low cobalt- 60 concentrations at the west end of the trench during geophysical logging of drive casings that were placed to determine the point in the trench having highest contamination. The 216-B-26 trench, in the 200-TW-1 Operable Unit, was also sampled following approval of a sampling and analysis plan (DOE/RL-2003-44).
Specific data from waste sites within the $\mathrm{BC}$ cribs and trenches area were deemed essential to adequately characterize waste sites in this area. Efforts were also completed to transfer four 200-LW-1 Operable Unit waste sites in the $\mathrm{BC}$ cribs and trenches area to the 200-TW-1 Operable Unit. This assembly of waste sites will be included in a focused feasibility study and proposed plan for remediation of the $\mathrm{BC}$ cribs and trenches area waste sites that will be submitted for regulatory review in 2005.

\section{0-PW-1, 200-PW-3, and 200-PW-6 Operable Units.}

The 200-PW-1 Operable Unit contains waste sites that received significant quantities of carbon tetrachloride and plutonium as well as other contaminants associated with process waste from the Plutonium Finishing Plant. This operable unit also includes the carbon tetrachloride plume in the vadose zone that has migrated beyond the boundaries of the waste sites. A remedial investigation/feasibility study work plan for this operable unit was submitted for review during 2001 (DOE/RL-2001-01, Draft A). The work plan included a strategy to reach final decisions for remediation of carbon tetrachloride in the 200-West Area. The work plan was revised to include the 200-PW-3 and 200-PW-6 Operable Units. The 200-PW-3 Operable Unit waste sites received organic-rich process waste from separation facilities such as the Reduction-Oxidation (REDOX) Plant, Plutonium-Uranium Extraction (PUREX) Plant, U Plant, and C Plant. The 200-PW-6 Operable Unit waste sites received plutonium-rich process waste from the Plutonium Finishing Plant. The revised work plan (DOE/RL-2001-01, Rev. 0) was approved during 2004.

The remedial investigation at the 200-PW-1 Operable Unit is expected to focus on one representative waste site, the 216-Z-9 trench, and on other potential sources of carbon tetrachloride contamination. The first step in the carbon tetrachloride vadose zone investigation began during 2002 and was completed in 2003 (CP-13514). Soil-vapor sampling and analysis were used to explore the shallow vadose zone in the vicinity of the Plutonium Finishing Plant. The sampling was conducted at engineered structures that had the potential to release carbon tetrachloride to the vadose zone. The engineered structures included liquid waste discharge sites, pipelines that conveyed liquid waste to those discharge sites, and solid waste burial ground trenches. The second step in the carbon tetrachloride investigation will extend deeper in the vadose zone and to locations beyond the study area 
investigated during the first step. The representative waste site investigation includes soil sampling, soil-vapor sampling, and geophysical logging during drilling of a slant borehole beneath the 216-Z-9 trench. The representative waste site investigation and initiation of the second step in the carbon tetrachloride vadose zone investigation are scheduled for 2005.

The remedial investigation at the 200-PW-3 Operable Unit is expected to focus on one representative waste site, the 216-A-8 crib. The representative waste site investigation, which includes soil sampling and geophysical logging, is scheduled for 2005. Through the process of consolidating these three operable units, it was determined that no specific investigation of waste sites in the 200-PW-6 Operable Unit was required.

200-SW-1 and 200-SW-2 Operable Units. The 200-SW-1 Operable Unit includes a number of nonradioactive landfills and dump sites that were created during the construction and operation of the 200 Areas facilities. Although a few sites were excavated engineered structures that were operated in a manner to contain waste releases, most sites were accumulation points for materials not regarded at the time to be potentially hazardous. The 200-SW-2 Operable Unit includes engineered burial grounds that were constructed to receive radioactive waste. The dry waste burial grounds received all types of miscellaneous radioactive waste and the industrial burial grounds received large pieces of failed or obsolete equipment from the chemical processing facilities. A remedial investigation/feasibility study work plan for these operable units was submitted for regulatory review during 2004 (DOE/RL-2004-60), fulfilling Tri-Party Agreement Milestone M-13-000.

200-IS-1 and 200-ST-1 Operable Units. The 200-IS-1 Operable Unit consists primarily of pipelines, diversion boxes, catch tanks, and related structures used to transfer single-shell tank waste within and between the 200 Areas. These facilities are the responsibility of the tank farms (groupings of underground waste-storage tanks) contractor, CH2M HILL Hanford Group, Inc. Also included in this operable unit are five RCRA treatment, storage, and disposal unit tanks belonging to Fluor Hanford, Inc., the 241-CX-70, 241-CX-71, and 241-CX-72 tanks, and the 276-S-141 and 276-S-142 tanks. The 200-ST-1 Operable Unit consists of septic tanks and tile fields that are thought to have potentially received minor quantities of radioactively contaminated liquid waste from showers, floor drains, and janitor sinks. Work on the 200-IS-1 and 200-ST-1 Operable Units was resumed in 2004 with the preparation and release of Revision 1, Draft A of the work plan (DOE/RL-2002-14). This revision of the work plan addressed a series of comments and requirements submitted by the Washington State Department of Ecology following their review of Revision 0 of the work plan in 2002. Through a series of technical meetings, a strategy for the work plan was developed to address the comments, acceptable to both Fluor Hanford, Inc. and CH2M HILL Hanford Group, Inc. Sixteen site profiles were identified for the 200-IS-1 Operable Unit pipelines that provided a basis from which to develop a remediation strategy during the remedial investigation/feasibility study process. The work plan was submitted to the Washington State Department of Ecology in December 2004 for their review.

Simultaneously, an operable-unit-based pipeline mapping activity was restarted in 2004, picking up from work previously performed in 2002. Mapping is a process by which historical drawings are reviewed, coordinates and other key attributes are documented, and detailed location maps are generated. In the 2002 effort, an estimated $40 \%$ of the pipelines leading to waste disposal sites were mapped, including pipelines in six operable units. Another 49 lines were identified for mapping in 2004, nearly completing work for another four operable units. These 49 pipelines will be mapped during 2005 . The need to coordinate pipeline mapping activities between the tank farms contractor and Fluor Hanford, Inc. has been recognized as an integral part of remediation activities, and efforts are being made to track pipeline mapping activities in a centralized mapping system.

200-UR-1 Waste Group Operable Unit. The 200-UR-1 Waste Group Operable Unit includes unplanned release sites that generally consisted of small volume spills to the ground surface or subsurface or windblown radioactive particulates, plant materials, and/or animal feces. Many of the unplanned release sites in the 200 Areas resulted from loss of control of radioactive materials during waste transfer or loss of containment in areas with process facilities, roads, railroad lines, or tank farms. A small number of unplanned release sites were associated with burial grounds, trenches, and cribs. Causes for the releases were attributed to administrative failures, equipment failures, 
and operator error as well as to vegetation and animal intrusion. In fall 2003, a work plan and data quality objectives process were initiated. The data quality objectives process grouped the 147 unplanned release sites to allow consistent and streamlined remedial decision making. A work plan (DOE/RL-2004-39) was issued to the regulatory agencies in June 2004, fulfilling the requirements of Tri-Party Agreement Milestone M-013-00N. Comments from the Washington State Department of Ecology are being incorporated and the Revision 0 version is expected to be issued in 2005. The Revision 0 version of the data quality objectives summary report (WMP-19920) has been prepared and is also expected to be issued in 2005 .

Significant changes to the scope of this work plan that resulted from the Washington State Department of Ecology comments were the addition of the West Lake waste site (216-N-8) to the operable unit and the decision to perform the full remedial investigation/feasibility study process for West Lake and the BC cribs Controlled Area.

200-BP-1 Prototype Barrier. The 200-BP-1 prototype barrier is a surface barrier to reduce the infiltration of water that drives contaminants through the soil to groundwater. Monitoring of the performance of the 200-BP-1 prototype barrier continued during 2004. Activities included water balance monitoring, stability surveys, and biotic surveys. A draft report to document the monitoring results was prepared during 2004.

U Plant Closure Area. The U Plant Closure Area Project is a prototype for area closures that will focus on addressing high-risk sites and associated contiguous areas in a cost-effective and integrated manner. Key components of this strategy include cleanup of waste sites, facilities, and pipelines within a defined geographic area. For this area closure, it is anticipated that separate records of decision will be needed for the high-risk sites, the 221-U facility, and for the 200-UP-1 Groundwater Operable Unit. Also, separate engineering evaluations, cost analyses, and action memoranda will be needed for ancillary facilities and pipelines. These components are being executed separately because they require distinct alternatives and specific responses. A Focused Feasibility Study for the U Plant Closure Area Waste Sites (DOE/RL-2003-23) and the Proposed Plan for the U Plant Closure Area Waste Sites (DOE/RL-2003-24) was submitted to EPA and the Washington State Department of Ecology on June 27, 2003, which satisfied Tri-Party Agreement Milestone M-015-47. The focused feasibility study and proposed plan continued to undergo regulatory review and comment resolution during 2004. The most recent version of the proposed plan recommends that 4 high-risk cribs (216-U-1, 216-U-2, 216-U-8, and 216-U-12) be modified with barriers or caps; a remove-and-dispose alternative be implemented at 14 waste sites (e.g., trenches, unplanned release sites, French drains, and one pipeline); institutional controls, monitoring of natural attenuation, and maintenance of existing soil cover be implemented at 8 sites (e.g., cribs, reverse injection wells, and septic systems); and no action be taken at 4 sites (e.g., dump sites and septic tanks). The record of decision on the proposed plan is expected to be issued in 2005 and remedial action initiated in 2006. A remedial design report and remedial action work plan for these waste sites are expected to be completed in 2005 . To support confirmation of the proposed actions and collect needed remedial design data, the Data Quality Objectives Summary Report for the U Plant Closure Area Waste Sites (CP-16244) was completed in 2003.

Regulatory agencies continued their review of a sampling and analysis plan (DOE/RL-2003-51) during 2004 based on the data quality objectives. The document is expected to be issued in 2005. Characterization activities conducted in 2004 in the U Plant Closure Area included installation of 30 drive casings to facilitate spectral gamma logging at the 216-U-1, 216-U-2, 216-U-8, and 216-U-12 high-risk cribs.

Central Plateau Ecological Risk Assessment. An ecological risk assessment that includes a data quality objectives process and a field characterization effort was initiated for the Central Plateau in October 2004. This ecological risk assessment is being performed to support remedial decision making for all of the operable units within the Central Plateau area, to determine the health of the ecosystem on and surrounding the Central Plateau, and to provide information that can assist the Hanford Natural Resource Trustee Council (see Section 2.0.3). There are three phases to this effort: Phase I focuses on Central Plateau CERCLA waste sites; Phase II addresses single-shell and double-shell tank farms, the US Ecology, Inc. site, West Lake, and the BC Controlled Area; and Phase III investigates habitat surrounding the 200-East and 200-West Areas as well as the potential for additional characterization in the areas addressed in Phases I and II. 
Phase I and II field characterizations will be performed during the spring and summer of 2005. Phase III field characterization is scheduled for the spring and summer of 2006. A final ecological risk assessment will be performed in 2007 to summarize the results of the field characterizations and to assess the risks to the ecological receptors. Results from the risk assessment will feed into remedial decision making for all of the Central Plateau operable units. This phased approach supports Tri-Party Agreement Milestone M-015-00 for completion of the remedial investigation/feasibility study process for all operable units by December 31, 2008.

\subsubsection{Cleanup and Remediation Activities in the 100 Areas}

This section describes the cleanup and remediation activities occurring within the 100 Areas.

\subsubsection{K Basins Closure Activities}

\section{S. Gerber}

For 10 years, cleanout of the $\mathrm{K}$ Basins was managed by the Spent Nuclear Fuel Project. This project was established in February 1994 to provide safe, economical, and environmentally sound management of Hanford Site spent (irradiated) nuclear fuel and to prepare the fuel for long-term storage leading to final disposal. Most of Hanford's spent nuclear fuel was stored in the $\mathrm{K}$ Basins, attached to the now deactivated K-East and $\mathrm{K}$-West Reactors. The $\mathrm{K}$ Basins contained 2,100 metric tons (2,300 tons) of Hanford N Reactor spent fuel and a small quantity of irradiated single-pass reactor fuel (fuel from older Hanford reactors).

The Spent Nuclear Fuel Project successfully removed the spent fuel from underwater storage in the K Basins, dried it, and placed it in dry interim storage in the 200-East Area. Fuel in the K-East Basin was transferred into the K-West Basin for processing. In the K-West Basin, the fuel was cleaned (washed) and packaged into containers called multi-canister overpacks. The multi-canister overpacks were then vacuum processed to remove any water and mechanically sealed at the Cold Vacuum Drying Facility located in the 100-K Area. The dried overpacks were then transported to the Canister Storage Building in the 200-East Area where they were placed in storage in belowground steel tubes.

After an observation period, each multi-canister overpack was brought back to the ground-level operating deck of the Canister Storage Building. In 2003, crews began welding permanent steel caps over the mechanical seals of the multi-canister overpacks. The multi-canister overpacks are being maintained in dry storage pending a federal decision on final disposition. If necessary, the re-packaged spent fuel could remain in dry storage for up to 40 years. Fuel removal from the $\mathrm{K}$ Basins was a binding commitment in the Tri-Party Agreement.

In mid-2004, responsibility for $\mathrm{K}$ Basins cleanout passed to the new K Basins Closure Project, and the Spent Nuclear Fuel Project was phased out.

During 2004, the Spent Nuclear Fuel Project, later the $\mathrm{K}$ Basins Closure Project, made progress in cleaning out the $\mathrm{K}$ Basins as follows:

- Completed all shipments (370 shipments) of fuel from the K-East Basin to the K-West Basin.

- Removed and dried the last 93 multi-canister overpacks of fuel from the K-West Basin, completing a total of 386 shipments to achieve 100\% completion, satisfying a major Tri-Party Agreement milestone. Over 1.8 million kilograms (4 million pounds) of fuel, containing over 50 million curies (1,850 million gigabecquerels) of radioactivity, were removed from the K-West Basin.

- Welded 170 multi-canister overpacks with permanent, N-Stamped closure welds (those meeting the highest nuclear quality standards of the American Society of Mechanical Engineers), for a total of 290 multi-canister overpacks welded by year's end. This welding effort remained consistently ahead of schedule.

- Continued the washing and load-out of aged fuel canisters from the $\mathrm{K}$ Basins for disposal as low-level nuclear waste. By the end of 2004, 5,830 cans (78\% of the total) had been washed and disposed. Also $100 \%$ of the contaminated, long-handled pole tools from the K-West Basin (212 tools) were removed, washed, and packaged as waste. 
- Began pumping sludge from two locations in the $\mathrm{K}$-East Basin, with two pumping systems, in June and October 2004. By the year's end, nearly $25 \%$ of the total sludge volume in the K-East Basin had been transferred to containers.

- Sealed the discharge chute of the K-East Basin permanently closed by filling it with special cement called grout. Putting grout in the discharge chute resolved some key environmental issues because it sealed the construction joint between the K-East Basin and the K-East Reactor structure, a joint that had leaked contaminated water to the environment in the past. Also, placing grout in the discharge chute permanently removed approximately 397,000 liters (105,000 gallons) of contaminated water from the K-East Basin (about 10\% of the total water volume).

- Successfully demonstrated an underwater hydrolasing technique that will remove and clean the contaminated outermost surface of the K Basins walls and floor. By the end of 2004, the K Basins Closure Project was actively procuring full-scale hydrolasing equipment, in preparation for beginning to hydrolase the K-East Basin walls in mid-2005.

\subsubsection{Remediation of Waste Sites in the 100 Areas}

\section{J. W. Donnelly and A. K. Smet}

Full-scale remediation of waste sites in the 100 Areas began in 1996. Remediation activities in 2004 were performed in multiple areas of the 100 Areas, including 100-B/C, 100-K, and 100-N. Additionally, backfill activities were completed in portions of the 100-F Area and 100-B/C Area. Various records of decision authorized the remediation activities and were issued by DOE, EPA, and the Washington State Department of Ecology. At the 100-N Area, remediation of the treatment, storage, and disposal units is performed in accordance with the Hanford Facility RCRA Permit (Ecology 1994). Figure 1.0.1 shows the former reactor areas along the Columbia River.

A total of 470,060 metric tons (518,006 tons) of contaminated soil from the 100 Areas remediation activities was disposed of at the Environmental Restoration Disposal Facility:

- 104,018 metric tons (114,628 tons) from the $100-\mathrm{B} / \mathrm{C}$ Area.
- 318,221 metric tons $(350,679$ tons) from the $100-\mathrm{K}$ Area.

- 47,821 metric tons (52,699 tons) from the $100-\mathrm{N}$ Area.

Since cleanup activities began in 1996, the primary focus has been on liquid effluent waste sites. After nearly 8 years of work, the number of liquid effluent waste sites requiring remediation is significantly reduced and nearing completion. Cleanup activities now focus on remediation of burial ground waste sites. The volume of contaminated soil in burial grounds is less than that found at liquid effluent sites. Burial grounds are presenting challenges because unknown material has been discovered, requiring additional time to characterize and properly dispose of the waste. Also, unknown material may require revisions to the authorization basis documents including assumptions and inventory data.

\subsubsection{Cleanup and Remediation Activities in the 300 Area}

\section{J. A. Lerch}

Remediation work at the 300-FF-1 Operable Unit began in the 300 Area in 1997 and was completed in 2003. Backfill and re-grading operations at the remediated 300-FF-1 waste sites began in November 2003 and were completed February 2004. No additional remediation is necessary in this operable unit.

The 300-FF-2 record of decision (EPA 2001) authorizes remediation activities for the 300-FF-2 Operable Unit. Remediation for the 300-FF-2 Operable Unit began in September 2002.

In $2004,21,640$ metric tons (23,800 tons) of contaminated soil resulting from 300 Area remediation activities were removed and disposed of at the Environmental Restoration Disposal Facility. 


\section{Revegetation of 300 Area Waste Sites}

\section{A. L. Johnson}

Bechtel Hanford Inc.'s Remedial Action Project remediated the 300-FF-1 Operable Unit (as well as several 300-FF-2 Operable Unit waste sites, which were selected based on proximity to waste sites in the 300-FF-1 Operable Unit) waste sites in the 300 Area under the record of decision (EPA 1996b) for the 300-FF-1 Operable Unit. During 2004, the remediated sites were backfilled with fill material from Pit 6, which is located on the west side of Stevens Drive adjacent to the 300 Area complex. Following backfill, the entire area disturbed during remedial actions, approximately 28 hectares (70 acres), was revegetated. Revegetation was performed with guidance provided in the Hanford Site Biological Resources Management Plan (DOE/RL-96-32). The plan prescribed industrial areas to be stabilized with crested wheatgrass (Agropyron cristatum). To promote a more diverse plant community, the backfilled and recontoured area was broadcast seeded with 11.2 kilograms per hectare (10 pounds per acre) Sandberg's bluegrass (Poa sandbergii), 11.2 kilograms per hectare (10 pounds per acre) crested wheatgrass, 5.6 kilograms per hectare ( 5 pounds per acre) Regreen (Agropyron hybrid), 5.6 kilograms per hectare ( 5 pounds per acre) Indian ricegrass (Oryzopsis hymenoides), 5.6 kilograms per hectare ( 5 pounds per acre) thickspike wheatgrass (Agropyron dasytachyum), 5.6 kilograms per hectare (5 pounds per acre) bluebunch wheatgrass (Agropyron spicatum), and 2.45 kilograms per hectare (2.2 pounds per acre) needle-and-thread grass (Stipa comata). To help prevent soil erosion and promote successful germination, 16.8 kilograms per hectare (15 pounds per acre) Terra Bond was co-applied during seeding. Straw mulch was distributed across the site and crimped with a serrated disk.

\subsubsection{Cleanup and Remediation Activities in the 600 Area}

In July 2004, the annual update of the 618-10 and 61811 Waste Burial Grounds Basis for Interim Operations (CP-14592) was completed. The basis for interim operations is a type of documented safety analysis that defines the hazards associated with surveillance, characterization, and groundwater monitoring activities within the burial grounds. It is a requirement of 10 CFR 830, Nuclear Safety Management, that an annual update be performed and issued. Activities associated with an unreviewed safety question process (a nuclear facilities requirement promoting safe operations) and preliminary remedial design for these burial grounds continued. An update to a 1995 geophysical survey (WMP-21465) was completed at both burial grounds in 2004. To support completion of Tri-Party Agreement Milestone M-016-66, a preliminary design basis and design criteria report (WMP-20394) was issued on September 30, 2004. In addition to this document, other activities conducted in 2004 included the completion of a biological and cultural review; completion of initial engineering site layout drawings detailing the location of proposed roads, facilities, and utilities; generation of a historical-document database; completion of several technical specifications; update of previous waste volume calculations; drafting of an air monitoring plan for monitoring during remediation activities; and the completion of a document (D\&D-23840) summarizing the radiological survey records for both burial grounds. In parallel with these design activities, a program to demonstrate technologies for the in situ delineation and excavation of transuranic waste using innovative technologies was continued. As part of this program, contractor teams worked on developing the necessary safety basis documents and conducted initial demonstration tests at facilities near the Hanford Site. 


\subsection{Facility Decommissioning Activities}

This section provides information about the transition of facilities on the Hanford Site from operation to stabilization, surveillance and maintenance, and decommissioning. Decommissioning activities include the interim safe storage of plutonium production reactors and the decommissioning of ancillary reactor facilities.

\subsubsection{Facility Decommissioning in the 200 Areas (Central Plateau)}

This section provides information about the transition and decommissioning of facilities within the 200 Areas.

\subsubsection{Decommissioning of the 224-T Plutonium Concentration Facility}

\section{R. Haas and D. L. Klages}

The 224-T Plutonium Concentration Facility (224-T facility) is currently an inactive surplus facility and is administered under a surveillance and maintenance program while awaiting final disposition. DOE has identified no further use for the 224-T facility, making the facility a candidate for decontamination and decommissioning.

Presently, the decontamination and decommissioning project for the 224-T facility, which is to be accomplished as a CERCLA non-time-critical removal action, has been deferred to a later time because of limited funding and the need to complete more significant priorities.

The 224-T facility is located in the 200-West Area, to the south and parallel to the T Plant Complex Canyon Building (221-T). (Canyon is a vernacular term used at the Hanford Site for the chemical separations plants, inspired by their long, high, narrow structure.) Completed in 1944 and originally designated the 224-T Bulk Reduction Building, the purpose of the 224-T facility was to concentrate the plutonium nitrate solution produced in the first major step during the plutonium recovery process conducted at the T Plant complex. It operated in this capacity from January 16, 1945, until early 1956, when the $\mathrm{T}$ Plant complex was retired from active service as a chemical processing facility.

The 224-T facility was idle before being modified in 1975 to meet the requirements for storing plutonium-bearing waste. In 1985, the building became the 224-T Waste Storage and Assay Facility and operated in that capacity until the late 1990s. These past operations resulted in contamination throughout the structure.

\subsubsection{Decommissioning of the 224-B Plutonium Concentration Facility}

\section{L. Klages}

The 224-B Plutonium Concentration Facility (224-B Building) is located within the B Plant complex in the 200-East Area. The 224-B Building is a deactivated plutonium concentration facility that formerly was associated with the B Plant complex.

The 224-B Building was used to facilitate plutonium recovery following the reprocessing of spent nuclear fuel. The 224-B Building was used to purify and concentrate diluted plutonium nitrate solution that was the product of the 221-B (B Plant complex) bismuth-phosphate process. The purified solution was transferred to the 231-Z Isolation Building. Plutonium concentration operations were 
performed in conjunction with B Plant complex separations activities from approximately 1944 to 1952 . The process components were deactivated shortly thereafter. These past operations resulted in contamination throughout the process portion of the structure.

In addition to the 224-B Building, the area adjacent to the facility, which is identified as the B Plant construction laydown yard, was included as part of the CERCLA nontime-critical removal action. The B Plant laydown yard is located south of the 221-B Building in the 200-East Area. The laydown yard contains potentially radiologically contaminated materials, equipment, mobile offices, and miscellaneous trailers. The 224-B Building and the additional laydown yard structures and equipment will be included as part of this response action and will be identified as the 224-B facility.

The B Plant construction laydown yard has a history of contaminated biological components including rodents, tumbleweeds, and fruit flies. The source of contamination that led to the 1998 fruit fly contamination event was the 241-ER-152 diversion box located in the laydown yard. Trailers, materials, and equipment in the vicinity of this diversion box were placed within a Radiological Buffer Area until surveys could be performed to verify the presence or absence of radiological contamination.

After the 1998 fruit fly contamination event, there were efforts to survey some of the trailers, materials, and equipment within the laydown yard for reuse or excess. Specks of low-level fixed contamination were found on a small number of tools, equipment, and building surfaces. These specks are believed to be tumbleweed fragments, mouse feces, and/or fruit fly remnants.

The 224-B Facility Decommissioning Project for the B Plant construction laydown yard was conducted as a non-time-critical removal action under CERCLA and involved the safe demolition, waste packaging, and disposal of 23 contaminated structures, including mobile trailers and storage units, in the B Plant construction laydown yard. Demolition began in June 2004 and was completed in September 2004.

\subsubsection{Decommissioning of the 233-S Plutonium Concentration Facility}

\section{L. Klages}

Decontamination and demolition activities were completed in 2004 at the 233-S Plutonium Concentration Facility (233-S facility) located in the 200-West Area adjacent to the Reduction-Oxidation (REDOX) Plant. The 233-S facility and associated process equipment were used to concentrate plutonium produced at the REDOX Plant from 1955 to 1967.

The 233-S Facility Decommissioning Project was conducted as a non-time-critical removal action under CERCLA and involved the safe demolition, waste packaging, and disposal of the 233-S facility. The scope of this project included the demolition of the 233-S Plutonium Concentration Building, the 233-SA Exhaust Filter Building, and the Mobile Office-317. This project represented the first open-air demolition of a highly contaminated plutonium facility at the Hanford Site. This project may also represent the first plutonium facility in the DOE complex to have been demolished without first decontaminating surfaces to near "free release" standards. This project used an excavator with concrete shears, diamond circular saws, water misting and fogging equipment, commercially available fixatives and dust suppressants, conventional mobile crane and rigging services, and near real-time modeling of meteorological and radiological conditions. Following a significant amount of preparation, actual demolition of the 233-S facility began in October 2003 and was completed in late April 2004.

\subsubsection{Removal of Ancillary Facilities at the 221-U Chemical Processing Facility}

\section{L. Klages}

The 221-U Chemical Processing Facility (U Plant) ancillary facilities are being decontaminated and demolished as a CERCLA non-time-critical removal action. The 
facilities are located within the U Plant complex in the 200-West Area and consist of processing, support, and administrative buildings.

The main building associated with the U Plant ancillary facilities is the Uranium Trioxide Facility (224-U), which was used to convert uranyl nitrate hexahydrate solution from the Plutonium-Uranium Extraction (PUREX) Plant into a solid uranium trioxide powder. The Uranium Trioxide Facility's processing schedule was determined by the uranium product inventory buildup in the PlutoniumUranium Extraction (PUREX) Plant. The last operating campaign was completed in June 1993. Deactivation of the facility began shortly thereafter. The Uranium Trioxide Facility is designated as a key facility in the Tri-Party Agreement (Ecology et al. 1989). The majority of the other U Plant buildings and structures were used in support of the uranium trioxide process.

The U Plant ancillary facilities removal action began in November 2004 and demolition of at least 11 of the structures will begin in January 2005. Demolition of the 224-U and 224-UA Buildings is expected to be deferred to coincide to the remedial action for the 221-U Canyon Facility.

\subsubsection{Decommissioning of the Plutonium Finishing Plant}

\section{S. Gerber}

During 1949, the Plutonium Finishing Plant began processing plutonium nitrate solutions into metallic plutonium for shipment to nuclear weapons production facilities. Operation of this plant continued into the late 1980s. During 1990, DOE issued a shutdown order for the plant, and in 1996 authorized deactivation and transition of the plutonium processing portions of the facility in preparation for decommissioning.

Workers at the Plutonium Finishing Plant complex embarked on a large and multifaceted effort to stabilize, immobilize, re-package, and/or properly dispose of nearly 18 metric tons (19.8 tons) of plutonium-bearing materials in the plant, and completed this mission in February 2004. The workers then turned their full energies to a large closure project, to decontaminate and deactivate the processing facilities, while still providing for the safe and secure storage of nuclear materials until final disposition.
Significant accomplishments achieved at the Plutonium Finishing Plant during 2004 included:

- Completing stabilization of all (nearly 18.1 metric tons [20 tons]) plutonium-bearing scraps and leftovers identified by the Defense Nuclear Facilities Safety Board as needing stabilization and repackaging.

- Shipping 4.5 metric tons (5 tons) of re-packaged plutonium-bearing residues off of the Hanford Site to permanent disposal at the Waste Isolation Pilot Plant in Carlsbad, New Mexico.

- Cleaning out contaminated equipment from seven plutonium processing gloveboxes, allowing the gloveboxes to be downgraded to low-level radioactive waste status. Plant workers were cleaning out equipment from several other gloveboxes by the end of 2004 .

- Removing nearly $50 \%$ of the designated legacy plutonium remaining in processing equipment in Plutonium Finishing Plant facilities.

- Completing a chemical risk mitigation program in the main Plutonium Finishing Plant building (the 234-5Z facility) and in the Plutonium Reclamation Facility by flushing, draining, capping, and/or removing 128 pipes and headers contaminated with mixed transuranic waste.

- Entering the highly contaminated Plutonium Reclamation Facility canyon area for the first time in 11 years to re-activate the canyon crane and perform decontamination work necessary to use the crane in upcoming cleanout work. Nearly 20 entries were made by the end of 2004 .

- Transferring the last batch of liquid wastes from the 241-Z Liquid Waste Treatment Facility to Hanford Site tank waste storage, 7 months ahead of a Tri-Party Agreement milestone. The transfer ended 55 years of contaminated liquid waste transfers out of the 241-Z facility.

- Entering the sump pits beneath the 241-Z facility to perform characterization and cleanout work. When inspection showed that cover blocks over the sump pits were thinning, workers constructed a safe new platform to conduct work in the 241-Z facility.

- Decontaminating 176 of 625 large highly contaminated drums that once held plutonium nitrate stored beneath the 234-5Z facility. 
- Removing eight uncontaminated ancillary buildings within the Plutonium Finishing Plant complex and creating over 929 square meters (10,000 square feet) of new storage space for transuranic waste being prepared for shipment off the Hanford Site.

\subsubsection{Surveillance, Maintenance, and Deactivation Activities in the 200 Areas and on the Fitzner/Eberhart Arid Lands Ecology Reserve Unit}

\section{G. J. LeBaron}

Disposition of 200 Areas facilities includes the surveillance, maintenance, and deactivation of buildings and waste sites in the 200-East, 200-West, and 200-North Areas, and on the Fitzner/Eberhardt Arid Lands Ecology Reserve Unit.

Facilities include interim status RCRA treatment, storage, and disposal units awaiting closure, the canyon facilities (Plutonium-Uranium Extraction Plant [PUREX], B Plant, Reduction-Oxidation [REDOX] Plant, and U Plant), three operating major air emission units (two stacks and a passive vent), and three operating minor emission stacks.

In 2004, data were collected at the B Plant and the Plutonium-Uranium Extraction (PUREX) Plant stacks to show that they are minor emission units. This work was done in addition to the normal surveillance and maintenance that were conducted to ensure that the facilities were secure and maintained and did not pose a threat to human health or the environment.

Surveillance, maintenance, and decontamination or stabilization of over 500 waste sites including former cribs, ponds, ditches, trenches, unplanned release sites, and burial grounds continued in 2004. Periodic surveillances, radiation surveys, and herbicide applications were performed at these sites and timely responses to identified problems were initiated. The overall objective was to maintain these sites in a safe and stable configuration and to prevent contaminants at these sites from spreading in the environment.

\subsubsection{Investigating the Potential for Using the 200 Areas Chemical Separations Plants as Waste Disposal Facilities}

\section{J. R. Robertson}

The Canyon Disposition Initiative was created to investigate the potential for using the five canyon buildings (B Plant, T Plant, U Plant, Plutonium-Uranium Extraction [PUREX] Plant, and Reduction-Oxidation [REDOX] Plant) at the Hanford Site as disposal facilities for Hanford Site remediation waste, rather than demolishing the structures. While planning and sampling activities of the Canyon Disposition Initiative actually began in the mid1990s, the bulk of the work to prepare the final feasibility study (DOE/RL-2001-11) was completed in 2001 as the final phase of the CERCLA remedial investigation/ feasibility study for disposition of the U Plant. The U Plant was used as the pilot project for the Canyon Disposition Initiative.

In December 2004, the final feasibility study (DOE/RL2001-11) and the associated proposed plan (DOE/RL2001-29) were released for public review. These documents examine five alternatives for the remediation of the 221-U facility: (1) no action, (2) full removal and disposal, (3) entombment with internal waste disposal, (4) entombment with internal and external waste disposal, and (5) close in place - collapsed structure. The proposed plan (DOE/RL-2001-29) identifies the close in place - collapsed structure alternative as the preferred alternative. Under this alternative, process equipment already in the U Plant would be consolidated into the below-ground U Plant process cells, the cells would be backfilled with grout, the exterior walls and roof would be collapsed in place, and the site would be covered with a barrier. The final disposition path for the U Plant will be selected during the record of decision process.

\subsubsection{Decommissioning of Facilities in the 300 Area}

This section provides information about the transition and decommissioning of facilities within the 300 Area. 


\subsubsection{Deactivation of the 327 and 324 Facilities}

\section{E. Rasmussen}

Construction of the 327 and 324 Buildings was completed and operations began in 1953 and 1966, respectively. These facilities contain hot cells that were used for radiological research and development work. Deactivation of both buildings was assigned to Fluor Hanford, Inc. during 1996 and will be completed by the contractor managing the River Corridor Closure contract.

Significant accomplishments achieved at the 327 Building during 2004 included:

- Initiating equipment and facility preparations for removal of remaining waste items in support of the 327 Building portion of a Tri-Party Agreement milestone. Activities were proceeding on track for completion ahead of the September 30, 2006, milestone due date.

- Maintaining the 327 Building in surveillance and maintenance mode in compliance with safety and regulatory requirements.

Significant accomplishments achieved at the 324 Building during 2004 included:

- Completing procurement of the Liquid Waste Handling System equipment for use in future 324 Building deactivation and decontamination activities.

- Maintaining the 324 Building in surveillance and maintenance mode in compliance with facility safety and regulatory requirements.

\subsubsection{Status of the 309 Plutonium Recycle Test Reactor Facility}

\section{E. Rasmussen}

The original 309 Plutonium Recycle Test Reactor Facility mission was to provide an operating test reactor to research and develop nuclear fuel technology during the 1960s. The facility was shut down in 1969. It currently contains a cold replica of the Fast Flux Test Facility Interim Examination and Maintenance Cell (built in 1975), which has been used by Fast Flux Test Facility staff for training and procedure purposes. Facility disposition is to be completed by the contractor managing the River Corridor Closure contract. Activities at the 309 facility during 2004 included surveillance and maintenance activities to maintain compliance with facility and regulatory requirements.

\subsubsection{Decommissioning of the 313 and 314 Buildings}

\section{E. Rasmussen}

The 313 and 314 Buildings were used during the 1950s to support uranium metal fuel fabrication development and engineering activities associated with Hanford's production reactors. The 313 Building was used during the 1980s for N Reactor fuel fabrication activities. The 314 Building was used during the 1970s through 1990s for laboratory work. The 313 and 314 Buildings have been in a surveillance and maintenance mode in recent years. These two facilities were turned over to Bechtel Hanford, Inc. in October 2004 to start preparation for facility decontamination and decommissioning activities. Planning and preparatory activities supporting achievement of a new Tri-Party Agreement milestone applicable to the two buildings were initiated and are proceeding on track. Completion of decontamination and decommissioning of the 313 and 314 Buildings is scheduled for September 30, 2006.

\subsubsection{Decommissioning of Facilities in the 400 Area}

This section provides information about the transition and decommissioning of facilities within the 400 Area.

\section{Deactivation of the Fast Flux Test Facility}

\section{A. Gantt}

The Fast Flux Test Facility is a 400-megawatt thermal, liquid-metal-cooled reactor located in the 400 Area. It was built in the late 1970s to test equipment and fuel for the Liquid Metal Fast Breeder Reactor Program. The Fast Flux Test Facility operated from April 1982 to April 1992, during which time it successfully tested advanced nuclear fuels, materials, and safety designs and also produced a 
variety of isotopes for medical research. The reactor has been in a standby mode since December 1993. Fuel has been removed from the reactor vessel and stored in two sodium-filled vessels and in aboveground dry-storage casks. Twenty-three of the facility's 100 systems were deactivated during the previous deactivation period from 1993 to 1997.

The Fast Flux Test Facility continued with deactivation actions in 2004. Liquid sodium was drained from the primary heat transport system loops and auxiliary systems, as well as the upper portion of the reactor vessel to the Sodium Storage Facility tanks, where approximately 567,812 liters (150,000 gallons) of liquid sodium metal are now stored, pending future conversion to sodium hydroxide for use by the Waste Treatment Plant. The sodium-potassium alloy systems containing approximately 3,407 liters (900 gallons) of sodium-potassium alloy were drained or flushed into associated sodium systems for disposition with the sodium. Eighty-four fueled components were washed and packaged into 12 interim storage casks. These interim storage casks and 22 filled interim storage casks previously stored in the 400 Area Interim Storage Area were transferred to the 200 Areas Interim Storage Area.

TransNuclear, Inc. began fabrication of the remainder of the interim storage casks and the first nine were delivered. Work continued on design and fabrication of the reactor vessel drain pump. Three polychlorinated biphenyl(PCB-) cooled transformers were removed from service and shipped offsite for disposal; this leaves 10 of the original 19 PCB transformers in service. Additionally, selected process systems were deactivated that are no longer required since the secondary heat transport system sodium has been drained.

\subsubsection{Decommissioning of Facilities in the 100 Areas}

This section provides information about the transition and decommissioning of facilities within the 100 Areas.

\section{Decommissioning of Facilities in the 100-D, 100-H, 100-N, and 100-K Areas}

\section{J. W. Golden, Jr.}

Decontamination and decommissioning activities continued during 2004 in the 100-D, 100-H, and 100-N Areas. Activities to support the interim safe storage of reactor buildings ( $\mathrm{D}$ and $\mathrm{H}$ ) for up to 75 years were conducted in 2004. The interim safe storage of the D Reactor was completed in 2004, while work on the H Reactor will continue through 2005. Installation of a 75-year roof and decontamination of areas at the $\mathrm{H}$ Reactor will be addressed. These activities are conducted as non-timecritical removal actions under CERCLA.

Facility demolition was conducted at the $100-\mathrm{N}$ Area in 2004. Facilities and structures demolished included the 1304-N emergency dump tank, 1300-N emergency dump basin, 11-N, 13-N, 1714-N, 1714-NA, and 1714-NB facilities. During 2004, work began on the demolition of the 190-DR pump house.

Engineering evaluation cost analyses were produced for the 105-N/109 Reactor interim safe storage and the demolition of 27 facilities at the 100-K West Area. 


\subsection{Waste Management Operations}

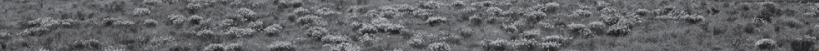

This section provides information about liquid and solid waste management on the Hanford Site. The underground single-shell and double-shell waste storage tanks and the status of the Hanford Tank Waste Treatment and Immobilization Plant (Waste Treatment Plant) construction are also discussed.

\subsubsection{Waste Classifications}

\section{P. Diediker and D. L. Dyekman}

Waste produced from Hanford Site cleanup operations is classified as either radioactive, non-radioactive, mixed, or dangerous. Radioactive waste is categorized as transuranic, high-level, and low-level. Mixed waste has both radioactive and dangerous non-radioactive substances. Dangerous waste contains hazardous substances. Hanford's dangerous waste is managed in accordance with the state of Washington Dangerous Waste Regulations (WAC 173-303).

Radioactive waste and mixed waste are currently handled in several ways. High-level waste is stored in underground single-shell and double-shell tanks. The method used to manage low-level waste is dependent on the source, composition, and concentration of the waste. Low-level waste is stored in either the underground waste storage tank system, on storage pads, or is buried. Transuranic waste is stored in vaults or on underground and aboveground storage pads from which it can be retrieved.

Approximately 33 Hanford Site generators (as defined in WAC 173-303-040, Definitions) have the capacity to produce dangerous waste during site cleanup activities. An annual report lists the dangerous waste generated, treated, stored, and disposed of onsite and offsite (e.g., DOE/RL2004-23). Dangerous waste is treated, stored, and prepared for disposal at several Hanford Site facilities. Dangerous waste generated at the site also is shipped offsite for disposal or destruction. Some types of dangerous waste, such as used lead acid batteries and used aerosol products, are shipped offsite for recycling.

Non-dangerous waste is waste that does not contain hazardous or radioactive substances. Non-dangerous waste generated at the Hanford Site historically has been buried near the 200 Areas Solid Waste Landfill. Beginning in 1999, non-dangerous waste has been disposed of at the Roosevelt Regional landfill near Goldendale, Washington, through a contract with Basin Disposal, Inc. Since 1996, medical waste has been shipped to Waste Management of Kennewick, Washington. Asbestos has been shipped to Basin Disposal, Inc. in Pasco, Washington, and the onsite Environmental Restoration Disposal Facility. Since 1996, non-regulated drummed waste has been shipped to Waste Management of Kennewick.

Non-dangerous waste originates at a number of areas across the site. Examples include construction debris, office trash, cafeteria waste, and packaging materials. Other materials and items classified as non-dangerous waste are solidified filter backwash and sludge from the treatment of river water, failed and broken equipment and tools, air filters, uncontaminated used gloves and other clothing, and certain chemical precipitates such as oxalates. Nondangerous demolition waste from 100 Areas decommissioning projects is buried in situ or in designated sites in the 100 Areas.

\subsubsection{Solid Waste Inventories}

Annual reports document the quantities and types of solid waste generated onsite, received, shipped offsite, and disposed of at the Hanford Site (e.g., HNF-EP-0125-16). Solid waste program activities are regulated by RCRA and the Toxic Substances Control Act, discussed in Section 5.1.3. Solid waste quantities generated onsite or received from offsite and disposed of at the Hanford Site from 1999 through 2004 are shown in Tables 6.3.1 and 


\begin{tabular}{|c|c|c|c|c|c|c|}
\hline \multicolumn{7}{|c|}{ Table 6.3.1. Quantities of Solid Waste ${ }^{(a)}$ Generated on the Hanford Site, 1999 through 2004, kg (lb) } \\
\hline Waste Category & 1999 & $\underline{2000}$ & $\underline{2001}$ & $\underline{2002}$ & $\underline{2003}$ & $\underline{2004}$ \\
\hline Mixed & $\begin{array}{c}421,000 \\
(928,300)\end{array}$ & $\begin{array}{c}441,000 \\
(973,500)\end{array}$ & $\begin{array}{c}328,500 \\
(724,300)\end{array}$ & $\begin{array}{c}1,025,200 \\
(2,260,600)\end{array}$ & $\begin{array}{c}421,000 \\
(929,000)\end{array}$ & $\begin{array}{c}144,512 \\
(319,000)\end{array}$ \\
\hline Radioactive & $\begin{array}{c}957,000 \\
(2,109,700)\end{array}$ & $\begin{array}{c}700,000 \\
(1,544,300)\end{array}$ & $\begin{array}{c}1,675,200 \\
(3,693,800)\end{array}$ & $\begin{array}{c}1,588,000 \\
(3,500,900)\end{array}$ & $\begin{array}{c}758,000 \\
(1,671,000)\end{array}$ & $\begin{array}{c}906,591 \\
(1,999,000)\end{array}$ \\
\hline
\end{tabular}

6.3.2. Quantities of dangerous waste shipped offsite from 1999 through 2004 are shown in Table 6.3.3. Table 6.3.4 provides a detailed summary of the radioactive solid waste stored or disposed of in 2004.

\subsubsection{Solid Waste Management}

Solid waste management includes the treatment, storage, and/or disposal of solid waste produced as a result of Hanford Site operations or received from offsite sources that are authorized by DOE to ship waste to the site. The following sections contain information regarding specific waste treatment, storage, or disposal locations at Hanford.

\subsubsection{Central Waste Complex}

\section{G. Saueressig}

Waste is received at the Central Waste Complex in the 200-West Area from sources at the Hanford Site and any offsite sources that are authorized by DOE to ship waste to the Hanford Site for treatment, storage, and disposal. Ongoing cleanup, research, and development activities on the Hanford Site, as well as remediation activities, generate most of the waste received at the Central Waste Complex. Offsite waste has been primarily from other DOE sites and U.S. Department of Defense facilities. The characteristics of the waste received vary greatly, including low-level, transuranic, or mixed waste, and radioactively contaminated PCBs.

The Central Waste Complex can store as much as 22,710 cubic meters (801,996 cubic feet) of low-level mixed waste and transuranic waste. This capacity is adequate to store the projected volumes of low-level, transuranic, mixed waste, and radioactively contaminated PCBs to be generated from the sites identified above, assuming on-schedule treatment of the stored waste. Treatment will reduce the amount of waste in storage and make room for newly generated mixed waste. The dangerous waste designation of each container of waste is established at the point of origin based on process knowledge or sample analysis.

On April 28, 2004, the Washington State Department of Ecology approved the transfer of the 2404-WB and 2404-WC buildings (including the 1,913,600-liter

\begin{tabular}{|c|c|c|c|c|c|c|c|}
\hline \multirow{2}{*}{\multicolumn{2}{|c|}{$\underline{\text { Waste Category }}$}} & \multicolumn{5}{|c|}{$\begin{array}{l}\text { able 6.3.2. Quantities of Solid Waste (a) Received on the Hanford Site from Offsite Sources, } \\
1999 \text { through 2004, kg (lb) }\end{array}$} & \multirow[b]{2}{*}{$\underline{2004}$} \\
\hline & & $\underline{1999}$ & $\underline{2000}$ & $\underline{2001}$ & $\underline{2002}$ & $\underline{2003}$ & \\
\hline Mixed & & $\begin{array}{l}1,306 \\
(2,880)\end{array}$ & $\begin{array}{c}1,381 \\
(3,045)\end{array}$ & $\begin{array}{c}127,000 \\
(280,000)\end{array}$ & $\begin{array}{c}112,000 \\
(246,200)\end{array}$ & $\begin{array}{l}667,000^{(b)} \\
(1,470,500)\end{array}$ & $\begin{array}{l}255,690^{(b)} \\
(563,800)\end{array}$ \\
\hline \multicolumn{2}{|c|}{ Radioactive } & $\begin{array}{l}2,325,700 \\
(5,128,100)\end{array}$ & $\begin{array}{c}6,958,000 \\
(15,343,500)\end{array}$ & $\begin{array}{c}4,736,500 \\
(10,444,100)\end{array}$ & $\begin{array}{l}1,517,000 \\
(3,345,800)\end{array}$ & $\begin{array}{l}407,000 \\
(898,200)\end{array}$ & $\begin{array}{c}519,609 \\
(1,145,700)\end{array}$ \\
\hline
\end{tabular}




\begin{tabular}{|c|c|c|c|c|c|c|}
\hline \multirow[b]{2}{*}{ Waste Category } & \multicolumn{5}{|c|}{$\begin{array}{l}\text { Table 6.3.3. Quantities of Dangerous Waste(a) Shipped Off the Hanford Site, } \\
1999 \text { through } 2004, \mathrm{~kg}(\mathrm{lb})\end{array}$} & \multirow[b]{2}{*}{$\underline{2004}$} \\
\hline & $\underline{1999}$ & $\underline{2000}$ & $\underline{2001}$ & $\underline{2002}$ & $\underline{2003}$ & \\
\hline \multirow[t]{2}{*}{ Containerized } & $\begin{array}{c}1,732,700^{(\mathrm{b})} \\
(3,820,700)\end{array}$ & $\begin{array}{l}33,200^{(\mathrm{b})} \\
(73,200)\end{array}$ & $\begin{array}{c}56,000^{(b)} \\
(124,200)\end{array}$ & $\begin{array}{c}78,400^{(\mathrm{b})} \\
(172,900)\end{array}$ & $\begin{array}{c}83,500^{(\mathrm{b})} \\
(184,100)\end{array}$ & $\begin{array}{c}75,296^{(\mathrm{b})} \\
(166,000)\end{array}$ \\
\hline & $\begin{array}{c}70,000^{(c)} \\
(154,300)\end{array}$ & $\begin{array}{l}315,500^{(c)} \\
(695,700)\end{array}$ & $\begin{array}{l}2,600^{(c)} \\
(5,800)\end{array}$ & $\begin{array}{l}3,500^{(c)} \\
(7,800)\end{array}$ & $\begin{array}{c}91,800^{(c)} \\
(202,400)\end{array}$ & $\begin{array}{r}49,560^{(c)} \\
(109,300)\end{array}$ \\
\hline Bulk Solids & $\begin{array}{l}402,300^{(\mathrm{d})} \\
(887,000)\end{array}$ & 0 & 0 & 0 & 0 & 0 \\
\hline Bulk Liquids & 0 & 0 & 0 & $\begin{array}{c}50,700 \\
(111,700)\end{array}$ & $\begin{array}{c}48,400 \\
(106,900)\end{array}$ & $\begin{array}{c}35,057 \\
(77,300)\end{array}$ \\
\hline Total & $\begin{array}{c}2,205,000 \\
(4,862,000)\end{array}$ & $\begin{array}{c}348,700 \\
(768,900)\end{array}$ & $\begin{array}{c}58,600 \\
(130,000)\end{array}$ & $\begin{array}{c}132,600 \\
(292,400)\end{array}$ & $\begin{array}{c}223,700 \\
(493,400)\end{array}$ & $\begin{array}{c}159,913 \\
(352,600)\end{array}$ \\
\hline $\begin{array}{l}\text { (a) Does not inc } \\
\text { (b) Dangerous w } \\
\text { (c) Mixed waste } \\
\text { (d) Includes } 399\end{array}$ & $\begin{array}{l}\text { de Toxic Substance } \\
\text { ste only. } \\
\text { radioactive and da } \\
75 \mathrm{~kg}(881,724 \mathrm{lb})\end{array}$ & $\begin{array}{l}\text { ntrol Act was } \\
\text { ous). } \\
\text { n extraction }\end{array}$ & bon tetrac & from soil. & & \\
\hline
\end{tabular}

[421,000-gallon] storage capacity) from Central Waste Complex management to Waste Receiving and Processing Facility management.

\subsubsection{Waste Receiving and Processing Facility}

\section{H. C. Boynton}

Waste destined for the Waste Receiving and Processing Facility includes stored waste as well as newly generated waste from current site cleanup activities. The waste consists primarily of contaminated cloth, paper, rubber, metal, and plastic. Processed waste that qualifies as lowlevel radioactive waste and meets disposal requirements is buried onsite. Low-level radioactive waste not meeting burial requirements is processed in the facility for onsite burial or prepared for future treatment at other onsite or offsite treatment, storage, and disposal facilities. Waste determined at the facility to be transuranic is certified and packaged for shipment to the Waste Isolation Pilot Plant in Carlsbad, New Mexico, for permanent disposal. Other materials requiring further processing to meet disposal criteria are retained, pending treatment.

The Waste Receiving and Processing Facility, which began operating in 1997, analyzes, characterizes, and prepares drums and boxes of waste for disposal. The 4,800-squaremeter (52,000-square-foot) facility along with two 2,000-square-meter (21,900-square-foot) storage buildings is located north of the Central Waste Complex in the 200-West Area. The facility dispositioned and shipped 154 cubic meters (5,440 cubic feet) of waste during 2004.

\subsubsection{T Plant Complex}

\section{B. M. Barnes}

The T Plant complex in the 200-West Area provides waste treatment, storage, and decontamination services for the Hanford Site as well as for offsite facilities. The T Plant complex currently operates under RCRA interim status. In 2004, the following activities occurred at the T Plant complex:

- Head-space gas was sampled in hundreds of containers of transuranic waste to support Waste Isolation Pilot Plant Project waste acceptance criteria.

- Numerous containers and boxes of waste were re-packaged, treated, sampled, and characterized to meet waste acceptance criteria and land disposal restriction requirements.

- Approximately 28 Shippingport reactor fuel elements were shipped to the Canister Storage Building. All 72 Shippingport fuel elements have been removed 


\begin{tabular}{|c|c|c|c|c|}
\hline \multicolumn{4}{|c|}{$\begin{array}{c}\text { Table 6.3.4. Radioactive Solid Waste Stored or Disposed of on } \\
\text { the Hanford Site, } 2004\end{array}$} & \\
\hline \multirow{2}{*}{\multicolumn{2}{|c|}{ Constituent $^{(\mathbf{b})}$}} & \multicolumn{2}{|c|}{ Quantity, $\mathbf{C i}^{(\mathrm{a})}$} & \multirow[b]{2}{*}{$\begin{array}{l}\text { Transuranic } \\
\text { Waste }\end{array}$} \\
\hline & & $\begin{array}{l}\text { Low-Level } \\
\text { Waste }\end{array}$ & $\begin{array}{l}\text { Mixed Low- } \\
\text { Level Waste }\end{array}$ & \\
\hline \multicolumn{2}{|c|}{ Tritium } & 0.373 & 48.6 & 0.0443 \\
\hline \multicolumn{2}{|c|}{ Carbon-14 } & 0.0000703 & 0.150 & (c) \\
\hline \multicolumn{2}{|c|}{ Manganese-54 } & (c) & 0.682 & (c) \\
\hline \multicolumn{2}{|c|}{ Iron-55 } & 1,900 & 5,670 & (c) \\
\hline \multicolumn{2}{|c|}{ Nickel-59 } & (c) & 0.147 & (c) \\
\hline \multicolumn{2}{|c|}{ Cobalt-60 } & 0.0000206 & 4,800 & 0.10 \\
\hline \multicolumn{2}{|c|}{ Nickel-63 } & 26,600 & 15,800 & (c) \\
\hline \multicolumn{2}{|c|}{ Strontium-90 } & 0.288 & 17.2 & 705 \\
\hline \multicolumn{2}{|c|}{ Yttrium-90 } & 0.288 & 17.2 & 705 \\
\hline \multicolumn{2}{|c|}{ Technetium-99 } & 0.0115 & 22.7 & (c) \\
\hline \multicolumn{2}{|c|}{ Iodine-129 } & 0.0000201 & 0.00000463 & (c) \\
\hline \multicolumn{2}{|c|}{ Cesium-137 } & 0.538 & 25.5 & 17.6 \\
\hline \multicolumn{2}{|c|}{ Barium-137m } & 0.510 & 24.2 & 16.6 \\
\hline \multicolumn{2}{|c|}{ Uranium-233 } & 0.00000000198 & 0.458 & (c) \\
\hline \multicolumn{2}{|c|}{ Uranium-234 } & 0.0000496 & 53.6 & 0.00710 \\
\hline \multicolumn{2}{|c|}{ Uranium-235 } & 0.0000299 & 2.64 & 0.000701 \\
\hline \multicolumn{2}{|c|}{ Uranium-236 } & 0.0000209 & 4.90 & 0.000000158 \\
\hline \multicolumn{2}{|c|}{ Neptunium-237 } & 0.00000338 & 0.00000338 & 0.000647 \\
\hline \multicolumn{2}{|c|}{ Uranium-238 } & 0.000527 & 42.7 & 0.015 \\
\hline \multicolumn{2}{|c|}{ Plutonium-238 } & 0.00728 & 0.155 & 607 \\
\hline \multicolumn{2}{|c|}{ Plutonium-239 } & 607 & 1.29 & 1,740 \\
\hline \multicolumn{2}{|c|}{ Plutonium-240 } & 0.0129 & 0.0129 & 488 \\
\hline \multicolumn{2}{|c|}{ Plutonium-241 } & 0.179 & 5.54 & 5.54 \\
\hline \multicolumn{2}{|c|}{ Plutonium-242 } & 0.000121 & 0.000835 & 0.0745 \\
\hline \multicolumn{2}{|c|}{ Americium-241 } & 0.0139 & 0.0139 & 543 \\
\hline \multicolumn{2}{|c|}{ Total } & 28,500 & 28,500 & 15,200 \\
\hline \multicolumn{5}{|c|}{$\begin{array}{l}\text { (b) Constituents for which values are given are those that are in abundance, or are otherwise } \\
\text { thought to be of interest. } \\
\text { (c) No inventory was reported for this waste type. }\end{array}$} \\
\hline
\end{tabular}

from the 221-T Building and are now stored at the Canister Storage Building. The fuel elements are from the Shippingport Atomic Power Station, a nuclear generating station in western Pennsylvania that has been decommissioned.

- Approximately 25 containers of material including lead-acid batteries; alkali batteries; fluorescent light bulbs; incandescent, sodium, and mercury light bulbs; and aerosol cans were shipped to the 400 Area Consolidation Center.

- Equipment was decontaminated for re-use or disposal as waste.
The T Plant Complex Part B Permit was submitted to the Washington State Department of Ecology in September 2002 for inclusion in the Hanford Facility RCRA Permit (Ecology 1994). The Washington State Department of Ecology has requested an update to this permit for their review. This review is in support of the Washington State Department of Ecology eventually incorporating this permit into the Hanford Facility RCRA Permit (Ecology 1994).

The T Plant complex has completed all necessary activities to receive $\mathrm{K}$ Basin sludge for storage. 
The T Plant complex continued with upgrades to the 291-T-1 stack. Upgrades included removal of obsolete fans \#1 and \#2 from service, installation of a new modern fan (fan \#4), removal of ducting, and installation of new ducting. Upgrades in 2004 also included installation of a new stack cabinet monitoring system containing continuous air monitors for alpha and beta/gamma.

\subsubsection{Mixed Low-Level Waste Treatment and Disposal}

\section{E. Nester}

During 2004, 2,272 cubic meters (2,972 cubic yards) of mixed low-level waste were treated and/or directly disposed. These included:

- 457 cubic meters (598 cubic yards) of waste, or approximately 2,200 drum equivalents (based on a standard 208-liter [55-gallon] drum), that were non-thermally treated to RCRA land disposal restriction standards at the Pacific EcoSolutions facility located in Richland, Washington. The treated waste was returned to Hanford and disposed of in trench 34 of the Radioactive Mixed Waste Disposal Facility.

- 67 cubic meters (88 cubic yards) of waste, or approximately 320 drum equivalents of waste, that were removed from inventory at the Central Waste Complex after it was determined that they met disposal standards. This waste was direct-disposed in the Hanford Site low-level burial grounds.

- 230 cubic meters (301 cubic yards) of waste, or approximately 1,100 drum equivalents of waste, that were directly disposed into the Radioactive Mixed Waste Disposal Facility. This waste came from various Hanford Site operations and either met land disposal restriction standards in the "as generated" state, or was treated by the generators to meet RCRA and state land disposal restrictions.

- 1,518 cubic meters (1,986 cubic yards) of waste, or approximately 7,300 drum equivalents of waste, that were shipped from the Central Waste Complex to the Environmental Restoration Disposal Facility where the waste was treated and disposed. The waste was all originally from the $183-\mathrm{H}$ evaporation basins and had been stored in the Central Waste Complex since the late 1980s. Approval to dispose of this waste at the Environmental Restoration Disposal Facility was obtained through an engineering evaluation and cost analysis determination, which was approved in July 2003. There remains in the Central Waste Complex approximately 700 cubic meters (915 cubic yards) of this waste, which is scheduled to be shipped to the Environmental Restoration Disposal Facility during 2005.

Additionally during 2004, two commercial treatment contracts were issued, one to Perma-Fix Environmental Services and the other to Pacific EcoSolutions. Both contracts are for the thermal treatment of mixed lowlevel waste labpacks and solids contaminated with RCRA organic constituents. Since both of the contracts were let in the later part of 2004, no waste was treated during the year.

\subsubsection{Disposal of Navy Reactor Compartments}

\section{S. G. Arnold}

Two disposal packages containing defueled U.S. Navy reactor compartments were received and placed in trench 94 in the 200-East Area during 2004. This brings the total number of reactor compartments received to 114 . All Navy reactor compartments shipped to the Hanford Site for disposal have originated from decommissioned nuclear-powered submarines or cruisers. Decommissioned submarine reactor compartments are approximately 10 meters (33 feet) in diameter and 14.3 meters ( 47 feet) long. They weigh between 908 and 1,362 metric tons (1,000 and 1,500 tons). Decommissioned cruiser reactor compartments are approximately 10 meters (33 feet) in diameter and 12.8 meters (42 feet) high. They weigh approximately 1,362 metric tons (1,500 tons).

\subsubsection{Environmental Restoration Disposal Facility}

\section{A. Casbon}

The Environmental Restoration Disposal Facility is located near the 200-West Area. The facility began operations during July 1996 and serves as the central disposal site for contaminated waste removed during cleanup operations conducted under CERCLA on the Hanford Site. 
To provide a barrier to contaminant migration from the facility, the Environmental Restoration Disposal Facility was constructed to RCRA Subtitle C Minimum Technology Requirements including a double liner and leachate collection system. Remediation waste disposed in the facility includes soil, rubble, or other solid waste materials contaminated with hazardous, low-level radioactive, or mixed (combined hazardous and radioactive) waste.

There are currently six waste cells associated with the Environmental Restoration Disposal Facility site. Initially, cells 1 and 2 were constructed and the placement of waste in these cells has since been completed. An interim cover has been placed over the parts of cells 1 and 2 that have been brought up to grade. Cells 3 and 4 were later constructed at the site and are currently receiving waste. Construction of cells 5 and 6 has been completed and the cells are scheduled to start receiving waste during 2005. All six cells are roughly equal in size. Throughout 2004, approximately 566,733 metric tons (624,719 tons) of remediation wastes were disposed at the facility. A total of approximately 4.8 million metric tons ( 5.2 million tons) of remediation wastes have been placed in the Environmental Restoration Disposal Facility from initial operations start-up through 2004. The total available expansion area of the Environmental Restoration Disposal Facility site was authorized in the 1995 record of decision to cover as much as 4.1 square kilometers (1.6 square miles).

\subsubsection{Radioactive Mixed Waste Disposal Facility}

\section{E. Nester}

The Radioactive Mixed Waste Disposal Facility is located in the 218-W-5 low-level waste burial ground in the 200-West Area and is designated as trenches 31 and 34.

Disposal to trench 34 began during September 1999. Currently, there are approximately 3,020 cubic meters (106,600 cubic feet) of waste disposed in about 2,150 waste packages in trench 34. During the summer of 2004, the first operational layer of waste packages was covered with compacted gravel and soil. The second waste operational layer was started and continues to be filled.

Trench 31 became operational for disposal during July 2004; however, no waste packages are currently disposed.
This trench is being used to store waste pending final disposal. Currently, there are approximately 80 cubic meters ( 2,825 cubic feet) of waste stored in about 210 waste packages in trench 31 .

These trenches are rectangular landfills, with approximate base dimensions of 76 by 30 meters ( 250 by 100 feet). The bottom of the excavations slopes slightly, giving a variable depth of 9 to 12 meters ( 30 to 40 feet). These trenches comply with RCRA requirements because they have double liners and systems to collect and remove leachate. The bottom and sides of the facilities are covered with a layer of soil 1 meter (3.3 feet) deep to protect the liner system during fill operations. There is a recessed section at the end of each excavation that houses a sump for leachate collection. Access to the bottom of each trench is provided by ramps along the perimeter walls.

\subsubsection{Low-Level Burial Grounds}

\section{G. Saueressig}

The low-level burial grounds are a land-based unit consisting of eight burial grounds located in the 200-East and 200-West Areas of the Hanford Site used for disposal of low-level waste and mixed waste (i.e., low-level radioactive waste with a dangerous waste component regulated by WAC 173-303). The low-level burial grounds have been permitted under a RCRA Part A permit since 1985.

Three trenches receive mixed waste regulated by WAC 173-303. Trenches 31 and 34 in burial ground 218-W-5 are lined trenches with leachate collection and removal systems (Sections 6.3.3.4 and 6.3.3.7). Trench 94 in burial ground 218-E-12B is used for disposal of defueled navy reactor compartments (Section 6.3.3.5). Low-level waste and transuranic waste have been placed in the other burial grounds. Transuranic waste has not been placed in the low-level burial grounds without specific DOE approval since August 19, 1987. Soil is placed over some of the waste containers to provide radiological protections. The transuranic waste was placed in a manner that allows for retrieval and/or removal in the future.

On June 23, 2004, DOE issued a record of decision for the Solid Waste Program at Hanford. Part of the record of decision stated that DOE will dispose of low-level waste in lined disposal facilities. Only two of the low-level burial 
ground trenches are lined (trenches 31 and 34); therefore, since this date, all low-level waste as well as mixed low-level waste is being disposed in these two trenches (Section 6.3.3.7). Disposal of navy reactor compartments (Section 6.3.3.5) in the low-level burial grounds is not affected by this record of decision.

A draft revision to the Part B permit application for the low-level burial grounds was submitted to the Washington State Department of Ecology in June 2002. Discussions between DOE and the state concerning the permit application are ongoing. In addition, the low-level burial grounds are included in a draft remedial investigation/ feasibility study work plan completed December 2004. The plan outlines possible characterization and remediation activities for specified landfills and dump sites at Hanford.

\subsubsection{Liquid Waste Management}

Facilities are operated on the Hanford Site to store, treat, and dispose of various types of liquid effluent generated by site cleanup activities. These facilities are operated and maintained in accordance with state and federal regulations and facility permits.

\subsubsection{Liquid Effluent Retention Facility}

\section{S. S. Lowe}

The Liquid Effluent Retention Facility in the 200-East Area consists of three RCRA-compliant surface basins to temporarily store process condensate from the 242-A evaporator and other aqueous waste. The Liquid Effluent Retention Facility provides for a steady flow and consistent $\mathrm{pH}$ of the feed to the Effluent Treatment Facility. Each basin has a maximum capacity of 29.5 million liters (7.8 million gallons). Generally, spare capacity is maintained in the event a leak should develop in an operating basin. Each basin is constructed of two flexible high-density polyethylene membrane liners. A system is provided to detect, collect, and remove leachate from between the primary and secondary liners. Beneath the secondary liner is a soil and bentonite clay barrier should both the primary and secondary liners fail. Each basin has a floating membrane cover constructed of very low-density polyethylene to keep out windblown soil and weeds and to minimize evaporation of small amounts of organic compounds and tritium that may be present in the basin contents. The facility began operating in April 1994 and receives liquid waste from both RCRA- and CERCLA-regulated cleanup activities.

The volume of wastewater received for interim storage during 2004 was approximately 107.5 million liters (28.4 million gallons). The wastewater received for interim storage during 2004 included approximately 2.8 million liters (750,000 gallons) of RCRA-regulated wastewater (primarily 242-A evaporator process condensate and mixed waste trench leachate) and approximately 104.8 million liters (27.7 million gallons) of CERCLAregulated wastewater (primarily Environmental Restoration Disposal Facility leachate and contaminated groundwater from the 200-UP-1 Operable Unit in the 200-West Area). The majority of the wastewater was received via pipeline direct from the originating facility. Approximately 2.93 million liters (775,000 gallons) of wastewater were received from various facilities by tanker trucks. The volume of wastewater transferred to the Effluent Treatment Facility for treatment and disposal during 2004 was 106.9 million liters (28.25 million gallons).

The volume of wastewater being stored in the Liquid Effluent Retention Facility at the end of 2004 was 46.84 million liters (12.38 million gallons). This included 5.62 million liters ( 1.49 million gallons) of RCRAregulated wastewater and 41.22 million liters (10.89 million gallons) of CERCLA-regulated wastewater.

\subsubsection{Effluent Treatment Facility}

\section{S. S. Lowe}

The Effluent Treatment Facility (200-East Area) treats liquid effluent to remove toxic metals, radionuclides, and ammonia, and destroy organic compounds. The treated effluent is stored in tanks, sampled and analyzed, and discharged to the State-Approved Land Disposal Site (also known as the 616-A crib). The treatment process constitutes best available technology and includes $\mathrm{pH}$ adjustment, filtration, ultraviolet light and peroxide destruction of organic compounds, reverse osmosis to remove dissolved solids, and ion exchange to remove the last traces of contaminants. The facility began operating in December 
1995. Treatment capacity of the facility is a maximum of 570 liters (150 gallons) per minute.

The volume of wastewater treated and disposed of in 2004 was approximately 106.9 million liters (28.25 million gallons). This was primarily CERCLA-regulated wastewater (groundwater from the 200-UP-1 Operable Unit in the 200-West Area and Environmental Restoration Disposal Facility leachate).

\subsubsection{200 Area Treated Effluent Disposal Facility}

\section{S. S. Lowe}

The 200 Area Treated Effluent Disposal Facility is a collection and disposal system for non-RCRA-permitted waste streams. The individual waste streams must be treated or otherwise comply with best available technology and all known available and reasonable treatment in accordance with WAC 173-240, Submission of Plans and Reports for Construction of Wastewater Facilities, which is the responsibility of the generating facilities. The 200 Area Treated Effluent Disposal Facility consists of approximately 18 kilometers (11 miles) of buried pipeline connecting three pumping stations, one disposal sample station (the 6653 Building), and two 2-hectare (5-acre) disposal ponds located east of the 200-East Area. The facility began operating in April 1995 and has a capacity of 12,900 liters (3,400 gallons) per minute. The volume of unregulated effluent disposed of in 2004 was 540.9 million liters (142.9 million gallons). The major source of this effluent was uncontaminated cooling water and steam condensate from the 242-A evaporator, with a variety of other uncontaminated waste streams received from other Hanford facilities.

\subsubsection{300 Area Treated Effluent Disposal Facility}

\section{S. S. Lowe}

Industrial wastewater generated throughout the Hanford Site is collected and treated in the 300 Area Treated Effluent Disposal Facility. Laboratories, research facilities, office buildings, and former fuel fabrication facilities in the 300 Area are the primary sources of the wastewater. The wastewater consists of once-through cooling water, steam condensate, and other industrial wastewater. The facility began operation in December 1994. Wastewater that is potentially contaminated is collected in the nearby 307 retention basins where it is monitored and released to the 300 Area process sewer for treatment by the 300 Area Treated Effluent Disposal Facility.

This facility is designed to continuously receive wastewater, with a storage capacity of up to 5 days at the design flow rate of 1,100 liters (300 gallons) per minute. The treatment process includes iron co-precipitation to remove heavy metals, ion exchange to remove mercury, and ultraviolet light and hydrogen peroxide oxidation to destroy organics and cyanide. Sludge from the iron co-precipitation process is dewatered and used for backfill in the low-level waste burial grounds. The treated liquid effluent is monitored and discharged through an outfall to the Columbia River under a National Pollutant Discharge Elimination System permit (No. WA 002591-7 [Section 5.4.1]). The volume of industrial wastewater treated and disposed of during 2004 was 136.8 million liters (36.13 million gallons). The volume of wastewater monitored and released to the 300 Area Treated Effluent Disposal Facility for treatment and disposal from the 307 Retention Basins in 2004 was 7.46 million liters (1.97 million gallons).

\subsubsection{242-A Evaporator}

\section{J. A. Voogd}

The 242-A evaporator in the 200-East Area concentrates dilute liquid tank waste by evaporation. This reduces the volume of liquid waste sent to double-shell waste storage tanks for storage and reduces the potential need for additional double-shell tanks. The 242-A evaporator completed one campaign during 2004. The volume of waste treated was 3.69 million liters (974,000 gallons), reducing the waste volume by 619,000 liters (164,000 gallons), or approximately $17 \%$ of the total volume. The volume of process condensate transferred to the Liquid Effluent Retention Facility for subsequent treatment in the Effluent Treatment Facility was 1.36 million liters (360,000 gallons). 


\subsection{Underground Waste Storage Tanks}

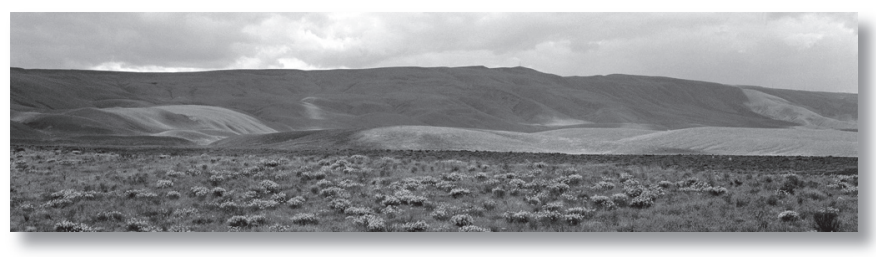

Much of the waste stored at Hanford is contained in large underground single-shell (1 wall) and double-shell ( 2 walls) tanks. These tanks are located in the 200 Areas; a grouping of tanks is referred to as a tank farm. The single-shell tanks are older, and some are known to have leaked. Liquid in the single-shell tanks is being transferred to double-shell tanks to prevent additional environmental releases. The following sections summarize waste tankrelated activities that took place in 2004. Additional information on Hanford's underground waste storage tanks can be found in Section 5.8.2.

\subsubsection{Waste Tank Status}

\section{P. Diediker and D. L. Dyekman}

This section provides information about the 149 singleshell and 28 double-shell tanks on the Hanford Site and activities related to their closure. The quantities of liquid waste generated in 2004 and stored in underground storage tanks are included in an annual dangerous waste report (e.g., DOE/RL-2004-23). Table 6.4.1 is a summary of the liquid waste generated from 1999 through 2004 and stored in underground storage tanks.

\subsubsection{Single-Shell Tanks}

\section{J. D. Doughty}

The Tri-Party Agreement (Ecology et al. 1989) formally establishes a schedule for interim stabilization, retrieval, and closure of the Hanford 200 Areas waste storage tanks. Interim stabilization is achieved by removing all pumpable liquid from a tank; pumpable liquid is that which will, under the force of gravity, flow from the waste matrix to the pump intake. Retrieval is achieved by removing all waste that can be accessed, mobilized, and retrieved from a tank to the limits specified in a Tri-Party Agreement

\begin{tabular}{|c|c|c|c|c|c|c|c|}
\hline \multicolumn{8}{|c|}{$\begin{array}{l}\text { Table 6.4.1. Quantities of Liquid Waste }{ }^{(a)} \text { Generated and Stored Within the Tank Farm System on } \\
\text { the Hanford Site During } 2004 \text { and During Each of the Previous } 5 \text { Years, L (gal) }\end{array}$} \\
\hline \multicolumn{2}{|c|}{ Type of Waste } & $\underline{1999}^{(\mathbf{b}, \mathbf{c})}$ & $\underline{2000}^{(\mathrm{b})}$ & $\underline{2001}^{(\text {b) }}$ & $\underline{2002}$ & $\underline{2003}$ & $\underline{2004}$ \\
\hline \multicolumn{2}{|c|}{$\begin{array}{l}\text { Volume of waste added } \\
\text { to double-shell tanks }\end{array}$} & $\begin{array}{l}5,420,000 \\
(1,432,000)\end{array}$ & $\begin{array}{l}8,920,000 \\
(2,357,000)\end{array}$ & $\begin{array}{l}2,980,000 \\
(788,000)\end{array}$ & $\begin{array}{l}9,280,000 \\
(2,452,000)\end{array}$ & $\begin{array}{l}9,710,000 \\
(2,565,000)\end{array}$ & $\begin{array}{r}3,316,000 \\
(876,000)\end{array}$ \\
\hline \multicolumn{2}{|c|}{$\begin{array}{l}\text { Total volume in double- } \\
\text { shell tanks (year end) }\end{array}$} & $\begin{array}{l}73,290,000 \\
(19,363,200)\end{array}$ & $\begin{array}{c}79,630,000 \\
(21,038,000)\end{array}$ & $\begin{array}{c}79,980,000 \\
(21,131,000)\end{array}$ & $\begin{array}{c}87,683,000 \\
(23,166,000)\end{array}$ & $\begin{array}{c}92,693,000 \\
(24,487,000)\end{array}$ & $\begin{array}{c}95,275,000 \\
(25,169,000)\end{array}$ \\
\hline \multicolumn{2}{|c|}{$\begin{array}{l}\text { Volume evaporated at } \\
242 \text {-A evaporator }\end{array}$} & $\begin{array}{l}3,097,000 \\
(818,200)\end{array}$ & $\begin{array}{l}2,580,000 \\
(682,000)\end{array}$ & $\begin{array}{l}2,580,000 \\
(682,000)\end{array}$ & $\begin{array}{l}1,578,000 \\
(417,000)\end{array}$ & $\begin{array}{c}4,720,000 \\
(1,247,000)\end{array}$ & $\begin{array}{c}734,000 \\
(194,000)\end{array}$ \\
\hline \multicolumn{2}{|c|}{$\begin{array}{l}\text { Volume pumped from } \\
\text { single-shell tanks }{ }^{(\mathrm{d})}\end{array}$} & $\begin{array}{l}2,930,000 \\
(774,100)\end{array}$ & $\begin{array}{c}2,250,000 \\
(595,000)\end{array}$ & $\begin{array}{c}590,000 \\
(155,000)\end{array}$ & $\begin{array}{c}5,288,000 \\
(1,397,000)\end{array}$ & $\begin{array}{c}6,185,000 \\
(1,634,000)\end{array}$ & $\begin{array}{r}2,778,000 \\
(734,000)\end{array}$ \\
\hline $\begin{array}{l}\text { (a) } \\
\text { (b) } \\
\text { (c) } \\
\text { (d) }\end{array}$ & $\begin{array}{l}\text { Quantity of liquid w } \\
\text { does not include cor } \\
\text { Quantity of liquid w } \\
\text { not include contain } \\
\text { Quantity of liquid w } \\
\text { Volume does not in }\end{array}$ & $\begin{array}{l}\text { ste is defined as l } \\
\text { tainerized waste ( } \\
\text { ste is defined as s } \\
\text { tized waste (e.g., } \\
\text { ste shown is corr } \\
\text { ude dilution or fl }\end{array}$ & $\begin{array}{l}\text { quid waste sent } \\
\text { o., barreled) in } \\
\text { own by differen } \\
\text { arreled) include } \\
\text { cted figure for tl } \\
\text { sh water. }\end{array}$ & $\begin{array}{l}\text { double-shell un } \\
\text { uded in the solid } \\
\text { categories on lef } \\
\text { in the solid wast } \\
\text { se years. }\end{array}$ & $\begin{array}{l}\text { rground storage } \\
\text { vaste category. } \\
\text { hand side of tabl } \\
\text { category. }\end{array}$ & $\begin{array}{l}\text { ks during these } \\
\text { aring these yea }\end{array}$ & $\begin{array}{l}\text { years. This } \\
\text { s. This does }\end{array}$ \\
\hline
\end{tabular}


milestone. All waste removed from a single-shell tank during stabilization and retrieval activities is transferred to the double-shell tank system.

The Tri-Party Agreement established a September 2004 due date for completion of single-shell tank interim stabilization. Roughly 6 months ahead of this due date, CH2M HILL Hanford Group, Inc. concluded its interim stabilization field work. Through the remainder of 2004, CH2M HILL Hanford Group, Inc. continued to collect data to document that tank-specific interim stabilization criteria had been met; this activity continued into 2005 .

Eighteen single-shell tanks were in retrieval status at the end of 2004, meaning that they had been formally selected for retrieval or were in some stage of planning or construction. Waste retrieval activities were conducted throughout the year in tank 241-S-112; completion is expected in early 2005. Retrieval activities were initiated in tank 241-S-102 in December 2004; completion is scheduled in 2006. The Washington State Department of Ecology stated that waste retrieval in tanks 241-S-112 and 241-S-102 were so close to being completed that the tanks did not require interim stabilization. Therefore, the September 2004 milestone date for completion of interim stabilization did not apply to tanks 241-S-102 and 241-S-112.

During 2004, CH2M HILL Hanford Group, Inc. conducted post-retrieval evaluation of the modified sluicing retrieval technology, used in combination with acid dissolution, for waste retrieval in tank 241-C-106. The use of saltcake dissolution technology, where water is used to dissolve and mobilize tank waste, continued at tank 241-S-112. During 2004, CH2M HILL Hanford Group, Inc. also prepared to implement an additional retrieval technology, the mobile retrieval system, intended for use on solid waste. The mobile retrieval system consists of a remote-controlled in-tank vehicle (used to push tank waste to a central location) and an articulated mast (used to guide the vacuum pump intake to the waste positioned for retrieval by the in-tank vehicle). The articulated mast, coupled with a vacuum retrieval system, was deployed for retrieval of waste in the four C-200 series tanks, the first being tank 241-C-203. The entire mobile retrieval system, both mast and in-tank vehicle, is planned for deployment to retrieve waste from selected C-100 series tanks.

\subsubsection{Double-Shell Tanks}

\section{J. D. Doughty}

The tank farms contain 28 double-shell tanks. Current fill limits give the double-shell tank system a storage capacity of approximately 119 million liters (31.44 million gallons). This storage space is being managed to store waste pending treatment by the Waste Treatment Plant or a supplemental treatment process (i.e., bulk vitrification). At the end of 2004, there were 95.26 million liters (25.16 million gallons) of waste in the double-shell tanks. During the year, 605,800 liters (160,100 gallons) of waste were transferred from the single-shell tank system into the double-shell tank system. Waste was received from retrievals in tanks 241-C-106, 241-C-203, 241-S-112, and 241-S-102. In addition, 1.778 million liters $(470,000$ gallons) of miscellaneous waste (condensates, laboratory waste, chemicals, Plutonium Finishing Plant [Z Plant], etc.) were transferred into double-shell tanks.

Activities were underway in 2004 to improve the use of double-shell tank storage space to support further singleshell tank waste retrievals. Activities to improve storage space in the double-shell tanks included:

- Improving the ability of the waste transfer system and waste tanks to receive and store more highly concentrated waste from the 242-A evaporator.

- Evaluating, by an expert panel, to raise the operating waste level in selected tanks to increase storage capacity.

- Coordinating the allocation of emergency space with the Waste Treatment Plant to reduce the number of tanks and tank storage space set aside for emergency use only and using the space in tanks that had previously been restricted.

\subsubsection{Waste Tank Closure Acceleration}

\section{J. D. Doughty}

In 2004, CH2M HILL Hanford Group, Inc. continued to evaluate bulk vitrification as a supplemental treatment technology, working toward a 2005 field demonstration of the technology. The demonstration will be conducted 
as a Research Development and Demonstration Project for treatment of the saltcake fraction of low-activity tank waste. The demonstration project will evaluate the ability of bulk vitrification, or in-container vitrification, to produce immobilized low-activity waste in a form comparable to that proposed for the Hanford Site Waste Treatment and Immobilization Plant immobilized low-activity waste. Vitrification will be achieved by mixing waste from tank 241-S-109 and matrix materials (glass formers) in a container and then applying electrical resistance heating through electrodes buried in the waste and glass-forming mixture. The heat produced will melt the glass formers and encapsulate the low-activity waste. If selected for fullscale implementation, this technology will provide treatment capacity to supplement that provided by the Waste Treatment Plant, facilitating accelerated tank retrieval and closure. A Research Development and Demonstration permit and air permits were obtained to support the demonstration project. Construction of a new bulk vitrification research and development facility is scheduled to begin in early 2005, and the demonstration will commence in late 2005.
CH2M HILL Hanford Group, Inc. continued its evaluation of a separate disposal path for contact-handled transuranic mixed tank waste. Contact-handled transuranic mixed tank waste will be retrieved, treated by dewatering, and packaged in 208-liter (55-gallon) drums for shipment and final disposal at the DOE Waste Isolation Pilot Plant in New Mexico. The Waste Isolation Pilot Plant is not currently authorized to receive this tank waste. Shipment cannot occur until the Pilot Plant RCRA permit has been modified to allow receipt of this waste and the packaged waste has been certified to meet the waste acceptance criteria. CH2M HILL Hanford Group, Inc. submitted National Environmental Policy Act documentation and a RCRA permit application to DOE for review and approval. Supporting atmospheric release permit applications were submitted to the regulatory agencies. A contract was awarded in 2004 to design and fabricate the waste treatment and packaging system. Current plans call for the construction of two mobile systems. Initially one will be located in the T Tank Farm and the other in B Tank Farm. 


\subsection{Hanford Waste}

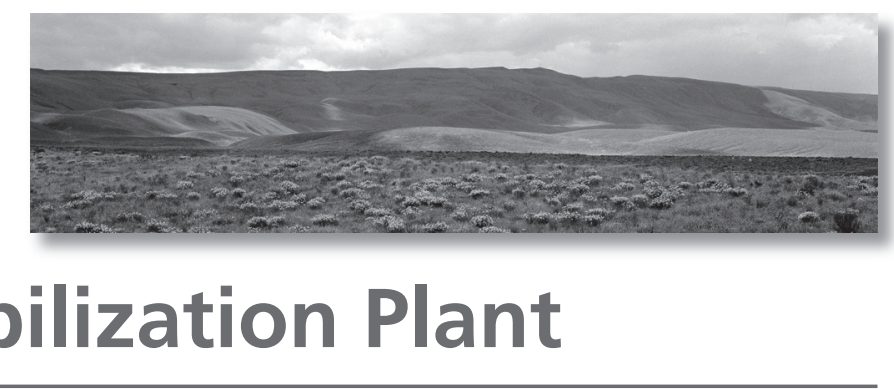

\section{B. L. Curn}

The Hanford Waste Treatment and Immobilization Plant (Waste Treatment Plant) is being built on 26 hectares (65 acres) located on the Central Plateau outside of the 200-East Area to treat radioactive and hazardous waste currently stored in 177 underground tanks. Currently, four major facilities are being constructed: a pretreatment facility, a high-level waste vitrification facility, a lowactivity waste vitrification facility, and new in 2004, an analytical laboratory. Supporting facilities also are being constructed.

Engineering design and construction for the pretreatment, high-level waste vitrification, and the low-activity waste vitrification facilities progressed in 2004, with designs approximately $77 \%$ complete and construction 37\% complete by year's end. Site excavation for the Waste
Treatment Plant analytical laboratory was completed and construction was approximately $10 \%$ complete at the end of 2004. A notable Waste Treatment Plant achievement in 2004 was installation of the pretreatment 4-pack waste receipt vessels. Each 1.42-million-liter (375,000-gallon) stainless steel tank was fabricated onsite, then lifted over walls and set in place. During 2004, workers at the Waste Treatment Plant installed more than 39,624 meters $(130,000$ feet $)$ of piping and 20,865 metric tons $(23,000$ tons $)$ of rebar, and poured over 12,000 truckloads of concrete.

Additional information about the Waste Treatment Plant, including a discussion of safety issues related to plant design, can be found in Section 5.8.2. 


\subsection{Tank Treatment Technologies}

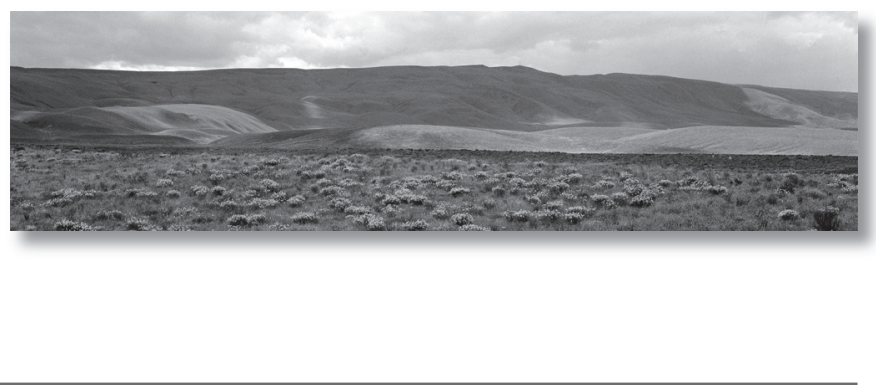

T. M. Brouns

In 2004, Pacific Northwest National Laboratory provided analyses, reviews, testing, and new tools to assist $\mathrm{CH} 2 \mathrm{M}$ HILL Hanford Group, Inc. in accomplishing their River Protection Project objectives. These objectives are safe storage, retrieval, and treatment of radioactive waste from Hanford's underground waste storage tanks, closure of tanks, and disposal of treated waste.

While certain portions of the waste in Hanford's 177 tanks will be vitrified at the Waste Treatment Plant, DOE has given CH2M HILL Hanford Group, Inc. the task of evaluating supplemental treatment processes to immobilize part of the less radioactive or low-activity waste. $\mathrm{CH} 2 \mathrm{M}$ HILL Hanford Group, Inc. and their contractor, AMEC Earth and Environmental Inc., are conducting tests to determine if bulk vitrification can be used to supplement the treatment capacity of the Waste Treatment Plant. This process creates large glass blocks, greater than 6.1 meters (20 feet) in length. In 2004, Pacific Northwest National Laboratory developed a simulated waste and used it in tests to evaluate and refine the glass formula and bulk vitrification process.

After the bulk of the waste is removed from the tanks, CH2M HILL Hanford Group, Inc. prepares the tanks for closure, marking the end of their time as storage vessels. In 2004, Pacific Northwest National Laboratory assisted CH2M HILL Hanford Group, Inc. in assessing the fate of the small fraction of remaining waste. Using residual waste samples and more than 40 years of experience with Hanford's geochemistry, Pacific Northwest National Laboratory developed computer models that predicted how and under what conditions contaminants would be released from the residual waste. In addition, Pacific Northwest National Laboratory is conducting detailed studies on the soil under the tanks to assess waste migration pathways if a leak occurred during retrieval.

Vitrified low-activity waste and other solid waste will be disposed at the Integrated Disposal Facility, a landfill being built in Hanford's 200-East Area. In 2004, Pacific Northwest National Laboratory provided data on the geology, hydrology, and geochemistry of the area. Pacific Northwest National Laboratory also tested waste glasses that will be in the facility, looking at how technetium and other contaminants would behave when the glass is placed in a disposal environment.

Chemical vapors from the tanks are a concern when retrieving waste from the tanks, as well as during day-today operations. Supporting CH2M HILL Hanford Group, Inc.'s efforts to protect its workers, Pacific Northwest National Laboratory provided data and analyses on the vapors emitted through the ventilation systems on each tank and how the vapors were dispersed. In addition, Pacific Northwest National Laboratory tested the accuracy, precision, and response time of several commercially available industrial hygiene field instruments potentially to be used by tank farm workers.

To help CH2M HILL Hanford Group, Inc. achieve the accelerated schedule for retrieving double-shell tank waste, a new software tool called the Compatibility Assessment Automation Tool was developed. Using existing data within the Tank Waste Information Network System, this software simplifies solving a number of calculations regarding tank waste transfers.

Because the River Protection Project schedule requires waste be held in the double-shell tanks beyond their original design life, CH2M HILL Hanford Group, Inc. is evaluating the tanks to ensure they are fit for duty. In support of this evaluation, Pacific Northwest National Laboratory analyzed the tanks' interiors and evaluated the potential effects of temperature changes, tank waste, and earthquakes. Environmental Solutions, A Summary of Contributions for FY04: PNNL Contributions to CH2M HILL Hanford Group, Inc. (PNNL-15094) provides greater detail on the technologies provided for tank technology improvements. 


\subsection{Site Closure Activities}

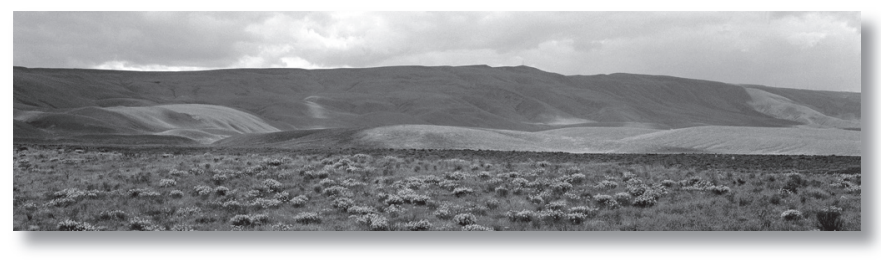

This section provides information about activities to support Hanford Site cleanup as the U.S. Department of Energy (DOE) moves toward site closure and possible transfer of land to other entities.

\subsubsection{Radiological Release of Property from Hanford}

\section{W. M. Glines}

The principal requirements for the control and release of property at Hanford containing residual radioactivity are given in DOE Order 5400.5, Radiation Protection of the Public and the Environment. These requirements are designed to ensure that:

- Property is evaluated; radiologically characterized; and, where appropriate, decontaminated before release.

- The level of residual radioactivity in property to be released is as near background levels as is reasonably practicable, as determined through DOE's as low as reasonably achievable process requirements, and meets DOE authorized limits.

- All property releases are appropriately certified, verified, documented, and reported; public participation needs are addressed; and processes are in place to appropriately maintain records.

No property with detectable residual radioactivity was released from the Hanford Site in 2004.

\subsubsection{Radiological Clearance for Release of Selected Hanford Reach National Monument Lands}

\section{W. M. Glines}

In June 2000, a Presidential Proclamation created the 78,900-hectare (195,000-acre) Hanford Reach National
Monument within the boundaries of the DOE Hanford Site (Establishment of the Hanford Reach National Monument, 65 FR 114). Although DOE maintains administrative control and jurisdiction over the land within the Hanford Reach National Monument, the Department of Interior's U.S. Fish and Wildlife Service manages about $84 \%$ of the land. In July 2001, the DOE Office of Inspector General issued an audit report (Administrative Control of the Hanford Reach National Monument, DOE/IG-0514). This audit concluded that it was not in DOE's best interest to retain administrative control of all land within the Hanford Reach National Monument and identified approximately 57,900 hectares (143,000 acres) of land within the monument that could be transferred to the Department of Interior without adversely affecting DOE operations at the Hanford Site. The lands identified for transfer included (1) the Fitzner/Eberhardt Arid Lands Ecology Reserve Unit (a 311-square-kilometer [120-squaremile] tract in the southwestern portion of the Hanford Site), (2) the combined Saddle Mountain Unit (a 130-squarekilometer [50-square-mile] tract located north-northwest of the Columbia River and generally south and east of State Highway 24) and Wahluke Unit (an 225-squarekilometer [87-square-mile] tract located north and east of both the Columbia River and the Saddle Mountain Unit); the Saddle Mountain Unit and the Wahluke Unit together are referred to as the North Slope, and (3) the McGee Ranch/Riverlands Unit (located on the western portion of the Hanford Site and bordered by State Highway 24, the Columbia River, private land in the Cold Creek Valley, and the Yakima Firing Center).

Subsequently, the DOE Richland Operations Office entered into negotiations with the Department of Interior regarding the release and transfer of these selected portions of the Hanford Reach National Monument from DOE control to the jurisdiction of the U.S. Fish and Wildlife Service. In addition to being consistent with the DOE 
Office of Inspector General audit report, transfer of these lands would support the primary DOE environmental management mission to remediate and/or release as much of the Hanford Site as possible.

As part of the radiological clearance process for this property, an historical site assessment was performed and documented in Historical Site Assessment: Select Hanford Reach National Monument Lands - Fitzner/Eberhardt Arid Lands Ecology Reserve (ALE), McGee Ranch/Riverlands, and North Slope Units (PNNL-13989). Staff conducting this historical site assessment reviewed historical environmental data collected on and around these lands and developed a contaminant transport conceptual model. Interviews were conducted with people who were knowledgeable of past Hanford Site operations that may have contributed to residual contamination on this property.

The historical site assessment (PNNL-13989) concluded that while some activities using radioactive materials had taken place on the selected lands, "In general, the data available indicate that the Hanford Reach National Monument units of interest have very low concentrations of radionuclides. Radionuclide concentrations are very near the analytical detection levels for most media and locations... Further, the data do not indicate a strong likelihood of transport of significant amounts of longlived radioactive material from Hanford operating areas to national monument lands ... The median radionuclide concentrations in each media were generally similar at each unit. In addition, the majority of the observed concentrations on the Fitzner/Eberhardt Arid Lands Ecology Reserve Unit, McGee/Riverlands and North Slope Units were similar to the concentrations observed at reference locations. This implies that atmospheric fallout from above ground weapons testing contributed significantly to the low levels of manmade radionuclides that were measured in the Hanford Reach National Monument environs."

Thus, the expected concentrations of residual radionuclides in the soil on the site are very low, i.e., in the range of background concentrations.

Before control of these lands may be transferred from DOE to the Department of Interior, the DOE Richland
Operations Office must verify the presence or absence of residual radioactive contamination on these lands and demonstrate compliance with the requirements of DOE Order 5400.5. For any land with the potential for residual radioactive contamination, DOE Order 5400.5 requires that radiological clearance or release criteria, i.e., authorized limits, be developed and submitted to the applicable DOE Headquarters program office, which for the Hanford Site is the Office of Environmental Management, for approval. Authorized limits are defined as levels of residual radioactivity that shall not be exceeded if the property is to be released without restrictions on use resulting from residual radioactivity. Residual radioactivity is defined as any radioactive material that is in or on soil, air, equipment, or structures as a consequence of past DOE operations or activities. Accordingly, authorized limits control the amount of residual radioactivity on property that is released from DOE radiological controls. Specifically, DOE Order 5400.5 states that: "The authorized limits shall be established to (1) provide that, at a minimum, the basic dose limits... will not be exceeded, or (2) be consistent with applicable generic guidelines." Since generic guidelines have not been established for residual radioactivity for the radionuclides of concern for these selected Hanford Reach National Monument lands, the authorized limits were established on the basis of ensuring that the DOE public dose limit of $100 \mathrm{mrem}(1 \mathrm{mSv})$ per year would not be exceeded.

Surface soils were identified as the most significant medium for quantifying potential radiation doses resulting from any residual radioactivity on the selected Hanford Reach National Monument lands. Accordingly, authorized limits, in units of picocuries per gram in soil above background, were required that would result in radiation doses less than 100 mrem $(1 \mathrm{mSv})$ per year to any member of the public. To develop these authorized limits, a radiation dose analysis was conducted based on likely and worst-use scenarios and conditions on the selected Hanford Reach National Monument lands. In accordance with the Presidential Proclamation, which created the Hanford Reach National Monument, the expected end-use, i.e., likely use scenario, for these Hanford Reach National Monument lands is recreational use. In accordance with the guidance in DOE G 441.1-XX, ${ }^{(a)}$ a dose constraint of

(a) DOE G 441.1-XX. Draft. Implementation Guide. Control and Release of Property with Residual Radioactive Material for Use with DOE 5400.5, Radiation Protection of the Public and the Environment. U.S. Department of Energy, Washington, D.C. 
$25 \mathrm{mrem}(0.25 \mathrm{mSv})$ per year was applied to this likely use scenario for developing the authorized limits.

The worst-use scenario was considered to be a subsistence farmer. This scenario represents the situation in which restrictions that control end-use of these Hanford Reach National Monument lands fail or the actual end-use is different from the expected end-use. The DOE public dose limit of 100 mrem $(1 \mathrm{mSv})$ per year was applied to this worst-use scenario. While the Presidential Proclamation and the expected terms and conditions of the transfer of these selected Hanford Reach National Monument lands to the Department of Interior would preclude such a worstuse scenario, it provides a conservative, bounding scenario to assure that the DOE public dose limit will not be exceeded by an unlikely, future agricultural resident on these selected Hanford Reach National Monument lands.

Accordingly, for the radiation dose analyses used to develop these authorized limits, two types of exposed individuals were identified: (1) recreational users of the Hanford Reach National Monument and (2) agricultural residents. Primary data for these exposure scenarios, including the radionuclides selected for analysis and the parameter values and data used as input to the computer models, were obtained from recent literature and from the historical site assessment. The RESRAD Version 6.21 (ANL/EAD-4) computer program was used as the calculational model for translating these dose values into surface soil concentrations. Soil concentrations were developed for each of the radionuclides of concern, for each of the exposure scenarios, and for several geographical units of the selected Hanford Reach National Monument lands. The final authorized limits (Table 7.0.1) were determined as the most limiting (smallest) soil concentrations for each radionuclide across the scenarios and Hanford Reach National Monument locations.

The request for these authorized limits for the selected Hanford Reach National Monument lands with supporting technical documentation was submitted to the Office of Environmental Management on December 22, 2003. The requested authorized limits were approved on March 1, 2004, subject to reconciliation of comments regarding the application of the DOE public dose limit to the agricultural resident scenario. These comments were reconciled in the final authorized limits request (PNNL-14622) and supporting technical basis document (PNNL-14531).

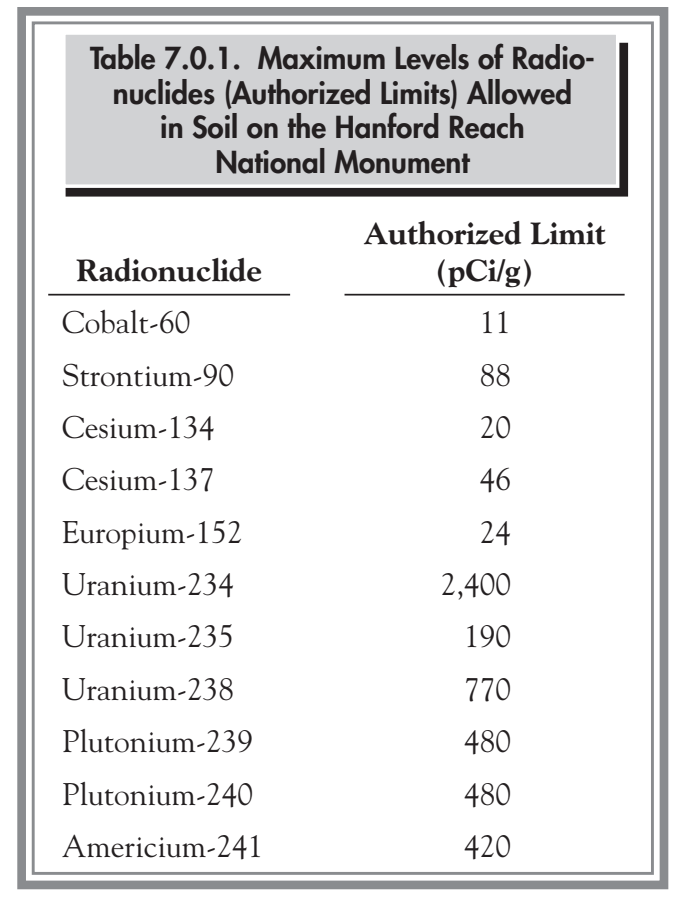

In order to demonstrate compliance with these approved authorized limits, soil samples must be collected and analyzed in accordance with a DOE-approved sampling and analysis plan. This sampling and analysis plan includes the collection and analyses of soil, assessment of the analytical data against the authorized limits, generation of a final report, and the inclusion of all pertinent data and information into a formal records management system. For purposes of implementing this required sampling, the selected Hanford Reach National Monument lands were divided into two sections: (1) the Fitzner/Eberhardt Arid Lands Ecology Reserve Unit and (2) the remainder of the selected Hanford Reach National Monument lands, i.e., the combined Saddle Mountain Unit and Wahluke Unit and the McGee Ranch/Riverlands Unit. A sampling and analysis plan (PNNL-14633) was developed for the Fitzner/ Eberhardt Arid Lands Ecology Reserve unit. The goal and design criteria of this plan were to collect an adequate number of soil samples to determine if the concentrations of radionuclides of concern in Fitzner/Eberhardt Arid Lands Ecology Reserve soil are below the approved authorized limits with a high degree of statistical confidence, i.e., 99\%. The collection and analysis of soil samples from the Fitzner/Eberhardt Arid Lands Ecology Reserve was initiated in 2004 (see Section 7.0.1.3).

A sampling and analysis plan (PNNL-14950) for the remainder of the selected Hanford Reach National 
Monument lands has been developed and approved. Soil sampling on these remaining Hanford Reach National Monument lands will be conducted in 2005 .

\subsubsection{Assessment of Fitzner/ Eberhardt Arid Lands Ecology Reserve Unit Soil for Residual Radioactive Contamination}

\section{B. G. Fritz}

In 2004, soil sampling was conducted on the Fitzner/ Eberhardt Arid Lands Ecology Reserve Unit to determine if the concentrations of radionuclides in its soil were below the authorized limits for the Hanford Reach National Monument (PNNL-14950).

Fifty soil samples were collected from the Fitzner/Eberhardt Arid Lands Ecology Reserve Unit. The number of samples necessary to decide with a high level of confidence (99\%) that the soil concentrations of radionuclides did not exceed the authorized limits was determined through the use of a computer program, Visual Sample Plan. Complete rationale for the determination of the number and location of samples was published in the sampling and analysis plan for this work (PNNL-14633).
The 50 soil samples collected from the Fitzner/Eberhardt Arid Lands Ecology Reserve Unit had concentrations of radionuclides far below the authorized limits for the Hanford Reach National Monument (Figure 7.0.1). Spatial analysis of the results indicated no observable statistically significant differences between radionuclide concentrations across the Fitzner/Eberhardt Arid Lands Ecology Reserve Unit. Furthermore, the maximum observed soil concentrations for the radionuclides included in the authorized limits would result in an annual dose of 0.22 mrem $(2.2 \mu \mathrm{Sv})$ for the most likely use scenario (PNNL-14937). This dose is well below the DOE 100 mrem $(1 \mathrm{mSv})$ per year dose limit for a member of the public. Also, the results of the biota dose assessment screen indicated that the levels of radionuclides on the Fitzner/Eberhardt Arid Lands Ecology Reserve Unit pose no significant health risk to biota.

\subsubsection{Emergency Decontamination Facility}

In October 1965, the former U.S. Atomic Energy Commission, now DOE, signed a 99-year land lease agreement with the Kadlec Methodist Hospital, now Kadlec Medical Center, for a plot of land adjacent to the hospital. The Hanford Radiosurgery Unit (Building Number 748), later

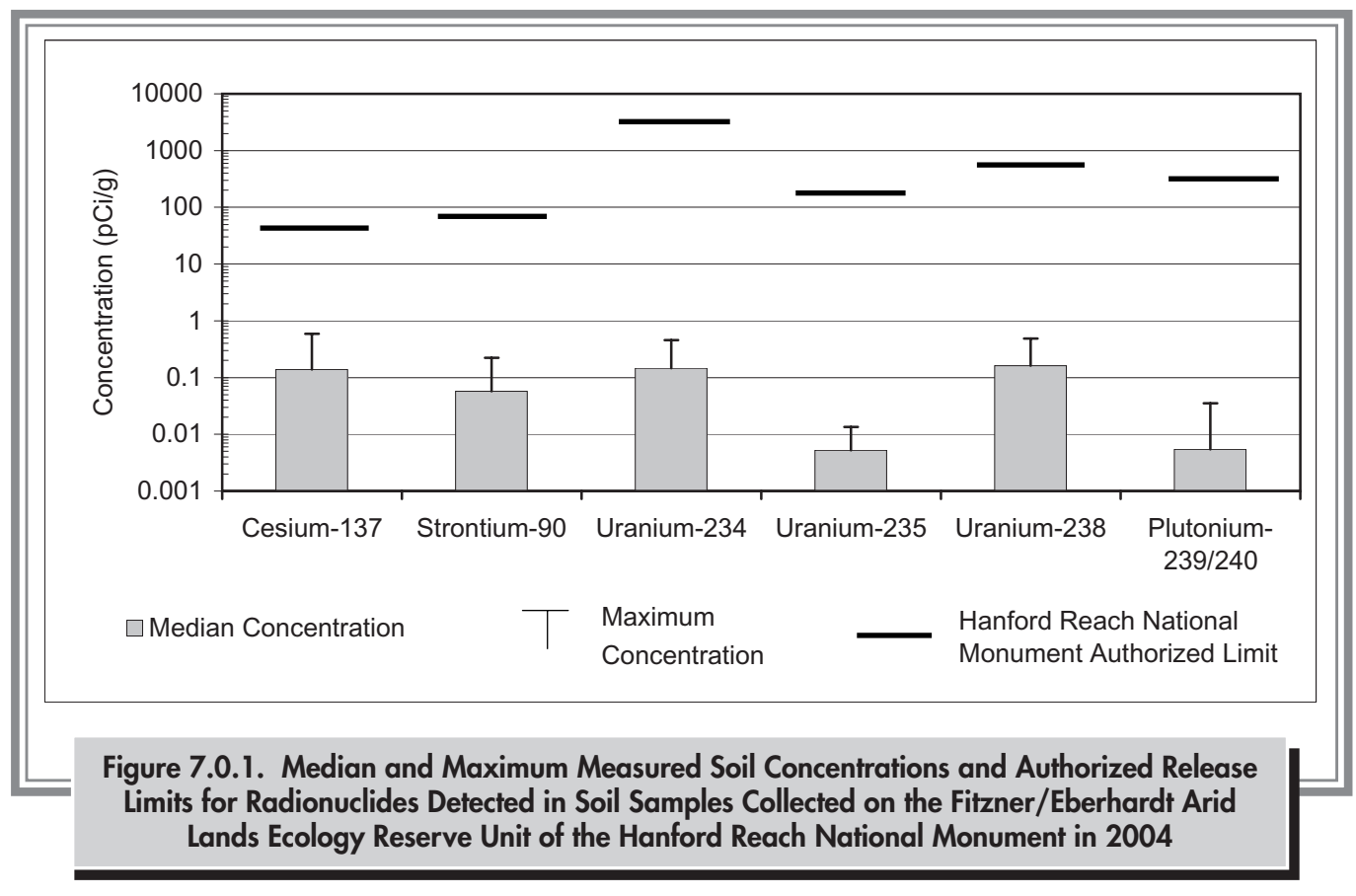


known as the Emergency Decontamination Facility, was subsequently constructed on this leased property. The only major use of the Emergency Decontamination Facility was in 1976 for the treatment and decontamination of a patient who was injured and significantly contaminated with americium-241. Widespread contamination of the Emergency Decontamination Facility occurred as a result of the treatment of this individual.

In 2002, Kadlec Medical Center and the DOE Richland Operations Office entered into discussions regarding the termination of this lease agreement. Kadlec Medical Center wishes to expand its current medical facilities onto the leased property currently occupied by the Emergency Decontamination Facility. Because of the construction of other decontamination facilities at Kadlec Medical Center and on the Hanford Site, maintaining the Emergency Decontamination Facility is no longer necessary or cost-effective. In 2004, as part of the termination of this lease agreement and return of control of the Emergency Decontamination Facility site to Kadlec Medical Center, the DOE Richland Operations Office initiated development of authorized limits for the Emergency Decontamination Facility site. A request for these authorized limits was submitted to the DOE Office of Environmental Management in January 2005.

\subsubsection{Columbia River Corridor Risk Assessment}

\section{K. A. Gano}

The River Corridor Baseline Risk Assessment Project's objective is to support DOE's cleanup efforts in the Columbia River corridor. The project consists of three components: (1) the 100 Areas and 300 Area Component, (2) the 100-B/C Area Pilot Project, and (3) the Columbia River Component. These assessments address an array of potential human uses, multiple environments, and all of the hazardous substances released from hundreds of waste sites along the Columbia River corridor. The results of the assessments will help determine the level of cleanup required to protect human health and the environment at or around facilities within the Hanford Site's Columbia River corridor.
DOE's Hanford cleanup plan and the project team's work are based on the Comprehensive Environmental Response, Compensation and Liability Act (CERCLA). In 1991, DOE, the U.S. Environmental Protection Agency (EPA), and the Washington State Department of Ecology agreed to pursue interim cleanup of the 100 and 300 Areas to focus on protecting the Columbia River. Typically, risk assessments are done before cleanup begins, but the regulatory agencies granted interim records of decision to initiate cleanup first and postpone conducting risk assessments until a later date.

To perform a risk assessment, the Environmental Restoration Project team uses a multi-step process. The process begins by compiling and summarizing the existing data, then using the data quality objectives process to identify both data gaps and unresolved issues through open workshops with the regulatory agencies, stakeholders, tribes, and the public. Based on these discussions, a sampling and analysis plan is developed to collect the data needed to fill the gaps and address the issues. Once all of the necessary data are collected, the risks to human health and the environment are calculated.

In 2002, DOE and EPA agreed to develop a pilot risk assessment at the 100-B/C Area that could be adapted for use at all the 100 and 300 Areas. This project initiated the process for evaluating site conditions after cleanup and determined the environmental measurements that were needed to assess the cleanup actions. This project pioneered the collection of culturally significant plants for inclusion in the risk assessment by working directly with the Wanapum Band, who want to be sure that traditional uses of plants would not carry unacceptable risks to them or their descendants. The pilot project will be complete in 2006.

The risk assessment for the 100 and 300 Areas has opened the process to the public and to the tribes even more by providing initial working drafts of sections of reports for review and comment. These reviews are taking place well before documents are usually considered ready for regulatory, stakeholder, tribal, or public comment to make this process as transparent as possible to ensure its acceptance. The risk assessment report for the 100 and 300 Areas is expected in 2007. 
The third element of the project team's work is the Columbia River Component. This is the first component that will move far outside the Hanford Site boundaries in assessing risk. It will assess 644 kilometers (400 miles) of the river, including both shorelines and islands. It will take a broad view of the river corridor in terms of its length and width and will allow the data to determine where the final study boundaries will be drawn. The Columbia River Component is scheduled for completion in 2009.

Ongoing, open communication among the many parties interested in Hanford Site cleanup is the guiding principle of the River Corridor Baseline Risk Assessment Project. Team members regularly consult with regulatory agencies, Native American tribes, the Natural Resources Trustees Council, Hanford Advisory Board, and the public about the project. A website has been created to provide an information repository for the project. The site includes the dates of public involvement opportunities, documents available for review and comment, administrative information, and links to related projects. The website can be found at http://www.bhi-erc.com/Projects/risk/risk.htm. 


\subsection{Environmental and Resource Protection Programs}

R. W. Hanf

U.S. Department of Energy (DOE) Orders 450.1, Environmental Protection Program, and 5400.5, Radiation Protection of the Public and the Environment, require that DOE conduct monitoring at Hanford to protect the site's environmental and cultural resources, the public, and workers on the site. The monitoring activities support the site's Integrated Safety Management System Policy (DOE P 450.4) and its component Environmental Management System (see Section 4.0.1). These component systems are tools for achieving site and contractor compliance with environmental, public health, and resource protection laws, regulations, and DOE Orders.

The Environmental Monitoring Plan, United States Department of Energy, Richland Operations Office (DOE/RL-91-50) is the mechanism through which monitoring programs and projects are implemented at Hanford. The plan contains the rationale for the required programs and projects including design criteria, sampling locations and schedules, quality assurance requirements, program and project implementation procedures, analytical procedures, and reporting requirements. The early identification of, and appropriate response to, potentially adverse environmental and resource effects associated with DOE operations are assured by routinely conducting pre-operational environmental characterization and assessment activities, monitoring effluent and emissions, performing environmental monitoring and surveillance (as defined in DOE Order 5400.5 and in Appendix B, Glossary), monitoring cultural resources, performing periodic sampling of Hanford Site drinking water, and monitoring and controlling contaminated and undesirable biota.

The objectives of the monitoring programs include:

- Detecting, characterizing, and responding to contaminant releases from Hanford Site DOE facilities and operations.
- Providing data for assessing the human health and ecological impacts of Hanford-produced contaminants.

- Estimating contaminant dispersal patterns in the environment.

- Characterizing the pathways of exposure to members of the public and biota.

- Characterizing the exposures and doses to individuals, the nearby population, and biota.

- Evaluating potential impacts to biota (and the Columbia River) in the vicinity of DOE Hanford Site activities.

- Assuring that environmental monitoring programs are conducted in an integrated fashion to preclude collection of duplicative environmental data.

- Ensuring early identification of, and appropriate response to, the potentially adverse environmental impact associated with DOE operations.

- Promoting long-term stewardship of the Hanford Site's natural and cultural resources.

- Protecting natural and cultural resources.

There are other important reasons for conducting these monitoring activities:

- Complying with local, state, and federal laws and regulations and DOE Orders.

- Confirming site compliance with local, state, and federal laws and regulations and DOE Orders.

- Verifying the efficacy of waste management practices on the Hanford Site.

- Providing information to assure the public that facilities and operations are not adversely affecting people or the environment.

- Answering questions or providing information to stakeholders, activist organizations, and the public. 
- Supporting DOE decisions.

- Providing information to support DOE in environmental litigations.

The primary environmental and resource monitoring program and projects at Hanford include the Effluent Monitoring Program, conducted by Fluor Hanford, Inc.; the Public Safety and Resource Protection Project, managed by the Pacific Northwest National Laboratory; and the Groundwater Performance Assessment Project, also managed by the Pacific Northwest National Laboratory. These efforts are managed through the DOE Richland Operations Office. Detailed program and project information, including the specific objectives of each program and project element, is included in the Hanford Site Environmental Monitoring Plan (DOE/RL-91-50).

Pacific Northwest National Laboratory personnel through a contract with Fluor Hanford, Inc. monitor radiological contaminants in Hanford Site drinking water. Sample collection for the Drinking Water Monitoring Project is done in conjunction with sampling activities of the Surface Environmental Surveillance Project (an element of the Public Safety and Resource Protection Project), and sample analyses are accomplished through the Surface Environmental Surveillance Project's analytical contract. Data management and quality assurance are also tied to surveillance project requirements and staff.

The Biological Control Program manages activities on the Hanford Site to prevent, limit, and clean up contaminated or undesirable plants or animals and to remediate their impact to the environment and human health and safety. This program, managed for DOE by Fluor Hanford, Inc., was established in 1998 in response to increasing incidents of radiological contamination spread by biological vectors (DOE/RL-98-77). The radiological component of the project includes activities to control plants and animals that have spread or have the potential to spread radioactive contamination. The non-radiological component of the program deals with control of pests, such as noxious weeds, that may adversely affect the workplace or the environment.

Brief overviews of environmental monitoring program and project elements, the Drinking Water Monitoring Project, and the Biological Control Program are provided in the following sections.

\subsubsection{Effluent Monitoring Program}

Effluent monitoring at Hanford has two elements: (1) liquid effluent and airborne emissions monitoring at site facilities and operations and (2) environmental monitoring near facilities and operations that have the potential to discharge, or have discharged, stored, or disposed of radioactive and hazardous materials. Categories of effluent that normally or potentially contain radionuclides or hazardous materials include cooling water, steam condensates, process condensates, and wastewater from laboratories and chemical sewers. Airborne emissions can include both radioactive and non-radioactive particulate, gaseous, and volatilized materials from facility stacks.

\subsubsection{Liquid Effluent and Airborne Emissions Monitoring}

The Hanford Site's contractors perform real-time monitoring of liquid effluent and airborne emissions at each facility to assess the effectiveness of effluent and emissions treatment and control systems, pollution management practices, and to determine facility and site compliance with state and federal regulatory requirements. Information on effluent discharged from site facilities in 2004 is summarized in Section 8.3 and in an annual environmental releases report (e.g., HNF-EP-0527-14). Emissions data for 2004 are summarized in Section 8.1 and in several other reports (e.g., DOE/RL-2005-06).

\subsubsection{Near-Facility Environmental Monitoring}

Near-facility environmental monitoring is conducted near DOE facilities and operations on the Hanford Site that have the potential to discharge, or have discharged, stored, or disposed of radioactive or hazardous contaminants. Monitoring locations are associated with nuclear facilities such as the Canister Storage Building and the 100-K Basins; inactive nuclear facilities such as N Reactor and the Plutonium-Uranium Extraction (PUREX) Plant; and active and inactive waste storage or disposal facilities such as burial grounds, cribs, ditches, ponds, underground waste storage tanks, and trenches. 
Much of the monitoring program consists of collecting and analyzing environmental samples and conducting radiological surveys in areas near facilities. The program also is designed to evaluate and report analytical data, determine the effectiveness of facility effluent monitoring and controls, measure the adequacy of containment at waste disposal sites, and detect and monitor unusual conditions. The program implements applicable portions of DOE Orders 435.1, Radioactive Waste Management, 450.1 (replaced DOE Order 5400.1, General Environmental Protection Program, in January 2003), and 5400.5; DOE Manual 231.1-1A, Environment, Safety, and Health Reporting Manual; Title 10, Code of Federal Regulations, Part 835 (10 CFR 835, Occupational Radiation Protection) and 40 CFR 61, National Emission Standards for Hazardous Air Pollutants; and Washington Administrative Code (WAC) 246-247, Radiation Protection-Air Emissions.

Several types of environmental media are routinely sampled near Hanford Site facilities and various radiological and non-radiological measurements are taken. The media sampled include air, Columbia River shoreline-spring water (seep wells in the 100-N Area), soil, and vegetation. In addition, surface contamination and external radiation levels are monitored. Media samples are collected from known or expected emissions and effluent pathways, which are generally downwind of potential or actual airborne releases and downgradient of liquid discharges.

Active and inactive waste disposal sites and the terrain surrounding them are surveyed to detect and characterize radioactive surface contamination. Routine radiological survey locations include former waste disposal cribs and trenches, retention basin perimeters, ditch banks, solid waste disposal sites (e.g., burial grounds), unplanned release sites, tank farm perimeters, stabilized waste disposal sites, roads, and firebreaks in and around the site operational areas.

Investigations of contaminated biota, soil, and other materials are conducted in the operational areas to monitor the presence or movement of radioactive and/or hazardous materials around areas of known or suspected contamination or to verify radiological conditions at specific project (e.g., cleanup or construction) sites. Investigations for contaminants are conducted for at least one of the following reasons:

- To follow up surface radiological surveys that had indicated radioactive contamination was present
- To conduct pre-operational surveys to characterize the radiological and chemical conditions at a site before facility construction, operation, or ultimate remediation

- To determine if biotic intrusion (e.g., animal burrows or deep-rooted vegetation) had created a potential for contaminants to spread

- To determine the integrity of waste containment systems.

Contamination incidents investigated in 2004 focused on soil, vegetation, wildlife, and wildlife-related materials. Most materials were surveyed in the field to detect radioactive contamination. Some materials were sampled and the samples were submitted to an analytical laboratory for analysis. Methods for surveying and sampling these contaminated materials are described in DTS-OEM-001, Operational Environmental Monitoring. Laboratory analyses results and field survey readings for contamination incidents investigated in 2004 are provided in PNNL-15222, APP. 2, Hanford Site Near-Facility Environmental Monitoring Data Report for Calendar Year 2004.

Information on contaminant concentrations or radiation levels measured onsite near facilities and operations during 2004 is summarized in Sections 8.2, 8.5, 8.9, 8.10, 8.13, and 8.18. Additional data may be found in PNNL-15222, APP. 2). The type and general locations of samples collected for near-facility monitoring during 2004 are summarized in Table 8.0.1. Information on contamination incidents investigated during 2004 is summarized in Sections 8.9, 8.10, and 8.11.

\subsubsection{Public Safety and Resource Protection Project}

The Public Safety and Resource Protection Project is managed for the DOE Richland Operations Office by Pacific Northwest National Laboratory. Its purpose is to monitor the Hanford environment, provide assurance that the site operates in compliance with applicable environmental regulations, and conduct impact assessments to protect public and worker safety as well as Hanford's significant ecological and cultural resources. The project obtains environmental information related to public health and environmental effects that is necessary for DOE to manage environmental risk at Hanford. Whereas effluent and near-facility environmental monitoring are 


\begin{tabular}{|c|c|c|c|c|c|c|c|c|c|c|}
\hline \multirow[b]{3}{*}{ Sample Type } & \multicolumn{8}{|c|}{$\begin{array}{c}\text { Table 8.0.1. Routine Environmental Monitoring Samples and Locations Near } \\
\text { Hanford Site Facilities and Operations, } 2004\end{array}$} & & \\
\hline & \multirow{2}{*}{$\begin{array}{c}\text { Number of } \\
\text { Sample } \\
\text { Locations }\end{array}$} & \multicolumn{9}{|c|}{ Operational Area } \\
\hline & & $\underline{100-B / C}$ & $\underline{100-\mathrm{D} / \mathrm{DR}}$ & $\underline{100-K}$ & $\underline{100-\mathrm{F}}$ & $\underline{100-\mathrm{H}}$ & $\underline{100-N}$ & $\underline{E R D F}^{(a)}$ & $\underline{600}$ & $\underline{400}$ \\
\hline Air & 85 & 5 & 3 & 11 & 2 & 2 & 4 & 3 & $47^{(\text {b) }}$ & 8 \\
\hline Soil & 83 & 2 & 0 & 1 & 2 & 0 & 7 & 1 & 56 & 14 \\
\hline Vegetation & 69 & 0 & 0 & 0 & 0 & 0 & 6 & 0 & 49 & 14 \\
\hline External radiation & 135 & 4 & 0 & 20 & 0 & 0 & 14 & 3 & 67 & 27 \\
\hline Water & 8 & 0 & 0 & 0 & 0 & 0 & 8 & 0 & 0 & 0 \\
\hline \multicolumn{11}{|c|}{$\begin{array}{l}\text { (a) Environmental Restoration Disposal Facility in the 200-West Area. } \\
\text { (b) Includes } 1 \text { station at the Wye Barricade, } 23 \text { in the 200-East Area, and } 23 \text { in the 200-West Area. }\end{array}$} \\
\hline
\end{tabular}

conducted by the facility operating contractor or designated subcontractor, environmental surveillance is conducted under an independent program that reports directly to the DOE Richland Operations Office.

The project is managed as an integrated unit that consists of the following five elements:

- Hanford Environmental Oversight

- Meteorological and Climatological Services Project

- Surface Environmental Surveillance Project

- Ecological Monitoring and Compliance Project

- Cultural Resources Project.

Brief overviews of these elements are provided in the following sections.

\subsubsection{Hanford Environmental Oversight}

Hanford Environmental Oversight manages the Public Safety and Resource Protection Project. This element is responsible for the integration of activities performed within the Public Safety and Resource Protection Project and the coordination of related environmental assessment and resource protection activities across the site. In addition, it is responsible for the optimization of other Public Safety and Resource Protection Project elements and operations, including self-assessments, performance assessments, and design reviews. This element also provides for the:

- Stewardship of long-term historical environmental, ecological, climatological, and cultural resource databases
- Coordination and control of the Hanford Site Environmental Monitoring Plan (DOE/RL-91-50) consistent with 65 FR 24595, Greening the Government Through Leadership in Environmental Management, and DOE Order 450.1.

- Annual updates of the Hanford Site National Environmental Policy Act (NEPA) Characterization Report (PNNL-6415).

\subsubsection{Meteorological and Climatological Services Project}

The Meteorological and Climatological Services Project provides information to help ensure that DOE activities on the Hanford Site, which could be affected by adverse meteorological conditions (thunderstorms, strong winds, blowing dust, dense fog, and snowstorms), operate in as safe and efficient a manner as possible. Meteorological data are essential for planning day-to-day work activities. The project also provides meteorological response in the event of a suspected or actual release of radioactive or hazardous material to the atmosphere so that personnel involved in responding to the event can make appropriate and timely decisions. Meteorological data are also integral to the annual estimation of potential public radiation exposure. Comprehensive climatological data records are maintained for use in a variety of other applications, such as post-accident analysis, dose reconstruction, building designs, and environmental impact assessments. Summary meteorological monitoring data for 2004 and some historical climatological information are provided in Section 8.16. Detailed monitoring data are reported in the Hanford Site Climatological Data Summary 2004 with Historical Data (PNNL-15160). 


\subsubsection{Surface Environmental Surveillance Project}

The Surface Environmental Surveillance Project is an element responsible for measuring the concentrations of radionuclides and chemicals in environmental media onsite at locations away from facilities (site-wide) and offsite at perimeter, community, and distant locations, and assessing the potential effects of these materials on the environment and the public. Samples of agricultural products, air, fish and wildlife, soil, surface water and sediment, Columbia River shoreline seep water and sediment, and vegetation are collected routinely. The samples are analyzed for radionuclides and chemicals, including metals and anions. In addition, ambient external radiation is measured at selected locations on and off the site and ambient gamma radiation levels are monitored at four offsite air sampling locations.

Project monitoring activities focus on routine releases from DOE facilities on the Hanford Site; however, the project also conducts sampling and analysis in response to known unplanned releases and releases from non-DOE operations on and near the site. Monitoring results are provided to the DOE and the public annually through this report series. Unusually high contaminant concentrations, should they occur, are reported to the DOE Richland Operations Office and the appropriate facility managers.

The general requirements and objectives for this Surface Environmental Surveillance Project are to monitor routine and non-routine contaminant releases to the environment from DOE facilities and operations, to assess doses to members of the public, to monitor potential impacts of contaminants on other biota, and to alert DOE to the possible need for corrective action (DOE Orders 450.1 and 5400.5; DOE/EH-0173T, Environmental Regulatory Guide for Radiological Effluent Monitoring and Environmental Surveillance). The specific objectives of the monitoring activities include:

- Collecting and analyzing samples, reviewing and interpreting analytical data, and maintaining a longterm computer database for trend analysis

- Determining compliance with applicable environmental quality standards, public exposure limits, and applicable laws and regulations; the requirements of DOE Orders; and the environmental commitments made in environmental impact statements, environmental assessments, safety analysis reports, or other official DOE documents

- Conducting pre-operational assessments

- Assessing radiological doses to the public and environment

- Assessing doses from other local sources

- Reporting alarm levels and potential doses exceeding reporting limits

- Determining background levels and site contributions of contaminants in the environment

- Determining long-term accumulations of site-related contaminants in the environment and predicting trends

- Characterizing and defining trends in the physical, chemical, and biological conditions of environmental media

- Determining the effectiveness of treatments and controls in reducing effluents and emissions

- Determining the validity and effectiveness of models to predict concentrations of pollutants in the environment

- Detecting and quantifying unplanned releases

- Identifying and quantifying new environmental quality problems

- Maintaining the capability to assess the consequence of accidental contaminant releases.

- Providing public assurance and addressing issues of concern to the public, stakeholders, regulatory agencies, and business community

- Enhancing public understanding of site environmental issues, primarily through public involvement and by providing environmental information to the public

- Providing environmental data and assessments to assist DOE and its contractors in environmental management of the site.

Annual design reviews are performed to assure the project is aligned with current operations and missions, focused on those contaminants having the greatest contribution to the potential offsite dose, and providing the greatest amount of useful information for the waste management, cleanup, and environmental assessment activities planned or ongoing at Hanford. Site-wide and offsite surveillance 
is closely related to and coordinated with the Near-Facility Environmental Monitoring Program described in Section 8.0.1.2 and the Groundwater Performance Assessment Project (Section 8.0.3).

Information on contaminant concentrations in project samples collected at site-wide and offsite locations during 2004 is summarized in Sections 8.2, 8.4, 8.5, 8.8, 8.9, 8.10, $8.11,8.13$, and 8.14 . Other project information is summarized in Sections 8.12, 8.17, and 8.18. More detailed contaminant data are provided in Hanford Site Environmental Surveillance Data Report for Calendar Year 2004 (PNNL15222, APP. 1). The types and general locations of samples collected for site-wide and offsite environmental monitoring during 2004 are summarized in Table 8.0.2.

\subsubsection{Ecological Monitoring and Compliance Project}

The Ecological Monitoring and Compliance Project has multiple objectives that support both activity-specific ecological compliance requirements and site-wide requirements to assure the protection of Hanford's natural resources. Project personnel monitor the abundance, vigor, and distribution of plant and animal populations on the Hanford Site and evaluate the cumulative impact of site operations on these resources. In addition, project staff perform baseline ecological resource surveys to document the occurrence of protected resources, evaluate and document impacts to protected species and habitats as required

\begin{tabular}{|c|c|c|c|c|c|c|c|c|}
\hline \multirow[b]{4}{*}{ Type } & \multirow{4}{*}{$\begin{array}{c}\text { Table 8.0.2. } \\
\\
\text { Total } \\
\text { Number }\end{array}$} & \multicolumn{6}{|c|}{$\begin{array}{l}\text { Routine Hanford Site Environmental Surveillance Samples and Locations } \\
\text { at Site-Wide and Offsite Locations, } 2004\end{array}$} & \multirow{3}{*}{ iver } \\
\hline & & \multicolumn{6}{|c|}{ Sample Locations } & \\
\hline & & \multirow[b]{2}{*}{$\underline{\text { Onsite }}^{(a)}$} & \multirow[b]{2}{*}{$\begin{array}{c}\text { Site } \\
\text { Perimeter }^{(\mathbf{b})}\end{array}$} & \multirow[b]{2}{*}{$\underline{\text { Nearby }}^{(\mathrm{c})}$} & \multirow[b]{2}{*}{$\underline{\text { Distant }}^{(\mathfrak{c})}$} & \multicolumn{2}{|c|}{ Columbia River } & \\
\hline & & & & & & $\underline{\text { Upstream }}^{(\mathrm{c})}$ & $\begin{array}{l}\text { Hanford } \\
\underline{\text { Reach }}^{(\mathbf{b})}\end{array}$ & $\underline{\text { Downstream }}^{(\mathrm{c})}$ \\
\hline Air & 44 & 23 & 11 & $8^{(\mathrm{d})}$ & $2^{(\mathrm{d})}$ & & & \\
\hline Spring water & 9 & & & & & & 9 & \\
\hline Spring sediment & 5 & & & & & & 5 & \\
\hline $\begin{array}{l}\text { Columbia River } \\
\text { water }\end{array}$ & 7 & & & & & 2 & 4 & 1 \\
\hline Irrigation water & 2 & & 2 & & & & & \\
\hline Drinking water & 4 & 4 & & & & & & \\
\hline River sediment & 6 & & & & & 1 & 3 & 2 \\
\hline Ponds & 2 & 2 & & & & & & \\
\hline Pond sediment & 1 & 1 & & & & & & \\
\hline Foodstuffs & 9 & & 2 & 4 & 3 & & & \\
\hline Wildlife & 11 & 9 & & & 2 & & & \\
\hline Aquatic biota & 2 & & & & & 1 & 1 & \\
\hline Vegetation & 17 & 8 & 4 & 1 & 4 & & & \\
\hline Soil & 42 & 20 & 13 & 2 & 7 & & & \\
\hline External dose $\mathrm{e}^{(\mathrm{e})}$ & 81 & 33 & 12 & 6 & 2 & 1 & 24 & 3 \\
\hline $\begin{array}{l}\text { External shoreline } \\
\text { radiation }^{(f)}\end{array}$ & 15 & & & & & 1 & 14 & \\
\hline $\begin{array}{l}\text { Exposure rate } \\
(\mathrm{PIC})^{(\mathrm{g})}\end{array}$ & 4 & & & 3 & 1 & & & \\
\hline $\begin{array}{ll}\text { (a) } & \text { Surveillance } \\
& \text { perimeter). } \\
\text { (b) } & \text { Surveillance } \\
\text { (c) } & \text { Surveillance } \\
\text { (d) } & \text { Includes com } \\
\text { (e) } & \text { Measured by } \\
\text { (f) } & \text { Measured by } \\
\text { (g) } & \text { Pressurized io }\end{array}$ & $\begin{array}{l}\text { Zone } 1 \text { (betwe } \\
\text { Zone } 2 \text { (near } \\
\text { Zone } 3 \text { (in an } \\
\text { nmunity-opera } \\
\text { thermolumine } \\
\text { handheld surv } \\
\text { onization chan }\end{array}$ & $\begin{array}{l}\text { oen the Nea } \\
\text { or just insid } \\
d \text { between c } \\
\text { ted environ } \\
\text { escent dosin } \\
\text { yey instrume } \\
\text { hbers. }\end{array}$ & $\begin{array}{l}\text {-Facility Envirc } \\
\text { the site bound } \\
\text { mmunities wit } \\
\text { nental surveilla } \\
\text { eters. } \\
\text { nts. }\end{array}$ & $\begin{array}{l}\text { nmental Mo } \\
\text { ry). } \\
\text { in an } 80 \text {-kil } \\
\text { he stations. }\end{array}$ & meter $[50-\mathrm{m}$ & $\begin{array}{l}\text { am sampling lo } \\
\text { le] radius of the }\end{array}$ & $\begin{array}{l}\text { cations and t } \\
\text { site's indust }\end{array}$ & $\begin{array}{l}\text { the site } \\
\text { rial areas). }\end{array}$ \\
\hline
\end{tabular}


by the National Environmental Policy Act and the Endangered Species Act, facilitate cost-effective regulatory compliance, and assure fulfillment of DOE natural resource protection responsibilities. This project also supports multiple objectives for completion of Hanford's waste management and environmental restoration mission through the following activities:

- Assuring Hanford Site operational compliance with laws and regulations including the Endangered Species Act, the Bald and Golden Eagle Protection Act, and the Migratory Bird Treaty Act

- Providing data for environmental impact and ecological risk assessments

- Providing maps and information useful for biological resource impact mitigation during facility expansions

- Supporting Hanford Site land-use planning and stewardship.

These activities are intended to help protect the natural resources within the DOE-operated portions of the Hanford Site, including the DOE-managed portion of the Hanford Reach National Monument, and provide information useful to the Hanford natural resource stakeholders and the public on the status of some of Hanford's most highly valued biological resources.

Ecosystem and compliance monitoring information for 2004 for plant and animal species and communities found on the Hanford Site is summarized in Sections 8.10 and 8.11 .

\subsubsection{Cultural Resources Project}

The Cultural Resources Project operates the Hanford Cultural Resources Laboratory for DOE. Project staff perform baseline cultural resource surveys to document the occurrence of protected resources; evaluate and document impacts to protected resources as required by the National Historic Preservation Act, the American Indian Religious Freedom Act, and the Archaeological Resources Protection Act; facilitate regulatory compliance; and assure fulfillment of DOE cultural resource protection responsibilities. A summary of Hanford Site cultural resource monitoring activities conducted in 2004 is provided in Section 8.15.

\subsubsection{Groundwater Performance Assessment Project}

The Groundwater Performance Assessment Project is responsible for assessing the distribution and movement of existing groundwater contamination (both radiological and chemical) beneath the Hanford Site and for identifying and characterizing potential and emerging groundwater contamination problems. Monitoring activities are conducted to comply with requirements of the Resource Conservation and Recovery Act (RCRA), DOE Orders (e.g., 5400.5), and Washington State regulations, as well as requirements for operational monitoring around retired reactors and chemical-processing facilities, and requirements for environmental surveillance. Groundwater monitoring is also carried out during cleanup investigations under the Comprehensive Environmental Response, Compensation, and Liability Act (CERCLA). Groundwater samples are currently collected from approximately 730 wells, both on and off the site. A summary of groundwater monitoring activities and analytical results for 2004 is provided in Section 8.7.

\subsubsection{Drinking Water Monitoring Project}

DOE Order 5400.5 sets the radiation dose limits for persons consuming water from a public drinking water supply operated by DOE, or by a DOE contractor, to levels equivalent to those mandated by law in 40 CFR 141, National Primary Drinking Water Regulations; Radionuclides; Proposed Rule (federal drinking water standards). The U.S. Environmental Protection Agency (EPA) sets legal limits on the levels of certain contaminants in drinking water. State governments, through their health departments and environmental agencies, are expected to accept the major responsibility for the administration and enforcement of the limits set by EPA. In the state of Washington, federal drinking water laws are enforced by the Washington State Department of Health through state administrative codes. At Hanford, radiological monitoring of DOE-owned, contractor-operated drinking water systems is conducted through the Drinking Water Monitoring Project. Descriptions of the Hanford Site drinking water systems and 
drinking water radiological-monitoring results for 2004 are summarized in Section 8.6.

\subsubsection{Biological Control Program}

Biological control is any activity to prevent, limit, clean up, or remediate the impact to the environment, or human health and safety, from contaminated or undesirable plants or animals. The Biological Control Program is responsible for integration of (1) expanded radiological surveillance for contaminated biota and soil, (2) control of undesirable plants and animals, (3) cleanup of legacy and new contamination related to biota, and (4) remediation, following cleanup, of sites affected by radioactive contamination spread by plants and animals.

The control of weeds and pests is an important part of the Biological Control Program. Weeds on industrial sites at Hanford are a threat to accumulate radionuclides, become fire hazards, and reduce the efficiency of people and machines. At Hanford, the control of weeds occurs at tank farms (clusters of underground radioactive-waste storage tanks), radioactive-waste pumping installations, industrial sites, power stations and along transmission lines, buildings, storage and work areas, and along fence lines. Pest control prevents, limits, or removes undesirable animals through the application of chemical, cultural, or mechanical methods.

Noxious weeds are controlled onsite to prevent their spread and reduce or eliminate their populations. A noxious weed is a legal and administrative category designated by federal or state regulatory agencies (e.g., U.S. Department of Agriculture or Washington State Department of Agriculture). Noxious weeds are non-native, aggressively invasive, and hard to control. Damage to natural ecosystems and loss of productive agricultural lands can occur unless control measures are taken. Control measures can be mechanical, chemical, or biological.

Biological control may include preventive measures or measures in response to existing contamination spread. Activities to prevent the spread of contamination include radiological surveys, preventive controls (e.g., herbicide spraying), and the placement of engineered barriers. If contamination has already spread, typical response measures may include posting the area with radiation signs, stabilizing the contamination to keep it from spreading, and cleaning up and removing the contamination to an approved disposal location.

In some cases, restoration is necessary following cleanup and removal of contamination. Restoration is a common activity on the Hanford Site but has specific meanings and limitations when applied to biological control. Restoration may include soil removal and replacement, revegetation of the soil surface, or placement of engineered barriers to stop biological intrusion (biological barriers). Such restoration on radioactive waste sites is typically performed to prevent reoccurrence of surface radioactive contamination or unwanted biota.

Activities conducted for the Biological Control Program in 2004 are discussed in Sections 8.10 and 8.11. 


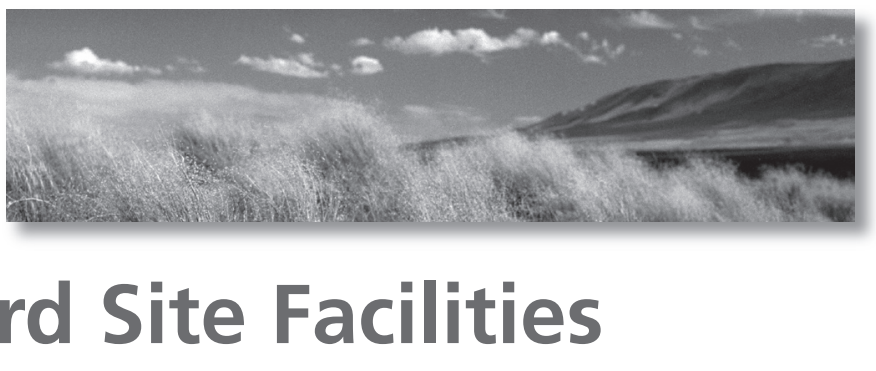

L. P. Diediker and D. J. Rokkan

Measuring devices quantify most facility emission flows, while other emission flows are calculated using process information or fan manufacturer's specifications. For most radioactive air emission units, which are primarily ventilated stacks, sampling is performed either continuously or periodically. Airborne emissions with a potential to contain radioactive materials at prescribed threshold levels are measured for gross alpha and gross beta concentrations, and, as warranted, specific radionuclides. Non-radioactive constituents and parameters are monitored directly, sampled and analyzed, or estimated based upon inventory usage.

Emissions release data are documented in several reports besides this one, all available to the public. For instance, DOE annually submits to EPA and the Washington State Department of Health a report of radionuclide air emissions from the site (DOE/RL-2005-06), in compliance with 40 CFR 61 and WAC 246-247.

\subsubsection{Radioactive Airborne Emissions}

Small quantities of tritium (i.e., hydrogen-3), strontium-90, iodine-129, cesium-137, plutonium-238, plutonium239/240, plutonium-241, americium-241, and several other longer-lived isotopes are still released to the environment through state and federally permitted release points. Most of the radionuclides in emissions released at the Hanford Site are near concentrations indistinguishable from background concentrations of radionuclides in the environment that occur naturally or originated from historical atmospheric nuclear weapons testing. The cessation of nuclear processing operations and the evolution of the site mission toward environmental cleanup are largely responsible for the downward trend in radioactive-emission concentrations and the resulting very low radiological doses to the public. Figure 8.1.1 depicts quantities of two longerlived radionuclides released from the site over the past 11 years.

Radioactive airborne emissions from Hanford Site activities contain particulate and volatilized forms of radionuclides. Emissions having the potential to exceed $1 \%$ of the 10 mrem $(100 \mathrm{mSv})$ per year standard for public dose are monitored continuously.

The continuous monitoring of radioactive emissions involves analyzing samples collected at points of discharge to the environment, usually from a stack but sometimes a vent. Samples are analyzed for gross alpha and gross beta,

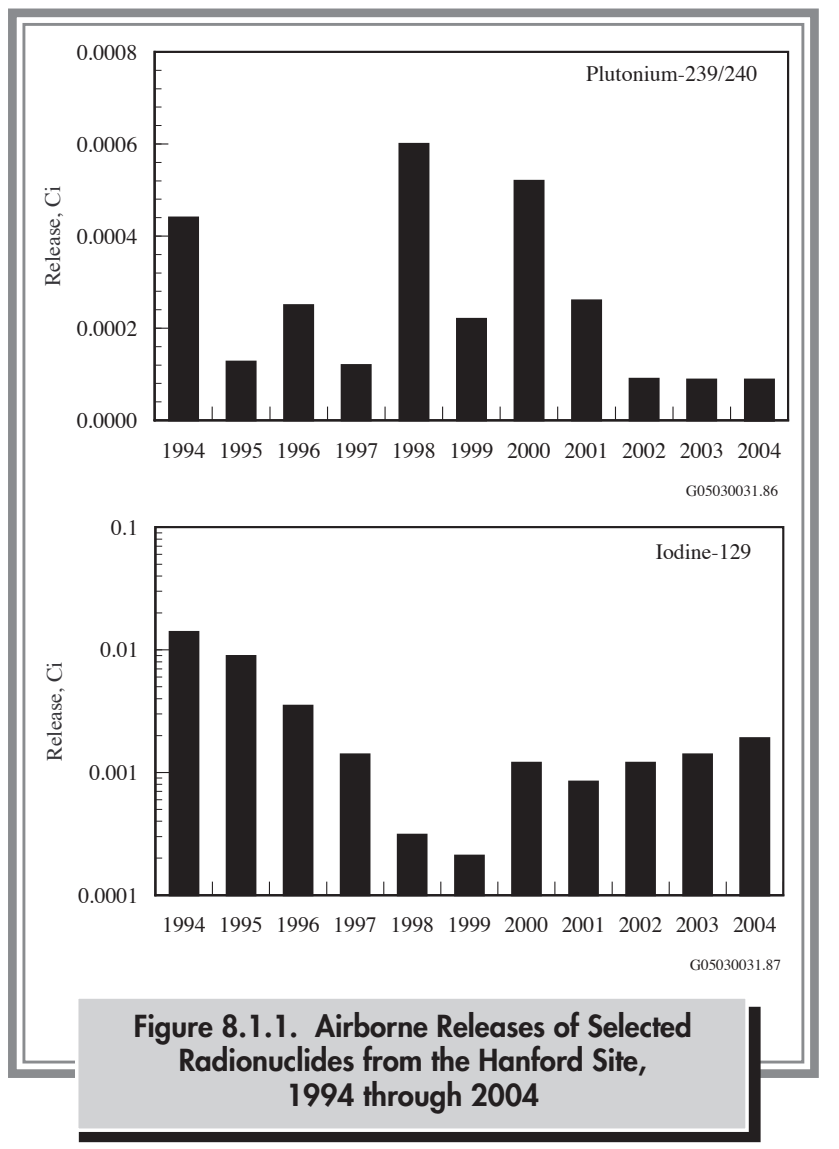


as well as selected radionuclides. The selection of the specific radionuclides sampled, analyzed, and reported is based on (1) an evaluation of the hypothetical maximum potential of unabated emissions under normal operating conditions from known radionuclide inventories in a facility or an outside activity area, (2) the sampling criteria given in contractor environmental compliance manuals, and (3) the potential each radionuclide has to contribute to the public dose. Continuous air monitoring systems with alarms are also used at selected emission points when the potential exists for radioactive emissions to exceed normal operating ranges to levels that require immediate personnel alert.

Radioactive-emission points, which usually are actively ventilated stacks, are located in the 100, 200,300,400, and 600 Areas. The prime sources of emissions and the number of emission points by operational area are summarized as follows:

- In the 100 Areas, emissions originated from normal evaporation at two water-filled storage basins (100-K East and 100-K West Fuel Storage Basins [K Basins], which contain irradiated nuclear fuel), the Cold Vacuum Drying Facility, the 105-KW Integrated Water Treatment filter backwash system, the 105-KE Basin Sludge and Water System, and a low-level radiological laboratory in the 1706-KE Building. During 2004, there were 11 radioactive-emission points in the 100 Areas, all of which operated.

- In the 200 Areas, the primary sources of radionuclide emissions were the Plutonium Finishing Plant, T Plant, Waste Encapsulation and Storage Facility, underground tanks storing high-level radioactive waste, waste evaporators, and the inactive Plutonium-Uranium Extraction (PUREX) Plant. During 2004, there were 57 radioactive-emission points in the 200 Areas, the majority of which operated.

- The 300 Area primarily has laboratories and research facilities. Primary sources of airborne radionuclide emissions were the 324 Waste Technology Engineering Laboratory, the 325 Applied Chemistry Laboratory, the 327 Post-Irradiation Laboratory, and the 340 Complex Vault and Tanks. During 2004, there were 20 radioactive-emission points in the 300 Area, the majority of which operated.

- The 400 Area has the Fast Flux Test Facility, the Maintenance and Storage Facility, and the Fuels and
Materials Examination Facility, all of which have been shut down. Operations and support activities at the Fast Flux Test Facility and Maintenance and Storage Facility released small quantities of radioactive material to the environment. During 2004, there were five radioactive-emission points in the 400 Area, all of which operated.

- The 600 Area has the Waste Sampling and Characterization Facility, at which low-level radiological and chemical analyses are performed on various types of samples (e.g., particulate air filters, liquids, soil, and vegetation). This facility had two radioactiveemission points during 2004, both of which operated. For dose-modeling purposes, emissions from the Waste Sampling and Characterization Facility, which is very close to the eastern entrance to the 200-West Area, were grouped with emissions reported for the 200-West Area.

A summary of the Hanford Site radioactive airborne emissions in 2004 is provided in Table 8.1.1.

\subsubsection{Non-Radioactive Airborne Emissions}

Non-radioactive air pollutants emitted from powergenerating and chemical processing facilities are monitored when activities at a facility are known to generate potential pollutants of concern.

In past years, gaseous ammonia has been emitted from the Plutonium-Uranium Extraction (PUREX) Plant, 242-A evaporator, AP Tank Farm, and AW Tank Farm, all located in the 200-East Area. Ammonia emissions are tracked only when activities at these facilities are capable of generating them. During 2004, the 200 Areas tank farms (groups of underground waste storage tanks) produced reportable ammonia emissions, summarized in Table 8.1.2.

Onsite diesel-powered electrical generating plants emitted particulate matter, sulfur oxides, nitrogen oxides, volatile organic compounds, carbon monoxide, and lead. The total annual releases of these constituents are reported in accordance with the air quality standards established in General Regulations for Air Pollution Sources (WAC 173-400). Power plant emissions are calculated 


\begin{tabular}{|c|c|c|c|c|c|c|}
\hline \multirow[b]{2}{*}{$\underline{\text { Radionuclide }}$} & \multirow[b]{2}{*}{$\underline{\text { Half-Life }}$} & \multicolumn{5}{|c|}{ Release, $\mathbf{C i}^{(\mathrm{a})}$} \\
\hline & & $\underline{100 \text { Areas }}$ & 200-East Area & 200-West Area & 300 Area & $\underline{400 \text { Area }}$ \\
\hline Tritium (as HT) & $12.3 \mathrm{yr}$ & NM & NM & NM & 1.8 & NM \\
\hline Tritium (as HTO) & $12.3 \mathrm{yr}$ & NM & NM & NM & 6.0 & $3.6 \times 10^{-1}$ \\
\hline Cobalt- 60 & $5.3 \mathrm{yr}$ & ND & NM & ND & ND & NM \\
\hline Krypton-85 & $10.7 \mathrm{yr}$ & NM & NM & NM & $2.0 \times 10^{-4}$ & NM \\
\hline Strontium-90 & $29.1 \mathrm{yr}$ & $2.3 \times 10^{-5(\mathrm{~b})}$ & $4.8 \times 10^{-5(b)}$ & $6.3 \times 10^{-5(b)}$ & $1.6 \times 10^{-6(b)}$ & NM \\
\hline Ruthenium-106 & $373 \mathrm{~d}$ & NM & $\mathrm{ND}$ & ND & $\mathrm{ND}$ & NM \\
\hline Iodine-129 & $16,000,000 \mathrm{yr}$ & NM & $1.9 \times 10^{-3}$ & NM & NM & NM \\
\hline Cesium-137 & $30 \mathrm{yr}$ & $4.7 \times 10^{-8}$ & $2.0 \times 10^{-5}$ & $4.3 \times 10^{-6}$ & $1.2 \times 10^{-5(c)}$ & $1.2 \times 10^{-5(c)}$ \\
\hline Radon-220 & $55.6 \mathrm{~s}$ & NM & NM & NM & $8.9 \times 10^{1}$ & NM \\
\hline Radon-222 & $3.8 \mathrm{~d}$ & NM & NM & NM & 5.8 & NM \\
\hline Thorium-232 & $14,000,000,000 \mathrm{yr}$ & $\mathrm{NM}$ & NM & NM & ND & NM \\
\hline Uranium-234 & $240,000 \mathrm{yr}$ & NM & NM & NM & ND & NM \\
\hline Uranium-235 & $704,000,000 \mathrm{yr}$ & NM & NM & NM & ND & NM \\
\hline Uranium-238 & $4,500,000,000 \mathrm{yr}$ & NM & NM & NM & ND & NM \\
\hline Plutonium-238 & $87.7 \mathrm{yr}$ & $2.7 \times 10^{-6}$ & NM & $1.2 \times 10^{-6}$ & $1.1 \times 10^{-8}$ & NM \\
\hline Plutonium-239/240 & $24,000 \mathrm{yr}$ & $1.9 \times 10^{-5(\mathrm{~d})}$ & $1.7 \times 10^{-6(\mathrm{~d})}$ & $6.7 \times 10^{-5(\mathrm{~d})}$ & $2.7 \times 10^{-7(\mathrm{~d})}$ & $1.4 \times 10^{-7(\mathrm{~d})}$ \\
\hline Plutonium-241 & $14.4 \mathrm{yr}$ & $1.5 \times 10^{-4}$ & ND & $5.3 \times 10^{-5}$ & ND & NM \\
\hline Americium-241 & $432 \mathrm{yr}$ & $1.5 \times 10^{-5}$ & $1.3 \times 10^{-6}$ & $1.1 \times 10^{-5}$ & $8.3 \times 10^{-7(\mathrm{e})}$ & NM \\
\hline Americium-243 & $7,380 \mathrm{yr}$ & NM & NM & NM & $9.0 \times 10^{-10}$ & NM \\
\hline Curium-242/244 & $18.1 \mathrm{yr}$ & NM & NM & NM & ND & NM \\
\hline $\begin{array}{l}\text { (a) } 1 \mathrm{Ci}=3.7 \times 10 \\
\text { (b) This value incl } \\
\text { (c) This value inc } \\
\text { (d) This value incl } \\
\text { (e) This value incl } \\
\mathrm{HT}=\text { Elemental } \mathrm{t} \\
\mathrm{HTO}=\text { Tritiated w: } \\
\mathrm{ND}=\begin{array}{l}\text { Not detecte } \\
\text { measureme }\end{array} \\
\mathrm{NM}=\text { Not measur }\end{array}$ & $\begin{array}{l}\text { becquerels. } \\
\text { les gross beta release } \\
\text { les gross beta release } \\
\text { les gross alpha releas } \\
\text { les gross alpha releas } \\
\text { ium } \\
\text { r vapor. } \\
\text { (i.e., either the radic } \\
\text { for that given radio } \\
\text { l. }\end{array}$ & $\begin{array}{l}\text { data, treated a } \\
\text { data, treated } \\
\text { e data, treated } \\
\text { e data, treated } \\
\text { nuclide was } n \\
\text { nuclide or typ }\end{array}$ & $\begin{array}{l}\text { trontium-90 in dos } \\
\text { esium-137 in dose } \\
\text { plutonium-239/24 } \\
\text { americium-241 in } \\
\text { detected in any san } \\
\text { f radioactivity mad }\end{array}$ & $\begin{array}{l}\text { alculations. } \\
\text { lculations. } \\
\text { n dose calculations. } \\
\text { se calculations. }\end{array}$ & w backgrc & els). \\
\hline
\end{tabular}

from the quantities of fossil fuel consumed, using EPAapproved formulas (Compilation of Air Pollutant Emission Factors, Volume I: Stationary Point and Area Sources, AP-42).

Should activities result in chemical emissions in excess of quantities reportable under the CERCLA, the release totals are immediately reported to EPA. If the emissions remain stable at predicted levels, they may be reported annually with EPA's permission. Table 8.1.2 summarizes the emissions of non-radioactive pollutants discharged to the atmosphere at Hanford during 2004 (Note: the 100,400 , and 600 Areas had no non-radioactive-emission sources of regulatory concern). Table 8.1.2 also includes emission estimates from the carbon tetrachloride vapor extraction work in the 200-West Area. Those emissions are accounted for in the table category "other toxic air pollutants" and do not require reporting because they are below the respective reportable quantity. 


\begin{tabular}{|c|c|c|}
\hline & \multicolumn{2}{|c|}{$\begin{array}{l}\text { Table 8.1.2. Non-Radioactive Constituents } \\
\text { Discharged to the Atmosphere at the } \\
\text { Hanford Site, } 2004\end{array}$} \\
\hline \multirow{2}{*}{\multicolumn{2}{|c|}{$\begin{array}{c}\text { Constituent } \\
\text { Total particulate matter (PM) }\end{array}$}} & Release, kg (lb) \\
\hline & & $5,000 \quad(11,000)$ \\
\hline \multicolumn{2}{|c|}{$\mathrm{PM}_{10}^{(\mathrm{a})}$} & $2,000 \quad(4,500)$ \\
\hline \multicolumn{2}{|c|}{$\mathrm{PM}_{2.5}^{(\text {(b) }}$} & $(1,600)$ \\
\hline \multicolumn{2}{|c|}{ Nitrogen oxides } & $11,000 \quad(25,000)$ \\
\hline \multicolumn{2}{|c|}{ Sulfur oxides } & $2,700 \quad(6,000)$ \\
\hline \multicolumn{2}{|c|}{ Carbon monoxide } & $16,000 \quad(34,000)$ \\
\hline \multicolumn{2}{|c|}{ Lead } & $(1.0)$ \\
\hline \multicolumn{2}{|c|}{ Volatile organic compounds $s^{(c, d)}$} & $11,000 \quad(25,000)$ \\
\hline \multicolumn{2}{|c|}{$\operatorname{Ammonia}^{(\mathrm{e})}$} & $13,000 \quad(28,000)$ \\
\hline \multicolumn{3}{|c|}{ Other toxic air pollutants ${ }^{(\mathrm{f})}$} \\
\hline $\begin{array}{l}\text { (a) } \\
\text { (b) } \\
\text { (c) }\end{array}$ & \multicolumn{2}{|c|}{$\begin{array}{l}\text { Produced from burning fossil fuel for steam and elec- } \\
\text { trical generators and calculated estimates from the } \\
200 \text {-East and } 200 \text {-West Areas tank farms, evaporation } \\
\text { losses from fuel dispensing, and operation of the } \\
242 \text {-A evaporator, } 200 \text { Area Effluent Treatment } \\
\text { Facility, Central Waste Complex, T Plant complex, } \\
\text { and Waste Receiving and Processing Facility. }\end{array}$} \\
\hline (e) & \multicolumn{2}{|c|}{$\begin{array}{l}\text { Ammonia releases are calculated estimates from the } \\
200 \text {-East and 200-West Areas tank farms and opera- } \\
\text { tion of the 242-A evaporator and } 200 \text { Area Effluent } \\
\text { Treatment Facility. }\end{array}$} \\
\hline (f) & \multicolumn{2}{|c|}{$\begin{array}{l}\text { Releases are a composite of calculated estimates of } \\
\text { toxic air pollutants, excluding ammonia, from the } \\
\text { 200-East and 200-West Areas tank farms and opera- } \\
\text { tion of the 242-A evaporator, } 200 \text { Area Effluent } \\
\text { Treatment Facility, Central Waste Complex, T Plant } \\
\text { complex, and Waste Receiving and Processing } \\
\text { Facility. Toxic air pollutant emissions, excluding } \\
\text { ammonia, are a subset of volatile organic compounds } \\
\text { and included in the total of those emissions. }\end{array}$} \\
\hline
\end{tabular}




\title{
8.2 Ambient-Air Monitoring
}

\author{
B. G. Fritz and C. J. Perkins
}

Atmospheric releases of radioactive materials from Hanford Site facilities and operations to the surrounding region are potential sources of human exposure. At the Hanford Site, radioactive constituents in air are monitored onsite near facilities and operations and at site-wide locations away from facilities, and offsite around the perimeter of the site and in nearby and distant communities. Information about these ambient-air monitoring efforts, including detailed descriptions of air sampling and analysis techniques is provided in DOE's Environmental Monitoring Plan for the Hanford Site (DOE/RL-91-50). Brief summaries of the ambient-air monitoring objectives and the projects that support them can be found in this report in Section 8.0.

Comparing measured radionuclide concentrations from locations on and around the Hanford Site to concentrations measured at upwind sites assumed to be uninfluenced by Hanford Site operations provides an evaluation of the impact of radionuclide air emissions from the Hanford Site on surrounding ambient air. Complete listings of all radiological analytical results summarized in the following sections are reported separately (PNNL-15222, APP. 1; PNNL-15222, APP. 2).

In addition to the radiological monitoring networks, a small non-radiological air-monitoring system is operated onsite. This system measures atmospheric particulate matter (dust) concentrations at a few locations on the Hanford Site. Results are mainly used for scientific studies in an attempt to better understand windblown dust on and around the Hanford Site.

\subsubsection{Ambient-Air Monitoring Near Facilities and Operations}

\section{J. Perkins}

During 2004, a network of continuously operating samplers at 85 locations (Table 8.2.1) (sampling locations illustrated in PNNL-15222, APP. 2) was used to monitor radioactive materials in air near Hanford Site facilities and operations. Air samplers were located primarily at or within approximately 500 meters (1,500 feet) of sites and/or facilities having the potential for, or a history of, environmental releases and were predominantly located in the prevailing downwind direction. Samples were collected according to a schedule established before the 2004 monitoring year. Airborne particles were sampled at each sampling location by drawing air through a glass-fiber filter. The filters were collected biweekly, field surveyed for gross radioactivity, held for at least 7 days, and then analyzed for gross alpha and beta activity. The 7-day holding period was necessary to allow for the decay of naturally occurring, short-lived radionuclides that would otherwise obscure detection of longer-lived radionuclides associated with emissions from nuclear facilities. The gross radioactivity measurements were used to indicate changes in trends in the near-facility environment.

For most specific radionuclide analyses, the amount of radioactive material collected on a single filter during a 2-week period was too small to be measured accurately. To increase the accuracy of the analysis, the samples were combined into either quarterly or semiannual composite 


\begin{tabular}{|c|c|c|c|c|c|}
\hline \multicolumn{6}{|c|}{$\begin{array}{l}\text { Table 8.2.1. Monitoring Locations and Analyses for Ambient-Air Monitoring Samples } \\
\text { Collected Near Hanford Site Facilities and Operations, } 2004\end{array}$} \\
\hline \multirow{2}{*}{\multicolumn{2}{|c|}{$\underline{\text { Site }}$}} & \multirow{2}{*}{$\begin{array}{l}\text { Number of } \\
\text { Samplers }\end{array}$} & \multirow[b]{2}{*}{$\underline{\text { EDP Code }}^{(\mathrm{a})}$} & \multicolumn{2}{|r|}{ Analyses } \\
\hline & & & & \multirow{2}{*}{$\begin{array}{l}\text { Biweekly } \\
\text { Gross alpha, } \\
\text { gross beta }\end{array}$} & \multirow{2}{*}{$\begin{array}{r}\text { Composite }^{(b)} \\
\text { Gamma, Sr, Pu, U }\end{array}$} \\
\hline & $\begin{array}{l}0-\mathrm{B} / \mathrm{C} \text { remedial action } \\
\text { jject }\end{array}$ & 5 & $\begin{array}{l}\text { N464, N465, N466, N496, } \\
\text { N497 }\end{array}$ & & \\
\hline & $\begin{array}{l}\text { 5-D interim safe storage } \\
\text { ject }\end{array}$ & 1 & N523 & $\begin{array}{l}\text { Gross alpha, } \\
\text { gross beta }\end{array}$ & Gamma, Sr, Pu, U \\
\hline & $\begin{array}{l}\text { 5-DR interim safe storage } \\
\text { jject }\end{array}$ & 2 & N492, N515 & $\begin{array}{l}\text { Gross alpha, } \\
\text { gross beta }\end{array}$ & Gamma, Sr, Pu, U \\
\hline & $\begin{array}{l}\text { 5-F interim safe storage } \\
\text { pject }\end{array}$ & 2 & N494, N495 & $\begin{array}{l}\text { Gross alpha, } \\
\text { gross beta }\end{array}$ & Gamma, Sr, Pu, U \\
\hline & $\begin{array}{l}\text { 5-H interim safe storage } \\
\text { jject }\end{array}$ & 2 & N524, N525 & $\begin{array}{l}\text { Gross alpha, } \\
\text { gross beta }\end{array}$ & Gamma, $\mathrm{Sr}, \mathrm{Pu}, \mathrm{U}$ \\
\hline & $\mathrm{O}-\mathrm{K}$ spent nuclear fuels & 8 & $\begin{array}{l}\text { N401, N402, N403, N404, } \\
\text { N476, N477, N478, N479 }\end{array}$ & $\begin{array}{l}\text { Gross alpha, } \\
\text { gross beta }\end{array}$ & $\begin{array}{l}\text { Gamma, Sr, Pu, U, } \\
{ }^{241} \mathrm{Pu},{ }^{241} \mathrm{Am}\end{array}$ \\
\hline & $\begin{array}{l}\text { O-KR-1 remedial action } \\
\text { jject }\end{array}$ & 3 & N528, N529, N530 & $\begin{array}{l}\text { Gross alpha, } \\
\text { gross beta }\end{array}$ & Gamma, Sr, Pu, U \\
\hline & $\begin{array}{l}\text { D-NR-1 remedial action } \\
\text { d 100-N surveillance, } \\
\text { intenance/transition } \\
\text { jects }\end{array}$ & 4 & N102, N103, N106, N526 & $\begin{array}{l}\text { Gross alpha, } \\
\text { gross beta }\end{array}$ & Gamma, Sr, Pu, U \\
\hline & D-East Area & 17 & $\begin{array}{l}\text { N019, N158, N498, N499, } \\
\text { N957, N967, N968, N969, } \\
\text { N970, N972, N973, N976, } \\
\text { N977, N978, N984, N985, } \\
\text { N999 }\end{array}$ & $\begin{array}{l}\text { Gross alpha, } \\
\text { gross beta }\end{array}$ & Gamma, Sr, Pu, U \\
\hline & $\begin{array}{l}\text { nister Storage Building, } \\
\text {-East Area }\end{array}$ & 2 & N480, N481 & $\begin{array}{l}\text { Gross alpha, } \\
\text { gross beta }\end{array}$ & $\begin{array}{l}\text { Gamma, Sr, Pu, U, } \\
{ }^{241} \mathrm{Pu},{ }^{241} \mathrm{Am}\end{array}$ \\
\hline & $\begin{array}{l}\text { 4-B demolition project, } \\
\text { O-East Area }\end{array}$ & 3 & N541, N542, N543 & $\begin{array}{l}\text { Gross alpha, } \\
\text { gross beta }\end{array}$ & Gamma, Sr, Pu, U \\
\hline & $\begin{array}{l}\text { egrated Disposal Facility, } \\
\text { D-East Area }\end{array}$ & 1 & N532 & $\begin{array}{l}\text { Gross alpha, } \\
\text { gross beta }\end{array}$ & Gamma, Sr, Pu, U \\
\hline & D-West Area & 21 & $\begin{array}{l}\text { N155, N161, N165, N168, } \\
\text { N200, N304, N433, N441, } \\
\text { N442, N449, N456, N457, } \\
\text { N956, N963, N964, N965, } \\
\text { N966, N974, N975, N987, } \\
\text { N994 }\end{array}$ & $\begin{array}{l}\text { Gross alpha, } \\
\text { gross beta }\end{array}$ & Gamma, Sr, Pu, U \\
\hline & $\begin{array}{l}\text { Ancillary Decontamination } \\
\text { d Demolition, 200-West Area }\end{array}$ & 2 & N550, N551 & $\begin{array}{l}\text { Gross alpha, } \\
\text { gross beta }\end{array}$ & Gamma, Sr, Pu, U \\
\hline & $\begin{array}{l}\text { D-FF-2 remedial action project, } \\
\text { Area }\end{array}$ & 8 & $\begin{array}{l}\text { N130, N527, N537, N538, } \\
\text { N539, N540, N548, N549, }\end{array}$ & $\begin{array}{l}\text { Gross alpha, } \\
\text { gross beta }\end{array}$ & Gamma, Sr, Pu, U \\
\hline & $\begin{array}{l}\text { vironmental Restoration } \\
\text { sposal Facility }\end{array}$ & 3 & N482, N517, N518 & $\begin{array}{l}\text { Gross alpha, } \\
\text { gross beta }\end{array}$ & Gamma, Sr, Pu, U \\
\hline & Area & 1 & N981 & $\begin{array}{l}\text { Gross alpha, } \\
\text { gross beta }\end{array}$ & Gamma, Sr, Pu, U \\
\hline & $\begin{array}{l}\text { EDP Code = Sampler locatic } \\
\text { Gamma spectroscopy, stront }\end{array}$ & $\begin{array}{l}\text { on code. Se } \\
\text { tium- } 90 \text {, isot }\end{array}$ & $\begin{array}{l}\text { NL-15222, APP. } 2 \text {. } \\
\text { plutonium }\left({ }^{238} \mathrm{Pu},{ }^{239 / 240} \mathrm{Pu}\right), \text { a }\end{array}$ & pic uranium & $\mathrm{J},{ }^{235} \mathrm{U}$, and $\left.{ }^{238} \mathrm{U}\right)$. \\
\hline
\end{tabular}


samples for each location. Composite samples were routinely analyzed for gamma-emitting isotopes, strontium-90, plutonium-238, plutonium-239/240, uranium-234, uranium-235, and uranium-238, and at locations associated with processing spent nuclear fuel, americium-241, and plutonium-241 (Table 8.2.1). Naturally occurring radionuclides beryllium- 7 and potassium -40 were routinely identified.

\section{Ambient-Air Monitoring Results for Locations Near Facilities and Operations}

Figure 8.2.1 shows the annual average air concentrations of selected radionuclides in the 100 and 200/600 Areas compared to the DOE derived concentration guides and, when available, air concentrations measured in distant communities. The DOE derived concentration guides (DOE Order 5400.5; Appendix D, Table D.5) are dosebased reference values that are used as indexes of performance. The 2004 data indicate a large degree of variability. Air samples collected from locations at or directly adjacent to Hanford Site facilities had higher radionuclide concentrations than did those samples collected farther away. In general, analytical results for most radionuclides were at or near Hanford Site background levels, which are much less than DOE derived concentration guides but greater than those measured off the site. The data also show that concentrations of certain radionuclides were higher and widely variable within different onsite operational areas. Table 8.2.2 shows the annual average and maximum concentrations of radionuclides in air samples collected near facilities and operations during 2004. A complete listing of the 2004 near-facility ambient-air monitoring results can be found in PNNL-15222, APP. 2. Concentrations of radionuclides in air in the 300 and 400 Areas, near some onsite remediation projects, and offsite at distant locations were collected by Pacific Northwest National Laboratory personnel. Results for Pacific Northwest National Laboratory air samples are summarized in Section 8.2.2.

At the remedial action project site in the 100-B/C Area, ambient air monitoring was conducted at five locations in 2004. The radionuclides uranium-234, uranium-235, and uranium-238 were consistently detected and plutonium$239 / 240$ was detected in $25 \%$ of the composited samples.
During 2004, air monitoring continued at seven locations associated with the interim safe storage of the reactor buildings in the 100-D/DR, 100-F, and 100-H Areas. The quarterly analytical results from these air samples showed radionuclide concentrations and frequency of detection consistent with results observed over the past 5 years. Uranium-234 and uranium-238 were consistently detected (in $82 \%$ and $71 \%$ of the samples, respectively). Plutonium$239 / 240$ was detected in approximately $18 \%$ of the quarterly composite samples.

The airborne contaminant levels in the $100-\mathrm{K}$ Area were similar to those measured over the previous years. Ambient-air monitoring was conducted at eight locations during 2004 (four stations each at the 100-K East and 100-K West Areas). Uranium-234 and uranium-238 were detected in approximately $90 \%$ of the composite samples obtained during 2004. Americium-241 and plutonium-241 were detected in about half of the composite samples, while uranium-235 and plutonium-239/240 were detected in approximately $25 \%$ of the samples.

Air sampling continued in 2004 at three locations at the 100-KR-1 remedial action site. Uranium-234 and uranium-238 were detected in approximately $90 \%$ of the composite samples obtained during 2004. Uranium-235 and plutonium-239/240 were detected in approximately $25 \%$ and $38 \%$ of the samples, respectively.

Analytical results from four ambient-air sampling locations at the 100-NR-1 remedial action site and 100-N Area surveillance and maintenance and transition site in 2004 were similar to those measured in previous years. Uranium-234 and uranium-238 were detected in all the composite samples. Cesium-137 and plutonium-239/240 were detected in $50 \%$ of the samples, while cobalt- 60 and uranium-235 were detected in $25 \%$ of the samples.

Air sampling was conducted at 23 locations in the 200-East Area during 2004. Four of these locations were established in September 2004: three were project-specific air sampling locations at the 224-B Demolition Project site, and one was a pre-operational monitoring location at the Integrated Disposal Facility. During 2004, radionuclide levels measured in the 200-East Area ambient air composite samples were similar to those measured over the previous years. Uranium-234 and uranium-238 were detected in more than $90 \%$ of the samples and uranium-235 was detected in less than $20 \%$ of the samples. 


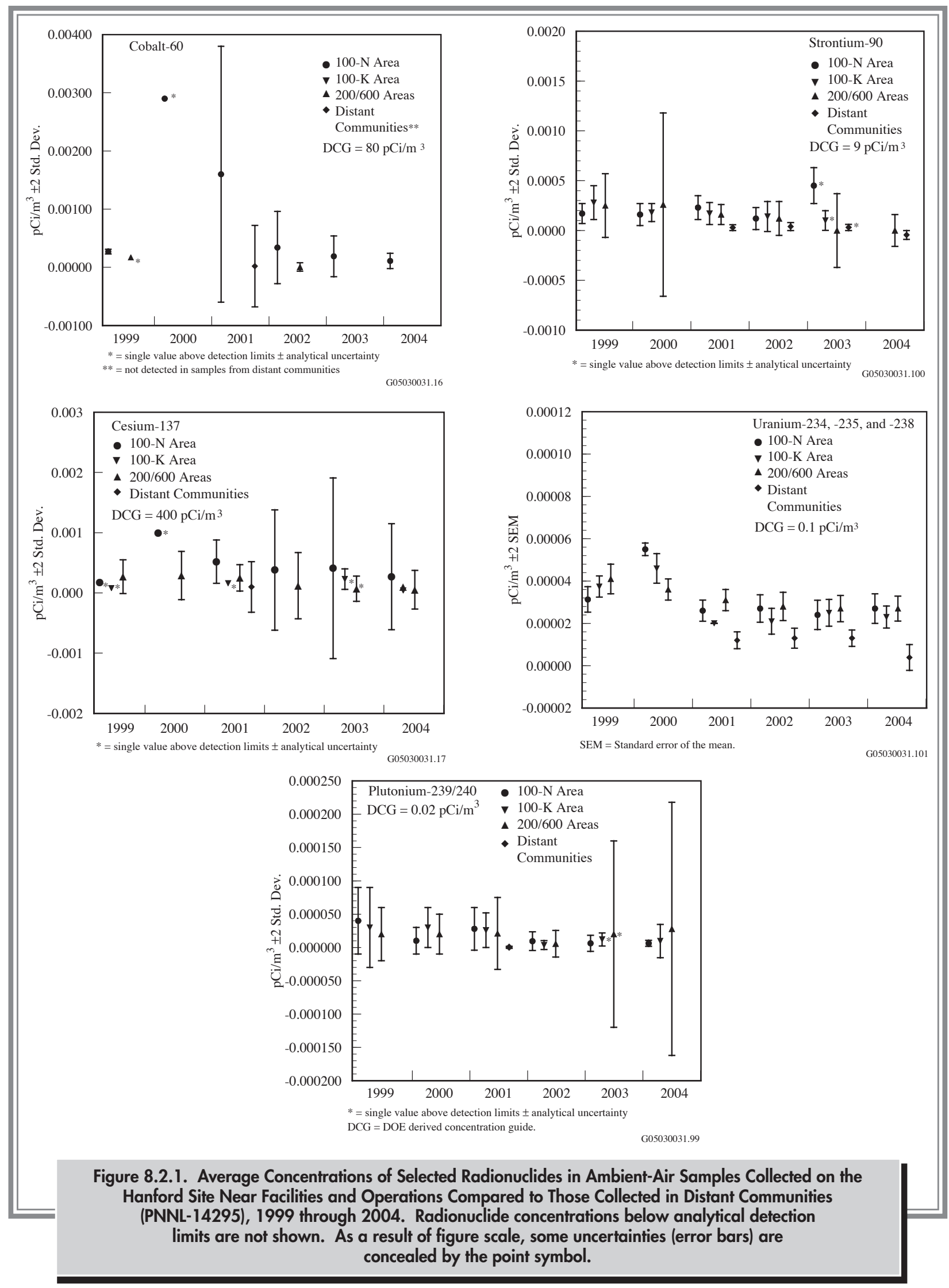


Table 8.2.2. Annual Average and Maximum Concentrations $\left(\mathrm{aCi} / \mathrm{m}^{3}\right)^{(\mathrm{al})}$ of Selected Radionuclides in Ambient-Air Samples Collected Near Facilities and Operations on the Hanford Site, 2004

\begin{tabular}{|c|c|c|c|c|c|c|c|}
\hline \multicolumn{4}{|c|}{$\underline{\text { Cobalt }-60}$} & \multicolumn{4}{|c|}{$\underline{\text { Uranium-238 }}$} \\
\hline Site & Average $^{(\mathbf{b})}$ & $\underline{\text { Maximum }}^{(\mathrm{c})}$ & EDP Code $^{(\mathrm{d})}$ & Site & $\underline{\text { Average }}^{(\mathrm{b})}$ & $\underline{\text { Maximum }}^{(\mathrm{c})}$ & EDP Code $^{(\mathrm{d})}$ \\
\hline $100-B / C$ RA & $15 \pm 83$ & $73 \pm 81$ & N497 & $100-\mathrm{B} / \mathrm{C} \mathrm{RA}$ & $11 \pm 7.9$ & $17 \pm 16$ & N465 \\
\hline 100 Area ISS & $70 \pm 290$ & $560 \pm 1,300$ & N515 & 100 Area ISS & $20 \pm 34$ & $78 \pm 73$ & N515 \\
\hline 100-K SNF & $17 \pm 94$ & $120 \pm 85$ & N478 & 100-K SNF & $9.1 \pm 6.1$ & $17 \pm 9.7$ & N403 \\
\hline 100-K RA & $0.33 \pm 110$ & $49 \pm 85$ & N528 & 100-K RA & $9.7 \pm 6.3$ & $15 \pm 8.7$ & N529 \\
\hline $100-\mathrm{N}$ & $110 \pm 130$ & $200 \pm 110$ & $\mathrm{~N} 102$ & $100-\mathrm{N}$ & $11 \pm 7.7$ & $15 \pm 9.5$ & N102 \\
\hline 200-East & $-7.2 \pm 85$ & $92 \pm 85$ & N970 & 200-East & $12 \pm 13$ & $33 \pm 18$ & N541 \\
\hline 200-West & $18 \pm 110$ & $150 \pm 130$ & $\mathrm{~N} 200$ & 200-West & $11 \pm 10$ & $24 \pm 19$ & N987 \\
\hline 300-FF-2 & & & & 300-FF-2 & & & \\
\hline (300 Area) & $-150 \pm 410$ & $36 \pm 73$ & N130 & (300 Area) & $67 \pm 110$ & $130 \pm 79$ & N537 \\
\hline ERDF & $5.4 \pm 120$ & $69 \pm 120$ & N517 & ERDF & $21 \pm 26$ & $49 \pm 22$ & N517 \\
\hline $\begin{array}{l}\text { Distant } \\
\text { community }^{(e)} \\
\text { DCG }\end{array}$ & $100 \pm 600$ & $\begin{array}{l}670 \pm 610 \\
80,000,000\end{array}$ & & $\begin{array}{l}\text { Distant } \\
\text { community } \\
\text { DCG }\end{array}$ & $20 \pm 14$ & $\begin{array}{l}28 \pm 11 \\
100,000\end{array}$ & \\
\hline \multicolumn{4}{|c|}{$\underline{\text { Strontium-90 }}$} & \multicolumn{4}{|c|}{ Plutonium-239/240 } \\
\hline Site & Average $^{(\mathbf{b})}$ & $\underline{\text { Maximum }}^{(\mathrm{c})}$ & EDP Code ${ }^{(\mathrm{d})}$ & Site & $\underline{A v e r a g e}^{(b)}$ & $\underline{\text { Maximum }}^{(\mathrm{c})}$ & EDP Code $^{(\mathrm{d})}$ \\
\hline $100-B / C R A$ & $-140 \pm 320$ & $-83 \pm 86$ & N466 & $100-B / C R A$ & $\frac{14}{4.5 \pm 14}$ & $19 \pm 16$ & $\frac{N 465}{N}$ \\
\hline 100 Area ISS & $-160 \pm 400$ & $140 \pm 160$ & N492 & 100 Area ISS & $7.3 \pm 32$ & $67 \pm 63$ & N515 \\
\hline 100-K SNF & $-49 \pm 170$ & $70 \pm 74$ & N479 & 100-K SNF & $9.7 \pm 22$ & $41 \pm 24$ & N402 \\
\hline 100-K RA & $-72 \pm 150$ & $35 \pm 92$ & N529 & 100-K RA & $3.4 \pm 5.3$ & $6.7 \pm 5.4$ & N526 \\
\hline $100-\mathrm{N}$ & $-26 \pm 76$ & $28 \pm 87$ & N102 & $100-\mathrm{N}$ & $6.2 \pm 4.6$ & $9.7 \pm 6.3$ & N526 \\
\hline 200-East & $-22 \pm 180$ & $360 \pm 160$ & N984 & 200-East & $2.0 \pm 6.8$ & $13 \pm 14$ & N481 \\
\hline 200-West & $-55 \pm 140$ & $98 \pm 100$ & N981 & 200-West & $51 \pm 260$ & $540 \pm 210$ & N165 \\
\hline $\begin{array}{l}\text { 300-FF-2 } \\
\text { (300 Area) }\end{array}$ & $-28+81$ & $0.14+1.4$ & N130 & 300-FF-2 & $28+15$ & $15+90$ & N130 \\
\hline ERDF & $-27 \pm 150$ & $\begin{aligned} 0.14 & \pm 1.4 \\
120 & \pm 130\end{aligned}$ & N517 & ERDF & $\begin{array}{r}2.8 \pm 15 \\
22 \pm 89\end{array}$ & $\begin{aligned} 15 & \pm 9.0 \\
130 & \pm 52\end{aligned}$ & N963 \\
\hline $\begin{array}{l}\text { Distant } \\
\text { community }{ }^{(e)} \\
\text { DCG }\end{array}$ & $-45 \pm 180$ & $\begin{array}{l}100 \pm 47 \\
9,000,000\end{array}$ & & $\begin{array}{l}\text { Distant } \\
\text { community } \\
\text { DCG }\end{array}$ & $-0.030 \pm 1.3$ & $\begin{array}{c}1.5 \pm 4.3 \\
20,000\end{array}$ & \\
\hline \multicolumn{4}{|c|}{ Cesium-137 } & \multicolumn{4}{|c|}{$\underline{\text { Plutonium-241 }}$} \\
\hline Site & Average $^{(\mathbf{b})}$ & $\underline{\text { Maximum }}^{(\mathrm{c})}$ & $\underline{E D P ~ C o d e}^{(\mathrm{d})}$ & Site & $\underline{A v e r a g e}^{(b)}$ & Maximum $^{(\mathrm{c})}$ & EDP Code $^{(\mathrm{d})}$ \\
\hline $100-\mathrm{B} / \mathrm{C}$ RA & $21 \pm 110$ & $150 \pm 200$ & N464 & $100-\mathrm{K} S \mathrm{SNF}$ & $210 \pm 2,400$ & $1,700 \pm 830$ & N478 \\
\hline 100 Area ISS & $36 \pm 370$ & $510 \pm 300$ & N524 & 200-East & $50 \pm 3,200$ & $1,700 \pm 870$ & N480 \\
\hline 100-K SNF & $41 \pm 95$ & $140 \pm 130$ & N403 & Distant & & & \\
\hline $100-\mathrm{K} R A$ & $20 \pm 100$ & $74 \pm 78$ & N529 & community $^{(\mathrm{e})}$ & & Not reported & \\
\hline $100-\mathrm{N}$ & $270 \pm 880$ & $1,300 \pm 480$ & N526 & DCG & & $1,000,000$ & \\
\hline 200-East & $26 \pm 87$ & $140 \pm 97$ & N984 & \multicolumn{4}{|c|}{ Americium-241 } \\
\hline $\begin{array}{l}\text { 200-West } \\
\text { 300-FF-2 }\end{array}$ & $74 \pm 410$ & $1,300 \pm 510$ & N155 & Site & Average $^{(b)}$ & Maximum $^{(\mathrm{c})}$ & EDP Code $(\mathrm{d})$ \\
\hline (300 Area) & $110 \pm 340$ & $460 \pm 780$ & N540 & $100-\mathrm{K} S \mathrm{SNF}$ & $10 \pm 19$ & $36 \pm 19$ & $\frac{N 402}{N}$ \\
\hline ERDF & $33 \pm 41$ & $56 \pm 74$ & N517 & 200-East & $5.1 \pm 2.2$ & $6.4 \pm 5.0$ & N481 \\
\hline $\begin{array}{l}\text { Distant } \\
\text { community }^{(\mathrm{e})} \\
\text { DCG }\end{array}$ & $-88 \pm 510$ & $\begin{array}{c}430 \pm 690 \\
400,000,000\end{array}$ & & $\begin{array}{l}\text { Distant } \\
\text { community }^{(\mathrm{e})} \\
\text { DCG }\end{array}$ & & $\begin{array}{c}\text { Not reported } \\
20,000\end{array}$ & \\
\hline \multicolumn{4}{|c|}{ Uranium-234 } & & & & \\
\hline Site & Average $^{(b)}$ & Maximum $^{(\mathrm{c})}$ & EDP Code $\mathrm{C}^{(\mathrm{d})}$ & & & & \\
\hline $100-\mathrm{B} / \mathrm{C} \mathrm{RA}$ & $14 \pm 18$ & $36 \pm 21$ & N464 & & & & \\
\hline 100 Area ISS & $23 \pm 27$ & $63 \pm 75$ & N515 & & & & \\
\hline 100-K SNF & $11 \pm 9.5$ & $22 \pm 11$ & N401 & & & & \\
\hline $100-\mathrm{K} R A$ & $12 \pm 5.3$ & $15 \pm 8.9$ & N529 & & & & \\
\hline $100-\mathrm{N}$ & $14 \pm 7.0$ & $18 \pm 10$ & N102 & & & & \\
\hline 200-East & $14 \pm 16$ & $40 \pm 22$ & N543 & & & & \\
\hline 200-West & $12 \pm 9.0$ & $28 \pm 14$ & N161 & & & & \\
\hline 300-FF-2 & & & & & & & \\
\hline (300 Area) & $89 \pm 160$ & $190 \pm 97$ & N538 & & & & \\
\hline ERDF & $21 \pm 26$ & $48 \pm 22$ & N517 & & & & \\
\hline $\begin{array}{l}\text { Distant } \\
\text { community }\end{array}$ & $-5.8 \pm 42$ & $26 \pm 10$ & & & & & \\
\hline DCG & & 90,000 & & & & & \\
\hline
\end{tabular}

(a) To convert to international metric system units, multiply $\mathrm{aCi} / \mathrm{m}^{3}$ by 0.000000037 to obtain $\mathrm{Bq} / \mathrm{m}^{3}$.

(b) \pm 2 times the standard deviation.

(c) \pm total analytical uncertainty.

(d) EDP Code $=$ Sampler location code. See PNNL-15222, APP. 2.

(e) See Section 8.2.2.

$\mathrm{DCG}=\mathrm{DOE}$ derived concentration guide.

ERDF $=$ Environmental Restoration Disposal Facility

ISS $=$ Interim safe storage projects at $105-\mathrm{DR} / \mathrm{F} / \mathrm{D} / \mathrm{H}$

RA $=$ Remedial action project.

$\mathrm{SNF}=$ Spent nuclear fuel. 
Air sampling was conducted at 23 locations in the 200-West Area during 2004. Generally, radionuclide levels measured in the 200-West Area were similar to results for previous years. Uranium-234 and uranium-238 were detected in approximately $85 \%$ of the samples. Plutonium$239 / 240$ was detected in approximately $50 \%$ of the samples and uranium-235 in approximately $30 \%$. Two locations were established in 2004 at the U Ancillary Decontamination and Demolition Project site. Three previously established air sampling locations provided ambient air monitoring data for the 233-S Demolition Project, which concluded in June 2004. The highest plutonium-239/240 and cesium-137 concentrations observed in near-facility air samples during 2004 were from two of the three sampling stations in the vicinity of the 233-S Demolition Project site and were measured in composite samples collected during the first half of the year. There may be a correlation between the elevated plutonium-239/240 results and the elevated total alpha results observed at all three air sampling locations during the period March 29, 2004 through April 12, 2004. The plutonium-239/240 results were less than $3 \%$ of the DOE derived concentration guide and the cesium-137 results were approximately $0.0003 \%$ of the DOE derived concentration guide (Appendix D, Table D.5).

The air sampling network at the Environmental Restoration Disposal Facility (200-West Area) used two established samplers for upwind monitoring (one near-facility sampler, N-963, and one Pacific Northwest National Laboratory sampler, station \#13 at the $200 \mathrm{~W}$ SE location) (Section 8.2.2) and three air samplers at the facility that provided downwind coverage. The 2004 analytical results were comparable to those obtained in 2003. Uranium-234 and uranium-238 were detected in over $90 \%$ of the nearfacility composite samples and plutonium-239/240 was detected in approximately $38 \%$.

Remediation work in the 300-FF-2 Operable Unit (located near the 300 Area) during 2004 was conducted at several locations at different times and as a result, eight ambientair monitoring stations were intermittently employed during the year. Uranium-234 and uranium-238 were detected in approximately $95 \%$ of the samples and uranium-235 in approximately $20 \%$ of the samples. The highest uranium-234 and uranium-238 concentrations observed in near-facility air samples during 2004 were from two sampling stations at the 618-7 remediation site within the 300-FF-2 Operable Unit and were measured in composite samples collected during August and September. The uranium-234 and uranium-238 results were, respectively, $0.2 \%$ and $0.1 \%$ of the DOE derived concentration guide (Appendix D, Table D.5) and may have been associated with the remediation activities.

The 300 Area cleanup and decommissioning activities discussed above are described in more detail in Section 6.1.4.

\subsubsection{Site-Wide and Offsite Ambient-Air Monitoring}

\section{B. G. Fritz}

During 2004, airborne radionuclide samples were collected by 44 continuously operating samplers. The sampling stations were grouped into four location groups: site-wide (onsite) (23 stations), perimeter (11 stations), community (8 stations), and distant (2 stations) (Figure 8.2.2 and Table 8.2.3). Four of the stations were community-operated environmental surveillance stations (Section 8.17) that were managed and operated by local schoolteachers as part of an ongoing DOE-sponsored program to promote public awareness of Hanford Site environmental monitoring programs. Air samplers on the Hanford Site were located primarily around major operational areas to maximize the ability to detect radiological contaminants resulting from site operations. Perimeter samplers were located around the site boundary, with emphasis on the prevailing downwind directions to the south and east of the site. Samplers located in Basin City, Benton City, Kennewick, Mattawa, Othello, Pasco, and Richland, Washington, provided data for the nearest population centers. Samplers in Toppenish and Yakima, Washington, provided background data for communities essentially unaffected by Hanford Site operations.

\subsubsection{Collection of Site-Wide and Offsite Ambient-Air Samples and Analytes Tested}

Samples were collected according to a schedule established before the monitoring year (Hanford Site Environmental Surveillance Master Sampling Schedule, PNNL-14184) and analyzed for up to eight analytes (Table 8.2.3). Airborne 


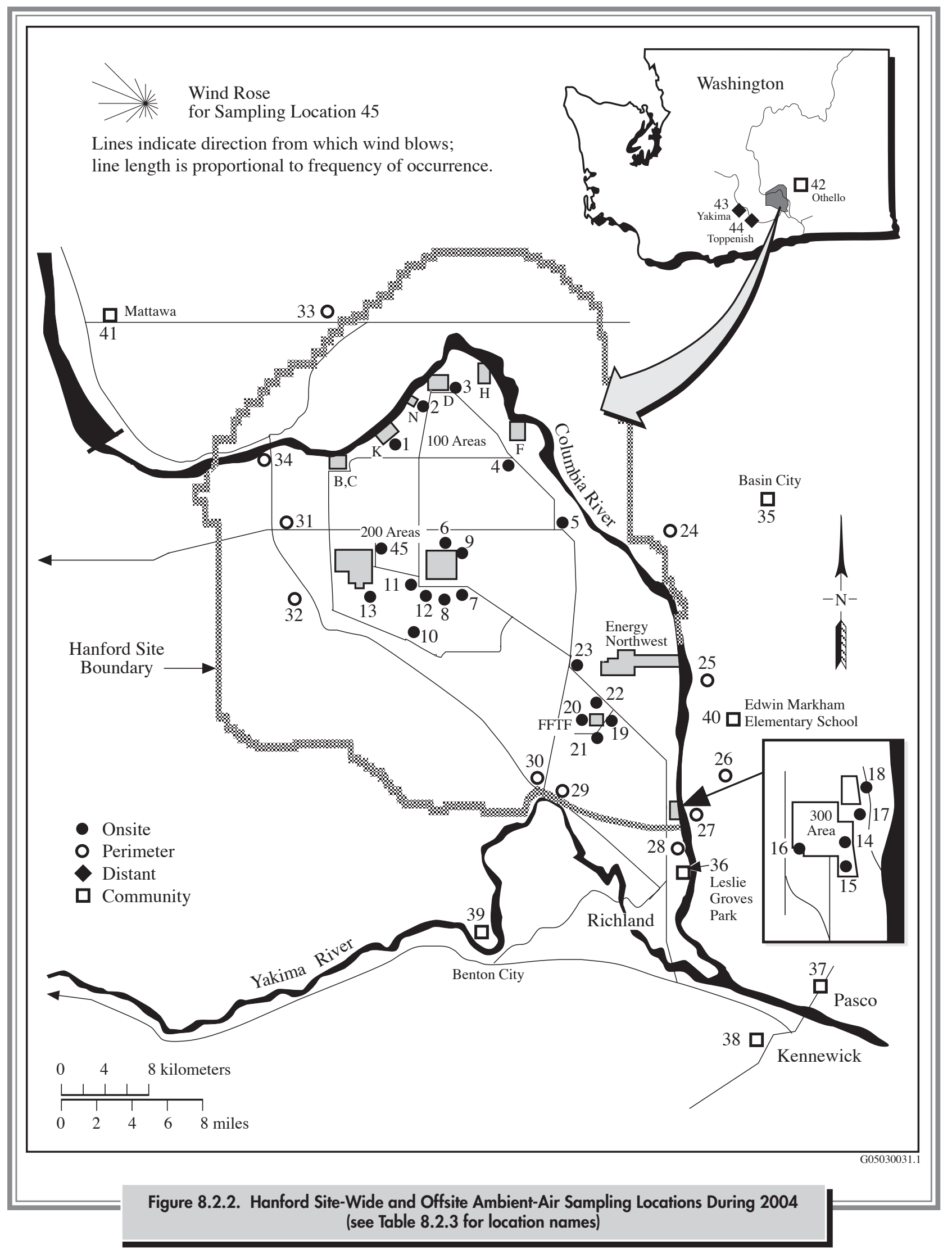




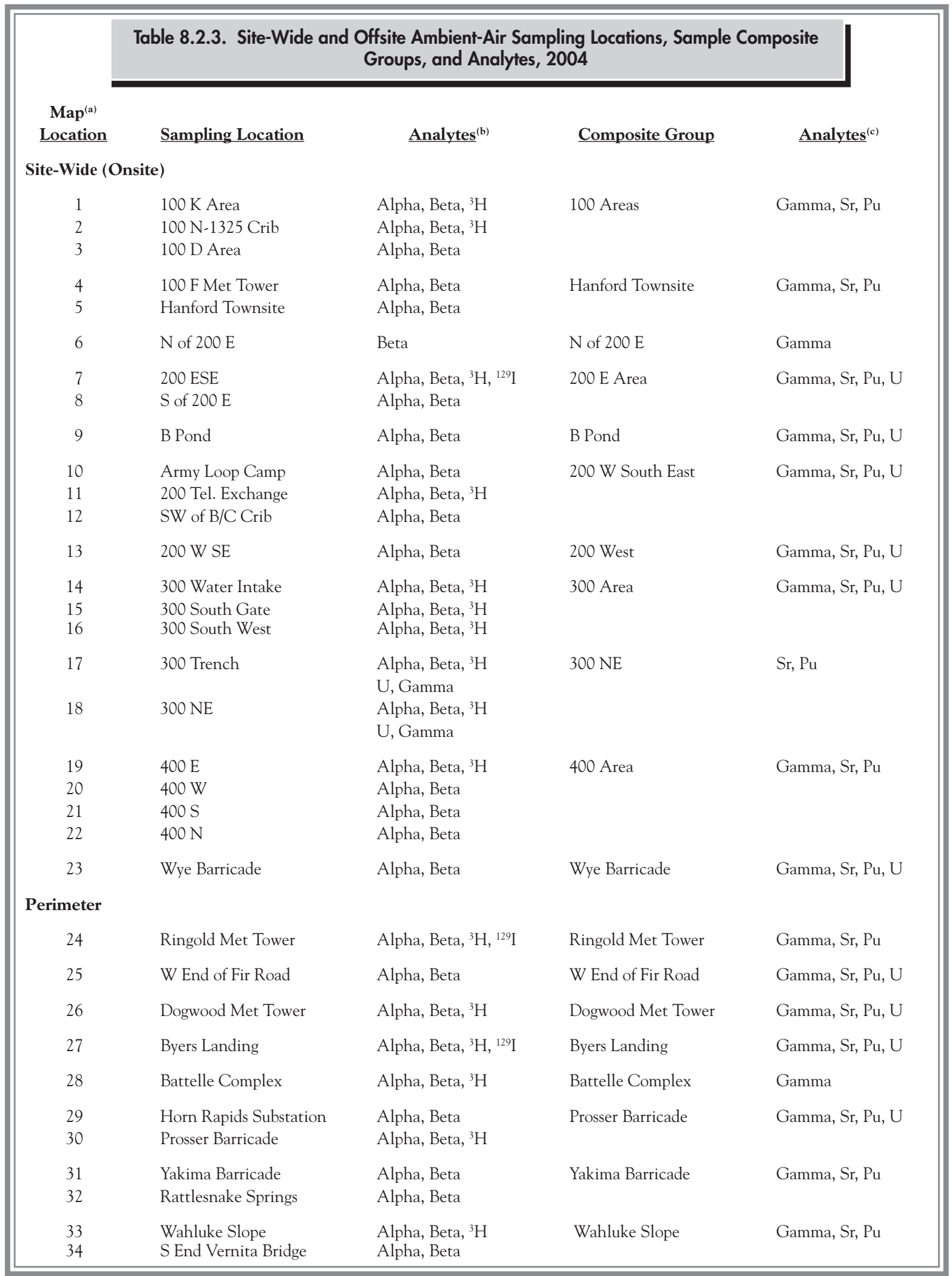


Table 8.2.3. (contd)

$\operatorname{Map}^{(a)}$

Location

Sampling Location

Nearby Communities

$\begin{array}{ll}35 & \text { Basin City School }{ }^{(\mathrm{d})} \\ 36 & \text { Leslie Groves-Rchlnd }{ }^{(\mathrm{d})} \\ 37 & \text { Pasco } \\ 38 & \text { Kennewick } \\ 39 & \text { Benton City } \\ 40 & \text { Edwin Markham } \\ & \text { School }{ }^{(\mathrm{d})} \\ 41 & \text { Mattawa } \\ 42 & \text { Othello }\end{array}$

Distant Communities

$\begin{array}{ll}43 & \text { Yakima } \\ 44 & \text { Toppenish }^{(\mathrm{d})}\end{array}$

Non-Radiological Monitoring

45 Hanford Meteorology Station
Composite Group

Analytes $^{(\mathrm{c})}$

Analytes $^{(\mathrm{b})}$

Alpha, Beta, ${ }^{3} \mathrm{H}$

Basin City School

Gamma, Sr, Pu, U

Alpha, Beta, ${ }^{3} \mathrm{H}$

Leslie Groves-Rchlnd

Gamma, Sr, Pu, U

Beta

Tri-Cities

Gamma, Sr, Pu

Alpha, Beta

Beta

Benton City

Gamma

Alpha, Beta, ${ }^{3} \mathrm{H}$

Edwin Markham

School

Beta

Mattawa

Gamma, Sr, Pu, U

Beta

Othello

Gamma

Gamma

Gamma, Sr, Pu, U

Alpha, Beta, ${ }^{3} \mathrm{H}$

Toppenish

Gamma, Sr, Pu, U

(b) Alpha (gross) and beta (gross) samples are collected and analyzed every 2 weeks, ${ }^{3} \mathrm{H}$ samples are collected and analyzed every 4 weeks, and ${ }^{129} \mathrm{I}$ samples are collected every 4 weeks, combined into a quarterly composite sample and analyzed for each location.

(c) Gamma spectroscopy, strontium-90, isotopic plutonium $\left({ }^{238} \mathrm{Pu},{ }^{239 / 240} \mathrm{Pu}\right)$, and isotopic uranium $\left({ }^{234} \mathrm{U},{ }^{235} \mathrm{U},{ }^{238} \mathrm{U}\right)$ analyses are performed on quarterly composite samples.

(d) A community-operated environmental surveillance station.

(e) See Section 8.2.2.3.

particle samples were collected biweekly at each location by continuously drawing air through a high efficiency glass-fiber filter. The samples were transported to an analytical laboratory and stored for at least 72 hours. The storage period was necessary to allow for the decay of shortlived, naturally occurring radionuclides (e.g., radon gas decay products) that would otherwise obscure detection of longer-lived radionuclides potentially present from Hanford Site emissions. The filters were then analyzed for gross beta radiation. Selected filters were also analyzed for gross alpha radiation. Historically, for most radionuclides, the amount of radioactive material collected on a filter during a 2-week period has been too small for accurate analysis of radionuclides of concern. In order to increase the sensitivity and accuracy of the analysis, biweekly samples were combined into quarterly composite samples. The compositing procedure results in a 12 -week-average concentration.
The quarterly composite samples were analyzed for gammaemitting radionuclides (Appendix F). Most composite samples were also analyzed for strontium-90, plutonium238, plutonium-239/240, uranium-234, uranium-235, and uranium-238.

Samples were collected for iodine-129 analysis at four locations by drawing air through a cartridge containing an adsorbent material. Samples were collected monthly and combined to form quarterly composite samples for each location.

Atmospheric water vapor was collected for tritium analysis at 21 locations by continuously drawing air through multicolumn samplers containing adsorbent silica gel. The water-vapor samplers were exchanged every 4 weeks to prevent loss of the sample as a result of breakthrough (i.e., over saturation). The collection efficiency of the silica gel 
adsorbent is discussed in Patton et al. (1997). The collected water was distilled from the silica gel and analyzed for its tritium content.

\subsubsection{Ambient-Air Monitoring Results for Site-Wide and Offsite Samples}

All sample results showed very low radiological concentrations in air during 2004. All concentrations were below the DOE derived concentration guides (Appendix D, Table D.5) for each radionuclide analyzed (Table 8.2.4). The DOE derived concentration guide values are based on a $100 \mathrm{mrem}(1 \mathrm{mSv})$ per year dose. A more conservative dose standard is the EPA Clean Air Act standard of 10 mrem $(100 \mu \mathrm{Sv})$ per year from airborne radiological material. All radionuclide concentrations in air samples collected in 2004 were less than one-tenth of the DOE derived concentration guide values, which correlates to concentrations that would result in a $10 \mathrm{mrem}(100 \mu \mathrm{Sv})$ per year dose.

Gross alpha concentrations were essentially the same at all site-wide and offsite locations during 2004 (Table 8.2.4). Samples collected around the Hanford Site perimeter had slightly lower average gross alpha concentrations than samples collected at site-wide, distant, and community locations, but the differences were not statistically significant (two-sample means t-test, 95\% confidence level). The average site-wide and distant alpha concentrations were the same in 2004 (Figure 8.2.3). The highest gross alpha concentration for 2004 was observed at a site-wide location near the 400 Area $\left(3,900 \mathrm{aCi} / \mathrm{m}^{3}\left[140 \mu \mathrm{Bq} / \mathrm{m}^{3}\right]\right)$. The average gross alpha concentrations observed in individual location groups during 2004 were slightly lower than the 5 -year average concentrations observed in the groups from 1999 through 2003 (Table 8.2.4).

Gross beta concentrations in air peaked during the winter months in 2004 (Figure 8.2.4), repeating a pattern of natural radioactivity fluctuations (Eisenbud 1987). The annual average gross beta concentration at site-wide locations during 2004 was slightly higher than at the distant locations. The difference was small and not statistically significant (two-sample means t-test, 95\% confidence level). The average gross beta concentrations reported for 2004 were similar to concentrations measured from 1999 through 2003 (Table 8.2.4). Concentrations appeared to be inversely proportional to the average wind speed over the sampling period (Figures 8.2.4 and 8.2.5). This is similar to other studies that have seen a negative correlation between wind speed and the concentrations of radon and radon decay products (Duenas et al. 2003; Ho and Measday 2005; Marcazzan et al. 2003; Winkler et al. 2001). It is likely that a majority of the gross beta activity observed in site-wide and offsite air samples is lead-210, a radon decay product, explaining the similarity between gross beta concentrations at all sampling locations on and off of the Hanford Site.

Tritium concentrations measured at all locations during 2004 were similar to average values reported for 1999 through 2003 (Table 8.2.4). The annual average 300 Area, perimeter, and community concentrations were higher than the average distant concentration, although the differences were not statistically significant (two-sample means t-test, 95\% confidence level). The sample with the highest tritium concentration measured during 2004 $\left(66 \mathrm{pCi} / \mathrm{m}^{3}\left[2.4 \mathrm{~Bq} / \mathrm{m}^{3}\right]\right)$ was collected at the Battelle Complex in Richland (location 28 on Figure 8.2.2) during May. This concentration was $0.55 \%$ of the DOE derived concentration guide (Appendix D, Table D.5).

Iodine-129 analyses were performed on samples collected at a site-wide location downwind of the PlutoniumUranium Extraction (PUREX) Plant, at two downwind perimeter locations, and at a distant location (Yakima) in 2004 (Table 8.2.3). Concentrations measured site-wide during 2004 were elevated compared to those measured at the site perimeter, and perimeter levels were higher than those measured at the distant location in Yakima (Figure 8.2.6). Concentration differences between these locations were statistically significant and indicated a Hanford Site source. Site-wide and perimeter concentrations observed in 2004 were consistent with the levels observed from 1999 through 2003 (Table 8.2.4). Site-wide air concentrations of iodine-129 were influenced by minor emissions (Table 8.1.1) from the Plutonium-Uranium Extraction (PUREX) Plant and possible releases from waste storage tanks and cribs. The annual average iodine-129 concentration observed at the downwind perimeter in $2004\left(0.90 \mathrm{aCi} / \mathrm{m}^{3}\left[0.033 \mu \mathrm{Bq} / \mathrm{m}^{3}\right]\right)$ was $0.00000013 \%$ of the DOE derived concentration guide (70 million $\mathrm{aCi} / \mathrm{m}^{3}\left[2.6 \mathrm{~Bq} / \mathrm{m}^{3}\right]$ ). 


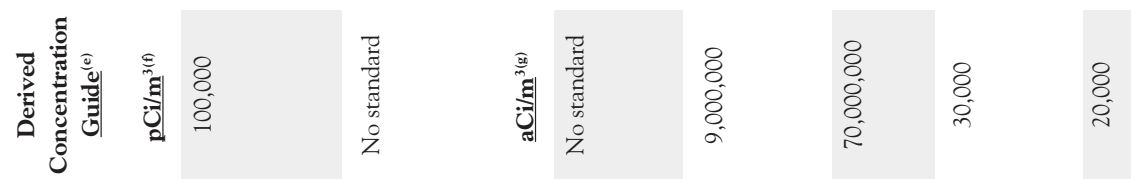

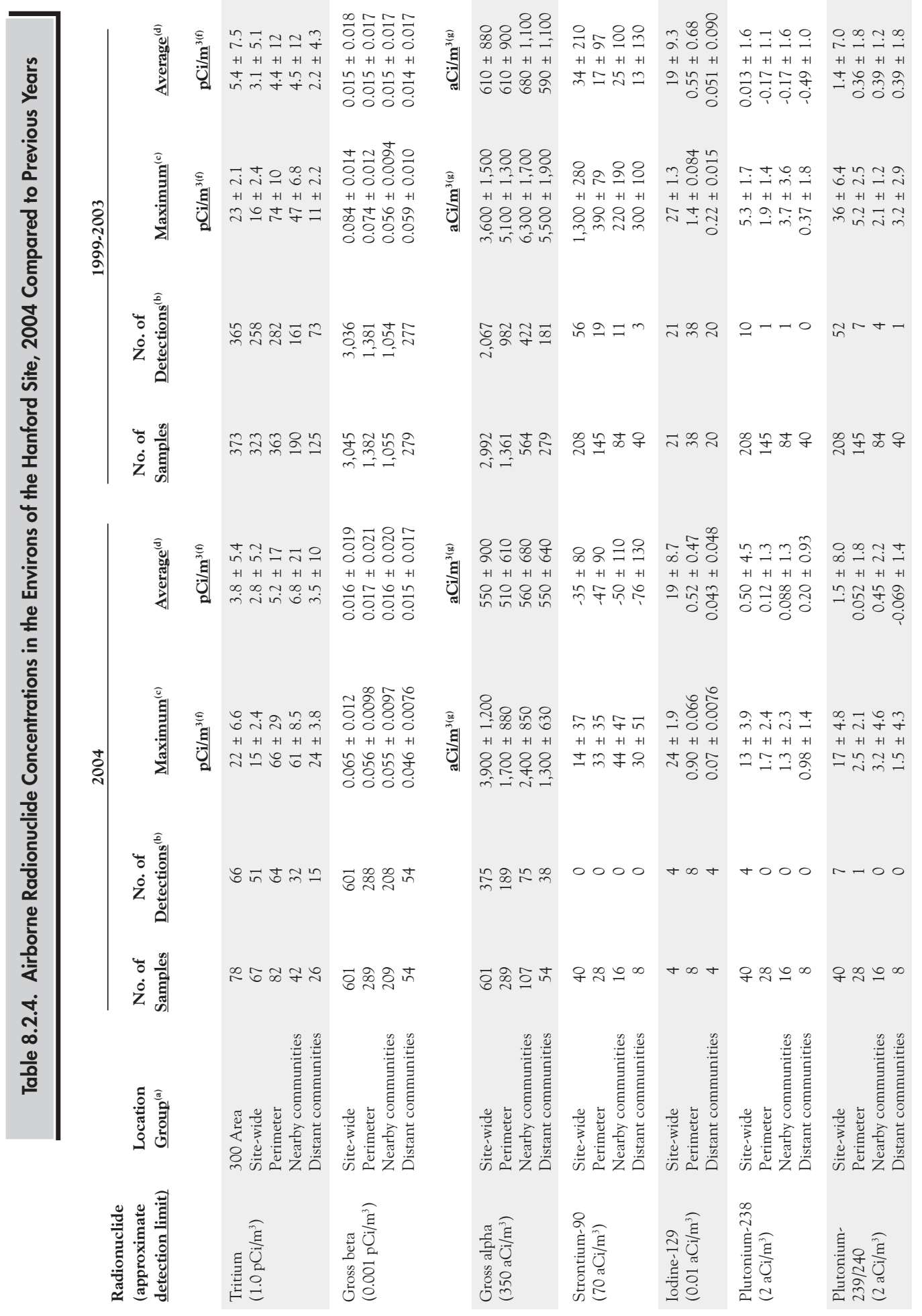




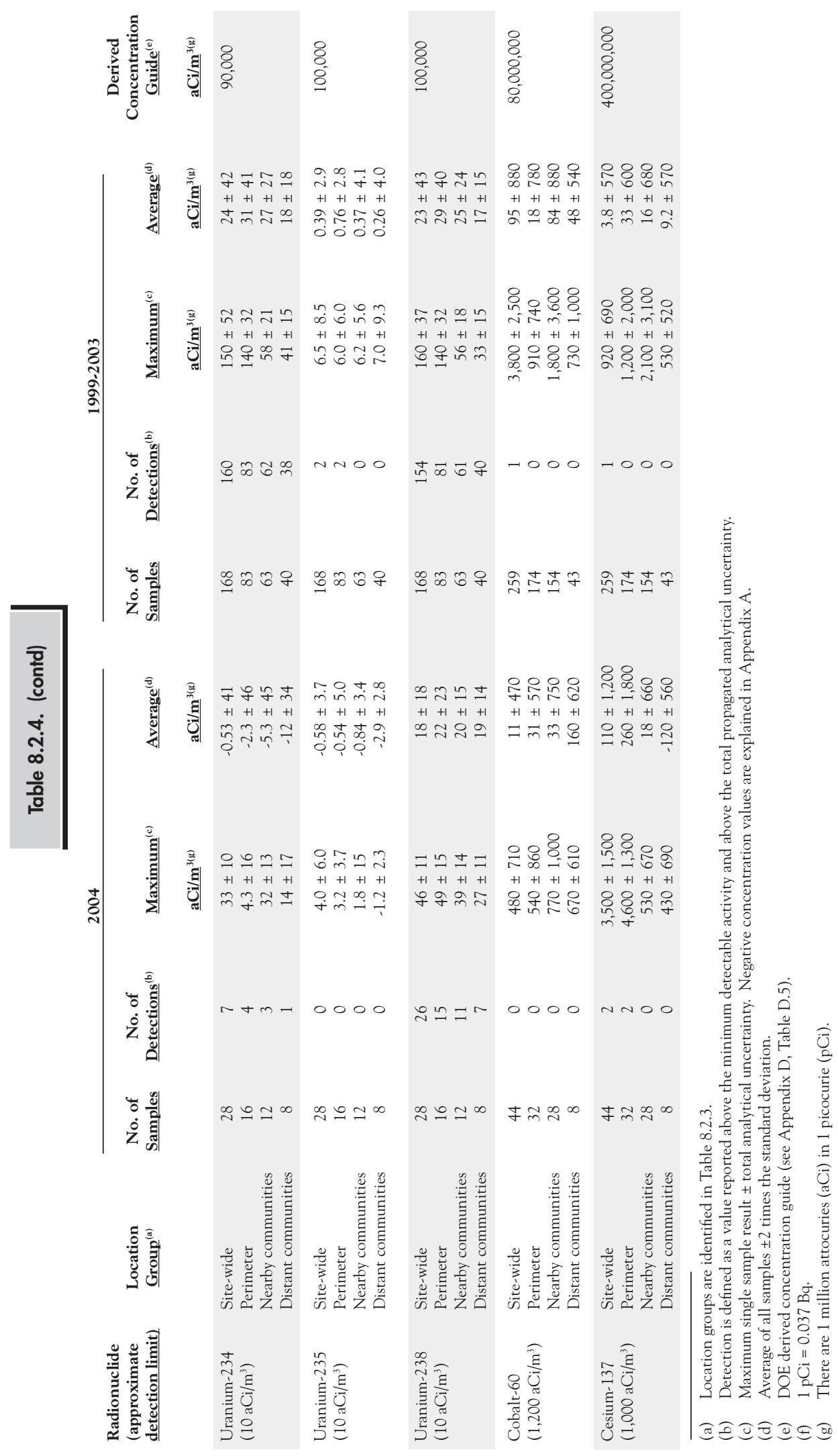



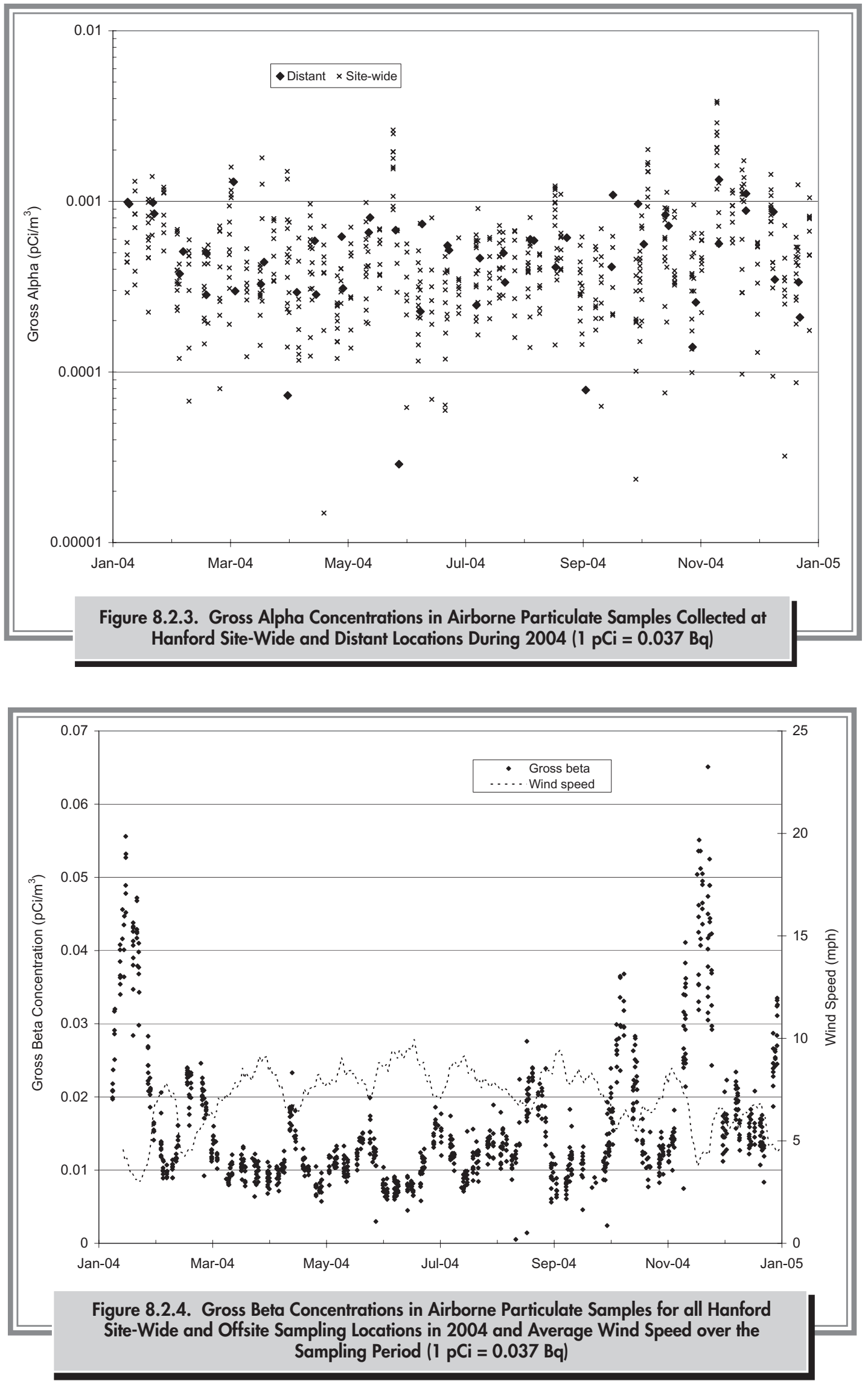


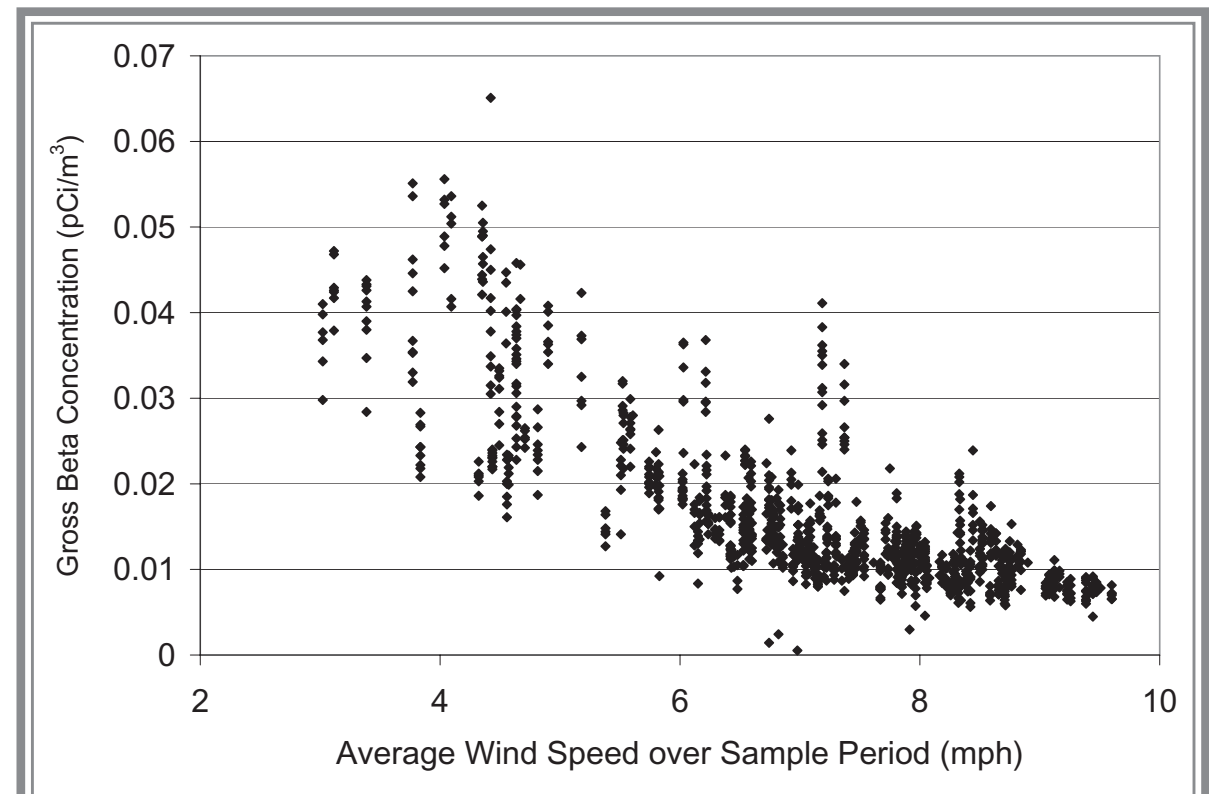

Figure 8.2.5. Gross Beta Concentrations Measured in Airborne Particulate Samples for Hanford Site-Wide and Offsite Sampling Locations in 2004 Versus the Average Wind Speed over the Sampling Period $(1 \mathrm{pCi}=0.037 \mathrm{~Bq})$

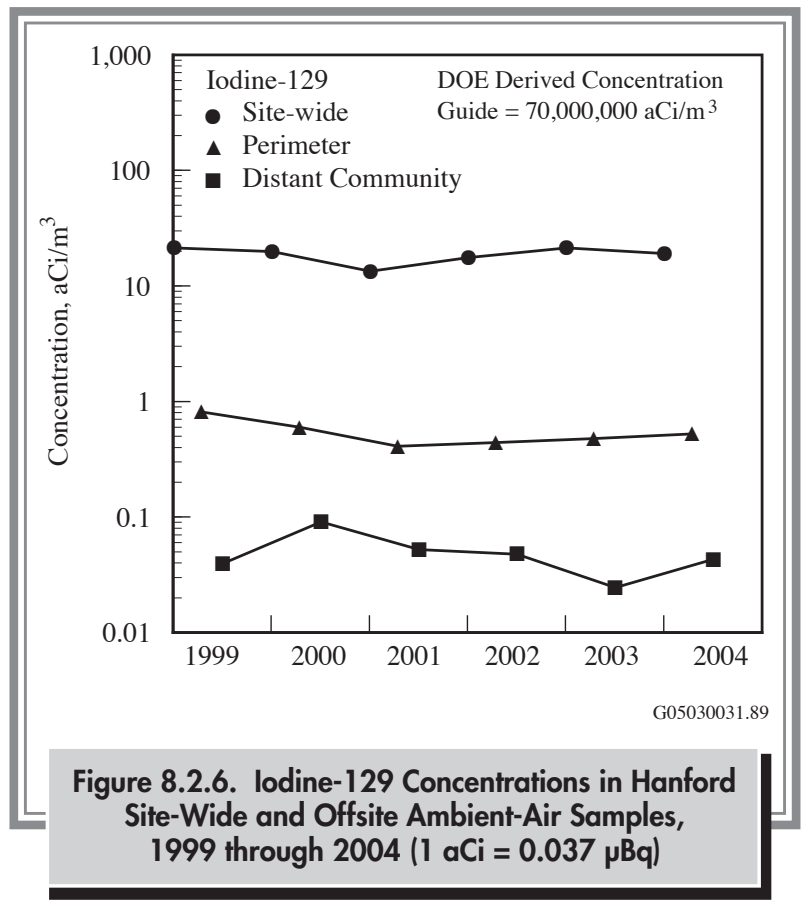

2004 Annual Environmental Report
Plutonium-238 was detected in four site-wide composite samples during 2004 (Table 8.2.4). The maximum reported plutonium-238 concentration in 2004 was $13 \mathrm{aCi} / \mathrm{m}^{3}\left(0.48 \mu \mathrm{Bq} / \mathrm{m}^{3}\right)$, or 2,300 times below the DOE derived concentration guide for plutonium-238 (30,000 aCi $/ \mathrm{m}^{3}$ $\left.\left[1,100 \mu \mathrm{Bq} / \mathrm{m}^{3}\right]\right)$.

The annual average plutonium$239 / 240$ concentration in air samples collected in 2004 at sitewide locations was $1.5 \mathrm{aCi} / \mathrm{m}^{3}$ $\left(0.056 \mu \mathrm{Bq} / \mathrm{m}^{3}\right)$. Of the 40 sitewide samples analyzed for plutonium-239/240, 7 had detectable amounts in the sample (Table 8.2.4). Three of the detectable concentrations were from samples collected in the 100 Areas composite group (Table 8.2.3), which may have been affected by cleanup activities ongoing at various locations in the 100 Areas. Only 1 of the 52 perimeter, community, and distant samples collected in 2004 had a detectable amount of plutonium-239/240. The maximum Hanford Site plutonium-239/240 air concentration $\left(17 \mathrm{aCi} / \mathrm{m}^{3}\left[0.63 \mu \mathrm{Bq} / \mathrm{m}^{3}\right]\right)$ was observed for the $300 \mathrm{NE}$ fourth quarter composite group sample (locations 1, 2, and 3 on Figure 8.2.2). This sampling period included the time period covering a Category 3 environmental occurrence at the 300 Area Remediation Project (see Section 5.9.2). This event resulted in some elevated gross alpha readings in the remediation work area, and may have contributed to the maximum plutonium-239/240 air concentration measured in 2004. This maximum reported concentration was $0.09 \%$ of the DOE derived concentration guide $\left(20,000 \mathrm{aCi} / \mathrm{m}^{3}\left[730 \mu \mathrm{Bq} / \mathrm{m}^{3}\right]\right)$ for plutonium-239/240.

Isotopic uranium concentrations (uranium-234, uranium-235, and uranium-238) in airborne particulate matter in 2004 were lower than average concentrations measured from 1999 through 2003 for all location groups (Table 8.2.4). The 2004 annual average uranium-238 concentration for the site perimeter was $22 \mathrm{aCi} / \mathrm{m}^{3}$ $\left(0.81 \mu \mathrm{Bq} / \mathrm{m}^{3}\right)$, which is $0.02 \%$ of the DOE derived 
concentration guide $\left(100,000 \mathrm{aCi} / \mathrm{m}^{3}\left[3,700 \mu \mathrm{Bq} / \mathrm{m}^{3}\right]\right)$. The site-wide and perimeter uranium-234 and uranium-238 average concentrations were not different than the distant concentrations by a statistically significant amount (two-sample means t-test, 95\% confidence level). Similar to plutonium-239/240, the highest measured uranium-238 concentration was measured at the $300 \mathrm{NE}$ composite group during the fourth quarter of 2004. This sampling period included the time period when a Category 3 environmental occurrence at the 300 Area Remediation Project occurred (see Section 5.9.2). This event resulted in some elevated gross alpha readings in the remediation work area, and may have contributed to the maximum site-wide uranium-238 air concentration measured in 2004. This concentration $\left(46 \mathrm{aCi} / \mathrm{m}^{3}\left[1.7 \mu \mathrm{Bq} / \mathrm{m}^{3}\right]\right)$ was only $0.05 \%$ of the DOE derived concentration guide for uranium-238.

Strontium-90 was analyzed in 92 airborne particulate samples in 2004 (Table 8.2.4). No samples had detectable concentrations. Comparison of the average concentrations was unnecessary since there were no detectable results.

Gamma spectroscopy was conducted on all quarterly composite samples collected in 2004. Naturally occurring beryllium- 7 and potassium- 40 were routinely identified. The potential Hanford-origin gamma-emitting radionuclides of cobalt- 60 and cesium-137 were of particular interest. Four of the 112 samples analyzed by gamma spectroscopy had concentrations of cesium-137 above the minimum detectable concentration. None of the samples collected in 2004 had detectable concentrations of cobalt -60 . This is consistent with the 5-year average data from 1999 though 2003 (Table 8.2.4).

\subsubsection{Monitoring of Airborne Particulate Matter on the Hanford Site}

Airborne particulate matter (dust) is one of EPA's criteria pollutants. EPA classifies particulate matter by particle size. $\mathrm{PM}_{10}$ is an air pollutant consisting of small particles with aerodynamic diameters less than or equal to 10 micrometers. Similarly, $\mathrm{PM}_{2.5}$ is an air pollutant consisting of small particles with aerodynamic diameters less than or equal to 2.5 micrometers $\left(\mathrm{PM}_{10}\right.$ particles can include $\mathrm{PM}_{2.5}$, since particles smaller than 2.5 micrometers are also smaller than 10 micrometers). The EPA's National Primary and Secondary Ambient Air Quality Standards (40 CFR 50) for $\mathrm{PM}_{10}$ requires a 24-hour average concentration of less than $150 \mu \mathrm{g} / \mathrm{m}^{3}$, and an annual average concentration less than $50 \mu \mathrm{g} / \mathrm{m}^{3}$. There is currently no enforced EPA standard for $\mathrm{PM}_{2.5}$, although proposed standards are $65 \mu \mathrm{g} / \mathrm{m}^{3}$ for a 24-hour average concentration and a $15 \mu \mathrm{g} / \mathrm{m}^{3}$ annual average concentration. Health risk studies have shown a positive correlation between increases in concentrations of airborne particulate matter and increased hospital admissions for pulmonary and heart conditions (Schwartz 1994; Morgan et al. 1998; Ostro et al. 1999). Studies have indicated that a $100 \mu \mathrm{g} / \mathrm{m}^{3}$ increase in $\mathrm{PM}_{10}$ concentrations results in a $17 \%$ increase in hospital admissions for pneumonia and chronic obstructive pulmonary disorder (Schwartz 1994). Similar relationships were found between $\mathrm{PM}_{10}$ concentrations and daily human mortality in areas where windblown dust was the main contributor to high $\mathrm{PM}_{10}$ concentrations (similar to the Hanford Site) (Ostro et al. 1999).

During February 2001, monitoring of particulate matter mass concentrations in air on the Hanford Site began. The motivation for this was the decrease in vegetative cover on a large portion of the site after the 24 Command Hanford Site Wildfire in 2000 (Hanford Site Environmental Report for Calendar Year 2000, PNNL-13487), as well as information requests from the public. It was expected that the decrease in vegetative cover would result in increased wind erosion, and subsequently, increased particulate matter (dust) concentrations in air. In 2004, particulate monitoring was done at the Hanford Meteorological Station (location 45, Figure 8.2.2 and Table 8.2.3) using a tapered element oscillating microbalance. The unique design of this instrument measures the difference in mass collected on a filter by measuring the change in frequency of oscillation of the filter. The instrument records an hourly average concentration, but daily average concentration data were calculated for this report. $\mathrm{PM}_{10}$ concentration data have been collected at the Hanford Meteorology Station since February 2001, while PM $_{2.5}$ concentration data collection began at the Hanford Meteorology Station in October 2001.

Figure 8.2.7 illustrates the daily average $\mathrm{PM}_{10}$ concentrations recorded at the Hanford Meteorology Station during 2004 for all time periods when the instrument was operating. The instrument operated $79 \%$ of the time during 


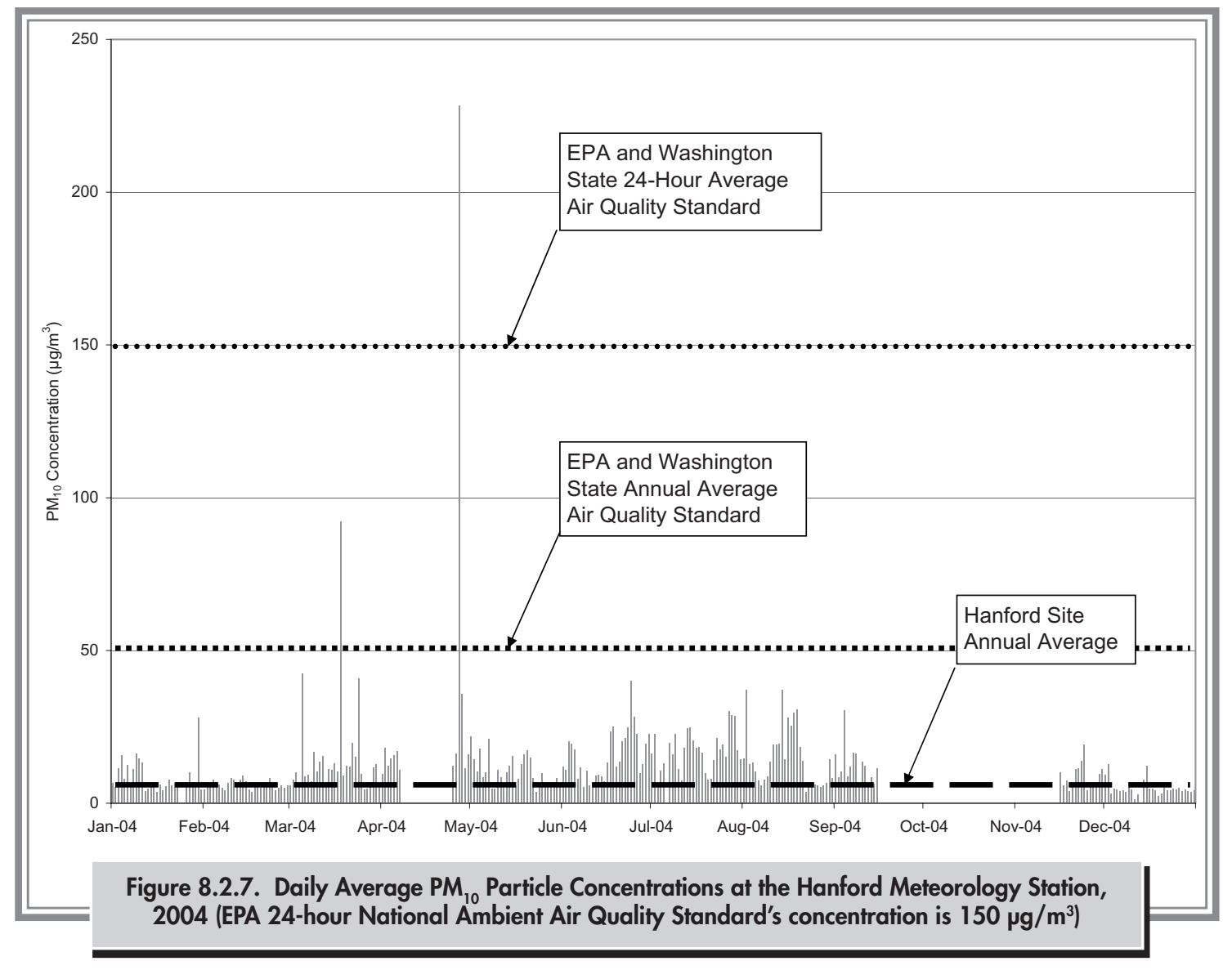

2004. Although Hanford Site measurements are not used to determine compliance with air quality standards (Section 5.3.1), EPA standards were not exceeded at the measurement locations on the Hanford Site. The observed annual average $\mathrm{PM}_{10}$ concentration at the Hanford Meteorology Station during $2004\left(12 \mu \mathrm{g} / \mathrm{m}^{3}\right)$ was well below the EPA annual average standard $\left(50 \mu \mathrm{g} / \mathrm{m}^{3}\right)$. Daily average $\mathrm{PM}_{10}$ concentrations on the Hanford Site were higher than the EPA 24-hour average standard once during 2004 (April 27), but EPA policy allows exemptions for natural events that result in high particulate matter concentrations, such as windstorms. Wind speeds on April 27, 2004, exceeded 22 meters per second (50 miles per hour).
There is currently no enforced EPA concentration standard for $\mathrm{PM}_{2.5}$. However, the $\mathrm{PM}_{2.5}$ concentrations measured at the Hanford Meteorology Station during 2004 (Figure 8.2.8) were well below the proposed EPA standards for $\mathrm{PM}_{2.5}\left(15 \mu \mathrm{g} / \mathrm{m}^{3}\right.$ annual average, $65 \mu \mathrm{g} / \mathrm{m}^{3}$ 24-hour average). The measured annual average $\mathrm{PM}_{2.5}$ concentration at the Hanford Meteorology Station during 2003 was $6.5 \mu \mathrm{g} / \mathrm{m}^{3}$, while the highest 24 -hour average concentration observed was $21 \mu \mathrm{g} / \mathrm{m}^{3}$. 


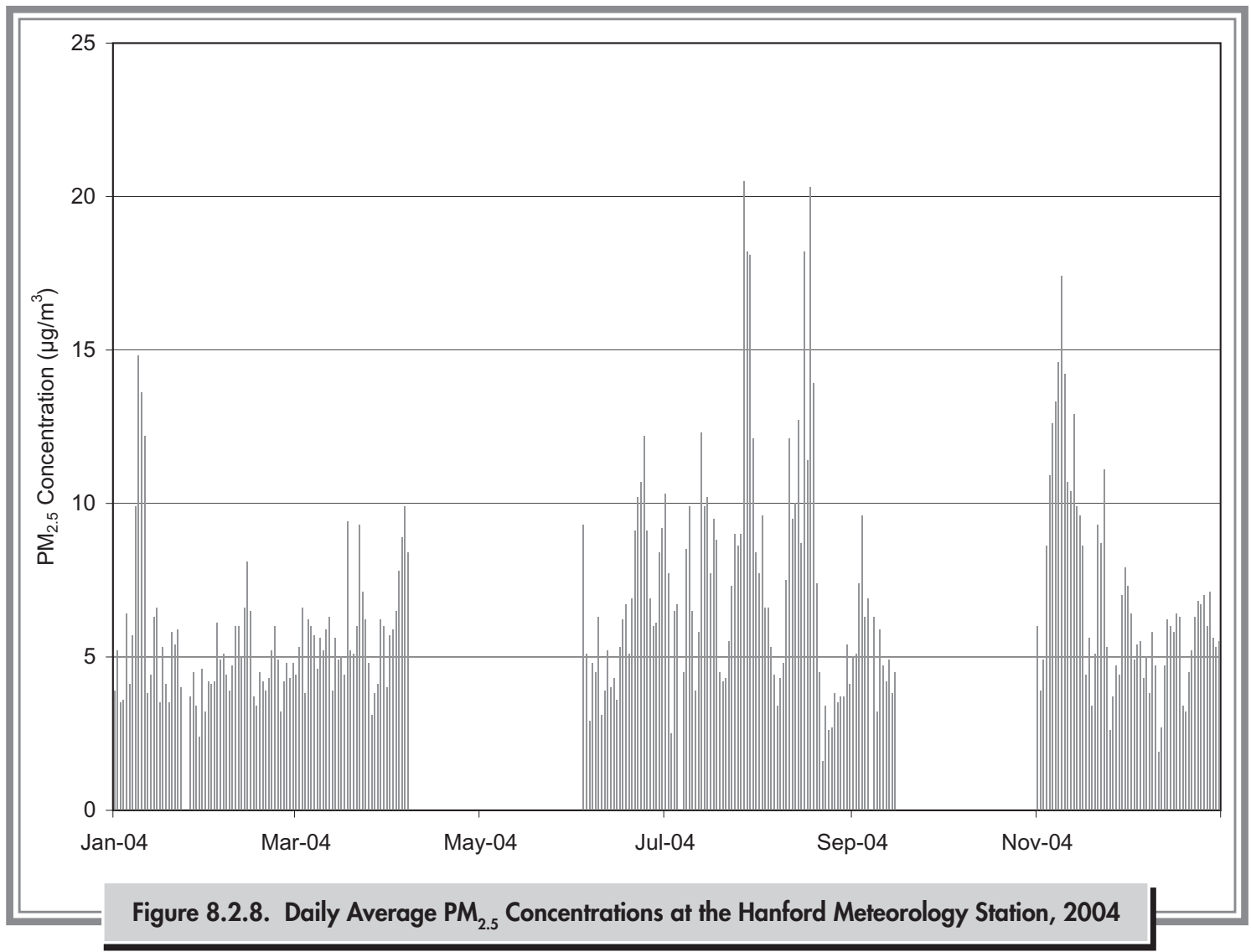




\title{
8.3 Liquid Effluent from Hanford Site Facilities
}

\author{
L. P. Diediker and D. J. Rokkan
}

Liquid effluent is discharged from some facilities at the Hanford Site. Effluent streams are sampled and analyzed for gross alpha and gross beta concentrations, as well as for concentrations of selected radionuclides.

Contaminant data from liquid effluent sampling and analyses are reported to DOE annually in an environmental releases report (HNF-EP-0527-14). This report also includes summaries of monitoring results on liquid effluent discharged to the Columbia River; activities regulated by the National Pollutant Discharge Elimination System permit and reported quarterly to the EPA; liquid effluent discharges to the soil regulated by WAC 173-216, State Waste Discharge Program, and reported quarterly to the Washington State Department of Ecology; and nonradioactive air emissions, which are reported annually to the Washington State Department of Ecology. Short summaries of effluent monitoring data for 2004, with some historical results, are provided in the following sections.

\subsubsection{Radionuclides in Liquid Effluent}

During 2004, only facilities in the 200 Areas discharged radioactive liquid effluent to the ground, which all went to a single location, the 616-A crib, also known as the State-Approved Land Disposal Site. A summary of radioactive liquid effluent is provided in Table 8.3.1. Table 8.3.2 summarizes data on radionuclides in liquid effluent released from the 100 Areas to the Columbia River, the sources of which include secondary cooling water used at the $\mathrm{K}$ Basins and shoreline seepage of groundwater that has passed near the retired $116-\mathrm{N}-1$ and $116-\mathrm{N}-3$ cribs in the 100-N Area. Figure 8.3.1 depicts quantities of tritium released to the ground and strontium-90 released to the Columbia River over the past 11 years.

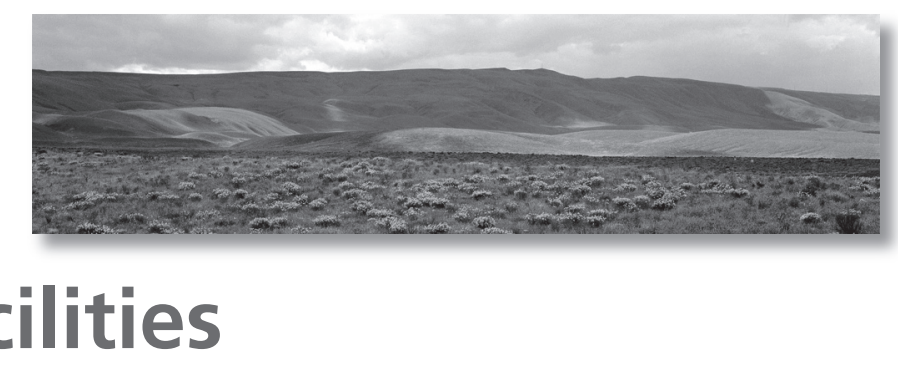

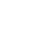 \\ .}



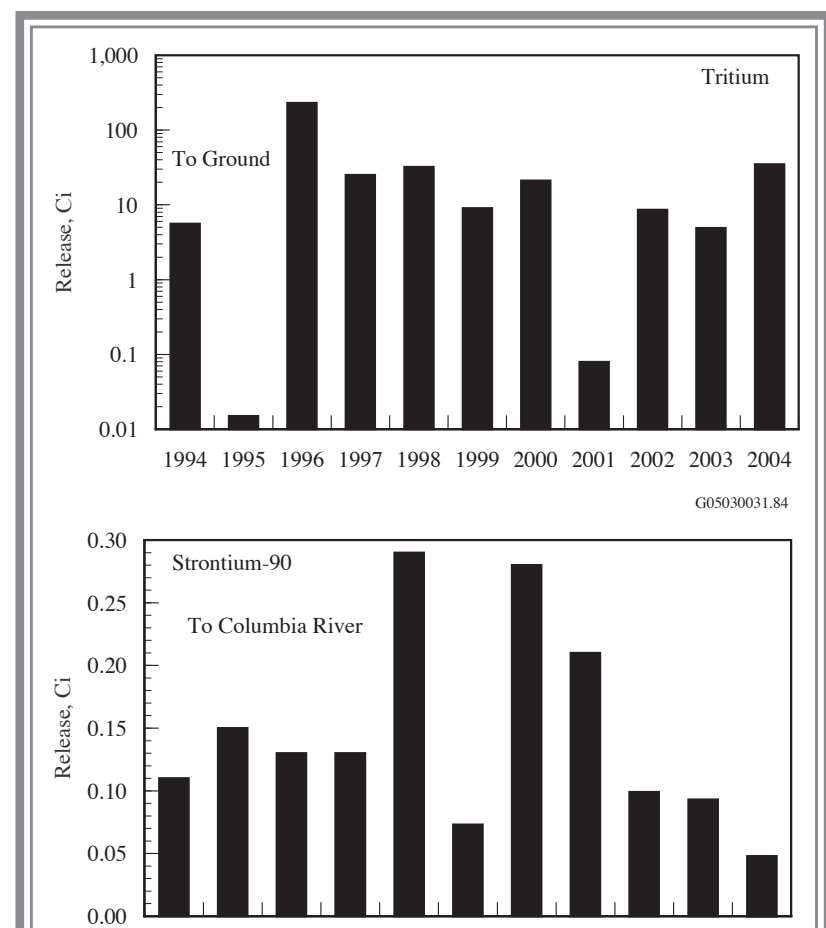

$1994199519961997 \quad 199819992000 \quad 20012002 \quad 2003 \quad 2004$

G05030031.85

Figure 8.3.1. Liquid Releases of Selected Radionuclides from the Hanford Site, 1994 through 2004
Pollutant Discharge Elimination System permits and the state waste discharge permits for the site (EPA Administrated Permit Programs: The National Pollutant Discharge Elimination System [40 CFR 122] and WAC 173-216). Should chemicals in liquid effluent exceed quantities reportable under CERCLA, the release totals are immediately reported to EPA. If effluent remains stable at predicted levels, the release totals may, with EPA's permission, be reported annually. Section 5.4.1 provides a synopsis of the National Pollutant Discharge Elimination System and state waste discharge permit. 


\subsection{Surface-Water and Sediment Monitoring}

G. W. Patton

Samples of surface water and sediment on and near the Hanford Site were collected and analyzed to determine the concentrations of radiological and chemical contaminants from Hanford in the aquatic environment. Surface-water bodies monitored included the Columbia River, onsite ponds, and offsite irrigation sources (Figure 8.4.1). Aquatic sediment monitoring was conducted for the Columbia River and one onsite pond. Tables 8.4.1 and 8.4.2 summarize the sampling locations, types, frequencies, and analyses included in surface-water and sediment monitoring during 2004. This section describes the monitoring efforts and summarizes the results for these aquatic environments. Detailed analytical results are reported in PNNL-15222, APP. 1.

\subsubsection{Monitoring of Columbia River Water}

The Columbia River is the second largest river in the continental United States in terms of total flow and is the dominant surface-water body on the Hanford Site. The original selection of the Hanford Site for plutonium production was based, in part, on the abundant water supply offered by the river. The river flows through the northern portion of the site and forms part of the site's eastern boundary. The river is used as a source of drinking water for onsite facilities and communities located downstream from the Hanford Site. Water from the river immediately downstream of the site also is used for crop irrigation in Benton and Franklin Counties. In addition, the Hanford Reach of the Columbia River is used for a variety of recreational activities, including hunting, fishing, boating, water-skiing, and swimming.

Originating in the Rocky Mountains of eastern British Columbia, the Columbia River and its tributaries drain an area of approximately 670,000 square kilometers
(260,000 square miles) en route to the Pacific Ocean. The flow of the river is regulated by three dams in Canada and eleven dams in the United States; four of the dams are downstream of the Hanford Site. Priest Rapids Dam is the nearest upstream dam and McNary Dam is the nearest downstream dam from the site. The Hanford Reach of the Columbia River extends from Priest Rapids Dam downstream to the head of Lake Wallula, created by McNary Dam, near Richland, Washington. The Hanford Reach is the last stretch of the Columbia River in the United States upstream of Bonneville Dam (the first dam upstream from the ocean) that remains unimpounded.

River flow through the Hanford Reach fluctuates significantly and is controlled primarily by operations at upstream dams. Changing river flows result in changes in concentrations of contaminants in river water for users downstream of Hanford (PNL-8531). Annual average flow of the Columbia River downstream of Priest Rapids Dam is approximately 3,400 cubic meters $(120,000$ cubic feet) per second (WA-94-1). In 2004, the Columbia River had below normal flow; the average daily flow rate downstream of Priest Rapids Dam was 2,830 cubic meters $(99,890$ cubic feet) per second. The peak monthly average flow rate occurred during June (3,910 cubic meters $[138,000$ cubic feet] per second) (Figure 8.4.2). The lowest monthly average flow rate occurred during March (2,170 cubic meters [76,700 cubic feet] per second). Daily flow rates varied from 1,380 to 4,840 cubic meters (48,800 to 171,000 cubic feet) per second during 2004 . As a result of fluctuation in discharges, the depth of the river varies significantly over time. River stage (watersurface level) may change along the Hanford Reach by up to 3 meters (10 feet) within a few hours (see Section 3.3.7 in PNL-10698). Seasonal changes of approximately the same magnitude are also observed. River-stage fluctuations measured at the 300 Area are approximately half the 


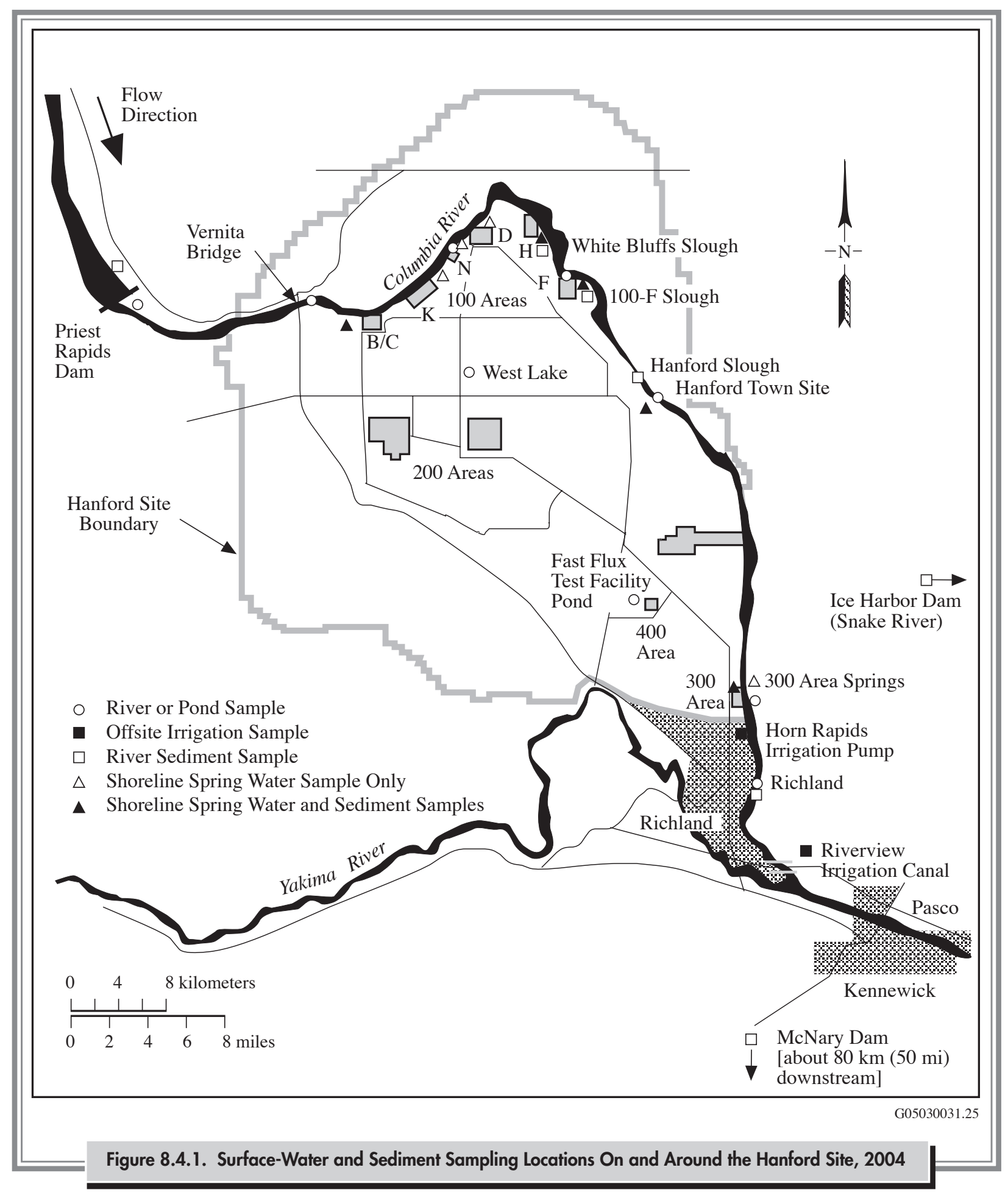




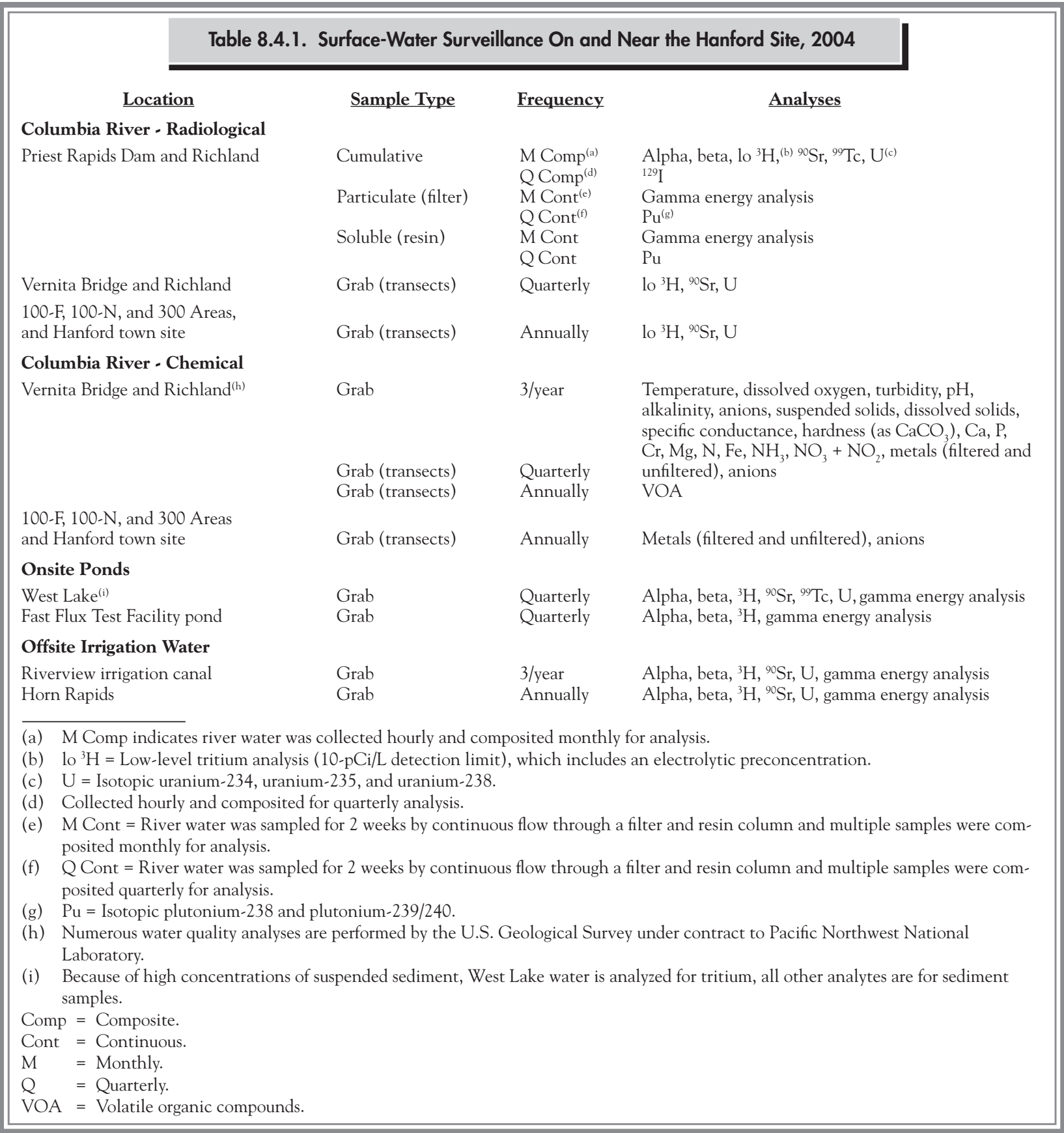

magnitude of those measured near the 100 Areas because of the effect of the pool behind McNary Dam (PNL-8580) and the relative distance of each area from Priest Rapids Dam. The width of the river varies from approximately 300 to 1,000 meters (980 to 3,300 feet) through the Hanford Site.

Hanford pollutants, both radiological and chemical, enter the Columbia River along the Hanford Reach. Effluent from each direct discharge point is monitored routinely and reported by the responsible operating contractor (Section 8.3). Direct discharges are identified and regulated for non-radiological constituents under the National Pollutant Discharge Elimination System in compliance with the Clean Water Act (Section 5.4.1). In addition to permitted direct discharges of liquid effluent from Hanford facilities, contaminants in groundwater from past operational discharges to the ground seep into the river (DOE/RL-92-12; PNL-5289; PNL-7500; WHC-SD-EN-TI006; Section 8.5 of this report). 


\begin{tabular}{|c|c|c|c|}
\hline \multirow{2}{*}{ Location } & \multicolumn{3}{|c|}{ Table 8.4.2. Columbia and Snake River Sediment Surveillance, 2004} \\
\hline & & $\underline{\text { Frequency }}$ & $\underline{\text { Analyses }}$ \\
\hline \multicolumn{3}{|c|}{ Columbia River } & $\begin{array}{l}\text { River sediment analyses included gamma energy } \\
\text { analysis, }{ }^{90} \mathrm{Sr}, \mathrm{U}^{(b)}, \mathrm{Pu}^{(c)} \text {, metals, SEM/AVS }\end{array}$ \\
\hline \multicolumn{3}{|c|}{$\begin{array}{l}\text { Priest Rapids Dam: } \\
3 \text { locations near the dam }\end{array}$} & \\
\hline \multicolumn{2}{|l|}{ White Bluffs Slough } & Annually & \\
\hline \multicolumn{2}{|l|}{ 100-F Slough } & Annually & \\
\hline \multicolumn{2}{|l|}{ Hanford Slough } & Annually & \\
\hline \multicolumn{2}{|l|}{ Richland } & Annually & \\
\hline \multicolumn{2}{|l|}{$\begin{array}{l}\text { McNary Dam: } \\
5 \text { locations }\end{array}$} & Annually & \\
\hline \multicolumn{4}{|l|}{ Snake River } \\
\hline \multicolumn{4}{|c|}{ Ice Harbor Dam: } \\
\hline \multicolumn{4}{|c|}{$\begin{array}{l}\text { (a) See Figure 8.4.1. } \\
\text { (b) U = Isotopic uranium-234, uranium-235, and uranium-238 analyzed by low-energy photon analysis. } \\
\text { (c) } \mathrm{Pu}=\text { Isotopic plutonium-238 and plutonium-239/240. } \\
\text { SEM/AVS = Simultaneously extracted metals and acid volatile sulfide. }\end{array}$} \\
\hline
\end{tabular}

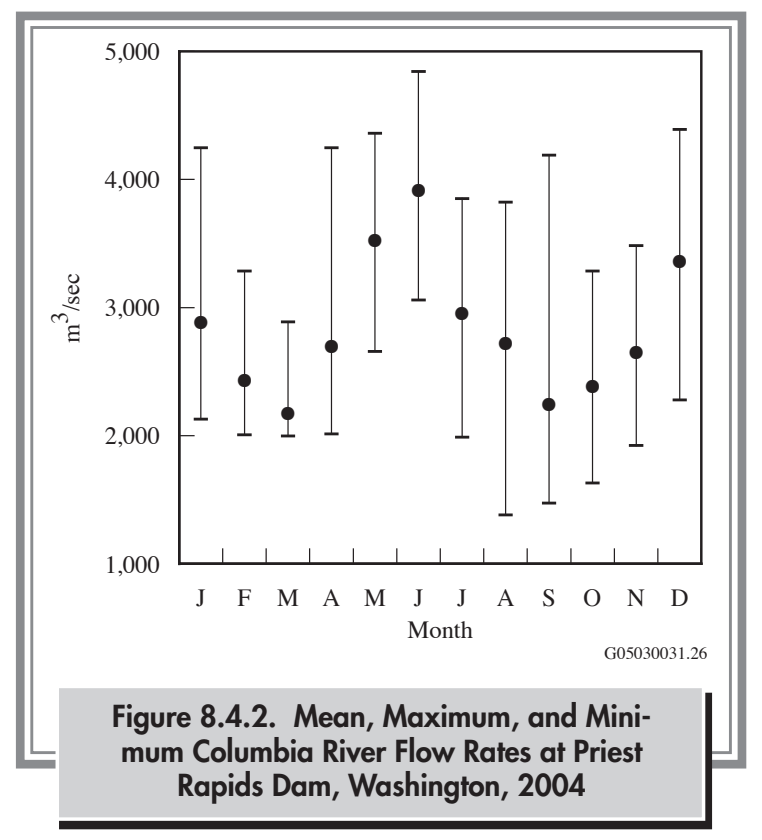

Washington State has classified the general water use and water quality criteria for the stretch of the Columbia River from Grand Coulee Dam to the Washington-Oregon border, which includes the Hanford Reach, as Class A, Excellent (WAC 173-201A). Water quality criteria and water use guidelines have been established in conjunction with this designation and are provided in Appendix D (Table D.1). In 2003, the Washington State Department of Ecology revised the surface-water quality standards and submitted them to EPA for approval in July 2003 (WAC 173-201A). Under the submitted surface water quality standards, the Class A (Excellent) designated uses criteria will be replaced with separate designations for aquatic life uses, recreational uses, water supply uses, and miscellaneous uses. For the Columbia River downstream from Grand Coulee Dam, the aquatic life designation will be "salmon and trout spawning, noncore rearing, and migration," which provides for the protection of spawning, noncore rearing, and migration of salmon and trout, and other associated aquatic life. The recreational uses designation for the Columbia River downstream from Grand Coulee Dam will be "primary contact," which provides for activities that may involve complete submersion by the participant. The entire Columbia River will be designated for all water supply and miscellaneous uses by the state of Washington. 


\subsubsection{Collection of Columbia River Water Samples and Analytes of Interest}

During 2004, Columbia River water samples were collected from fixed-location monitoring stations at Priest Rapids Dam and Richland, Washington, and from cross-river transects and near-shore locations near the Vernita Bridge, 100-N Area, 100-F Area, Hanford town site, 300 Area, and the city of Richland, Washington (Figure 8.4.1). Samples were collected upstream from Hanford Site facilities at Priest Rapids Dam and the Vernita Bridge to provide background data from locations unaffected by site operations. Samples were collected from all other locations to identify any increase in contaminant concentrations attributable to Hanford Site operations, including a municipal drinking water supply and points of withdrawal for irrigation water downstream of the Hanford Site. Sampling of irrigation water systems is discussed in Section 8.4.4.

The fixed-location monitoring stations at Priest Rapids Dam and Richland, Washington, consisted of both an automated sampler and a continuous flow system. Using the automated sampler, unfiltered samples of Columbia River water (cumulative samples) were obtained hourly to collect a composite sample for a period of 7 days. These weekly samples were combined into monthly and quarterly composite samples for radiological analyses (Table 8.4.1). Using the continuous flow system, particulate and soluble constituents in Columbia River water were collected by passing water through a filter and then through a resin column. Filter and resin samples were exchanged approximately every 14 days and were combined into quarterly composite samples for radiological analyses. The river sampling locations and the methods used for sample collection are discussed in detail in DOE/RL-91-50.

Radionuclides of interest were selected for analysis based on the following criteria:

- Their presence in effluent discharged from site facilities or in near-river groundwater underlying the Hanford Site

- Their importance in determining water quality, verifying facility effluent controls and monitoring systems, and determining compliance with applicable water quality standards.
Analytes of interest in river water samples collected at Priest Rapids Dam and Richland, Washington, included gross alpha, gross beta, selected gamma-emitting radionuclides, tritium, strontium-90, technetium-99, iodine-129, uranium-234, uranium-235, uranium-238, plutonium-238, and plutonium-239/240. Gross alpha and beta measurements are indicators of the general radiological quality of the river and provide a timely indication of change. Gamma energy analysis provides the ability to detect numerous specific radionuclides (Appendix F). Analytical detection levels (defined as the laboratory reported minimum detectable concentration) for all radionuclides were less than or equal to $10 \%$ of their respective water quality criteria levels (Appendix D, Tables D.1 and D.2). Unless otherwise noted in this section, the statistical tests for differences are paired sample comparisons and two-tailed t-tests, with alpha at $5 \%$ significance level.

Transect sampling (multiple samples collected along a line across the Columbia River) was initiated as a result of findings of a special study conducted during 1987 and 1988 (PNL-8531). That study concluded that, under certain flow conditions, contaminants entering the river from the Hanford Site are not completely mixed when sampled at routine monitoring stations located downriver. Incomplete mixing results in a slightly conservative (high) bias in the data generated using the routine, single-point, sampling system at Richland. During 1999, the transect sampling strategy was modified, with some of the mid-river sampling points shifted to near-shore locations in the vicinity of the transect. For example, at the 100-N Area instead of collecting ten evenly spaced cross-river transect samples, only six cross-river samples were collected, and the other four samples were obtained at near-shore locations (typically less than 5 meters [16 feet] from shore). This sampling pattern was used during 2004 and allowed the cross-river concentration profile to be determined and also provided information over a larger portion of the Hanford shoreline where the highest contaminant concentrations would be expected. The Vernita Bridge and Richland transects and near-shore locations were sampled quarterly during 2004. Annual transect and near-shore sampling were conducted at the $100-\mathrm{N}$ and 100-F Areas, Hanford town site, and 300 Area locations in late summer when river flows were low, to provide the highest probability of detecting Hanford contaminants (PNL-8531). 
Columbia River transect water samples collected during 2004 were analyzed for both radiological and chemical contaminants (Table 8.4.1). Specific metals and anions were selected for analysis following reviews of existing surface-water and groundwater data, various remedial investigation/feasibility study work plans, and preliminary Hanford Site risk assessments (DOE/RL-92-67; PNL-8073; PNL-8654; PNL-10400; PNL-10535). All radiological and chemical analyses of transect samples were performed on grab samples of unfiltered water, except for metals analyses, which were performed on both filtered and unfiltered samples.

In addition to water quality monitoring conducted by the Pacific Northwest National Laboratory, water quality monitoring was performed by the U.S. Geological Survey for the Pacific Northwest National Laboratory. Samples were collected three times per year along Columbia River transects at the Vernita Bridge and Richland (Appendix C, Table C.6). Sample analyses were performed at the U.S. Geological Survey laboratory in Denver, Colorado, for numerous physical parameters and chemical constituents.

\subsubsection{Radiological Results for Columbia River Water Sample Analyses}

Fixed Location Samples. Results of the radiological analyses of Columbia River water samples collected at Priest Rapids Dam and Richland, Washington, during 2004 are reported in PNNL-15222, APP. 1 and summarized in Appendix C (Tables C.1 and C.2). These tables also list the maximum and average concentrations of selected radionuclides detected in Columbia River water in 2004 and for the previous 5 years. All individual radiological contaminant concentrations measured in Columbia River water during 2004 were less than 1/25 of DOE derived concentration guides (DOE Order 5400.5, Appendix D, Table D.5.) (i.e., DOE derived concentration guides are based on a $100 \mathrm{mrem}$ [1 mSv] per year standard; dividing by 25 allows for more direct comparison of the $4 \mathrm{mrem}$ [0.04 mSv] per year standard used for drinking water), and Washington State ambient surface-water quality criteria (WAC 173-201A and 40 CFR 141; Appendix D, Tables D.2, D.3, and D.5). Significant results are discussed in the following paragraphs, and comparisons to previous years are provided.
Radionuclide concentrations monitored in Columbia River water were low throughout the year. During 2004, tritium, strontium-90, iodine-129, uranium-234, uranium-238, plutonium-239/240, and naturally occurring beryllium -7 and potassium- 40 were consistently measured in river water at levels greater than their reported minimum detectable concentrations. The concentrations of all other radionuclides were typically below the minimum detectable concentrations. Tritium, strontium-90, iodine-129, and plutonium-239/240 exist in worldwide fallout from historical nuclear weapons testing as well as in effluent from Hanford Site facilities. Tritium and uranium occur naturally in the environment, in addition to being present in Hanford Site effluent.

The 2004 average gross alpha and gross beta concentrations measured upstream and downstream of the Hanford Site were similar to those observed during recent years (Figures 8.4.3 and 8.4.4). Statistical comparisons for gross alpha and gross beta concentrations at Priest Rapids Dam and Richland were not performed because the majority of the concentrations were below the 1 and $3 \mathrm{pCi} / \mathrm{L}(0.037$ and $0.11 \mathrm{~Bq} / \mathrm{L}$ ) minimum detectable concentrations, respectively. The average gross alpha and gross beta concentrations in Columbia River water at Richland during 2004 were less than the Washington State ambient surfacewater quality criteria of 15 and $50 \mathrm{pCi} / \mathrm{L}(0.56$ and $1.9 \mathrm{~Bq} / \mathrm{L})$.

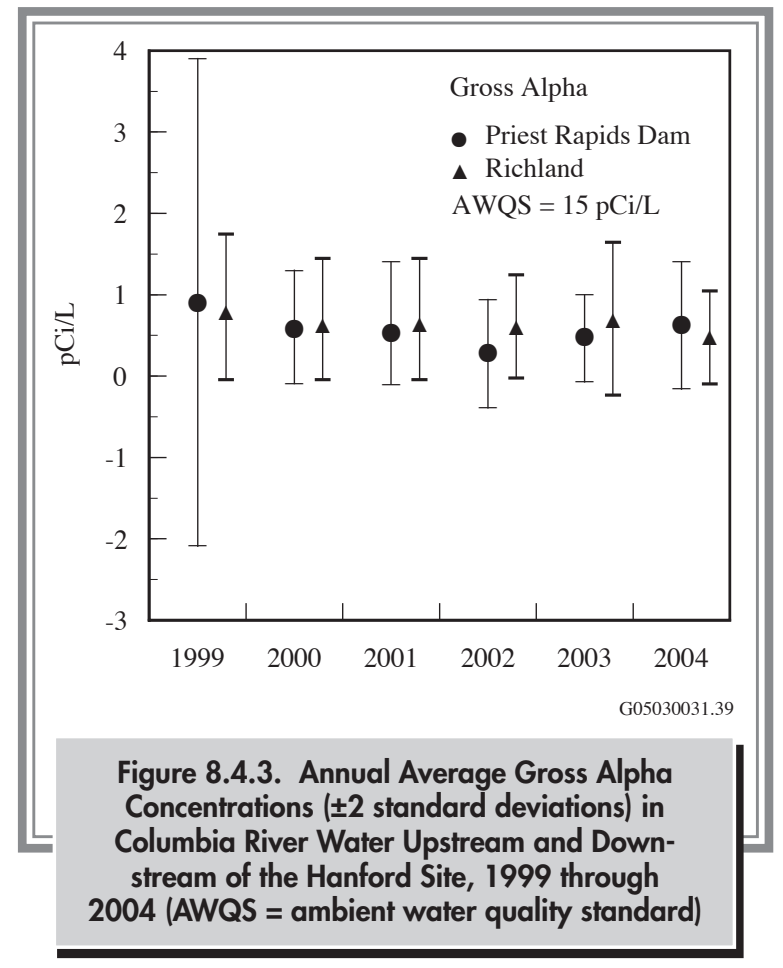




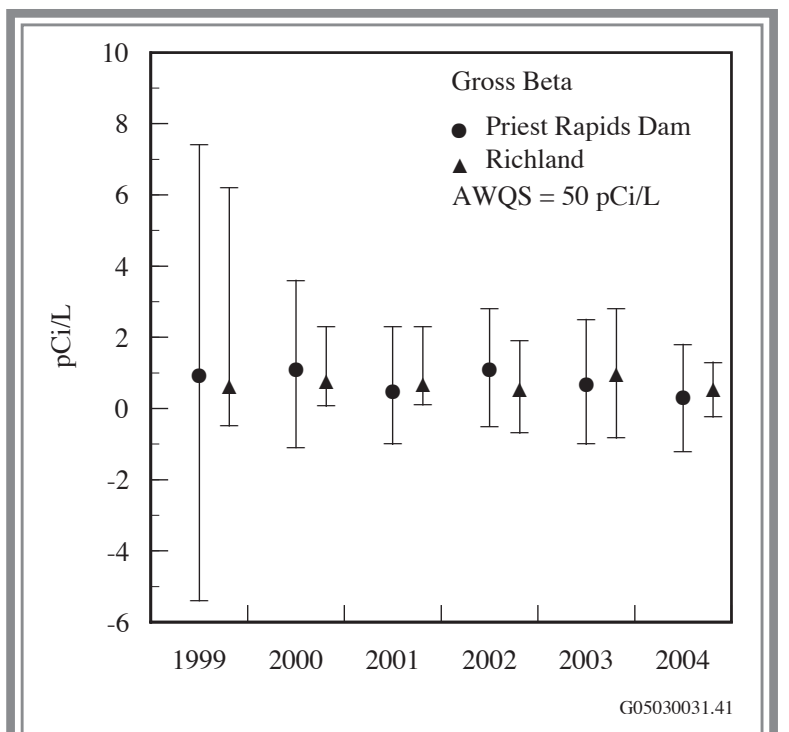

Figure 8.4.4. Annual Average Gross Beta Concentrations ( \pm 2 standard deviations) in Columbia River Water Upstream and Downstream of the Hanford Site, 1999 through 2004 (AWQS = ambient water quality standard)

The 2004 annual average tritium concentrations measured upstream and downstream of the Hanford Site were similar to concentrations measured in recent years. Statistical analyses indicated that monthly tritium concentrations in river water samples at Richland were higher than concentrations in samples from Priest Rapids Dam (Figure 8.4.5). However, 2004 average tritium concentrations in Columbia River water collected at Richland were only $0.24 \%$ of the Washington State ambient surface-water quality criterion of $20,000 \mathrm{pCi} / \mathrm{L}(740 \mathrm{~Bq} / \mathrm{L})$. Onsite sources of tritium entering the river included groundwater seepage and direct discharge from the $100-\mathrm{K}$ Area permitted outfall (Section 8.3). Tritium concentrations measured at Richland, while representative of river water used by the city of Richland for drinking water, tend to overestimate the average tritium concentrations across the river at this location (PNL-8531). This bias is attributable to the contaminated 200 Areas' groundwater plume entering the river along the portion of shoreline extending from the Hanford town site to below the 300 Area, which is relatively close to the Richland sample intake. This plume is not completely mixed within the river at Richland. Sampling along cross-river transects at Richland during 2004 confirmed the existence of a concentration gradient in the river under certain flow conditions and is discussed subsequently in this section. The extent to which samples

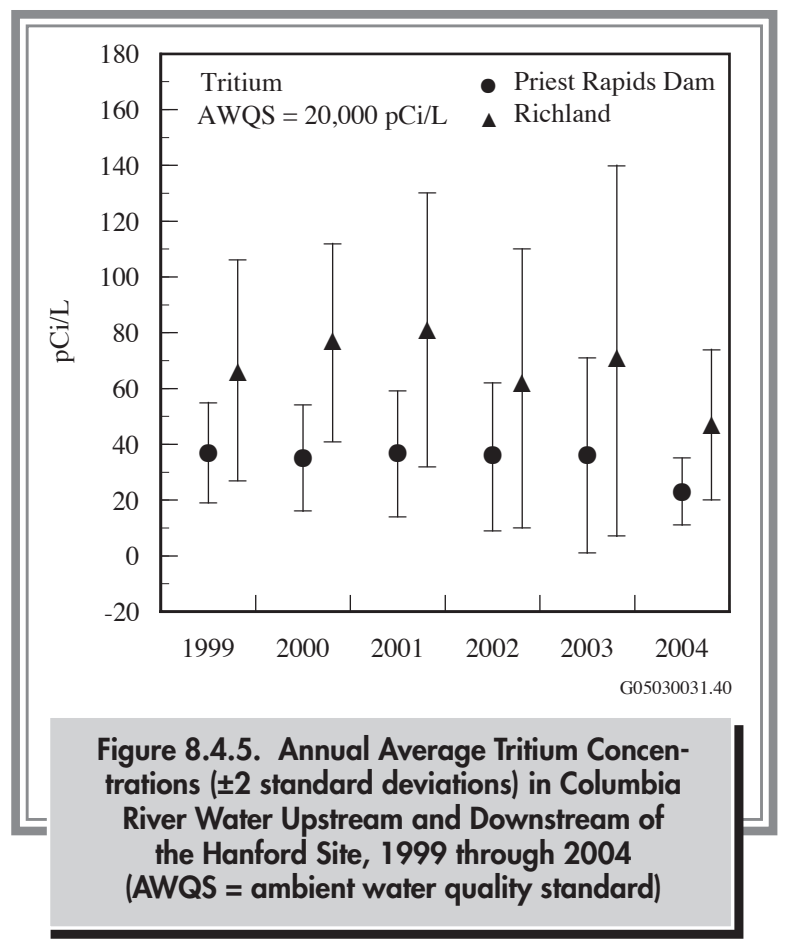

taken at Richland overestimate the average tritium concentrations in the Columbia River at this location is variable and appears to be related to the flow rate of the river just before and during sample collection.

Strontium-90 levels measured in Columbia River water collected upstream and downstream of the Hanford Site during 2004 were similar to those reported previously (Figure 8.4.6). Groundwater plumes containing strontium-90 enter the Columbia River throughout the 100 Areas. Some of the highest strontium-90 levels that have been found in onsite groundwater are the result of past discharges to the 100-N Area liquid waste disposal facilities. Despite the Hanford Site source, there was no statistical difference between monthly strontium-90 concentrations at Priest Rapids Dam and Richland. Average strontium-90 concentrations in Columbia River water at Richland were less than $0.86 \%$ of the Washington State ambient surfacewater quality criterion $(8 \mathrm{pCi} / \mathrm{L}[0.30 \mathrm{~Bq} / \mathrm{L}])$.

Annual average total uranium concentrations (i.e., the sum of uranium-234, uranium-235, and uranium-238) observed in water samples collected upstream and downstream of the Hanford Site during 2004 were similar to those observed during recent years (Figure 8.4.7). Monthly total uranium concentrations measured at Richland during 2004 were statistically higher (for a one-tailed paired t-test) than 


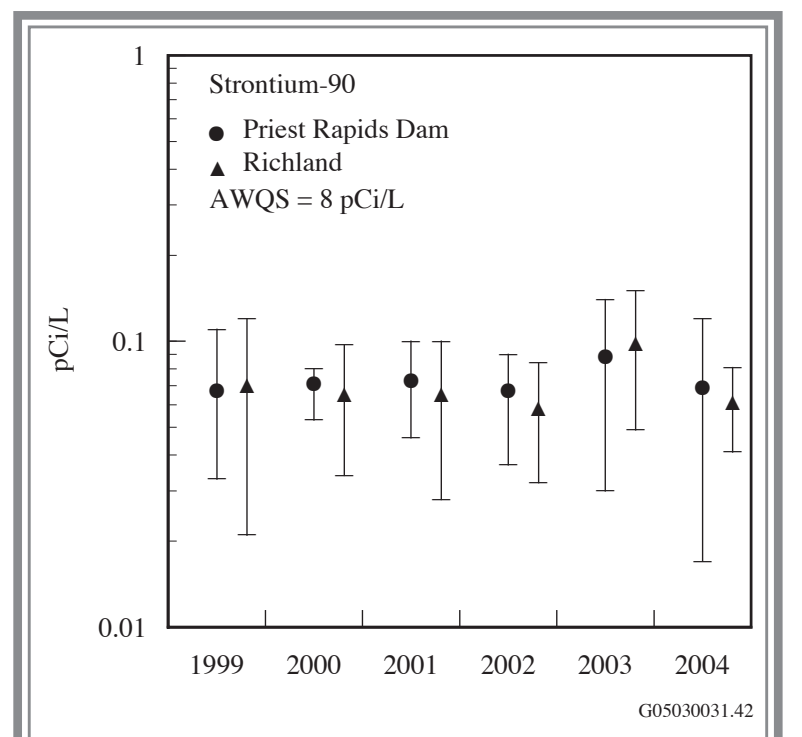

Figure 8.4.6. Annual Average Strontium-90 Concentrations ( \pm 2 standard deviations) in Columbia River Water Upstream and Downstream of the Hanford Site, 1999 through 2004 (AWQS = ambient water quality standard)

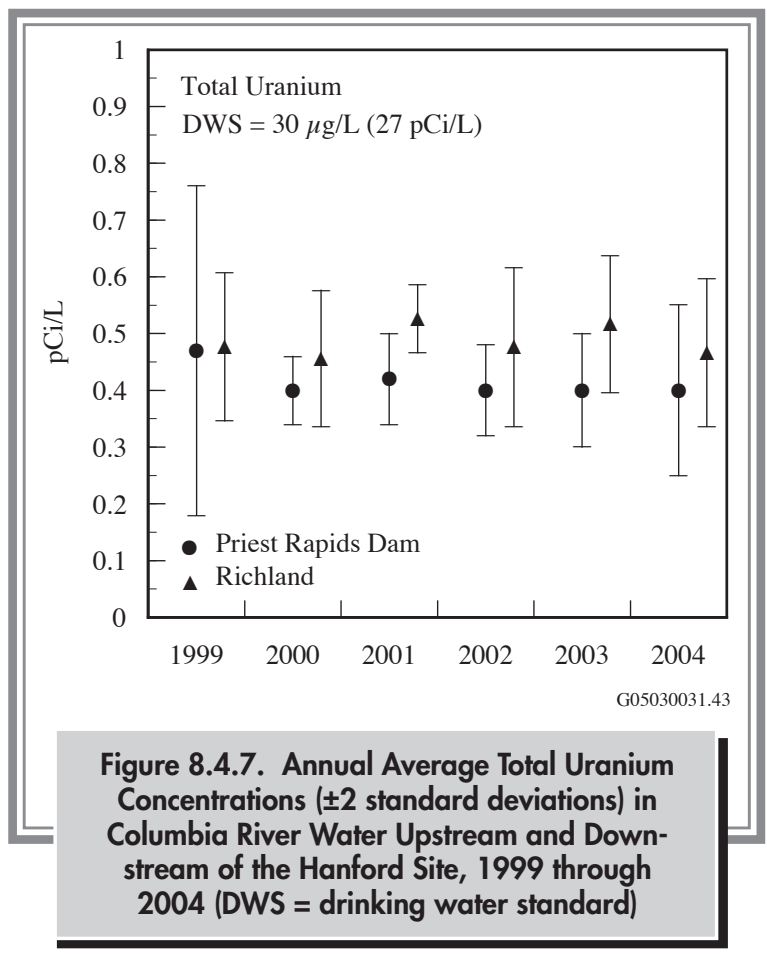

those measured at Priest Rapids Dam. Although there is no direct process discharge of uranium to the river, uranium is present in the groundwater beneath the 300 Area as a result of past Hanford operations. Groundwater contaminants have been detected at elevated levels in riverbank springs at the 300 Area in the past (Section 8.5; PNNL13692). Uranium is also known to enter the river across from the Hanford Site via irrigation return water and groundwater seepage associated with extensive irrigation north and east of the Columbia River (PNL-7500). There are no Washington State ambient surface-water quality criteria directly applicable to uranium. However, total uranium levels in the river during 2004 were well below the EPA drinking water standard of $30 \mu \mathrm{g} / \mathrm{L}$ (approximately 27 pCi/L [1.0 Bq/L], Appendix D, Table D.2).

The average iodine-129 concentration in Columbia River water measured downstream of the Hanford Site at Richland was extremely low during 2004 (0.007\% of the Washington State ambient surface-water quality criterion of $1 \mathrm{pCi} / \mathrm{L}[0.037 \mathrm{~Bq} / \mathrm{L}])$ and similar to levels observed during recent years (Figure 8.4.8). The onsite source of iodine-129 to the Columbia River is the discharge of contaminated groundwater along the portion of shoreline downstream of the Hanford town site. The iodine-129 plume originated in the 200 Areas from past waste disposal practices. Quarterly iodine-129 concentrations in Columbia River water at Richland were statistically higher than those at Priest Rapids Dam indicating a Hanford source of iodine-129. In general, the iodine-129 values at Priest Rapids Dam are largely unaffected by river stage; however, the concentrations measured for river

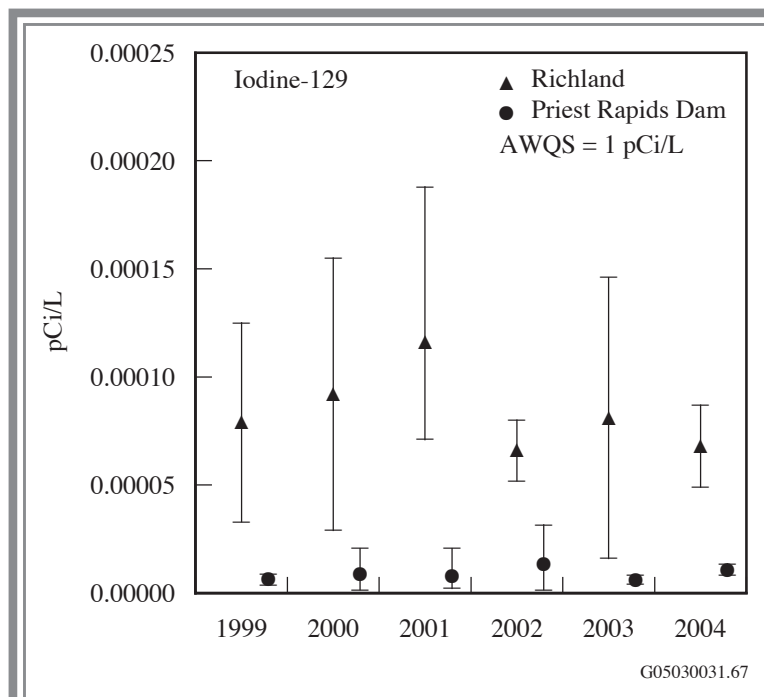

Figure 8.4.8. Annual Average lodine-129 Concentrations ( \pm 2 standard deviations) in Columbia River Water Upstream and Downstream of the Hanford Site, 1999 through 2004 (AWQS = ambient water quality standard) 
water at Richland are inversely proportional to river stage (i.e., during lower flow, the concentrations of iodine-129 are higher and vise versa). The influence of river stage on concentrations of iodine-129 at Richland is reflected in the larger standard deviation, compared to the samples from Priest Rapids Dam, for the annual averages shown in Figure 8.4.8.

Plutonium-239/240 concentrations for filtered river water samples at Richland were extremely low during 2004. All plutonium concentrations for both particle and dissolved fractions were reported as undetected by the analytical laboratory, except in one particle fraction sample from Richland $(0.000012 \pm 0.000010 \mathrm{pCi} / \mathrm{L}[0.00000044 \pm$ $0.00000037 \mathrm{~Bq} / \mathrm{L}]$ ). The average minimum detectable concentrations were $0.00002 \mathrm{pCi} / \mathrm{L}(0.00000074 \mathrm{~Bq} / \mathrm{L})$ for the particle fraction and $0.00006 \mathrm{pCi} / \mathrm{L}(0.0000022 \mathrm{~Bq} / \mathrm{L})$ for the dissolved fraction. All concentrations and detection limits were well below the DOE derived concentration guide of $30 \mathrm{pCi} / \mathrm{L}(1.1 \mathrm{~Bq} / \mathrm{L}$ ) (Appendix D, Table D.5). No Washington State ambient surface-water quality criterion exists for plutonium-239/240. Statistical comparisons for dissolved plutonium concentrations at Priest Rapids Dam and Richland were not performed because most of the concentrations were below the reported minimum detectable concentrations.

Columbia River Transect and Near-Shore Samples. Radiological results from samples collected along Columbia River transects and at near-shore locations near the Vernita Bridge, 100-N and 100-F Areas, Hanford town site, 300 Area, and Richland during 2004 are presented in Appendix C (Tables C.3 and C.4) and PNNL-15222, APP. 1. Sampling locations were documented using a global positioning system. Radionuclides consistently measured at concentrations greater than the minimum detectable activity included tritium, strontium-90, uranium-234, and uranium-238. All measured concentrations of these radionuclides were less than applicable Washington State ambient surface-water quality criteria.

Tritium concentrations measured along Columbia River transects during September 2004 are depicted in Figure 8.4.9. The results are displayed such that the observer's

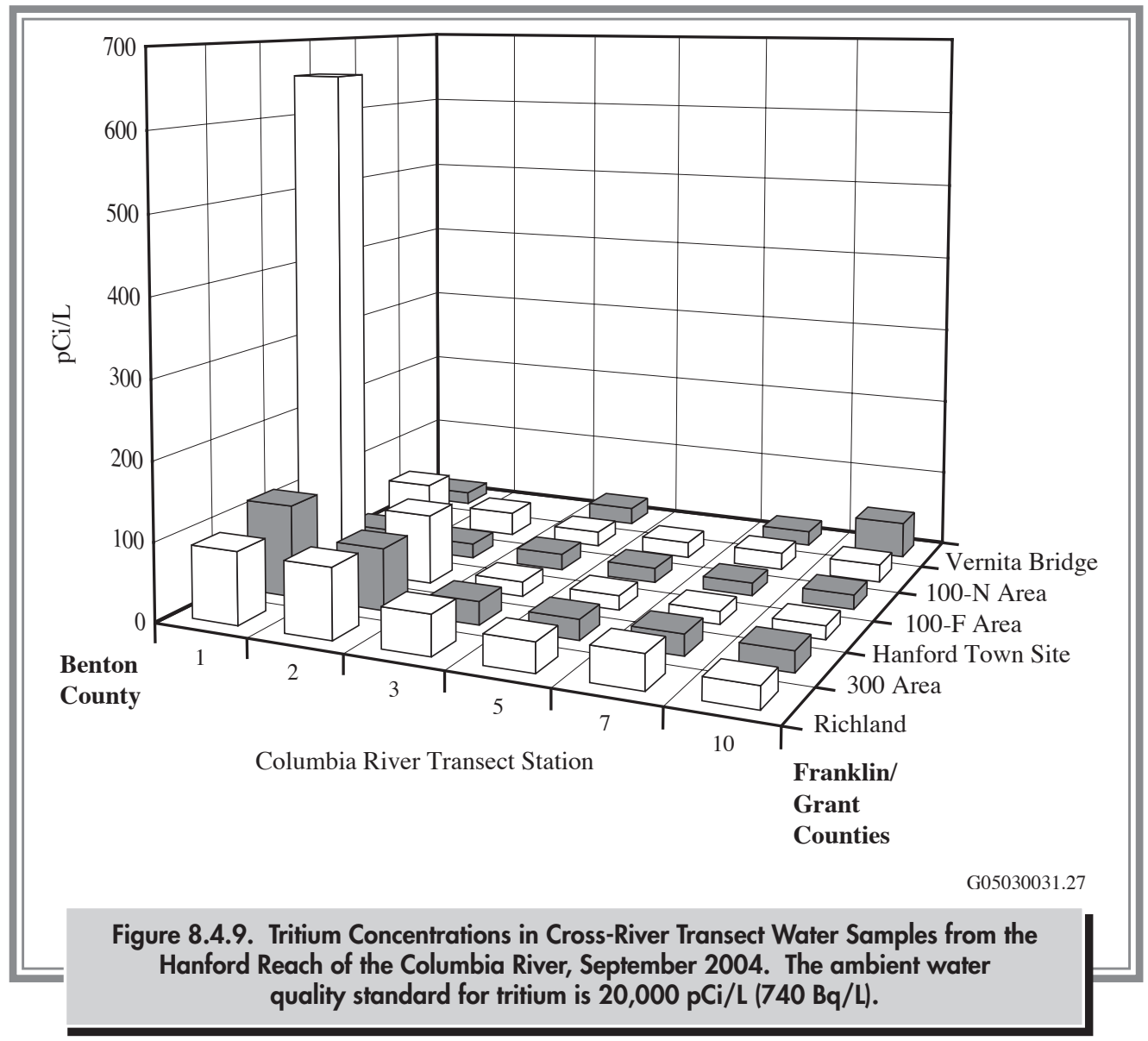


view is upstream from Richland. The transect of the Vernita Bridge is the most upstream transect. Stations 1 and 10 are located along the Benton County and Grant/ Franklin Counties shorelines, respectively. The 100-N Area, Hanford town site, 300 Area, and Richland transects have higher tritium concentrations near the Hanford (Benton County) shore relative to the opposite shore. The presence of a tritium concentration gradient in the Columbia River at Richland supports previous studies showing that contaminants in the 200 Areas' groundwater plume entering the river at, and upstream of, the 300 Area are not completely mixed at Richland (HW-73672; PNL-8531). The gradient is most pronounced during periods of relatively low river flow. Since transect sampling began during 1987, the average tritium concentration measured along the Richland transect has been less than that measured in monthly composited samples from the fixed-location monitoring station in Richland, illustrating the conservative bias (i.e., overestimate) of the fixedlocation monitoring station. For samples collected in 2004, the highest tritium concentration measured in crossriver transect water was $660 \pm 56 \mathrm{pCi} / \mathrm{L}(24 \pm 2.1 \mathrm{~Bq} / \mathrm{L})$ (Appendix C, Table C.3), which was detected along the shoreline of the Hanford town site. This is a location where groundwater containing tritium at concentrations greater than the Washington State ambient surface-water quality criterion $(20,000 \mathrm{pCi} / \mathrm{L}[740 \mathrm{~Bq} / \mathrm{L}])$ is known to discharge to the river (Section 8.7, Figure 8.7.4).

Tritium concentrations for near-shore water samples collected at the Hanford (Benton County) shoreline (typically less than 5 meters [16 feet] from shore) during September 2004 are shown in Figure 8.4.10. The nearshore sampling locations are identified according to Hanford river markers, which are a series of signpost markers, approximately 1.6 kilometers ( 1 mile) apart, that originate at the Vernita Bridge (Hanford river marker \#0) and end

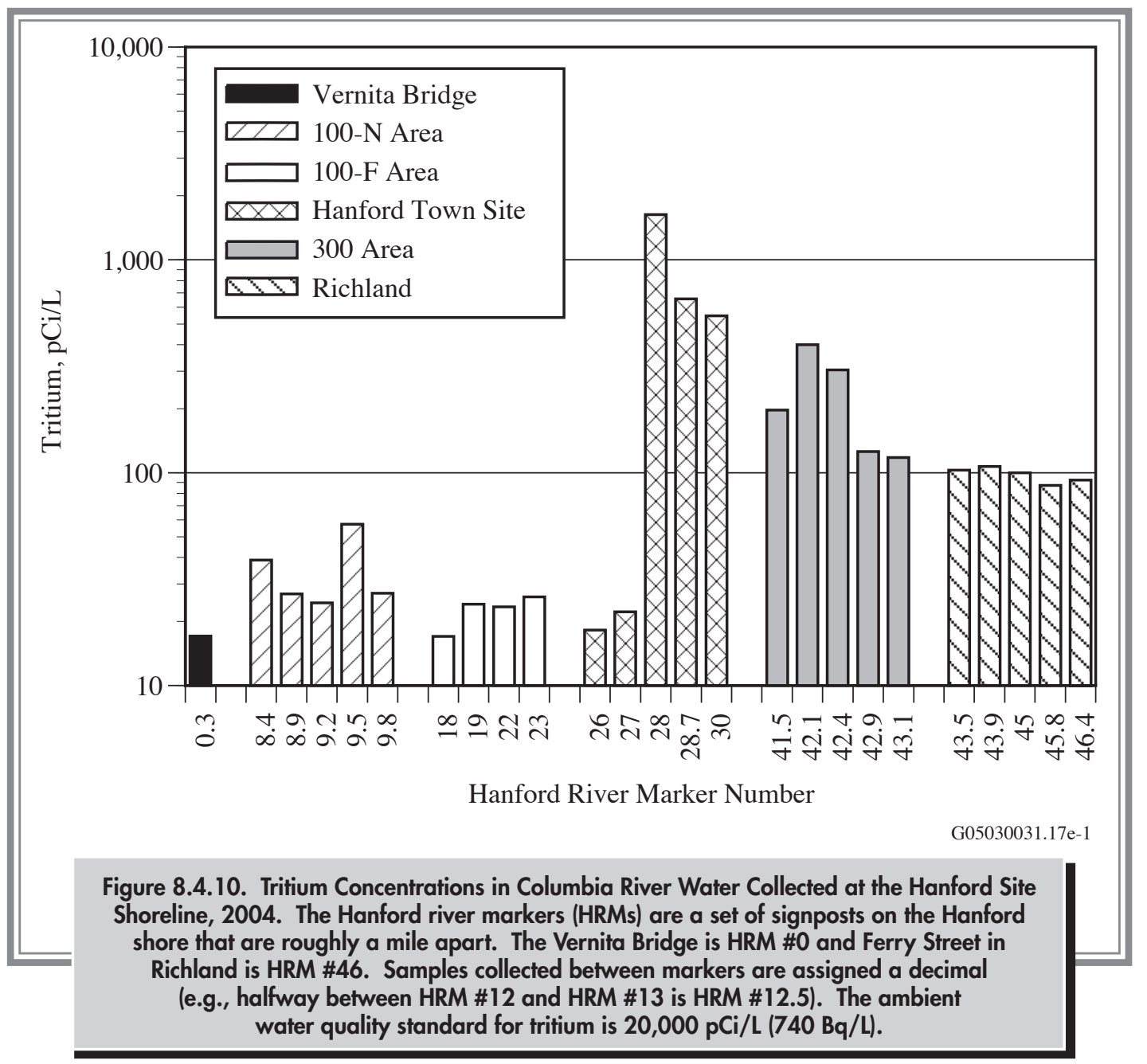


at Ferry Street in Richland (Hanford river marker \#46). The concentrations of tritium in near-shore water samples collected at the 100-N Area, Hanford town site, 300 Area, and Richland were elevated compared to concentrations in samples collected near the Vernita Bridge. There was a wide range of tritium concentrations measured for the shoreline samples with the concentrations increasing near discharge points for the groundwater tritium plume (Section 8.7, Figure 8.7.4). During 2004, the highest tritium concentration observed in near-shore water samples was $1,600 \pm 140 \mathrm{pCi} / \mathrm{L}(59 \pm 5.2 \mathrm{~Bq} / \mathrm{L})$ (Appendix C, Table C.4), which was detected along the shoreline of the Hanford town site at Hanford river marker $\# 28$. This location is roughly 1 kilometer ( 0.6 mile $)$ upriver from the cross-river transect sampling location where the maximum tritium level was $660 \pm 56 \mathrm{pCi} / \mathrm{L}$ $(24 \pm 2.1 \mathrm{~Bq} / \mathrm{L})$.

During 2004, strontium-90 concentrations in Hanford Reach river water for both transect and near-shore samples were similar to background concentrations for all locations, including the $100-\mathrm{N}$ Area where in previous years elevated strontium-90 concentrations were measured in some samples obtained at near-shore locations. The average strontium-90 concentration found during transect sampling at Richland was similar to those measured in monthly composite samples from Richland, indicating that strontium- 90 concentrations in water collected from the fixed-location monitoring station are representative of the average strontium-90 concentrations in the river at this location.

Total uranium concentrations in Hanford Reach water during 2004 were elevated along the Benton and Franklin County shorelines for the 300 Area transect. Total uranium concentrations were also elevated along the Franklin County shoreline for the Richland transect. The highest total uranium concentration was measured along the 300 Area transect in September near the Franklin County shoreline $(1.8 \pm 0.26 \mathrm{pCi} / \mathrm{L}[0.067 \pm 0.0096 \mathrm{~Bq} / \mathrm{L}])$ (Appendix C, Table C.3; PNNL-15222, APP. 1) and likely resulted from groundwater seepage and water from irrigation return canals on the Franklin County side of the river that contained naturally occurring uranium (PNL-7500).

\subsubsection{Chemical and Physical Water Quality Results for Columbia River Water Samples}

The Pacific Northwest National Laboratory and the U.S. Geological Survey (under contract to the Pacific Northwest National Laboratory) compiled chemical and physical water quality data for the Columbia River during 2004. A number of the parameters measured have no regulatory limits; however, they are useful as indicators of water quality and contaminants of Hanford origin. Potential sources of pollutants not associated with Hanford include irrigation return water and groundwater seepage associated with extensive irrigation north and east of the Columbia River (PNL-7500) and industrial, agricultural, and mining effluent introduced upstream from the Hanford Site.

Pacific Northwest National Laboratory Samples. Results of chemical sampling conducted by the Pacific Northwest National Laboratory along transect and nearshore locations of the Columbia River at the Vernita Bridge, 100-F and 100-N Areas, Hanford town site, 300 Area, and Richland are provided in PNNL-15222, APP. 1. The concentrations of metals and anions observed in river water during 2004 were similar to those observed in the past and remain below regulatory limits. Several metals and anions were detected in Columbia River transect samples both upstream and downstream of the Hanford Site. Arsenic, antimony, cadmium, copper, lead, mercury, nickel, and zinc were detected in the majority of samples, with similar levels at most locations. Beryllium, cadmium, chromium, lead, selenium, silver, and thallium were detected occasionally. Washington State ambient surface-water quality criteria for cadmium, copper, lead, nickel, silver, and zinc are total-hardness dependent (WAC 173-201A; Appendix D, Table D.3). Increased water hardness (i.e., primarily higher concentrations of calcium and magnesium ions) can reduce the toxicity of some metals by limiting their absorption into aquatic organisms. Criteria for Columbia River water were calculated using a total hardness of $47 \mathrm{mg} / \mathrm{L}$ as calcium carbonate, the lowest value based on U.S. Geological Survey monitoring of Columbia River water near the Vernita Bridge and Richland over the past years. The total hardness reported by the U.S. Geological Survey at those locations from 1992 through 2004 ranged from 47 to $77 \mathrm{mg} / \mathrm{L}$ as 
calcium carbonate. All metal and anion concentrations in river water were less than the Washington State ambient surface-water quality criteria for the protection of aquatic life (Appendix C, Table C.5 and Appendix D, Table D.3). Arsenic concentrations exceeded the EPA standard for the protection of human health for the consumption of water and organisms; however, this EPA value is approximately 10,500 times lower than the Washington State chronic toxicity value and similar concentrations were found at the Vernita Bridge and Richland (Appendix D, Table D.3).

For samples collected on the cross-river transects, concentrations of nitrate and sulfate measured near the Hanford shoreline transect samples were elevated at the 300 Area and the Hanford town site. Elevated nitrate concentrations at the Hanford town site shoreline are from the 200 Areas' contaminated groundwater plume, while elevated levels at the 300 Area appear (based on groundwater contaminant contours) to be from agricultural areas to the south. Nitrate concentrations for water samples from the Benton County shoreline near Richland were slightly higher compared to mid-river samples. Chloride, nitrate, and sulfate concentrations were elevated, compared to mid-river samples, along the Franklin County shoreline at Richland and 300 Area transects and likely resulted from groundwater seepage associated with extensive irrigation (the water for which is withdrawn from the Columbia River upstream of the Hanford Site) north and east of the Columbia River. Nitrate contamination of some Franklin County groundwater has been documented by the U.S. Geological Survey (1995) and is associated with high fertilizer and water usage in agricultural areas. Numerous wells in western Franklin County exceed the EPA maximum contaminant level for nitrate (40 CFR 141; U.S. Geological Survey Circular 1144). Average chloride, nitrate, and sulfate results were higher for quarterly concentrations at the Richland transect compared to the Vernita Bridge transect. The concentrations of volatile organic compounds in Columbia River water samples (e.g., chlorinated solvents, and benzene) were below the analytical laboratory's required detection limits for all samples, with no indication of a Hanford source.

U.S. Geological Survey Samples. Figure 8.4.11 illustrates U.S. Geological Survey Columbia River water quality data for samples collected at the Vernita Bridge and Richland for 1999 through 2004 (2004 results are preliminary). Preliminary results for 2004 are also tabulated in PNNL-15222, APP. 1 and summarized in Appendix C (Table C.6). These results are not considered final until they are published by the U.S. Geological Survey (e.g., WA-99-1). The 2004 U.S. Geological Survey results were comparable to those reported during the previous 5 years. Applicable standards for a Class A-designated surface-water body were met. During 2004, there was no indication of any deterioration of water quality resulting from site operations along the Hanford Reach of the Columbia River (Appendix D, Table D.1).

\subsubsection{Monitoring of Columbia River Sediment}

As a result of past operations at the Hanford Site, radioactive and non-radioactive materials were discharged to the Columbia River. Upon release to the Columbia River, some of these materials were deposited on the riverbed as sediment, particularly in upstream areas near downstream dams. The concentrations of the radioactive materials decreased as they underwent radioactive decay. Fluctuations in the river flow, as a result of the operation of upriver hydroelectric dams, annual spring high river flows, and occasional floods, have resulted in the resuspension, relocation, and subsequent redeposition of the sediment (DOE/RL-91-50). Upper layer sediment in the Columbia River contains low concentrations of radionuclides and metals of Hanford Site origin as well as radionuclides from nuclear weapons testing fallout and metals and other non-radioactive contaminants from mining and agricultural activities (Beasley et al. 1981; BNWL-2305; PNL-8148; PNL-10535; Cox et al. 2004). Periodic sediment sampling is necessary to confirm that concentrations remain low and to assure that no significant changes in concentrations have occurred. The accumulation of radioactive materials in sediment can lead to human exposure by ingestion of aquatic organisms associated with the sediment, sediment resuspension into drinking water supplies, or as an external radiation source irradiating people who are fishing, wading, sunbathing, or participating in other recreational activities associated with the river or shoreline (DOE/EH-0173T).

Since the shutdown of the last single-pass reactor at Hanford during 1971, the contaminant concentrations in Columbia River surface sediment have been decreasing 

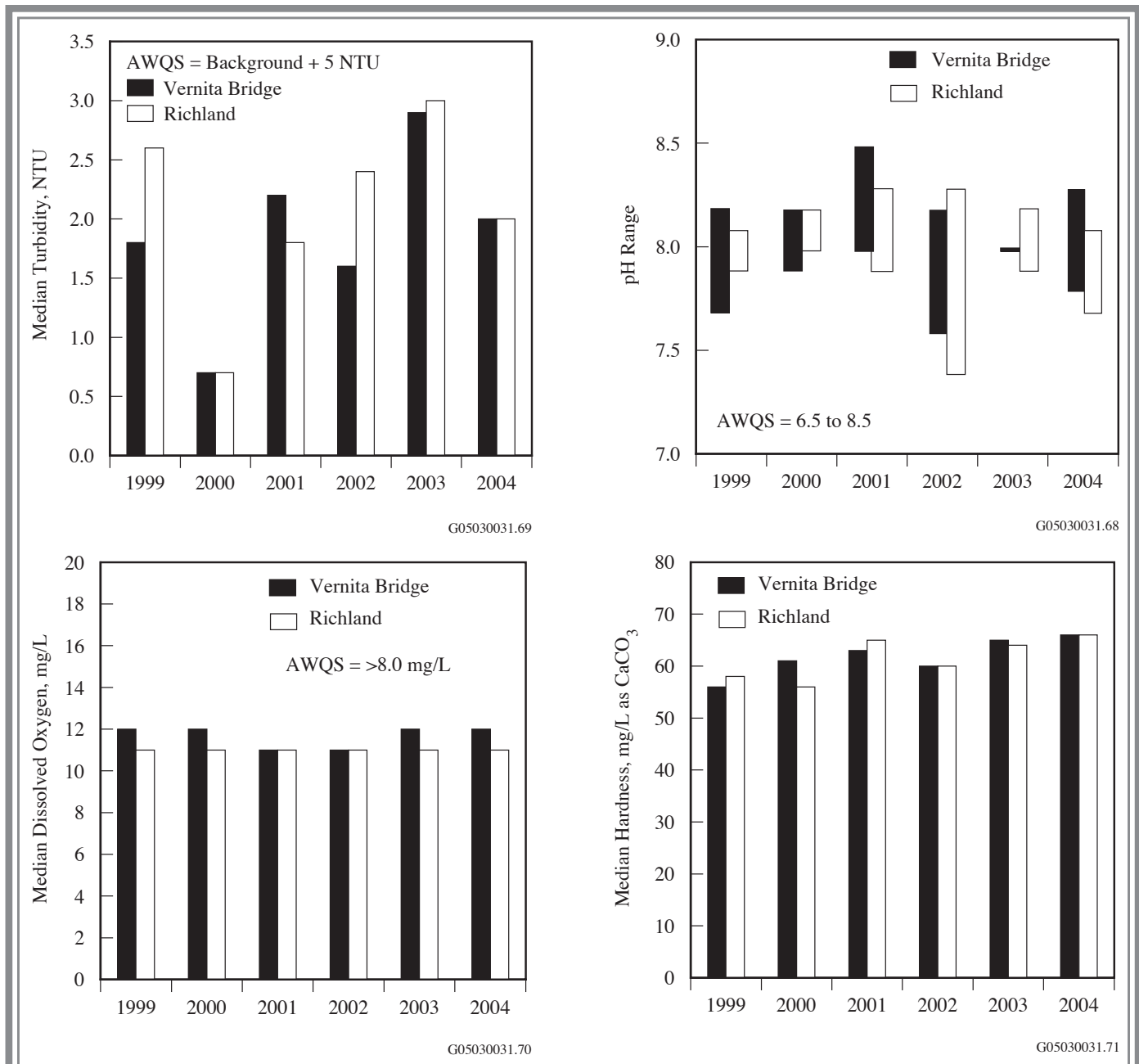

AWQS = Washington State Ambient Water Quality Standard; NTU = Nephelometric turbidity unit.

Figure 8.4.11. U.S. Geological Survey Water Quality Measurements for the Columbia River Upstream and Downstream of the Hanford Site, 1999 through 2004 (2004 results are preliminary)

as a result of radioactive decay and the deposition of uncontaminated material on top of the older sediment, which occurs in the reservoirs of the dams located downstream of Hanford (Cushing et al. 1981). However, discharges of some pollutants from the Hanford Site to the Columbia River still occur via permit-regulated liquid effluent discharges at the 100-K Area (Sections 5.4.1 and 8.3) and via contaminated groundwater seepage (Section 8.5).

Several studies have been conducted on the Columbia River to investigate the difference in sediment grain-size composition and total organic carbon content at routine monitoring sites (Beasley et al. 1981; PNL-10535; PNNL13417). Physical and chemical sediment characteristics were found to be highly variable among monitoring sites along the Columbia River. Samples containing the highest percentage of silts, clays, and total organic carbon were generally collected from reservoirs behind dams located upstream of the site and from White Bluffs Slough on the Hanford Reach.

In 2003 and 2004, the Oregon Department of Energy, Washington State Department of Health, Washington State Department of Ecology, DOE, and Pacific Northwest National Laboratory conducted a multi-agency cooperative study of the four reservoirs (McNary Dam, John Day Dam, The Dalles Dam, and Bonneville Dam) that are downriver from Hanford Site operations (DOH 320-034). Sediment samples and adjacent beach sediment (where 
available) were collected from each reservoir. Samples were analyzed for radionuclides, chemicals, and physical parameters. In 2003, sediment samples were collected in the reservoir upriver from McNary, John Day, The Dalles, and Bonneville Dams. Beach sediment sampling locations were limited to above McNary Dam and at the mouth of Eagle Creek on the Oregon side of the Bonneville Dam reservoir. In general, the river sediment samples were composed primarily of very fine sand, silt, and clay; the beach sediment was composed primarily of coarse and medium sand. At McNary Dam and The Dalles Dam, there was a trend for coarse-grained sediment on the Washington side of the Columbia River. Total organic content of the river sediment at most locations was above $10,000 \mathrm{mg} / \mathrm{kg}$ and the locations with the highest concentrations generally had finer grain sediment. Sediment samples collected in 2003 and analyzed for radionuclides had detectable levels of potassium-40, cobalt-60, strontium-90, cesium-137, europium-152, isotopic uranium, and isotopic plutonium (DOH 320-034). In general, the values were similar to previously reported concentrations at Priest Rapids Dam (Wells 1994; OHD 1994; PNNL-14687). In 2004, the study collected sediment samples at Priest Rapids Dam, McNary Dam, and John Day Dam on the Columbia River and at Ice Harbor Dam on the Snake River. Analytical results and reporting for sediment samples collected in 2004 have not been published at this time.

\subsubsection{Collection of Columbia River Sediment Samples and Analytes of Interest}

During 2004, samples of the surface layer of Columbia River sediment were collected at depths of 0 to 15 centimeters ( 0 to 6 inches) from six river locations that were permanently submerged (some Hanford Reach sampling locations may not be submerged during extremely low river stage) (Figure 8.4.1 and Table 8.4.2). Sampling locations were documented using a global positioning system.

Samples were collected upstream of Hanford Site facilities from the Priest Rapids Dam reservoir (the nearest upstream impoundment) to provide background data from an area unaffected by site operations. Samples were collected downstream of the Hanford Site above McNary Dam (the nearest downstream impoundment) to identify any increase in contaminant concentrations. Any increases in contaminant concentrations found in sediment above McNary Dam compared to that found above Priest Rapids Dam do not necessarily reflect a Hanford Site source. The confluences of the Columbia River with the Yakima, Snake, and Walla Walla Rivers lie between the Hanford Site and McNary Dam. Several towns, irrigation water returns, and factories in these drainages, as well as atmospheric fallout from weapons testing also may contribute to the contaminant load found in McNary Dam sediment. Thus, sediment samples are periodically taken in the reservoir above Ice Harbor Dam (the first dam on the Snake River upstream of the river mouth) to assess Snake River inputs. Sediment samples also were collected along the Hanford Reach of the Columbia River, from slackwater areas where fine-grained material is known to deposit (e.g., the White Bluffs, 100-F Area, and Hanford Sloughs), and from the publicly accessible Richland shoreline that lies within the influence of the McNary Dam impoundment.

Monitoring sites in the reservoirs behind McNary and Priest Rapids Dams consisted of two stations spaced approximately equidistant on a transect line crossing the Columbia River; the samples were collected near the boat-exclusion buoys immediately upstream of each dam. All other monitoring sites consisted of a single sampling location. Samples were collected using a clam-shell style sediment dredge. The sampling method is discussed in detail in DOE/RL-91-50. All sediment samples were analyzed for gamma-emitting radionuclides (Appendix F), strontium-90, uranium-234, uranium-235, uranium-238, and metals (DOE/RL-91-50). Selected samples were also analyzed for plutonium-238 and plutonium-239/240. The specific analytes selected for sediment samples were based on findings of previous Columbia River sediment investigations, reviews of past and present effluent contaminants discharged from site facilities, and reviews of contaminant concentrations observed in Hanford Site groundwater monitoring wells located near the river.

\subsubsection{Radiological Results for Columbia River Sediment Sample Analyses}

Radionuclides consistently detected in river sediment adjacent to and downstream of the Hanford Site during 
2004 included potassium-40, strontium-90, cesium-137, uranium-238, plutonium-238, and plutonium-239/240. The concentrations of all other radionuclides were below the reported minimum detectable concentrations for most samples (PNNL-15222, APP. 1). Cesium-137 and plutonium isotopes exist in worldwide fallout as well as in effluent from Hanford Site facilities. Potassium-40 and uranium occur naturally in the environment, and uranium is also present in Hanford Site effluent. No federal or state freshwater sediment criteria are available to assess the sediment quality of the Columbia River (EPA 822-R-96-001).
Radionuclide concentrations reported in river sediment during 2004 were similar to those reported for previous years (Appendix C, Table C.7), and there were no obvious differences between locations. The only unusual value for 2004 sediment samples was for cesium-137 at the White Bluffs Slough, which was roughly 3 times higher than values from the previous 5 years. Median, maximum, and minimum concentrations of selected radionuclides measured in Columbia River sediment (1999 through 2004) are presented in Figure 8.4.12.

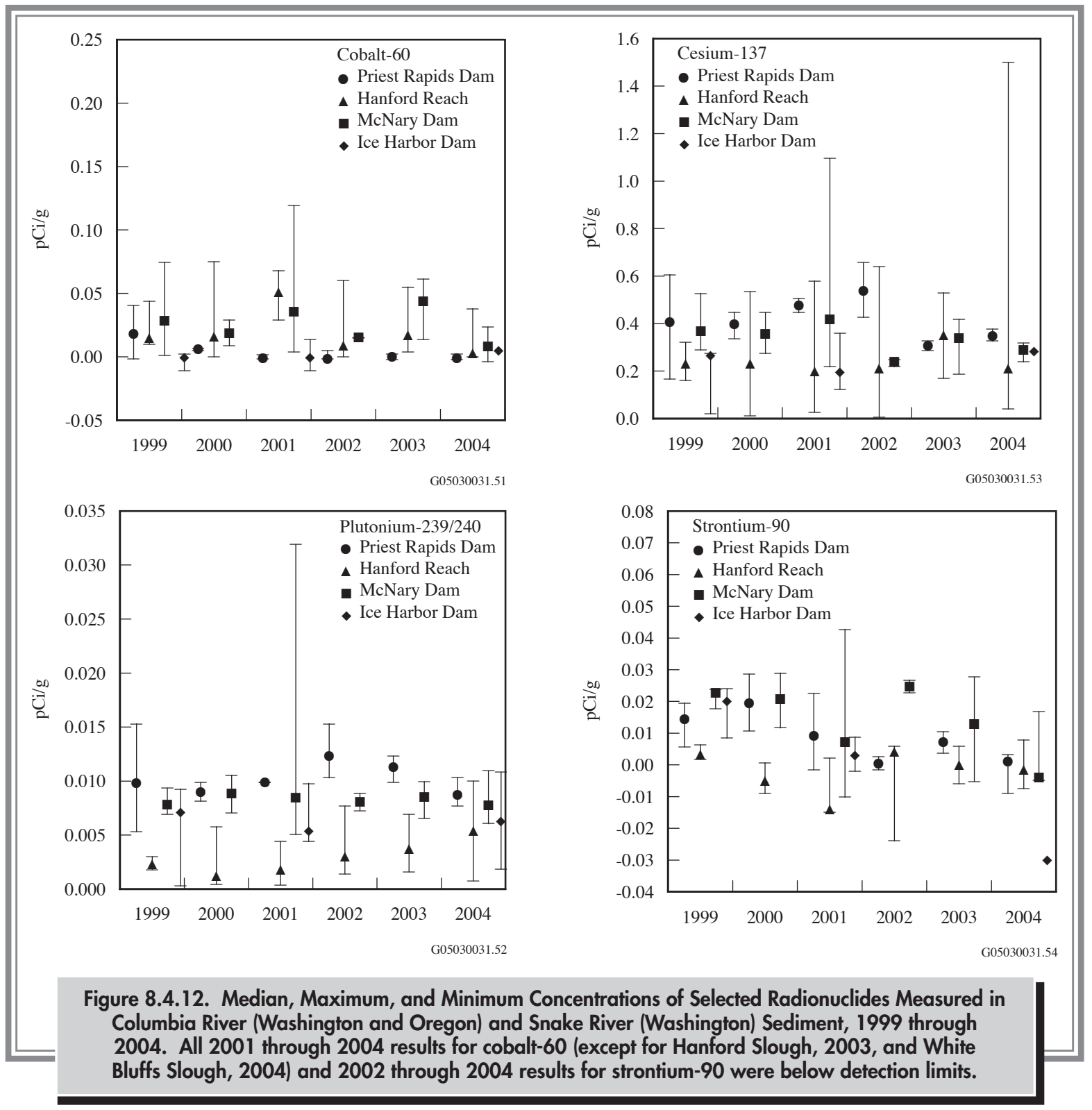




\subsubsection{Chemical Results for Columbia River Sediment Sample Analyses}

Detectable amounts of most metals were found in all river sediment samples (Figure 8.4.13; Appendix C, Table C.8; PNNL-15222, APP. 1). Maximum and median concentrations of most metals were higher for sediment collected in the reservoir upstream of Priest Rapids Dam compared to either Hanford Reach or McNary Dam sediment. The concentrations of cadmium, mercury, and zinc had the largest differences between locations. Currently, there are no Washington State freshwater sediment quality criteria for comparison to the measured values.

Since 1997 (no samples were collected in 2001), Columbia River sediment samples have been analyzed for simultaneously extracted metals/acid volatile sulfide (SEM/AVS). This analysis involves a cold-acid extraction of the sediment followed by analysis for acid volatile sulfide and metals. Acid volatile sulfide is an important binding phase for divalent metals (i.e., metals with a valance state of $2+$, such as $\mathrm{Pb}^{2+}$ ) in sediment. These metals readily bind to sulfides and form metal sulfide precipitates, which are typically very insoluble, and this limits the amount of dissolved metal available in the sediment porewater. The

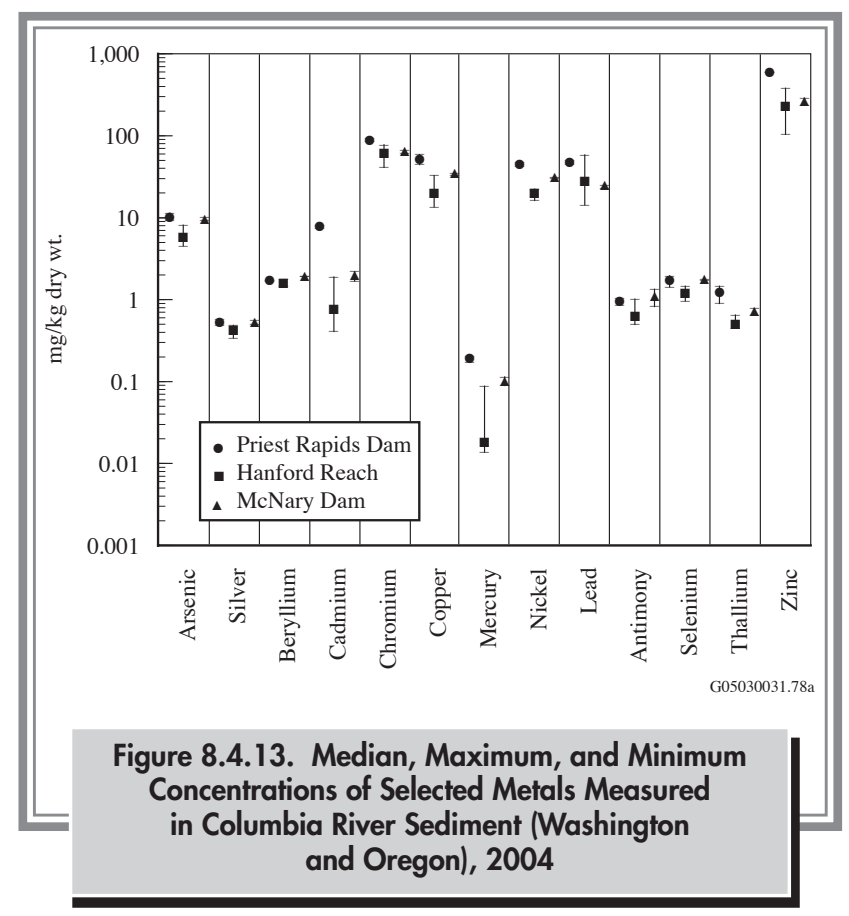

SEM/AVS ratios are an indicator of potential sediment toxicity (DeWitt et al. 1996; Hansen et al. 1996; PNNL13417). For an individual metal, when the amount of acid volatile sulfide exceeds the amount of the metal (i.e., the SEM/AVS molar ratio is below 1), the dissolved metal concentration in the sediment porewater will be low. For a suite of divalent metals, the sum of the simultaneously extracted metals must be considered, with the assumption that the metal with the lowest solubility will be the first to combine with the acid volatile sulfide.

The SEM/AVS results for the sediment collected during 2004 from the Priest Rapids Dam and McNary Dam reservoirs were similar to results from previous years (Figure 8.4.14). The average SEM/AVS results for the Hanford Reach sediment collected during 2004 were considerably lower than previous years and were likely influenced by the lower than normal Columbia River flows for 2004, which may have exposed portions of these sediment beds to air. The sediment deposition locations in the Hanford Reach are more subject to annual variations in sediment parameters that can influence SEM/AVS results (e.g., sediment deposition rate, scouring by floods, changes in total organic carbon concentrations, and potential exposure to air during dry periods) than the sediment deposition areas upstream of the dams. During 2004, the acid volatile sulfide values in sediment from the Priest Rapid Dam reservoir had concentrations ranging from 5.0 to $6.7 \mu \mathrm{mol} / \mathrm{g}$. Sediment from the McNary Dam reservoir had lower concentrations of acid volatile sulfide, with values ranging from 0.97 to $1.8 \mu \mathrm{mol} / \mathrm{g}$. SEM/AVS molar ratios for sediment from the Priest Rapids Dam reservoir, the Hanford Reach, and McNary Dam reservoir were above 1.0, indicating a potential for some dissolved metals to be present in the sediment porewater. For all locations, zinc was the primary metal present.

Overall results from 1997 through 2004 reveal that acid volatile sulfide concentrations in sediment from the Priest Rapids Dam reservoir are generally higher than concentrations in sediment from the Hanford Reach and the McNary Dam reservoir. An apportionment of acid volatile sulfide by divalent metals according to solubility values revealed that sufficient acid volatile sulfide should exist in all locations to limit the porewater concentrations of cadmium, copper, lead, and mercury. In Priest Rapids Dam sediment, average zinc values were of similar 


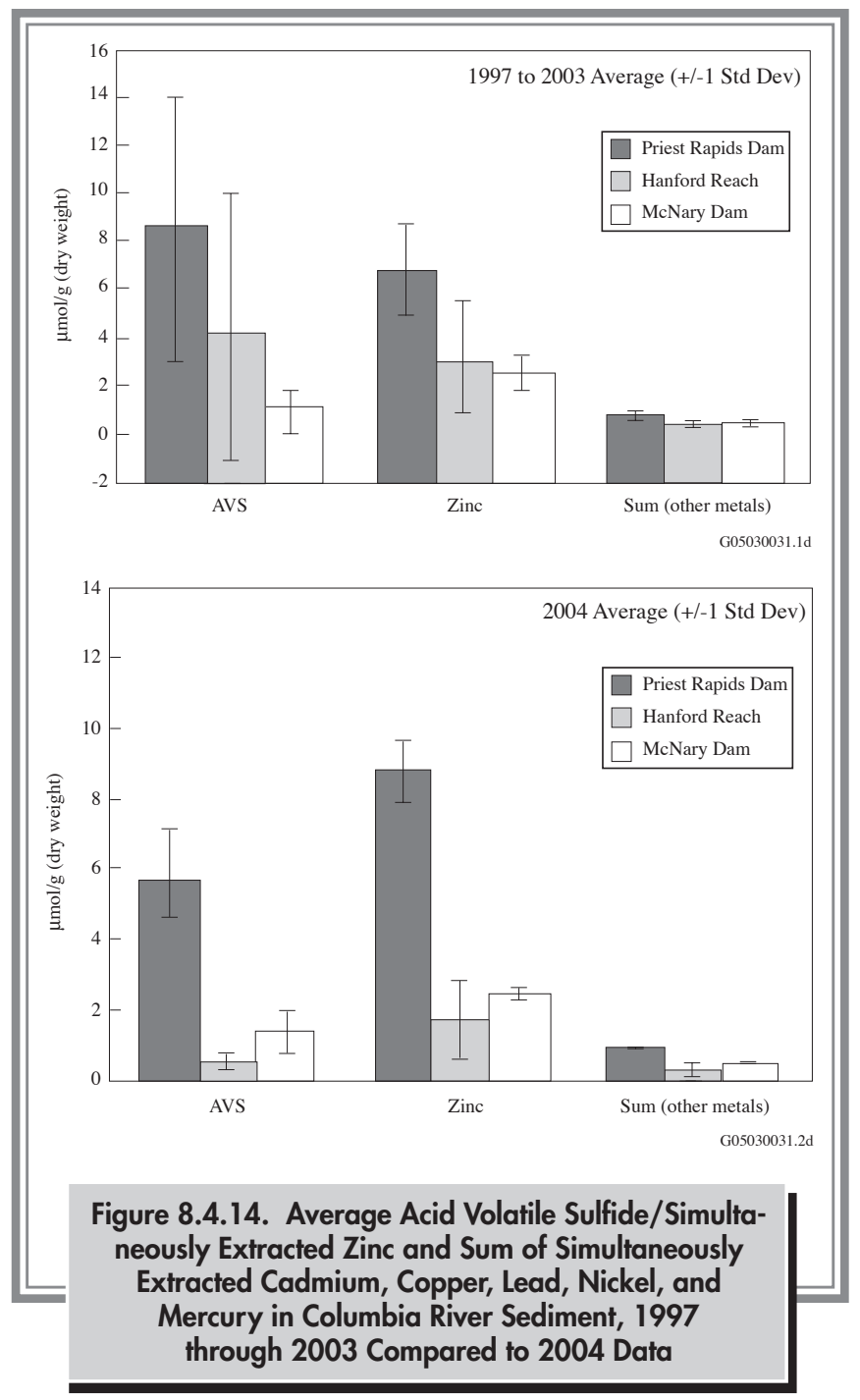

magnitude as the average acid volatile sulfide concentrations. In McNary Dam sediment, the average zinc concentrations were higher than the available mean acid volatile sulfide pool, indicating the potential for zinc and possibly other dissolved metals to be present in the sediment porewater.

\subsubsection{Monitoring of Onsite Pond Water and Sediment}

Two onsite ponds, West Lake and the Fast Flux Test Facility pond (Figure 8.4.1), located near facilities in various stages of remediation, were sampled periodically during 2004 . The ponds were inaccessible to the public and, therefore, did not constitute a direct offsite environmental impact during 2004. However, they were accessible to migratory waterfowl and deer, creating a potential biological pathway for the dispersion of contaminants (PNL-10174). The Fast Flux Test Facility pond is a disposal site for process water, primarily cooling water drawn from groundwater wells. West Lake, the only naturally occurring pond on the site, is located north of the 200-East Area (ARH-CD-775). West Lake has not received direct effluent discharges from Hanford Site facilities but it is influenced by changing water-table elevations that are related to the discharge of water to the ground in the 200 Areas. The water level in West Lake fluctuates and changes from standing water in winter and spring to nearly dry in summer and fall.

\subsubsection{Collection of Pond Water and Sediment Samples and Analytes of Interest}

During 2004, grab samples were collected quarterly from the Fast Flux Test Facility pond (water) and from West Lake (water and sediment). All water samples were analyzed for tritium. Water samples from the Fast Flux Test Facility pond were also analyzed for gross alpha and gross beta concentrations as well as gamma-emitting radionuclides. The groundwater table in the 200-East Area has dropped in recent years (Section 8.7) and this has decreased the size of West Lake and caused the suspended sediment loading to increase. Starting in 2002, it has not been practical for the analytical laboratory to process West Lake water samples for gross alpha, gross beta, strontium-90, technetium-99, uranium-234, uranium-235, and uranium-238 because of the high sediment load; thus, sediment samples were submitted for these analytes. Constituents were chosen for analysis based on their known presence in local groundwater and their potential to contribute to the overall radiation dose to biota that frequent the ponds.

\subsubsection{Radiological Results for Pond Water and Sediment Sample Analyses}

All radionuclide concentrations in onsite pond water samples were less than applicable DOE derived concentration guides (DOE Order 5400.5; Appendix D, Table D.5) and Washington State ambient surface-water quality criteria (WAC 173-201A; 40 CFR 141; PNNL-15222, APP. 1; Appendix D, Tables D.1 and D.2). 
Figure 8.4.15 shows the annual gross beta and tritium concentrations in Fast Flux Test Facility pond water from 1999 through 2004. Median levels of both constituents have remained stable in recent years. The median tritium concentration in Fast Flux Test Facility pond water during 2004 was 14\% of the Washington State ambient surfacewater quality criterion of $20,000 \mathrm{pCi} / \mathrm{L}(740 \mathrm{~Bq} / \mathrm{L})$. The sources of contaminants in the pond water are groundwater contaminant plumes from the 200 Areas that have migrated to wells near the Fast Flux Test Facility that supply water to facility operations.

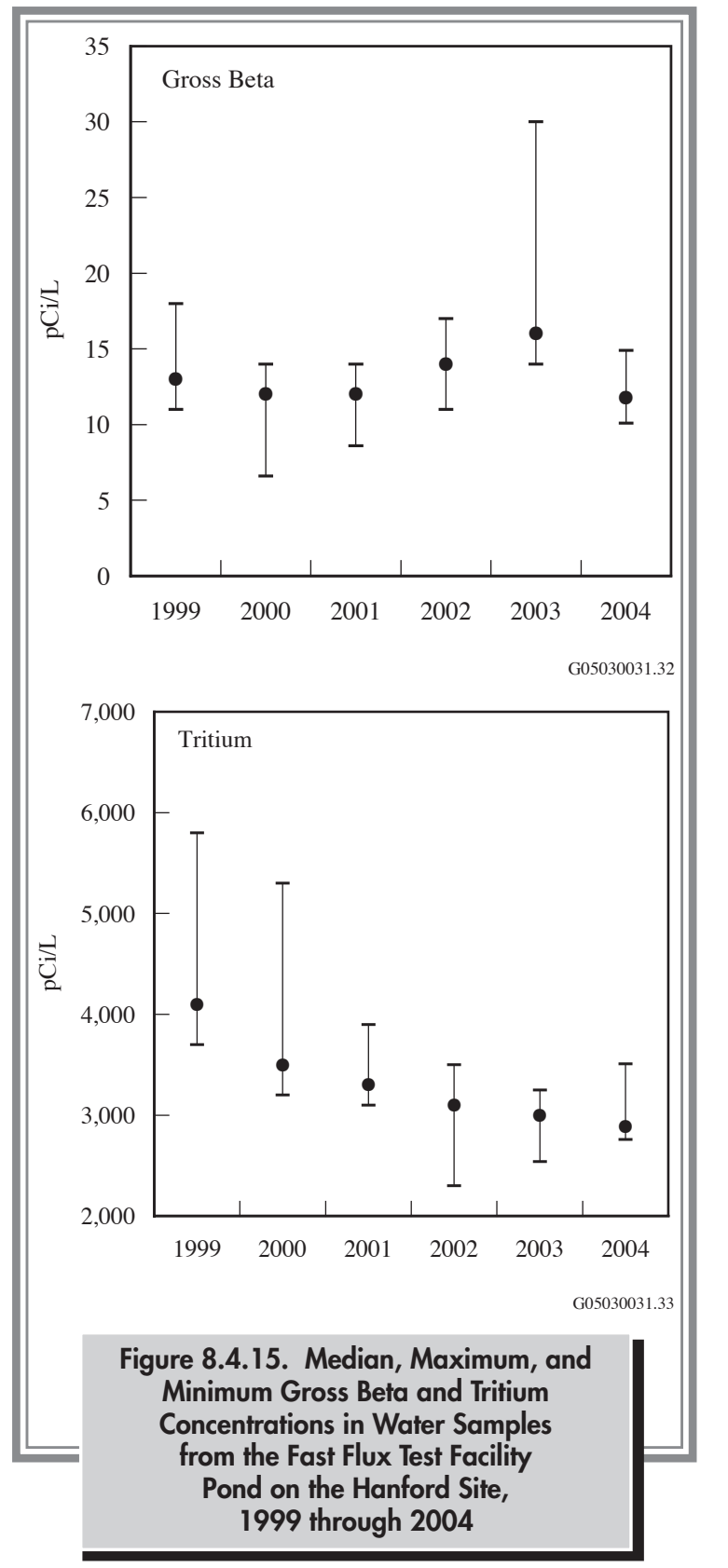

Tritium concentrations in West Lake water during 2004 were similar to those observed in the past (Figure 8.4.16). The median concentration of tritium in West Lake water in 2004 was $0.9 \%$ of the Washington State ambient surface-water quality criterion level $(20,000 \mathrm{pCi} / \mathrm{L}$ $[740 \mathrm{~Bq} / \mathrm{L}])$ and reflected groundwater concentrations in the area.

Samples of West Lake sediment in 2004 had the following range of detectable values:

- gross alpha - 3.3 to $12 \mathrm{pCi} / \mathrm{g}(0.12$ to $0.44 \mathrm{~Bq} / \mathrm{g}$ )

- gross beta - 22 to $26 \mathrm{pCi} / \mathrm{g}(0.81$ to $0.96 \mathrm{~Bq} / \mathrm{g}$ )

- potassium-40 - 14 to $21 \mathrm{pCi} / \mathrm{g}$ (0.52 to $0.78 \mathrm{~Bq} / \mathrm{g}$ )

- strontium-90 - 0.11 to $0.60 \mathrm{pCi} / \mathrm{g}$ (0.0041 to $0.022 \mathrm{~Bq} / \mathrm{g}$ )

- cesium-137 - 0.49 to $1.8 \mathrm{pCi} / \mathrm{g}$ (0.018 to $0.067 \mathrm{~Bq} / \mathrm{g}$ )

- uranium-234- 0.38 to $4.8 \mathrm{pCi} / \mathrm{g}$ (0.014 to $0.18 \mathrm{~Bq} / \mathrm{g}$ )

- uranium-235 - 0.011 to $0.17 \mathrm{pCi} / \mathrm{g}$ (0.00041 to $0.0063 \mathrm{~Bq} / \mathrm{g}$ )

- uranium-238 - 0.34 to $4.4 \mathrm{pCi} / \mathrm{g}(0.013$ to $0.16 \mathrm{~Bq} / \mathrm{g})$.

These levels of radionuclides are similar to previous measurements (PNL-7662). Uranium concentrations are believed to result from naturally occurring uranium in the surrounding soil (BNWL-1979).

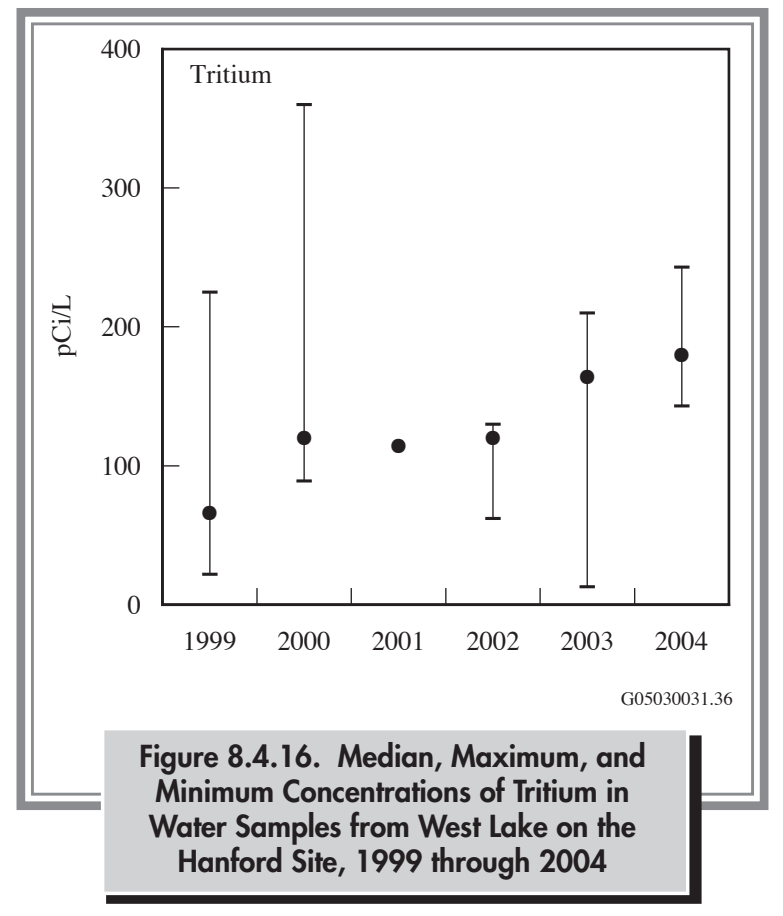




\subsubsection{Monitoring of Offsite Irrigation Water}

During 2004, water samples were collected from an irrigation canal located across the Columbia River and downstream from the Hanford Site at Riverview and from an irrigation water supply on the Benton County shoreline near the southern boundary of the Hanford Site (Horn Rapids irrigation pumping station) (Figure 8.4.1). As a result of public concerns about the potential for Hanfordassociated contaminants in offsite water, sampling was conducted to document the levels of radionuclides in water used by the public. Consumption of vegetation irrigated with Columbia River water downstream of the site has been identified as one of the primary pathways contributing to the potential dose to the hypothetical maximally exposed individual and any other member of the public (Section 8.14).

\section{Collection, Analysis, and Results for Offsite Irrigation Water Samples}

Water from the Riverview irrigation canal and the Horn Rapids irrigation pumping station was sampled three times during the 2004 irrigation season. Unfiltered samples were analyzed for gross alpha, gross beta, gamma emitters, tritium, strontium-90, uranium-234, uranium-235, and uranium-238. During 2004, radionuclide concentrations measured in irrigation water were at the same levels detected in the Columbia River (PNNL-15222, APP. 1). All radionuclide concentrations were below their respective DOE derived concentration guides and Washington State ambient surface-water quality criteria (DOE Order 5400.5; WAC 173-201A; 40 CFR 141). 


\subsection{Columbia River Shoreline Springs Monitoring}

Samples of shoreline spring water and associated sediment were collected along the Hanford Reach and analyzed to determine the potential impact of radiological and chemical contaminants from Hanford on the public and the aquatic environment. In addition, at the 100-N Area, water samples were collected from a set of shoreline seep wells to verify reported radionuclide releases for $100-\mathrm{N}$ Area seeps. Sections 8.5.1 and 8.5.2 discuss the results for Columbia River shoreline spring water and sediment samples and Section 8.5.3 discusses the results from the shoreline seep-well water samples at the 100-N Area.

\subsubsection{Water Monitoring at Columbia River Shoreline Springs}

\section{G. W. Patton}

The Columbia River is the discharge area for the unconfined aquifer underlying the Hanford Site. Groundwater provides a means for transporting Hanford-associated contaminants, which have leached into groundwater from past waste disposal practices, to the Columbia River (DOE/RL-92-12; PNL-5289; PNL-7500; WHC-SD-ENTI-006). Contaminated groundwater enters the Columbia River via surface and subsurface discharge. Discharge zones located above the water level of the river are identified in this report as shoreline springs. Routine monitoring of shoreline springs offers the opportunity to characterize the quality of groundwater being discharged to the river and to assess the potential human and ecological risk associated with the spring water. In addition, contaminants in groundwater near the Columbia River are monitored using shoreline groundwater-sampling tubes (aquifer tubes) (Section 8.7; PNNL-14444).
Shoreline springs were documented along the Hanford Reach long before Hanford Site operations began during World War II (Jenkins 1922). During the early 1980s, researchers walked a 66-kilometer (41-mile) stretch of the Benton County shoreline of the Hanford Reach and identified 115 springs (PNL-5289). They reported that the predominant areas of groundwater discharge at that time were in the vicinity of the 100-N Area, Hanford town site, and 300 Area. The predominance of the 100-N Area may no longer be valid because of declining water-table elevations in response to the cessation of liquid waste discharges to the ground from Hanford Site operations and the pumpand-treat systems that are being used to decontaminate groundwater at the 100-N Area. In recent years, it has become increasingly difficult to locate shoreline springs in the $100-\mathrm{N}$ Area.

The presence of shoreline springs also varies with river stage (river-level height). Groundwater levels in the Hanford Reach are heavily influenced by river stage fluctuations. Water levels in the Hanford Reach of the Columbia River are controlled by upriver conditions and operations at upriver dams. As water levels fluctuate, groundwater levels and, thus, the presence of shoreline springs in the Hanford Reach vary. In addition, for the 300 Area, the water levels are influenced by the height of the McNary Dam pool. Water flows into the Hanford Site aquifer (as bank storage) as the river stage rises and then discharges from the aquifer in the form of shoreline springs as the river stage falls. Following an extended period of low river flow, groundwater discharge zones located above the water level of the river may cease to exist once the level of the aquifer comes into equilibrium with the level of the river. Thus, springs are most readily identified immediately following a decline in river stage. Bank storage of river water also affects the contaminant concentration of the springs. Spring water discharged immediately following a river stage decline generally consists of river water or a 
mixture of river water and groundwater. The percentage of groundwater in the spring water discharge increases over time following a drop in river stage. Measuring the specific conductivity of the spring water discharge provides an indicator of the extent of bank storage because Hanford Site groundwater has a higher specific conductivity than Columbia River water.

Because of the effect of bank storage on groundwater discharges and contaminant concentrations, as well as variations in aquifer thickness, porosity, and plume concentrations, it is difficult to accurately estimate the volume of contaminated groundwater discharging to the Columbia River within the Hanford Reach. Studies of shoreline springs conducted during 1983 (PNL-5289) and 1988 (PNL-7500) and results of near-shore studies
(PNNL-11933; PNNL-13692) noted that discharges from the springs had only localized effects on river contaminant concentrations.

\subsubsection{Collection of Water Samples from Columbia River Shoreline Springs and Analytes of Interest}

Routine monitoring of selected shoreline springs was initiated during 1988. Currently, shoreline spring water samples are collected for contaminant monitoring and to support groundwater operable unit investigations (DOE/RL-91-50). Tables 8.5.1 and 8.5.2 and Figure 8.4.1 summarize the sampling locations, types, frequencies, and analyses included in shoreline springs monitoring during

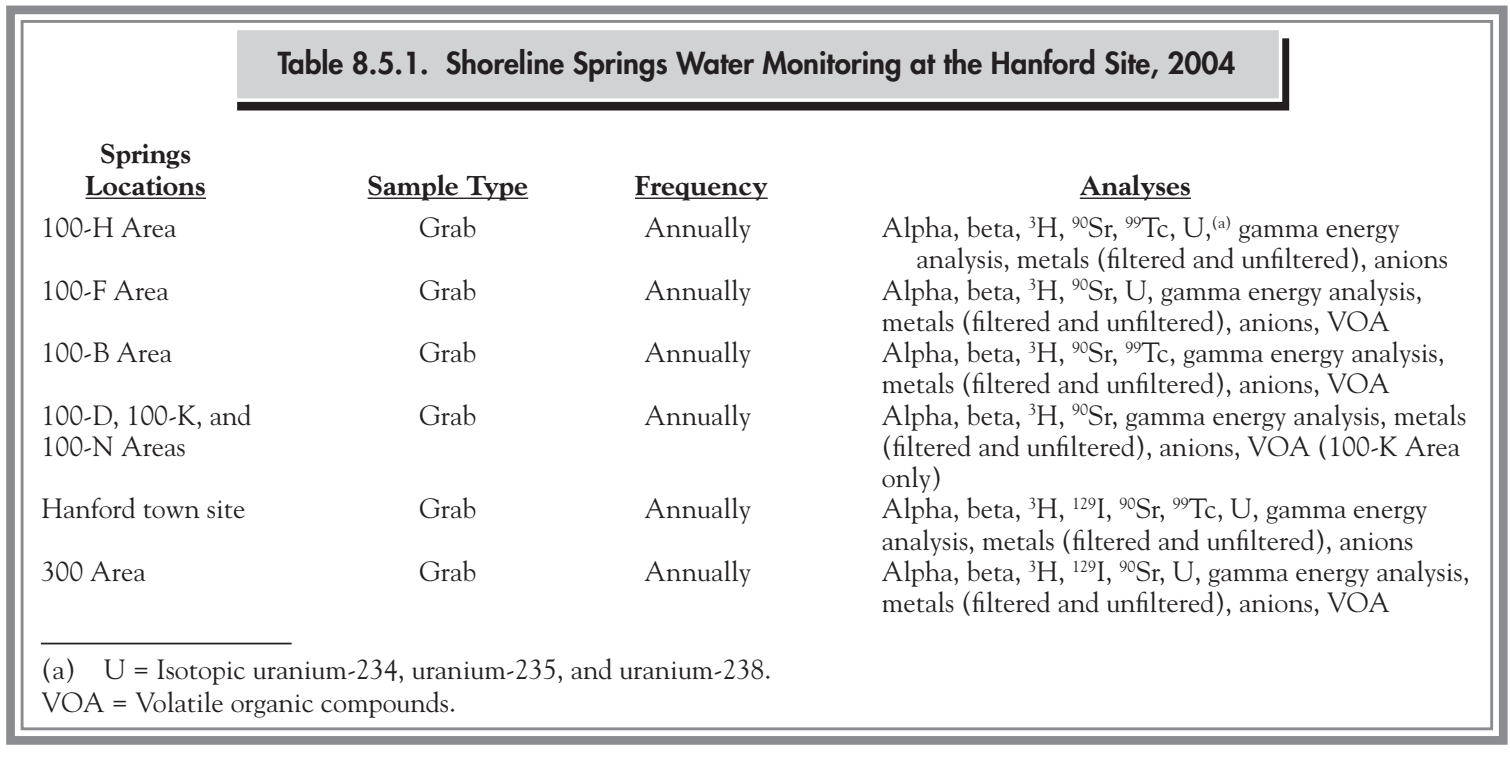

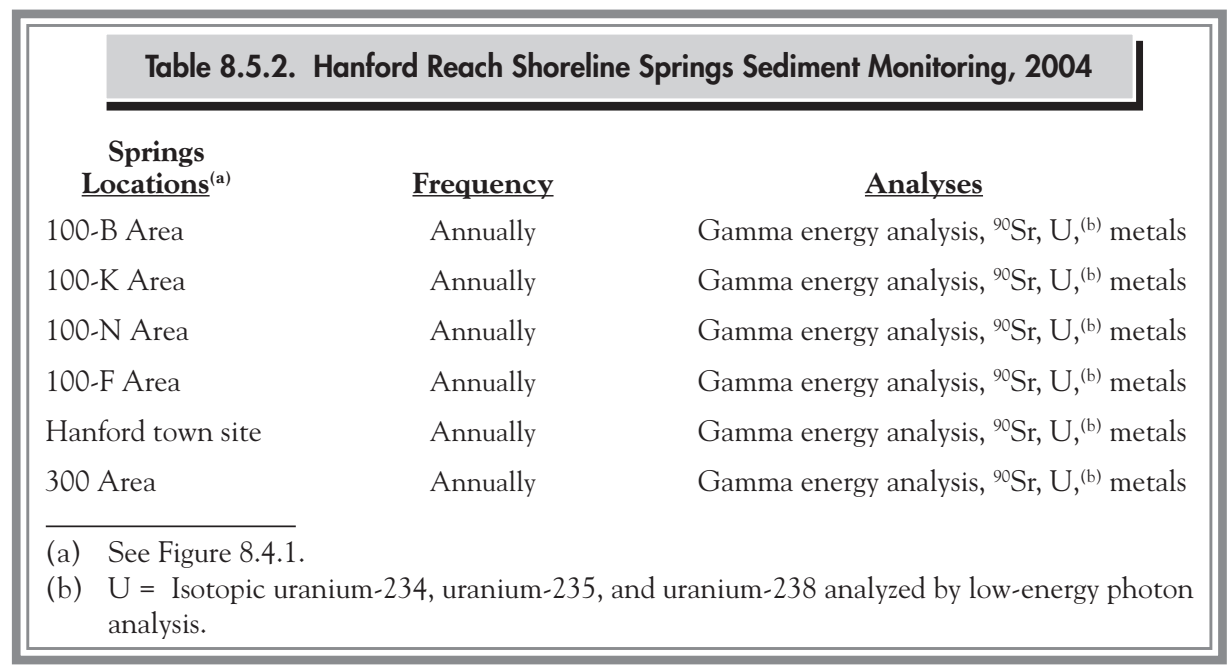


2004. This section describes the monitoring efforts and summarizes the results for these aquatic environments. Detailed analytical results are reported in PNNL-15222, APP. 1. Analytes of interest for samples from shoreline springs were selected based on findings of previous investigations, reviews of contaminant concentrations observed in nearby groundwater monitoring wells, and results of preliminary risk assessments. Sampling is conducted annually when river flows are low, typically in early fall.

All samples collected during 2004 were analyzed for gamma-emitting radionuclides, gross alpha, gross beta, and tritium. Samples from selected springs were analyzed for strontium-90, technetium-99, iodine-129, uranium-234, uranium-235, and uranium-238. All samples were analyzed for metals and anions. Samples from selected locations were analyzed for volatile organic compounds. All analyses were conducted on unfiltered samples, except for metals analyses, which were conducted on both filtered and unfiltered samples (Appendix C, Table C.9; PNNL-15222, APP. 1).

\subsubsection{Radiological Results for Water Samples from Columbia River Shoreline Springs}

Contaminants of Hanford origin continued to be detected in water from shoreline springs entering the Columbia River along the Hanford Site during 2004. Tritium, strontium-90, technetium-99, iodine-129, uranium-234, uranium-235, and uranium-238 were detected in spring water (Appendix C, Table C.9). All radiological contaminant concentrations measured in shoreline springs during 2004 were less than applicable DOE derived concentration guides (DOE Order 5400.5; Appendix D, Table D.5).

Gross beta concentrations in shoreline spring water at the 100-B Area, 100-H Area, Hanford town site, and 300 Area were elevated compared to other shoreline spring water locations.

Tritium concentrations varied widely with location. The highest tritium concentration measured in shoreline springs was at the Hanford town site $(67,000 \pm 4,800 \mathrm{pCi} / \mathrm{L}$ $[2,500 \pm 180 \mathrm{~Bq} / \mathrm{L}])$, which was above the Washington State ambient surface-water quality criterion of $20,000 \mathrm{pCi} / \mathrm{L}$ (740 Bq/L) (WAC 173-201A; 40 CFR 141), followed by $11,000 \pm 430 \mathrm{pCi} / \mathrm{L}(420 \pm 16 \mathrm{~Bq} / \mathrm{L})$ in the $100-\mathrm{N}$ Area, and $11,000 \pm 880 \mathrm{pCi} / \mathrm{L}(430 \pm 33 \mathrm{~Bq} / \mathrm{L})$ in the 300 Area. Tritium concentrations in all shoreline spring samples were elevated compared to the 2004 average Columbia River concentration at Priest Rapids Dam $(23 \pm 12$ pCi/L $[0.85 \pm 0.44 \mathrm{~Bq} / \mathrm{L}])$. Figure 8.5.1 depicts concentrations of selected radionuclides in 300 Area shoreline spring water (spring 42-2 and spring DR 42-2) from 1999 through 2004. Concentrations of radionuclides in 300 Area shoreline springs in 2004 were lower than in previous years and reflected the lower specific conductivity values reported with the samples (i.e., bank storage effect). The elevated tritium levels measured in 300 Area shoreline springs are indicators of the contaminated groundwater plume from the 200 Areas (Section 5.9 in PNL-10698). Tritium was the only specific radionuclide detected in 100-N Area shoreline spring water during 2004.

Samples from shoreline springs were analyzed for strontium-90 in the 100-B, 100-K, 100-N, 100-D, 100-H, 100-F, and 300 Areas. The highest strontium-90 concentration detected in shoreline spring water was at the $100-\mathrm{H}$ Area $(6.8 \pm 1.1 \mathrm{pCi} / \mathrm{L}[0.25 \pm 0.041 \mathrm{~Bq} / \mathrm{L}])$. This value was $85 \%$ of the ambient surface-water quality criterion of $8 \mathrm{pCi} / \mathrm{L}(0.30 \mathrm{~Bq} / \mathrm{L})$. Groundwater at the $100-\mathrm{N}$ Area has historically had the highest strontium-90 concentrations; however, since 1997, no visible shoreline springs have been observed along the shoreline where strontium-90 concentrations in groundwater are elevated.

Samples from shoreline springs in the $100-\mathrm{B}, 100-\mathrm{K}$, 100-H Areas, and at the Hanford town site were analyzed for technetium-99. All results for technetium-99 were below the EPA drinking water standard of $900 \mathrm{pCi} / \mathrm{L}$ (33 Bq/L) (Appendix D, Table D.2). The highest technetium-99 concentration was found in shoreline spring water from the Hanford town site $(78 \pm 4.5 \mathrm{pCi} / \mathrm{L}$ $[2.9 \pm 0.17 \mathrm{~Bq} / \mathrm{L}]$.

Samples from shoreline springs at the Hanford town site and 300 Area were analyzed for iodine-129. The highest concentration was measured in a water sample from the Hanford town site spring $(0.20 \pm 0.014 \mathrm{pCi} / \mathrm{L}[0.0074 \pm$ $0.00052 \mathrm{~Bq} / \mathrm{L}])$. This Hanford town site value was roughly 22,000 times higher than the 2004 average concentration measured at Priest Rapids Dam (0.0000091 \pm $0.0000050 \mathrm{pCi} / \mathrm{L}[0.00000034 \pm 0.000000018 \mathrm{~Bq} / \mathrm{L}])$ but was below the surface-water quality criterion of $1 \mathrm{pCi} / \mathrm{L}$ (0.037 Bq/L) (Appendix D, Table D.2). Concentrations 

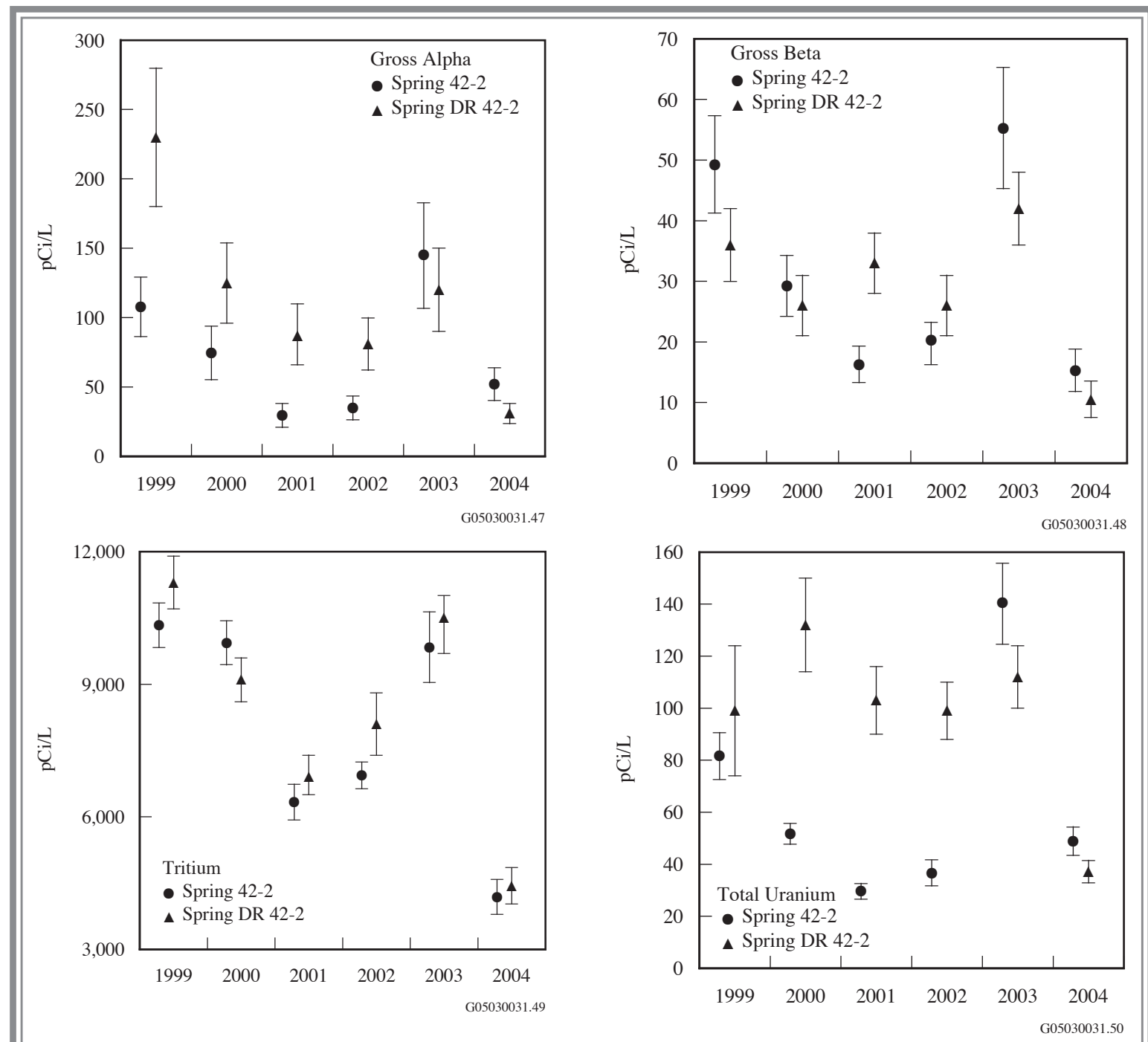

Figure 8.5.1. Concentrations (results \pm 2 total propagated analytical uncertainty) of Selected Radionuclides in Water from Columbia River Shoreline Springs Near the Hanford Site's 300 Area, 1999 through 2004. Multiple samples were collected for 300 Area shoreline springs in 2001, the results are for the May 10, 2001 sampling event. Note: DR refers to downriver, thus DR 42-2 is a spring located downriver from Hanford Mile Marker 42-2.

of selected radionuclides in shoreline spring water near the Hanford town site (spring 28-2) from 1999 through 2004 are provided in Figure 8.5.2. Annual fluctuations in these values reflect the influence of bank storage during the sampling period.

Uranium was analyzed for in shoreline spring water samples from the 100-H Area, 100-F Area, Hanford town site, and 300 Area in 2004 (Figure 8.4.1). The highest total uranium level was found in 300 Area spring water $(48 \pm$ $5.5 \mathrm{pCi} / \mathrm{L}[1.8 \pm 0.20 \mathrm{~Bq} / \mathrm{L}]$ or approximately $43 \pm$ $5.0 \mu \mathrm{g} / \mathrm{L}$ ), which was collected downgradient from the retired 300 Area process trenches. The total uranium concentration in this spring exceeded the EPA drinking water standard of $30 \mu \mathrm{g} / \mathrm{L}$ (approximately $27 \mathrm{pCi} / \mathrm{L}$ $[1.0 \mathrm{~Bq} / \mathrm{L}])$. The 300 Area spring had an elevated gross alpha concentration $(48 \pm 11 \mathrm{pCi} / \mathrm{L}[1.8 \pm 0.041 \mathrm{~Bq} / \mathrm{L}]$, which exceeded the Washington State ambient surface water quality criterion of $15 \mathrm{pCi} / \mathrm{L}(0.56 \mathrm{~Bq} / \mathrm{L}$ ) (Appendix D, Table D.2). Elevated uranium concentrations exist in the unconfined aquifer beneath the 300 Area in the vicinity of former uranium fuel fabrication facilities and inactive waste sites. The increase in uranium concentrations in 2003 samples from shoreline spring 42-2 was not 


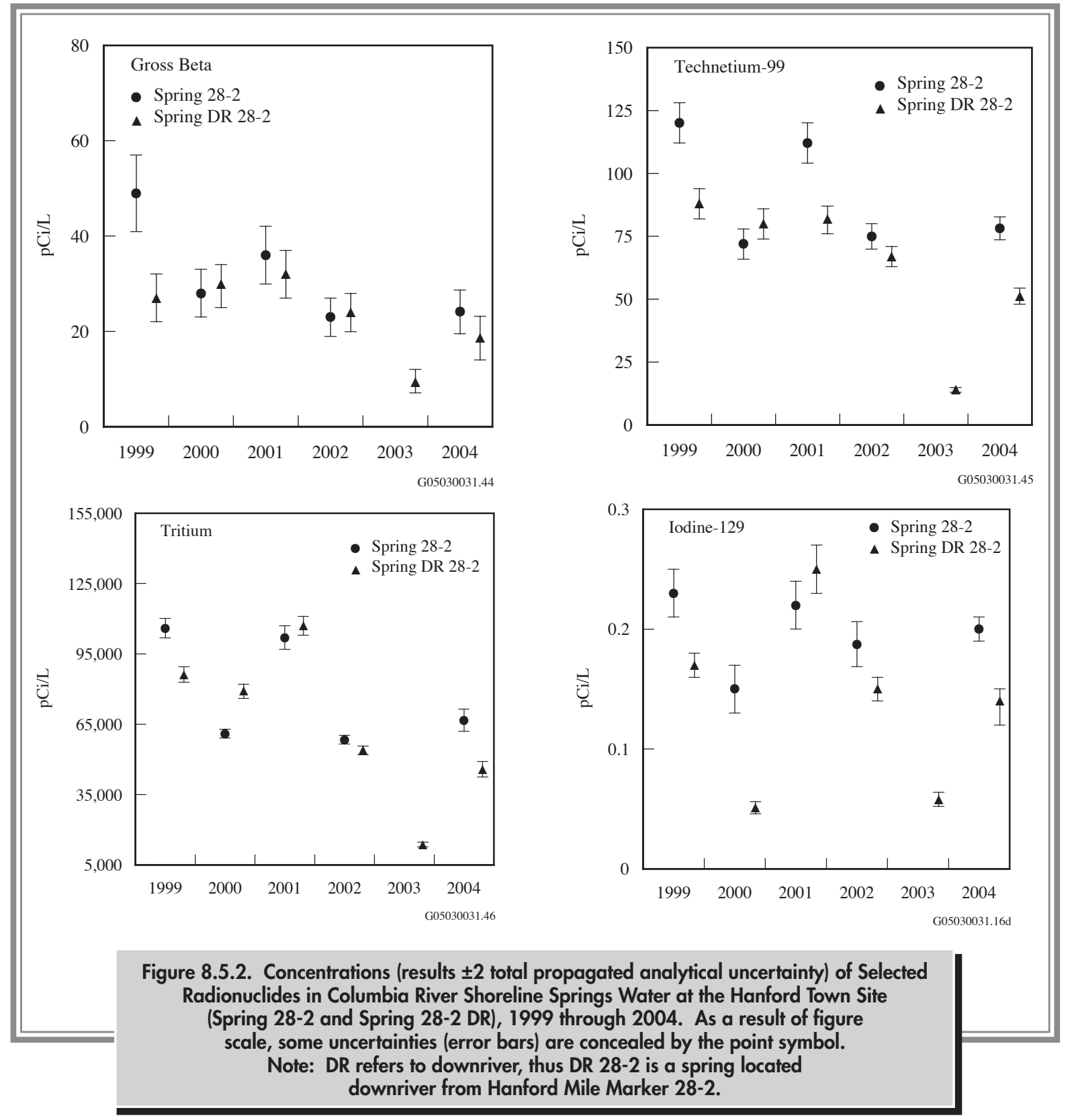

unexpected. A pulse of increased uranium concentrations in groundwater was created by waste site excavation activities during fall 2002 at a location just inland of this shoreline spring (PNNL-14548). The pulse has passed well 399-1-10A, located adjacent to the spring, and has now probably discharged to the river. The gross alpha and gross beta concentrations in 300 Area shoreline spring water from 1999 through 2004 parallel uranium and are likely associated with its presence. Concentrations of radionuclides in 300 Area shoreline springs in 2004 were lower than in previous years and reflected the lower specific conductivity values reported with the samples (i.e., bank storage effect).

\subsubsection{Chemical Results for Water Samples from Columbia River Shoreline Springs}

Hanford-origin contaminants continued to be detected in water from shoreline springs entering the Columbia River along the Hanford Site during 2004. Metals and anions 
(chloride, fluoride, nitrate, and sulfate) were detected in spring water. Volatile organic compounds were near or below the detection limits for all samples. Trichloroethene, toluene, and xylenes were detected in shoreline spring water samples from the 300 Area and were the only analytes with detectable values for all shoreline spring locations (all detected values were $<1 \mu \mathrm{g} / \mathrm{L}$ ). Trichloroethene has been consistently detected at low concentrations in 300 Area shoreline spring water.

Concentration ranges of selected chemicals measured in shoreline spring water during 1999 through 2004 are presented in Table 8.5.3. For most locations, the 2004 chemical sample results were similar to those reported previously (PNNL-14687). Nitrate concentrations were highest in spring water samples from the Hanford town site. Dissolved chromium concentrations were highest in the 100-D, 100-B, 100-H, and 100-N Areas' shoreline springs. Hanford groundwater monitoring results for 2004 indicated similar contaminant concentrations in shoreline areas (Section 8.7, Figure 8.7.6).

The ambient surface-water quality criteria for cadmium, copper, lead, nickel, silver, and zinc are total-hardness dependent (WAC 173-201A; Appendix D, Table D.3). For comparison purposes, spring water criteria were calculated using the same 47-milligram calcium carbonate per liter hardness given in Appendix D, Table D.3. The concentrations of most metals measured in water collected from shoreline springs along the Hanford Site shoreline during 1999 through 2004 were below Washington State ambient surface-water chronic toxicity levels (WAC 173-201A). However, concentrations of dissolved chromium in 100-B, 100-N, 100-D, 100-H, and 100-F Areas' shoreline spring water were above the Washington State ambient surface water chronic toxicity level (Appendix D, Table D.3) and above the acute toxicity level at the 100-B, 100-K, 100-D, 100-H, and 100-F Areas. Arsenic concentrations in shoreline spring water were well below the Washington State ambient surfacewater chronic toxicity level, but concentrations in all samples (including upriver Columbia River water samples) exceeded the federal limit for the protection of human health for the consumption of water and organisms; however, this EPA value is more than 10,500 times lower than the Washington State chronic toxicity standard (40 CFR 141; Appendix D, Table D.3). Nitrate concentrations at all spring water locations were below the drinking water standard (Appendix D, Table D.2).

\subsubsection{Monitoring Columbia River Shoreline Springs Sediment}

\section{G. W. Patton}

Sampling of sediment from shoreline springs began during 1993 at the Hanford town site and the 300 Area. Sampling of shoreline springs sediment in the 100-B, 100-K, and 100-F Areas began during 1995. Substrates at sampling locations of shoreline springs in the 100-N, 100-D, and 100-H Areas consist predominantly of large cobble and are unsuitable for sampling.

\section{Radiological Results for Sediment Samples from Columbia River Shoreline Springs}

During 2004, sediment samples were collected at shoreline springs in the 100-B, 100-F, and 300 Areas and the Hanford town site. No sediment was available for sampling at the 100-K Area location because the spring that was scheduled for sampling was not flowing and an alternate spring was sampled (i.e., only water samples were collected; no sediment was found). Results for 2004 samples were similar to those observed for previous years (PNNL-15222; APP. 1; Appendix C, Table C.7). Potassium-40, cesium-137, and uranium isotopes were the only radionuclides reported above the minimum detectable concentrations. During 2004, radionuclide concentrations in shoreline spring sediment were similar to those observed in Columbia River sediment, with the exception of the 300 Area where uranium concentrations were roughly two to four times the background concentrations measured for sediment from Priest Rapids Dam. Elevated uranium concentrations for 300 Area spring sediment compared to Priest Rapids Dam sediment have been previously reported (PNNL-14687).

Concentrations of metals in shoreline spring sediment samples during 2004 were similar to concentrations in Hanford Reach Columbia River sediment samples. Currently, there are no Washington State freshwater sediment quality criteria for comparison to the measured values. 


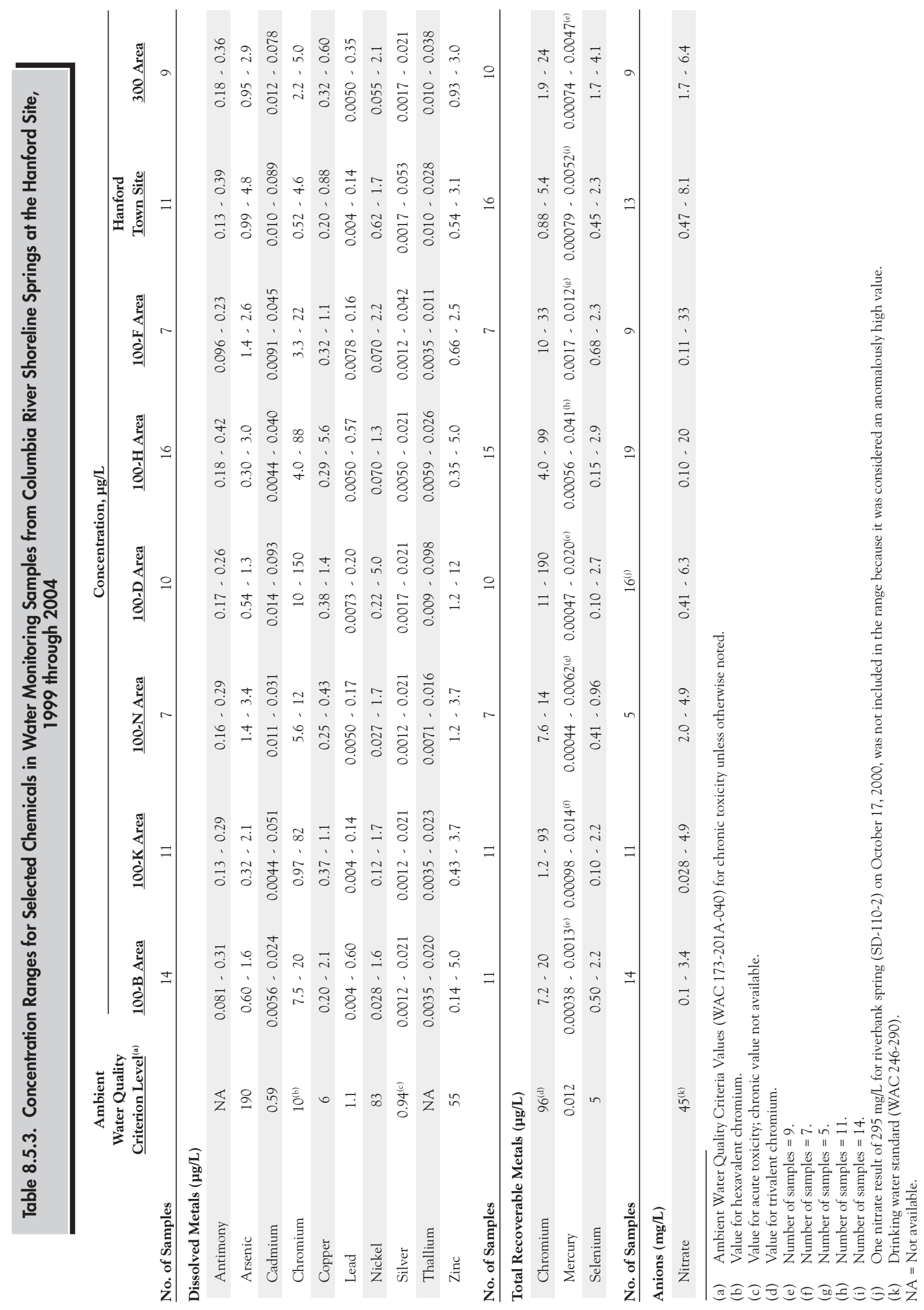




\subsubsection{Radiological Monitoring of Columbia River Shoreline Spring Water in Seep Wells in the 100-N Area (N Springs)}

\section{J. Perkins}

In the past, radioactive effluent streams from operations in the $100-\mathrm{N}$ Area were sent to the now retired $116-\mathrm{N}-1$ $(1301-\mathrm{N})$ and $116-\mathrm{N}-3(1325-\mathrm{N})$ liquid waste disposal facilities (i.e., engineered soil columns). After moving through the soil column to the water table, this wastewater migrated with the groundwater and entered the Columbia River via springs located along the adjacent shoreline region sometimes called N Springs. Historically, the highest concentrations of radionuclides have been in the general vicinity of monitoring well 199-N-46. Well $199-\mathrm{N}-46$ is a 7.5 -meter- (24.5-foot-) deep groundwater well with a 15.2-centimeter (6-inch) diameter located along the river shoreline at N Springs. Water from shoreline springs and/or shoreline seep wells along the N Springs area is sampled annually to verify that the radionuclide release estimates at $\mathrm{N}$ Springs, based on analyses of water samples collected routinely from monitoring well 199-N-46, are not under reported. The locations of the shoreline seep wells and monitoring well 199-N-46, as well as a comprehensive presentation of the analytical data from well water samples, are available in PNNL-15222, APP. 2.

The shoreline seep wells are constructed such that shallow, subsurface (down to 1.06 meters [3.5 feet]) run-off water is intercepted and collected within a 30.5-centimeter (12-inch) diameter casing. The series of 13 shoreline seep wells, approximately 46 to 61 meters (150 to 200 feet) apart, were installed in the late 1970s in locations where surface spring water run-off was visible. To prevent accidental contamination of personnel and wildlife that might wander through the area, the entire expanse of the N Springs run-off area was covered with large boulders immediately after the shoreline seep wells were installed.

Shoreline seep-well samples were analyzed for strontium-90, tritium, and gamma-emitting radionuclides. Analytical results and discussion of these releases may be found in Section 8.3 and in HNF-EP-0527-14, Environmental Releases for Calendar Year 2004. A groundwater pump-and-treat system designed to reduce the discharge of strontium-90 to the Columbia River in the 100-N Area was put into operation in 1995 and continued to operate in 2004. Additional discussion about this system and its effects may be found in Section 8.7.

During October 2004, samples were collected from eight of the thirteen 100-N Area shoreline seep wells (i.e., one sample from each well). Five of the wells were dry at the time of sample collection. The samples were collected using a bailer carefully lowered into the water column of each well to avoid sediment suspension, and a 4-liter (1-gallon) sample was obtained. Strontium-90 was detected in all eight of the seep-well water samples, and none of the concentrations exceeded DOE derived concentration guide values (Appendix D, Table D.5). Tritium and gamma-emitting radionuclide concentrations were below analytical detection limits in all eight samples. Maximum and average tritium and strontium- 90 concentrations in seep wells, and in well 199-N-46, are summarized in Table 8.5.4. Tritium and strontium-90 data from 2004 shoreline spring water samples, including surveillance samples collected near $\mathrm{N}$ Springs, are summarized in Appendix C, Table C.9. 


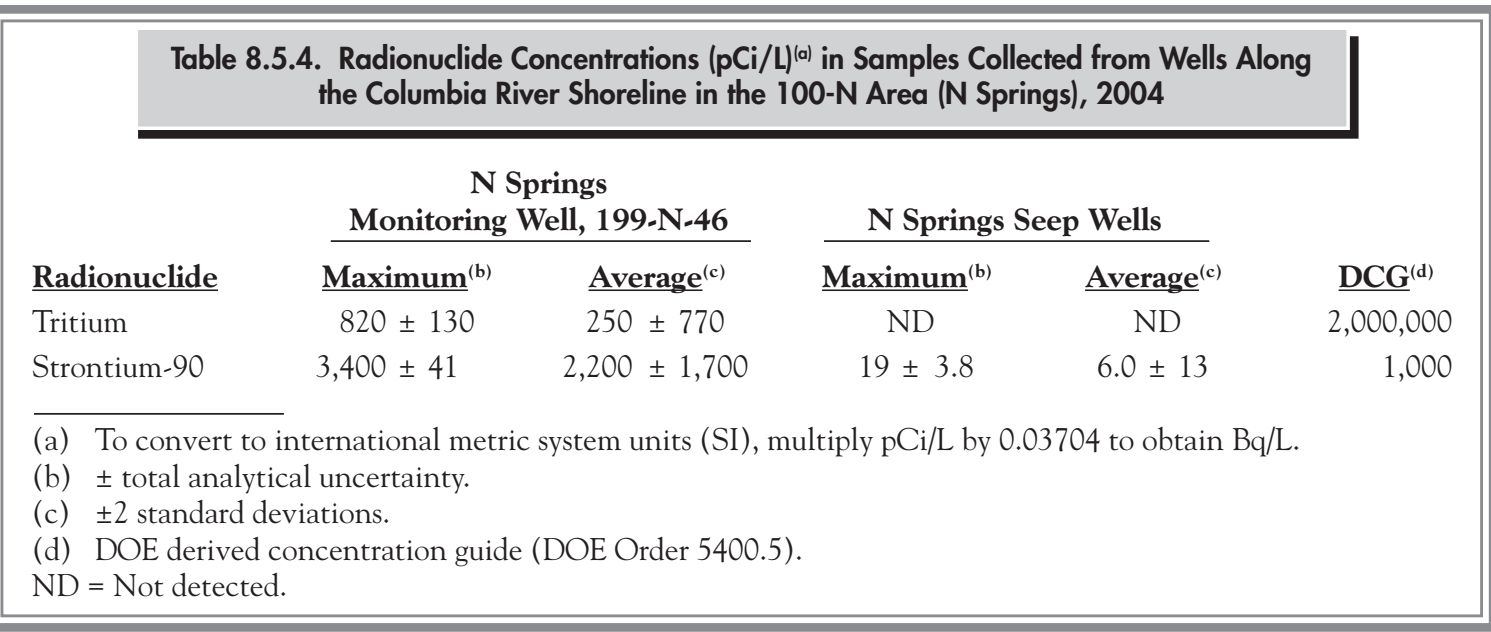




\subsection{Radiological Monitoring of Hanford Site Drinking Water}

R. W. Hanf and L. M. Kelly

The quality of drinking water at the Hanford Site is routinely checked to assure site compliance with the Safe Drinking Water Act (see Section 5.4.2). During 2004, Pacific Northwest National Laboratory conducted radiological monitoring of drinking water supplied to Hanford Site facilities by DOE-owned pumps and water treatment facilities. Fluor Hanford, Inc. conducted routine chemical and microbiological monitoring of onsite drinking water. WAC 246-290, Public Water Supplies, requires that all drinking water analytical results be reported routinely to the Washington State Department of Health. Radiological results for Hanford Site drinking water samples are reported to the state through this annual environmental report and through an annual supplemental data compilation (e.g., PNNL-15222, APP. 1). Chemical and microbiological data are reported to the state directly by the state-accredited laboratory performing the analyses and to Fluor Hanford, Inc. but are not otherwise published.

All DOE-owned drinking water systems on the Hanford Site were in compliance with drinking water standards for radiological, chemical, and microbiological contaminant levels during 2004. Contaminant concentrations measured during the year were similar to those observed in recent years (see Section 4.3 in PNNL-14295 for 2002; PNNL-14687 for 2003).

\subsubsection{Hanford Site Drinking Water Systems}

During 2004, drinking water was supplied to DOE facilities on the site by nine DOE-owned, contractor-operated, water systems and one DOE-owned, contractor-operated, distribution system in the 300 Area that obtained treated water from the city of Richland. Eight of these systems, including Richland's system, used water from the
Columbia River. One system used groundwater from the unconfined aquifer beneath the site. Fluor Hanford, Inc. operated most of the DOE systems. Bechtel Hanford, Inc. operated one system in the 100-N Area that was supplied with water from a pumping station operated by Fluor Hanford, Inc. The city of Richland provided drinking water to the 300 Area, Richland North Area, and Hazardous Materials Management and Emergency Response Training and Education Center (HAMMER) facility.

\subsubsection{Hanford Site Drinking Water Supply Facilities}

Radionuclide concentrations in onsite drinking water during 2004 were monitored at four DOE-owned water treatment facilities (Figure 8.6.1). Three of these facilities supplied treated Columbia River water to four DOE drinking water systems on the site. The fourth treatment facility furnished groundwater to the 400 Area drinking water system. The 400 Area continued to use well 499-S1-8J (P-16) as the primary drinking water supply well and wells 499-S0-8 (P-14) and 499-S0-7 (P-15) as backup sources. The backup well with the lowest tritium level, as demonstrated by sampling and analysis, is considered the primary backup water supply. The three wells supply water to a common header that supplies three above-ground storage tanks prior to dissemination through the distribution system. Well 499-S0-7 was not used as a drinking water source during 2004. Well 499-S0-8 supplied 250,000 liters (66,000 gallons) to the distribution system on November 23 and 2.83 million liters (747,600 gallons) from December 7 through December 15. Water for the system in the 300 Area was supplied by the city of Richland. 


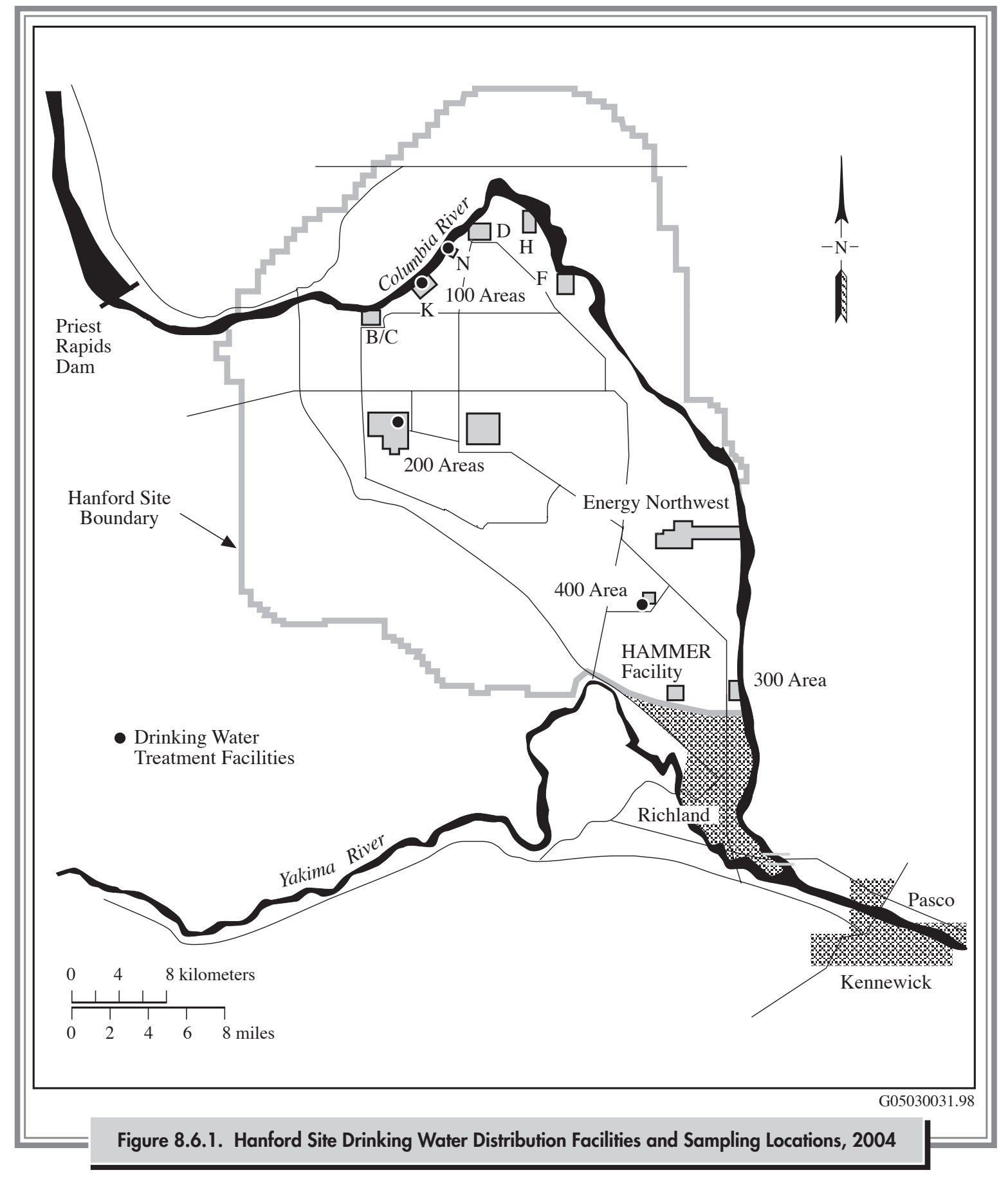

\subsubsection{Collection of} Drinking Water Samples and Analytes of Interest

Samples at all four drinking water treatment facilities were collected and analyzed quarterly. All were samples of treated water collected before the water was distributed for general use. Drinking water in the 300 and Richland North Areas and at the HAMMER facility was not routinely monitored for radiological contaminants by DOE contractor personnel. However, personnel from Pacific Northwest National Laboratory's Surface Environmental Surveillance Project routinely collected water samples from the Columbia River at the city's river water intake. The Columbia River is the primary source of the city of 
Richland's drinking water. The radiological analytical results for these river water samples are summarized in Section 8.4 and tabulated in Appendix C (Table C.2). The city of Richland also monitors its water for radiological and chemical contaminants, and for general water quality. As a community water system, the city is required to annually report monitoring results and characterize the risks (if any) from exposure to contaminants in the water, in what is known as a Consumer Confidence Report. The reports are mailed to all consumers as an insert with a monthly utility bill. Results are also made available on the city of Richland's web page (http://www.ci.richland. wa.us/RICHLAND/Utilities/index.cfm?PageNum=15).

\subsubsection{Radiological Results for Hanford Site Drinking Water Samples}

Drinking water samples collected for radiological analysis were analyzed for gross alpha, gross beta, tritium, strontium-90, iodine-131, radium-226, and radium-228.
Results for radiological monitoring of Hanford Site drinking water during 2004 are summarized in Table 8.6.1. Individual analytical results are reported in PNNL-15222, APP. 1. The maximum amount of beta-gamma radiation from manmade radionuclides allowed in drinking water by Washington State and EPA is an annual average concentration that will not produce an annual dose equivalent to the whole body or any internal organ greater than $4 \mathrm{mrem}(0.04 \mathrm{mSv})$. Maximum contaminant levels for gross alpha (excluding uranium and radon) and radium-226 and radium-228 (a combined total) are $15 \mathrm{pCi} / \mathrm{L}(0.56 \mathrm{~Bq} / \mathrm{L})$ and $5 \mathrm{pCi} / \mathrm{L}(0.18 \mathrm{~Bq} / \mathrm{L})$, respectively. The maximum allowable limit for tritium is $20,000 \mathrm{pCi} / \mathrm{L}$ (740 Bq/L) (40 CFR 141; WAC 246-290). These concentrations are assumed to produce a total body or organ dose of $4 \mathrm{mrem} / \mathrm{yr}(0.04 \mathrm{mSv} / \mathrm{yr})$. If two or more radionuclides are present, the sum of their annual dose equivalent to the total body or to any internal organ must not exceed 4 mrem (0.04 mSv).

During 2004, annual average concentrations of all monitored radionuclides in Hanford Site drinking water were below state and federal maximum contaminant levels. All

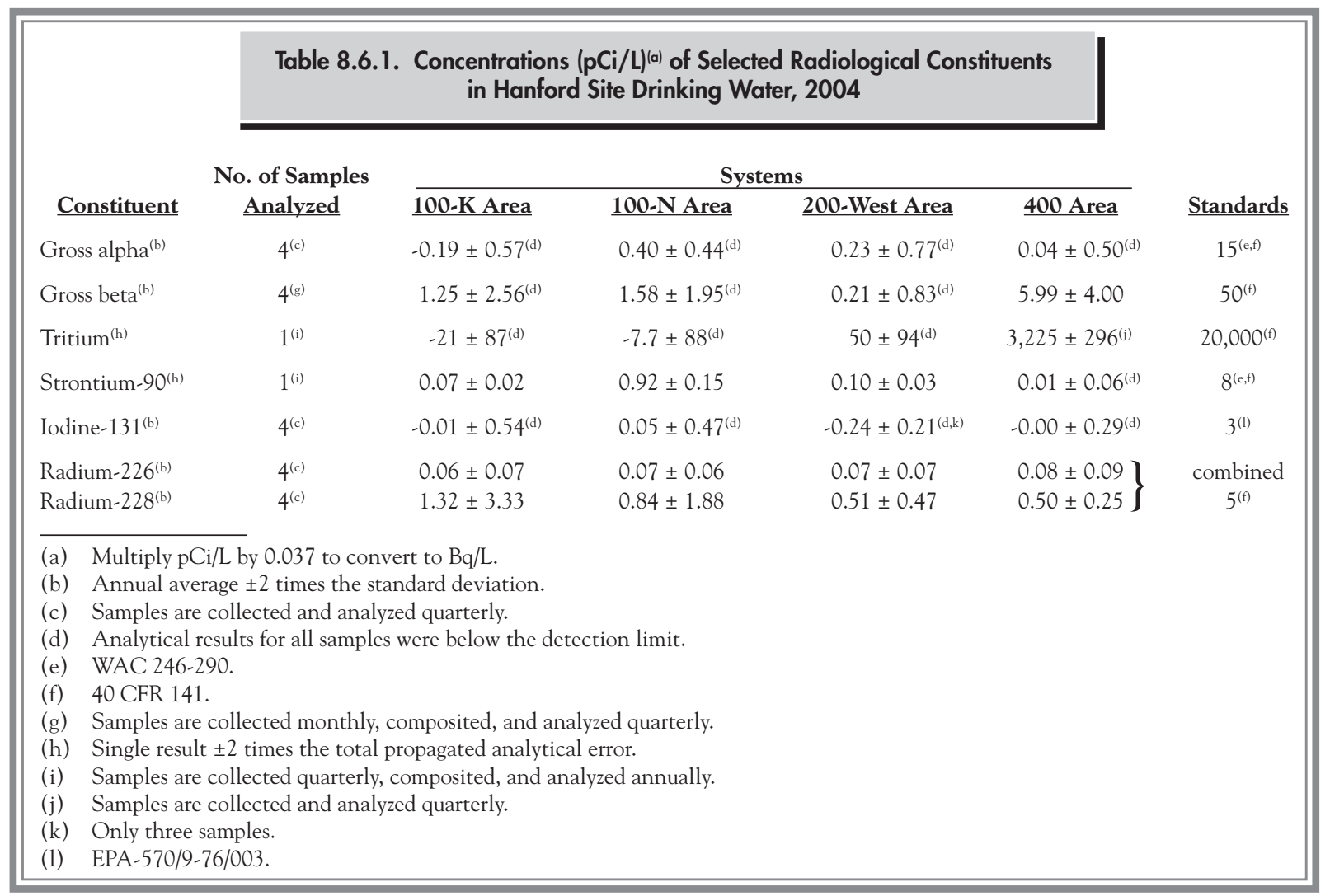


iodine-131 and gross alpha results were below their respective minimum detectable concentrations (i.e., concentrations were too low to measure). All gross beta results for river water samples were also below the minimum detectable concentration, as were all three river water tritium results and five of twelve river water radium-228 results. Radium-226 and strontium-90 were detected in every river water sample analyzed. Gross beta was found in three of four 400 Area well water samples, radium-226 was found in one of the four samples analyzed, and tritium was measured in all 400 Area samples. Strontium-90 was not detected in 400 Area well water (Table 8.6.1).
The Groundwater Performance Assessment Project collected and analyzed raw water samples from all three 400 Area drinking water wells. A tritium plume that originates in the 200-East Area extends under the 400 Area and has historically affected tritium concentrations in all 400 Area drinking water wells. During 2004, annual average tritium concentrations in all three wells were below the $20,000 \mathrm{pCi} / \mathrm{L}(740 \mathrm{~Bq} / \mathrm{L})$ state and federal annual average drinking water standard (Table 8.6.2; Figure 8.6.2).

\begin{tabular}{|c|c|c|c|c|}
\hline \multirow{2}{*}{\multicolumn{2}{|c|}{ Sampling Date }} & \multicolumn{3}{|c|}{$\begin{array}{l}\text { Table 8.6.2. Tritium Concentrations }(\mathrm{pCi} / \mathrm{L})^{(\mathrm{a})} \text { in Hanford Site } 400 \text { Area Drinking } \\
\text { Water Wells, 2004 }\end{array}$} \\
\hline & & $\begin{array}{c}\text { Primary Drinking Water } \\
\text { Well 499-S1-8J (P-16) }\end{array}$ & $\begin{array}{c}\text { Backup Drinking Water } \\
\text { Well 499-S0-8 (P-14) }\end{array}$ & $\begin{array}{c}\text { Backup Drinking Water } \\
\text { Well 499-S0.7 (P.15) }\end{array}$ \\
\hline \multicolumn{2}{|c|}{ January 22, 2004} & $2,830 \pm 270$ & $2,910 \pm 270$ & $11,600 \pm 610$ \\
\hline \multicolumn{2}{|c|}{ April 15, 2004} & $2,680 \pm 240$ & $2,750 \pm 240$ & $\begin{array}{l}11,000 \pm 550 \\
12,400 \pm 610\end{array}$ \\
\hline \multicolumn{2}{|c|}{ July 20, 2004} & $2,780 \pm 290$ & $3,050 \pm 300$ & $12,600 \pm 690$ \\
\hline \multicolumn{2}{|c|}{ October 13, 2004} & $2,120 \pm 190$ & $2,290 \pm 200$ & $10,700 \pm 530$ \\
\hline \multicolumn{2}{|c|}{ Annual Average } & 2,602 & 2,750 & 11,660 \\
\hline & $\begin{array}{l}\text { Multiply pC } \\
\text { Reported col }\end{array}$ & $\begin{array}{l}37 \text { to convert to } \mathrm{Bq} / \mathrm{L} \text {. } \\
\text { n } \pm 2 \text { total propagated analyt }\end{array}$ & & \\
\hline
\end{tabular}




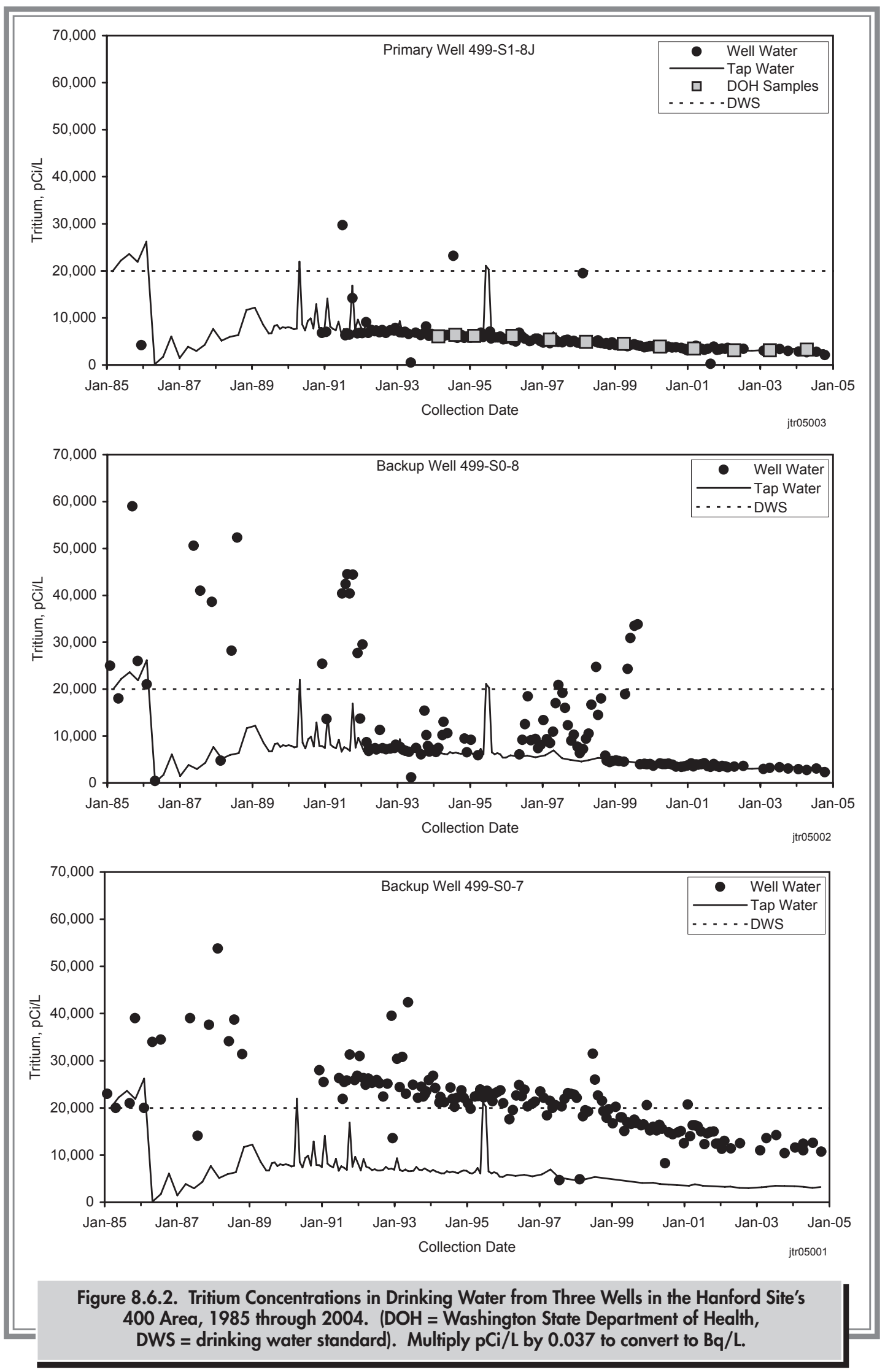




\subsection{Groundwater Monitoring}

D. R. Newcomer and M. J. Hartman

DOE has monitored groundwater on the Hanford Site since the 1940s to help determine what chemical and radiological contaminants have made their way into the groundwater. An evaluation of groundwater quality of the Hanford Site is documented in an annual groundwater monitoring report (PNNL-15070).

Plutonium production activities on the Hanford Site produced contaminants that reached the Columbia River by moving down through the vadose zone, into the groundwater, and then into the river. The analysis of groundwater samples helps determine the potential effects that contaminants could have on human health and the environment. DOE works with regulatory agencies, such as EPA and the Washington State Department of Ecology, to make groundwater-cleanup decisions based on sound technical information and the technical capabilities available.

\subsubsection{Highlights and Emerging Issues}

DOE's major accomplishments related to groundwater monitoring in 2004, and emerging issues of potential concern, are outlined in the following paragraphs.

\subsubsection{Groundwater Monitoring Highlights}

Number of Wells Sampled in 2004. Workers sampled 727 monitoring wells and 154 shoreline aquifer tubes in 2004 to determine the distribution and movement of contaminants in Hanford Site groundwater. Many of the wells were sampled multiple times during the year.

Number of Sample Analyses in 2004. Two thousand one hundred and sixty-five samples of Hanford groundwater were analyzed for chromium, 1,514 for nitrate, and 1,146 for tritium. Other constituents frequently analyzed for included carbon tetrachloride analyzed in 653 samples, technetium-99 analyzed in 779 samples, and uranium analyzed in 732 samples. Summaries that account for the number of all groundwater wells monitored and the number of analyses performed on samples from the wells during 2004 according to groundwater interest area and monitoring purpose are provided in Tables 8.7.1 and 8.7.2, respectively.

Monitoring Tritium in Groundwater at the KE Basin. Tritium levels began to rise in January 2003 in a well downgradient of the KE Basin, exceeding 100,000 pCi/L $(3,700 \mathrm{~Bq} / \mathrm{L})$ in October 2003 and subsequently declining to approximately $40,000 \mathrm{pCi} / \mathrm{L}(1,500 \mathrm{~Bq} / \mathrm{L})$ in October 2004. (The drinking water standard for tritium is $20,000 \mathrm{pCi} / \mathrm{L}[740 \mathrm{~Bq} / \mathrm{L}]$.) Because there are multiple sources of tritium in the area, no mobile co-contaminants such as technetium-99 are found with the tritium, and there is no evidence of measurable water losses from the KE Basin, scientists cannot conclude with certainty that the recent rise in tritium is a result of current loss of $\mathrm{KE}$ Basin shielding water to the ground. Other potential sources of tritium include remobilization of tritium in the soil from a 1993 basin leak and remobilization of tritium in the soil from the remediation of condensate cribs. Cracks have been found in the concrete basins that still contain sludge and shielding water contaminated with tritium and other radionuclides. The extent of the cracking and possible impact on groundwater are being investigated. The frequency of groundwater sample collection downgradient of the KE Basin has been increased.

Monitoring Technetium-99 in Groundwater at Waste Management Area T. Concentrations of technetium-99 continued to increase in wells on the east side (downgradient) of the T Tank Farm in 2004. Water from well 


\begin{tabular}{|c|c|c|c|c|c|c|c|}
\hline \multirow[b]{3}{*}{$\begin{array}{l}\text { Number of wells and } \\
\text { aquifer tubes }\end{array}$} & \multicolumn{6}{|c|}{$\begin{array}{c}\text { Table 8.7.1. Summary of Hanford Site Groundwater Performance Assessment Project by } \\
\text { Groundwater Interest Area, } 2004\end{array}$} & \multirow[b]{2}{*}{$\underline{100-N R-2}$} \\
\hline & Hanford Site & $\underline{100-B C-5}$ & 100-FR-3 & 100-HR-3-D & 100-HR-3-H & $100-K R-4$ & \\
\hline & 881 & 41 & 46 & 110 & 58 & 49 & 54 \\
\hline $\begin{array}{l}\text { Number of sampling } \\
\text { events }\end{array}$ & 2,233 & 51 & 62 & 345 & 168 & 191 & 170 \\
\hline Number of analyses & 25,835 & 379 & 560 & 2,569 & 1,072 & 1,189 & 2,066 \\
\hline Number of results & 79,093 & 693 & 2,214 & 4,758 & 2,548 & 2,832 & 4,748 \\
\hline \multirow[t]{2}{*}{$\begin{array}{l}\text { Percent of non- } \\
\text { detected results }\end{array}$} & 49 & 26 & 50 & 21 & 28 & 32 & 35 \\
\hline & 1100-EM-1 & 200-BP-5 & $\underline{200-P O-1}$ & 200-UP-1 & $\underline{200-\mathrm{ZP}-1}$ & $\underline{300-F F-5}$ & \\
\hline Number of wells & 58 & 109 & 132 & 67 & 89 & 68 & \\
\hline $\begin{array}{l}\text { Number of sampling } \\
\text { events }\end{array}$ & 81 & 239 & 230 & 207 & 296 & 193 & \\
\hline Number of analyses & 678 & 5,302 & 4,065 & 2,612 & 3,558 & 1,785 & \\
\hline Number of results & 1,921 & 13,354 & 11,367 & 11,453 & 15,702 & 7,503 & \\
\hline $\begin{array}{l}\text { Percent of non- } \\
\text { detected results }\end{array}$ & 54 & 45 & 49 & 58 & 59 & 65 & \\
\hline
\end{tabular}

Table 8.7.2. Summary of Hanford Site Groundwater Performance Assessment Project by Monitoring Purpose, ${ }^{(0)} 2004$

\begin{tabular}{|c|c|c|c|}
\hline & $\underline{\text { Restoration }}^{(\mathbf{b})}$ & $\begin{array}{c}\text { Waste } \\
\underline{\text { Management }}^{(\mathfrak{c})}\end{array}$ & $\begin{array}{l}\text { Environmental } \\
\text { Surveillance }^{(\mathrm{d})}\end{array}$ \\
\hline Number of wells & 565 & 243 & 329 \\
\hline $\begin{array}{l}\text { Number of sampling } \\
\text { events }\end{array}$ & 1,476 & 743 & 855 \\
\hline Number of analyses & 13,862 & 13,076 & 8,411 \\
\hline Number of results & 44,395 & 38,359 & 24,950 \\
\hline $\begin{array}{l}\text { Percent of non- } \\
\text { detected results }\end{array}$ & 51 & 48 & 49 \\
\hline \multicolumn{4}{|c|}{$\begin{array}{l}\text { (a) Because of the co-sampling among groundwater monitoring programs, the } \\
\text { wells monitored, sampling events, analyses, results, and non-detectable results } \\
\text { overlap between monitoring purposes. } \\
\text { (b) Wells associated with remediation activities. } \\
\text { (c) Wells sampled to determine impact, if any, to a waste management unit (e.g., } \\
\text { RCRA) on groundwater. } \\
\text { (d) Wells sampled to detect impact, if any, of site operations on groundwater over } \\
\text { the entire Hanford Site and adjacent offsite areas. }\end{array}$} \\
\hline
\end{tabular}

299-W11-39, near the northeast corner of the waste management area, had a technetium-99 concentration of $21,400 \mathrm{pCi} / \mathrm{L}(790 \mathrm{~Bq} / \mathrm{L})$ in 2004 , more than double the 2003 concentration of $9,140 \mathrm{pCi} / \mathrm{L}(338 \mathrm{~Bq} / \mathrm{L})$. (The drinking water standard for technetium-99 is $900 \mathrm{pCi} / \mathrm{L}$ [33 Bq/L].) Preliminary data from a new well installed in early 2005 east of Waste Management Area T showed a technetium-99 concentration in well water of $182,000 \mathrm{pCi} / \mathrm{L}(673 \mathrm{~Bq} / \mathrm{L})$ at approximately 10 meters
(33 feet) below the water table. DOE will work with the regulatory agencies to develop actions in response to the technetium-99 increases.

Well Spacing at Hanford Site Low-Level Burial Grounds. DOE and the Washington State Department of Ecology have been holding workshops regarding some aspects of groundwater monitoring at the low-level (low-activity waste) burial grounds, which are located in the 200-West and 200-East Areas. One of the issues to be resolved is the spacing and number of groundwater monitoring wells to be installed at these burial grounds to meet RCRA groundwater monitoring requirements.

\section{Alternative Statistics for Evaluating Data from} RCRA Sites. DOE completed data collection and evaluation of an alternative statistical method for evaluating groundwater monitoring data to determine if a site has affected groundwater quality. This method, using control charts (a graphical tool for monitoring changes), has been proposed to the Washington State Department of Ecology for use in RCRA groundwater monitoring. It is hoped that discussions with the Washington State Department of Ecology in the next year will resolve the applicability of this method. 
Well Decommissioning. DOE has accelerated the rate at which at-risk and unused Hanford Site wells are being decommissioned. This activity will continue to be a high priority for DOE to prevent unused wells from acting as a potential pathway for vertical movement of groundwater contaminants.

Cleanup Feasibility Studies. DOE began a focused feasibility study for cleanup of the 300-FF-5 Operable Unit, which will lead to final remediation decisions. A similar study is scheduled to begin for the 200-BP-5 Operable Unit in 2005.

\subsubsection{Groundwater Monitoring at Operable Units}

CERCLA-related groundwater monitoring continued at 11 operable units during 2004 (Figure 8.7.1).

Monitored Natural Attenuation. Average trichloroethene concentrations in monitoring wells in the 1100-EM-1 Operable Unit (in the former 1100 Area; Figure 8.7.1) remained below the $5-\mu \mathrm{g} / \mathrm{L}$ ( 0.005 parts per million) drinking water standard. This contaminant has been attenuating naturally. Average trichloroethene concentrations also remained below the drinking water standard in the 300-FF-5 Operable Unit (300 Area). Uranium, another contaminant of concern in the 300 Area, is slow to attenuate and DOE is investigating alternative remedial actions.

\section{Working Toward Final Groundwater Remediation}

Decisions. Final decisions for groundwater remediation have been made only for the 1100-EM-1 Operable Unit. During 2004, DOE and the regulatory agencies continued the process to determine what information is needed to make final decisions for the 100-BC-5, 100-FR-3, 200-BP-5, 200-UP-1, 200-ZP-1, 200-PO-1, and 300-FF-5 Operable Units (Figure 8.7.1).

\subsubsection{Groundwater Monitoring at Waste Facilities}

Monitoring at RCRA Units. Monitoring continued in 2004 at 24 RCRA units (or waste management areas) on the Hanford Site (Table 8.7.3 and Figure 8.7.2). At the end of 2004, 15 RCRA waste management areas were monitored to detect whether they were contaminating groundwater with hazardous constituents. Seven waste management areas were monitored to assess the extent of known contaminants, and two were monitored to determine the progress of corrective action for groundwater contamination. The facilities monitored under RCRA are scheduled for closure under the Hanford Site Part B RCRA Permit except for the Liquid Effluent Retention Facility, low-level burial grounds (Waste Management Areas 1 to 4), and the planned Integrated Disposal Facility; these will receive permits as operating facilities.

Monitoring at Other Regulated Units. Groundwater monitoring was required for four regulated, non-RCRA waste facilities in 2004 (Table 8.7.3). The 200 Area Treated Effluent Disposal Facility and State-Approved Land Disposal Site are monitored under state discharge permits (WAC 173-216). The Solid Waste Landfill is monitored for the requirements of WAC 173-304, Minimum Functional Standards for Solid Waste Handling. The Environmental Restoration Disposal Facility is a low-level, mixed waste facility where waste from surface remedial actions on the Hanford Site is disposed. Groundwater monitoring is conducted in accordance with a CERCLA record of decision. These facilities are monitored for waste constituents specified in their permits or other regulatory agreements.

\subsubsection{Groundwater Flow and Movement}

Groundwater in the unconfined aquifer generally flows from west to east across the Hanford Site to discharge areas along the Columbia River. The direction of groundwater flow is inferred from water-table elevations, barriers to flow (e.g., basalt or mud units at the water table), and the distributions of contaminants.

General directions of groundwater flow are illustrated on the map for March 2004 (Figure 8.7.3). Beneath the reactor areas, groundwater flows generally toward the Columbia River. Farther inland, north of Gable Mountain, flow is toward the northeast and east. Groundwater flows eastward beneath the 200 Areas and then flows to the southeast or north through the gap between Gable Butte and Gable Mountain. Groundwater converges on the 300 Area from the northwest, west, and southwest and discharges into the Columbia River to the east. Groundwater in the area south of the Hanford Site flows generally eastward to the Columbia River. 


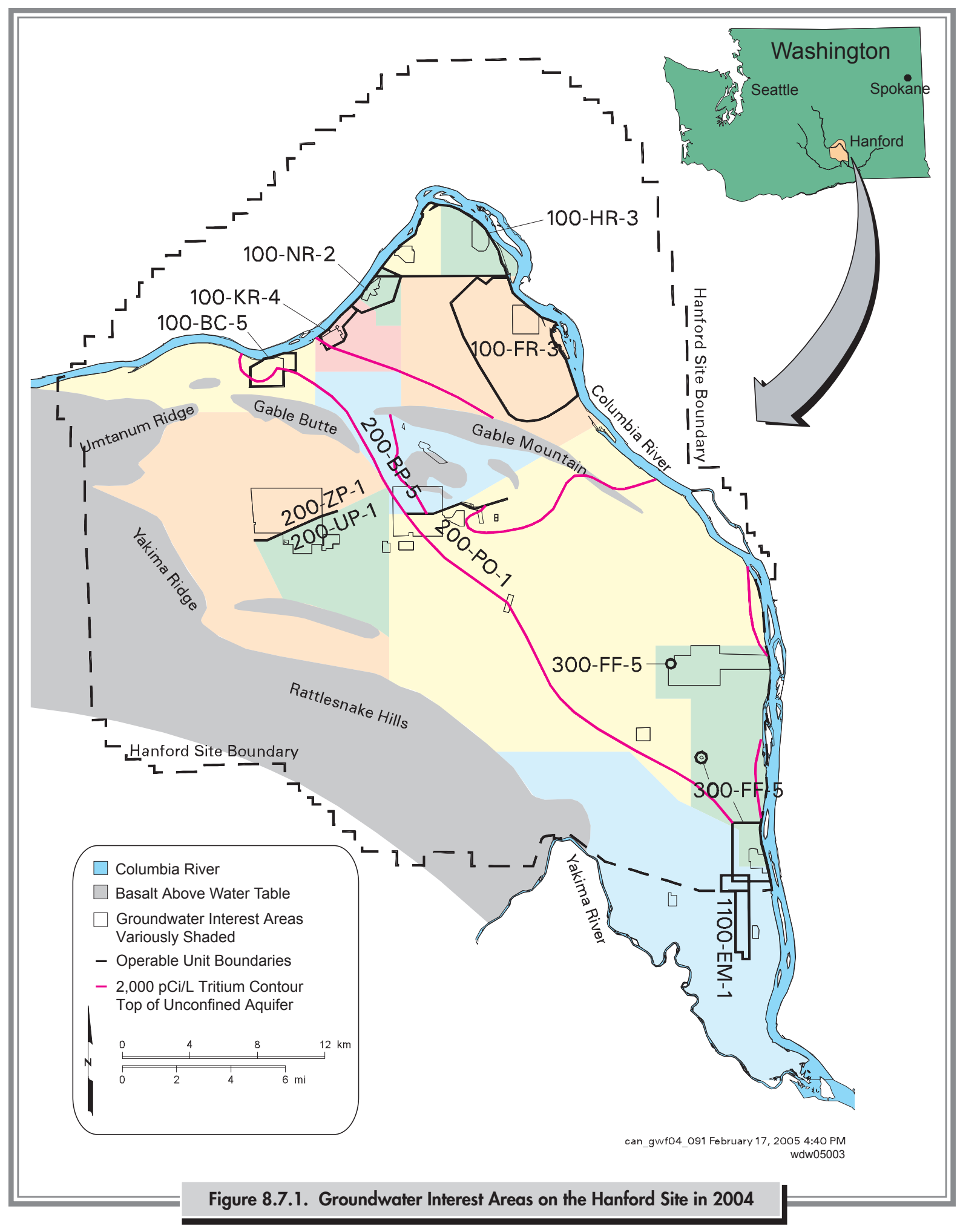


Table 8.7.3 Regulated Units Requiring Groundwater Monitoring on the Hanford Site, 2004

Site or Waste Management Area

116-N-1 (1301-N) facility

$116-\mathrm{N}-3(1325-\mathrm{N})$ facility

$120-\mathrm{N}-1,120-\mathrm{N}-2$

(1324-N/NA) facilities

116-H-6 (183-H) evaporation

basins

216-A-29 ditch

216-B-3 pond

216-S-10 pond and ditch

216-U-12 crib

$316-5$ process trenches

Integrated Disposal Facility

Liquid Effluent Retention

Facility

Low-Level Waste Management Area 1

Low-Level Waste Management Area 2

Low-Level Waste Management Area 3

Low-Level Waste Management Area 4

Nonradioactive Dangerous Waste Landfill

PUREX cribs

SST Waste Management

Area A-AX

SST Waste Management Area B-BX-BY

SST Waste Management Area C

SST Waste Management Area S-SX
Type of Monitoring

Program

Regulated Under

RCRA Regulated Units

Final status detection

Final status detection

Final status detection

Final status corrective action

Interim status detection

Interim status detection

Interim status detection

Interim status assessment

Final status corrective action

Pending completion of network

Interim status detection

Interim status detection

Interim status detection

Interim status detection

Interim status detection

Interim status detection

Interim status assessment

Interim status detection

Interim status assessment

Interim status detection

Interim status assessment
WAC 173-303-400; 40 CFR 265.93(b)

WAC 173-303-400; 40 CFR 265.93(b)

WAC 173-303-400;

40 CFR 265.93(b)

WAC 173-303-645(11)(g)

WAC 173-303-400; 40 CFR 265.93(b)

WAC 173-303-400; 40 CFR 265.93(b)

WAC 173-303-400; 40 CFR 265.93(b)

WAC 173-303-400; 40 CFR 265.93(d)

WAC 173-303-645(11)(g)

WAC 173-303-645

WAC 173-303-400; 40 CFR 265.93(b)

WAC 173-303-400; 40 CFR 265.93(b)

WAC 173-303-400; 40 CFR 265.93(b)

WAC 173-303-400; 40 CFR 265.93(b)

WAC 173-303-400; 40 CFR 265.93(b)

WAC 173-303-400; 40 CFR 265.93(b)

WAC 173-303-400; 40 CFR 265.93(d)

WAC 173-303-400; 40 CFR 265.93(b)

WAC 173-303-400; 40 CFR 265.93(d)

WAC 173-303-400; 40 CFR 265.93(b)

WAC 173-303-400; 40 CFR 265.93(d)

\section{Highlights}

Continued detection ${ }^{(\mathrm{a})}$

Continued detection ${ }^{(\mathrm{a})}$

Continued detection $^{(\mathrm{a})}$

Monitoring during CERCLA interim action; chromium, nitrate, technetium-99, uranium

Continued detection $^{(a)}$

Reverted to conventional statistics

Continued detection; ${ }^{(a)}$ only two shallow and one deep downgradient wells remain

Continued assessment; only two downgradient wells, no upgradient wells remain

Monitoring during CERCLA natural attenuation interim action; uranium and organics

Planned facility; 5 of 8 wells in place

Insufficient wells; no statistical comparisons

Continued detection ${ }^{(\mathrm{a})}$

Continued detection; $;^{(a)}$ north wells dry; no unconfined aquifer

Continued detection; ${ }^{(a)}$ three wells went dry

Continued detection ${ }^{(a)}$ until last shallow downgradient well went dry

Continued detection ${ }^{(a)}$

Continued assessment; iodine-129, nitrate, and tritium

Continued detection; ${ }^{(\mathrm{a})}$ two corroded wells decommissioned; two new wells installed

Continued assessment; nitrate, nitrite, technetium-99, uranium; 3 wells installed.

Temporarily ceased upgradient/ downgradient comparisons

Continued assessment; chromium, technetium-99; new well planned 


\begin{tabular}{|c|c|c|c|}
\hline & Table 8.7.3 (cont'd) & $\left.n t^{\prime} d\right)$ & \multirow[b]{2}{*}{2004 Highlights } \\
\hline $\begin{array}{c}\text { Site or Waste Management } \\
\text { Area }\end{array}$ & $\begin{array}{c}\text { Type of Monitoring } \\
\text { Program }\end{array}$ & Regulated Under & \\
\hline $\begin{array}{l}\text { SST Waste Management } \\
\text { Area T }\end{array}$ & Interim status assessment & $\begin{array}{l}\text { WAC 173-303-400; } \\
40 \text { CFR 265.93(d) }\end{array}$ & $\begin{array}{l}\text { Continued assessment; techne- } \\
\text { tium-99; } 3 \text { new wells planned }\end{array}$ \\
\hline $\begin{array}{l}\text { SST Waste Management } \\
\text { Area TX-TY }\end{array}$ & Interim status assessment & $\begin{array}{l}\text { WAC 173-303-400; } \\
\text { 40 CFR 265.93(d) }\end{array}$ & $\begin{array}{l}\text { Continued assessment; chromium, } \\
\text { technetium-99; new well planned }\end{array}$ \\
\hline $\begin{array}{l}\text { SST Waste Management } \\
\text { Area U }\end{array}$ & Interim status assessment & $\begin{array}{l}\text { WAC 173-303-400; } \\
\text { 40 CFR 265.93(d) }\end{array}$ & $\begin{array}{l}\text { Continued assessment; nitrate, } \\
\text { technetium-99; one well installed }\end{array}$ \\
\hline \multicolumn{4}{|c|}{ Other Regulated Units } \\
\hline $\begin{array}{l}200 \text { Area Treated Effluent } \\
\text { Disposal Facility }\end{array}$ & Compliance with permit & WAC $173-216$ & No influence on upper aquifer \\
\hline $\begin{array}{l}\text { Environmental Restoration } \\
\text { Disposal Facility }\end{array}$ & Similar to RCRA detection & ROD 1995 & No impact on groundwater \\
\hline $\begin{array}{l}\text { State Approved Land Disposal } \\
\text { Site }\end{array}$ & Compliance with permit & WAC $173-216$ & $\begin{array}{l}\text { No permit limits exceeded; } 2 \text { dry } \\
\text { wells }\end{array}$ \\
\hline Solid Waste Landfill & Compliance with permit & WAC 173-304 & $\begin{array}{l}\text { Five constituents exceeded back- } \\
\text { ground or standards; low levels of } \\
\text { organics }\end{array}$ \\
\hline $\begin{array}{ll}\text { (a) Analysis of RCRA CIP pro } \\
\text { CIP } & =\text { Contamination } \mathrm{i} \\
\text { CERCLA } & =\text { Comprehensive E } \\
\text { CFR } & =\text { Code of Federal } \\
\text { PUREX } & =\text { Plutonium-Uran } \\
\text { RCRA } & =\text { Resource Conserv } \\
\text { ROD } & =\text { Record of decisi } \\
\text { SST } & =\text { Single-shell tank } \\
\text { WAC } & =\text { Washington Admi }\end{array}$ & $\begin{array}{l}\text { no evidence of groundwater co } \\
\text { or parameters. } \\
\text { nental Response, Compensation } \\
\text { ons. } \\
\text { xtraction Plant. } \\
\text { nd Recovery Act. } \\
\text { ive Code. }\end{array}$ & $\begin{array}{l}\text { on with hazardous con } \\
\text { lity Act. }\end{array}$ & from the unit. \\
\hline
\end{tabular}

The natural pattern of groundwater flow was altered during the Hanford Site's operating years by the formation of mounds in the water table. The mounds were created by the discharge of large volumes of wastewater to the ground and were present in each reactor area and beneath the 200 Areas. Since effluent disposal decreased significantly in the 1990s, these mounds are disappearing.

East of the 200-East Area, a fine-grained confining unit creates a barrier to movement in the surrounding unconfined aquifer. Beneath this confining unit, the uppermost aquifer is a permeable unit in the Ringold Formation. Groundwater flow in this confined aquifer still is influenced by a recharge mound.

Groundwater in the upper basalt-confined aquifer generally flows from west to east across the Hanford Site, up through the unconfined aquifer, and into the Columbia River. Vertical gradients between the basalt-confined aquifer and the unconfined aquifer are upward on most of the Hanford Site. Therefore, there is little potential for contaminants to migrate from the unconfined aquifer into the basalt-confined aquifer, where it could move offsite. Downward gradients are measured beneath the west portion of the Hanford Site and north and east of the Columbia River.

\subsubsection{Groundwater Monitoring Results}

This section summarizes results of Hanford Site groundwater monitoring for various requirements, including RCRA and CERCLA monitoring.

\subsubsection{Overview}

DOE has developed a plan to accelerate cleanup of Hanford's groundwater, which will return it to its beneficial use where practicable or will at least prevent further degradation (DOE/RL-2002-68). Specific results that can be expected using the accelerated plan include (a) remediating 


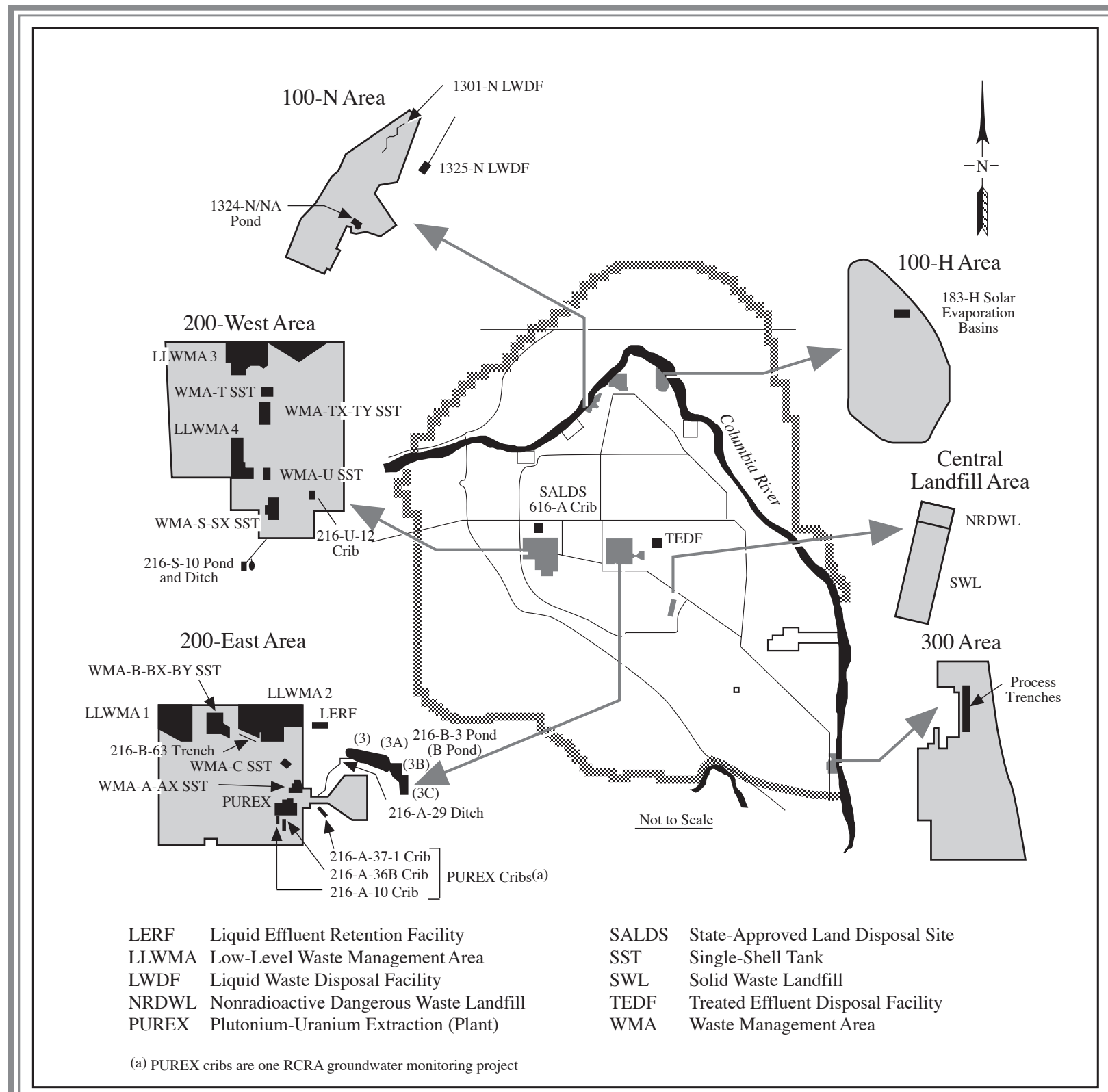

G05030031.94

\section{Figure 8.7.2. Locations of the Regulated Waste Management Units on the Hanford Site During 2004}

waste sites that pose the highest risk to groundwater, (b) shrinking the contaminated areas, (c) reducing groundwater recharge associated with operational discharges to the ground, (d) remediating groundwater, and (e) monitoring groundwater contaminant levels. Figures 8.7.4 and 8.7.5 show the distribution of nine principal groundwater contaminant plumes.

The total area of radiological and chemical contaminant plumes with contaminant concentrations exceeding drinking water standards was estimated to be approximately
170 square kilometers (66 square miles) during 2004 (Table 8.7.4). This area occupies $11.2 \%$ of the total area of the Hanford Site. The tritium and iodine-129 plumes have the largest areas with concentrations exceeding drinking water standards. These dominant plumes had sources in the 200-East Area and extend toward the east and southeast. Extensive tritium and iodine-129 plumes are also present in 200-West Area. Technetium-99 exceeds standards in plumes within both the 200-East and 200-West Areas. One technetium-99 plume has moved 


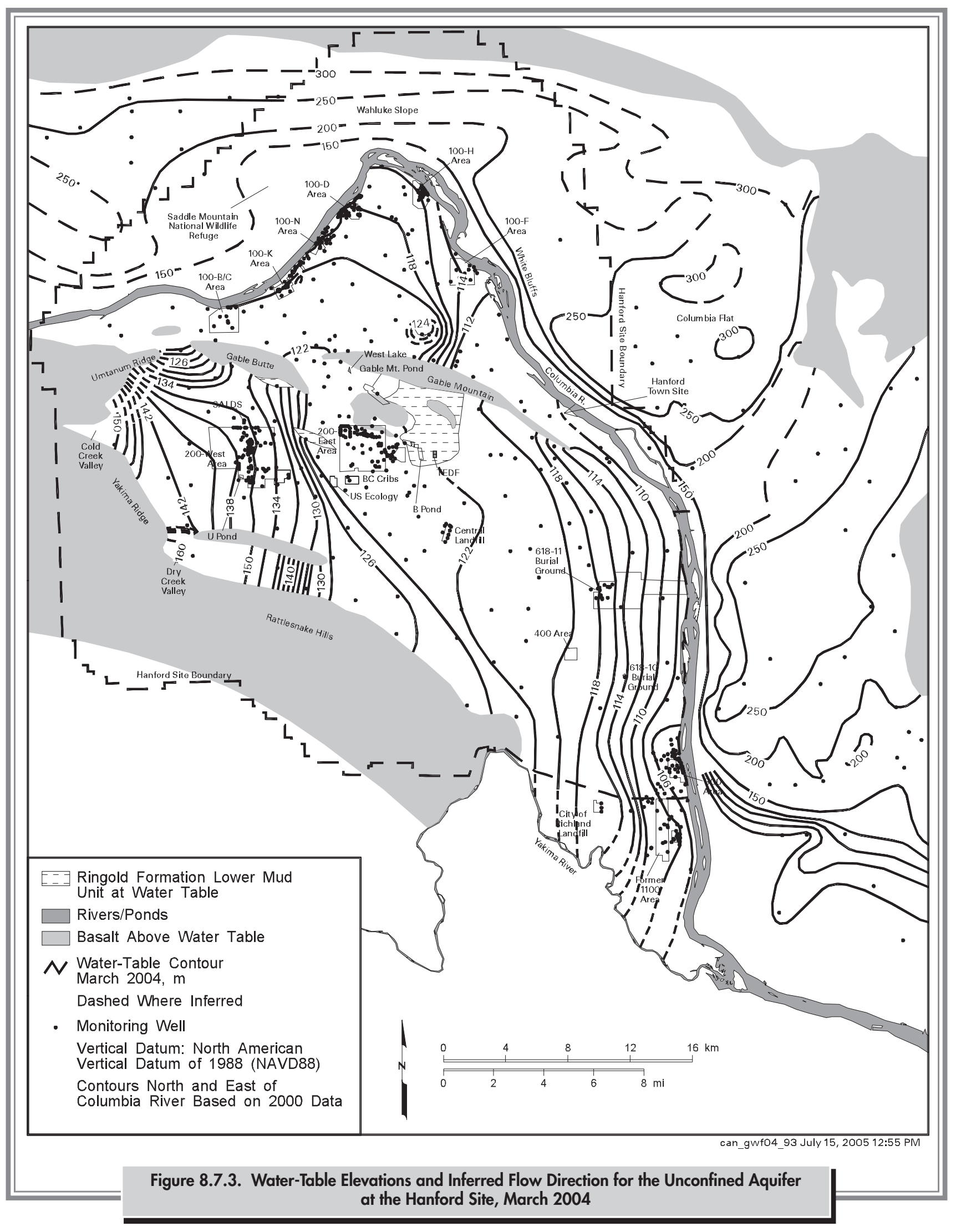




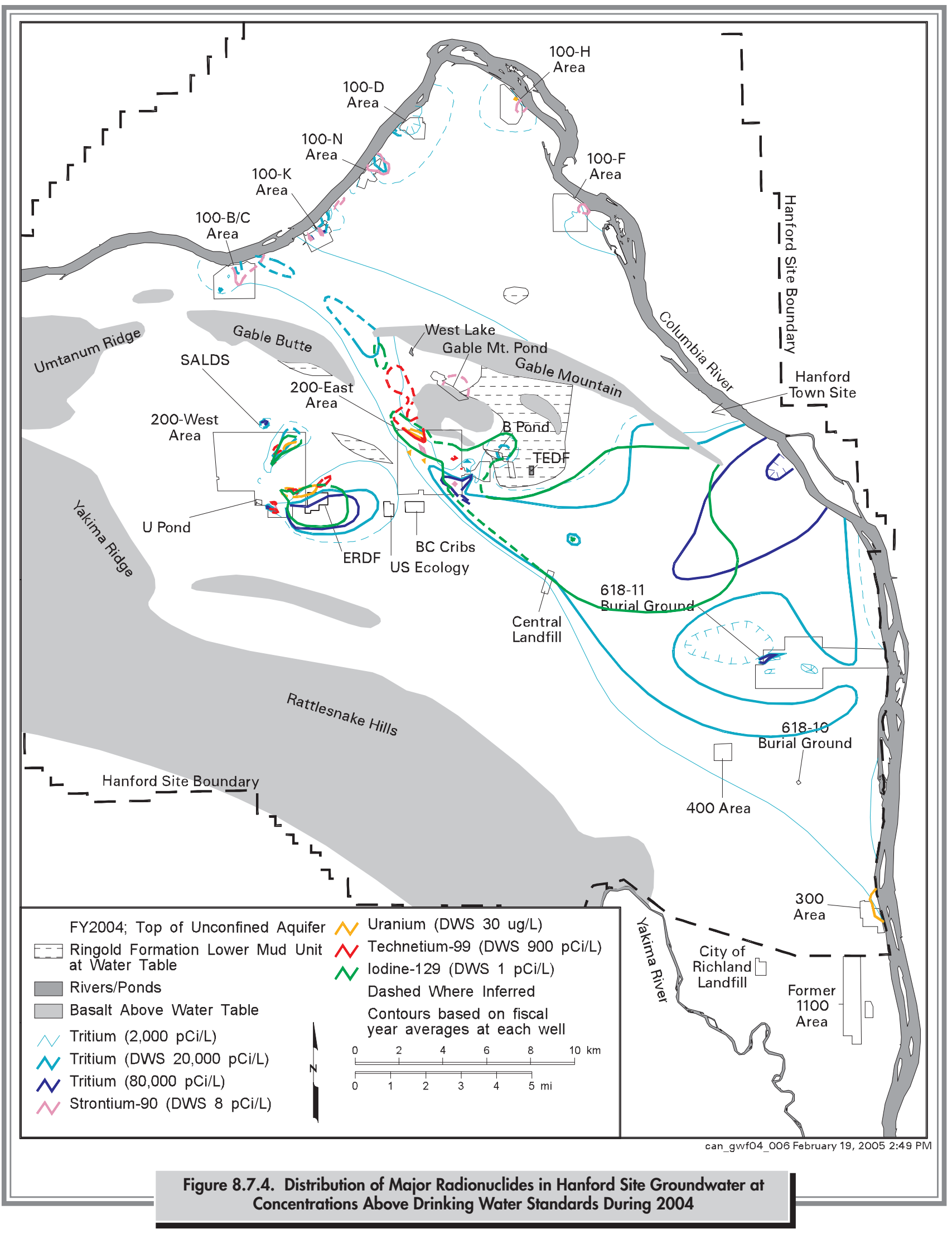




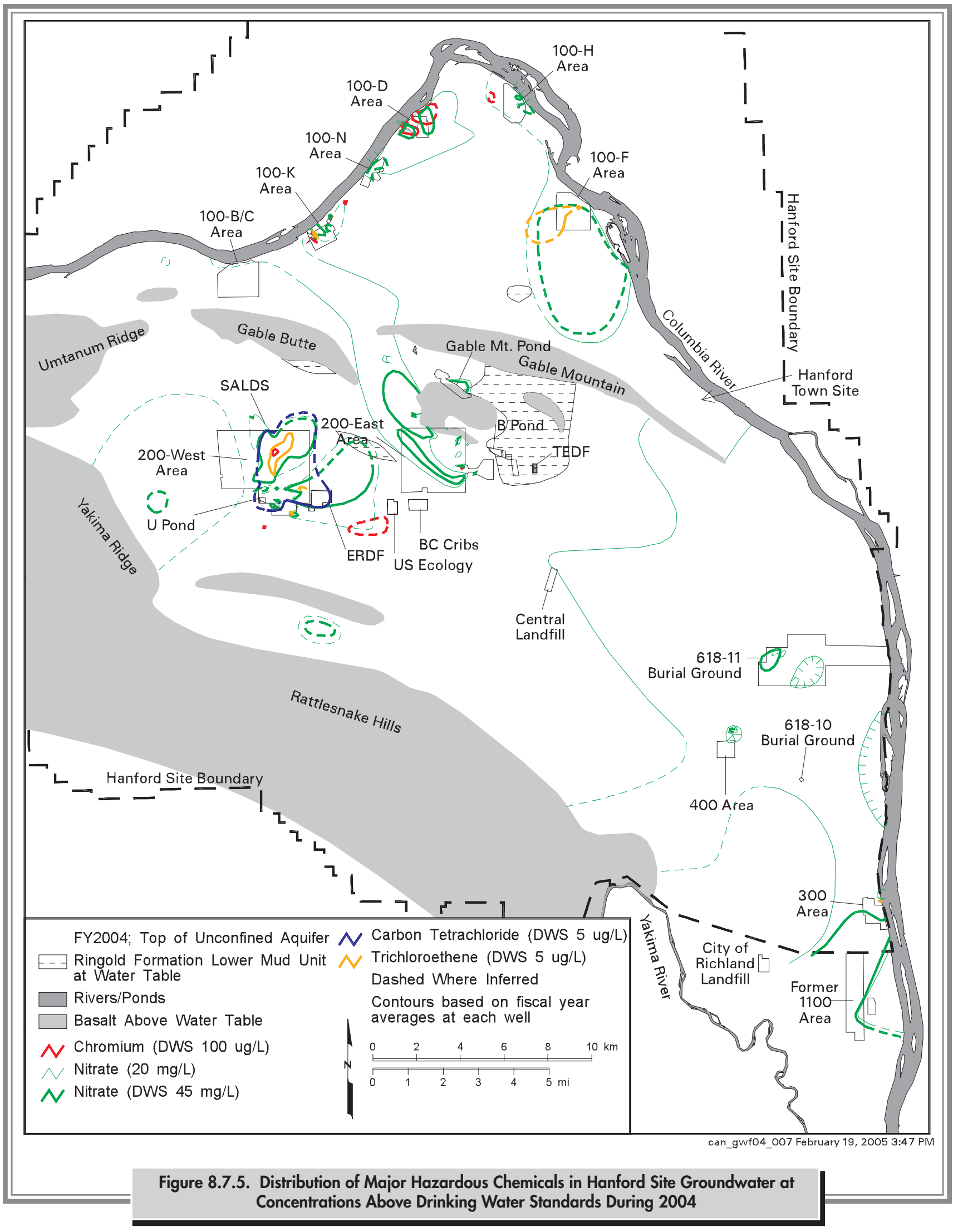




\begin{tabular}{|c|c|c|c|c|c|}
\hline \multirow[b]{2}{*}{$\underline{\text { Constituent }}$} & \multicolumn{5}{|c|}{$\begin{array}{l}\text { Areas of Contaminant Plumes on the Hanford Site at Levels Above Drinking Water } \\
\text { Standards, } 2004\end{array}$} \\
\hline & $\begin{array}{c}\text { Drinking Water } \\
\text { Standard }\end{array}$ & $\underline{\text { Area }\left(\mathbf{k m}^{2}\right)}$ & Constituent & $\begin{array}{c}\text { Drinking Water } \\
\text { Standard }\end{array}$ & $\underline{\text { Area }\left(\mathbf{k m}^{2}\right)}$ \\
\hline Tritium & $20,000 \mathrm{pCi} / \mathrm{L}$ & 138 & Dissolved chromium & $\overline{100 \mu \mathrm{g} / \mathrm{L}}$ & 2.3 \\
\hline Iodine-129 & 1 pCi/L & 74.4 & Strontium-90 & $8 \mathrm{pCi} / \mathrm{L}$ & 2.6 \\
\hline Nitrate & $45 \mathrm{mg} / \mathrm{L}$ & 42.2 & Technetium-99 & $900 \mathrm{pCi} / \mathrm{L}$ & 2.4 \\
\hline Carbon tetrachloride & $5 \mu \mathrm{g} / \mathrm{L}$ & 10.9 & Total uranium & $30 \mu \mathrm{g} / \mathrm{L}$ & 1.3 \\
\hline Trichloroethene & $5 \mu \mathrm{g} / \mathrm{L}$ & 3.3 & Combined plumes & & $171^{(\mathrm{a})}$ \\
\hline \multicolumn{6}{|c|}{$\begin{array}{l}\text { (a) Total reflects some overlap of contaminant plumes. } \\
1 \mathrm{pCi} / \mathrm{L}=0.037 \mathrm{~Bq} / \mathrm{L} \\
1 \mu \mathrm{L} / \mathrm{L}=0.001 \mathrm{ppm} . \\
1 \mathrm{mg} / \mathrm{L}=1 \mathrm{ppm} .\end{array}$} \\
\hline
\end{tabular}

northward from the 200-East Area. Uranium is less mobile than tritium, iodine-129, or technetium-99; smaller uranium plumes are found in the 200-East, 200-West, and 300 Areas. Strontium-90 is not very mobile in groundwater, but it forms a plume in the $100-\mathrm{N}$ Area and exceeds the drinking water standard in each of the 100 Areas. Other radionuclides including cesium-137 and cobalt- 60 are even less mobile in the subsurface and rarely exceed drinking water standards in Hanford Site groundwater.

Nitrate is a widespread chemical contaminant in Hanford Site groundwater; plumes originate from the 100 and 200 Areas and from offsite industry and agriculture. Carbon tetrachloride, the most widespread organic contaminant on the Hanford Site, forms a large plume beneath the 200-West Area. Other organic contaminants include chloroform, found in the 200-West Area, and trichloroethene. The largest trichloroethene plume is found in the 200-West Area with smaller plumes in the 100-K and 100-F Areas. Chromium contamination underlies portions of the 100-K, 100-D, and 100-H Areas. Smaller plumes of chromium contamination also are present in the 200 Areas, particularly the north part of 200-West Area.

Summaries of maximum concentrations in Hanford Site groundwater for the most widespread contaminants are presented by groundwater interest area in Table 8.7.5 and by monitoring purpose in Table 8.7.6. As expected, most of the maximum concentrations were detected in the 100 and 200 Areas because these areas contain the largest number of waste sites that have affected groundwater quality. For each monitoring purpose, the maximum concentrations detected were greater than the drinking water standards for all of the most widespread contaminants listed in Table 8.7.6. A list of drinking water standards for these contaminants is provided in Table D.2 in Appendix D.

The following text discusses groundwater contamination, monitoring, and remediation in each of the 11 groundwater operable units (Figure 8.7.1) and in the confined aquifers.

\subsubsection{Groundwater Monitoring Results for the 100-BC-5 Operable Unit}

The 100-BC-5 Operable Unit includes the groundwater beneath the 100-B/C Area (Figure 8.7.1). Most of the groundwater contamination in this unit is found in the north portion of the area, beneath former waste trenches and retention basins. In 2004, tritium and strontium-90 exceeded drinking water standards in several wells. Nitrate and chromium were somewhat elevated, but have been below drinking water standards in recent years.

\subsubsection{Groundwater Monitoring Results for the 100-KR-4 Operable Unit}

The principal groundwater issues in the 100-KR-4 Operable Unit include (a) remediation of groundwater beneath a large liquid-waste disposal trench, (b) tracking contaminant plumes from other past-practices sites, and (c) monitoring groundwater contaminants near the $\mathrm{KE}$ and $\mathrm{KW}$ Basins. Monitoring to detect leaks is underway for 


\begin{tabular}{|c|c|c|c|c|c|c|c|}
\hline & \multicolumn{6}{|c|}{$\begin{array}{l}\text { Table 8.7.5. Summary of Maximum Contaminant Concentrations in Hanford Site } \\
\text { Groundwater by Groundwater Interest Area, } 2004\end{array}$} & \multirow[b]{2}{*}{ 100-NR-2 } \\
\hline & Hanford Site & $100-\mathrm{BC}-5$ & 100-FR-3 & 100-HR-3-D & 100-HR-3-H & $100-K R-4$ & \\
\hline Tritium (pCi/L) & $2,320,000$ & 41,000 & 12,600 & 31,900 & 5,160 & 636,000 & 28,600 \\
\hline Iodine-129 (pCi/L) & 24.8 & NA & NA & NA & NA & NA & NA \\
\hline Nitrate (mg/L) & 7,610 & 28.8 & 166 & 70.8 & 244 & 132 & 270 \\
\hline $\begin{array}{l}\text { Carbon tetrachloride } \\
(\mu \mathrm{g} / \mathrm{L})\end{array}$ & 5,600 & ND & ND & NA & NA & ND & ND \\
\hline $\begin{array}{l}\text { Trichloroethene } \\
(\mu \mathrm{g} / \mathrm{L})\end{array}$ & 15 & NA & 9.2 & NA & NA & 5.5 & ND \\
\hline $\begin{array}{l}\text { Filtered chromium } \\
(\mu \mathrm{g} / \mathrm{L})\end{array}$ & 2,864 & 33 & 61.1 & 2,864 & 132 & 565 & 170 \\
\hline Strontium-90 (pCi/L) & 7,390 & 39 & 22.6 & 8.2 & 38.8 & 2,380 & 7,390 \\
\hline Technetium-99 (pCi/L) & 62,300 & 124 & 150 & ND & 694 & 148 & ND \\
\hline \multirow[t]{2}{*}{ Total uranium ( $\mu \mathrm{g} / \mathrm{L})$} & 599 & NA & 22.7 & 5.8 & 93.5 & NA & NA \\
\hline & $\underline{1100-E M-1}$ & $\underline{200-B P-5}$ & $\underline{200-P O-1}$ & $\underline{200-U P-1}$ & $\underline{200-Z P-1}$ & $\underline{300-F F-5}$ & \\
\hline Tritium (pCi/L) & 394 & 45,300 & 616,000 & 339,000 & $1,830,000$ & $2,320,000$ & \\
\hline Iodine-129 (pCi/L) & $\mathrm{ND}$ & 5.8 & 9.9 & 13.6 & 24.8 & ND & \\
\hline Nitrate (mg/L) & 239 & 1,590 & 132 & 522 & 7,610 & 111 & \\
\hline $\begin{array}{l}\text { Carbon tetrachloride } \\
(\mu \mathrm{g} / \mathrm{L})\end{array}$ & ND & ND & 0.29 & 650 & 5,600 & 0.45 & \\
\hline $\begin{array}{l}\text { Trichloroethene } \\
(\mu \mathrm{g} / \mathrm{L})\end{array}$ & 2.3 & ND & 1.1 & 7.1 & 15 & 6.8 & \\
\hline $\begin{array}{l}\text { Dissolved chromium } \\
(\mu \mathrm{g} / \mathrm{L})\end{array}$ & ND & 56.8 & 73.7 & 558 & 733 & 10.9 & \\
\hline Strontium-90 (pCi/L) & $\mathrm{ND}$ & 6,360 & 21.1 & 32 & 1.4 & 3.4 & \\
\hline Technetium-99 (pCi/L) & 24.4 & 23,100 & 13,000 & 62,300 & 21,400 & 36.2 & \\
\hline Total uranium ( $\mu \mathrm{g} / \mathrm{L})$ & 19.6 & 590 & 7.1 & 599 & 250 & 241 & \\
\hline $\begin{array}{l}\overline{N A}=\text { Not analyzed } \\
\text { ND }=\text { Not detected }\end{array}$ & & & & & & & \\
\hline
\end{tabular}

Table 8.7.6. Summary of Maximum Contaminant Concentrations in Hanford Site Groundwater by Monitoring Purpose, 2004

\begin{tabular}{lccc}
\hline Restoration & & $\begin{array}{c}\text { Waste } \\
\text { Management }\end{array}$ & $\begin{array}{c}\text { Environmental } \\
\text { Surveillance }\end{array}$ \\
Tritium $(\mathrm{pCi} / \mathrm{L})$ & $2,320,000$ & $1,830,000$ & $2,320,000$ \\
Iodine-129 $(\mathrm{pCi} / \mathrm{L})$ & 13.6 & 24.8 & 7.1 \\
Nitrate $(\mathrm{mg} / \mathrm{L})$ & 7,610 & 7,610 & 730 \\
Carbon tetrachloride $(\mu \mathrm{g} / \mathrm{L})$ & 5,600 & 3,000 & 1,700 \\
Trichloroethene $(\mu \mathrm{g} / \mathrm{L})$ & 15 & 15 & 14 \\
Dissolved chromium $(\mu \mathrm{g} / \mathrm{L})$ & 2,864 & 733 & 2,864 \\
Strontium-90 $(\mathrm{pCi} / \mathrm{L})$ & 7,390 & 1,200 & 7,390 \\
Technetium-99 $(\mathrm{pCi} / \mathrm{L})$ & 11,100 & 62,300 & 11,100 \\
Total uranium $(\mu \mathrm{g} / \mathrm{L})$ & 590 & 590 & 599 \\
\hline
\end{tabular}


the two basins, which are currently undergoing decontamination and decommissioning. New monitoring capabilities were added during 2004 in the form of additional aquifer tube sites along the $100-\mathrm{K}$ Area shoreline of the Columbia River. Two new groundwater wells were installed in 2004 to support the interim remedial action.

Interim Remedial Action. Groundwater beneath a liquidwaste disposal trench is being pumped and treated to reduce the amount of chromium reaching the Columbia River (see Section 8.7.4). The area of highest contamination has decreased in recent years.

Monitoring at Past-Practices Waste Sites. Contaminants of potential concern in the 100-KR-4 Operable Unit are carbon-14, nitrate, strontium-90, trichloroethene, and tritium. These contaminants are associated with waste disposal and facility operations that occurred during the years of reactor operations (1955 to 1971). While levels for all contaminants of concern remain above drinking water standards, decisions regarding remedial actions have been deferred until the waste sites are cleaned up. Some recent variability in contaminant concentrations is believed to be caused by remobilization of contaminants held in the vadose zone. Remobilization may result from infiltrating water from the ground surface or because of activities associated with remedial actions (e.g., excavation of waste sites).

Monitoring at $\mathrm{K}$ Basins. The $\mathrm{KE}$ and $\mathrm{KW}$ Basins are integral parts of the KE and KW Reactor buildings. Groundwater monitoring is conducted to help detect and evaluate any potential loss of water from the basins to the ground, because the remaining shielding water in the basins is highly contaminated with radionuclides. The last well-documented leakage of shielding water occurred in 1993 from a construction joint associated with the KE Basin. There has been no documented leakage from the KW Basin.

\subsubsection{Groundwater Monitoring Results for the 100-NR-2 Operable Unit}

The primary contaminant of concern in the 100-NR-2 Operable Unit is strontium-90, which is the focus of a pump-and-treat system that is intended to divert the contaminant from the Columbia River (see Section 8.7.4).
Strontium-90 concentrations are variable and the size and shape of the plume have been stable for many years.

Four RCRA units are located in the 100-NR-2 Operable Units: 116-N-1, 116-N-3, 120-N-1, and 120-N-2 (alsoknown as the 1301-N, 1325-N, 1324-N, and 1324-NA facilities). During 2004, these sites remained in detection monitoring programs to determine if the sites have affected groundwater quality with dangerous waste constituents.

\subsubsection{Groundwater Monitoring Results for the 100-HR-3-D Operable Unit}

The 100-HR-3 Operable Unit underlies the 100-D and 100- $\mathrm{H}$ Areas and the region between. The informally named 100-HR-3-D groundwater interest area comprises the west part of the 100-HR-3 Operable Unit, which includes the 100-D Area. Chromium is the primary contaminant of concern in the 100-D Area. The source of this contaminant was reactor cooling water treated with sodium dichromate to inhibit corrosion and discharged to cribs and ditches. Chromium is distributed in two plumes that are the targets of interim remedial actions (see Section 8.7.4). In 2004, concentrations of chromium remained above remediation goals in compliance wells. Three new wells and new aquifer tubes were installed in 2004 to support the interim remedial actions in this unit.

Sensor for Detecting Chromium in Groundwater. DOE deployed a sensor for detecting chromium on the 100-D Area Columbia River shoreline in 2004. The purpose of the deployment was to demonstrate the efficacy of such a system in the field. The system can measure chromium concentrations in monitoring wells and aquifer tubes at more frequent intervals than is practical using manual sampling techniques and can record and report results immediately. Results of the limited deployment showed that sensors are suitable for shoreline monitoring at the Hanford Site.

\subsubsection{Groundwater Monitoring Results for the 100-HR-3-H Operable Unit}

The east part of the 100-HR-3 Operable Unit, informally called the 100-HR-3-H groundwater interest area, 
underlies the $100-\mathrm{H}$ Area. Chromium is the primary groundwater contaminant of concern in this unit, but the plume is smaller and concentrations are lower than in the 100-D Area chromium plume. Nitrate also is elevated in groundwater here, but concentrations have declined from their peak levels. Strontium-90 concentrations exceed the drinking water standard beneath former wastewater retention basins. Groundwater levels of technetium-99 and uranium are elevated in a small area.

Chromium concentrations have decreased in recent years due to remediation and natural processes (Figure 8.7.6; see Section 8.7.4). However, concentrations in some compliance wells remained above the remediation goal $(22 \mu \mathrm{g} / \mathrm{L}$ [0.022 parts per million]). New aquifer tubes were installed in 2004 to improve monitoring coverage along the $100-\mathrm{H}$ Area Columbia River shoreline.
Monitoring at the 116-H-6 (183-H) Evaporation Basins. These former basins compose the only RCRA site in the 100-H Area. Leakage from the basins has contaminated groundwater with chromium, nitrate, and the non-RCRA regulated constituents, technetium-99(a) and uranium. The site is being monitored during the post-closure period to track contaminant trends during the operation of the CERCLA interim action (pump-and-treat system) for chromium.

\subsubsection{Groundwater Monitoring Results for the 100-FR-3 Operable Unit}

Nitrate concentrations exceed the drinking water standard in groundwater beneath much of the 100-F Area and

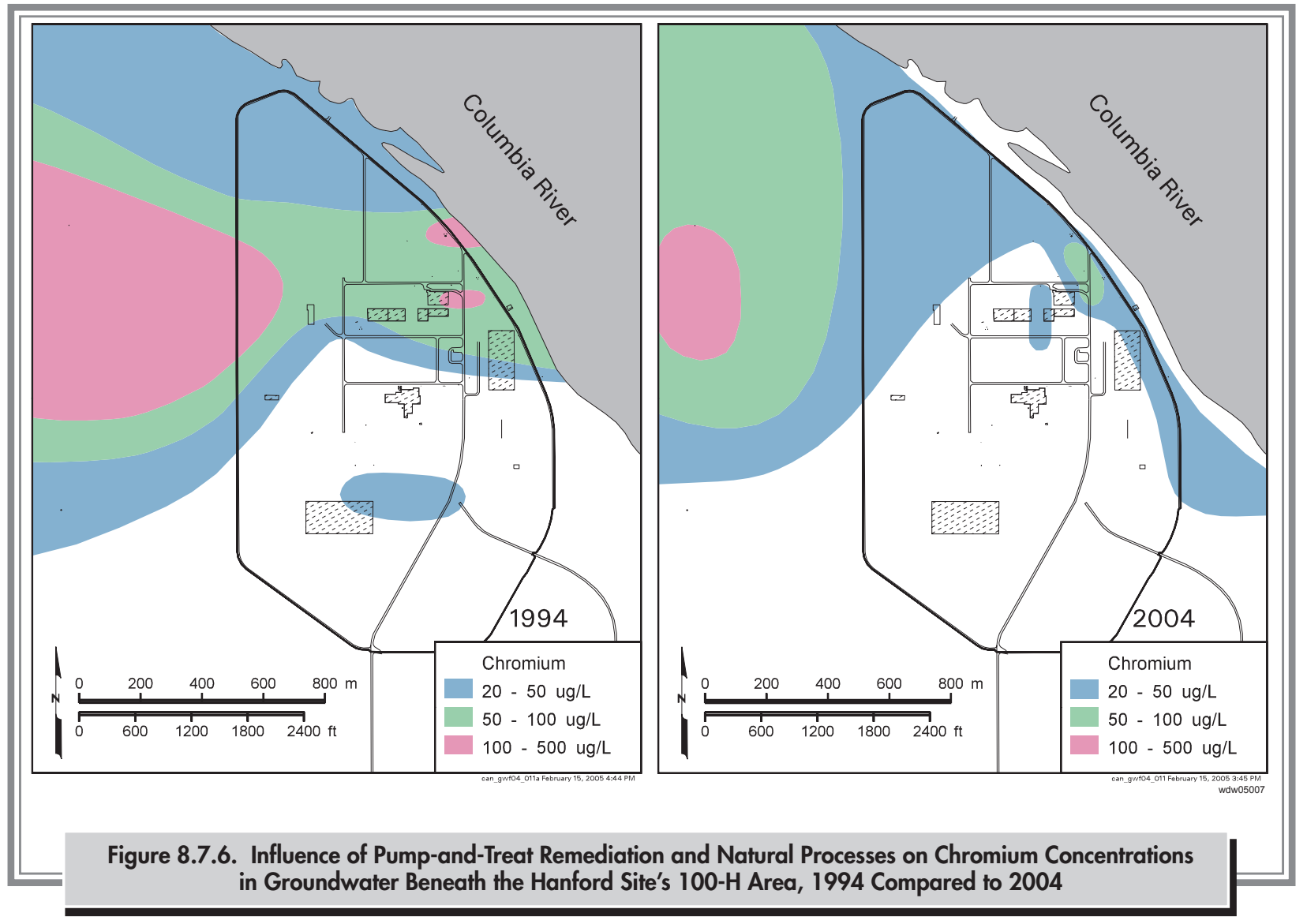

(a) For RCRA-regulated units, monitoring focuses on non-radioactive dangerous waste constituents. Radionuclides (source, special nuclear, and by-product materials) may be monitored in some RCRA unit wells to support objectives of monitoring under the Atomic Energy Act and/or CERCLA. Please note that pursuant to RCRA, the source, special nuclear, and by-product material components of radioactive mixed waste are not regulated under RCRA and are regulated by the DOE acting pursuant to its Atomic Energy Act authority. Therefore, while this report may be used to satisfy RCRA reporting requirements, the inclusion of information on radionuclides in such a context is for information only and may not be used to create conditions or other restrictions set forth in any RCRA permit or other RCRA regulatory requirements. 
the downgradient region. Other groundwater contaminants include strontium-90 and trichloroethene. New aquifer tubes were installed in 2004 to improve monitoring coverage in this unit at the Columbia River shoreline.

A record of decision has not yet been developed for the 100-FR-3 Operable Unit (Figure 8.7.1), and no active remediation of groundwater is underway. The monitoring of groundwater contaminants in this unit has continued since the initial remedial investigation.

\subsubsection{Groundwater Monitoring Results for the 200-ZP-1 Operable Unit}

The 200-ZP-1 Operable Unit encompasses the northern portion of the 200-West Area (Figure 8.7.1). The primary groundwater contaminant of concern is carbon tetrachloride, which forms the largest plume of chlorinated hydrocarbons on the Hanford Site and is the target of an interim remedial action (see Section 8.7.4). The carbon tetrachloride contamination had sources associated with past waste disposal from the Plutonium Finishing Plant, where organic chemicals were used to process plutonium. Trichloroethene and chloroform also are associated with this plume. Other contaminants in 200-ZP-1 Operable Unit groundwater include tritium, nitrate, chromium, fluoride, iodine-129, technetium-99, and uranium.

Carbon tetrachloride has migrated vertically and laterally farther in the aquifer than expected. The distribution of carbon tetrachloride is complex because it may travel as a dense, non-aqueous phase liquid, in the gaseous state, and dissolved in water. Most wells in the 200-West Area are screened at the top of the aquifer, but in recent years DOE has begun to study carbon tetrachloride deeper in the aquifer. In 2004, depth-discrete data collected during drilling of a well in the east-central region of the 200-West Area showed carbon tetrachloride concentrations of $32 \mu \mathrm{g} / \mathrm{L}$ (0.032 parts per million) near the water table and $1,300 \mu \mathrm{g} / \mathrm{L}$ (1.3 parts per million) at the bottom of the unconfined aquifer. Samples collected from the Ringold confined aquifer had lower concentrations, declining to $132 \mu \mathrm{g} / \mathrm{L}$ (0.132 parts per million) at the top of the basalt. Similar distribution with depth has been observed in other wells but not ubiquitously. DOE will continue to study the nature and extent of carbon tetrachloride contamination.
The 200-ZP-1 Operable Unit contains four facilities monitored under RCRA and the Atomic Energy Act and one site permitted by the state of Washington for waste discharge.

Monitoring at Low-Level Waste Management Areas 3 and 4. RCRA groundwater monitoring in Low-Level Waste Management Areas 3 and 4 (burial grounds) continued under interim status requirements in 2004. Monitoring networks for both of these waste management areas contain fewer than the optimal number of wells for groundwater monitoring because many wells have gone dry. DOE is working with the Washington State Department of Ecology to correct the deficiencies.

In June 2002, DOE submitted an application to incorporate the burial grounds into the Hanford Facility RCRA Permit (Ecology 1994). As part of the application, a groundwater monitoring program was proposed that included adding new wells, monitoring more constituents, and using a different method of statistically evaluating data to determine if the site is affecting groundwater quality. Workshops with the Washington State Department of Ecology to address their comments (i.e., Notice of Deficiency) on this application began in 2003 and continued through 2004.

Monitoring at Waste Management Area T. Results of a RCRA assessment and Atomic Energy Act monitoring indicate that Waste Management Area $\mathrm{T}$ probably has introduced technetium-99 and other contaminants from underground waste storage tanks to the uppermost aquifer in the area. Additional contamination (carbon tetrachloride, trichloroethene, chromium, and nitrate) from other facilities is likely also present in groundwater beneath the waste management area.

Monitoring at Waste Management Area TX-TY. Results of a RCRA assessment and Atomic Energy Act monitoring continued to indicate that groundwater in Waste Management Area TX-TY has been contaminated with chromium and other constituents from underground waste storage tanks. Other nearby sources of contamination make specific source determinations uncertain for some contaminants. Technetium-99, iodine-129, nitrate, and tritium are elevated in groundwater beneath this waste management area. 
Monitoring at the State-Approved Land Disposal Site. This active disposal facility is regulated under a Washington State waste discharge permit. The State-Approved Land Disposal Site is located just north of the 200-West Area. Groundwater beneath this facility is monitored for tritium and 15 other constituents. Concentrations in monitoring wells did not exceed permit enforcement limits during 2004.

\subsubsection{Groundwater Monitoring Results for the 200-UP-1 Operable Unit}

The 200-UP-1 Operable Unit underlies the south portion of the 200-West Area (Figure 8.7.1). The primary groundwater contaminants of concern in this operable unit are technetium-99 and uranium, which are the target of an interim remedial action (see Section 8.7.4). Tritium, iodine-129, and nitrate plumes also have sources in this operable unit. Sources of carbon tetrachloride were within the 200-ZP-1 Operable Unit, and the contamination underlies the 200-UP-1 Operable Unit as well.

There are four facilities monitored under RCRA and the Atomic Energy Act, one CERCLA interim action, and a CERCLA disposal site in the 200-UP-1 Operable Unit. Monitoring activities are summarized below.

Monitoring at the 216-U-12 Crib. A RCRA assessment and Atomic Energy Act monitoring continued at the 216-U-12 crib in 2004 (Figure 8.7.2). The crib is one of several sources that have contributed to nitrate and technetium-99 plumes in the area. Closure of the crib will be coordinated between RCRA and CERCLA regulations. The monitoring network contains just two usable, downgradient wells and no upgradient wells because some wells have gone dry.

Monitoring at the 216-S-10 Pond and Ditch. The 216-S-10 facility continued to be monitored under a RCRA interim status detection program in 2004 (Figure 8.7.2). The current RCRA monitoring network consists of only two downgradient wells because other wells have gone dry.

Monitoring at Waste Management Area S-SX. A RCRA assessment and Atomic Energy Act monitoring continued at Waste Management Area S-SX in 2004 (Figure 8.7.2).
Groundwater beneath this waste management area is contaminated with nitrate, chromium, and technetium-99 attributed to two general source areas within the waste management area. One well with very high technetium-99 concentrations continued to be purged at least 3,785 liters (1,000 gallons) after each quarterly sampling event in 2004, as the Washington State Department of Ecology requested beginning in 2003.

Monitoring at Waste Management Area U. A RCRA assessment and Atomic Energy Act monitoring continued at Waste Management Area U in 2004 (Figure 8.7.2). This waste management area has been identified as the source for a small contaminant plume that is limited to the downgradient (east) side of the site. Plume constituents of interest include chromium, nitrate, and technetium-99. One new well was installed at this waste management area in 2004.

Monitoring at the Environmental Restoration Disposal Facility. This facility is a low-level, mixed waste facility where waste from surface remedial actions on the Hanford Site is disposed. The site is designed to meet RCRA standards, although it is not permitted as a RCRA unit. Results of groundwater monitoring at the Environmental Restoration Disposal Facility continued to indicate that the facility has not adversely affected groundwater quality. Concentrations of gross beta emissions and chromium in groundwater at this facility declined in 2004 from those observed in 2003.

\subsubsection{Groundwater Monitoring Results for the 200-BP-5 Operable Unit}

The 200-BP-5 Operable Unit (Figure 8.7.1) includes groundwater beneath the north portion of the 200-East Area. Technetium-99 and tritium plumes extend northward between Gable Mountain and Gable Butte. Other contaminants include cesium-137, cobalt-60, cyanide, iodine-129, nitrate, plutonium, strontium-90, and uranium.

Groundwater monitoring under CERCLA continued in 2004. The sampling and analysis plan was revised to integrate Atomic Energy Act monitoring with CERCLA monitoring. There is no active groundwater remediation in this operable unit and final remediation decisions are yet to be made. 
There are five facilities in the 200-BP-5 Operable Unit that are monitored under RCRA and the Atomic Energy Act. Monitoring activities are summarized below.

Monitoring at Waste Management Area B-BX-BY. A RCRA assessment and Atomic Energy Act monitoring continued at Waste Management Area B-BX-BY in 2004. Uranium, technetium-99, nitrate, nitrite, and sulfate contamination observed in downgradient wells near this waste management area is believed to result from vertical movement of residual waste left in the soil under the B, BX, and BY Tank Farms. Three new wells were installed at this waste management area in 2004.

Monitoring at Waste Management Area C. Waste Management Area C (Figure 8.7.2) continued to be monitored under the Atomic Energy Act and an interim status RCRA detection program in 2004. Technetium-99 and nitrate are elevated in groundwater beneath the waste management area and may have originated in the C Tank Farm.

Monitoring at 216-B-63 Trench. The 216-B-63 trench (Figure 8.7.2) continued to be monitored under an interim status RCRA detection monitoring program in 2004. The average value for total organic carbon in one downgradient well near the 216-B-63 trench was higher in April 2004 than in previous samples. However, the value was below the limit of quantitation, so the results did not trigger assessment monitoring. The limit of quantitation is the level above which quantitative results may be obtained with a specified degree of confidence. The well was sampled in October 2004 and no total organic carbon was detected.

Monitoring at Low-Level Waste Management Areas 1 and 2. Low-Level Waste Management Areas 1 and 2 (Figure 8.7.2) continued to be monitored under RCRA interim status requirements and the Atomic Energy Act in 2004. Specific conductance continued to exceed its critical mean value at Low-Level Waste Management Area 1, and total organic carbon continued to exceed its critical mean value in an upgradient well at Low-Level Waste Management Area 2. However, both exceedances were reported previously and neither appears to indicate contamination from the burial grounds. Most wells in the north part of LowLevel Waste Management Area 2 are dry because of a declining water table.
In June 2002, DOE submitted an application to incorporate the low-level burial grounds into the Hanford Facility RCRA Permit (Ecology 1994). As part of the application, a groundwater monitoring program was proposed that included adding new wells, monitoring more constituents, and using a different method of statistically evaluating data to determine if the site is affecting groundwater quality. Workshops with the Washington State Department of Ecology to address comments (i.e., Notice of Deficiency) on this application began in 2003 and continued through 2004.

Monitoring at the Liquid Effluent Retention Facility. A 2001 letter from the Washington State Department of Ecology directed DOE to discontinue statistical evaluation of groundwater sample results at the Liquid Effluent Retention Facility (Figure 8.7.2) because all but two wells had gone dry and a 1999 variance to allow DOE to operate the remaining wells until an alternative monitoring system could be deployed had expired. DOE has continued to sample the two remaining wells at this facility but is not conducting statistical analyses of the analytical results. DOE and the Washington State Department of Ecology are exploring alternative approaches for monitoring groundwater at this facility.

\subsubsection{Groundwater Monitoring Results for the 200-PO-1 Operable Unit}

The 200-PO-1 Operable Unit (Figure 8.7.1) encompasses the south portion of the 200-East Area and a large portion of the Hanford Site extending to the east and southeast. This operable unit is contaminated with widespread plumes of tritium, nitrate, and iodine-129. Concentrations of tritium continued to decline as the plume attenuates naturally because of radioactive decay and dispersion (Figure 8.7.7). Other contaminants in this unit include strontium-90 and technetium-99, but these are limited to very small areas. CERCLA groundwater monitoring at the 200-PO-1 Operable Unit continued in 2004. There is no active groundwater remediation in this operable unit and final remediation decisions are yet to be made.

There are eight regulated units in the 200-PO-1 Operable Unit. Water supply wells in the 400 Area, which falls within the footprint of the 200-PO-1 Operable Unit, also are monitored. 


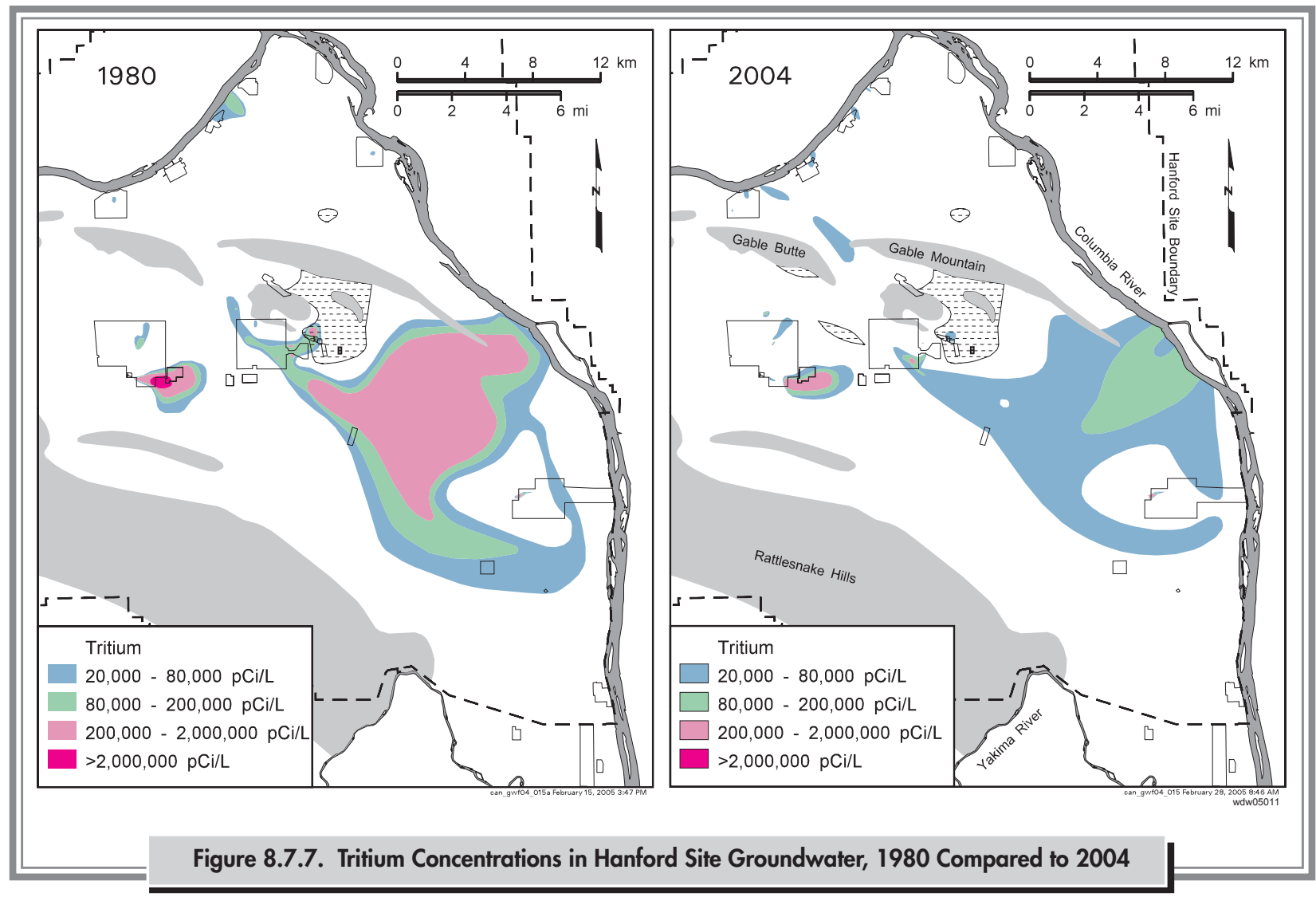

Monitoring at the Plutonium-Uranium Extraction (PUREX) Plant Cribs. Three cribs (216-A-10, 216-A-36B, and 216-A-37-1) are monitored at the Plutonium-Uranium Extraction (PUREX) Plant under a RCRA interim status assessment program and the Atomic Energy Act. The cribs have contributed to widespread contaminant plumes in the area, including nitrate, tritium, and iodine-129. Data show that over time the nitrate and tritium plumes are generally attenuating throughout most of their area. However, in recent years, the concentration of nitrate in wells near the Plutonium-Uranium Extraction (PUREX) Plant cribs has either held steady or increased.

Monitoring at Waste Management Area A-AX. Waste Management Area A-AX continued to be monitored under a RCRA interim status indicator evaluation program and the Atomic Energy Act in 2004. In 2004, one additional upgradient well and a replacement downgradient well were installed at this waste management area. Two downgradient wells formerly monitored for this site were decommissioned after it was confirmed with a borehole-video survey that each well suffered from extensive corrosion of the casing. Data in 2004 from a downgradient well installed in 2003 showed elevated nitrate and technetium-99. DOE is conducting additional studies to determine if the source of the contamination is the waste management area.

Monitoring at the 216-A-29 Ditch. The groundwater beneath the 216-A-29 ditch (Figure 8.7.2) continued to be monitored as required by RCRA interim status detection regulations. Specific conductance is increasing in three downgradient wells as groundwater quality returns to ambient conditions in response to the cessation of effluent disposal at B Pond (which has been decommissioned). Groundwater quality beneath the ditch closely resembles regional patterns.

Monitoring at the Integrated Disposal Facility. The Integrated Disposal Facility will be an expandable, lined, RCRA-compliant landfill. The groundwater monitoring network for this facility will consist of three upgradient wells and five downgradient wells. Three wells remain to be installed at the Integrated Disposal Facility; two will be installed in 2005 and the third will be installed at a future date when required by facility expansion. 
Monitoring at the 216-B-3 Pond. Monitoring for the 216-B-3 pond (B Pond) returned to a conventional RCRA interim status detection monitoring program in 2004. This change marked the end of a trial period for an alternate approach to groundwater monitoring and statistical data analysis at the site.

Monitoring at the Nonradioactive Dangerous Waste Landfill. The Nonradioactive Dangerous Waste Landfill is located in the 600 Area (Figure 8.7.2), within the footprint of the 200-PO-1 Operable Unit regional plume (Figure 8.7.1). Interim status detection monitoring continued 2004.

Monitoring at the Solid Waste Landfill. The Solid Waste Landfill (Figure 8.7.2) is adjacent to the Nonradioactive Dangerous Waste Landfill and is regulated under state solid waste regulations. In 2004, temperature, specific conductance, $\mathrm{pH}$, total organic carbon, chemical oxygen demand, chloride, sulfate, and coliform bacteria exceeded their background threshold levels (Table B.43 in PNNL-15070) in one or more samples.

Monitoring at the 200 Area Treated Effluent Disposal Facility. A state waste discharge permit governs groundwater sampling and analysis in the three monitoring wells at the 200 Area Treated Effluent Disposal Facility. No permit criteria for constituents in groundwater were exceeded in 2004. The groundwater monitoring network continues to show that effluent disposed to the ground at this facility is not affecting the uppermost aquifer, which is confined.

\subsubsection{Groundwater Monitoring Results for the 300-FF-5 Operable Unit}

The 300-FF-5 Operable Unit (Figure 8.7.1) is subdivided into three geographic regions: the 300 Area, the 618-11 burial ground region, and the 316-4 cribs and 618-10 burial ground region. The latter two regions are referred to informally as "300-FF-5 North." The operable unit is currently regulated under a record of decision that calls for continued monitoring of groundwater conditions and interim actions to help minimize the potential for human exposure to contaminants in groundwater (institutional controls) until contaminant source remedial actions are complete. The operable unit includes groundwater associated with a former liquid waste disposal site, where groundwater is also regulated under a RCRA final status, corrective action monitoring program.

Status of Interim Remedial Actions. Contaminants of concern in 300 Area groundwater are uranium, trichloroethene, and cis-1,2-dichloroethene. Monitoring and plume characterization activities indicate relatively constant or gradually decreasing levels for these contaminants. Uranium is the primary contaminant of concern and remains above the drinking water standard beneath approximately half of the 300 Area. The decrease in uranium concentrations predicted by modeling during the initial remedial investigation has not occurred as expected, so DOE has supported additional investigation of natural processes that lead to reduced concentrations as well as more detailed groundwater modeling. An update to the focused feasibility study for remedial action alternatives for uranium is also underway. The new information developed by these activities will be used to guide future remedial action decisions.

Groundwater downgradient of the 618-11 burial ground is contaminated by a high-concentration tritium plume, whose origin is believed to be materials in the burial ground. The concentration of tritium at a well adjacent to the burial ground has decreased since maximum values were measured in 2000 but is still the highest observed on the Hanford Site. Continued characterization and modeling are underway to predict the future movement of the narrow plume, which extends approximately 1 kilometer (0.62 mile) to the east of the waste site.

At the $316-4$ cribs and $618-10$ burial ground waste sites, uranium and tributyl phosphate are contaminants of potential concern; both are associated with the 316-4 cribs, which were removed during fall 2004. Current concentrations of uranium in the area are generally below the drinking water standard, although there is some suggestion that excavation activities may have remobilized vadose zone contamination. Tributyl phosphate has been undetected in recent samples. There is no evidence for impact to groundwater caused by contaminant releases from the 618-10 burial ground.

Monitoring at the 316-5 Process Trenches. This liquid waste disposal site, monitored under RCRA, was the last in the 300 Area to receive uranium-bearing effluent, with discharges ending in the early 1990s (Figure 8.7.2). The 
trenches have undergone two phases of remedial action (1991 and 1995), which included removal of contaminated soil and operational structures and backfilling with clean soil. Uranium currently exceeds the drinking water standard in wells downgradient from this waste site, although concentrations appear to be decreasing with time. Cis-1,2,dichloroethene exceeds the standard at only one downgradient well.

\subsubsection{Groundwater Monitoring Results for the 1100-EM-1 Operable Unit}

The 1100-EM-1 Operable Unit (Figure 8.7.1) includes a small, narrow plume of trichloroethene, which is attenuating naturally. Annual average concentrations have remained below the drinking water standard since 2001. Contaminants also flow into the unit from offsite sources (e.g., nitrate from agriculture and industry).

The city of Richland maintains a well field in the 1100-EM-1 groundwater interest area, which includes a much broader area than the operable unit. Wells near the well field are monitored frequently to detect any changes in Hanford contaminants near the city's wells. The tritium plume from the 200-East Area has not been detected in these wells. Low levels of tritium, similar to levels in Columbia River water, continued to be detected.

The selected remedy for cleaning up 1100-EM-1 Operable Unit groundwater is to continue to monitor the natural attenuation of volatile organic compounds.

\subsubsection{Groundwater Monitoring Results for the Confined Aquifers}

Although most of Hanford's groundwater contamination is in the unconfined aquifer, DOE monitors wells in deeper aquifers because of the potential for downward migration of contamination and migration of contamination offsite through the basalt-confined aquifer.

The Ringold Formation confined aquifer occurs within fluvial sand and gravel composing the lowest sedimentary unit of the Ringold Formation. It is confined below by basalt and above by the lower mud unit. Groundwater in this aquifer flows generally west to east in the vicinity of the 200-West Area. In the central portion of the aquifer, flow converges on the 200-East Area from the west, south, and east. Groundwater discharges from the confined aquifer into the overlying unconfined aquifer near the 200-East Area.

While effluent disposal was occurring at the $\mathrm{B}$ Pond system, which consists of 216-B-3, 216-B-3A, 216-B-3B, and $216-\mathrm{B}-3 \mathrm{C}$ ponds, groundwater mounding forced groundwater and any associated contamination a limited distance into the Ringold Formation confined aquifer. Groundwater analyses for 2004 at the 200 Area Treated Effluent Disposal Facility continued to demonstrate that the confined aquifer has not been influenced by disposal activities at this facility.

Within the upper basalt-confined aquifer system, groundwater occurs within basalt fractures and joints, interflow contacts, and sedimentary interbeds. Groundwater in the upper basalt-confined aquifer system generally flows from west to east across the Hanford Site, up through fractures or other pathways in the confining layers, into the unconfined aquifer, and into the Columbia River. Vertical gradients between the basalt-confined aquifer and the unconfined aquifer are upward on most of the Hanford Site. Downward gradients are measured west of the 200-East Area, near B Pond, and north and east of the Columbia River.

Results of sampling basalt-confined groundwater show that tritium was detected in some wells at very low levels, while iodine-129, strontium-90, gamma-emitting isotopes, and uranium isotopes were not detected. Cyanide, nitrate, and technetium-99 were elevated in one well in the north part of the 200-East Area, but contaminant migration during well construction is responsible for this contamination. Contaminants on the Hanford Site have not migrated through the upper basalt-confined aquifer system to offsite sampling locations south and southeast of the Hanford Site.

\subsubsection{Groundwater and Vadose Zone Remediation}

The overall objectives of groundwater and vadose zone remediation at sites adjacent to the Hanford Reach are to protect aquatic receptors in the river bottom substrate from contaminants in the groundwater entering the 
Columbia River, reduce levels of contamination in the areas of highest concentration, prevent further movement of contamination, and protect human health and the environment.

\subsubsection{Groundwater Remediation Using Pump-and-Treat Systems and In Situ Redox Manipulation Technology}

\section{G. G. Kelty and D. B. Erb}

Pump-and-treat systems continued to operate at five operable units, an in situ remediation system continued to operate at one operable unit, and a soil-gas vapor extraction system continued to operate at one operable unit during 2004 (Figure 8.7.8). A second pump-and-treat system was installed at the 100-HR-3 Operable Unit in 2004 to treat contaminated groundwater in the central part of the 100-D Area. Summary descriptions of groundwater remediation activities are provided in the following paragraphs. A summary of groundwater remediation activities at the Hanford Site is provided in Table 8.7.7.

Chromium. Groundwater contaminated with chromium underlies portions of the $100-\mathrm{D}, 100-\mathrm{H}$, and $100-\mathrm{K}$ Areas (the 100-HR-3 and 100-KR-4 Operable Units). Chromium is of concern because of its potential to affect the ecosystem of the Hanford Reach. Low levels of chromium are toxic to aquatic organisms, particularly those that use the riverbed sediment as habitat (DOE/RL-94-102; DOE/RL-94-113). The relevant standard for protection of freshwater aquatic life is $10 \mu \mathrm{g} / \mathrm{L}$ (0.01 parts per million) of chromium (WAC 173-201A). Chromium concentrations exceeding $600 \mu \mathrm{g} / \mathrm{L}$ ( 0.6 parts per million) have been measured in the porewater of riverbed sediment adjacent to the 100-D Area (BHI-00778). Background chromium concentrations are usually less than $1 \mu \mathrm{g} / \mathrm{L}$ (1 part per billion) in the river.

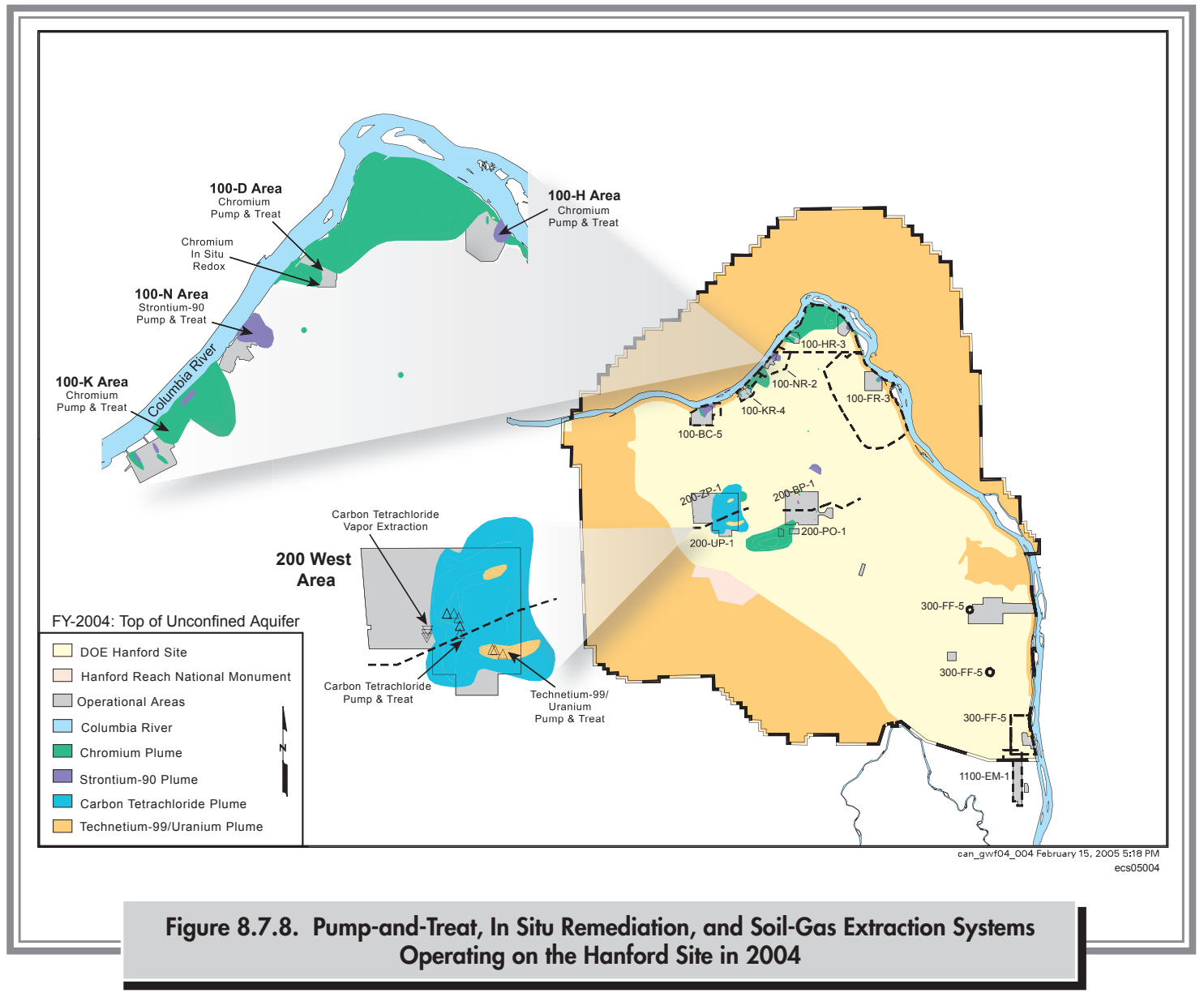




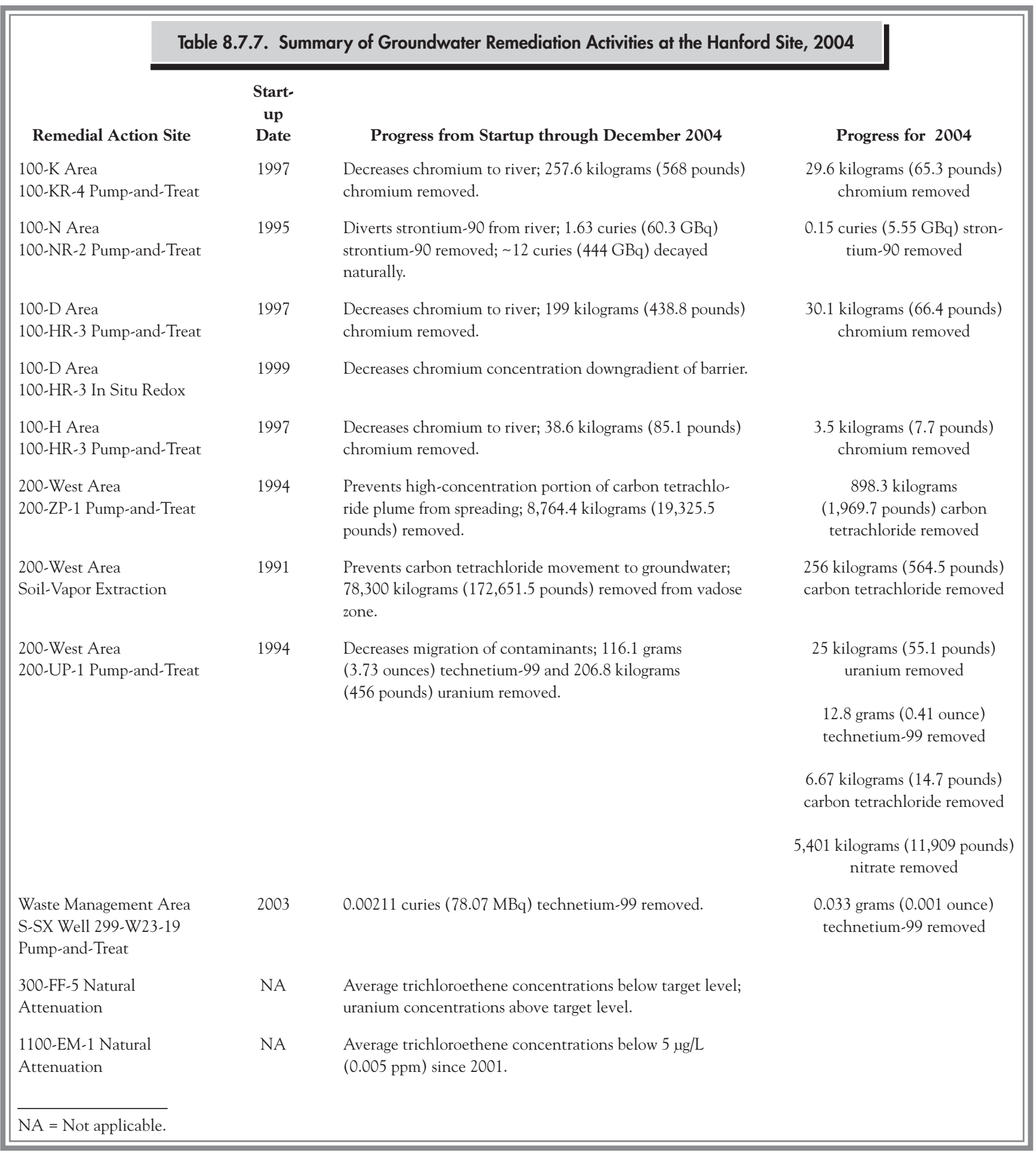


100-KR-4 Operable Unit. A pump-and-treat system is being used to remove chromium from the aquifer beneath a large, liquid-waste disposal trench in the 100-KR-4 Operable Unit. The purpose of the interim action is to reduce the amount of chromium entering the Columbia River at the 100-K Area (Figure 8.7.9). During 2004, the 100-KR-4 pump-and-treat system treated 493.3 million liters (130.3 million gallons) of groundwater and removed 29.2 kilograms (64.2 pounds) of chromium. Total chromium removed since operations began in 1997 is 249.9 kilograms (549.8 pounds) through treatment of 2.7 billion liters (713.3 million gallons) of water. Treated groundwater is re-injected into the aquifer upgradient from the 100-KR-4 extraction wells. Although the mapped extent of contamination has remained fairly constant during the past 10 years, the area of highest concentration has decreased markedly. The interim remedial action concentration goal for groundwater near the Columbia River is $22 \mu \mathrm{g} / \mathrm{L}$ (0.022 parts per million) chromium.

100-HR-3 Operable Unit Pump-and-Treat Systems.

During 1994, a pilot-scale groundwater extraction system was installed in the 100-D Area to test chromium removal from groundwater using ion exchange technology. Following the issuance of a record of decision in 1996 (EPA 1996a), full scale pump-and-treat systems were constructed in the 100-D, 100-H, and 100-K Areas (Figure 8.7.8). The objective of these systems is to remove chromium contamination from the groundwater and, thus, prevent or reduce the movement of chromium to the Columbia River.

During 2004, 310.5 million liters (82 million gallons) of groundwater were treated by pump-and-treat systems in the 100-D and 100-H Areas, and approximately 32.6 kilograms (71.8 pounds) of chromium were removed. Since 1997, more than 2.26 billion liters ( 596.7 million gallons) of groundwater have been treated, with 236.6 kilograms (520.6 pounds) of chromium removed. Treated groundwater is re-injected into the aquifer upgradient from the 100-H Area extraction wells. Groundwater from both the $100-\mathrm{D}$ and $100-\mathrm{H}$ Areas is treated in the $100-\mathrm{H}$ Area using separate treatment systems.

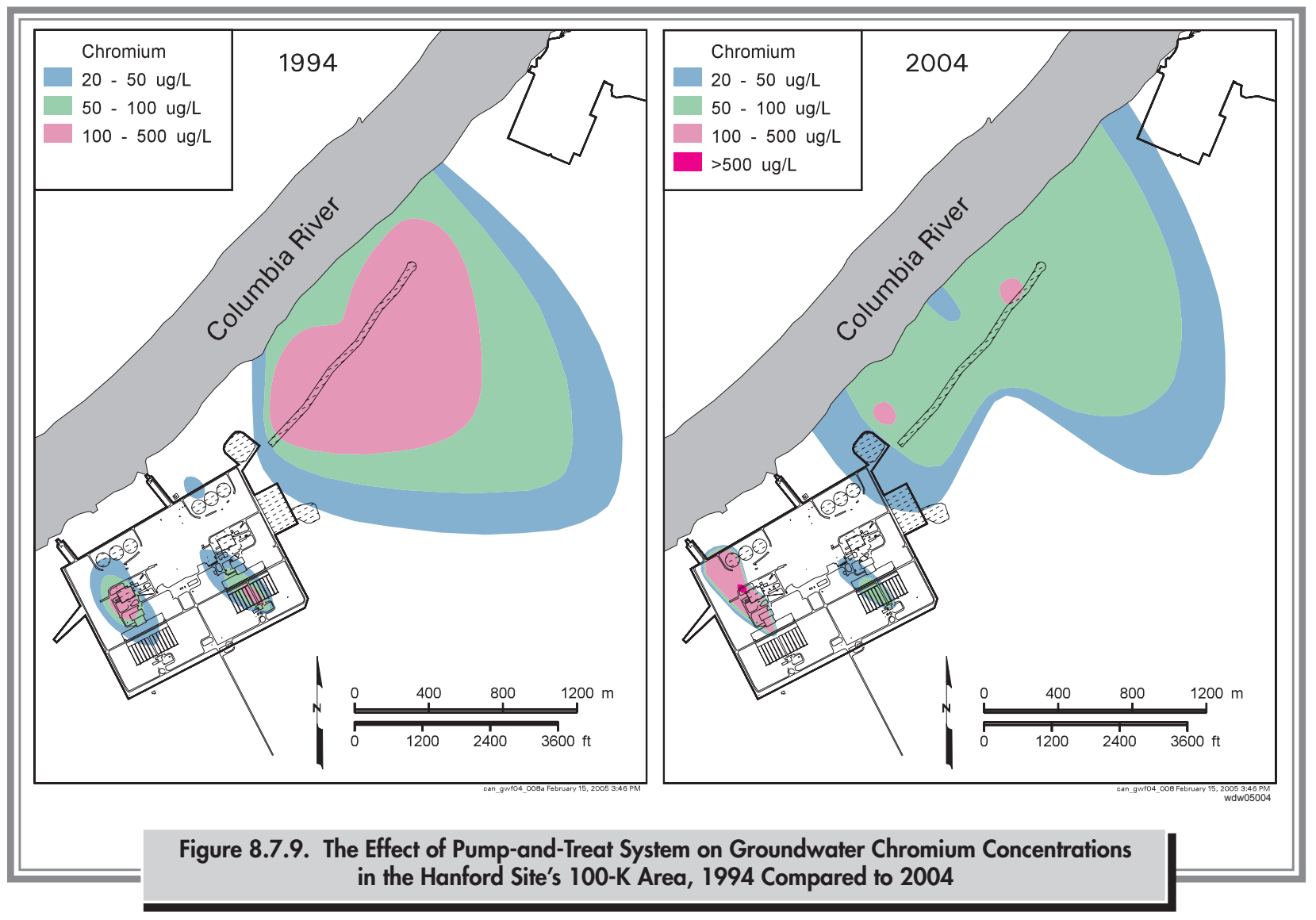


A new, $189 \mathrm{~L} / \mathrm{min}$ (50 gpm), ion exchange pump-and-treat system, 100-DR-5, was brought on line in the 100-D Area in June 2004 to intercept groundwater in the central 100-D Area near the Columbia River shoreline, where chromium concentrations had increased in recent years (Figure 8.7.10). Water is extracted at three downgradient wells at a combined rate of approximately $142 \mathrm{~L} / \mathrm{min}$ $(37.5 \mathrm{gpm})$, treated, and re-injected into an upgradient well. To date, 2.09 million liters (551,765 gallons) of water have been extracted and an estimated 1.9 kilograms (4.2 pounds) of chromium removed. This system is designed to capture a recently identified lobe of the chromium plume that is not contained by either the existing 100-D Area pump-and-treat system or an in situ redox manipulation barrier. This segment of the plume is suspected to have been mobilized by water leaks at the 182-D reservoir. The leaks were found to result when basin water depth exceeded 2.44 meters ( 8 feet); institutional controls no longer allow greater storage capacity. Monitoring wells were installed around the reservoir and delineated a significant water mound within the larger chromium plume. The leaks created a low-chromium concentration divide, forming two lobes initially. Since cessation of leaks, the two plumes appear to be merging.

\section{0-HR-3 Operable Unit In Situ Redox Manipulation.}

In addition to pump-and-treat remediation, use of in situ redox manipulation technology continued in the southwest portion of the 100-D Area to treat hexavalent chromium contamination in groundwater. This technology immobilizes hexavalent chromium by reducing the soluble, more toxic, chromate ion to highly insoluble, less toxic, chromic hydroxide or to a chromic-ferric hydroxide complex. This is accomplished by injecting a chemicalreducing agent into closely spaced wells to form a permeable reactive barrier. Following reduction, the reagent and reaction products are pumped out of the wells. Chromium is immobilized as groundwater naturally flows through the barrier. This groundwater cleanup technique was tested during 1997 through 1999 in five injection wells and then expanded to include additional injection wells in 2000, 2001, 2002, and 2003. During 2004, no additions were made to the system.

Past monitoring has shown that chromium concentrations in wells along the barrier axis are, generally, less than
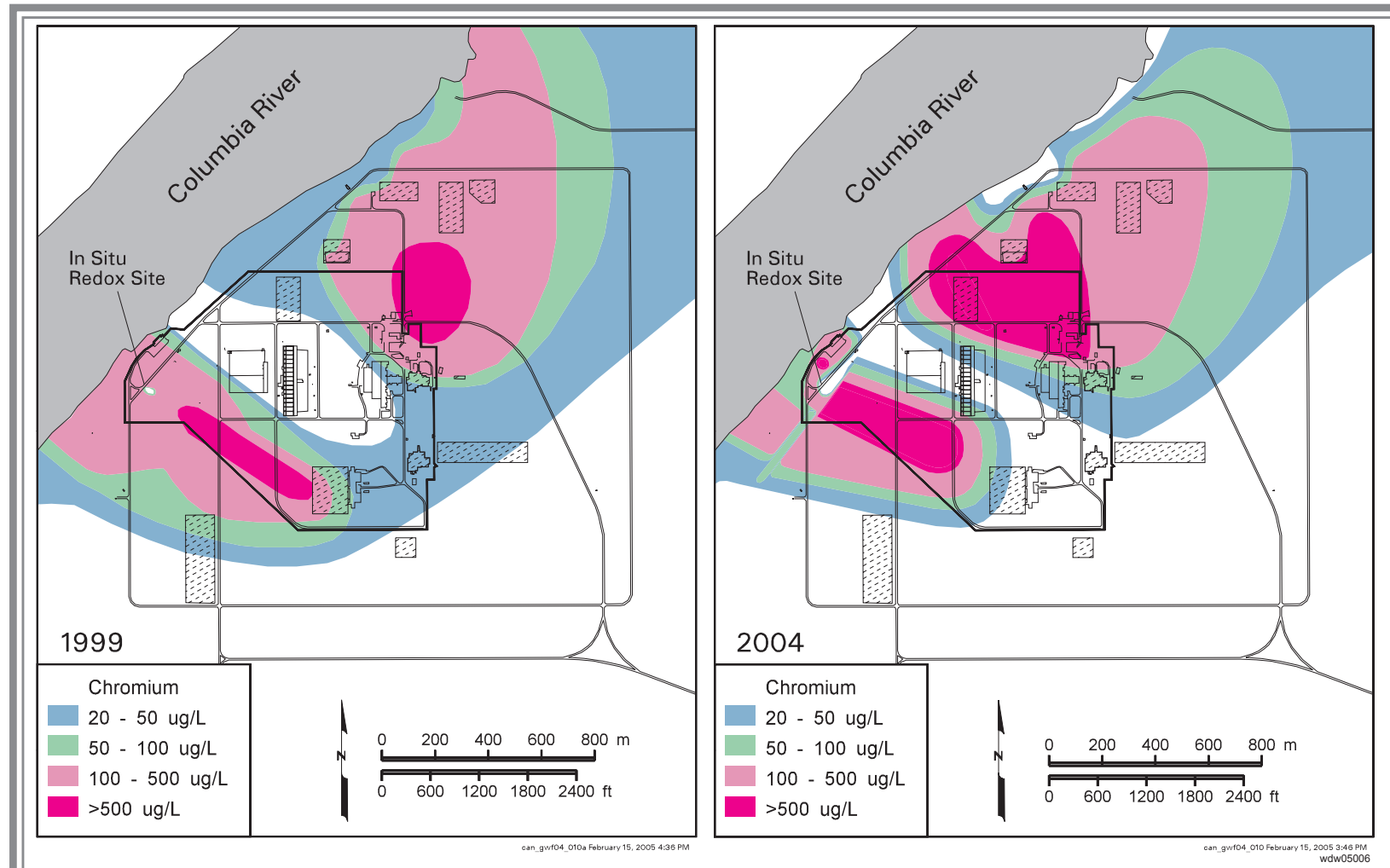

Figure 8.7.10. Chromium Concentrations in Hanford Site's Central 100-D Area Groundwater, 1999 Compared to 2004 
$20 \mu \mathrm{g} / \mathrm{L}$ (0.02 parts per million) except in 14 barrier wells where concentrations have increased to as high as $980 \mu \mathrm{g} / \mathrm{L}$ (0.98 parts per million). Compliance wells to the west of the barrier still have high concentrations ranging from 5 to $950 \mu \mathrm{g} / \mathrm{L}$ ( 0.005 to 0.95 parts per million). The barrier is 680 meters (2,230 feet) long and approximately 15 meters (48 feet) wide.

Bioremediation Research. DOE conducted field tests near the $100-\mathrm{H}$ Area in 2004 to demonstrate the feasibility of a remediation technology to immobilize hexavalent chromium in the aquifer. Researchers identified several types of bacteria in the sediment including species that are known to reduce or sorb hexavalent chromium. The natural microbial population is likely insufficient for direct chromium reduction, but the population was successfully stimulated during the field tests.

Strontium-90. The primary groundwater contaminant in the $100-\mathrm{N}$ Area is strontium-90, which originated at two former liquid waste disposal cribs. The extent of the strontium-90 plume has changed little in over 12 years; however, concentrations increased during the 1990s because of changing groundwater levels caused by fluctuating Columbia River levels.

A pump-and-treat system in the $100-\mathrm{N}$ Area operates as a CERCLA interim action to reduce the movement of strontium-90 toward the Columbia River (Figure 8.7.11). The pump-and-treat system creates a hydraulic barrier to flow, thereby, decreasing groundwater flow into the Columbia River. Approximately 107.2 million liters (28.3 million gallons) of water were processed during 2004. During that period, 0.15 curies (5.55 gigabecquerels) of strontium-90 were removed from the groundwater. More than 1.009 billion liters (266.7 million gallons) of groundwater have been processed since the system began operation in 1995, removing 1.63 curies (60.3 gigabecquerels) of strontium-90. Concentrations remained far above the $8-\mathrm{pCi} / \mathrm{L}(0.3-\mathrm{Bq} / \mathrm{L})$ drinking water standard in 2004.

Pump-and-treat technology has proven to be an ineffective way to remediate strontium-90 contamination because strontium-90 binds to sediment grains. DOE is considering alternative technologies for remediating the

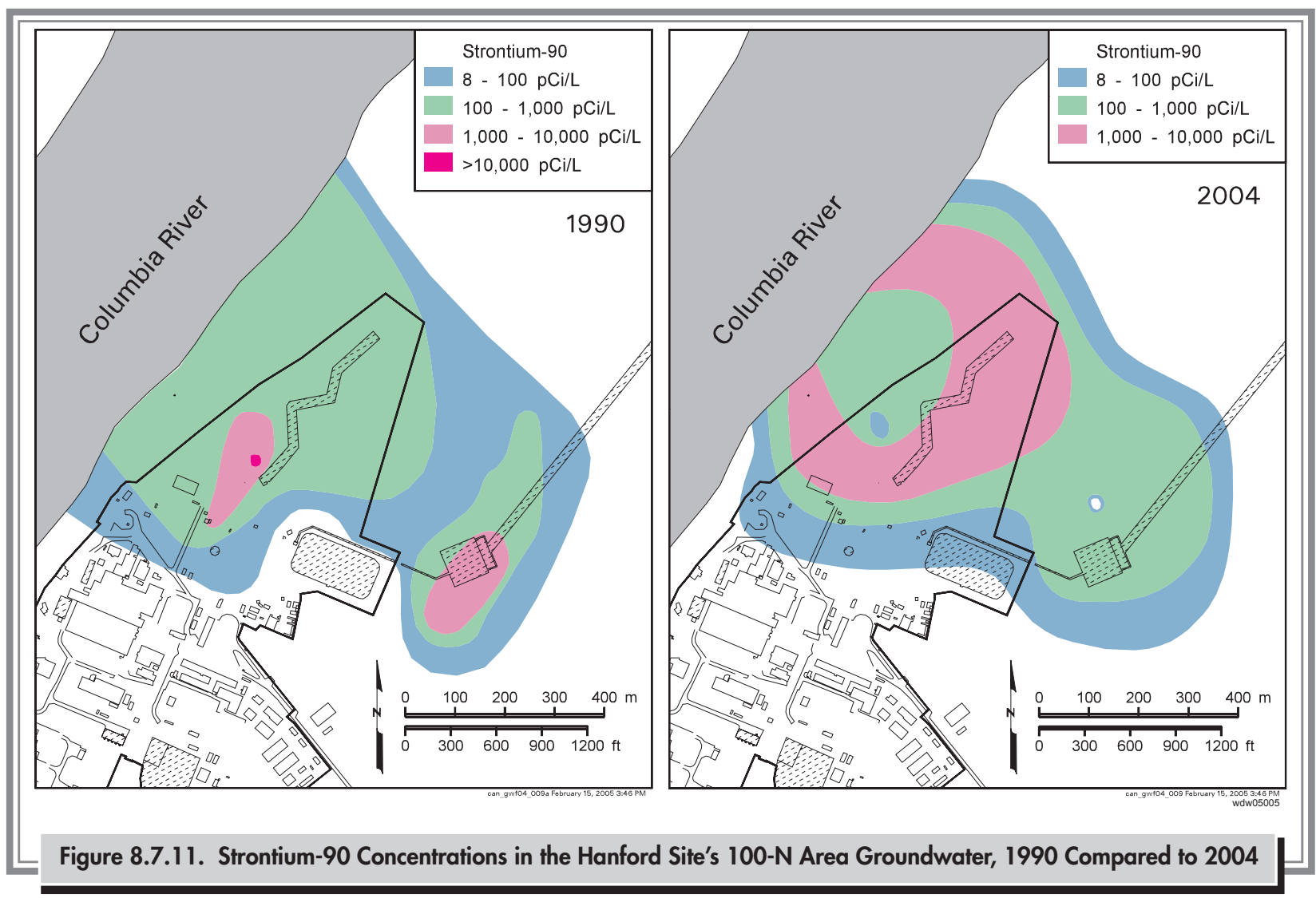


strontium-90 plume in this area. DOE has developed a treatability test plan to evaluate the effectiveness of one technology, sequestration, where chemicals injected into the aquifer immobilize strontium-90 so it does not flow with the groundwater into the Columbia River. The plan includes a contingency provision for a permeable reactive barrier installation to meet the same objective if sequestration fails. The test will also evaluate phytoremediation to enhance strontium-90 recovery along the Columbia River shoreline. Phytoremediation is a technology that uses plants to remove (take up) contaminants from groundwater. DOE has recommended temporarily suspending operation of the pump-and-treat system while they collect data to evaluate the alternative technologies. Sampling frequency was increased along the Columbia River shoreline in anticipation of suspending the pump-and-treat operations. Three new monitoring wells and new aquifer tubes along the 100-N Area shoreline of the Columbia River were installed to collect baseline data. DOE also recommends monitoring natural attenuation for that portion of the plume that is not expected to reach the Columbia River.
Carbon Tetrachloride. The carbon tetrachloride plume in the 200-West Area (originating in the 200-ZP-1 Operable Unit) covers over 11 square kilometers (4.2 square miles) (Figure 8.7.12). The 200-ZP-1 pump-and-treat system operated as a pilot-scale treatability test from 1994 to 1996, with full-scale operation beginning in 1996. A total of 2.48 billion liters (653.9 million gallons) of groundwater have been processed since startup, removing $8,746.4$ kilograms (19,242 pounds) of carbon tetrachloride. During 2004, 264.9 million liters (70.0 million gallons) of groundwater were treated, removing 898.3 kilograms (1,976.3 pounds) of carbon tetrachloride. The 2004 treated volume increased through the replacement of two extraction wells with two new wells. Following replacement, the extraction rate increased by approximately $379 \mathrm{~L} / \mathrm{min}$ (100 gpm).

Plans are being developed to expand the pump-and-treat system at 200-ZP-1 to existing monitoring wells west and southwest of the TX-TY Tank Farms. An extension to the 2,000- $\mu \mathrm{g} / \mathrm{L}$ plume was recognized recently north of the extraction well system installed to treat the 1996 baseline

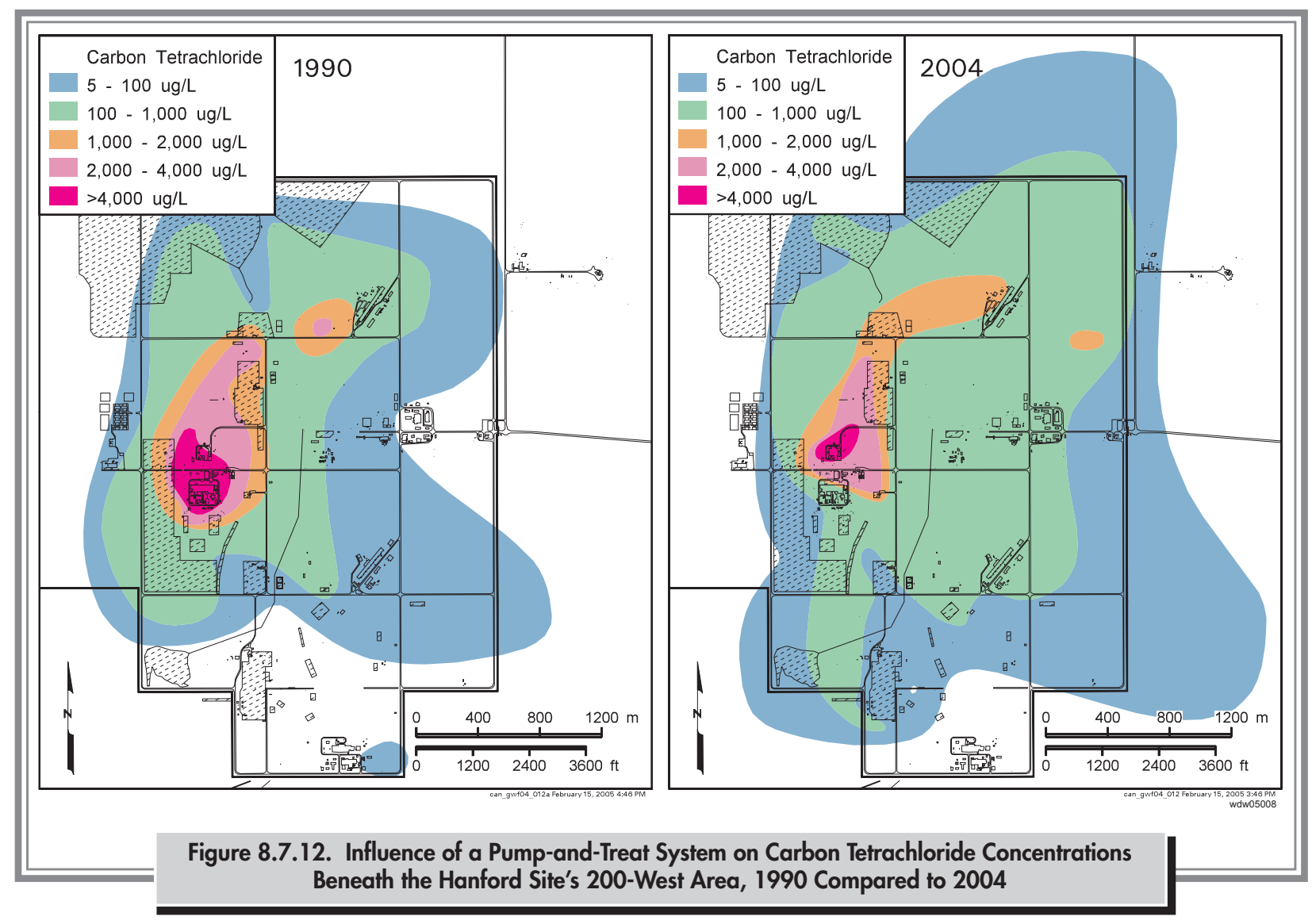


plume. Four monitoring wells will be converted to extraction wells and connected to the 200-ZP-1 treatment system. Extraction rates are expected to increase by approximately $379 \mathrm{~L} / \mathrm{min}$ (100 gpm).

\section{Uranium, Technetium-99, Carbon Tetrachloride,} and Nitrate. Treatment of the groundwater plume underlying the 200-UP-1 Operable Unit in the 200-West Area continued throughout 2004. The contaminant plume contains uranium, technetium-99, carbon tetrachloride, and nitrate. A pump-and-treat system has operated since 1994 to contain the high-concentration area of the uranium and technetium-99 plume. During early operations, groundwater was treated using ion-exchange resin to remove the uranium and technetium-99, and granular activated carbon was used to remove carbon tetrachloride. Since 1997, contaminated groundwater has been transferred by pipeline to basin 43 at the 200 Area Effluent Treatment Facility. Sophisticated treatment technology at the Effluent Treatment Facility removes all four contaminants. Treated groundwater is then discharged north of the 200-West Area at the StateApproved Land Disposal Site.

The pump-and-treat system operated continually during 2004, at rates at or above $189 \mathrm{~L} / \mathrm{min}$ (50 gpm). Three extraction wells were used during the year. The primary extraction well ran continuously and was supplemented with smaller amounts of more contaminated water from two upgradient wells in the high-concentration part of the plume.

In 2004, the Effluent Treatment Facility treated 103.5 million liters (27.3 million gallons) of groundwater. Treatment of groundwater removed 12.8 grams ( 0.0282 pound) of technetium-99, 25.0 kilograms ( 55 pounds) of uranium, 6.67 kilograms (14.7 pounds) of carbon tetrachloride, and 5,401 kilograms (11,882 pounds) of nitrate. To date, the system has treated 822.9 million liters (217.4 million gallons) of water, removing 116.1 grams (0.256 pound) of technetium-99 and 206.8 kilograms (454 pounds) of uranium.

The pump-and-treat operation made significant progress toward reducing uranium and technetium-99 to below required cleanup concentration levels (Figures 8.7.13 and 8.7.14). During 2004, concentrations in all monitoring and extraction wells were below the remedial action objectives of $9,000 \mathrm{pCi} / \mathrm{L}(333 \mathrm{~Bq} / \mathrm{L})$ for technetium- 99 and $480 \mu \mathrm{g} / \mathrm{L}$ for uranium. In 2004, a rebound study was agreed to between the DOE Richland Operations Office and Washington State Department of Ecology to test the effects of treatment. A rebound study assesses how well contaminants have been removed by the pump-and-treat system. Pumping is stopped, allowing groundwater flows to return to equilibrium and contaminants in the sediment

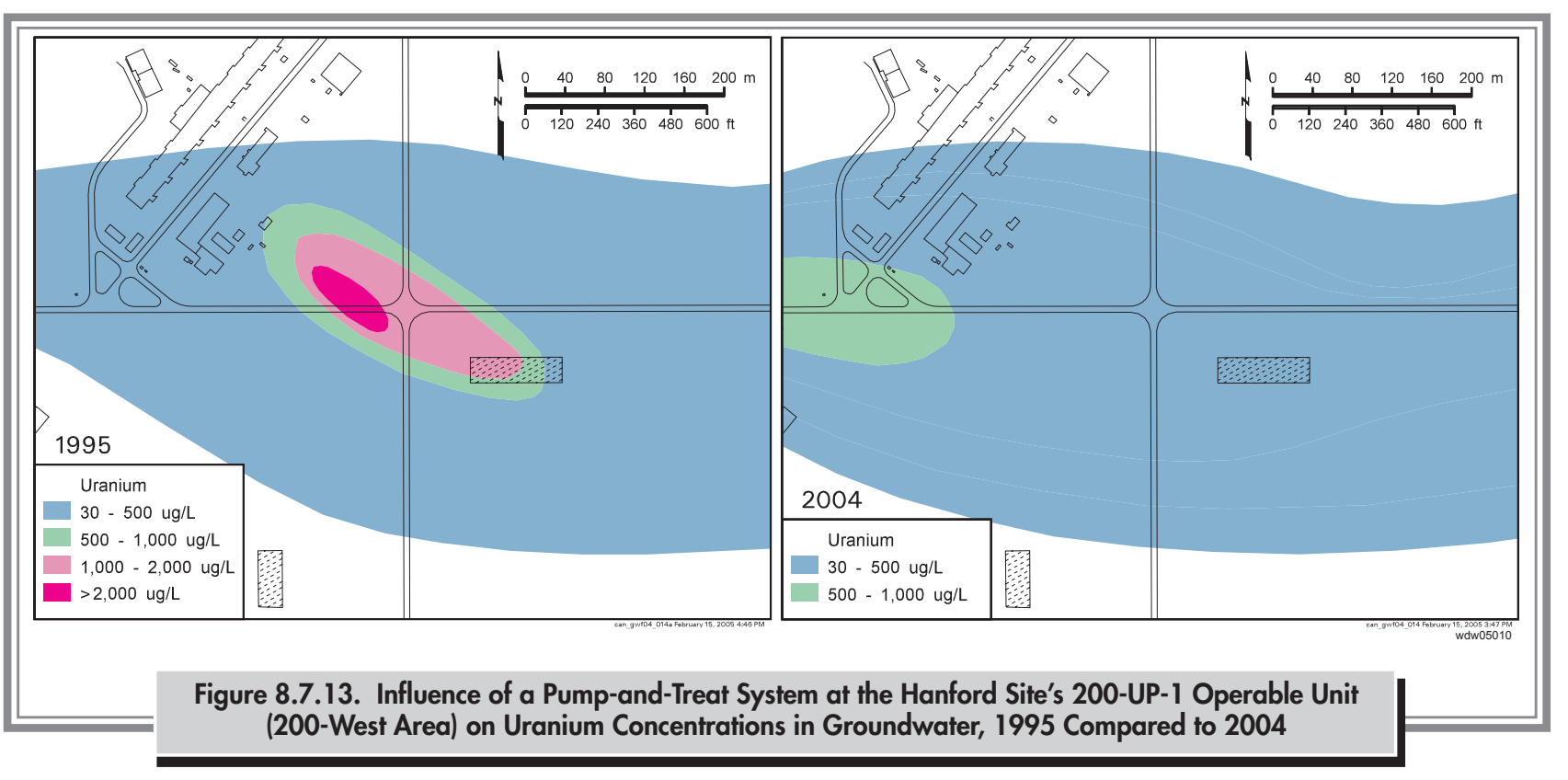




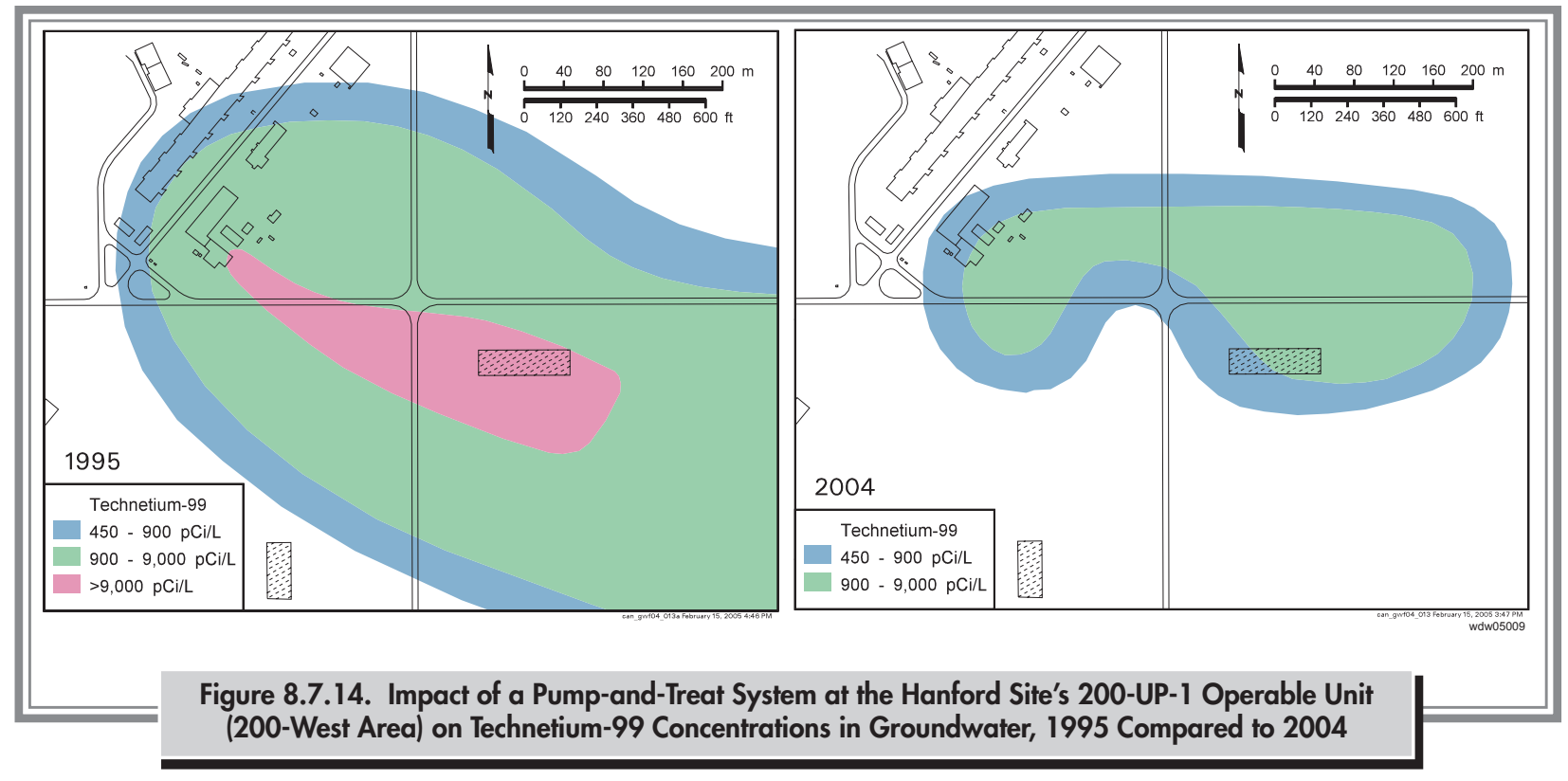

to dissolve back into the groundwater. The concentrations of contaminants in groundwater then reflect concentrations in soil and, thus, indicate if enough contamination has been removed to prevent future exceedences above the remedial action objective. The rebound test started on January 25, 2005.

Elevated concentrations of technetium-99 were observed at a well in the 200 Areas that was drilled in 2002 at the S-SX Tank Farm. The high values led to an agreement that this well should be extensively purged during sampling. The Washington State Department of Ecology and DOE agreed that, for each quarterly sample, more than 3,785 liters (1,000 gallons) of water should be contained and taken to the Effluent Treatment Facility for treatment. After completing a field evaluation and pipe extension modification, purging and treatment were implemented starting in March 2003 (RPP-10757). During 2003, and prior to the first purging, technetium-99 concentrations peaked at $188,000 \mathrm{pCi} / \mathrm{L}(6,956 \mathrm{~Bq} / \mathrm{L})$ at the S-SX Tank Farm then began a steep decline. In 2004, concentrations ranged between 41,800 and $62,300 \mathrm{pCi} / \mathrm{L}$ $(1,547$ and 2,305 Bq/L). Through 2004, at least 31,479 liters (8,304 gallons) of water have been treated at the Effluent Treatment Facility, yielding 0.00211 curies (78.07 megabecquerels) of technetium-99. Further actions will depend on how concentrations change in the future.

\subsubsection{Vadose Zone Remediation Using Soil-Vapor Extraction Systems}

\section{J. Rohay}

Soil-vapor extraction systems designed to remove carbon tetrachloride vapor from the vadose zone beneath the 200-West Area began operating during 1992 and continued through 2004. Soil-vapor extraction has been conducted in the vicinity of three historical carbon tetrachloride disposal sites: the 216-Z-1A tile field, the 216-Z-9 trench, and the 216-Z-18 crib. Extracted soil vapor is pumped through granular activated carbon, which absorbs carbon tetrachloride. The granular activated carbon is then shipped offsite for treatment. Three soilvapor extraction systems have operated at three different flow rates: 14.2 cubic meters ( 500 cubic feet) per minute, 28.3 cubic meters ( 1,000 cubic feet) per minute, and 42.5 cubic meters ( 1,500 cubic feet) per minute. However, only the 14.2 cubic meters (500 cubic feet) per minute system operated during 2004; the other two systems are no longer operational. In 2004, 256 kilograms (564 pounds) of carbon tetrachloride were removed. Since operations began, soil-vapor extraction has removed 78,348 kilograms (172,728 pounds) of carbon tetrachloride from the vadose zone. Passive soil-vapor extraction systems, which use atmospheric pressure fluctuations to pump carbon 
tetrachloride vapor from the vadose zone, were installed at wells near the 216-Z-1A tile field and 216-Z-18 crib during 1999. These passive systems operated throughout 2004.

\subsubsection{Well Installation, Maintenance, and Decommissioning}

DOE installs new wells when needed for monitoring or characterization, maintains wells to prevent or repair problems, and decommissions wells that are no longer needed. The Washington State Department of Ecology, EPA, and DOE worked together to develop a prioritized list of new wells needed to meet requirements of various groundwater monitoring regulations. During 2004, a total of 25 new wells were installed at the Hanford Site. This total included 6 RCRA wells and 19 CERCLA wells. In the 200 Areas, 51 vadose characterization holes were installed to support remediation and they were decommissioned after soil sampling was completed. A total of 278 wells received maintenance, and 98 were decommissioned (filled with grout) because they were no longer needed, were in poor condition, or were in the way of remediation activities. In 2004, a total of 108 new aquifer tubes were installed along the Columbia River shoreline of the 100 and 300 Areas.

\subsubsection{Groundwater Modeling}

Computer simulations of groundwater flow and contaminant movement help predict future conditions and assess the effects of remediation systems. A site-wide numerical model has been developed and is being improved and refined. During 2004, the pattern of geologic zones within the Hanford formation and Ringold Formation gravel units of the model has evolved in a continuing effort to improve the calibration of the model. The calibration involves adjusting the zonation configuration, the hydraulic conductivities associated with the geologic zones, and the amounts of recharge to the system in an effort to match historical changes in water-table elevation and the historical movement of tritium. Changes were also made to the configuration of hydrogeologic units in the model based on new well data and reinterpretation of geological contacts at some locations.
DOE applied the site-wide groundwater model to specific waste-site assessments in 2004:

- modeling the movement of tritium disposed to the State-Approved Land Disposal Site north of 200-West Area

- site-wide groundwater flow and transport calculations supporting the performance assessment for the Integrated Disposal Facility and the preliminary performance assessment for closure of single-shell waste tank farms

- site-wide modeling of dissolved carbon tetrachloride migration from the 200-West Area through the groundwater considering different source conditions and various degrees of sorption and natural degradation.

Local-scale simulations of the movement of dense, nonaqueous liquid (carbon tetrachloride) at the 216-Z-9 trench in the 200-West Area were performed in 2004. The purpose of this work was to better understand carbon tetrachloride movement in the subsurface beneath the trench to support remediation decisions. The modeling indicated the following results:

- The Cold Creek hydrogeologic unit has a large impact on the modeled migration of carbon tetrachloride through the vadose zone.

- The lateral extent of the modeled dense, non-aqueous liquid has not moved outside the footprint of the disposal facility.

- The lateral extent of the modeled vapor-phase plume was much greater than the lateral extent of the dense, non-aqueous liquid.

- The vapor-phase plume caused some contamination of underlying groundwater in the model.

\subsubsection{An Assessment Tool for Estimating the Impact of Groundwater Contaminants}

\section{R. W. Bryce and C. T. Kincaid}

During 1999, DOE initiated development of an assessment tool, the System Assessment Capability, that will enable users to model the movement of contaminants from all waste sites at Hanford through the vadose zone, groundwater, and the Columbia River and estimate the 
impact of contaminants on human health, the ecology, local cultures, and the local economy. An assessment was completed during 2002 with the System Assessment Capability that demonstrated its functionality. The results of that assessment were presented in An Initial Assessment of Hanford Impact Performed with the System Assessment Capability (PNNL-14027).

During 2004, the System Assessment Capability was used to update Hanford's Composite Analysis. A composite analysis is required by DOE Order 435.1, Radioactive Waste Management, to ensure public safety through the management of active and planned low-level radioactive waste disposal facilities associated with the Hanford Site. A composite analysis is defined in the Order as "a reasonably conservative assessment of the cumulative impact from active and planned low-level waste disposal facilities, and all other sources from radioactive contamination that could interact with the low-level waste disposal facility to affect the dose to future members of the public." A composite analysis was first performed for Hanford in 1998 (PNNL-11800).

During 2004, the Technical Scope and Approach for the 2004 Composite Analysis of Low-Level Waste Disposal at the Hanford Site (PNNL-14372) was published. This document describes the scope of the updated assessment, the region to be analyzed, the waste sites and contaminants to be included, the time period of the assessment, and the process followed to identify those aspects of the assessment. It also describes the technical approach taken for each element of the analysis, the models to be used, and the interaction between the composite analysis and other assessments being performed at Hanford. Calculations were also initiated during 2004 to support the update to the composite analysis.

Table 8.7.8 lists the contaminants to be examined in this assessment of the impact of radioactive wastes. Two key questions formed the basis for selecting these contaminants:

- What contaminants have been observed in the environment and have the potential to affect human or ecological health?

- What contaminants have sufficient inventory in waste sites and have the potential to affect human and/or ecological health as indicated through previous assessments?

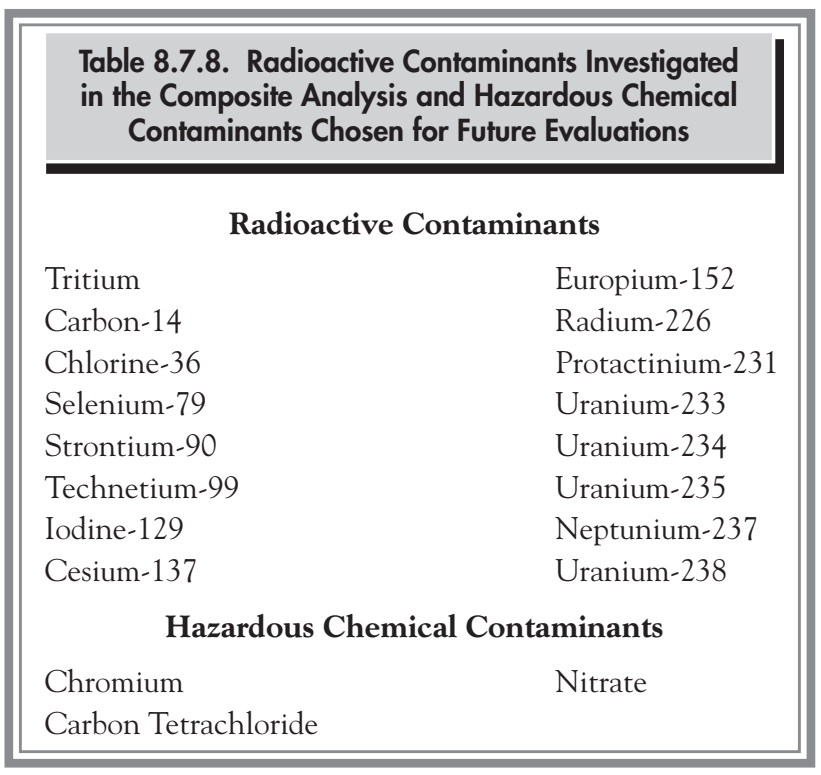

DOE has recently established a Configuration Management Group to review each assessment planned at Hanford, provide guidance to assure consistency among assessments, and ultimately approve the approach to be taken. The group is expected to review the plans for the composite analysis early in 2005 and may provide guidance that results in a change to the assessment and a rerun of simulations performed in 2004.

\subsubsection{New Science and Technology}

\section{D. Freshley}

The Groundwater Remediation Project includes a science and technology effort to provide data, tools, and scientific understanding to make remediation and site closure decisions. These activities are accomplished under the Remediation and Closure Science Project. During 2004, the project focused on updating soil inventory estimates to support the composite analysis, updating conceptual models for key waste sites, and continuing biological uptake studies.

Soil Inventories. During 2004, the Soil Inventory Model was applied to estimate contaminant inventories for Plutonium Finishing Plant waste sites and provided results to the Hanford Site-Wide Assessments Project. The Soil Inventory Model is continuing to be updated to provide data for additional waste sites and constituents to support the composite analysis. 
Conceptual Model Updates. Efforts during 2004 focused on updating the conceptual models of the 300 Area, 100-N Area, carbon tetrachloride transport in Hanford sediment, and the B-26 trench in the 200 Areas.

During 2004, experiments were completed on vadose zone, capillary fringe (the region of the vadose zone composed of sediment that is saturated or nearly saturated near the water table that gradually decreases in water content with increasing elevation above the water table), and aquifer sediment for the 300 Area to update the conceptual model of uranium(VI) fate and transport. These experimental results collectively provide scientific explanations of why the 300 Area uranium plume has been slow to disperse. These results also provide the basis for reactive transport models that are currently under development to forecast future behavior.

Three boreholes were drilled and completed at the 100-N Area along the Columbia River as part of the Remediation and Closure Science Project. These wells will allow the collection of depth-dependent concentration data to determine the distribution of strontium- 90 concentrations and strontium-90 flux to the river. Samples from these boreholes are being evaluated in the laboratory to provide data for a reactive transport model of strontium-90 at the 100-N Area. This model will be used to evaluate remediation alternatives to the pump-and-treat system currently in operation in the $100-\mathrm{N}$ Area.

A new theory for residual non-aqueous phase liquid carbon tetrachloride was developed during 2004. This theory was based on intermediate-scale experiments performed by the Remediation and Closure Science Project. The residual non-aqueous phase liquid theory was implemented in the Subsurface Transport Over Multiple Phases computer code and used to successfully simulate the soil-vapor extraction system in the 200-West Area. These simulations are being used to guide field characterization and remediation of the carbon tetrachloride plume.

Results from the Vadose Zone Transport Field Study were used to develop a method for incorporating small-scale heterogeneity into field-scale simulations. This approach was used to simulate moisture flow and contaminant transport beneath the B-26 trench. Predicted moisture contents and technetium-99 concentrations matched observed field data from a borehole drilled through the vadose zone and results from a high-resolution resistivity geophysical survey applied to the vadose zone. High-resolution resistivity was first applied at Hanford as part of the Vadose Zone Transport Field Study. The results of both modeling and subsurface geophysics show the potential extent of the lateral spreading of contaminants. The flow and transport modeling is being used to assist with remedial design.

Biological Uptake of Strontium-90. During 2004, the Remediation and Closure Science Project continued laboratory experiments to determine the uptake of strontium -90 by aquatic species via the food pathway. The goal of these experiments was to determine the rate at which uptake occurred and the total uptake amount. The results are being incorporated into ecological risk assessment modules for use in Hanford site-wide assessments.

\subsubsection{Groundwater Remediation Project: Strategic Planning, Public Involvement, and Database Management}

\section{T. W. Fogwell}

During 2004, the Groundwater Remediation Project continued to closely align the scope of project work with similar site-wide DOE work and align the project with end-state goals and remedial actions. Throughout the year, Groundwater Remediation Project personnel worked closely with the DOE and Hanford regulatory agencies to characterize, protect, remediate, and monitor Hanford Site groundwater. Project staff continued to coordinate and perform scientific research and development to support decision-making activities at Hanford and to manage Hanford's modeling and assessment capabilities aimed at cleaning up groundwater. The Integration Management team organized and coordinated several scientific and technology workshops that resulted in better scientific methods and technological advances being applied to the remediation of the Hanford Site. Also, the Data Access Network prototype was demonstrated. This tool allows for efficient retrieval and visualization of much of the data pertinent to writing reports and other documents at the Hanford Site. 
Strategic Planning. The Groundwater Remediation Project team worked throughout 2004 to complete work in the project's master plan, Hanford's Groundwater Plan: Accelerated Cleanup and Protection (DOE/RL-2002-68). The plan describes how and when accelerated cleanup work will be accomplished. Project personnel also worked to revise the Optimization Strategy for Central Plateau Closure (WMP-18061) and to complete a more detailed Plan for Central Plateau Closure (CP-22319).

Public Involvement. During 2004, open meetings, held the first Monday of every month, gave the public, Tribal Nations, regulatory agencies, DOE, and other stakeholders an opportunity to discuss and resolve issues and identify upcoming events. Groundwater project staff also provided regular information to the Hanford Advisory Board and its subcommittees and held several information sessions and workshops concerning specific program events and activities. The project's internet website (http://www.hanford. gov/cp/gpp/) provided information about the project's missions, a calendar of upcoming events, and links to a variety of valuable resources.

Database Management. The Groundwater Remediation Project manages several Hanford Site environmental databases. The Hanford Environmental Information System, as managed by the Groundwater Remediation Project, provides and integrates environmental databases. The environmental databases are required by the Tri-Party Agreement.

The Hanford environmental databases include the Hanford Environmental Information System, Hanford Well Information Data System, Waste Information Data System, and Hanford Geographic Information System. These databases document and track the progress of Hanford Site cleanup. The Hanford Environmental Information System contains the date, time, location, and results from samples taken during activities such as field investigations and groundwater monitoring. The Hanford Well Information Data System contains the details (well history, survey information, as-built information, well construction, and well maintenance records) of the wells and boreholes on the site. The Waste Information Data System tracks the waste sites from discovery through cleanup. The Hanford Geographic Information System keeps track of the locations for waste sites, wells and boreholes, and other sampling site locations. Each of the databases is supported by several software applications for entering or retrieving information.

Database integration supports the sample and data management needs of the Groundwater Remediation Project and waste site remediation. Additionally, the Sample and Data Management Group provides support to Pacific Northwest National Laboratory and the Liquids Effluent Monitoring Information System, and support is currently being planned for the Plutonium Finishing Plant. Sample and data management personnel track samples and data from approval of a sample authorization form to loading of the analytical results from the laboratories into the Hanford Environmental Information System database. The project-specific database stores the data taken from the pump-and-treat and in situ redox manipulation facilities managed by the Groundwater Remediation Project. The data in the Hanford Environmental Information System and the project-specific databases are used by engineers and scientists to prepare the reports required by records of decision and Tri-Party Agreement milestones.

The virtual library portion of database integration makes available the information needed to estimate contamination migration and impact across the Hanford Site. In addition to providing easier user access to the Hanford Environmental Information System, the virtual library includes inventory, geophysical, geochemical, hydrological, and other relevant data. Much of the existing information of this nature is currently scattered throughout several sources, some of which are not available across the Hanford Site. In addition, Fluor Hanford, Inc. and Pacific Northwest National Laboratory generate new information from their science and characterization activities. Key portions of this information are made available through the virtual library. 


\subsection{Food and Farm Products Monitoring}

R. W. Hanf

Food and farm products, including asparagus, grapes, leafy vegetables, milk, potatoes, tomatoes, and wines, were collected routinely during 2004 at places around the Hanford Site (Figure 8.8.1) and analyzed to monitor concentrations of radiological contaminants. Samples were obtained from locations generally downwind (east and southeast) of the site where airborne emissions or contaminated dust from the Hanford Site would normally be deposited, from other locations generally upwind of and distant from the site to provide information on reference (background) contaminant levels, and from farms irrigated with water taken from the Columbia River downstream of the site. Results of sample analyses are used to assess the amounts of Hanford Site contaminants in food and farm products by: (1) comparing analytical results obtained from like samples collected from the same regions over long periods of time, (2) comparing analytical results from samples collected at downwind locations to results from samples obtained from generally upwind or distant locations, and (3) comparing analytical results from samples collected in areas irrigated with water withdrawn from the Columbia River downstream from the Hanford Site to analytical results from samples obtained from locations irrigated with water from other regional sources. The concentrations of most radionuclides in food and farm product samples in 2004 were below levels that could be detected by the analytical laboratories. However, some contaminants potentially from Hanford (strontium-90, tritium, iodine-129) were found at low levels in some samples. These findings are discussed in the following sections. Data for naturally occurring potassium-40 and beryllium-7 are included to show these concentrations in food products relative to concentrations of materials potentially from Hanford. Radiological doses associated with possible Hanford-produced contaminants that were detected are discussed in Section 8.14.

\subsubsection{Collection of Food and Farm Product Samples}

Some food and farm product samples are collected every year on quarterly or annual schedules. Others may only be sampled every 2 or 3 years. The rationale for sampling and analyzing some media more frequently than others is discussed in the Hanford Site Environmental Monitoring Plan (DOE/RL-91-50). The types and number of samples scheduled for collection in any given year are documented in the annual Hanford Site Surveillance Master Sampling Schedule (e.g., PNNL-14553). Table 8.8.1 shows the types, sampling locations and frequencies, and numbers of food and farm product samples collected and analyzed for radioactive contaminants during 2004. Most samples were obtained from commercial dairies and farms. Leafy vegetables and tomatoes were obtained from backyard gardens because commercial growers could not be located.

\subsubsection{Milk}

During 2004, milk samples were obtained quarterly from three dairies in the East Wahluke sampling area, three in the Sagemoor sampling area, and one in the Sunnyside sampling area (Figure 8.8.1). The Sagemoor and East Wahluke sampling areas are located downwind of the site, near the site perimeter, and could potentially be affected by airborne contaminants from Hanford. The Sunnyside area is a reference location generally upwind of the site. Milk samples from all dairies within a sampling area were combined, and the combined (composite) samples from each area were analyzed for gamma-emitting radionuclides, strontium-90, and tritium. Twice each year, additional milk was obtained from each area to monitor for iodine-129 (Table 8.8.1). Milk sampling was conducted 


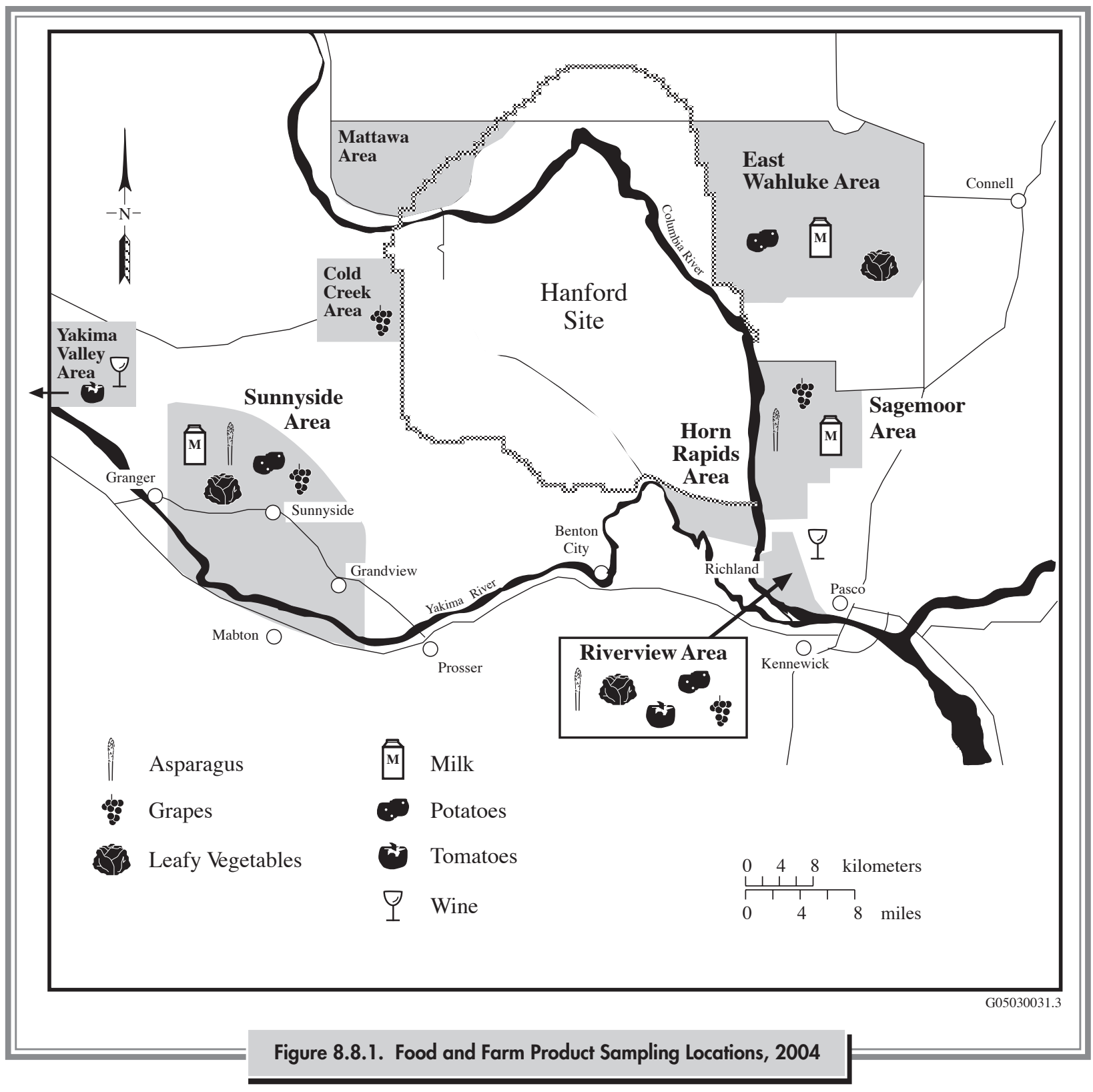

because Hanford-produced radionuclides have the potential to move through the air-pasture-cow-milk or waterpasture-cow-milk food chains to humans. However, in recent years, the levels of Hanford-produced radiological contaminants in milk samples have diminished, and concentrations in samples obtained from dairies located downwind of the site are now similar to levels measured in samples obtained from the dairy located generally upwind of the site.

Strontium-90 - Strontium-90 was detected in three of four combined milk samples collected in 2004 from the Sagemoor sampling area, two of four samples from the
East Wahluke sampling area, and one of four samples from the Sunnyside sampling area. Concentrations were low $(<1 \mathrm{pCi} / \mathrm{L}[0.037 \mathrm{~Bq} / \mathrm{L})$, were similar at all locations, and were comparable to concentrations measured in past years (PNNL-14687; PNNL-14295).

Tritium - Concentrations of tritium are generally monitored in all milk samples each year. However, in 2004, tritium concentrations were measured in only three of twelve samples. Analyses for tritium were stopped early in 2004 because of problems at the analytical laboratory. A replacement laboratory was identified in 2004 (Severn Trent Laboratory, Richland) but analyses of milk samples 


\begin{tabular}{|c|c|c|c|c|c|c|c|c|}
\hline \multirow[b]{3}{*}{$\underline{\text { Product }}$} & \multirow{2}{*}{\multicolumn{2}{|c|}{$\underline{\text { Number of Locations }}$}} & \multirow[b]{3}{*}{$\underline{\text { Sampling Frequency }}$} & \multirow{2}{*}{\multicolumn{4}{|c|}{$\begin{array}{c}\text { Types of Analyses and Number } \\
\text { of Samples Analyzed }\end{array}$}} & \multirow[b]{3}{*}{$\underline{\mathbf{U}}$} \\
\hline & & & & & & & & \\
\hline & \multicolumn{2}{|c|}{ Unwind Downwind } & & ${ }^{3} \underline{\mathbf{H}}$ & $\underline{\text { Gamma }}$ & ${ }^{90} \underline{\mathbf{S r}}$ & ${ }^{129} \underline{\mathbf{I}}$ & \\
\hline Milk & 1 & 2 & $\mathrm{Q}$ or $\mathrm{SA}$ & 12 & 12 & 12 & 7 & 0 \\
\hline Asparagus & 1 & 2 & A & 0 & 3 & 3 & 0 & 3 \\
\hline Grapes & 2 & 2 & TE & 0 & 4 & 4 & 0 & 0 \\
\hline Leafy vegetables & 1 & 2 & $\mathrm{~A}$ or $\mathrm{BE}$ & 0 & 3 & 3 & 0 & 0 \\
\hline Tomatoes & 1 & 1 & A & 2 & 2 & 2 & 0 & 0 \\
\hline Potatoes & 1 & 2 & A & 0 & 3 & 3 & 0 & 0 \\
\hline Wine & 2 & 2 & A & 4 & 4 & 0 & 0 & 0 \\
\hline \multicolumn{9}{|c|}{$\begin{array}{l}\text { (a) Products may include multiple varieties for each category. } \\
\mathrm{A}=\text { Annually. } \\
\mathrm{BE}=\text { Biennially. } \\
\mathrm{Q}=\text { Quarterly. } \\
\mathrm{SA}=\text { Semiannually. } \\
\mathrm{TE}=\text { Triennially. }\end{array}$} \\
\hline
\end{tabular}

collected from mid- to late-2004 had not been started by the end of 2004. The milk samples collected during the last half of 2004 are scheduled to be analyzed in 2005. The three 2004 milk samples analyzed were obtained from the Sagemoor sampling area in February and April and from the East Wahluke sampling area in April. Tritium was detected in all three samples and the highest concentration measured was $229.5 \mathrm{pCi} / \mathrm{L}(8.49 \mathrm{~Bq} / \mathrm{L})$ in the February sample from the Sagemoor area. This concentration is a little higher than concentrations measured in milk from this area in the recent past (PNNL-14295). In past years, tritium concentrations in Sagemoor area milk samples have been consistently higher than concentrations in samples from the East Wahluke and Sunnyside sampling areas (PNNL-14687). A reason for this has been proposed that suggests a relationship between tritium concentrations in Columbia River water used for irrigation in the Sagemoor area during past years and concentrations in groundwater used by some Sagemoor area dairies (PNNL-13910).

The tritium data for the 2003 milk samples were received in mid-2004. Twelve samples were submitted for analysis but only seven were analyzed. Five of the samples were lost at the laboratory. Tritium was detected in all of the samples analyzed and one sample from the Sagemoor sampling area had an unusually high tritium concentration (2,593 \pm $50 \mathrm{pCi} / \mathrm{L}[95.9 \pm 1.85 \mathrm{~Bq} / \mathrm{L}])$. A re-analysis of this sample to confirm the result was not possible because of the work stoppage discussed in the preceding paragraph. Of the other six samples analyzed, one was from the Sagemoor area, two were from the Wahluke area, and three were from the Sunnyside area. The highest tritium concentration measured in these samples $(160.8 \pm 5.3 \mathrm{pCi} / \mathrm{L}[5.95 \pm$ $0.2 \mathrm{~Bq} / \mathrm{L}])$ was seen in the sample from the Sagemoor area. This concentration was within the range of concentrations measured in milk in past years (PNNL-14687). While there is no standard for tritium in milk, the healthbased standard for drinking water is an annual average of 20,000 pCi/L (740 Bq/L).

Iodine-129 - Iodine-129 was detected in all milk samples collected for iodine-129 analyses in 2004. Concentrations were low, ranging from $0.0008 \mathrm{pCi} / \mathrm{L}\left(29.6 \times 10^{-6} \mathrm{~Bq} / \mathrm{L}\right)$ in a Wahluke area sample to $0.0002 \mathrm{pCi} / \mathrm{L}\left(7.4 \times 10^{-6} \mathrm{~Bq} / \mathrm{L}\right)$ in a Sunnyside area sample. The average concentration for five samples collected from dairies located downwind of Hanford was $0.0005 \mathrm{pCi} / \mathrm{L}\left(18.5 \times 10^{-6} \mathrm{~Bq} / \mathrm{L}\right)$. The average concentration in two samples from an upwind dairy was $0.0004 \mathrm{pCi} / \mathrm{L}\left(14.8 \times 10^{-6} \mathrm{~Bq} / \mathrm{L}\right)$. There is no iodine-129 standard for milk, but the health-based standard for drinking water is an annual average of $1.0 \mathrm{pCi} / \mathrm{L}(0.037 \mathrm{~Bq} / \mathrm{L})$.

Cesium-137 - There were no manmade gamma emitters (including cesium-137) detected in milk samples collected and analyzed in 2004 (PNNL-15222, APP. 1). 
Potassium-40 - Potassium-40 is a naturally occurring radionuclide that is found in soil and in fertilizers applied to soil. It is the predominant radionuclide in foods and human tissues (Eisenbud 1987). Potassium-40 was detected in all milk samples collected in 2004. Concentrations ranged from a maximum of $1,360 \mathrm{pCi} / \mathrm{L}$ $(50.3 \mathrm{~Bq} / \mathrm{L})$ in a Wahluke area sample to a minimum of $939 \mathrm{pCi} / \mathrm{L}(34.7 \mathrm{~Bq} / \mathrm{L})$ in a Sunnyside area sample. Average concentrations for the individual areas were $1,215 \mathrm{pCi} / \mathrm{L}$ (44.9 Bq/L) for the Sagemoor area; 1,205 pCi/L (44.6 Bq/L) for the East Wahluke area; and 1,087 pCi/L (40.2 Bq/L) for the Sunnyside area.

\subsubsection{Asparagus}

Three samples of asparagus shoots were collected in the spring from commercial fields in the Riverview, Sagemoor, and Sunnyside sampling areas (Figure 8.8.1). Samples were analyzed for gamma-producing radionuclides, strontium-90, and uranium isotopes (Table 8.8.1). The only radionuclide detected in the samples was naturally occurring potassium -40 . Concentrations of potassium- 40 in all samples were less than $3 \mathrm{pCi} / \mathrm{g}(0.11 \mathrm{~Bq} / \mathrm{L})$ wet weight.

\subsubsection{Grapes}

Four samples of concord grapes were collected in the fall from the Riverview, Sagemoor, Cold Creek, and Sunnyside sampling areas (Figure 8.8.1). Samples were analyzed for gamma-producing radionuclides and strontium-90 (Table 8.8.1). The only radionuclide found in measurable quantities was naturally occurring potassium-40. Concentrations of potassium- 40 in all samples were low $(<3 \mathrm{pCi} / \mathrm{g}$ $[0.11 \mathrm{~Bq} / \mathrm{L}]$ wet weight).

\subsubsection{Leafy Vegetables}

Three samples of leafy vegetables were collected during the summer from the East Wahluke, Riverview, and Sunnyside sampling areas (Figure 8.8.1). Leafy plants are sampled to monitor the potential deposition of airborne contaminants on agricultural food products. The Riverview area was also sampled because crops in this area were irrigated with Columbia River water withdrawn at places downstream of the Hanford Site. All samples were analyzed for gammaproducing radionuclides and strontium-90 (Table 8.8.1).
Low concentrations $(<6 \mathrm{pCi} / \mathrm{g}[0.22 \mathrm{~Bq} / \mathrm{L}]$ wet weight $)$ of naturally occurring potassium-40 were detected in the samples collected from all three areas. Another naturally occurring radionuclide, beryllium-7, was found at low levels $(<6 \mathrm{pCi} / \mathrm{g}[0.22 \mathrm{~Bq} / \mathrm{L}]$ wet weight $)$ in the East Wahluke and Riverview area samples. Strontium-90, a possible contaminant from the Hanford Site, was measured in both the Riverview and East Wahluke areas samples. The maximum strontium-90 concentration $(0.05 \pm$ $0.008 \mathrm{pCi} / \mathrm{g}[0.002 \pm 0.0003 \mathrm{~Bq} / \mathrm{L}]$ wet weight) was similar to concentrations measured in leafy vegetable samples from these areas in past years, although in recent years, few vegetable samples have contained measurable levels of this radionuclide (PNNL-14687; PNNL-14295; PNNL-13910).

\subsubsection{Potatoes and Tomatoes}

Three samples of potatoes and two samples of tomatoes were collected from both upwind and downwind sampling areas (Figure 8.8.1) in the summer and fall. All samples were analyzed for gamma-emitting radionuclides and strontium-90. Tomato samples were also monitored for tritium (Table 8.8.1). The only radionuclide detected in the samples was naturally occurring potassium- 40 . Concentrations of potassium- 40 in all samples were less than $6 \mathrm{pCi} / \mathrm{g}[0.22 \mathrm{~Bq} / \mathrm{L}]$ wet weight.

\subsubsection{Wines}

Samples of a red wine and a white wine were obtained from a winery in the vicinity of Pasco and a winery near Yakima. The wines were produced from 2004 vintage grapes that were harvested in the fall from vineyards located just north of Pasco (downwind of the site) and just east of Yakima (generally upwind of the site) (Figure 8.8.1). Each wine was divided (split) into two samples and all samples were analyzed for gamma-emitting radionuclides and tritium (Table 8.8.1).

Cesium-137 - There were no manmade gamma emitters (including cesium-137) detected in wine samples collected and analyzed in 2004 (PNNL-15222, APP. 1).

Potassium-40 - Potassium-40, a naturally occurring gamma emitter, was measured in all wine samples collected 
in 2004. Concentrations in all samples ranged from 110 to $170 \mathrm{pCi} / \mathrm{L}$ (4.1 to $6.3 \mathrm{~Bq} / \mathrm{L})$.

Tritium - Wine samples collected in 2004 were provided to an analytical laboratory for tritium analyses but the analyses were not completed in time to include the analytical data in this report.

Samples of red and white wines were also collected in 2003. Each wine was divided (split) into two samples and all samples were analyzed by gamma spectroscopy for gamma-emitting radionuclides and by an electrolytic enrichment method for tritium. The data from the gamma spectroscopy analyses were discussed in the 2003 Hanford Site environmental report (PNNL-14687), but tritium data for the wine samples were not available until after the 2003 report was published. The wines analyzed in 2003 were produced from 2003 vintage grapes that were harvested in the fall from vineyards located just north of Pasco and just east of Yakima. Tritium concentrations in all 2003 samples were elevated relative to concentrations seen in wines sampled in past years (PNNL-14295). Concentrations in the 2003 samples ranged from a low of $105 \pm 3 \mathrm{pCi} / \mathrm{L}(3.88 \pm 0.11 \mathrm{~Bq} / \mathrm{L})$ in a white wine from Yakima to a high of $812 \pm 10 \mathrm{pCi} / \mathrm{L}(30.0 \pm 0.37 \mathrm{~Bq} / \mathrm{L})$ in a red wine from Pasco. For comparison, tritium concentrations in all 2001 and 2002 samples combined ranged from 8.6 to $116.1 \mathrm{pCi} / \mathrm{L}(0.32 \pm 4.29 \mathrm{~Bq} / \mathrm{L})$. These concentrations are more in keeping with concentrations measured in prior years (PNNL-13910). The reason for the elevated 2003 concentrations is not known. A letter from the laboratory that accompanied the data did not indicate any problems with the data or analysis process. However, the fact that concentrations both upwind and downwind of the site were elevated may indicate a problem with the laboratory analyses (e.g., laboratory contamination). The fact that there was generally poor agreement between tritium concentrations in the sample splits may support this. The Pasco red and white wine split samples differed by $16 \%$ and $282 \%$, respectively, and the Yakima red and white wine split samples differed by $262 \%$ and $430 \%$, respectively. In 2001 and 2002, the differences in red and white split sample analyses ranged from $0.9 \%$ to $57.7 \%$ and $13.8 \%$ and $67 \%$, respectively. While there is no tritium standard for wine, the drinking water standard is an annual average concentration of $20,000 \mathrm{pCi} / \mathrm{L}(740 \mathrm{~Bq} / \mathrm{L})$. All tritium concentrations in 2003 wine samples were well below this health-based standard. 


\subsection{Soil Monitoring}

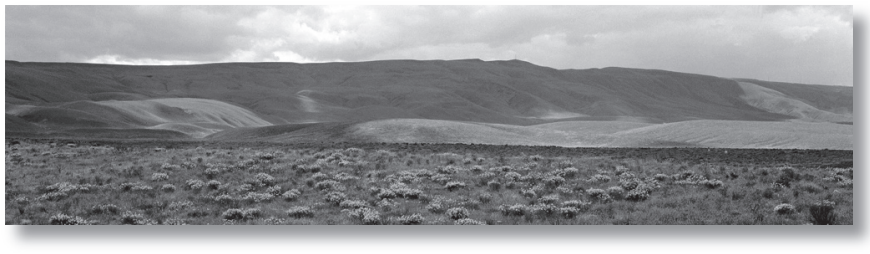

The following sections summarize soil monitoring efforts conducted on and around the Hanford Site in 2004. Radiological monitoring of soil is conducted onsite near facilities and operations, onsite away from facilities and operations (site-wide), and offsite at perimeter and distant locations and in nearby communities. Contaminant concentration data are used to determine the effectiveness of effluent monitoring and controls within facilities, to assess the adequacy of containment at waste disposal sites, to detect and monitor unusual conditions, and to provide information on long-term radionuclide contamination trends in soil at undisturbed locations. Soil samples have been collected on and around the Hanford Site for more than 40 years. Consequently, a large database documents onsite and offsite levels of manmade radionuclides in Hanford Site soil. These data provide a baseline against which unplanned releases can be compared. For further information about these monitoring efforts, the programs that support them, and their purposes see Section 8.0 and DOE/RL-91-50.

\subsubsection{Soil Monitoring Near Hanford Site Facilities and Operations}

\section{R. M. Mitchell}

Soil samples are collected near facilities and operations to evaluate long-term trends in the environmental accumulation of radioactive materials and to detect potential migration and deposition of facility emissions. Contamination in soils can occur as the result of resuspension of contaminants in air and movement from radiologically contaminated surface areas, uptake of contaminants into plants whose roots contact below-ground waste, or translocation of buried waste by intruding animals.

\subsubsection{Soil Sampling Near Hanford Site Facilities and Operations}

Soil samples were collected on or adjacent to waste disposal sites and from locations downwind and near or within the boundaries of operating facilities and remedial action sites. The number and locations of soil samples collected during 2004 are summarized in Table 8.9.1. Only radionuclide concentrations above analytical detection limits are discussed in this section. A comprehensive presentation of the analytical data from these samples can be found in PNNL-15222, APP. 2.

Each 1-kilogram (2.2-pound) soil sample represented a composite of five plugs of soil, each 2.5 centimeters ( 1 inch) deep and 10 centimeters (4 inches) in diameter. Soil samples were sieved in the field to remove rocks and plant debris and dried in the laboratory prior to analysis to remove residual moisture.

Hanford Site samples were analyzed for radionuclides expected to occur in the areas sampled (i.e., gammaemitting radionuclides [Appendix F, Table F.1],

Table 8.9.1. Number and Locations of Soil Samples Collected Near Hanford Site Facilities and Operations, 2004

\begin{tabular}{|c|c|c|c|c|c|c|c|c|c|c|}
\hline \multirow{2}{*}{$\begin{array}{c}\text { Sample } \\
\text { Type }\end{array}$} & \multirow{2}{*}{$\begin{array}{l}\text { Number of } \\
\text { Sampling } \\
\underline{\text { Locations }}\end{array}$} & \multicolumn{9}{|c|}{ Operational Area } \\
\hline & & $100-\mathrm{B} / \mathrm{C}$ & 100-D/DR & $\underline{100-K}$ & $\underline{100-F}$ & $\underline{100-H}$ & $\underline{100-N}$ & $\underline{E R D F}^{(a)}$ & $\underline{200 / 600}$ & $\underline{300 / 400}$ \\
\hline Soil & 83 & 2 & 0 & 1 & 2 & 0 & 7 & 1 & 56 & 14 \\
\hline
\end{tabular}

(a) Environmental Restoration Disposal Facility in the 200-West Area. 
strontium-90, uranium isotopes, and/or plutonium isotopes). The analytical results from Hanford Site samples were compared to concentrations of radionuclides measured in samples collected offsite at various sampling locations in Grant, Yakima, Walla Walla, Adams, Benton, and Franklin Counties. These comparisons were used to determine the level of measured radioactivity in samples resulting from site operations and remedial actions and resulting from natural sources and worldwide fallout.

Soil sampling results also were compared to the accessible soil concentrations (WHC-SD-EN-TI-070) developed specifically for use at the Hanford Site (see PNNL-15222, APP. 2 for a complete listing of concentrations). These concentration values for radionuclides were established to assure that effective dose equivalents to the public do not exceed the established limits for any reasonable scenario, such as direct exposure, inadvertent ingestion, inhalation, and ingestion of foods, including animal products. The accessible soil concentration values are based on a radiation dose estimate scenario in which an individual would have to spend 100 hours per year in direct contact with the contaminated soil. The conservatism inherent in pathway modeling assures that the required degrees of protection are in place (WHC-SD-EN-TI-070). These concentrations apply specifically to the Hanford Site with respect to onsite waste disposal operations and cleanup, decontamination, and decommissioning activities.

Some degree of variability is always associated with the collection and analysis of environmental samples. Therefore, variations in sample concentrations from year to year are expected. In general, radionuclide concentrations in soil samples collected from or adjacent to waste disposal facilities in 2004 were higher than the concentrations in samples collected farther away and were significantly higher than concentrations measured offsite. The data also show, as expected, that concentrations of certain radionuclides in 2004 were higher within different operational areas when compared to concentrations measured in distant communities. Generally, the predominant radionuclides detected were activation and fission products in the $100-\mathrm{N}$ Area, fission products in the 200 and 600 Areas, and uranium in the 300 and 400 Areas.

\subsubsection{Analytical Results for Soil Samples Collected Near Hanford Site Facilities and Operations}

Cobalt-60, strontium-90, cesium-137, plutonium-239/240, and uranium were detected consistently in 2004 samples. Concentrations of these radionuclides were elevated near and within facility boundaries when compared to historical concentrations measured offsite at distant communities. Figure 8.9.1 shows the average concentrations of selected radionuclides in soil samples collected during 2004 and the preceding 5 years. Some individual levels demonstrate a high degree of variability, though overall trends are stable.

Three surface soil samples were collected near the 116-N-3 liquid waste disposal facility $(1325-\mathrm{N})$ in the $100-\mathrm{N}$ Area in 2004. Their analytical results were comparable to results observed in past years. Average radionuclide concentrations detected in the surface soil samples collected in the 100-N Area from 1999 through 2004 are presented in Table 8.9.2. The 2004 results and the average for distant communities and accessible soil concentration limits are compared in Table 8.9.3.

Soil samples were collected from 56 sampling locations in the 200 and 600 Areas during 2004. Analytical results from the 2004 samples demonstrated comparable average radionuclide concentration levels to those seen in 2003, with the exceptions of strontium-90 and plutonium239/240, which were higher (Table 8.9.4). Consistent with historical results, the sampling location at the outlet end of the retired B Pond facility (east of the 200-East Area) had the highest concentrations of cesium-137, plutonium-238, and plutonium-239/240 of any soil sampling location near a facility or operation. The 2004 maximum, average, and distant community average concentrations and accessible soil concentration limits for commonly measured radionuclides are compared in Table 8.9.5. Complete listings of radionuclide concentrations and sampling location maps are provided in PNNL-15222, APP. 2.

Soil samples were collected from 13 sampling locations in the 300 Area and one location in the 400 Area in 2004. 

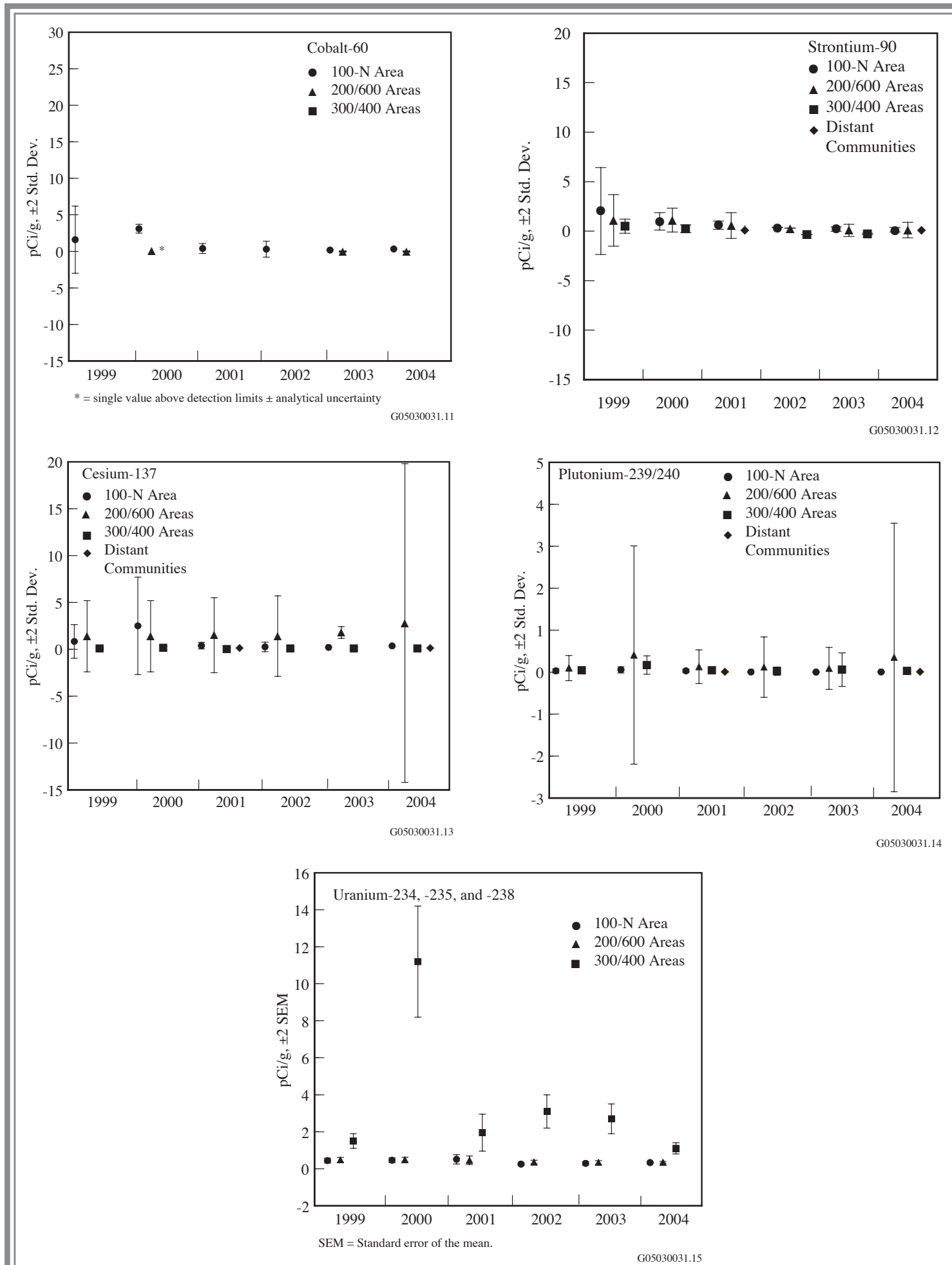

Figure 8.9.1. Average Concentrations of Selected Radionuclides in Soil Samples Collected on the Hanford Site Near Facilities and Operations Compared to Those Collected in Distant Communities (Section 8.9.2), 1999 through 2004. Radionuclide concentrations below analytical detection limits are not shown. As a result of figure scale, some uncertainties (error bars) are concealed by the point symbol. 
Table 8.9.2. Average Radionuclide Concentrations ( $\mathrm{pCi} / \mathrm{g}^{[\mathrm{ac}} \mathrm{dry}$ wt. (b) $^{(b)}$ in Surface Soil Samples Collected on the Hanford Site in the 100-N Area, 1999 through 2004

$\begin{array}{lcccccc}\text { Year } & \underline{{ }^{60} \mathbf{C o}} & \underline{{ }^{90} \mathbf{S r}} & \frac{{ }^{137} \mathbf{C s}}{{ }^{234} \mathbf{U}} & \underline{{ }^{238} \mathbf{U}} & \underline{{ }^{239 / 240} \mathbf{P u}} \\ 1999 & 1.6 \pm 4.6 & 1.9 \pm 4.4 & 0.84 \pm 1.8 & 0.22 \pm 0.04 & 0.20 \pm 0.03 & 0.026 \pm 0.05 \\ 2000 & 3.1 \pm 0.6 & 0.84 \pm 0.9 & 2.1 \pm 5.2 & 0.22 \pm 0.09 & 0.22 \pm 0.03 & 0.050 \pm 0.074 \\ 2001 & 0.27 \pm 0.68 & 0.20 \pm 0.42 & 0.32 \pm 0.44 & 0.24 \pm 0.09 & 0.25 \pm 0.07 & 0.022 \pm 0.04 \\ 2002^{(c)} & 0.3 \pm 1.1 & 0.15 \pm 0.47 & 0.26 \pm 0.51 & 0.13 \pm 0.05 & 0.11 \pm 0.04 & 0.006 \pm 0.006 \\ 2003^{(c)} & 0.18 \pm 0.02 & -0.08 \pm 0.24 & 0.21 \pm 0.04 & 0.14 \pm 0.05 & 0.15 \pm 0.05 & 0.002 \pm 0.006 \\ 2004 & 0.19 \pm 0.25 & -0.21 \pm 0.69 & 0.28 \pm 0.12 & 0.15 \pm 0.06 & 0.15 \pm 0.03 & 0.004 \pm 0.005\end{array}$

(a) To convert to international metric system units, multiply pCi/g by 0.037 to obtain $\mathrm{Bq} / \mathrm{g}$.

(b) \pm 2 times the standard deviation.

(c) Represents one sample site only; \pm total analytical uncertainty.

\begin{tabular}{|c|c|c|c|c|c|c|}
\hline & \multicolumn{6}{|c|}{$\begin{array}{l}\text { Table 8.9.3. Average Radionuclide Concentrations (pCi/g } \mathrm{g}^{[\mathrm{a}]} \mathrm{dry} \text { wt.) in Surface Soil } \\
\text { Samples Collected on the Hanford Site in the } 100-\mathrm{N} \text { Area in } 2004 \text {, Compared } \\
\text { to Distant Communities and Accessible Soil Concentration Limits }\end{array}$} \\
\hline & ${ }^{60} \mathrm{Co}$ & ${ }^{90} \mathrm{Sr}$ & ${ }^{137} \mathrm{Cs}$ & ${ }^{234} \mathbf{U}$ & $\underline{{ }^{238} \mathbf{U}}$ & ${ }^{239 / 240} \mathbf{P u}$ \\
\hline Result $^{(b)}$ & $0.19 \pm 0.25$ & $-0.21 \pm 0.69$ & $0.28 \pm 0.12$ & $0.15 \pm 0.06$ & $0.15 \pm 0.03$ & $0.004 \pm 0.005$ \\
\hline Distant community ${ }^{(b, c)}$ & NM & $0.029 \pm 0.054$ & $0.10 \pm 0.16$ & NM & $0.13 \pm 0.088$ & $0.0033 \pm 0.0060$ \\
\hline $\begin{array}{l}\text { Accessible soil } \\
\text { concentration limits } \\
(\text { WHC-SD-EN-TI-070)(d) }\end{array}$ & 7.1 & 2,800 & 30 & 630 & 370 & 190 \\
\hline $\begin{array}{l}\text { (a) To convert to intern } \\
\text { (b) } \pm 2 \text { times the standar } \\
\text { (c) See Section 8.9.2. } \\
\text { (d) Hanford soil that is } n \\
\text { NM }=\text { Not measured. }\end{array}$ & $\begin{array}{l}\text { tional metric } \\
\text { ot behind secu }\end{array}$ & $\begin{array}{l}\text { ystem units, mu } \\
\text { rity fences. }\end{array}$ & ltiply pCi/g by & 0.037 to obtair & & \\
\hline
\end{tabular}

\begin{tabular}{|c|c|c|c|c|c|c|}
\hline \multirow[b]{2}{*}{ Year } & \multicolumn{6}{|c|}{$\begin{array}{l}\left.\text { Table 8.9.4. Average Radionuclide Concentrations (pCi/g }{ }^{[a]} \text { dry wt. }\right)^{(b)} \text { in Surface } \\
\text { Soil Samples Collected Near Hanford Site Facilities and Operations in the } \\
\qquad 200 \text { and } 600 \text { Areas, } 1999 \text { through } 2004\end{array}$} \\
\hline & ${ }^{60} \mathrm{Co}$ & ${ }^{90} \mathrm{Sr}$ & ${ }^{137} \mathrm{Cs}$ & ${ }^{234} \mathbf{U}$ & ${ }^{238} \mathbf{U}$ & ${ }^{239 / 240} \mathbf{P u}$ \\
\hline 1999 & ND & $0.51 \pm 1.9$ & $1.3 \pm 3.8$ & $0.23 \pm 0.13$ & $0.22 \pm 0.13$ & $0.08 \pm 0.27$ \\
\hline 2000 & $0.006 \pm 0.006$ & $0.99 \pm 1.3$ & $1.4 \pm 3.8$ & $0.23 \pm 0.22$ & $0.23 \pm 0.22$ & $0.29 \pm 2.3$ \\
\hline 2001 & ND & $0.31 \pm 1.1$ & $1.5 \pm 4.0$ & $0.22 \pm 0.11$ & $0.22 \pm 0.11$ & $0.10 \pm 0.37$ \\
\hline 2002 & ND & $0.27 \pm 0.66$ & $1.4 \pm 4.3$ & $0.17 \pm 0.10$ & $0.17 \pm 0.11$ & $0.12 \pm 0.72$ \\
\hline 2003 & $0.002 \pm 0.013^{(\mathrm{c})}$ & $0.084 \pm 0.63$ & $1.8 \pm 0.63$ & $0.16 \pm 0.10$ & $0.17 \pm 0.10$ & $0.09 \pm 0.50$ \\
\hline 2004 & $0.001 \pm 0.011$ & $0.13 \pm 0.78$ & $2.8 \pm 17.0$ & $0.17 \pm 0.19$ & $0.17 \pm 0.15$ & $0.35 \pm 3.2$ \\
\hline $\begin{array}{l}\text { (a) } \\
\text { (b) } \\
\text { (c) } \\
\mathrm{ND}=\end{array}$ & \multicolumn{6}{|c|}{$\begin{array}{l}\text { To convert to international metric system units, multiply } \mathrm{pCi} / \mathrm{g} \text { by } 0.037 \text { to obtain } \mathrm{Bq} / \mathrm{g} \text {. } \\
\pm 2 \text { times the standard deviation. } \\
\text { Single value above detection limit. } \\
=\text { Not detected. }\end{array}$} \\
\hline
\end{tabular}




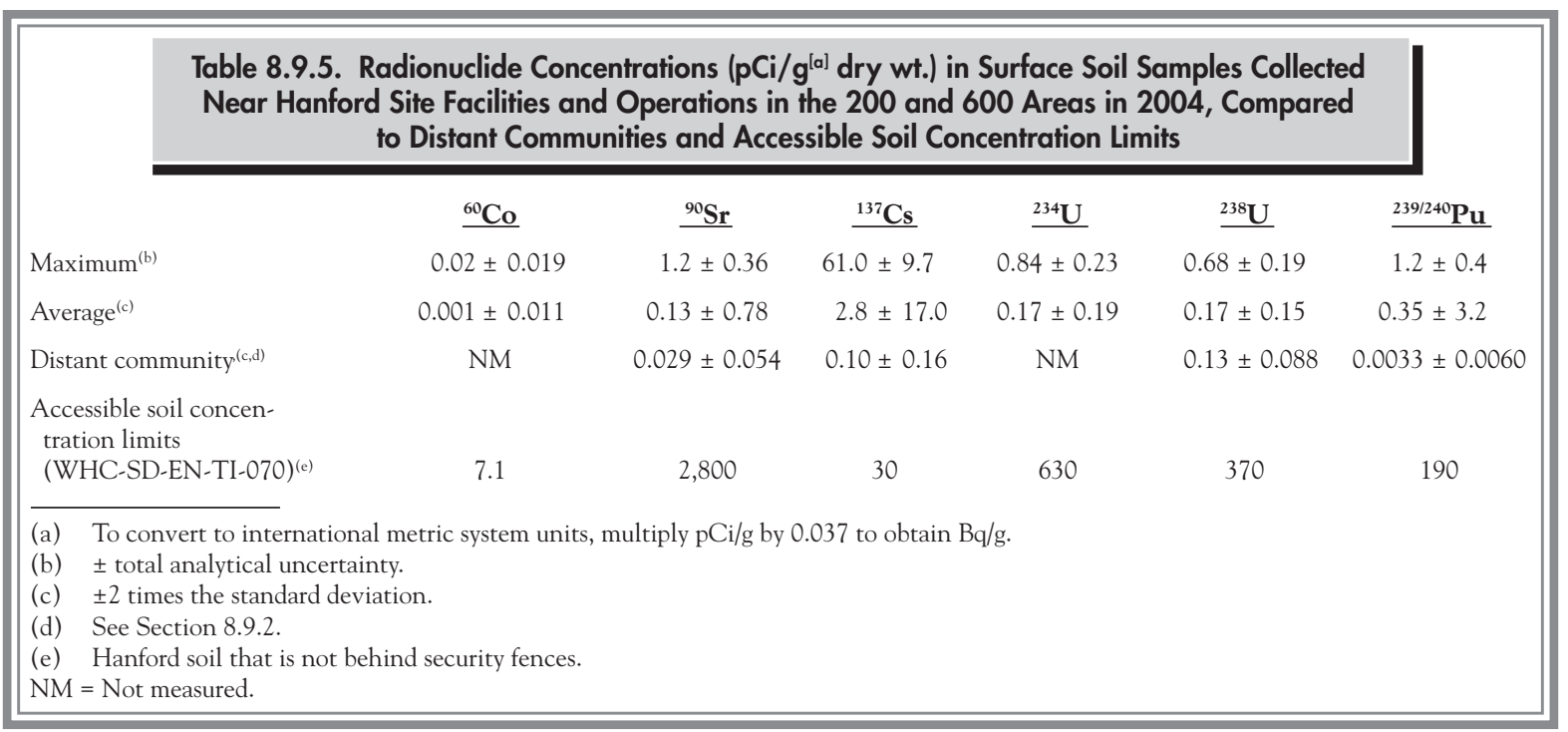

Average values reported for strontium-90 and uranium isotopes were somewhat less than the concentrations reported in 2003. Uranium concentrations were, as expected, higher in the 300 Area samples than at other site locations because uranium was processed during past fuel fabrication operations in the 300 Area. Analytical results for 2004 and the preceding 5 years are summarized in Table 8.9.6. The 2004 maximum and average concentrations, distant community average concentrations, and accessible soil concentration limits are compared in Table 8.9.7. Complete listings of radionuclide concentrations and sampling location maps are provided in PNNL-15222, APP. 2.

For non-routine soil sampling in support of the environmental restoration contractor projects in 2004, three soil samples were collected at the remedial action project in the $100-\mathrm{B} / \mathrm{C}$ Area, four at the 100-NR-1 remedial action project in the $100-\mathrm{N}$ Area, and one at the $100-K R-1$ remedial action project in the 100-K Area. A single sample was collected from the Environmental Restoration Disposal Facility in the 200-West Area to determine the effectiveness of contamination controls. Analytical results from each of these locations were comparable to those observed at other near-facility sampling locations at Hanford. Table 8.9 .8 provides a summary of selected analytical results for samples from these sites. All of the 2004 data are provided in PNNL-15222, APP. 2.

\subsubsection{Investigations of Radioactive Contamination in Soil Near Hanford Site Facilities and Operations}

\section{S. M. McKinney and R. M. Mitchell}

Investigative sampling is conducted in and near operational areas to monitor the presence or movement of radioactive materials around areas of known or suspected contamination or to verify radiological conditions at

\begin{tabular}{|c|c|c|c|c|c|c|}
\hline \multirow[b]{2}{*}{ Year } & \multicolumn{6}{|c|}{$\begin{array}{l}\text { Table 8.9.6. Average Radionuclide Concentrations (pCi/g }{ }^{[a]} \text { dry wt.)(b) in Surface } \\
\text { Soil Samples Collected Near Hanford Site Facilities and Operations in the } \\
\qquad 300 \text { and } 400 \text { Areas, } 1999 \text { through } 2004\end{array}$} \\
\hline & ${ }^{60} \mathrm{Co}$ & ${ }^{90} \mathrm{Sr}$ & ${ }^{137} \mathrm{Cs}$ & ${ }^{234} \mathbf{U}$ & ${ }^{238} \mathbf{U}$ & $\underline{239 / 240} \mathbf{P u}$ \\
\hline 1999 & ND & $0.85 \pm 0.70$ & $0.09 \pm 0.10$ & $0.70 \pm 1.8$ & $0.66 \pm 1.8$ & $0.03 \pm 0.05$ \\
\hline 2000 & ND & $0.56 \pm 0.40$ & $0.09 \pm 0.23$ & $5.4 \pm 24$ & $5.4 \pm 2.4$ & $0.07 \pm 0.21$ \\
\hline 2001 & ND & ND & $0.04 \pm 0.08$ & $0.94 \pm 3.0$ & $0.95 \pm 3.1$ & $0.03 \pm 0.10$ \\
\hline 2002 & ND & $0.03 \pm 0.03$ & $0.07 \pm 0.13$ & $1.5 \pm 6.4$ & $1.5 \pm 6.4$ & $0.02 \pm 0.10$ \\
\hline 2003 & ND & $0.06 \pm 0.07$ & $0.08 \pm 0.14$ & $1.3 \pm 5.1$ & $1.3 \pm 5.2$ & $0.08 \pm 0.40$ \\
\hline 2004 & ND & ND & $0.09 \pm 0.14$ & $1.0 \pm 2.9$ & $1.0 \pm 3.0$ & $0.03 \pm 0.07$ \\
\hline \multicolumn{7}{|c|}{$\begin{array}{l}\text { (a) To convert to international metric system units, multiply } \mathrm{pCi} / \mathrm{g} \text { by } 0.037 \text { to obtain } \mathrm{Bq} / \mathrm{g} \text {. } \\
\text { (b) } \pm 2 \text { times the standard deviation. } \\
\mathrm{ND}=\text { Not detected. }\end{array}$} \\
\hline
\end{tabular}




\begin{tabular}{|c|c|c|c|c|c|c|}
\hline \multicolumn{7}{|c|}{$\begin{array}{l}\text { Table 8.9.7. Radionuclide Concentrations (pCi/g } \mathrm{g}^{[\mathrm{a}]} \mathrm{dry} \text { wt.) in Surface Soil Samples Collected } \\
\text { Near Hanford Site Facilities and Operations in the } 300 \text { and } 400 \text { Areas in } 2004 \text {, Compared } \\
\text { to Distant Communities and Accessible Soil Concentration Limits }\end{array}$} \\
\hline & ${ }^{60} \mathrm{Co}$ & ${ }^{90} \mathrm{Sr}$ & ${ }^{137} \mathrm{Cs}$ & ${ }^{234} \mathbf{U}$ & ${ }^{238} \mathbf{U}$ & ${ }^{239 / 240} \mathbf{P u}$ \\
\hline Maximum $^{(b)}$ & $\mathrm{ND}$ & ND & $0.023 \pm 0.04$ & $4.7 \pm 1.2$ & $4.6 \pm 1.2$ & $0.12 \pm 0.43$ \\
\hline Average $^{(c)}$ & ND & ND & $0.09 \pm 0.14$ & $1.0 \pm 2.9$ & $1.0 \pm 3.0$ & $0.03 \pm 0.07$ \\
\hline Distant community ${ }^{(c, d)}$ & NM & $0.029 \pm 0.054$ & $0.10 \pm 0.16$ & NM & $0.13 \pm 0.088$ & $0.0033 \pm 0.0060$ \\
\hline $\begin{array}{l}\text { Accessible soil concen- } \\
\text { tration limits } \\
(\text { WHC-SD-EN-TI-070)(e) }\end{array}$ & 7.1 & 2,800 & 30 & 630 & 370 & 190 \\
\hline $\begin{array}{l}\text { (a) To convert to internati } \\
\text { (b) } \pm \text { total analytical unce } \\
\text { (c) } \pm 2 \text { times the standard } \\
\text { (d) See Section } 8.9 .2 . \\
\text { (e) Hanford soil that is not } \\
\mathrm{ND}=\text { Not detected. } \\
\mathrm{NM}=\text { Not measured. }\end{array}$ & $\begin{array}{l}\text { nal metr } \\
\text { ainty. } \\
\text { viation. } \\
\text { ehind s }\end{array}$ & $\begin{array}{l}\text { system units, mu } \\
\text { urity fences. }\end{array}$ & ly pCi/g by 0.0 & obtain $\mathrm{Bq} /$ & & \\
\hline
\end{tabular}

\begin{tabular}{|c|c|c|c|c|c|c|c|}
\hline \multirow[b]{2}{*}{$\underline{\text { Site }}$} & \multicolumn{7}{|c|}{$\begin{array}{l}\text { Table 8.9.8. Radionuclide Concentrations }\left(\mathrm{pCi} / \mathrm{g}^{[\mathrm{aj}]} \text { dry wt. }\right)^{(\mathrm{b})} \text { in Soil Samples Collected } \\
\text { on the Hanford Site for Environmental Restoration Contractor Projects, } 2004\end{array}$} \\
\hline & $\begin{array}{c}\text { Sample } \\
\text { Location }^{(c)}\end{array}$ & ${ }^{60} \mathrm{Co}$ & $\underline{{ }^{90} \mathrm{Sr}}$ & ${ }^{137} \mathrm{Cs}$ & ${ }^{234} \mathrm{U}$ & ${ }^{238} \mathbf{U}$ & ${ }^{239 / 240} \mathbf{P u}$ \\
\hline ERDF & D146 & ND & ND & ND & $0.24 \pm 0.079$ & $0.15 \pm 0.057$ & ND \\
\hline $100-B / C$ & D153 & ND & ND & $0.27 \pm 0.05$ & $0.14 \pm 0.049$ & $0.10 \pm 0.038$ & ND \\
\hline $100-\mathrm{F}$ & D154 & ND & ND & $0.029 \pm 0.01$ & $0.14 \pm 0.048$ & $0.21 \pm 0.063$ & ND \\
\hline $100-\mathrm{F}$ & D155 & ND & ND & $0.25 \pm 0.044$ & $0.09 \pm 0.036$ & $0.09 \pm 0.035$ & ND \\
\hline $100-\mathrm{N}$ & D156 & $0.03 \pm 0.009$ & $0.54 \pm 0.230$ & $0.06 \pm 0.017$ & $0.14 \pm 0.050$ & $0.15 \pm 0.053$ & ND \\
\hline $100-\mathrm{N}$ & D157 & $3.7 \pm 0.34$ & ND & $2.1 \pm 0.34$ & $0.14 \pm 0.050$ & $0.16 \pm 0.054$ & $0.05 \pm 0.022$ \\
\hline $100-\mathrm{N}$ & D158 & $0.17 \pm 0.02$ & ND & $0.24 \pm 0.043$ & $0.11 \pm 0.038$ & $0.11 \pm 0.04$ & ND \\
\hline $100-\mathrm{N}$ & D159 & $0.17 \pm 0.022$ & ND & $0.35 \pm 0.059$ & $0.18 \pm 0.056$ & $0.16 \pm 0.051$ & $0.07 \pm 0.031$ \\
\hline $100-\mathrm{KR}-1$ & D163 & $0.02 \pm 0.008$ & ND & $0.31 \pm 0.058$ & $0.13 \pm 0.051$ & $0.14 \pm 0.052$ & $1.1 \pm 0.30$ \\
\hline $100-\mathrm{B} / \mathrm{C}$ & D165 & ND & ND & $0.13 \pm 0.023$ & $0.09 \pm 0.042$ & $0.12 \pm 0.050$ & ND \\
\hline \multicolumn{2}{|c|}{ Distant communities $^{(\mathrm{d}, \mathrm{e})}$} & NM & $0.029 \pm 0.054$ & $0.10 \pm 0.16$ & NM & $0.13 \pm 0.088$ & $0.0033 \pm 0.0060$ \\
\hline \multicolumn{2}{|c|}{$\begin{array}{l}\text { Accessible soil } \\
\text { concentration }^{(f)}\end{array}$} & 7.1 & 2,800 & 30 & 630 & 370 & 190 \\
\hline \multicolumn{8}{|c|}{$\begin{array}{l}\text { (a) To convert to international metric system units, mult } \\
\text { (b) } \pm \text { total analytical uncertainty. } \\
\text { (c) Sampling location code. See PNNL-15222, APP. } 2 . \\
\text { (d) } \pm 2 \text { times the standard error of the mean. } \\
\text { (e) See Section 8.9.2. } \\
\text { (f) Hanford soil that is not behind security fences. } \\
\text { ERDF = Environmental Restoration Disposal Facility. } \\
\text { ND = Not detected. } \\
\text { NM = Not measured. }\end{array}$} \\
\hline
\end{tabular}

specific project sites. All investigative samples are field surveyed for alpha and beta/gamma radiation and some samples are analyzed at a laboratory to identify specific radionuclides. Most samples are disposed of without being analyzed. Generally, the predominant radionuclides in investigative samples from the 100 and 200 Areas are strontium-90, cesium-137, and plutonium-239/240.
Uranium-234, uranium-235, and uranium-238 are usually found in 300 Area samples.

During 2004, there were 19 instances of radiological contamination in investigative soil samples. Of the 19, 13 were identified as speck contamination. One of the investigative soil samples was submitted for radioisotopic 
analysis. Of the 19 locations, 16 were cleaned up, and the contaminated soil was disposed of onsite in burial grounds. At the remaining locations, the contamination levels did not exceed the radiological control limits for the sites and the soil was left in place. The number of investigative soil contamination incidents, range of radiation dose levels, and radionuclide concentrations in 2004 were generally within historical values (WHC-MR-0418). Contaminated soil found outside of a radiological control area was cleaned up and posted as surface contamination if the dose rate exceeded the established radiological control limit for the location.

The number and general locations of soil contamination incidents investigated during 2004 are summarized in Table 8.9.9. The number of contamination incidents investigated in 2004 and during the previous 10 years are provided in Table 8.9.10.

\begin{tabular}{|lc|}
\hline \multicolumn{2}{|c|}{ Table 8.9.9. Number and Location of Soil } \\
Contamination Incidents Investigated Near \\
Hanford Site Facilities and Operations, 2004
\end{tabular}

Table 8.9.10. Annual Number of Soil Contamination Incidents Investigated Near Hanford Site Facilities and Operations, 1994 through 2004

\begin{tabular}{cccc|}
\hline$\underline{\text { Year }}$ & $\begin{array}{c}\text { Number of } \\
\text { Incidents }\end{array}$ & $\underline{\text { Year }}$ & $\begin{array}{c}\text { Number of } \\
\text { Incidents }\end{array}$ \\
1994 & 94 & 2000 & 25 \\
1995 & 73 & 2001 & 20 \\
1996 & 37 & 2002 & 22 \\
1997 & 51 & 2003 & 30 \\
1998 & 41 & 2004 & 19 \\
1999 & 42 & & \\
\hline
\end{tabular}

\subsubsection{Soil Monitoring at Site-Wide and Offsite Locations}

\section{B. G. Fritz}

Soil monitoring provides information on long-term contamination trends and baseline environmental radionuclide activities at undisturbed locations both on and off the Hanford Site (DOE/RL-91-50). Soil samples have been collected on and around the Hanford Site for more than 50 years. Consequently, a large database exists that documents onsite and offsite levels of manmade radionuclides in soil at specific locations. This database contains baseline data against which analysis results from unplanned contaminant releases from the Hanford Site can be compared. Routine radiological monitoring of soil at site-wide (onsite away from facilities and operations) and offsite locations was last conducted in 2001 (Section 4.6 in PNNL-13910).

\section{Soil Sampling at Site-Wide and Offsite Locations}

In 2004, soil samples were collected at the locations shown in Figure 8.9.2. Samples were organized into four distinct groups: (1) site-wide (onsite), (2) perimeter, (3) the Fitzner/Eberhardt Arid Lands Ecology Reserve Unit of the Hanford Reach National Monument, and (4) distant. Site-wide samples were collected at undisturbed locations around areas of industrial development on the site. Perimeter samples were collected on the edge of 


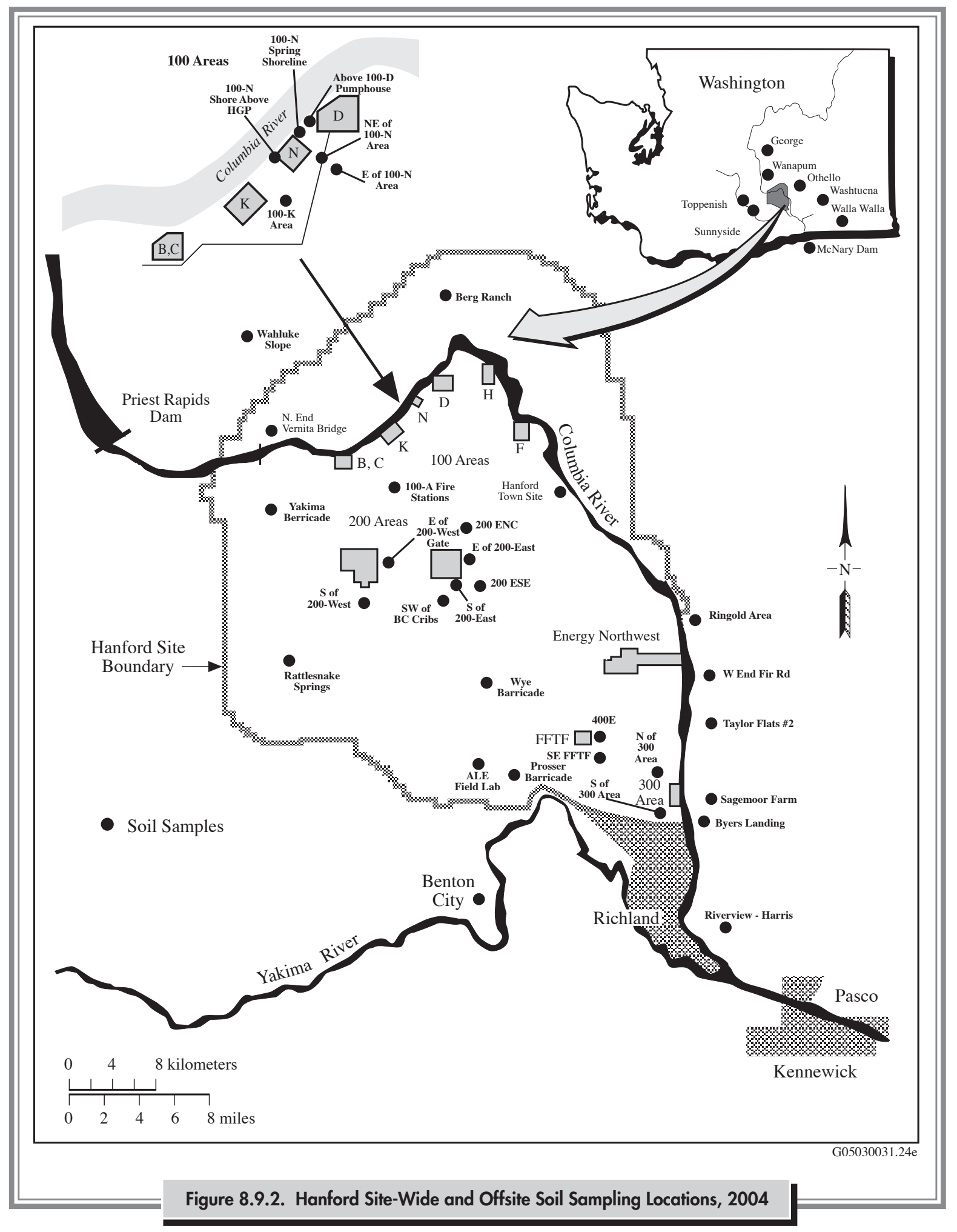




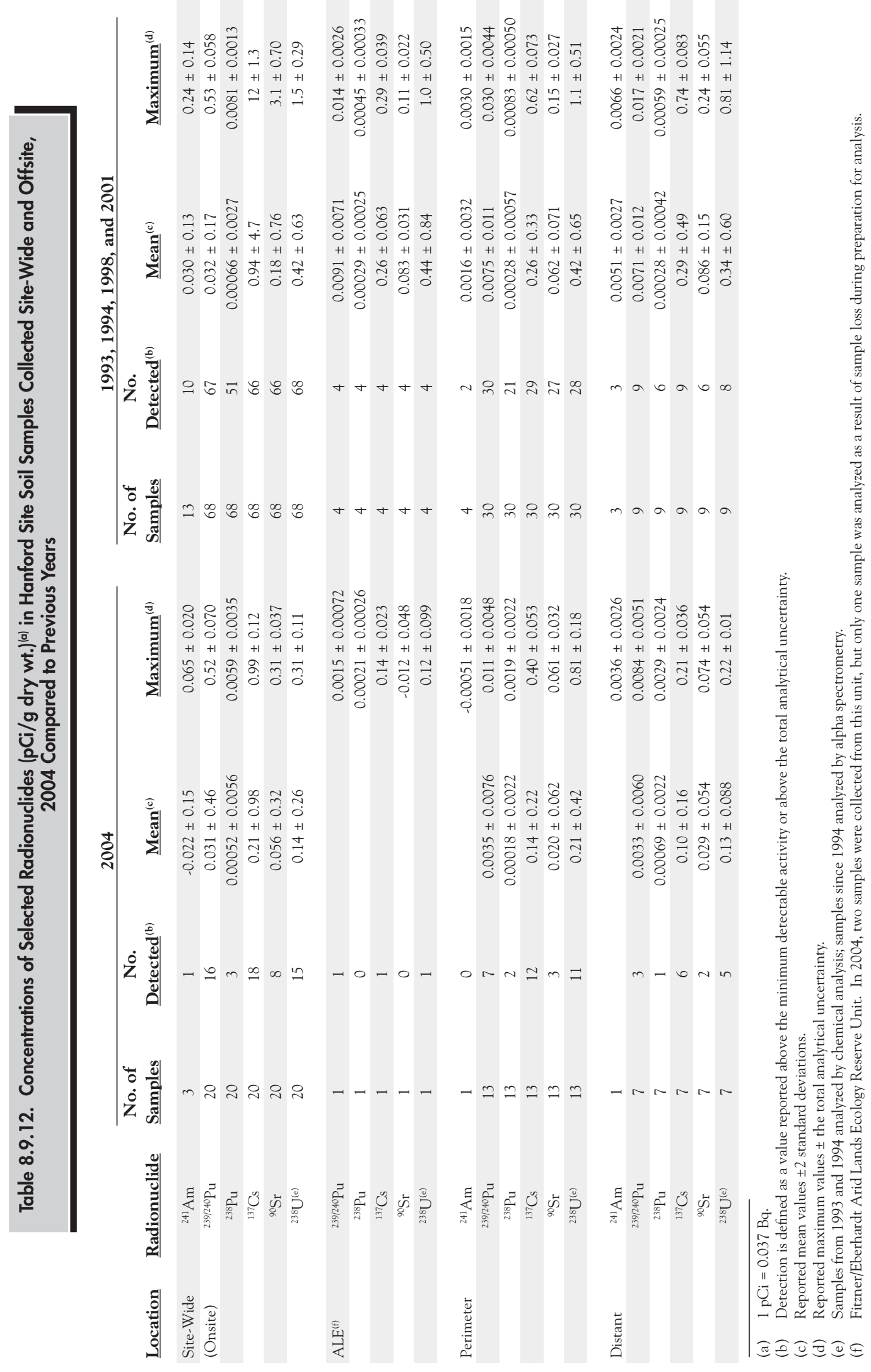




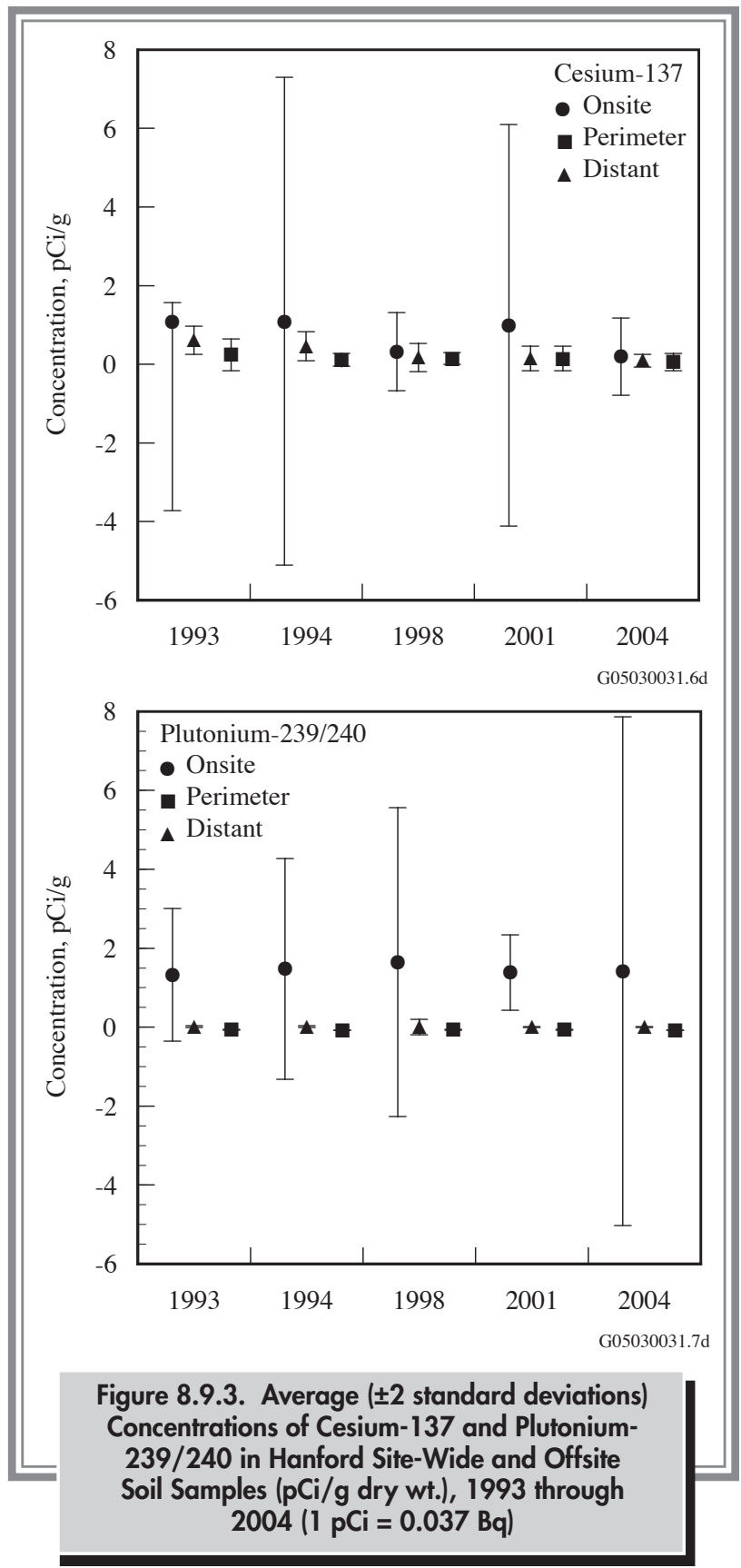




\subsection{Vegetation Monitoring}

Vegetation monitoring and control activities conducted on and around the Hanford Site in 2004 are summarized in the following sections. The sections include discussions on surveys and monitoring of Hanford Site plant populations; monitoring contaminants in perennial vegetation growing near facilities and operations on the site; monitoring contaminant concentrations in perennial vegetation growing onsite at locations away from facilities (site-wide) and at perimeter, community, and distant locations around the site (offsite); and control of contaminated or unwanted vegetation on the site. Surveys and monitoring of plant populations are conducted to assess the abundance, vigor or condition, and distribution of populations and species. These data can be integrated with contaminant monitoring results and used to help characterize potential risks or impact to biota. Radiological monitoring of vegetation near onsite facilities and operations is done to determine the effectiveness of effluent monitoring and controls within facilities, to assess the adequacy of containment at waste disposal sites, and to detect and monitor unusual conditions. Site-wide and offsite vegetation samples are analyzed for information on atmospheric deposition of contaminants in uncultivated areas offsite and around operational areas onsite. These data provide a baseline against which unplanned releases can be compared. Vegetation management activities help to prevent, limit, or clean up contaminated plants or undesirable plant species. For further information about these monitoring and control efforts, the programs that support them, and their purposes, see Section 8.0 in this report or DOE/RL-91-50.

\subsubsection{Plant Communities and Population Surveys on the Hanford Site}

\author{
J. L. Downs, M. R. Sackschewsky, K. D. Hand, \\ R. E. Durham, and R. K. Zufelt
}

The Hanford Site contains biologically diverse shrubsteppe plant communities that have been protected from most disturbances, except for fire and limited livestock grazing, for more than 60 years. This protection has allowed native plant species and communities that have been displaced by agriculture and development in other parts of the Columbia Basin to persist at Hanford. Surveys and mapping efforts have documented the occurrence and extent of rare plant populations and plant community types on the Hanford Site (PNNL-13688; PNL-8942; Soll et al. 1999). Plant populations monitored on the site include taxa listed by Washington State as endangered, threatened, or sensitive (Section 8.12), and those species listed as review group 1 (i.e., taxa in need of additional field work before status can be determined) (Washington Natural Heritage Program 1997). Data are collected for plant populations and plant communities on the Hanford Site to develop baseline information and to monitor any changes resulting from Hanford operations. The data provide information that is used for site planning processes and land-use policy development.

\subsubsection{Vegetation Cover Types and Habitats}

Monitoring of the plant communities and cover types at Hanford focuses on two main objectives: mapping the distribution and extent of major plant cover types on the 
uplands and riparian areas on the site and conducting periodic surveys to assess whether community composition and structure are changing. Mapping the distribution and extent of vegetation on the Hanford Site provides important information on potential and existing habitats of sensitive or rare species as well as provides information regarding the presence of ecological receptor species. The spatial data for upland habitats were updated to reflect changes in vegetation following the 24 Command Hanford Site Wildfire in 2000. Spatial information for the riparian vegetation cover types was updated during 2003 and 2004 to provide a continuous map of vegetation along the Benton County shoreline of the Hanford Reach. Information from these survey and monitoring efforts are also used to update maps depicting areas with highly valued biological resources (http://www.pnl.gov/ecomon/ Veg/Veg.html). Periodic surveys of the frequency, cover, and number of species found on permanent monitoring plots provide information on trends or changes in species diversity, presence of invasive and key species, and the overall condition of the plant community and available habitat.

\subsubsection{Rare Plant Monitoring}

More than 100 plant populations of 47 taxa listed by the Washington Natural Heritage program as endangered, threatened, sensitive, review, or watch list are found at the Hanford Site (http://www.pnl.gov/ecomon/Veg/ Habitat.html; PNNL-13688). The U.S. Fish and Wildlife Service has designated 5 of these 47 taxa, including the two species, Umtanum buckwheat (Eriogonum codium) and White Bluffs bladderpod (Lesquerella tuplashensis), as species of concern in the Columbia River Basin ecoregion (http://www.dnr.wa.gov/nhp/refdesk/lists/plantrnk.htm). These two species are proposed as candidates for federal listing. In addition to the rare plant populations, several areas on the Hanford Site are designated as special habitat types with regard to potential occurrence of plant species of concern listed by Washington State. These are areas that potentially support populations of rare annual forbs that have been documented in adjacent habitats.

In June 2004, a population of coyote tobacco, Nicotiana attenuata, was discovered in a disturbed, open sand dune adjacent to the $618-10$ burial ground, approximately 3.2 kilometers ( 2 miles) southeast of the 400 Area. A total of approximately 30 individual plants was found, and the habitat in the vicinity of the population was designated a rare plant protection area to help conserve the population while cleanup of the 618-10 burial ground proceeds. Similar habitats within 1.6 to 3.2 kilometers ( 1 to 2 miles) of the $618-10$ population site were surveyed, but no other populations were found. A small population of this species was observed on the Fitzner/Eberhardt Arid Lands Ecology Reserve Unit in 1999, but had otherwise not been observed within the area of the Hanford Site for nearly 100 years.

Transects established to examine condition and status of persistent sepal yellowcress (Rorippa columbiae) along the Columbia River shoreline near the 100-F Area and on several islands of the Hanford Reach of the Columbia River were not surveyed during 2003 because of high river flows. In September 2004, the Locke Island populations of this species were surveyed to compare numbers of individual stems with numbers counted during previous surveys. In 2004 , approximately 1,800 plants were counted in the Locke Island population, which is comparable to numbers of stems found on the island during the last count in 2001, but fewer than reported during the mid-1990s. Data that describe trends in plant numbers and the timing of growth for this species are of interest because large variations in population numbers have been observed. These variations are believed to be related to river-level fluctuations that inundate habitat for the species during a large proportion of the growing season.

\subsubsection{Vegetation Monitoring Near Hanford Site Facilities and Operations}

\section{R. M. Mitchell}

Vegetation samples were collected on, or adjacent to, waste disposal sites and from locations downwind and near or within the boundaries of operating facilities and remedial action sites. Samples were collected to evaluate longterm trends in environmental accumulation and potential migration of radioactive material. Contamination in vegetation can occur as the result of surface deposition of radioactive materials from other radiologically 
contaminated sources and/or by absorption of radionuclides by the roots of vegetation growing on or near waste disposal sites.

The number and location of vegetation samples collected near facilities and operations during 2004 are summarized in Table 8.10.1. Only those radionuclide concentrations reported above analytical detection limits are discussed in this section. A comprehensive presentation of the analytical data from these samples can be found in PNNL-15222, APP. 2.

\subsubsection{Vegetation Sampling Near Hanford Site Facilities and Operations}

Each sample (approximately 500 grams [16.1 ounces]) consisted of new-growth leaf cuttings taken from the available brushy, deep-rooted species (e.g., sagebrush and/or rabbitbrush) at a sample location. Often, the sample consisted of a composite of several like members of the sampling site plant community to avoid decimation of any individual plant through overharvesting. Vegetation samples were dried prior to analyses and analytical results were reported on a dry weight basis.

Samples were analyzed for the radionuclides expected to occur in the areas sampled (i.e., gamma-emitting radionuclides [cobalt-60 and cesium-137], strontium-90, uranium isotopes, and/or plutonium isotopes). Selected analytical results were compared to concentrations in samples collected by Pacific Northwest National Laboratory at offsite sampling locations in Yakima, Benton, and Franklin Counties. Comparisons were used to determine the differences between contributions from site operations and remedial action sites and contributions from natural sources and worldwide fallout.
Some degree of variability is always associated with the collection and analysis of environmental samples. Therefore, variations in sample concentrations from year to year are expected. In general, radionuclide concentrations in vegetation samples collected from, or adjacent to, waste disposal facilities in 2004 were higher than the concentrations in samples collected farther away and were significantly higher than concentrations measured offsite. The data also show, as expected, that concentrations of certain radionuclides in 2004 were higher within different operational areas when compared to concentrations measured in distant communities. Generally, the predominant radionuclides were activation and fission products in the 100-N Area, fission products in the 200 and 600 Areas, and uranium in the 300 and 400 Areas.

\subsubsection{Analytical Results for Vegetation Samples Collected Near Hanford Site Facilities and Operations}

Strontium-90, cesium-137, plutonium-239/240, and uranium were detected consistently from samples taken in 2004. Concentrations of these radionuclides were elevated near and within facility boundaries compared to concentrations measured at distant communities. Figure 8.10.1 shows the average concentrations in vegetation samples collected near onsite facilities and operations during 2004 and the preceding 5 years and results for 2004 for distant communities. The results demonstrate a high degree of variability.

Six vegetation samples were collected at locations in the 100-N Area in 2004. Analytical results from these samples were comparable to those observed in 100-N Area samples collected in 2003 and were within the range of historical

Table 8.10.1. Number and Locations of Vegetation Samples Collected Near Hanford Site Facilities and Operations in 2004

\begin{tabular}{|c|c|c|c|c|c|c|c|c|c|c|}
\hline \multirow{2}{*}{$\begin{array}{c}\text { Sample } \\
\text { Type }\end{array}$} & \multirow{2}{*}{$\begin{array}{l}\text { Number of } \\
\text { Sampling } \\
\text { Locations }\end{array}$} & \multicolumn{9}{|c|}{ Operational Area } \\
\hline & & $\underline{100-\mathrm{B} / \mathrm{C}}$ & 100-D/DR & $\underline{100-K}$ & $\underline{100-F}$ & $\underline{100-H}$ & $\underline{100-N}$ & $\underline{\text { ERDF }}^{(a)}$ & $\underline{200 / 600}$ & $300 / 400$ \\
\hline Vegetation & 69 & 0 & 0 & 0 & 0 & 0 & 6 & 0 & 49 & 14 \\
\hline
\end{tabular}



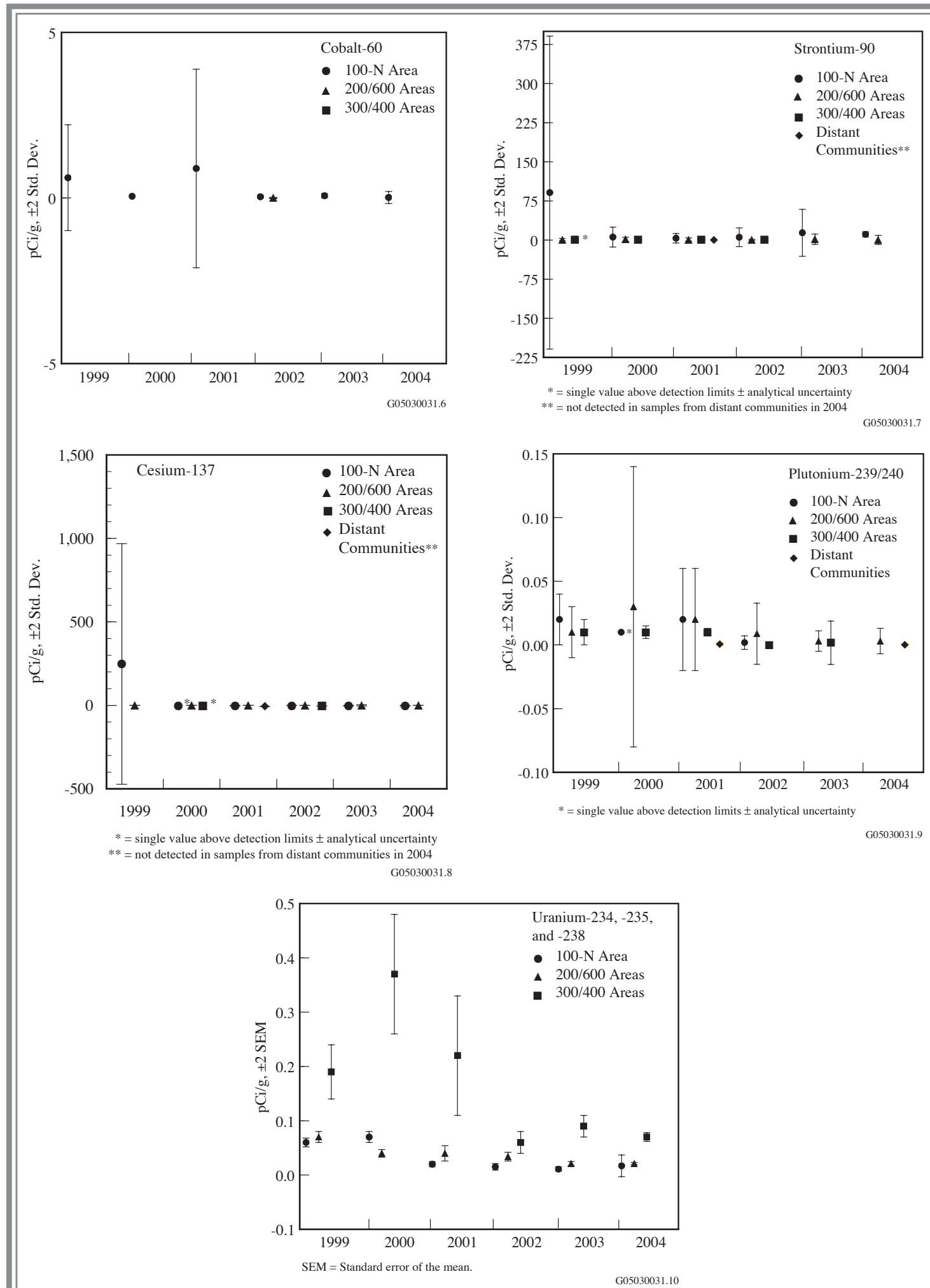

Figure 8.10.1. Average Concentrations of Selected Radionuclides in Vegetation Samples Collected Near Hanford Site Facilities and Operations Compared to Those Collected in Distant Communities (PNNL-13910), 1999 through 2004. Radionuclide concentrations below analytical detection limits are not shown. As a result of figure scale, some uncertainties (error bars) are concealed by the point symbol. 
values. The levels of strontium-90 in 100-N Area samples were higher than levels found samples from the 200 , 300, and 400 Areas. The radionuclide levels measured in 100-N Area vegetation in 2004 were greater than those measured at distant communities in 2004. The 2004 maximum and average concentrations for vegetation samples collected at the 100-N Area are compared to historic distant community averages in Table 8.10.2. Average radionuclide concentrations detected in all of the nearfacility vegetation samples collected in the 100-N Area from 1999 through 2004 are presented in Table 8.10.3. A complete list of radionuclide concentrations and sampling location maps are provided in PNNL-15222, APP. 2

Samples from 49 locations were collected in the 200 and 600 Areas during 2004. Concentrations of selected radionuclides reported for 1999 through 2004 are summarized in Table 8.10.4. Analytical results from samples taken from the 200 and 600 Areas were generally lower than those observed in previous years. Radionuclide levels for strontium-90, cesium-137, and plutonium-239/240 were greater than those measured off the Hanford Site. The 2004 maximum and average concentrations for selected radionuclides are compared to distant communities in Table 8.10.5. A complete list of radionuclide concentrations and sampling location maps are provided in PNNL-15222, APP. 2.

Fourteen samples were collected from the 300/400 Areas in 2004. Table 8.10 .6 provides a summary of the 300 and 400 Areas results from samples collected from 1999 through 2004. Uranium levels were higher than levels measured in the 100 and 200 Areas. The higher uranium levels were expected because uranium was released to the environment during past fuel fabrication operations in the 300 Area.

The 2004 maximum, average, and distant community average concentrations for 300 and 400 Areas samples

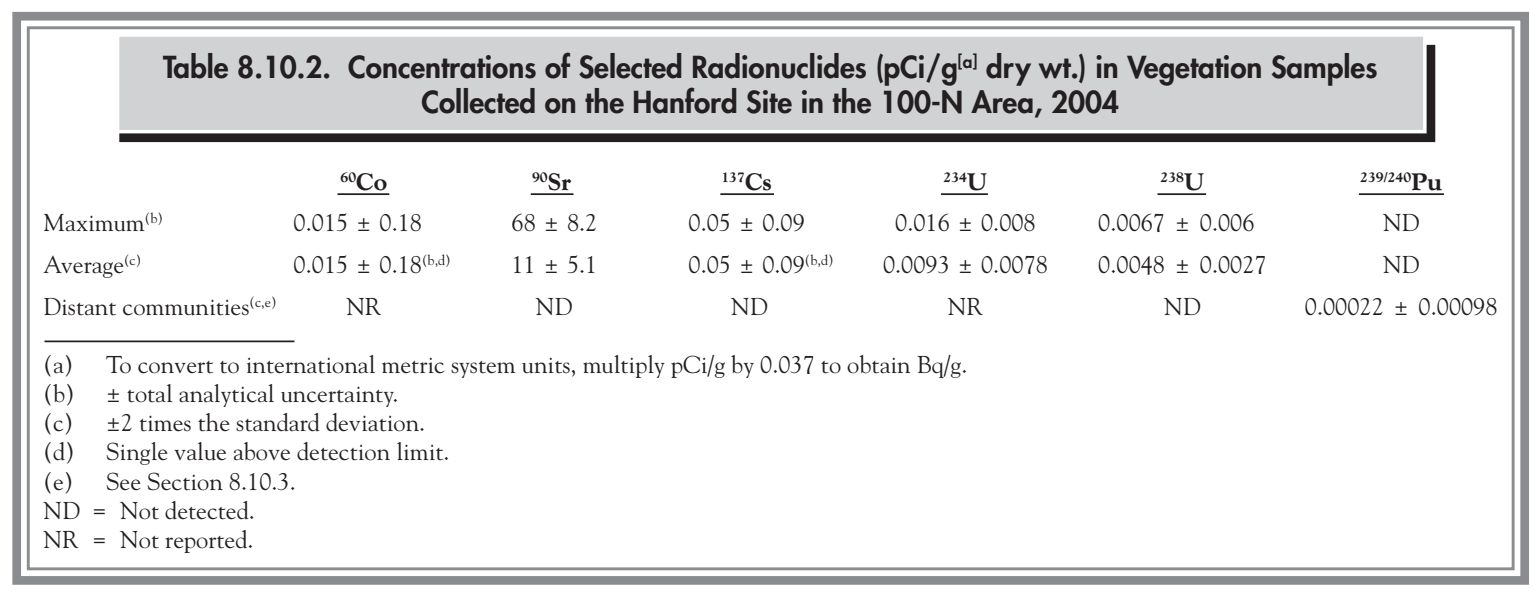

\begin{tabular}{|c|c|c|c|c|}
\hline \multirow[b]{2}{*}{$\underline{\text { Year }}$} & \multicolumn{4}{|c|}{$\begin{array}{l}\text { Table 8.10.3. Average Radionuclide Concentrations }{ }^{(a)}\left(\mathrm{pCi} / \mathrm{g}^{[\mathrm{b}]} \mathrm{dry} \text { wt.) }\right. \\
\text { Detected in Vegetation Samples Collected on the Hanford Site } \\
\text { in the } 100-\mathrm{N} \text { Area, } 1999 \text { through } 2004\end{array}$} \\
\hline & ${ }^{60} \mathrm{Co}$ & ${ }^{90} \mathrm{Sr}$ & ${ }^{137} \mathrm{Cs}$ & ${ }^{239 / 240} \mathbf{P u}$ \\
\hline 1999 & $0.61 \pm 1.4$ & $91 \pm 300$ & $250 \pm 670$ & $0.01 \pm 0.02$ \\
\hline 2000 & $0.05 \pm 0.09$ & $5.7 \pm 16$ & $0.2^{(c)} \pm 0.2$ & $0.0004 \pm 0.04$ \\
\hline 2001 & $0.89 \pm 2.3$ & $3.5 \pm 8.4$ & $0.38 \pm 0.44$ & $0.024 \pm 0.03$ \\
\hline 2002 & $0.004 \pm 0.037$ & $5.4 \pm 18.0$ & $0.002 \pm 0.008$ & $0.002 \pm 0.005$ \\
\hline 2003 & $0.066 \pm 0.068$ & $14 \pm 45$ & $0.15 \pm 0.15$ & ND \\
\hline 2004 & $0.015 \pm 0.18$ & $11 \pm 5.1$ & $0.05 \pm 0.09$ & ND \\
\hline \multicolumn{5}{|c|}{$\begin{array}{l}\text { (a) } \pm 2 \text { times the standard error of the mean. } \\
\text { (b) To convert to international metric system units, multiply } \mathrm{pCi} / \mathrm{g} \text { by } 0.037 \text { to obtain } \mathrm{Bq} / \mathrm{g} \text {. } \\
\text { (c) Single value above detection limit. } \\
\text { ND }=\text { Not detected. }\end{array}$} \\
\hline
\end{tabular}




\begin{tabular}{|c|c|c|c|c|c|c|}
\hline \multirow[b]{2}{*}{ Year } & \multicolumn{6}{|c|}{$\begin{array}{l}\text { Table 8.10.4. Average Radionuclide Concentrations }{ }^{[a]} \text { (pCi/ } g^{[b]} \text { dry wt.) Detected in Vegetation Samples } \\
\text { Collected Near Hanford Site Facilities and Operations in the } 200 \text { and } 600 \text { Areas, } 1999 \text { through } 2004\end{array}$} \\
\hline & ${ }^{60} \mathrm{Co}$ & ${ }^{90} \mathrm{Sr}$ & ${ }^{137} \mathrm{Cs}$ & ${ }^{234} \mathbf{U}$ & ${ }^{238} \mathbf{U}$ & ${ }^{239 / 240} \mathbf{P u}$ \\
\hline 1999 & ND & $0.79 \pm 2.3$ & $0.13 \pm 0.18$ & $0.033 \pm 0.004$ & $0.023 \pm 0.003$ & $0.009 \pm 0.017$ \\
\hline 2000 & ND & $1.30 \pm 3.3$ & $0.16 \pm 0.21$ & $0.020 \pm 0.02$ & $0.014 \pm 0.002$ & $0.033 \pm 0.06$ \\
\hline 2001 & ND & $1.00 \pm 2.3$ & $0.17 \pm 0.24$ & $0.019 \pm 0.002$ & $0.018 \pm 0.018$ & $0.021 \pm 0.03$ \\
\hline 2002 & $0.0003 \pm 0.0018$ & $0.32 \pm 1.10$ & $0.089 \pm 0.42$ & $0.016 \pm 0.016$ & $0.014 \pm 0.015$ & $0.009 \pm 0.024$ \\
\hline 2003 & ND & $1.5 \pm 10$ & $0.27 \pm 2.0$ & $0.01 \pm 0.01$ & $0.008 \pm 0.009$ & $0.003 \pm 0.008$ \\
\hline 2004 & ND & $0.22 \pm 8.8$ & $0.04 \pm 0.14$ & $0.0097 \pm 0.01$ & $0.0082 \pm 0.0093$ & $0.003 \pm 0.01$ \\
\hline \multicolumn{7}{|c|}{$\begin{array}{l}\text { (a) } \pm 2 \text { times the standard deviation. } \\
\text { (b) To convert to international metric system units, multiply } \mathrm{pCi} / \mathrm{g} \text { by } 0.037 \text { to obtain } \mathrm{Bq} / \mathrm{g} \text {. } \\
\mathrm{ND}=\text { Not detected. }\end{array}$} \\
\hline
\end{tabular}

\begin{tabular}{|c|c|c|c|c|c|c|}
\hline \multicolumn{7}{|c|}{$\begin{array}{l}\text { Table 8.10.5. Concentrations of Selected Radionuclides (pCi/g } g^{[a]} \text { dry wt.) in Vegetation Samples } \\
\text { Collected Near Hanford Site Facilities and Operations in the } 200 \text { and } 600 \text { Areas, } 2004\end{array}$} \\
\hline & ${ }^{60} \mathrm{Co}$ & ${ }^{90} \mathrm{Sr}$ & ${ }^{137} \mathrm{Cs}$ & ${ }^{234} \mathbf{U}$ & ${ }^{238} \mathbf{U}$ & $\underline{239 / 240} \mathbf{P u}$ \\
\hline & ND & $17 \pm 3.4$ & $0.33 \pm 0.1$ & $0.028 \pm 0.013$ & $0.022 \pm 0.011$ & $0.029 \pm 0.014$ \\
\hline Average $e^{(c)}$ & ND & $0.22 \pm 8.8$ & $0.04 \pm 0.14$ & $0.0097 \pm 0.01$ & $0.0082 \pm 0.0093$ & $0.003 \pm 0.01$ \\
\hline $\begin{array}{l}\text { Distant } \\
\text { communities }^{(\mathrm{c}, \mathrm{d})}\end{array}$ & NR & ND & ND & NR & ND & $0.00022 \pm 0.00098$ \\
\hline \multicolumn{7}{|c|}{$\begin{array}{l}\text { (a) To convert to international metric s } \\
\text { (b) } \pm \text { total analytical uncertainty. } \\
\text { (c) } \pm 2 \text { times the standard deviation. } \\
\text { (d) See Section } 8.10 .3 . \\
\text { ND }=\text { Not detected. } \\
\text { NR }=\text { Not reported. }\end{array}$} \\
\hline
\end{tabular}

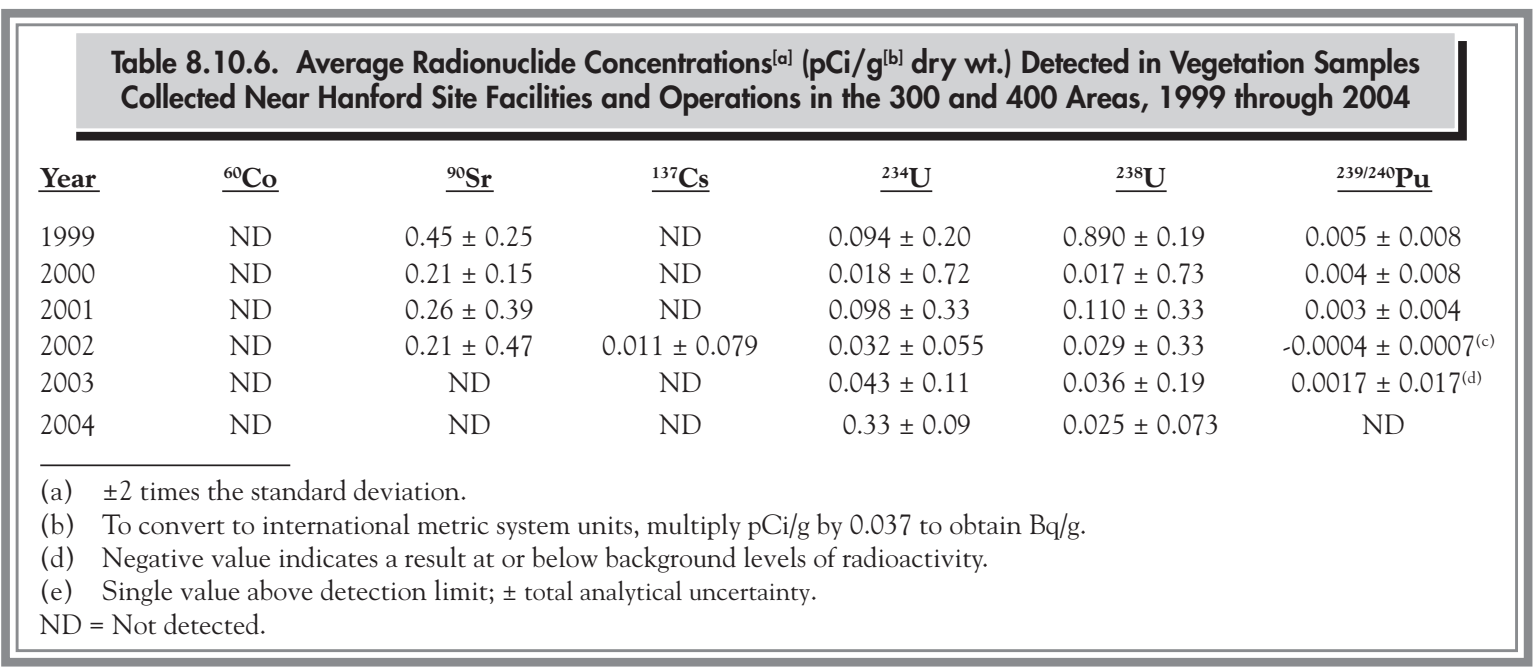


are listed in Table 8.10.7. Complete listings of radionuclide concentrations and sampling location maps are provided in PNNL-15222, APP. 2.

\subsubsection{Investigations of Radioactive Contamination in Vegetation Near Hanford Site Facilities and Operations}

\section{S. M. McKinney and R. M. Mitchell}

Investigative sampling was conducted in and near operational areas to monitor the presence or movement of radioactive materials around areas of known or suspected contamination or to verify radiological conditions at specific project sites. All investigative samples were field surveyed for alpha and beta/gamma radiation and some samples were analyzed at a laboratory to identify specific radionuclides. Most samples were disposed of without being analyzed. Generally, the predominant radionuclides in investigative samples from the 100 and 200 Areas were strontium-90, cesium-137, and plutonium-239/240. Uranium-234, uranium-235, and uranium-238 were usually found in 300 Area samples.

During 2004, radiological contamination was found in 60 investigative vegetation samples. Fifty-seven samples were tumbleweeds (Russian thistle) or tumbleweed fragments, two samples were rabbitbrush, and one sample was big sagebrush. Only one tumbleweed sample was analyzed for specific radionuclides. Samples not sent to the laboratory for analysis were disposed of onsite in burial grounds. A discussion of vegetation control efforts at Hanford during 2004 is provided in Section 8.10.4.
The number and general locations of vegetation contamination incidents investigated during 2004 are summarized in Table 8.10.8. The numbers of contamination incidents investigated in 2004 and during the previous 10 years are provided in Table 8.10.9.

\subsubsection{Vegetation Monitoring at Site-Wide and Offsite Locations}

\section{B. G. Fritz}

Monitoring of rabbitbrush and sagebrush leaves and stems provides information on atmospheric deposition of radioactive materials in uncultivated areas and at site-wide locations that could potentially be affected by contaminants from Hanford Site operations. Vegetation samples have been collected on and around the Hanford Site for more than 50 years. Data from these samples are maintained in a database to document onsite and offsite levels of manmade radionuclides in vegetation at specific locations. This database holds baseline data against which data from unplanned contaminant releases from the Hanford Site can be compared. Collection of vegetation samples at site-wide and offsite locations was last conducted in 2001 (Section 4.6 in PNNL-13910).

\subsubsection{Vegetation Sampling at Site-Wide and Offsite Locations}

Vegetation samples were collected at 14 locations on and around the Hanford Site in 2004 (Figure 8.10.2).

\begin{tabular}{|c|c|c|c|c|c|c|}
\hline \multicolumn{7}{|c|}{$\begin{array}{l}\text { Table 8.10.7. Concentrations of Selected Radionuclides (pCi/g }{ }^{[a]} \text { dry wt.) in Vegetation Sam- } \\
\text { ples Collected Near Hanford Site Facilities and Operations in the } 300 \text { and } 400 \text { Areas, } 2004\end{array}$} \\
\hline & ${ }^{60} \mathrm{Co}$ & ${ }^{90} \mathrm{Sr}$ & ${ }^{137} \mathrm{Cs}$ & ${ }^{234} \mathbf{U}$ & ${ }^{238} \mathbf{U}$ & ${ }^{239 / 240} \mathrm{Pu}$ \\
\hline Maximum $^{(\mathrm{b})}$ & ND & $\mathrm{ND}$ & ND & $0.18 \pm 0.05$ & $0.15 \pm 0.05$ & ND \\
\hline Average $^{(c)}$ & ND & $\mathrm{ND}$ & $\mathrm{ND}$ & $0.033 \pm 0.09$ & $0.025 \pm 0.073$ & ND \\
\hline Distant communities ${ }^{(\mathrm{c}, \mathrm{d})}$ & NR & ND & ND & NR & ND & $0.00022 \pm 0.00098$ \\
\hline \multicolumn{7}{|c|}{$\begin{array}{l}\text { (a) To convert to international metric } \\
\text { (b) } \pm \text { total analytical uncertainty. } \\
\text { (c) } \pm 2 \text { times the standard deviation. } \\
\text { (d) See Section 8.10.3. } \\
\text { ND = Not detected. } \\
\text { NR = Not reported. }\end{array}$} \\
\hline
\end{tabular}


Table 8.10.8. Number of Vegetation Contamination Incidents Investigated Near Hanford Site Facilities and Operations, 2004

\section{Location}

200-East Area tank farms 200-West Area tank farms 200-East Area burial grounds 200-West Area burial grounds 200-East Area cribs, ponds, and ditches 200-West Area cribs, ponds, and ditches 200-East Area fence lines 200-West Area fence lines 200-East Area roads and railroads 200-West Area road and railroads 200-East Area unplanned release sites 200-West Area unplanned release sites 200-East Area underground pipelines 200-West Area underground pipelines Cross-site transfer line 200-East Area miscellaneous 200-West Area miscellaneous 200-North Area

100 Areas

300 Area

400 Area

600 Area

1100 Area

Total

Table 8.10.9. Annual Number of Vegetation Contamination Incidents Investigated Near Hanford Site Facilities and Operations, 1994 through 2004

\begin{tabular}{cccc}
$\underline{\text { Year }}$ & $\begin{array}{c}\text { Number of } \\
\text { Incidents }\end{array}$ & $\underline{\text { Year }}$ & $\begin{array}{c}\text { Number of } \\
\text { Incidents }\end{array}$ \\
1994 & 39 & 2000 & 66 \\
1995 & 39 & 2001 & 31 \\
1996 & 21 & 2002 & 16 \\
1997 & 46 & 2003 & 32 \\
1998 & 51 & 2004 & 60 \\
1999 & 85 & & \\
\hline
\end{tabular}

Samples were organized into four distinct groups: (1) sitewide (onsite), (2) perimeter, (3) Columbia River shoreline, (4) and distant upwind (Table 8.10.10). Site-wide sampling locations were generally selected in areas around industrial development on the site. The perimeter locations were Ringold, Byers Landing, Sagemoor, and Riverview. These four locations lie generally downwind, i.e., east and southeast, of the site. They are expected to be in areas of highest deposition of contaminants from site atmospheric emissions.
Vegetation samples consisted of the current year's growth of leaves, stems, and new branches collected from sagebrush and rabbitbrush. Samples were dried before analyses, and analytical results were reported on a dry weight basis. Shoreline samples were usually taken from a predominant species at the sampling location. A contaminant was detected if the analytical result was greater than the minimum detectable activity and was larger than the total analytical error.

\subsubsection{Analytical Results for Vegetation Samples Collected at Site-Wide and Offsite Locations}

Vegetation sampling results in 2004 generally confirmed observations from past sampling efforts. Cesium-137, strontium-90, uranium-238, and plutonium-238 concentrations were all below nominal detection limits at distant and shoreline locations, as were cesium-137, strontium-90, and plutonium concentrations at perimeter locations (Table 8.10.11). Uranium-238 was detected in one of four perimeter samples. The maximum uranium-238 concentration measured in vegetation during 2004 was collected at Byers Landing (a perimeter sampling location) (0.018 \pm $0.0011 \mathrm{pCi} / \mathrm{g}[0.67 \pm 0.41 \mathrm{mBq} / \mathrm{g}])$. This result was higher than the maximum site-wide uranium-238 concentration measured in 2001 . The average uranium-238 concentration at perimeter locations was similar to the average of samples collected in 1993, 1994, 1998, and 2001.

Concentrations of cesium-137 and strontium-90 in sitewide samples were all less than the analytical detection limits. Plutonium-238 and uranium-238 were each measured at detectable levels in one sample, and results were similar to those from past years (Table 8.10.11).

In 2004, plutonium-239/240 was detected in three vegetation samples collected at one site-wide location, one Columbia River shoreline location, and one distant location (Table 8.10.11). A vegetation sample collected east of the 200-West gate sampling location had the highest measured plutonium-239/240 concentration (Figure 8.10.3). This is consistent with historical data, which show this sampling location to have higher concentrations of all radionuclides. 


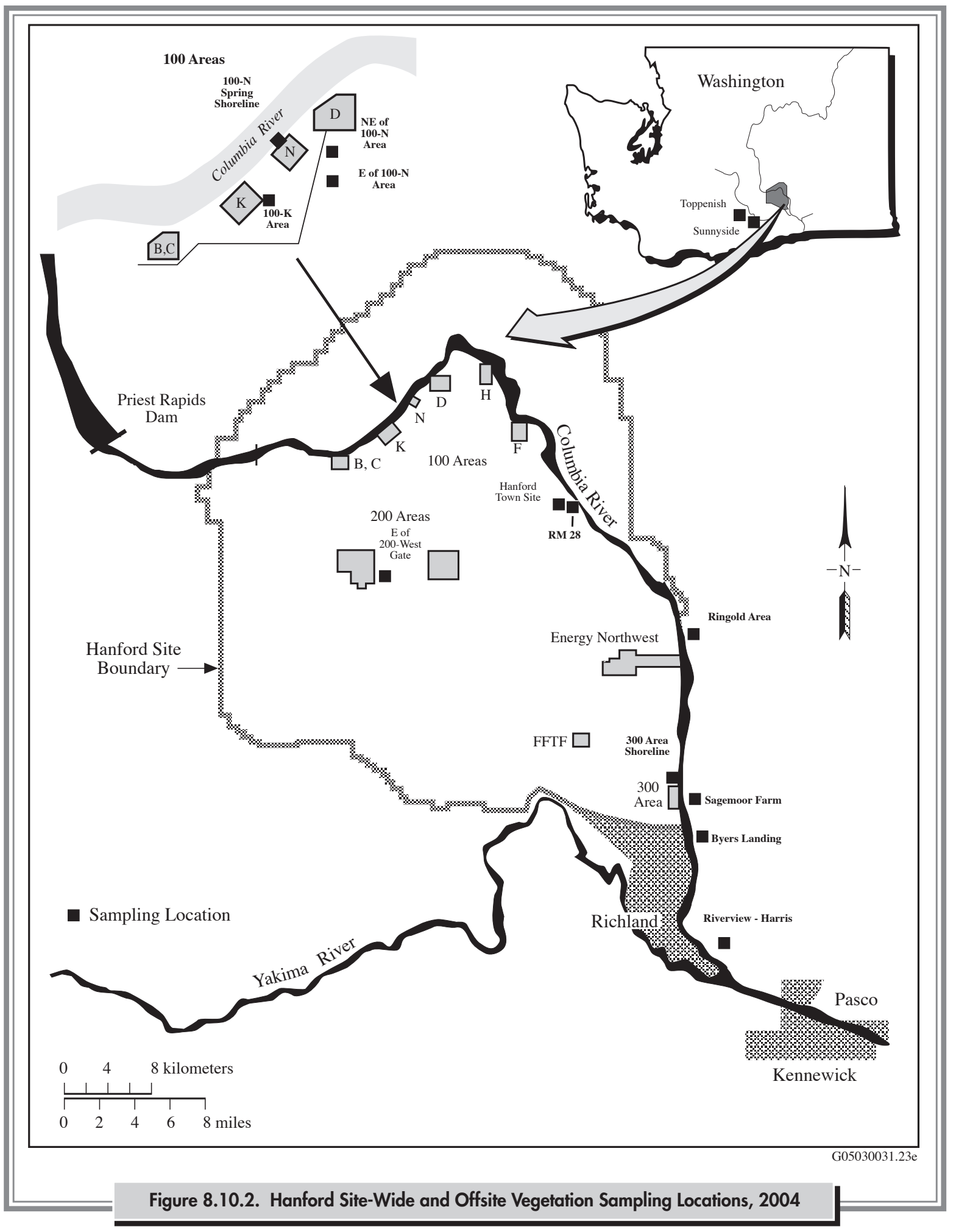




\begin{tabular}{|l|l|}
\hline & Table 8.10.10. Hanford Site-Wide and Offsite Vegetation Samples Collected \\
and Analyzed, 2004
\end{tabular}

\subsubsection{Vegetation Control Activities}

Vegetation control at Hanford consists of cleaning up contaminated plants that can be a threat to workers or the public (i.e., either safety, health, or radiation protection), controlling or preventing the growth or re-growth of plants in contaminated or potentially contaminated areas on the site, and monitoring and removing unwanted (noxious) plant species.

\subsubsection{Control of Contaminated or Potentially Contaminated Vegetation in 2004}

\section{A. R. Johnson, J. G. Caudill, R. C. Roos, J. M. Rodriguez, R. A. Schieffer, and R. K. Woodford}

There were no incidents of offsite contamination by plants during 2004, and all cases of new contamination reported onsite were cleaned up or scheduled for cleanup.

During 2004, 60 incidents of contaminated vegetation occurred on the Hanford Site. This is a decrease of $29 \%$ compared to the peak year of 1999 (84), but nearly double the number seen in 2003 (32). Severe wind-related soil erosion at several inactive waste disposal sites (e.g., the 216-U-10 and 216-S-17 inactive ponds in the 200-West Area and the 216-B-3 inactive pond in the 200-East
Area) where surrounding wind breaks were denuded by a fire resulted in seven cases of contaminated new-growth tumbleweeds. All contaminated vegetation was removed from these waste sites and revegetation of these sites began in autumn 2004.

Sites with recurring radioactive contamination events caused by deep-rooted vegetation or burrowing insects were covered with Biobarrier ${ }^{\circledR}$, an engineered fabric impregnated with herbicide to stop root penetration and also provide a physical barrier to burrowing insects. A total of approximately 1,000 square meters $(10,800$ square feet) of Biobarrier ${ }^{\circledR}$ was installed at seven sites in 2004 to prevent further invasion by biota. Hanford Site demonstrations have shown this barrier to be effective in preventing the spread of contamination. This installation brings the total number of sites at Hanford covered with Biobarrier $^{\circledR}$ since 1999 to 32 , amounting to 11,230 square meters $(120,834$ square feet).

Approximately 0.8 kilometer ( 0.5 mile) of roadway near the U Tank Farm was closed because of an accumulation of tumbleweeds, some of which were radiologically contaminated. The road, in the 200-West Area, was cleaned of windblown tumbleweeds and reopened.

Approximately 63,000 cubic meters (82,250 cubic yards) of compacted, windblown non-contaminated tumbleweeds that had accumulated along fences and around facilities were disposed of by burning in 2004, approximately the same volume burned in 2003. Tumbleweeds blown into a zoned contamination area were disposed of 


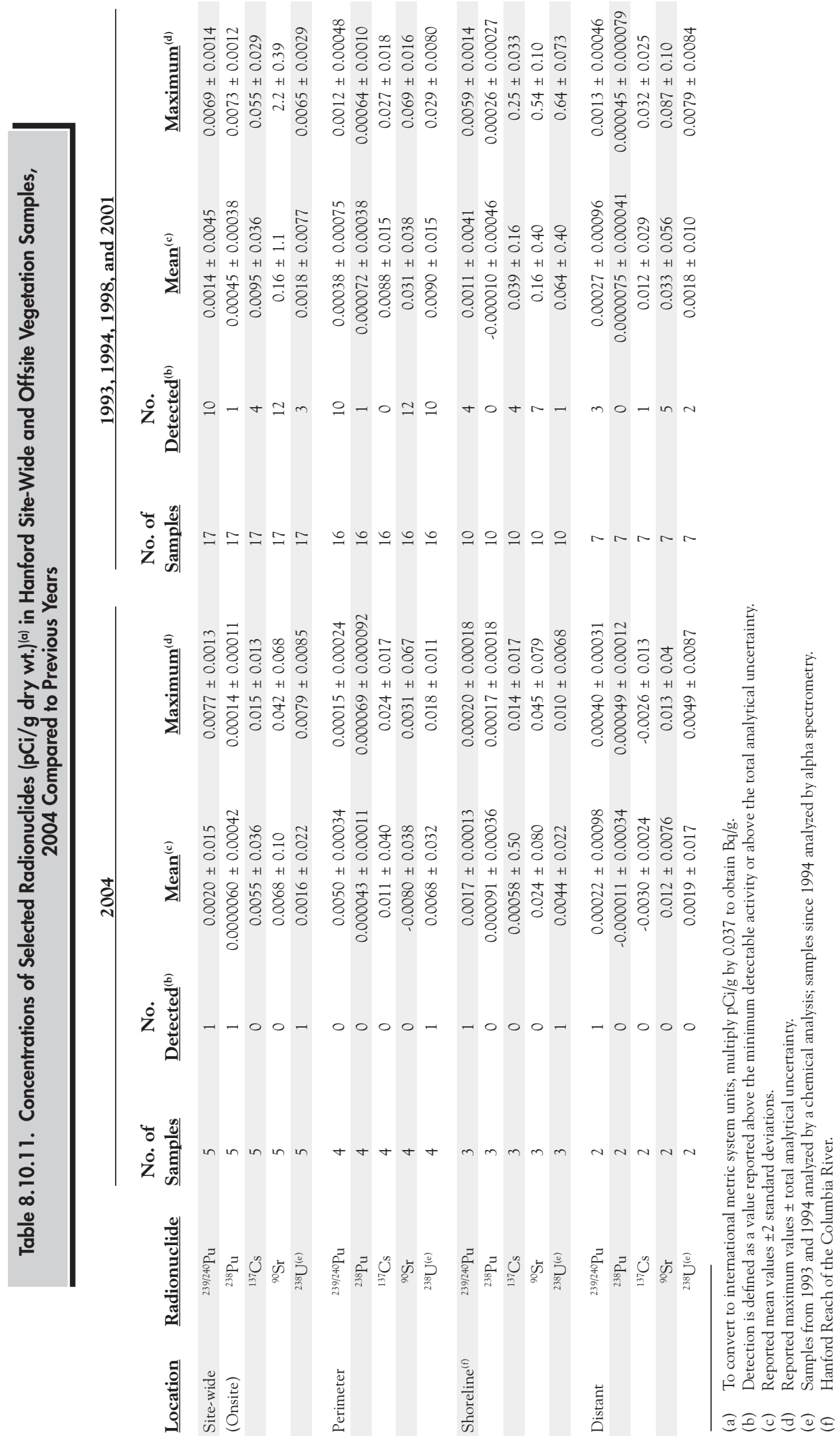




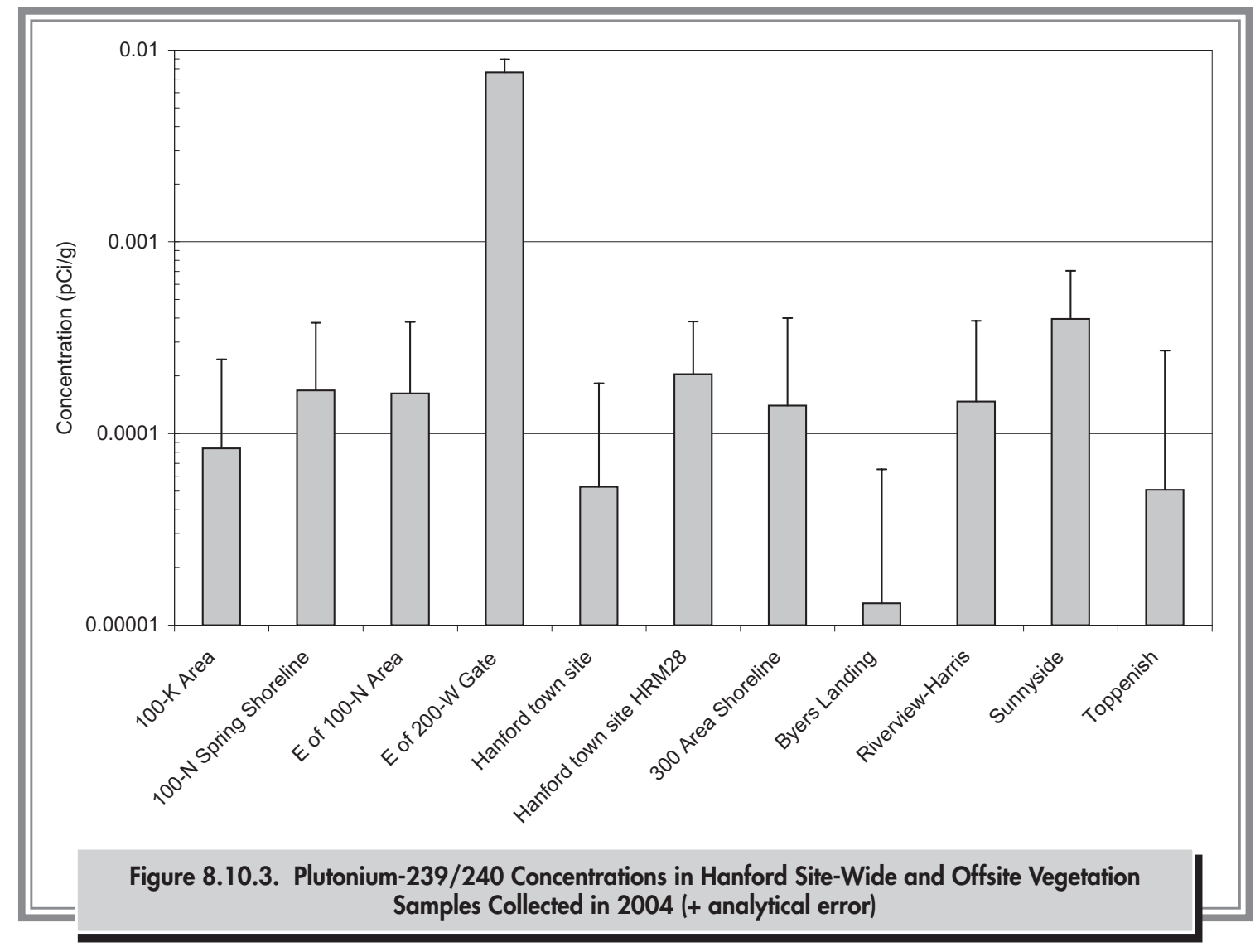

as though they were contaminated to avoid the expense and delay of testing for contaminants. In 2004, such tumbleweeds, previously disposed to a designated burial ground dedicated to receiving low-level contaminated waste, could no longer be disposed in this manner because of a Memorandum of Understanding among DOE and regulatory agencies. Arrangements were made for a licensed bulk process facility to receive the tumbleweeds in 2004. Approximately 2,800 cubic meters $(3,700$ cubic yards) of compacted tumbleweeds from contaminated areas were disposed in the bulk process facility operated by Pacific EcoSolutions located on Battelle Boulevard about 4 kilometers (2.5 miles) northwest of Richland, Washington.

\subsubsection{Revegetation Activities in 2004 to Control Blowing Weeds and Dust}

Four hundred hectares (1,000 acres) west of the 200-West Area that burned during the 24 Command Hanford Site Wildfire in 2000 were revegetated with such species as Indian rice grass (Oryzopsis hymenoides), bottleneck squirreltail (Sitanion hystrix), needle and thread grass (Stipa comata), Sandberg's bluegrass (Poa sandbergii), and big sagebrush (Artemisia tridentata) in 2001 and 2002. This revegetation effort resulted in well established grass and shrub communities. The revegetation was done to limit soil erosion and the growth of undesirable plants in the burned area. Windblown dust and tumbleweeds from this fire-damaged area could affect operations, facilities, and workers in the 200-West Area, located just downwind of the burn, and could spread the seeds of undesirable weeds to (and cause subsequent weed control issues at) other sensitive onsite locations. In 2004, 160 hectares (400 acres) of the burned area were overseeded with bunchgrass seed towards this effort.

\subsubsection{Noxious Weed Control}

\section{R. C. Roos, J. M. Rodriguez, J. G. Caudill, and A. R. Johnson}

Noxious weeds are controlled on the site to prevent their spread and eliminate populations. A noxious weed is a legal 
and administrative category designated by federal or state regulatory agencies (e.g., U.S. Department of Agriculture or Washington State Department of Agriculture). Noxious weeds are non-native, aggressively invasive, and hard to control. Entire native plant communities can be destroyed, altering ecosystems, unless control measures are taken. Control measures can be mechanical, chemical, cultural, or biological.

Populations of rare, threatened, or endangered species are identified and marked with visual and physical identifiers. These populations are identified to the control teams so that they know to avoid them.

Ten plant species, categorized as noxious weeds by the U.S. and Washington State Departments of Agriculture are on a high priority list for control at the Hanford Site. These species are discussed in the following paragraphs, with a summary of the 2004 control activities. Major populations of noxious weeds on the Hanford Site are illustrated in Figure 8.10.4.

In 2004, remote populations of noxious weeds were identified with fluorescent flags on 1.83-meter (6-foot) poles so that they could be located and treated by terrestrial herbicide application crews. Areas treated for noxious weed infestations in 2004 included 142 hectares (350 acres) treated by terrestrial application crews and 1,155 hectares $(2,850$ acres $)$ treated by helicopter.

Yellow Starthistle (Centaurea solstitialis). Yellow starthistle represents the most rapidly expanding weed infestation in the western United States. Hanford is at a critical point in the infestation cycle. More than 2,023 hectares (5,000 acres) have been infested and a seed bank has been established in the soil. Many additional hectares (acres) have scattered starthistle infestation. Applications of aerial herbicides in 1998 and 1999 have been effective, resulting in minimal germination prior to 2003. This minimal germination was controlled primarily through mechanical removal (i.e., pulling by hand). During 2003 and 2004, however, significant germination was observed indicating that residual action from prior chemical applications was no longer effective. These plants were again controlled in 2004 by aerial herbicide applications and by terrestrial applications to old agricultural fields with a boom sprayer capable of spraying large areas. Biological control organisms, primarily the hairy weevil (Eustenopus villosus) and the bud weevil (Bangasternus orientalis), were commonly found in starthistle during 2004. It was observed that plants flowering early through mid-summer were heavily infested with weevils. However, plants flowering late in the season showed reduced infestation of the flowering heads indicating that natural predators (i.e., biological control agents) are not totally effective in eliminating seed production.

Rush Skeletonweed (Chondrilla juncea). Rush skeletonweed is widely scattered over large areas on the Hanford Site. Although areas of dense infestation have largely been eliminated, a considerable population remains as scattered individuals. Populations of skeletonweed have increased on some areas burned in the 24 Command Hanford Site Wildfire of June 2000.

During 2004, control of rush skeletonweed concentrated on an area north of the Volpentest Hazardous Materials Management and Emergency Response Training and Education Center (HAMMER) and the Hanford Patrol Training Academy. Effectiveness of the spraying will be evaluated in spring 2005.

As in most years, some populations were highly affected by biological control agents that had been introduced over the past 10 years, and flowering was eliminated. Other populations were less affected. Because of inconsistency of biological control agents, herbicides will remain an important aspect of control for rush skeletonweed.

Medusahead (Taeniatherum asperum). Mechanical removal (i.e., pulling by hand) was once again used to control the small population of medusahead on the Central Plateau of the Hanford Site. Plants were pulled before seeds matured. Monitoring and eradication efforts continued in 2004 as the plants matured to the point at which they could be distinguished from neighboring grass species.

Babysbreath (Gypsophila paniculata). Efforts to control babysbreath during 2004 concentrated on the main infestation at the former Hanford town site. Although babysbreath is resistant to control by herbicides, herbicides exist that effectively kill the aboveground portions of the plant. Controlling the top of the plant prevents flowering and additional seed production. Killing the top of the 


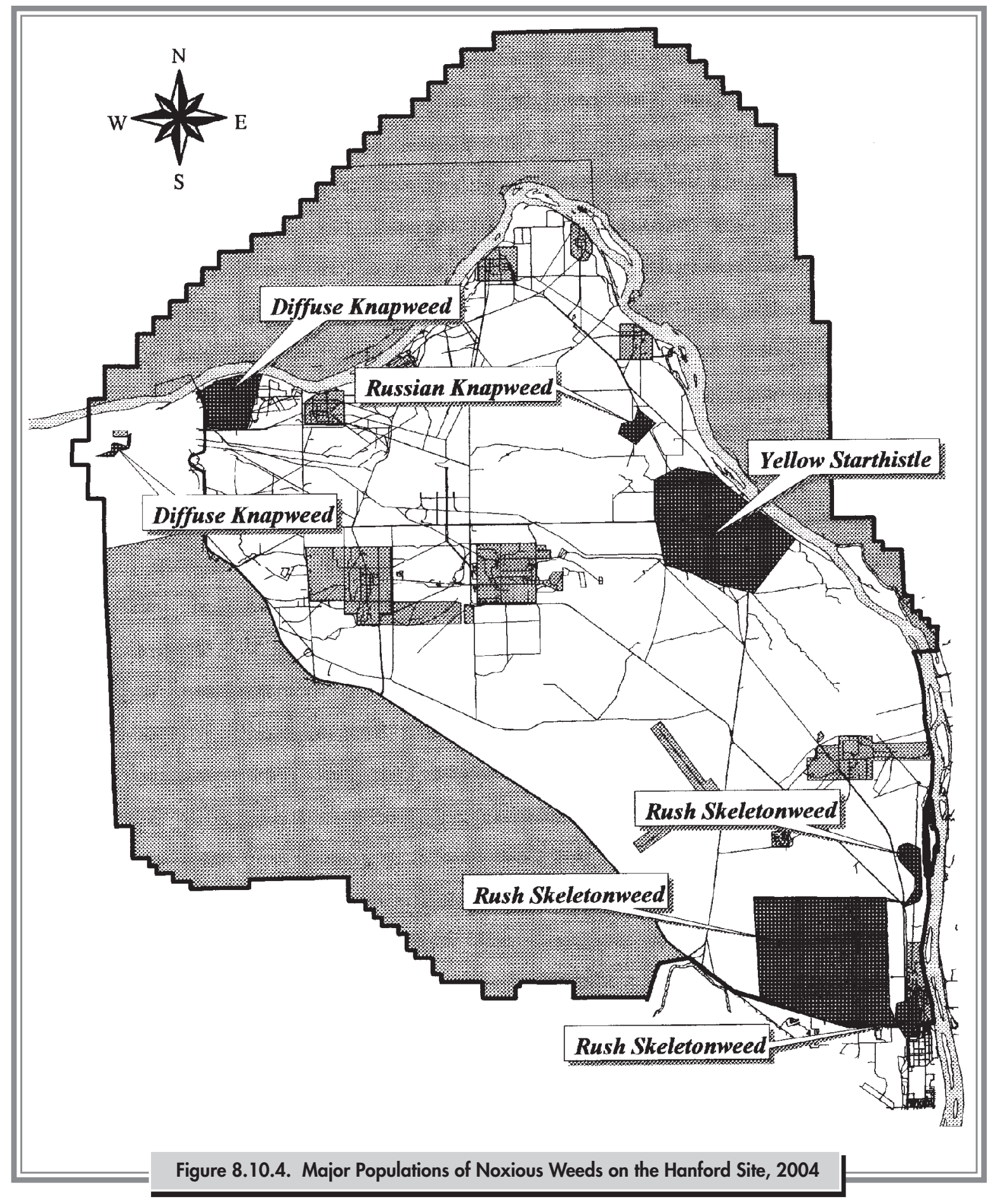

plant also depletes energy reserves in the roots until the plant dies. The number of these plants on the Hanford Site is relatively small.

Dalmatian Toadflax (Linaria genistifolia ssp. dalmatica). During 2004, control of dalmatian toadflax focused on a small population at the $100-\mathrm{B} / \mathrm{C}$ Area. The species at
Hanford has yielded to past control efforts. Seedlings of this long-lived perennial plant will be eliminated by mechanical removal or chemical treatments as they are identified. Currently, the only extant population of dalmatian toadflax is in the Energy Northwest area; it is being watched for signs of migration to other parts of the Hanford Site. 
Spotted Knapweed (Centaurea maculosa). Most populations of spotted knapweed throughout the Hanford Site have been reduced through mechanical removal and chemical applications to scattered individuals or seedlings germinating from long-lived seeds. Continued monitoring and control efforts are aimed at eliminating spotted knapweed near the Energy Northwest facilities on the Hanford Site.

Diffuse Knapweed (Centaurea diffusa). Aerial applications of herbicide to control diffuse knapweed have been effective in the past. Spot treatment with chemicals and mechanical removal of scattered individuals continued during 2004. The population of diffuse knapweed near the high-water mark of the Columbia River has not been controlled by herbicides because of the biological sensitivity of the area. Biological controls (i.e., parasitic insects) have been established in areas near the Columbia River and are monitored to observe effectiveness in controlling the weed. They are somewhat effective.

Russian Knapweed (Acroptilon repens). Biological control (e.g., parasitic nematode) of Russian knapweed at Hanford has been tried without success. This weed's largest population is found along the Columbia River, but small populations are found throughout the site. Chemicals, other biological control agents, and mechanical removal techniques that may prove effective with this difficult-to-control species are being developed by federal and state agricultural agencies.

Saltcedar (Tamarix spp.). Several individual plants of saltcedar are found on the Hanford Site. Most are remaining from ornamental plantings near homes in the early part of the previous century. A few plants are the result of natural seed dispersal. Most individuals on the site south and west of the Columbia River have been eliminated. Survivors will be treated with herbicide and will be monitored until they are eliminated.

Purple Loosestrife (Lythrum salicaria). Purple loosestrife has established only in sparse populations on the Hanford Site along the south and west shorelines of the Columbia River. Portions of the riverbank and shoreline slews are monitored for purple loosestrife and identified individuals are controlled with chemicals approved for wetland areas, with biological control agents, and by mechanical removal. 


\subsection{Fish and Wildlife Monitoring}

The following sections summarize wildlife-related monitoring activities conducted on and around the Hanford Site in 2004. Included is information on surveys and monitoring of Hanford Site animal populations, discussions of selected species that occur at Hanford and are protected by state and federal laws and regulations, results of activities to measure levels of Hanford-produced contaminants in fish and wildlife tissues, results of field studies to identify organisms that may be effective biological monitors of environmental contaminants (sentinel species), and activities to manage organisms that might affect workers or have become radiologically contaminated.

Wildlife populations at Hanford are monitored to assess the abundance, condition, and distribution of populations of selected species. Data collection and analyses are integrated with contaminant monitoring efforts, and analytical results may be used to help characterize potential risks or impacts to biota. They may also be used to support objectives for completing Hanford's waste management and environmental restoration missions. Information on threatened, endangered, and sensitive wildlife species is collected so DOE can determine site compliance with the requirements of applicable state and federal laws and regulations. Fish and wildlife that inhabit the Columbia River and the Hanford Site are monitored for contaminants because they could potentially be exposed to Hanford-produced materials and be adversely affected, and because contaminated animals could be harvested and consumed by members of the public. Sentinel species are being evaluated because some organisms may be useful for identifying changes in environmental conditions over time. When discovered, pest organisms are removed and disposed of to eliminate possible impact to worker safety and health and to control the spread of radioactive contamination. For further information about these monitoring and pest control efforts and the programs that support them, see Section 8.0 of this report or DOE/RL-91-50.

\subsubsection{Ecological Monitoring of Hanford Site Wildlife Populations}

This section provides current information on characterization, inventories, and monitoring of key fish and wildlife species and populations found on the Hanford Site and presents this information in the context of historical data and trend information. Wildlife populations of interest include wildlife potentially hunted offsite and used for food as well as special status species listed by Washington State or the U.S. Fish and Wildlife Service as threatened or endangered.

\subsubsection{Chinook Salmon}

\section{R. P. Mueller}

Chinook salmon (Oncorhynchus tshawytscha) are an important resource in the Pacific Northwest; they are caught commercially and for recreation and are also of cultural importance to Native Americans. Today, the most important natural spawning area in the mainstem Columbia River for fall Chinook salmon is the freeflowing Hanford Reach (Dauble and Watson 1997). In the first years of Hanford Site operations, monitoring identified only a few redds (spawning nests) in the Hanford Reach. Between 1943 and 1973, a number of dams were constructed on the Columbia River and the formation of reservoirs behind these dams eliminated many mainstem spawning areas. These changes resulted in increased numbers of salmon spawning in the Hanford Reach. Fisheries management strategies aimed at maintaining spawning populations in the mainstem Columbia River also have contributed to the increased number of redds found in the Hanford Reach. 
The number of fall Chinook salmon redds in the Hanford Reach are estimated through aerial surveys. Aerial surveys do not yield absolute redd counts due to environmental conditions that affect detection (e.g., water depth, water turbidity, and sun angle) and difficulty associated with accurately counting individual redds in high density spawning areas. However, redd survey estimates are highly correlated with adult salmon escapement estimates obtained by state and federal agencies within the Columbia River Basin.

Survey results show the number of redds increased from the early 1960s through the 1980s until reaching a high in 1989 of nearly 8,800 (Figure 8.11.1). In the early 1990s, survey estimates indicated a decline in the number of redds to approximately one-third of the 1989 peak. The number of redds peaked again in 1996 and 1997 and then declined before rising again in 2001. This trend continued though 2002 and a count of 9,400 redds was estimated in 2003, which was the highest count since monitoring began in 1948.

During 2004, approximately 8,470 redds were observed, which is a slight decrease from the record count in 2003. The primary spawning areas in the Hanford Reach in 2004 (Figure 8.11.2) were similar to areas used in previous years with the majority of redds occurring near Vernita Bar (Area 10), Locke Island (Areas 4 and 5), and the areas upstream (Areas 6 and 7) and downstream (Areas 2 and 3) of Locke Island. The general locations of the spawning areas have not changed appreciably over the past few years.

\subsubsection{Steelhead}

\section{R. P. Mueller and M. R. Sackschewsky}

In February 2003, two steelhead (Oncorhynchus mykiss) redds were discovered near the Columbia River shoreline adjacent to the north end of the 300 Area. Steelhead at this location are considered part of the upper Columbia River Evolutionarily Significant Unit, listed as endangered under the Endangered Species Act.

To address the presence of spawning steelhead near the 300 Area, DOE prepared a biological evaluation of the potential impact of site characterization and cleanup efforts on steelhead in the Hanford Reach and came to the conclusion that the ongoing characterization and cleanup project activities may affect, but are not likely to adversely affect, upper Columbia River steelhead. This biological evaluation was sent to the National Oceanographic and Atmosphere Administration Fisheries in December 2003. The National Oceanographic and Atmosphere Administration Fisheries concurred with the DOE conclusion in January 2004. DOE committed to increase monitoring efforts for steelhead redds in the Hanford Reach during 2004 and to limit activities in the

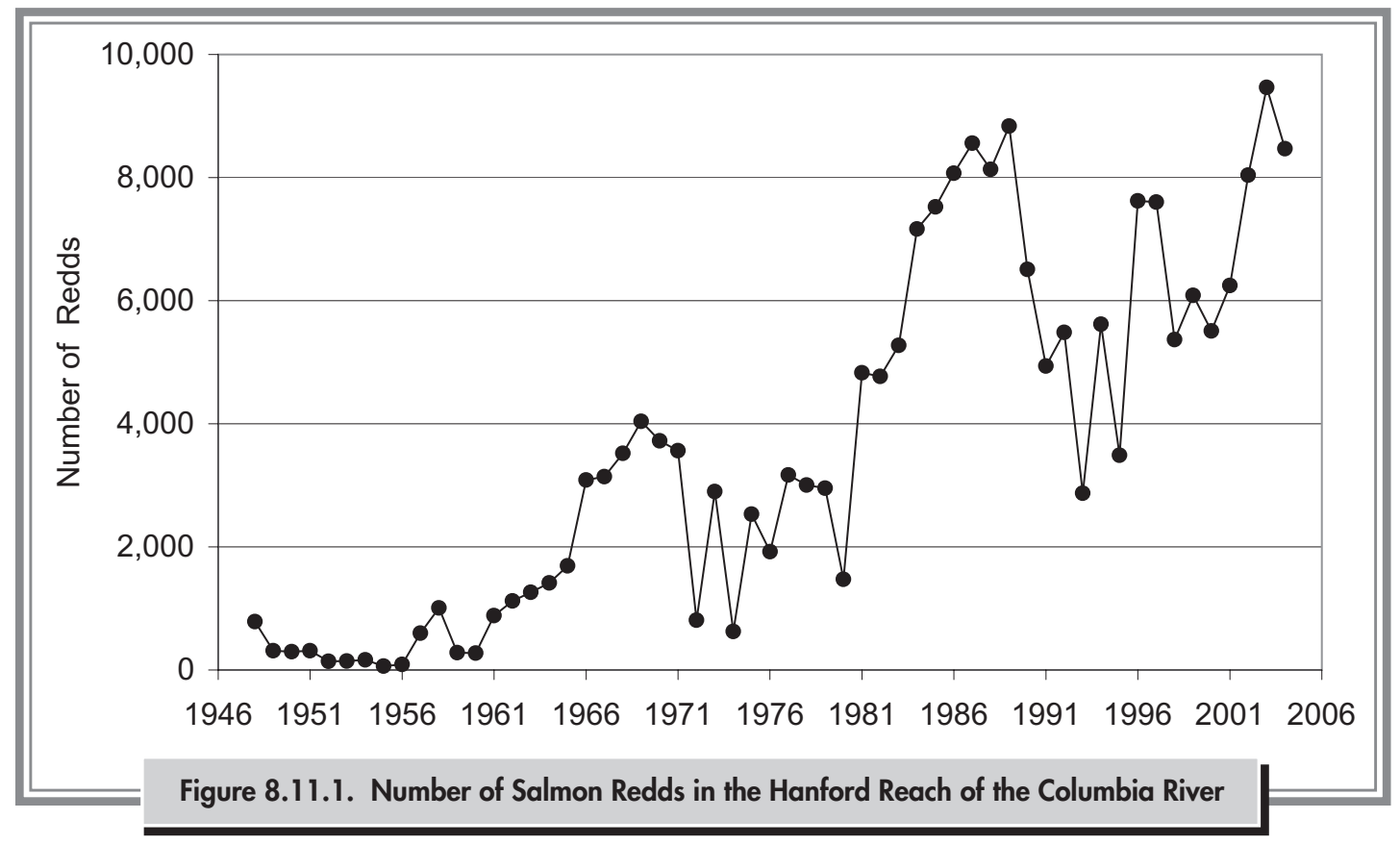




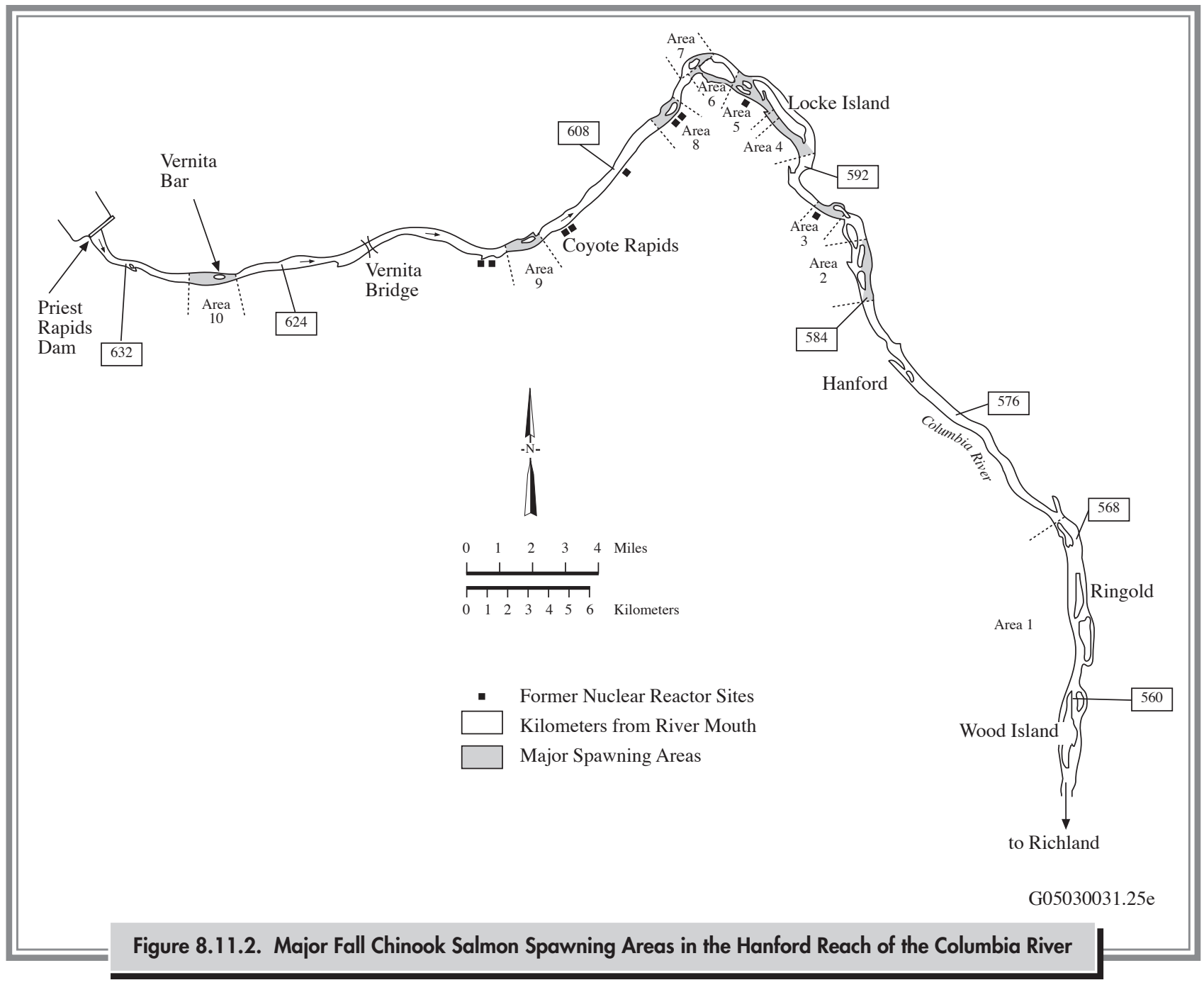

vicinity of any redds that were discovered. Aerial surveys during March and April 2004 indicated that steelhead had not returned to the redd site at the 300 Area nor were steelhead redds observed elsewhere in the Hanford Reach. Surveys in 2005 documented a few steelhead redds along the Benton County shoreline in fall Chinook salmon spawning Area 1 (Figure 8.11.2).

\subsubsection{Mule Deer}

\section{K. D. Hand and B. L. Tiller}

Population characteristics of mule deer (Odocoileus hemionus) on the Hanford Site have been monitored since 1994. Roadside surveys are conducted from mid-November to mid-January to assess age and sex ratios and the frequency of testicular atrophy in males. The survey route extends from near the 300 Area in the south to the 100-B/C Area in the north and is divided at the Hanford town site into north and south regions. Tiller and Poston (2000) found that there is little overlap in the home ranges of deer occupying these two regions.

Seven surveys were conducted between mid-November 2004 and late-January 2005. A combined total of 448 deer observations were made over the seven repeated surveys, which included multiple observations of the same animals in some cases. An average of 64 deer were recorded on each survey. Individual animals were identified according to sex and age class (fawn or adult). For male deer, the presence of misshapen, velvet covered antlers was used as an indicator of testicular atrophy.

Trends in the ratios of fawns to does over time can be used to monitor changes in mule deer population size and 
health. Data from the 2004-2005 surveys show a pattern of fawn to doe ratios that has been observed previously. In 2004, the north region fawn to doe mean estimate was 20 fawns per 100 does and the south region mean estimate was 24 fawns per 100 does (Figure 8.11.3). These estimates are lower than those seen in 2003 when the mean estimates were 47 and 56 fawns per 100 does for the north and south regions, respectively. For comparison, ratios reported by the Washington Department of Fish and Wildlife for Yakima and Benton Counties averaged 55 fawns per 100 does from 1996 to 2000 (Washington Department of Fish and Wildlife 2001). Hanford fawn to doe ratios for all survey years (1994-2004) are reported as weighted averages, using the total number of fawns and does seen per survey as the weighting factor.

In the early 1990s, testicular atrophy and sterility were observed in some male mule deer on the Hanford Site (Tiller et al. 1997; PNNL-11518). Further investigation found no clear cause for these conditions (Tiller et al. 1997). Testicular atrophy in male mule deer is associated with abnormal antler growth manifest as misshapen, velvet covered antlers, which can be easily noted in field surveys. The frequency of testicular atrophy in mule deer has varied (Figure 8.11.4) since surveys began in 1994. Since 1998, the frequency of apparent testicular atrophy decreased, with no abnormal antlers on bucks sighted in 2003. Note that no data were collected in 2002. However, data from 2004 and early 2005 show an apparent increase of this condition especially in the north region (12.5\% in the north region and 5\% in the south region). However, observations of affected deer and the resultant frequency estimates need to be interpreted with caution since small sample sizes may not fully reflect the population conditions. Table 8.11.1 shows the total number of bucks observed and the number with antler abnormalities observed during roadside surveys between 1994 and 2004.

\subsubsection{Freshwater Mollusks}

\section{R. P. Mueller and B. L. Tiller}

The Hanford Reach of the Columbia River has historically sustained a number of native freshwater mollusks. Mollusk species are declining globally and regionally (Frest and Johannes 1995), and native species are being

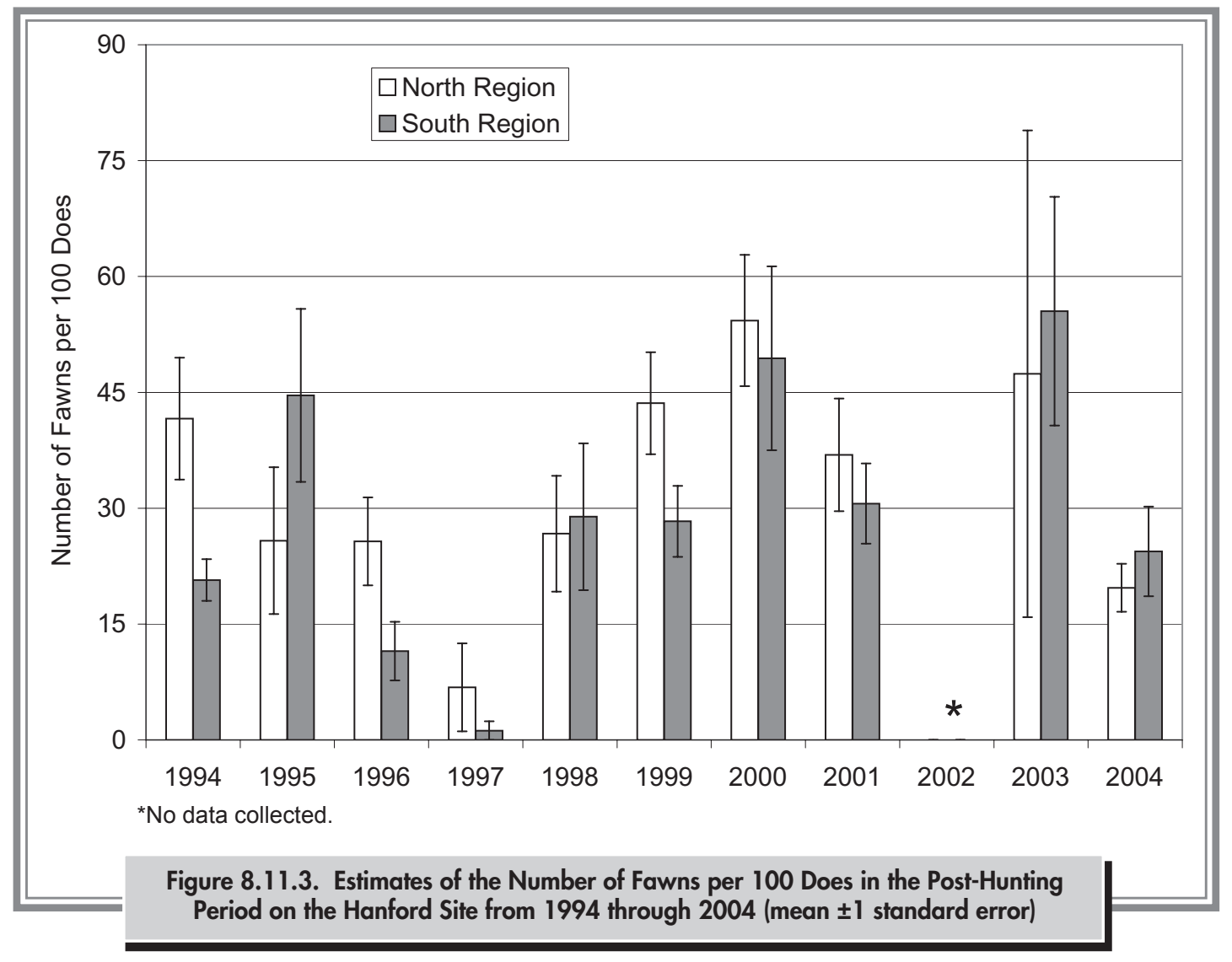




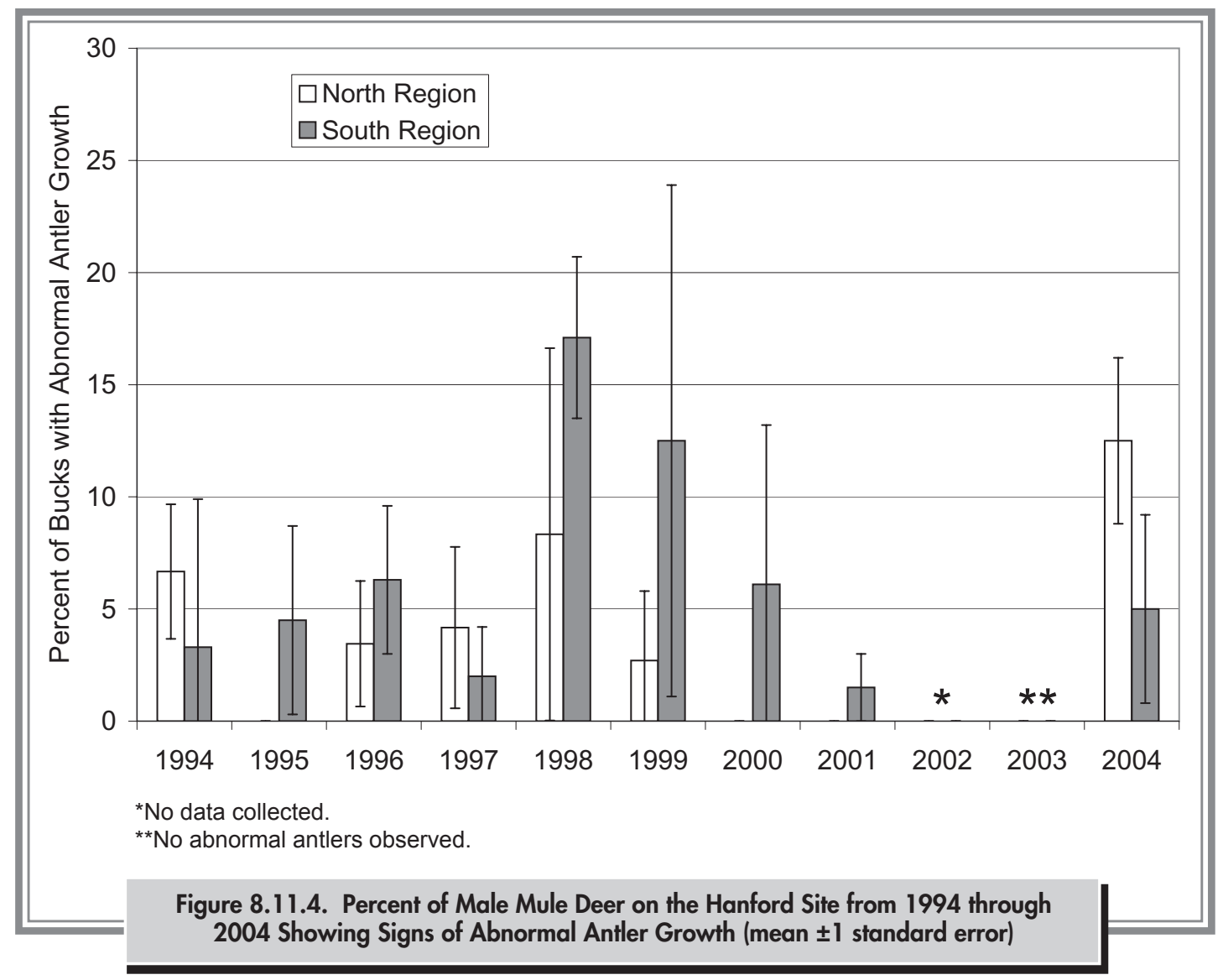

\begin{tabular}{|c|c|c|c|c|}
\hline \multirow[b]{3}{*}{ Year } & \multicolumn{4}{|c|}{$\begin{array}{l}\text { Table 8.11.1. Total Number of Bucks and Number of Bucks Showing Signs of } \\
\text { Antler Abnormality Observed in Roadside Surveys from } 1994 \text { through } 2004\end{array}$} \\
\hline & \multicolumn{2}{|c|}{ North Region } & \multicolumn{2}{|c|}{ South Region } \\
\hline & $\begin{array}{l}\text { Total Number } \\
\text { of Bucks }\end{array}$ & $\begin{array}{c}\text { Number of Bucks } \\
\text { with Antler } \\
\text { Abnormality }\end{array}$ & $\begin{array}{l}\text { Total Number } \\
\text { of Bucks }\end{array}$ & $\begin{array}{c}\text { Number of Bucks } \\
\text { with Antler } \\
\text { Abnormality }\end{array}$ \\
\hline 1994 & 30 & 2 & 90 & 3 \\
\hline 1995 & 19 & 0 & 22 & 1 \\
\hline 1996 & 29 & 1 & 16 & 1 \\
\hline 1997 & 24 & 1 & 51 & 1 \\
\hline 1998 & 12 & 1 & 70 & 12 \\
\hline 1999 & 37 & 1 & 80 & 10 \\
\hline 2000 & 37 & 0 & 33 & 2 \\
\hline 2001 & 50 & 0 & 68 & 1 \\
\hline 2002 & ND & ND & ND & ND \\
\hline 2003 & 11 & 0 & 17 & 0 \\
\hline 2004 & 64 & 8 & 40 & 2 \\
\hline
\end{tabular}


replaced by invasive aliens such as the Asiatic clam (Corbicula fluminea). These types of organisms are potential receptor species for Hanford contaminants because they are sedentary filter-feeders, which increases their potential for exposure to contaminated water and sediment. They are also food organisms and could transfer contaminants to aquatic and terrestrial predators that consume them. Surveys for mollusks along the Hanford Reach allows for an assessment of distribution and status of species and populations.

Mollusk surveys during 2003 and 2004 found 17 taxa (5 mussels and 12 snails) along the Hanford Reach; 3 taxa are considered to be special status species by federal or state agencies (Table 8.11.2). Survey results for mussels obtained by snorkeling during 2004 indicated that three Anadonta species were common in habitats dominated by sand and silt substrates. In addition, shells of the Western pearl mussel (Margaritinopsis falcata) were found in small numbers at two sites, but the species appears to be absent from its historic range.

Individuals of the Columbia springsnail (Pyrgulopsis sp.) were found in 2 of 17 surveys. This taxa has been collected elsewhere in the middle and lower Columbia River but has not been formally described. This species appears similar to the Idaho springsnail (Pyrgulopsis idahoensis), which is listed as a federal endangered species, but a recent taxonomic evaluation by the Smithsonian Institute indicated that the Columbia springsnail, Idaho springsnail, and two other Pyrgulopsis species should all be considered as a single species: the Jackson Lake springsnail (Pyrgulopsis robusta). Based on this taxonomic revision, the U.S. Fish and Wildlife Service initiated a re-evaluation of the federal status of the Idaho springsnail and is considering listing the Jackson Lake springsnail, including the Hanford Reach population, as threatened and endangered under the Endangered Species Act.

\begin{tabular}{|c|c|c|}
\hline \multirow[b]{2}{*}{ Common Name } & \multicolumn{2}{|c|}{$\begin{array}{l}\text { Mussels and Freshwater Snails Observed in the Hanford Reach } \\
\text { of the Columbia River in } 2003 \text { and } 2004\end{array}$} \\
\hline & Scientific Name & Status \\
\hline \multicolumn{3}{|l|}{ Mussels } \\
\hline California floater & Anadonta californiensis & State Candidate/Federal Species of Concern \\
\hline Kennerly floater & Anadonta kennerlyi & \\
\hline Oregon floater & Anadonta oregonensis & \\
\hline Asiatic clam & Corbicula flumine & \\
\hline Western pearl mussel & Margaritinopsis falcata & \\
\hline \multicolumn{3}{|l|}{ Freshwater Snails } \\
\hline Creeping ancylid & Ferrissia rivularis & \\
\hline Giant Columbia River limpet & Fisherola (Lanx) nuttalli & State Candidate \\
\hline Giant Columbia River spire snail ${ }^{(\mathrm{a})}$ & Fluminicola (Lithoglyphus) columbiana & State Candidate/Federal Species of Concern \\
\hline Pebblesnail & Fluminicola sp. & \\
\hline Olympia pebblesnail & Fluminicola virens & \\
\hline Prairie fossaria & Fossaria bulimoides & \\
\hline Golden fossaria & Fossaria obrussa & \\
\hline Ash gyro & Gyraulus parvus & \\
\hline Button sprite & Menetus cvallioglyptus & \\
\hline Physa & Physella sp. & \\
\hline Springsnail & Pyrgulopsis sp. & \\
\hline Abbreviate pondsnail & Stagnicola apicina & \\
\hline Artemesian rams-horn & Vorticifex effusus effusus & \\
\hline
\end{tabular}




\subsubsection{Amphibians}

\section{J. M. Becker and B. F. Miller}

Amphibians may serve as key indicators of ecological health and as receptor species for use in ecological assessments. Relatively little information exists on amphibian distribution and breeding sites along the Columbia River shoreline (Soll et al. 1999). During 2004, Pacific Northwest National Laboratory personnel conducted surveys along the Benton County shoreline of the Hanford Reach to locate and characterize potential and actual breeding sites and the amphibian species that use them. Varying water discharges at Priest Rapids Dam upstream cause the river level to fluctuate and create shoreline pools that may be used by amphibians as breeding sites. Amphibian breeding sites may occur in slough and backwater areas that are continuously inundated or in temporary pools that lie within the main river channel and are flooded periodically. The highest exposure of amphibians to contaminants could occur during larval life stages at breeding sites where contaminants enter the Columbia River.

Pools along the Hanford Reach that could serve as amphibian breeding sites were identified by evaluating Washington Department of Fish and Wildlife video tapes of aerial reconnaissance flights along the Columbia River shoreline from Priest Rapids Dam to Richland. Fifteen permanent and temporary pools were identified and surveyed during the summer of 2004. These included eight shoreline pools and five pools in sloughs or backwater areas. Survey data were also collected from pools in two upland borrow pits adjacent to the 100-B/C Area. Larvae (egg masses and/or tadpoles) and adults of three species were found within or around eight of these pools. Two species are native to the Columbia Basin, the Great Basin spadefoot (Spea intermontana) and Woodhouse's toad (Bufo woodhousii), and one species, the bullfrog (Rana catesbeiana), is an introduced species (Table 8.11.3). Survey results indicate that Woodhouse's toads were most abundant along the Hanford Reach, followed by the bullfrog and Great Basin spadefoot. The pools that form along the Columbia River shoreline at the Hanford Site may be especially important for Woodhouse's toad, a Washington State monitor species thought to occur only within the Columbia Basin of the Pacific Northwest (Washington Herp Atlas 2002).

The distribution of the bullfrog in the Columbia Basin parallels that of Woodhouse's toad (Washington State GAP Analysis Project 1997). The bullfrog, native to the eastern United States and introduced in western Oregon around 1930 (Corkran and Thoms 1996; Nussbaum et al. 1983), is known to consume other amphibians and is suspected as having displaced native amphibian species in the Pacific Northwest (Corkran and Thoms 1996; Environmental News Network 2000). Native species such as Woodhouse's toad and the Great Basin spadefoot may find it difficult to compete with this top-level predator. Results from these initial surveys will be used to guide future efforts to monitor habitat use and relative abundance of amphibian species along the Hanford Reach of the Columbia River.

\begin{tabular}{|c|c|c|c|c|c|}
\hline \multirow[b]{3}{*}{ Pool Type } & \multicolumn{4}{|c|}{$\begin{array}{l}\text { Table 8.11.3. Amphibian Species Observed in Pools Along the Shoreline of the } \\
\text { Hanford Reach of the Columbia River in } 2004\end{array}$} & \\
\hline & \multirow[b]{2}{*}{$\begin{array}{l}\text { Number of } \\
\text { Pools Surveyed }\end{array}$} & \multicolumn{2}{|c|}{$\begin{array}{l}\text { Amphibian Species } \\
\text { Observed (Adults) }\end{array}$} & \multicolumn{2}{|c|}{$\begin{array}{l}\text { Amphibian Species } \\
\text { Observed }\left(\text { Larvae }^{[\mathrm{a}]}\right)\end{array}$} \\
\hline & & $\begin{array}{l}\text { Pools } \\
\text { Occupied }\end{array}$ & Species & $\begin{array}{l}\text { Pools } \\
\text { Occupied }\end{array}$ & Species \\
\hline Shoreline & 8 & 3 & WT, BF & 3 & WT, BF \\
\hline Slough & 5 & 4 & WT, BF, GBS & 4 & WT, BF, GBS \\
\hline Borrow pit & 2 & 1 & WT, GBS & 1 & WT, GBS \\
\hline \multicolumn{6}{|c|}{$\begin{array}{l}\text { (a) Egg masses or tadpoles. } \\
\text { BF = Bullfrog. } \\
\text { GBS = Great Basin spadefoot. } \\
\text { WT = Woodhouse's toad. }\end{array}$} \\
\hline
\end{tabular}




\subsubsection{Small Mammals}

\author{
K. D. Hand and B. L. Tiller
}

Riparian (terrestrial shoreline) habitats along the Hanford Reach of the Columbia River, ranging from dense shrub to open cobble, are habitats for various species of small mammals (mostly rodents). Little is known about the habitat use, species diversity, and seasonal abundance of the small mammals that occupy these riparian areas. Small mammals are often key receptor species in ecological assessments. Those in riparian areas adjacent to Hanford reactor sites may be exposed to Hanford chemical or radiological contaminants. Surveys of Hanford Reach riparian habitats were undertaken in 2003 and 2004 to identify the species present and characterize their seasonal abundance.

Three species of small mammals were captured during the study (Table 8.11.4) in two riparian vegetation types (willow and low shrub-forb-cobble association) during four seasonal periods (early spring, late spring, late summer, and autumn). The most common species was the deer mouse (Peromyscus maniculatus), which was present in both vegetation types and was most abundant during the early spring period. The western harvest mouse (Reithrodontomys megalotis) was the second most abundant species and was also found in both vegetation types but was captured primarily during the early spring and autumn. The least abundant species found was the Great Basin pocket mouse (Perognathus parvus), which was captured only in the willow habitat during the late summer period. This information will be used for selecting species when planning Hanford Site ecological assessments.

\subsubsection{Bald Eagles}

\section{R. E. Durham and M. R. Sackschewsky}

Bald eagles (Haliaeetus leucocephalus) have wintered along the Hanford Reach for many years. In accordance with DOE's Bald Eagle Site Management Plan for the Hanford Site, South-Central Washington (DOE/RL-94-150), limitedaccess road closures within 800 meters ( 875 yards) of major perching and roost sites and within 400 meters ( 437 yards) of out of line-of-sight major perching and roost sites have been in force from November 15 through March 15 since 1994. While these dates generally encompass the arrival and departure times of wintering bald eagles, nest-tending activities and territorial displays in the late 1990s have been observed as early as October with nest occupancy continuing to as late as August. However, all nesting attempts documented along the Hanford Reach have so far been unsuccessful.

During 2004, a pair of adult bald eagles returned during November to occupy the historical nest site in the vicinity of the former White Bluffs town site. This was the only site occupied by an eagle pair during 2004. Visual surveys in late February through March 4, 2005, revealed the nest site was unoccupied.

Primary causes of eagle nest abandonment may include (1) adverse weather, (2) food availability, (3) human activity near the nest, and (4) avian predator interactions (hazing and harassment by magpies and ravens). The causes of eagle nest abandonment along the Hanford Reach have not been determined. Food resources do not appear to be limiting as a pair of eagles stayed through

\begin{tabular}{|c|c|c|c|c|c|c|c|c|}
\hline \multirow[b]{2}{*}{ Species } & \multicolumn{4}{|c|}{ Willow } & \multicolumn{4}{|c|}{ Low Shrub-Forb-Cobble } \\
\hline & $\begin{array}{l}\text { Early } \\
\text { Spring }\end{array}$ & $\begin{array}{l}\text { Late } \\
\text { Spring }\end{array}$ & $\begin{array}{c}\text { Late } \\
\text { Summer }\end{array}$ & Autumn & $\begin{array}{c}\text { Early } \\
\text { Spring }\end{array}$ & $\begin{array}{l}\text { Late } \\
\text { Spring }\end{array}$ & $\begin{array}{c}\text { Late } \\
\text { Summer }\end{array}$ & Autumn \\
\hline Deer mouse & 8.4 & 0.0 & 0.0 & NS & 10.7 & 2.4 & 0.3 & 4.5 \\
\hline Western harvest mouse & 2.1 & 0.0 & 0.6 & NS & 2.5 & 0.2 & 0.6 & 3.0 \\
\hline Great Basin pocket mouse & 0.0 & 0.0 & 1.1 & NS & 0.0 & 0.0 & 0.0 & 0.0 \\
\hline
\end{tabular}


August in 1999 (PNNL-13230); thus, some other factor is likely responsible for nest desertion on the Hanford Site. A large buoy was placed in the Columbia River near the nesting site to help minimize disturbance from boating activities. During 2001 and 2002, traffic monitors (instruments to count passing vehicles) were placed at the entrance to the nesting area access road at a location approximately 400 meters (437 yards) from the nesting site used by the eagle pair. Vehicle counts were low between November and January and increased dramatically during late February and early March (PNNL-14295).

\subsubsection{Sage Sparrow}

\section{A. Duberstein, M. A. Simmons, M. R. Sackschewsky, and J. M. Becker}

Big sagebrush (Artemisia tridentata) communities found on the Hanford Site provide critical habitat for several sagebrush-obligate species, including the sage sparrow (Amphispiza belli). Sage sparrows are protected under the Migratory Bird Treaty Act. They were identified as an evaluation species for the development of Hanford-specific habitat-usage computer models (DOE/RL-96-88). A habitat-usage computer model, called the habitat-value index, is being developed to assign a value to habitats for nesting sage sparrows. The habitat-value index will be used to calculate the cost to restore or create habitat of similar value that may be lost during cleanup activities. The first step in developing the index is to quantify the relationships between the size of sage sparrow nesting territories and the characteristics of the associated sagebrush habitat.

To develop the index, 37 sage sparrow territories were mapped and the vegetation characteristics within the territories were measured. The variables most strongly associated with territory size included sagebrush cover, annual grass and forb cover, and the amount of bare ground. Analysis further indicated that two landscapescale features are also associated with territory size: fire history and the patchiness of sagebrush cover. Areas that burned within the last 26 years have less sagebrush cover than areas that did not burn recently (Figure 8.11.5a), and the sage sparrow territories are larger in previously burned areas than in unburned areas (Figure 8.11.5b). Also, sagebrush cover is patchy in burned areas (Figure 8.11.5c). Sage sparrows may require larger territories in areas with lower, patchy sagebrush cover in order to obtain sufficient resources (e.g., food and hiding cover).

Four habitat types were identified for use by nesting sage sparrows: (1) mature sagebrush overstory with an undisturbed understory, (2) a mature sagebrush overstory with a disturbed understory, (3) a recovering sagebrush overstory with an undisturbed understory, and (4) a recovering sagebrush overstory with a disturbed understory. Mature overstory habitats are characterized by a higher, more contiguous sagebrush cover and increased time since the last fire compared to recovering habitats. Disturbed understory habitats are characterized by more annual grass and forb cover and less bare ground than can be found in undisturbed areas. Sage sparrow territories were found in all four habitat types, with 14 of the 37 in the matureundisturbed habitat, 7 each in both mature-disturbed and recovering-undisturbed habitats, and 9 in the recoveringdisturbed habitat. The habitat-value index is being tested during 2005 to examine the relationships between habitat variables and sage sparrow distribution and abundance as well as to determine the types of habitat that cannot support sage sparrow territories.

\subsubsection{Monitoring of Fish and Wildlife for Hanford- Produced Contaminants}

\section{J. A. Stegen}

In 2004, several types of wildlife and fish were collected at locations on and around the Hanford Site (Figure 8.11.6) as part of routine monitoring for Hanfordproduced contaminants. Samples from these organisms were analyzed for selected radionuclides and metals that are suspected or known to be present on the Hanford Site (Table 8.11.5). Samples were also collected at locations that are distant from the site to obtain reference (background) contaminant measurements.

Most fish and wildlife samples collected on or near the Hanford Site for routine human-exposure pathway assessments are obtained annually, but specific species are only sampled every 2 or 3 years. Samples routinely obtained at locations believed to be unaffected by Hanford Site effluents and emissions are collected approximately every 5 years. 

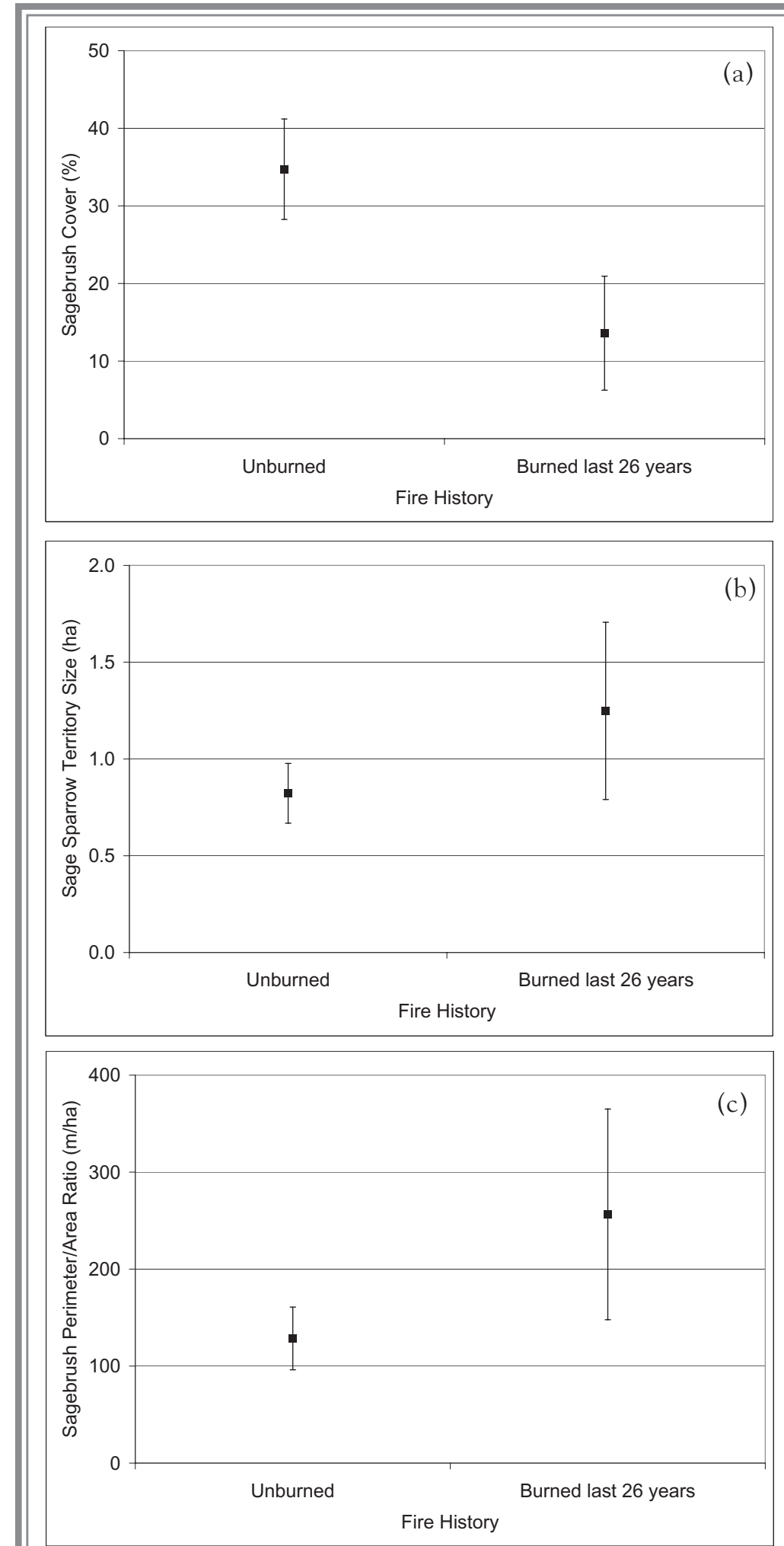

Figure 8.11.5. Mean ( $\pm 95 \%$ confidence limits) Sagebrush Cover (a), Territory Size (b), and Sagebrush Patchiness (c) for Burned Versus Unburned Sage Sparrow Territories on the Hanford Site in 2003 and 2004 


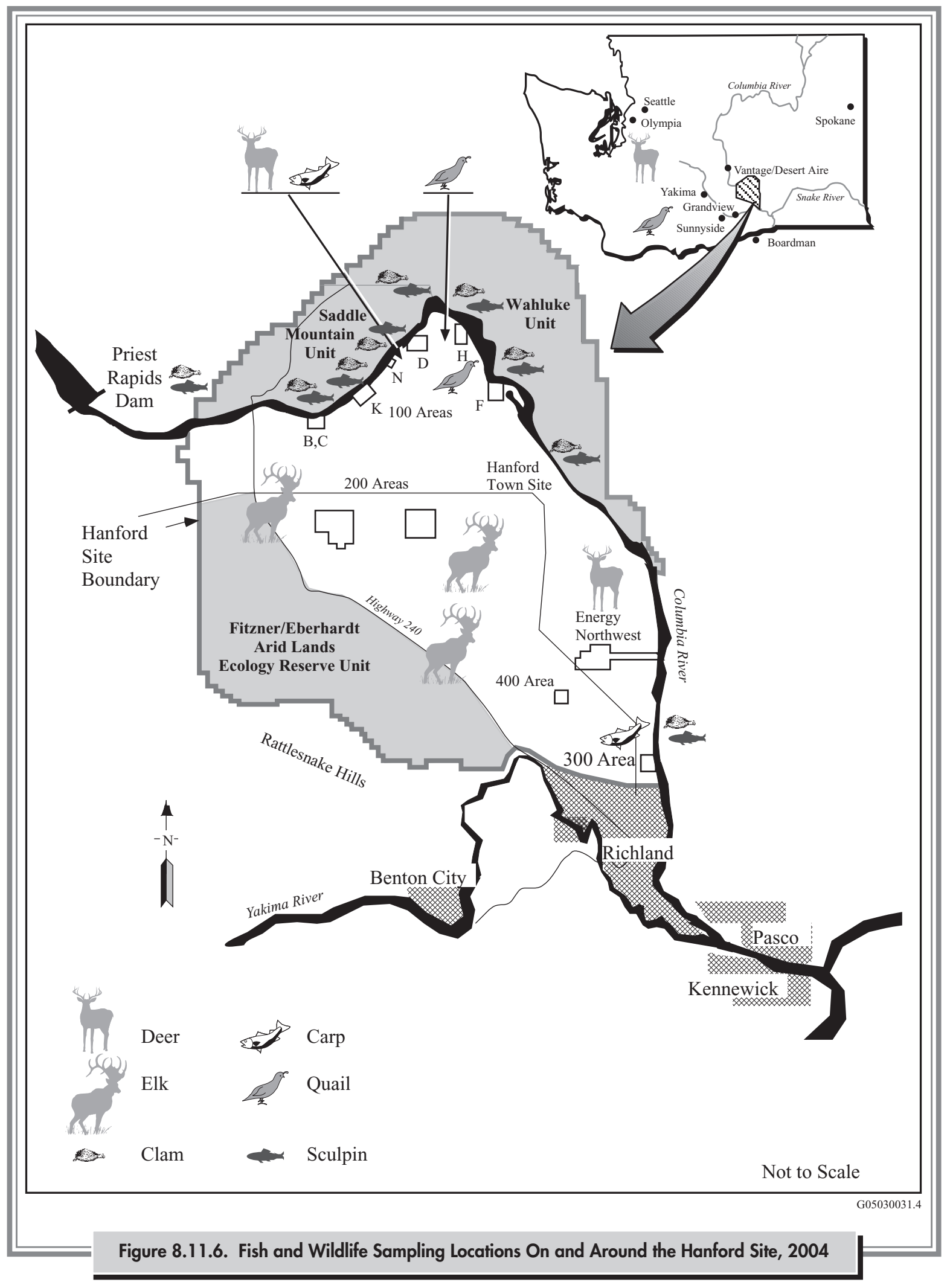




\begin{tabular}{|c|c|c|c|c|c|c|}
\hline \multirow[b]{3}{*}{$\underline{\text { Biota }}$} & \multirow[b]{3}{*}{$\begin{array}{l}\text { No. of Reference } \\
\text { Locations }\end{array}$} & \multirow[b]{3}{*}{$\begin{array}{l}\text { No. of Onsite } \\
\text { Locations }\end{array}$} & & \multirow[b]{3}{*}{$\begin{array}{r}\text { Trace } \\
\text { Metals }\end{array}$} \\
\hline & & & \multicolumn{3}{|c|}{ No. of Analyses } & \\
\hline & & & Gamma & Strontium-90 & Technetium-99 & \\
\hline Fish (carp) & 0 & 2 & 10 & 10 & 0 & 10 \\
\hline (sculpin) & $1^{(\mathrm{a})}$ & 22 & 0 & 17 & 16 & 29 \\
\hline $\begin{array}{l}\text { Upland game } \\
\text { (California quail } \\
\text { and pheasant) }\end{array}$ & $1^{(\mathrm{b})}$ & 2 & 12 & 12 & 0 & 12 \\
\hline Asiatic clams & $3^{(\mathrm{a})}$ & 54 & 0 & 63 & 63 & 55 \\
\hline $\begin{array}{l}\text { Big game } \\
\text { (deer) } \\
\text { (elk) }\end{array}$ & $\begin{array}{l}1^{(c)} \\
0\end{array}$ & $\begin{array}{l}2 \\
3\end{array}$ & $\begin{array}{r}10 \\
3\end{array}$ & $\begin{array}{r}10 \\
3\end{array}$ & $\begin{array}{l}0 \\
0\end{array}$ & $\begin{array}{l}3 \\
0\end{array}$ \\
\hline $\begin{array}{l}\text { (a) Collected ne: } \\
\text { (b) Collected ne } \\
\text { (c) Black-tailed }\end{array}$ & $\begin{array}{l}\text { Vernita Bridge. } \\
\text { samplview, Washingto collected nea }\end{array}$ & Olympia, Washin & & & & \\
\hline
\end{tabular}

In 2004, all fish and wildlife samples collected were monitored for strontium- 90 contamination and were analyzed by gamma spectrometry to detect a number of gamma emitters (Appendix F) including cesium-137. Since the 1990s, strontium-90 and cesium-137 have been the most frequently measured radionuclides in fish and wildlife samples.

Strontium-90 is chemically similar to calcium; consequently, it accumulates in hard tissues rich in calcium such as bone, antlers, and eggshells. Strontium- 90 has a biological half-life in hard tissue of 14 to 600 days (PNL-9394). Hard-tissue concentrations may profile an organism's lifetime exposure to strontium-90. However, strontium-90 generally does not contribute much to human dose because it does not accumulate in edible portions of fish and wildlife. Strontium-90 is present in the Hanford environs as a result of past operating and waste disposal practices. Currently, contaminated groundwater entering the Columbia River via shoreline springs in the $100-\mathrm{N}$ and $100-\mathrm{H}$ Areas is the primary source of Hanford-produced strontium-90 measurable in the Hanford environment; however, the current contaminant contribution relative to historical fallout from atmospheric weapons testing is small $(<2 \%)$ (PNL-8817).

Cesium-137 is particularly important to the human food chain because it is chemically similar to potassium and is found in the muscle tissues of fish and wildlife. Having a relatively short biological half-life $(<200$ days in muscle and $<20$ days in the gastrointestinal tract [PNL-9394]), cesium-137 is an indicator of recent exposure to radioactive materials. Cesium-137 is present in the environment as a result of past Hanford Site operating and waste disposal practices as well as from historical worldwide fallout resulting from nuclear weapons testing.

Gamma spectrometry results for most radionuclides are not discussed here because levels were too low to measure or measured concentrations were considered artifacts of low-background counts. Low-background counts occur at random intervals during sample counting and can produce occasional spurious false-positive results. For many radionuclides, concentrations were below levels that could be detected by the analytical laboratory. When this occurred for an entire group of samples, two times the total propagated analytical uncertainty was used as an estimate of the nominal detection level for that analyte and particular medium. Results, propagated analytical uncertainties, and minimum detection amounts for all results may be found in PNNL-15222, APP. 1.

Monitoring various biota for uptake and exposure to radionuclides both near and distant from Hanford Site operations continues to assure that consumption of fish and wildlife does not pose a threat to humans. Monitoring also provides long-term trends of contamination in selected components of the ecosystem. Wildlife and fish sampled and analyzed during 2004 for radioactive constituents included carp (Eyprinus cyprinus), upland game 
(California quail [Callipepla californica] and ring-necked pheasant [Phasianus colchicus]), deer (mule deer [Odocoileus hemionus] and black-tailed deer [Odocoileushemionus columbianus]), and elk (Cervus elaphus).

A number of trace metals that have the potential to accumulate in certain fish and wildlife tissues have been identified in the Hanford Site environment as potential contaminants of concern (e.g., chromium, copper, lead, and mercury), particularly in areas of the site where contaminated groundwater enters the Columbia River along the shoreline (PNNL-14295). Historical operations at Hanford resulted in the production of both radiological and non-radiological wastes, including metals, in liquid, solid, and gaseous forms. These wastes were placed in various disposal sites at Hanford, including trenches, cribs, ditches, ponds, and underground storage tanks (PNNL-13487). Atmospheric releases included fly ash from coal-fired steam/power plants that were associated with each reactor. Fly ash contains trace metals and natural radionuclides that may have deposited on the soil around the reactor areas. In addition to waste associated with past Hanford operations, other sources of contamination have impacted the site. Heavy metals generated from upriver mining and smelting activities have been transported down the Columbia River (Johnson et al. 1990) and into the Hanford Reach. Also, contaminants associated with past and present agricultural practices have contributed to the contaminant inventory at the Hanford Site (Yokel and Delistraty 2003). For example, arsenic is likely associated with historical applications of lead arsenate on fruit orchards prior to World War II. Lead arsenate was once the most commonly used insecticide in fruit orchards and studies that examined the extent of arsenic contamination in pre-World War II orchard soil near the 100 Areas showed elevated levels of arsenic compared to levels in soil from reference locations (Yokel and Delistraty 2003).

Organisms can accumulate metals through incidental soil ingestion, by drinking contaminated water, and by consuming contaminated foods. The spatial variability of concentrations of metals in the environment is influenced by the contributions of both natural sources and industrial contaminants. Thus, concentrations of metals and organism exposures can vary between locations. This variability can produce some uncertainty in the source of the metals within the sampled organism. To determine the Hanford
Site's contribution to levels of metals in biota collected on the Hanford Site or in the Hanford Reach, samples were also collected from the Columbia River both upstream and downstream of the site and from reference areas distant from the site. A comparison of concentrations of metals in upstream, downstream, and reference samples with concentrations in Hanford Reach or Hanford Site samples may provide information on increases in concentrations of metals potentially due to activities on the Hanford Site. Currently, there is not a large dataset for metals in wildlife and fish from the Hanford Reach, the Hanford Site, or from reference locations and the data that do exist show some degree of variability. Additional monitoring data may help to reduce the variability.

Trace metal concentrations were monitored in carp, deer, and upland game in 2004 and results are summarized in the following discussions. Individual results and the associated uncertainties may be found in PNNL-15222, APP. 1.

\subsubsection{Analytical Results for Carp Samples}

Fishing is a popular activity along the Hanford Reach of the Columbia River and fish, such as carp, are harvested for food and could potentially contribute to human exposure. Carp are nomadic and generally have large home ranges. These fish are likely moving up and down the Hanford Reach and may be exposed to metals and persistent radionuclides in the river environment. Monitoring fish for uptake and exposure to radionuclides and metals at locations both near to and distant from the Hanford Site continues to be important to track the extent and longterm trends of contamination in the Hanford Reach environment. During 2004, ten carp were collected from two locations in the Hanford Reach: five between the 100-N and 100-D Areas and five near the 300 Area (Figure 8.11.6). Fillets and the eviscerated remains (carcass) of carp were analyzed for a variety of radiological contaminants and liver samples were analyzed for metals in 2004.

Cesium-137 results were below the analytical detection limit $(0.03 \mathrm{pCi} / \mathrm{g}[0.001 \mathrm{~Bq} / \mathrm{g}]$ wet weight $)$ in all ten carp fillet samples collected from the Hanford Reach during 2004. These results are consistent with results reported throughout the past 10 years that indicated a gradual decline in cesium-137 levels in fish found both at background locations and near the Hanford Site. 
Strontium-90 concentrations in carp carcass samples collected from near the 300 Area were all below the analytical detection limit $(0.05 \mathrm{pCi} / \mathrm{g}$ [0.0019 Bq/g] wet weight). Strontium-90 was found in all the carp carcass samples collected between the 100-N and 100-D Areas during 2004. The median level of strontium-90 in carcass tissues collected from the region between the $100-\mathrm{N}$ and 100-D Areas during 2004 was 0.33 pCi/g (0.012 Bq/g) wet weight (Figure 8.11.7). The strontium-90 concentration in one of the five carp samples collected between the $100-\mathrm{N}$ and 100-D Areas (1.5 pCi/g [0.055 Bq/g] wet weight) was approximately two times greater than the highest value reported over the preceding 10-year period. Elevated amounts of strontium-90 have been consistently measured in carp and other bottom-feeding fishes (suckers and whitefish) collected near the 100-N Area in the past. The median- and maximum-result pattern near the 100-N Area may indicate some of the fish have consumed items containing elevated amounts of strontium-90 from Hanford sources and have incorporated some strontium into their tissues. Strontium-90 concentrations in carcass tissue would have to be around $600 \mathrm{pCi} / \mathrm{g}$ (22 Bq/g) wet weight (in the absence of other radionuclides and external exposure) to be near the DOE dose limit of $1.0 \mathrm{rad}$ (10 $\mathrm{mGy}$ ) per day established for aquatic organisms (Section 8.14.6).

Liver samples from 5 carp collected near the 300 Area and 5 carp collected between the 100-N and 100-D Areas

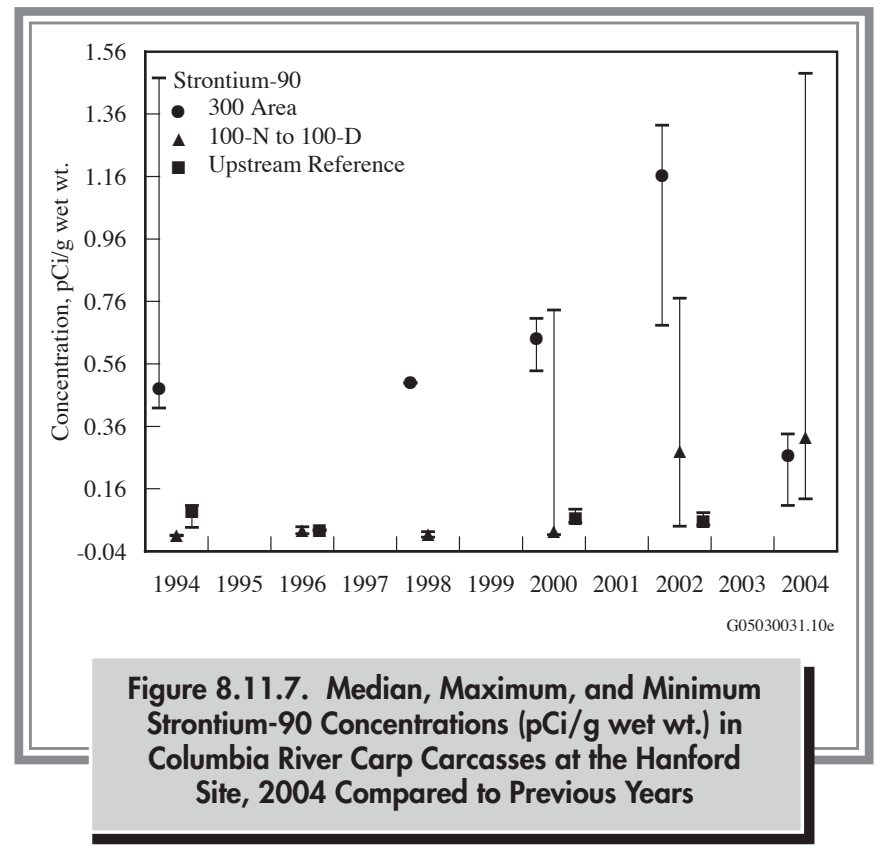

were analyzed for 18 trace metals during 2004. Concentrations in the samples were compared to concentrations in carp samples collected at a reference location upstream of the site, near Desert Aire, Washington, in 2002 (PNNL-14295, APP. 1). The samples from the reference location were not analyzed for mercury and barium, and beryllium was the only trace metal not detected above analytical detection limits $(0.02 \mu \mathrm{g} / \mathrm{g}$ dry weight $)$ in samples from all locations (Appendix C, Table C.11; PNNL-14295, APP. 1). The median and maximum concentrations of cadmium, arsenic, silver, thallium, and zinc were elevated in the carp samples collected between the 100-N and 100-D Areas in 2004 compared to concentrations in samples collected near Desert Aire in 2002 (Appendix C, Table C.11; PNNL-14295, APP. 1). However, with the exception of cadmium, concentrations were similar to concentrations in liver samples collected from carp near the 100-N Area in 1997 and 2002 (PNNL-11795, APP. 1; PNNL-14295, APP. 1).

The maximum concentration of cadmium in 2004 (209 $\mu \mathrm{g} / \mathrm{g}$ dry weight) was more than two times greater in carp livers collected between the 100-N and 100-D Areas compared to the maximum concentration of cadmium in carp livers collected near Desert Aire ( $87 \mu \mathrm{g} / \mathrm{g}$ dry weight) and near the 100-N Area in 1997 (94 $\mu \mathrm{g} / \mathrm{g}$ dry weight) and in 2002 (89 $\mu \mathrm{g} / \mathrm{g}$ dry weight) (Appendix C, Table C.11; PNNL-14295, APP. 1; PNNL-11795, APP. 1). The median concentration of cadmium in carp sampled between the 100-N and 100-D Areas (36 $\mathrm{\mu g} / \mathrm{g}$ dry weight) was over five times greater than the median concentration measured in Desert Aire carp (6.5 $\mu \mathrm{g} / \mathrm{g}$ dry weight) but was similar to the median concentrations measured in carp collected near the 100-N Area in 1997 (41 $\mu \mathrm{g} / \mathrm{g}$ dry weight) and 2002 (38 $\mu \mathrm{g} / \mathrm{g}$ dry weight) (PNNL-11795, APP. 1; PNNL-14295, APP. 1). The median and maximum concentrations of cadmium in carp livers collected near the 300 Area in 2004 were elevated compared to concentrations measured in samples from Desert Aire in 2002 but were similar to concentrations measured in carp livers collected in 1997 and 2002 near the 300 Area (PNNL-11795, APP. 1; PNNL-14295, APP. 1).

The maximum uranium concentration in carp livers collected between the $100-\mathrm{N}$ and $100-\mathrm{D}$ Areas $(0.24 \mu \mathrm{g} / \mathrm{g}$ dry weight) was elevated compared to the maximum uranium concentration in carp livers collected at Desert Aire (0.085 $\mu \mathrm{g} / \mathrm{g}$ dry weight) (Appendix C, Table C.11; 
PNNL-14295, APP. 1). However, the median uranium concentration in samples collected between the $100-\mathrm{N}$ and

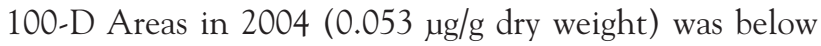
the median concentrations measured in carp collected at Desert Aire $(0.055 \mu \mathrm{g} / \mathrm{g}$ dry weight $)$ and collected between

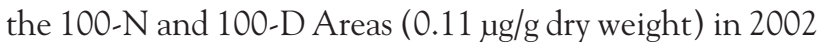
(PNNL-14295, APP. 1). Carp livers were not analyzed for uranium in 1997. The maximum concentration of uranium in carp livers collected near the 300 Area $(0.38 \mu \mathrm{g} / \mathrm{g}$ dry weight $)$ was elevated compared to the maximum concentration in samples collected at Desert Aire $(0.085 \mu \mathrm{g} / \mathrm{g}$ dry weight $)$ and the maximum concentration previously reported for carp sampled near the

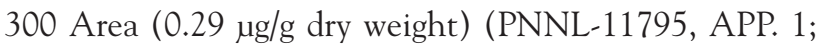
PNNL-14295, APP. 1). The median concentration of uranium in carp liver collected near the 300 Area in 2004 $(0.09 \mu \mathrm{g} / \mathrm{g}$ dry weight) was elevated compared to the median concentration in samples from Desert Aire in 2002 ( $0.055 \mu \mathrm{g} / \mathrm{g}$ dry weight) but was below the median concentration reported in carp liver samples collected near the 300 Area in 2002 ( $0.13 \mu \mathrm{g} / \mathrm{g}$ dry weight) (PNNL-14295, APP. 1). Elevated uranium concentrations in carp liver samples from near the 300 Area is consistent with the elevated uranium concentrations measured in 300 Area clam samples in 2004.

The maximum concentration of chromium in carp livers collected between the 100-N and 100-D Areas in 2004 (12 $\mathrm{\mu g} / \mathrm{g}$ dry weight) was approximately seven times higher than the maximum concentration measured in carp livers collected at Desert Aire (1.6 ug/gdry weight) (PNNL-14295, APP. 1). However, the median concentration in samples collected between the 100-N and 100-D Areas $(0.50 \mu \mathrm{g} / \mathrm{g}$ dry weight) was below the median concentrations measured in carp collected at Desert Aire (1.3 $\mu \mathrm{g} / \mathrm{g}$ dry weight) and near the $100-\mathrm{N}$ Area in 2002 (1.8 $\mu \mathrm{g} / \mathrm{g}$ dry weight) (PNNL-14295, APP. 1).

The median concentrations of zinc, copper, and silver in liver samples from carp collected near the 300 Area during 2004 were elevated compared to concentrations in samples collected at Desert Aire (Appendix C, Table C.11; PNNL-14295, APP. 1) but were similar to concentrations measured in carp liver samples collected near the 300 Area in 1997 and 2002 (PNNL-11795, APP. 1; PNNL-14295, APP. 1). The median concentrations of arsenic and manganese were elevated in liver samples collected near the 300 Area in 2004 compared to concentrations measured in the 2002 Desert Aire samples and in liver samples collected in 1997 and 2002 near the 300 Area (PNNL-11795, APP. 1; PNNL-14295, APP. 1). However, maximum concentrations of arsenic and manganese in samples collected near the 300 Area in 2004 were below the maximum concentrations measured in Desert Aire samples in 2002 (PNNL-14295, APP. 1).

The dataset for metals in carp near the Hanford Site is relatively small and results are variable; therefore, it is difficult to draw conclusions. In addition, no state or federal benchmark criteria are available for tissue concentrations of metals in fish. However, Washington State has developed acute and chronic aquatic life criteria for ambient surface water. Both Columbia River and Columbia River shoreline spring water samples have been collected near Hanford operational facilities for many years and results for river and spring water samples collected during 2004 are presented in Sections 8.4 and 8.5. In general, concentrations of metals in river and spring water samples, including cadmium, were less than the Washington State ambient surface water quality acute and chronic criteria for the protection of aquatic life (Appendix C, Table C.5; Appendix D, Table D.3). Median concentrations of most metals, including cadmium, in Hanford Reach sediment samples collected during 2004 were lower than concentrations in sediment collected at the Priest Rapids Dam upstream of the Hanford Site (see Section 8.4.2 for discussion).

Currently, Washington State does not have a surface water quality criterion for uranium. There were elevated concentrations of uranium in near-shore Columbia River water samples, shoreline spring water samples, and Columbia River and shoreline springs sediment samples collected near the 300 Area in 2004. Uranium concentrations at the 300 Area were roughly two to four times the concentration measured in sediment collected near Priest Rapids Dam (see Sections 8.4.2 and 8.5.2 for discussion). However, median and maximum concentrations of uranium in river and riverbank spring sediment were at or below concentrations of uranium found in sediment collected at the Priest Rapids Dam in 2004. 


\subsubsection{Analytical Results for Upland Game Samples}

California quail are one of the most prevalent upland game birds found on the Hanford Site. Most of the quail that reside onsite are found along the shoreline of the Columbia River where trees and shrubs provide shelter. Quail forage for seeds, other plant parts, and grit in grassy and weedy places not far from cover. Ordinarily, quail do not travel far from where they hatch. Individual birds on the Hanford Site may spend their entire lives near one of the retired plutonium reactors. Quail can be exposed to metals and persistent radionuclides when they forage on materials from plants that have roots in contact with contaminated groundwater or soil, drink contaminated water, or ingest contaminated grit. Seven California quail were collected in the region between the $100-\mathrm{H}$ and $100-\mathrm{F}$ Areas and in the region between the 100-D and 100-H Areas on the Hanford Site in the fall of 2004. Radionuclide levels found in muscle and bone samples analyzed during 2004 were compared to levels measured in upland game samples collected onsite during the previous 10-year period and were also compared to levels found in five upland game samples collected from a reference location near Grandview, Washington, in 2004.

Concentrations of cesium-137 were below the analytical detection limit $(0.03 \mathrm{pCi} / \mathrm{g}$ $[0.001 \mathrm{~Bq} / \mathrm{g}]$ wet weight) in the three quail muscle samples collected between the $100-\mathrm{H}$ and 100-F Areas, in the four samples collected between the 100-D and 100-H Areas, and in the five samples collected at the reference location. The number of samples with cesium-137 concentrations at or below the analytical detection limit from 1998 to 2004 ( 36 of 36 collectively) reflects the continued downward trend in worldwide levels of cesium-137 fallout from atmospheric weapons testing that took place from the 1950s through the 1970s.

One quail bone sample collected onsite between the 100-D and 100-H Areas, and one quail bone sample collected from the reference location in 2004 had strontium-90 concentrations above the analytical detection limit $(0.04 \mathrm{pCi} / \mathrm{g}[0.001 \mathrm{~Bq} / \mathrm{g}]$ wet weight). The maximum concentration found in quail bones collected in 2004 between the 100-D and 100-H Areas $(0.11 \mathrm{pCi} / \mathrm{g}$ [0.004 Bq/g] wet weight) was similar to the maximum concentration reported in bones collected in 2004 from the reference location $(0.10 \mathrm{pCi} / \mathrm{g}[0.004 \mathrm{~Bq} / \mathrm{g}]$ wet weight). Results from all other bone samples collected onsite and at the reference location were below the analytical detection limit. These results are consistent with results obtained in past years and do not indicate elevated levels of strontium-90 in upland game (Figure 8.11.8).

Three liver samples from quail collected between the 100-H and 100-F Areas and 4 liver samples from quail collected between the 100-D and 100-H Areas on the Hanford Site were analyzed for 18 trace metals during 2004. Liver samples from 5 pheasants collected at a reference location near Grandview, Washington, were analyzed for 16 metals in 2004. The reference samples were not analyzed for barium and mercury. For most trace metals, concentrations in samples collected on the Hanford Site were the same as or below concentrations in samples collected at the reference location (Appendix C, Table C.12).

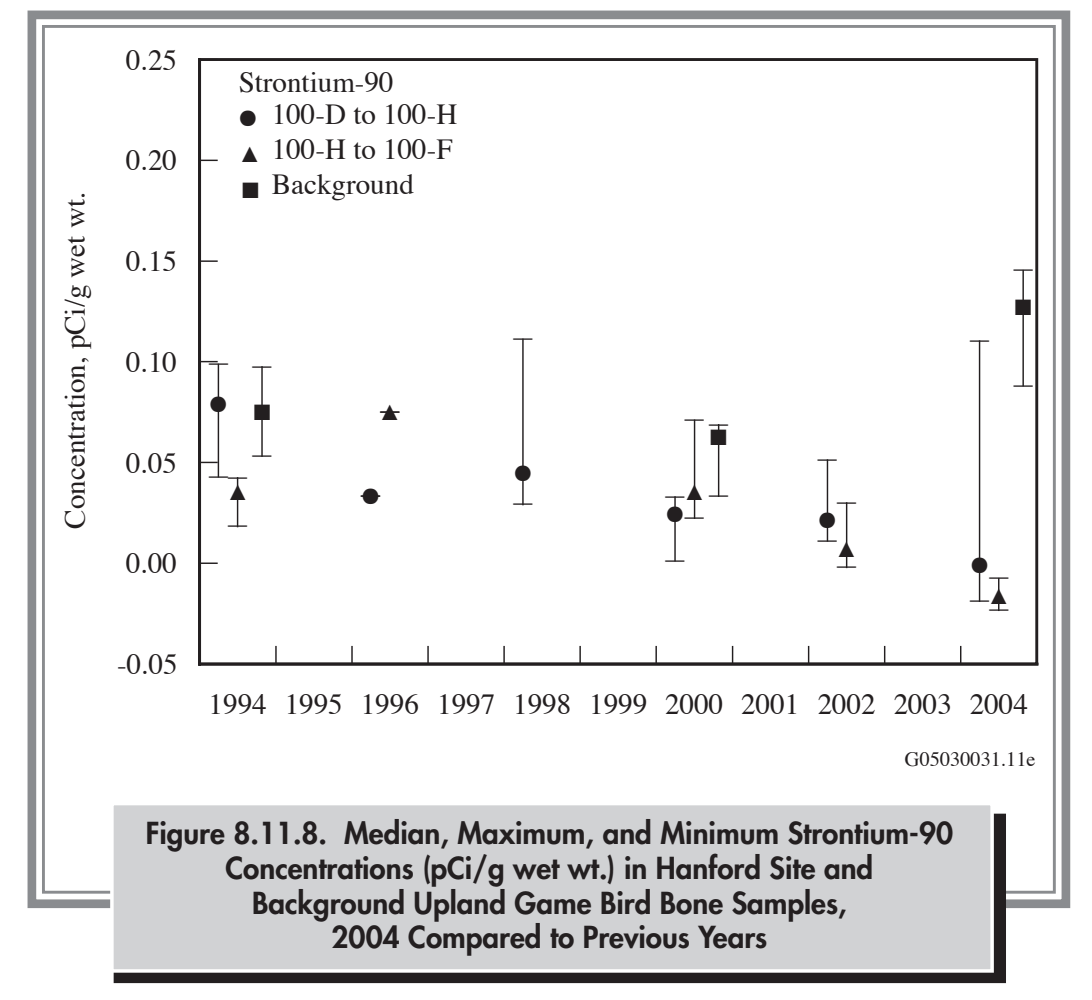


Beryllium, antimony, thorium, and uranium were not detected above analytical detection limits in any of the upland game bird liver samples collected on the Hanford Site in 2004. The median and maximum concentrations of aluminum, chromium, cadmium, selenium, and thallium were two to five times higher in liver samples collected between the 100-D and 100-H Areas compared to the median and maximum concentrations measured in liver samples from the reference location. Cadmium concentrations in three of the four samples collected in 2004 between the 100-D and 100-H Areas exceeded the maximum concentration measured in upland game bird samples from the same general area in 2002 (PNNL-14295). The maximum concentrations of aluminum, chromium, and selenium in liver samples collected in 2004 between the $100-\mathrm{N}$ and 100-D Areas were below the minimum concentrations of aluminum (12 $\mathrm{\mu g} / \mathrm{g}$ dry weight), chromium $(1.9 \mu \mathrm{g} / \mathrm{g}$ dry weight), and selenium $(7.1 \mu \mathrm{g} / \mathrm{g}$ dry weight) measured in upland game bird liver samples collected in the same general area in 2002 (PNNL-14295).

The maximum concentration of aluminum $(9.5 \mu \mathrm{g} / \mathrm{g}$ dry weight) in upland game liver samples collected between the $100-\mathrm{H}$ and $100-\mathrm{F}$ Areas was more than five times higher than the maximum aluminum concentration measured in samples from the reference location ( $1.5 \mu \mathrm{g} / \mathrm{g}$ dry weight). However, the median concentration in the three samples collected between the 100- $\mathrm{H}$ and 100-F Areas was below the median concentration measured in samples collected at the reference location and two of the three samples had concentrations of aluminum below the minimum concentration measured at the reference location.

\subsubsection{Analytical Results for Deer Samples}

Studies of mule deer populations residing on the central portions of the Hanford Site indicate their division into three relatively distinct groups (Tiller and Poston 2000): (1) deer that live near the retired reactors in the 100 Areas are designated the north area population; (2) deer that reside from the Hanford town site south to the 300 Area are designated the south area population; and (3) by default, deer living around the 200 Areas, away from the river, are designated the central area population. The central area population has decreased significantly with the eliminations of Gable Mountain Pond and B Pond.
Deer can be exposed to metals and persistent radionuclides when they forage on plants that grow in places where plant roots have access to contaminated groundwater or soil, drink contaminated water, or incidentally ingest contaminated soil. Deer hunting is not allowed above the high water mark on the Benton County side of the Columbia River (on the Hanford Site), but the river is not a barrier to deer movements. Deer captured and tagged on the Hanford Site have been legally killed by hunters on the Hanford Reach shoreline below the high water mark and across the river in Franklin County.

Radionuclide levels in muscle and bone samples harvested from nine deer collected onsite in 2004 were compared to levels in tissues from a deer collected distant from the site and to results measured in samples collected during the preceding 10-year period. Four deer were from the north population and five were from the south population. In 2004, reference tissue samples from a black-tailed deer collected near Olympia, Washington, were donated to DOE by the Washington State Department of Health. Additionally, reference samples were collected between 1992 and 1995 near Boardman, Oregon, and in Stevens County, Washington (see PNNL-11472, Section 4.5), and during 2000 from the lower Yakima Valley, near Sunnyside, Washington (see PNNL-13487, Section 4.5). Contaminant concentrations measured in a white-tailed deer that was co-sampled with the Washington State Department of Health during 1996 from Vail, Washington (see PNNL-12088, Section 4.5), were also used for comparisons. These comparisons with samples from distant locations are useful in evaluating Hanford's relative contribution of radionuclides in deer. The deer collected in Stevens County and Vail, Washington, inhabited mountain regions that received more rainfall (and more atmospheric fallout over a period of several decades) than Hanford, increasing background levels of fallout radionuclides there (Tiller and Poston 2000). The climate and precipitation of the Boardman, Oregon, and the Sunnyside, Washington, regions are similar to Hanford.

Cesium-137 was not detected (at or below the detection limit of $0.03 \mathrm{pCi} / \mathrm{g}[0.001 \mathrm{~Bq} / \mathrm{g}]$ wet weight) in any of the nine deer muscle samples collected onsite in 2004 or in the muscle sample from the black-tailed deer collected near Olympia in 2004. These results are consistent with a decline in cesium-137 levels in all wildlife examined from 1983 through 1992 (PNL-10174) and with data obtained 
over the preceding 10 years. During this period, the levels of cesium-137 in more than 60 Hanford Site deer muscle samples were less than levels measured in reference deer samples collected from 1991 through 1995 from Stevens County, Washington, and, during 1996, from Vail, Washington.

Strontium-90 was detected in all nine deer bone samples collected onsite and analyzed in 2004 and continues to demonstrate the utility of this organism to accumulate this radionuclide and to depict trends of strontium- 90 contamination in the environment. Median levels of strontium-90 found in deer bone in 2004 were similar between the north and south sampling areas (Figure 8.11.9). The highest concentration of strontium-90 (1.24 $\pm 0.22 \mathrm{pCi} / \mathrm{g}[0.05 \pm$ $0.008 \mathrm{~Bq} / \mathrm{g}$ ] wet weight) obtained onsite during 2004 was obtained from the north area near the $100-\mathrm{N}$ Area. When compared to the bone samples from the south area, strontium-90 concentrations in bone samples from the north area were typically elevated in about one of three samples collected there throughout the preceding 10-year period, with the highest concentration $(20.8 \pm 5.2 \mathrm{pCi} / \mathrm{g}$ $[0.77 \pm 0.19 \mathrm{~Bq} / \mathrm{g}]$ wet weight) reported during 1992 (see PNNL-13487, Section 4.5). The apparently higher concentrations reported in samples from the north area may indicate some exposure to localized contamination in the $100-\mathrm{N}$ Area. Strontium-90 was detected in the

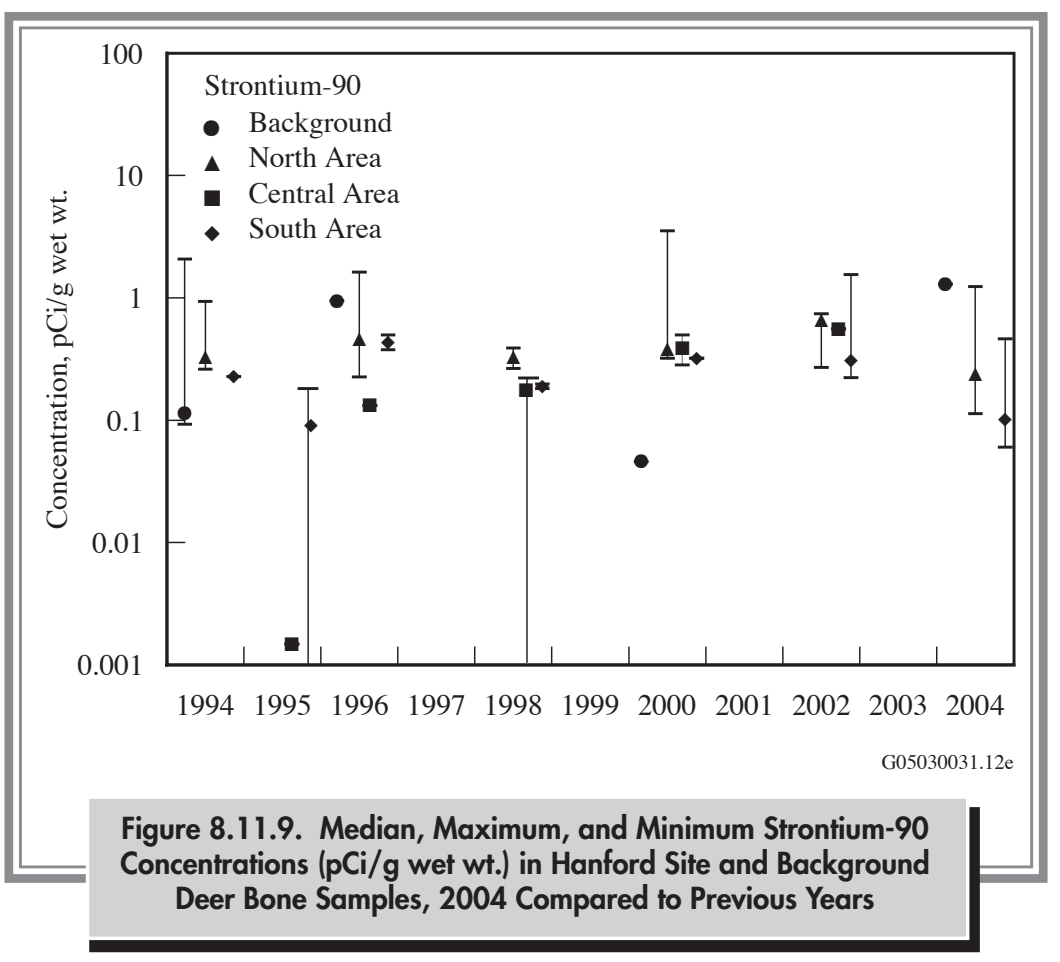

2004 reference sample from Olympia, Washington (1.29 \pm $0.19 \mathrm{pCi} / \mathrm{g}[0.05 \pm 0.007]$ wet weight). Previous reference samples of deer bone indicate strontium-90 concentrations can be as high as $2.06 \pm 0.4 \mathrm{pCi} / \mathrm{g}(0.08 \pm 0.01 \mathrm{~Bq} / \mathrm{g})$ wet weight.

Liver samples from two mule deer collected near the 100-N Area and the black-tailed deer from near Olympia, Washington, were analyzed for trace metals in 2004. Concentrations measured in Hanford Site deer were compared to concentrations in four mule deer samples obtained at a reference location near Boardman, Oregon, in 1994 (PNNL-11518) and to concentrations measured in samples from the black-tailed deer (Appendix C, Table C.13; PNNL-11518).

Most trace metal concentrations in liver samples collected from deer near the 100-N Area in 2004 were similar to or less than concentrations measured in samples from the reference locations (Appendix C, Table C.13). Uranium, nickel, beryllium, thorium, and antimony were not detected above analytical detection limits in samples collected on the Hanford Site in 2004. Concentrations of copper were elevated in samples collected onsite compared to the sample collected near Olympia, Washington, but were not elevated compared to concentrations in samples collected near Boardman, Oregon. Thallium concentrations were above the analytical detection limit in samples collected onsite. Thallium concentrations were below the analytical detection limits in samples collected near Olympia, Washington $(0.004 \mu \mathrm{g} / \mathrm{g}$ dry weight), and Boardman, Oregon (0.04 $\mu \mathrm{g} / \mathrm{g}$ dry weight). However, the detection limit for the samples collected near Boardman exceeded the maximum concentration found in samples collected on the Hanford Site (PNNL-11518).

Cadmium, selenium, and arsenic levels were elevated in samples collected onsite compared to concentrations in all reference samples. The median and maximum concentrations of cadmium measured in the samples collected onsite were approximately two times higher than the median and maximum concentrations measured in the samples from Boardman, Oregon (PNNL-11518), and six to 
seven times higher than the concentration measured in the sample from Olympia, Washington. The median and maximum concentrations of selenium in samples collected onsite were slightly elevated compared to levels in samples collected near Boardman, Oregon, but were over four times higher than the concentration measured in the sample collected near Olympia, Washington. Arsenic concentrations measured in samples collected onsite were over 20 times higher than the concentration measured in the sample collected near Olympia, Washington, and concentrations measured in samples collected near Boardman, Oregon. The elevated arsenic seen in deer collected near the $100-\mathrm{N}$ Area is likely associated with eating grass from fields that were fruit orchards prior to World War II. These orchards were commonly sprayed with lead arsenate to control insects. A 2002 study that examined the extent of arsenic contamination in pre-Hanford orchard soil near the 100 Areas showed elevated levels of arsenic compared to levels in soil from reference areas (Yokel and Delistraty 2003).

\subsubsection{Analytical Results for Elk Samples}

Radionuclide levels in elk samples collected on the Hanford Site in 2004 were compared to levels in elk samples previously collected onsite, along roads near the Hanford Site (killed by traffic), on the Fitzner/Eberhardt Arid Lands Ecology Reserve Unit of the Hanford Reach National Monument, and from a reference location in central Idaho. In 2004, samples of muscle and bone were collected from two animals killed by traffic on Highway 240 on the Hanford Site and one killed by traffic near the 200-East Area (Figure 8.11.6). Muscle samples were analyzed for gamma emitters, including cesium-137, and bone samples were analyzed for strontium-90.

Cesium-137 was not detected above the analytical detection limit $(0.03 \mathrm{pCi} / \mathrm{g}[0.001 \mathrm{~Bq} / \mathrm{g}]$ wet weight $)$ in any of the elk muscle samples collected in 2004. Three muscle samples collected from central Idaho in 1999 were the only elk samples analyzed in the last 10 years with cesium-137 concentrations above analytical detection limits. These results were consistent with historical big game results and with the trends observed in a Hanford wildlife summary report (PNL-10174).
Strontium-90 was detected in all elk bone samples analyzed in 2004. The median concentration in the samples (0.272 pCi/g [0.01 Bq/g] wet weight) was consistent with levels previously observed on the Hanford Site and on the Fitzner/Eberhardt Arid Lands Ecology Reserve Unit (Figure 8.11.10). Interestingly, the highest concentration of strontium-90 observed in elk in recent years comes from reference samples collected in 1999 from central Idaho and is likely associated with the historical accumulation of fallout in the central Idaho area.

\subsubsection{Sentinel Organisms}

\section{B. L. Tiller}

For environmental monitoring purposes, organisms can be used to (1) detect and quantify contaminants in a given ecosystem (sentinel organisms) and (2) indicate risks to an ecosystem (indicator organisms). Organisms that are best suited for accumulating contaminants and serving as biological monitors of environmental contaminants are termed sentinel species, whereas organisms (or defined assemblages of organisms) that are sensitive to damage or injury from elevated levels of environmental contaminants are referred to as indicator species. In practice, the desirable features of both the sentinel and indicator species are often found only in a limited number of organisms. The organisms chosen for monitoring environmental health often have both sentinel and indicator species attributes.

\subsubsection{Asiatic Clam Sample Results and Analytes of Interest}

Asiatic clams (Corbicula fluminea) may be one of the best sentinel organisms along the Hanford Reach of the Columbia River to support DOE cleanup and monitoring objectives on the Hanford Site. This organism is relatively immobile its entire life ( 0 to 3 years), lives in shallow shoreline areas, is a filter-feeder that feeds on phytoplankton and microbes, and is common along the Hanford Reach shoreline. These habitat and food source preferences make this organism an ideal candidate for monitoring contaminants in groundwater seeping into the Columbia River. 


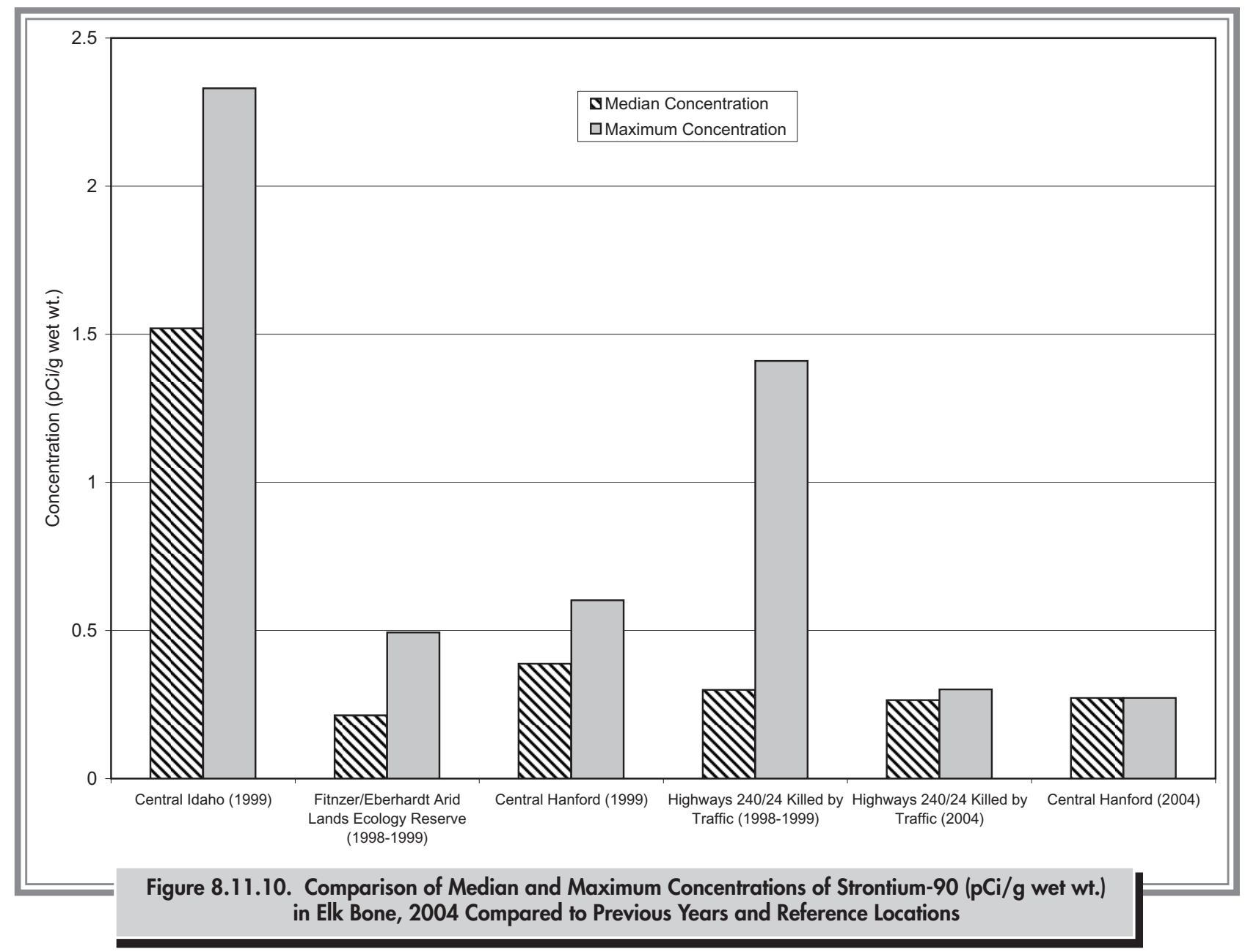

Asiatic clams were collected along the Hanford Reach during August 2004 through September 2004 to evaluate the spatial patterns of Hanford radiological and nonradiological contaminants entering the Columbia River. Clam tissue samples were collected near each of the six Hanford Site reactor areas (100-B/C, 100-K, 100-N, 100-D, 100-H, and 100-F Areas), the 300 Area, the Hanford town site, and from an area upstream of the Hanford Site near the Vernita Bridge that serves as a reference location (Figure 8.11.6). Sampling locations near each of the Hanford Site facilities were selected based on known or suspected elevated levels of legacy contaminants entering the Columbia River via shallow groundwater.

At each site, sampling points were selected near the river's low-water mark, which was visually identified by the presence of persistent periphyton colonies growing on the river bottom (during portions of the year, periphyton dries out and dies above the low-water mark). Clam samples were systematically collected from this point and at another point extending into the river perpendicular to the shoreline at a water depth of 2 meters ( 6 feet). Clam samples were flash-steamed for approximately 15 to 30 seconds using deionized water and the shells were separated from the soft tissues. Shells from 15 to 30 individual clams from each sampling site were composited for strontium-90 and technetium-99 analyses. Soft tissues were composited (from 2 to 50 organisms per sample) and analyzed for 18 trace metals, including chromium, mercury, and uranium (Table 8.11.5).

Strontium-90 was detected in 61 of 63 (96\%) of the clam shell samples collected and analyzed during 2004. Levels measured in clam shells collected from the reference location near the Vernita Bridge during 2004 ranged from 0.19 to $0.228 \mathrm{pCi} / \mathrm{g}(0.007$ to $0.009 \mathrm{~Bq} / \mathrm{g})$ wet weight. The maximum strontium-90 concentration measured near the $100-\mathrm{N}$ Area during 2004 (10.1 pCi/g [0.4 Bq/g] wet weight) was 44 times higher than the maximum reference location level, and the level near the 100-H Area 
(0.78 pCi/g $[0.03 \mathrm{~Bq} / \mathrm{g}]$ wet weight) was 3.4 times higher than the maximum reference location level (Table 8.11.6). Strontium-90 was also detected in samples collected during a 2004 special study near the 100-N Area. The maximum concentration measured in clam shells as part of this study was $50.5 \mathrm{pCi} / \mathrm{g}(1.87 \mathrm{~Bq} / \mathrm{g})$ wet weight (DOE/RL-2005-22).

Technetium-99 was not found above analytical detection limits (ranging from 0.55 to $0.64 \mathrm{pCi} / \mathrm{g}[0.02$ to $0.025 \mathrm{~Bq} / \mathrm{g}$ ] wet weight) in any of the clam shell samples collected and analyzed during 2004. This was consistent with results reported during 2003 (PNNL-14687).

With the exception of beryllium, trace metals were consistently detected in soft tissue clam samples collected during 2004 (Table 8.11.6). Concentrations of most metals in Hanford Reach clam samples were equal to or below levels found in three samples collected upstream of the Hanford Site during 2004. Chromium concentrations in clam soft tissues were elevated near the 100-B/C, 100-K, 100-N, and 100-D Areas compared to concentrations measured near the Vernita Bridge (ranging from 2.34 to $5.75 \mu \mathrm{g} / \mathrm{g}$ dry weight). The highest concentration of chromium reported in clam tissue during 2004 (70.1 $\mu \mathrm{g} / \mathrm{g}$ dry weight) was collected between the $100-\mathrm{K}$ and $100-\mathrm{N}$ Areas, a location that had not been previously sampled or noted to have active flowing spring water (Figure 8.11.11).
The tissue concentrations of chromium reported in clams generally indicated the highest exposures occurred in the shallowest areas and decreased as water depth increased (Figure 8.11.11). Elevated chromium concentrations in clam tissues collected during 2004 were generally consistent with results reported during 2002 (PNNL-14687). Chromium concentrations measured in 16 of 19 (84\%) clam samples collected at 2 meters ( 6 feet) below the low-water line during 2004 were at or below the reference concentrations measured near the Vernita Bridge (ranging from 2.34 to $5.75 \mu \mathrm{g} / \mathrm{g}$ dry weight). Elevated chromium concentrations appeared to extend beyond the 2-meter (6-foot) water depth at two sampling points near the 100-D Area and one sampling point near the 100-K Area (Figure 8.11.11). The perpendicular distances corresponding to the 2-meter (6-foot) water depth varied according to the slope of the shoreline at each location sampled and ranged from 8 to 123 meters ( 25 to 381 feet).

No state or federal agency benchmark criteria are available to compare to tissue concentrations of chromium measured near the 100-B/C, 100-K, 100-N, and 100-D Areas. However, water samples collected at some of the sites where clam samples were collected indicated elevated exposure to Hanford sources of chromium (Table 8.11.7). Surface water quality criteria for aquatic life are found in WAC 173-201A-040, Toxic Substances (Appendix D, Table D.3). Water collected from springs near the 100-B/C,

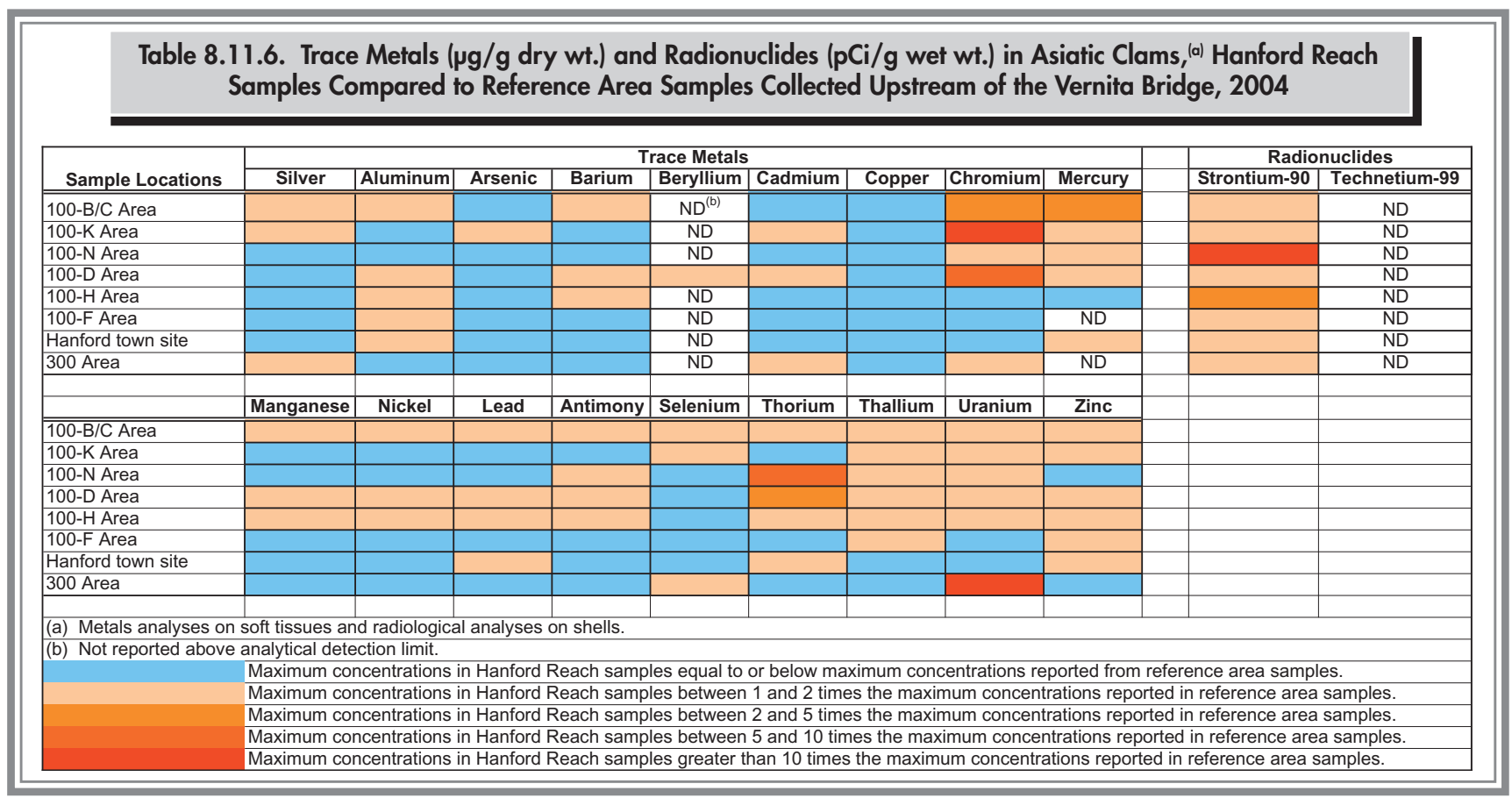




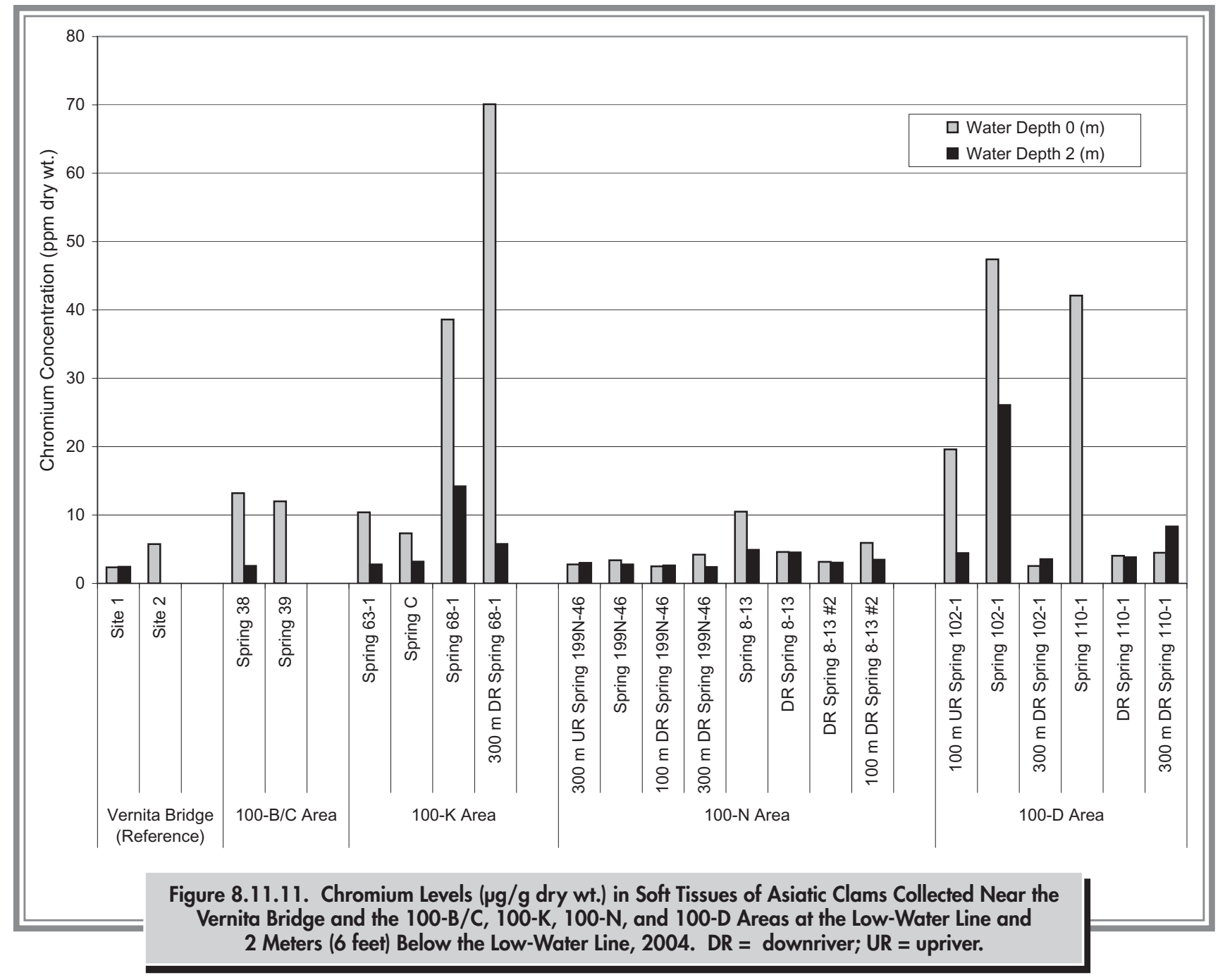

\begin{tabular}{|c|c|c|c|}
\hline \multicolumn{4}{|c|}{$\begin{array}{l}\text { Table 8.11.7. Comparison of Chromium Levels in Clam Tissue (2004), } \\
\text { Spring Water (2003), and Riverbank Spring Sediment (2003) Samples } \\
\text { Collected Along the Benton County Shoreline of the Hanford Reach }\end{array}$} \\
\hline General Region & $\begin{array}{l}2004 \text { Clam } \\
\text { Tissue }{ }^{(a)} \\
(\mu g / g \text { dry wt. })\end{array}$ & $\begin{array}{l}2003 \text { Spring } \\
\text { Water }(\mu g / L)\end{array}$ & $\begin{array}{c}2003 \text { Sediment } \\
\text { (pg/g dry wt.) }\end{array}$ \\
\hline $\begin{array}{l}\text { The Vernita Bridge } \\
\text { (Reference) }\end{array}$ & $2.34-5.75$ & No sample & 92.1 \\
\hline 100-B/C Area & $12-13.2^{(\mathrm{b})}$ & $7.5-20$ & $68.4-112$ \\
\hline 100-K Area & $7.3-70.1^{(\mathrm{b})}$ & $0.97-82$ & 110.0 \\
\hline 100-N Area & $10.5^{(\mathrm{c})}$ & $5.6-12$ & No sample \\
\hline 100-D Area & $42.1-47.4^{(c)}$ & $12-150$ & No sample \\
\hline \multicolumn{4}{|c|}{$\begin{array}{l}\text { (a) Not blank corrected. } \\
\text { (b) Blank contained } 0.78 \mu \mathrm{g} / \mathrm{g} \text { dry wt. } \\
\text { (c) Blank contained } 0.8 \mu \mathrm{g} / \mathrm{g} \text { dry wt. }\end{array}$} \\
\hline
\end{tabular}


100-K, 100-N, and 100-D Areas during 2003 contained chromium at concentrations exceeding WAC guideline levels that may produce chronic toxic effects (Table 8.11.7; Appendix D, Table D.3). Water concentrations of chromium at the 100-B/C, 100-K, and 100-D Areas also exceeded WAC guideline levels that may produce acute toxic effects (Table 8.11.7; Appendix D, Table D.3). In 2004, spring water was not collected at the site where the highest chromium levels $(70.1 \mu \mathrm{g} / \mathrm{g}$ dry weight) were observed in clams, which were collected near the $100-\mathrm{K}$ Area in 2004 (Table 8.11.7).

One clam sample collected near the 300 Area contained over 15 times the concentration of uranium $(2.7 \mu \mathrm{g} / \mathrm{g}$ dry weight) compared to the maximum concentration measured near the Vernita Bridge during $2004(0.18 \mu \mathrm{g} / \mathrm{g}$ dry weight, Table 8.11.6). Uranium was not appreciably elevated in the samples collected near the other Hanford Site reactor areas or near the Hanford town site. These results are consistent with results observed during 2003 and 2001 (PNNL-14687; PNNL-13692).

\subsubsection{Sculpin Sample Results and Analytes of Interest}

Sculpin probably best represent the ideal sentinel fish along the Hanford Reach of the Columbia River because they have relatively small home ranges, eat aquatic insects, dwell on the river bottom, and are relatively abundant. Prickly sculpin (Cottus asper) represent a different feeding guild than Asiatic clams because they are predators and have the potential to accumulate contaminants such as mercury, arsenic, and organic materials in their tissues that otherwise may go undetected in non-predator organisms, soil, sediment, or water.

Prickly sculpin samples were collected during 2004 near six of the Hanford Site reactor areas (100-B/C, 100-K, $100-\mathrm{N}, 100-\mathrm{D}, 100-\mathrm{H}$, and 100-F Areas), the 300 Area, the Hanford town site, and an area upstream of the Hanford Site near the Vernita Bridge that serves as a reference location (Figure 8.11.6). Sculpin tissues were analyzed for strontium-90, technetium-99, and trace metals (Table 8.11.5). Sculpin samples were not analyzed for gamma-emitting radionuclides in 2004. However, no gamma-emitting radionuclides were detected in sculpin samples (whole organisms) collected and analyzed in 2003.
During 2004, 17 whole body sculpin samples were analyzed for strontium-90 and 16 for technetium-99. Liver samples from 32 sculpin were analyzed for 18 trace metals (Appendix C, Table C.14). For the radionuclide and metals analyses, each sample consisted of a number of individual organisms or livers because the mass required for these analyses was larger than the weight of any individual organism or organ. The three reference samples collected in 2004 near the Vernita Bridge had concentrations of several metals including lead, aluminum, cadmium, chromium, and mercury that were elevated compared to concentrations in samples collected upstream of the Vernita Bridge in 2003 and near Hanford Site reactor areas in 2004. To be conservative, concentrations in samples collected near the Hanford reactor areas in 2004 were compared to concentrations in ten sculpin samples collected upstream of the Vernita Bridge in 2003.

For most trace metals and radionuclides, concentrations measured in sculpin samples collected near the Hanford reactor areas were generally equal to or less than concentrations measured in sculpins collected in 2003 and 2004 upstream of the Vernita Bridge (Appendix C, Table C.14). The median concentrations for chromium, aluminum, barium, and lead in sculpin collected near the Hanford reactor areas were two to three times greater than the median concentrations of these metals in sculpin collected upstream of the Vernita Bridge in 2003. The median concentrations of lead, manganese, and barium were approximately five times higher in sculpin samples collected near the 100-D Area than the median concentrations of these metals measured in the sculpin samples collected in 2003 upstream of the Vernita Bridge. The median concentrations of aluminum in sculpin samples collected near the 100-K Area and chromium in sculpin samples collected near the 100-B/C Area were approximately five times higher than the median concentrations of these metals in the sculpin samples collected in 2003 upstream of the Vernita Bridge.

Strontium-90 concentrations were only measured above analytical detection limits $(0.03$ to $0.12 \mathrm{pCi} / \mathrm{g}$ [0.001 to $0.005 \mathrm{~Bq} / \mathrm{g}])$ in 2 of $17(11 \%)$ sculpin samples collected and analyzed during 2004 and did not appear to be appreciably elevated near the $100-\mathrm{N}$ Area where high strontium-90 concentrations were observed in Asiatic clam samples (Table 8.11.6). Technetium-99 was measured above the analytical detection limits $(0.25$ to $0.28 \mathrm{pCi} / \mathrm{g}$ 
[0.01 to $0.11 \mathrm{~Bq} / \mathrm{g}]$ ) in 5 of $16(31 \%)$ sculpin samples collected and analyzed during 2004. The median technetium-99 concentration measured in sculpin samples collected near Hanford Site facilities ( $0.18 \mathrm{pCi} / \mathrm{g}$ [0.007 Bq/g]) was elevated compared to the median concentration observed in samples collected from the upstream reference area in 2003 (0.08 pCi/g [0.003 Bq/g]).

\subsubsection{Investigations of Radioactive Contamination in Wildlife and Wildlife- Related Materials Near Hanford Site Facilities and Operations}

\section{S. M. McKinney and R. M. Mitchell}

Investigative sampling is conducted in and near operational areas to monitor the presence or movement of radioactive materials around areas of known or suspected contamination and to verify radiological conditions at specific project sites. All investigative samples are field surveyed for alpha and beta/gamma radiation and some samples are analyzed at a laboratory to identify specific radionuclides. Generally, the predominant radionuclides in investigative samples from the 100 and 200 Areas are strontium-90, cesium-137, and plutonium-239/240. Uranium-234, uranium-235, and uranium-238 are usually found in 300 Area samples.

Twenty incidents of radiologically contaminated wildlife and wildlife-related materials were investigated during 2004 and from these, three samples were submitted for laboratory analyses. The analytical results obtained from each of these can be found in PNNL-15222, APP. 2. The number of samples submitted for analysis depended on opportunity (i.e., resulting from the pest control activities), the technical merits of having isotopic analyses results, and the analytical budget, rather than prescheduled sampling at established sampling points. Of the 20 cases of contaminated wildlife or wildlife-related samples investigated, 7 were found during routine environmental surveys and 13 were found during cleanup operations. These samples included mud dauber wasp nests; rabbit, bird, and mice feces; mice; and ant hills.
When wildlife was investigated, radiological surveys were performed to determine whether an animal was contaminated. If a live animal was found to be free of contamination, it was taken to an area of suitable habitat and released. If an animal was contaminated, a decision was made based on the level of contamination, collection location, and frequency of occurrence either to collect the animal as a sample or to dispose of the animal in a burial ground. The number of contaminated animals discovered during 2004 and their levels and ranges of radioactivity were within historical levels (WHC-MR-0418). A discussion of the efforts to control undesirable or contaminated biota at Hanford during 2004 is provided in Section 8.11.5.

The number and general locations of wildlife contamination incidents investigated during 2004 are summarized in Table 8.11.8. The numbers of contamination incidents investigated in 2004 and during the previous 10 years are provided in Table 8.11.9.

Table 8.11.8. Number of Wildlife or Wildlife-Related Contamination Incidents Investigated Near Hanford Site Facilities and Operations, 2004

\section{Location}

Number of Incidents

200-East Area tank farms

200-West Area tank farms

200-East Area burial grounds

200-West Area burial grounds

200-East Area cribs, ponds, and ditches

200-West Area cribs, ponds, and ditches

200-East Area fence lines

200-West Area fence lines

200-East Area roads and railroads

200-West Area road and railroads

200-East Area unplanned release sites

200-West Area unplanned release sites

200-East Area underground pipelines

200-West Area underground pipelines

Cross-site transfer line

200-East Area miscellaneous

200-West Area miscellaneous

200-North Area

100 Areas

300 Area

400 Area

600 Area

former 1100 Area

Totals
4

2

1

0

1

0

0

0

0

0

0

0

0

0

1

2

2

0 


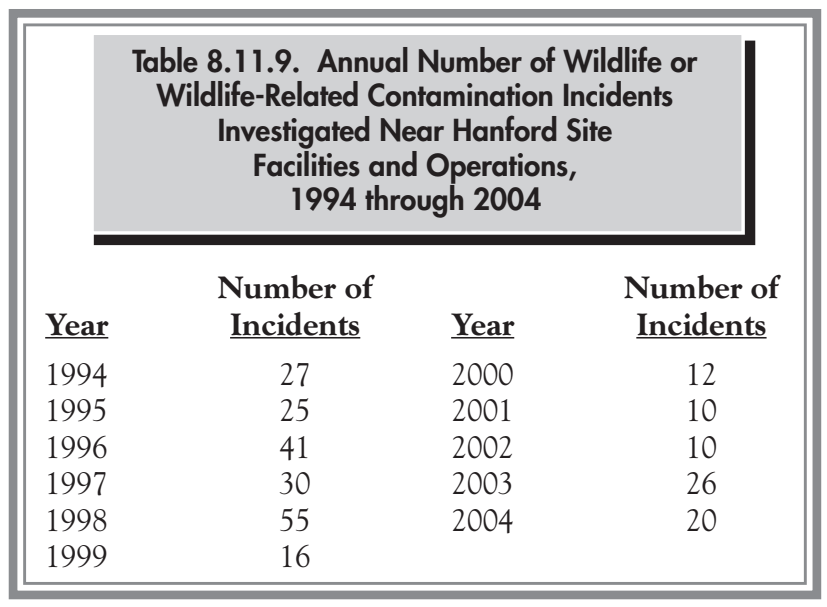

\subsubsection{Control of Pests and Contaminated Biota}

\author{
A. R. Johnson, J. G. Caudill, R. C. Roos, \\ J. M. Rodriguez, R. A. Schieffer, and \\ R. K. Woodford
}

Species of animals such as the domestic pigeon (Columbia livia), Northern pocket gopher (Thomomus talpoides), house mouse (Mus musculus), and deer mouse (Peromyscus maniculatus) must be controlled when they become a nuisance, health problem, or contaminated with radioactivity. Biological control personnel responded to 20,850 animal control requests from Hanford employees in 2004. Control responses ranged from requests to remove animals within radioactive waste facilities to eradicating insect invasions of work areas. Approximately 1,900 trap and bait stations were used to control populations of animals in and near facilities and offices. Increased vegetation control appears to have resulted in fewer locations for animals to hide and live in critical areas. There were 20 contaminated animals discovered during 2004. This is approximately $57 \%$ less than the peak number of 46 in 1999 and is a $23 \%$ decrease compared to the total for 2003 (26).

Flying insects and insect-related material collected during operations on the Hanford Site are monitored for radiological contaminants. In 2003, wasps were using contaminated mud from the $105-\mathrm{H}$ Basin, as it was being decommissioned and demolished, to build nests (PNNL-14687). Because demolition of the 105-H Basin in the $100-\mathrm{H}$ Area was completed in 2003, monitoring of mud dauber wasps in that area was terminated. Only seven of the contaminated animal samples collected in 2004 related to insects (five inactive wasp nests and two active ant mounds) in the operations areas $(100-\mathrm{H}, 100-\mathrm{N}$, 200-East, and 300 Areas).

There were no incidents of offsite contamination by animals during 2004, and all cases of new contamination reported onsite were cleaned up or scheduled for cleanup. 


\subsection{Threatened and Endangered Species at Hanford}

M. R. Sackschewsky

This section discusses the federal and state threatened and endangered species, candidate or sensitive animal species, and plant species of concern potentially found on the Hanford Site. Endangered species are those that are in danger of extinction within all or a significant portion of their range. Threatened species are those that are likely to become endangered in the foreseeable future. Threatened and endangered species are listed in Endangered and Threatened Wildlife and Plants (50 CFR 17), Washington Natural Heritage Program (2005), and Washington Department of Fish and Wildlife (2005).

The purposes of the Endangered Species Act, as amended, are to (1) provide a means to conserve critical ecosystems, (2) provide a program for the conservation of threatened and endangered species, and (3) ensure that appropriate steps are taken to achieve the purposes of the treaties and conventions established in the act. The state of Washington also lists species as threatened or endangered, but such listing does not carry the protection of the federal Endangered Species Act. Species of plants and animals listed as threatened or endangered by either the federal or state governments that occur or potentially occur on the Hanford Site are listed in Table 8.12.1.

Identification of candidate species can assist environmental planning efforts by providing advance notice of the potential for listing as a threatened or endangered species. This advance notice allows resource managers to alleviate threats and, thereby, possibly eliminate the need to list species as endangered or threatened. Even if a candidate species is subsequently listed, the early notice could result in fewer restrictions on human activities in the environment by prompting candidate conservation measures that alleviate threats to the species. Washington State candidate and sensitive animal species occurring or potentially occurring on the Hanford Site are listed in Table 8.12.2. Plant species potentially found on the Hanford Site that are listed at lower levels than threatened or endangered by Washington State are listed in Table 8.12.3.

One bird species (bald eagle) and two fish species (springrun Chinook salmon and steelhead) on the federal list of threatened and endangered species are known to regularly occur on the Hanford Site (Table 8.12.1). One additional fish species (Bull trout [Salvelinus confluentus]) has been recorded on the Hanford Site but is believed to be transient. No plants or mammals known to occur on the Hanford Site are currently on the federal list of endangered and threatened species (50 CFR 17), but two species of plants, one species of mammal, and one species of bird are currently candidates for listing under the Endangered Species Act (Tables 8.12.1 and 8.12.2). In addition, 11 plant species and 5 bird species have been listed as either threatened or endangered by Washington State.

The National Oceanic and Atmospheric Administration Fisheries (NOAA 2005) has the responsibility for the federal listing of anadromous fish (i.e., fish which require both saltwater and freshwater to complete a life cycle such as the steelhead [Oncorhynchus mykiss] and springrun Chinook salmon [Oncorhynchus tshawytscha]). The U.S. Fish and Wildlife Service has responsibility for all other federally listed species on the Hanford Site.

Several species of animals and plants are listed at the candidate species, sensitive species, or other levels by Washington State. There are 29 state-level candidate and sensitive species of animals (Table 8.12.2) and 40 plant species of concern occurring or potentially occurring on the Hanford Site (Table 8.12.3). 


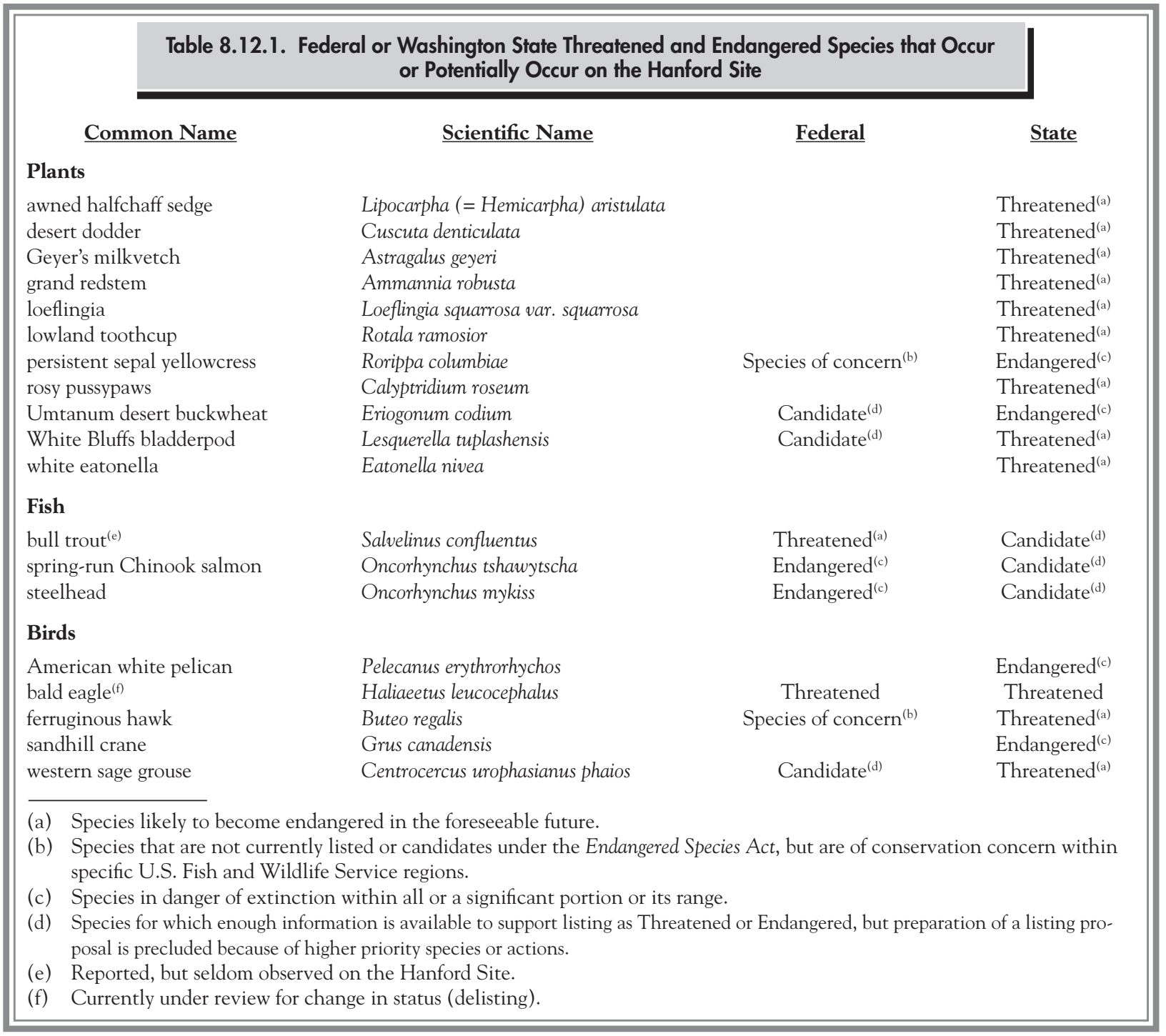


Table 8.12.2. Washington State Candidate and Sensitive Animal Species Occurring or Potentially Occurring on the Hanford Site

\section{Common Name}

\section{Mollusks}

giant Columbia River limpet giant Columbia River spire snail ${ }^{(a)}$

California floater

\section{Fish}

bull trout ${ }^{(\mathrm{b}, \mathrm{c})}$ mountain sucker ${ }^{(c)}$

leopard dace $e^{(\mathrm{c})}$

river lamprey ${ }^{(\mathrm{c})}$

spring-run Chinook salmon ${ }^{(\mathrm{d})}$

steelhead $^{(\mathrm{d})}$

\section{Insects}

Columbia River tiger beetle $\mathrm{e}^{(\mathrm{e})}$

\section{Birds}

burrowing owl ${ }^{(\mathrm{a})}$ common loon $^{(f)}$

flamulated owl ${ }^{(\mathrm{c})}$

golden eagle

Lewis woodpecker ${ }^{(\mathrm{c})}$

loggerhead shrike ${ }^{(a)}$

peregrine falcon ${ }^{(a, f)}$

merlin

northern goshawk ${ }^{(a, c)}$

sage sparrow

sage thrasher

western grebe

\section{Reptiles}

sagebrush lizard ${ }^{(a)}$

striped whipsnake

\section{Mammals}

black-tailed jackrabbit

Merriam's shrew

Townsend's ground squirrel

Washington ground squirrel ${ }^{(c, g)}$ white-tailed jackrabbit

\section{Scientific Name}

Fisherola $(=$ Lanx $)$ nuttalli

Fluminicola (= Lithoglyphus) columbiana

Anodonta californiensis

Salvelinus confluentus

Catastomus platyrhynchus

Rhinichthys flacatus

Lampetra ayresi

Oncorhynchus tshawytscha

Oncorhynchus mykiss

Cicindela columbica

Athene cunicularia

Gavia immer

Otus flammeolus

Aquila chrysaetos

Melanerpes lewisi

Lanius ludovicianus

Falco peregrinus

Falco columbarius

Accipter gentilis

Amphispiza belli

Oreoscoptes montanus

Aechmorus occidentalis

Sceloporus graciosus

Masticophis taeniatus

Lepus californicus

Sorex merriami

Spermophilus townsendii

Spermophilus washingtoni

Lepus townsendii

(a) Federal species of concern.

(b) Federal threatened.

(c) Reported, but seldom observed, on the Hanford Site.

(d) Federal endangered.

(e) Probable, but not observed, on the Hanford Site.

(f) State sensitive (i.e., taxa vulnerable or declining) and could become endangered or threatened.

(g) Federal candidate. 
Table 8.12.3. Washington State Plant Species of Concern on the Hanford Site

\section{Common Name}

annual paintbrush

annual sandwort

basalt milk-vetch

beaked spike-rush

bristly combseed

brittle prickly pear

Canadian St. John's wort

chaffweed

Columbia milkvetch

Columbia River mugwort

coyote tobacco

crouching milkvetch

desert evening-primrose

dwarf evening primrose

false pimpernel

fuzzytongue penstemon

giant helleborine

gray cryptantha

Great Basin gilia

hedge hog cactus

Hoover's desert parsley

Kittitas larkspur

medic milkvetch

miner's candle

mousetail

Piper's daisy

porcupine sedge

Robinson's onion

rosy balsamroot

scilla onion

shining flatsedge

small-flowered evening-primrose

small-flowered nama

smooth cliffbrake

Snake River cryptantha

southern mudwort

stalked pod milkvetch

Suksdorf's monkey flower

Thompson's sandwort

winged combseed
Scientific Name

Castilleja exilis

Minuartia pusilla var. pusilla

Astragalus conjunctus var. rickardii

Eleocharis rostellata

Pectocarya setosa

Opuntia fragilis

Hypericum majus

Centunculus minimus

Astragalus columbianus

Artemisia lindleyana

Nicotiana attenuata

Astragalus succumbens

Oenothera caespitosa

Camissonia (= Oenothera) pygmaea

Lindernia dubia anagallidea

Penstemon eriantherus whitedii

Epipactis gigantea

Cryptantha leucophaea

Gilia leptomeria

Pediocactus simpsonii var. robustior

Lomatium tuberosum

Delphinium multiplex

Astragalus speirocarpus

Cryptantha scoparia

Myosurus clavicaulis

Erigeron piperianus

Carex hystericina

Allium robinsonii

Balsamorhiza rosea

Allium scilloides

Cyperus bipartitus (rivularis)

Camissonia (= Oenothera) minor

Nama densum var. parviflorum

Pellaea glabella simplex

Cryptantha spiculifera (= C. interrupta)

Limosella acaulis

Astragalus sclerocarpus

Mimulus suksdorfii

Arenaria franklinii thompsonii

Pectocarya penicillata
State Listing

W

R1

W

S

W

R1

$\mathrm{S}$

R1

$S^{(a)}$

W

S

W

S

$S$

W

S

W

$S^{(a)}$

$\mathrm{S}$

R1

$S^{(a)}$

W

W

$S$

S

S

W

W

W

W

S

$S$

W

W

$S$

W

W

$\mathrm{S}$

R2

W

(a) U.S. Fish and Wildlife Service federal species of concern.

$\mathrm{S}=$ Sensitive (i.e., taxa vulnerable or declining) and could become endangered or threatened without active management or removal of threats.

R1 = Review List 1 - Taxa for which there are insufficient data available to support listing as threatened, endangered, or sensitive.

R2 = Review List 2 - Taxa with unresolved taxonomic questions.

$\mathrm{W}=$ Watch List - Taxa that are more abundant and/or less threatened than previously assumed. 


\subsection{External Radiation Monitoring}

External radiation at Hanford is monitored (1) onsite in relative close proximity to known, suspected, or potential radiation sources; (2) onsite at locations away from facilities and operations (site-wide); and (3) offsite in local communities, at locations distant from the site, and on or near the site perimeter. External radiation is defined as radiation originating from a source external to the body. Sources of external radiation at Hanford include waste materials associated with the historical production of plutonium for defense; residual nuclear inventories in former production and processing facilities; radioactivewaste handling, storage, and disposal activities; waste cleanup and remediation actions; atmospheric fallout from historical nuclear weapons testing; and natural sources such as cosmic radiation. During the year, external radiation levels can vary from $15 \%$ to $25 \%$ at any location because of changes in soil moisture and snow cover (National Council on Radiation Protection and Measurements 1975).

The Harshaw thermoluminescent dosimeter system is used to measure external radiation at the Hanford Site. This system includes the Harshaw 8800-series dosimeter and the Harshaw 8800 reader. The Harshaw 8800 -series environmental dosimeter consists of two TLD-700 chips and two TLD-200 chips and provides both shallow and deep dose measurement capabilities using filters within the dosimeter. The two TLD-700 chips were used to determine the average total environmental dose at each location. The average daily dose rate was determined by dividing the average total environmental dose by the number of days the dosimeter was exposed. Daily dose equivalent rates (millirem per day) at each location were converted to annual dose equivalent rates (millirem per year) by averaging the daily dose rates and multiplying by
365 days per year. The two TLD-200 chips were included only to determine doses in the event of a radiological emergency and were not used during 2004 . Thermoluminescent dosimeters were positioned approximately 1 meter (3.3 feet) above the ground and were collected and read quarterly.

Radiation surveys with portable instruments are conducted to monitor and detect contamination and to provide a coarse screening for external radiation fields. The types of areas surveyed in 2004 included underground radioactive materials areas, contamination areas, soil contamination areas, high contamination areas, roads, fence lines, and selected Columbia River shoreline locations.

Gamma radiation levels were monitored with pressurized ionization chambers at four offsite community-operated air-monitoring stations. A pressurized ionization chamber is a stainless steel spherical 8-liter (2.1-gallon) chamber, about the size of a basketball, that is filled to a pressure of 25 atmospheres with ultra-high purity argon gas. Radiation penetrating the chamber wall is captured and converted by instruments to an electric current that can be related directly to an exposure rate. Results from locations near and downwind of the site are compared to results from a distant location and to thermoluminescent dosimeter measurements obtained at each chamber location.

In the following sections, all 2004 external radiation measurements are compared to results from previous years, and 2004 onsite measurements are compared to measurements obtained at perimeter and distant locations in 2004. For further information about the monitoring and surveillance programs that support these efforts, see Section 8.0 or DOE/RL-91-50. 


\subsubsection{External Radiation Monitoring Onsite Near Facilities and Operations}

\section{J. Perkins}

During 2004, external radiation fields were monitored with thermoluminescent dosimeters at 135 locations near onsite facilities and operations. Thermoluminescent dosimeter results were used individually or averaged to determine dose rates in a given area for a particular sampling period. A comparison of 2004 and 2003 results for thermoluminescent dosimeters located near waste handling facilities on the Hanford Site as well as historical comparative results from offsite locations for 1999 through 2004 can be found in Table 8.13.1. Individual thermoluminescent dosimeter results and detailed monitoring-location maps are provided in PNNL-15222, APP. 2.

\subsubsection{External Radiation Measurements Onsite Near Facilities and Operations}

100-B/C Area. At the former 116-B-11 and 116-C-1 liquid waste disposal facilities (located in the 100-B/C Area), dose rate levels in 2004 were, as in past years, approximately $85 \mathrm{mrem} / \mathrm{yr}$.

100-K Area. Cleanup activities at the 100-K Area basins and adjacent retired reactor buildings continued in 2004, and average dose rates measured in 2004 increased by approximately $41 \%$ relative to 2003 values. As with a similar increase observed during 2003, the 2004 increase

\begin{tabular}{|c|c|c|c|c|c|c|}
\hline \multicolumn{7}{|c|}{ 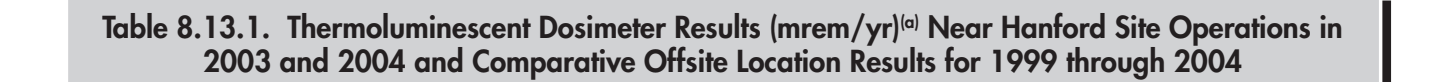 } \\
\hline \multirow{2}{*}{$\begin{array}{l}\text { Hanford Site } \\
\underline{\text { Locations }}\end{array}$} & \multirow{2}{*}{$\begin{array}{c}\text { No. of } \\
\text { Dosimeters, } 2004\end{array}$} & \multicolumn{2}{|c|}{2003} & \multicolumn{2}{|c|}{2004} & \multirow[b]{2}{*}{$\underline{\%}$ Change $^{(\mathrm{d})}$} \\
\hline & & Maximum $^{(\mathbf{b})}$ & ${\underline{\text { Mean }^{(c)}}}^{(1)}$ & Maximum $^{(\mathbf{b})}$ & ${\underline{\text { Mean }^{(c)}}}^{\left({ }^{2}\right.}$ & \\
\hline 100-B/C Area & 4 & $88 \pm 6$ & $85 \pm 5$ & $88 \pm 7$ & $86 \pm 5$ & $<1$ \\
\hline 100-K Area & 11 & $523 \pm 1,060$ & $162 \pm 304$ & $1,352 \pm 3,329$ & $229 \pm 748$ & 41 \\
\hline $100-\mathrm{KR}-1$ & 5 & $103 \pm 11$ & $95 \pm 15$ & $104 \pm 10$ & $97 \pm 15$ & 2 \\
\hline $100-\mathrm{N}$ Area & 14 & $993 \pm 71$ & $261 \pm 485$ & $475 \pm 76$ & $210 \pm 257$ & -19 \\
\hline 200-East Area & 42 & $482 \pm 225$ & $118 \pm 138$ & $4,000 \pm 12,000$ & $200 \pm 1,202$ & 69 \\
\hline 200-West Area & 24 & $189 \pm 21$ & $106 \pm 52$ & $3,000 \pm 10,000$ & $225 \pm 1,196$ & 112 \\
\hline 200-North Area ${ }^{(b)}$ & 1 & $3,400 \pm 131$ & $3,000 \pm 570$ & $3,000 \pm 472$ & $3,000 \pm 295$ & -4 \\
\hline 300 Area & 8 & $112 \pm 2$ & $92 \pm 24$ & $112 \pm 12$ & $92 \pm 25$ & $<1$ \\
\hline 300 TEDF & 6 & $90 \pm 12$ & $85 \pm 5$ & $87 \pm 5$ & $85 \pm 4$ & $<1$ \\
\hline $300-F F-2$ & 6 & \multicolumn{2}{|c|}{ NA; new for 2004} & $91 \pm 40$ & $87 \pm 5$ & NA \\
\hline 400 Area & 7 & $85 \pm 7$ & $81 \pm 5$ & $85 \pm 6$ & $83 \pm 2$ & 3 \\
\hline CVDF & 4 & $82 \pm 4$ & $80 \pm 6$ & $258 \pm 445$ & $177 \pm 175$ & 122 \\
\hline ERDF & 3 & $99 \pm 11$ & $94 \pm 11$ & $100 \pm 22$ & $95 \pm 8$ & 1 \\
\hline Offsite & No. of & \multicolumn{2}{|c|}{$1999-2003$} & \multicolumn{2}{|c|}{2004} & \\
\hline$\underline{\text { Locations }}^{(\mathrm{e})}$ & Dosimeters, 2004 & ${\underline{\text { Maximum }^{(b)}}}^{\left({ }^{\prime}\right.}$ & $\underline{\text { Mean }}^{(f)}$ & ${\underline{\text { Maximum }^{(b)}}}^{(\mathbf{b}}$ & ${\underline{\text { Mean }^{(f)}}}^{(1)}$ & \\
\hline Perimeter & 11 & $106 \pm 7$ & $91 \pm 2$ & $97 \pm 5$ & $89 \pm 3$ & \\
\hline Community & 7 & $89 \pm 3$ & $79 \pm 2$ & $87 \pm 8$ & $79 \pm 3$ & \\
\hline Distant & 2 & $75 \pm 8$ & $72 \pm 1$ & $71 \pm 4$ & $71 \pm 1$ & \\
\hline $\begin{array}{l}\text { (a) To convert t } \\
\text { (b) Maximum v } \\
\text { (c) } \pm 2 \text { standard } \\
\text { (d) Numbers inc } \\
\text { (e) Section } 8.13 \\
\text { (f) } \pm 2 \text { times the } \\
\text { CVDF = Cold V } \\
\text { ERDF }=\text { Enviro } \\
\mathrm{NA}=\text { Not ap } \\
\text { TEDF }=300 \mathrm{Ar}\end{array}$ & $\begin{array}{l}\text { to international metric } \\
\text { alues are } \pm \text { analytical u } \\
\text { deviation. } \\
\text { dicate a decrease (-) or } \\
\text { 3.2. } \\
\text { e standard error of the } \\
\text { Jacuum Drying Facility } \\
\text { nmental Restoration I } \\
\text { plicable. } \\
\text { rea Treated Effluent Di }\end{array}$ & $\begin{array}{l}\text { em units, multip } \\
\text { tainty. } \\
\text { rease from the } 2 \\
\text { n. } \\
\text { sal Facility. } \\
\text { al Facility. }\end{array}$ & $\begin{array}{l}\text { y mrem/yr by } \\
03 \text { mean. }\end{array}$ & 1 to obtain $\mathrm{mSv} /$ & & \\
\hline
\end{tabular}


was primarily due to elevated dose rates at two monitoring locations situated near radioactive materials transfer and storage areas. One location was near the 105-K East spent nuclear fuel storage basin load-out station and the other was near the 105-K West spent nuclear fuel storage basin. Dose rates at the 105-K East location, which were elevated during the first half of the year as spent nuclear fuel was removed from the storage basin, decreased by the year's end to a level slightly higher than typical site background levels. Dose rates at the 105-K West location, which had declined during the first quarter of the year from levels measured at the end of 2003, steadily decreased during the next two quarters of 2004 and then increased significantly during the fourth quarter when radioactive materials destined for disposal were temporarily stored in outdoor staging areas.

Dosimeter monitoring sites around the 100-K Area's Cold Vacuum Drying Facility showed a significant annual dose rate increase of $122 \%$ in 2004 compared to 2003. Dose rates at all four monitoring locations began increasing noticeably at mid-year when radioactive materials associated with cleanup activities in the $\mathrm{K}$ Basins began to be stored on the east side of the facility. As more of these materials were added, dose rates at two monitoring locations situated on the east side of the facility continued to increase significantly during the last half of the year. The dose rates observed at two locations on the west side of the facility showed a more moderate, though continual, increase during the third and fourth quarters of the year.

Dose rate levels measured at the 100-KR-1 (100-K Area) remedial action site in 2004, as in 2003, were approximately $95 \mathrm{mrem} / \mathrm{yr}$.

100-N Area. The average dose rate measured in the 100-N Area in 2004 was approximately 19\% lower than that measured in 2003. Direct radiation levels were, again, highest near facilities that contained or received liquid effluent from the $\mathrm{N}$ Reactor. These facilities primarily included the retired 116-N-1 (also known as 1301-N) and 116-N-3 (also known as 1325-N) liquid waste disposal trenches. Annual average dose rates at five monitoring locations near the 116-N-1 trench showed an increase of approximately $13 \%$ compared to levels measured at the same locations in 2003. The 2004 annual average dose rate levels at the three monitoring locations near the 116-N-3 facility showed a decrease of approximately 35\% from 2003 levels. This reduction in dose rates was directly attributable to the removal of contaminated materials from the facility during 2003. Also significantly reduced were the dose rates near the retired 1304-N Emergency Dump Tank, which was decontaminated and demolished during 2004. Average dose rates at two monitoring locations near the tank were approximately 50\% lower in 2004 than they were in 2003. Annual average thermoluminescent dosimeter results for the entire 100-N Area from 1994 through 2004 are presented in Figure 8.13.1.

100-N Area Shoreline (N Springs). Dose rates were measured along the Columbia River shoreline in the 100-N Area (N Springs) to determine potential external radiation doses to onsite workers and to members of the public using the river. Cleanup activities at the retired 116-N-1 and 116-N-3 trenches (located near the Columbia River) have reduced the skyshine effect (i.e., radiation reflected by the atmosphere back to the earth's surface) at the shoreline and the dose rates there have decreased notably over the past few years (Figure 8.13.1). The 2004 dose rates were similar to the 2003 dose rates.

200-East and 200-West Areas. The highest dose rates in the 200 Areas were measured near waste handling facilities. One such location in the 200-East Area and another in the 200-West Area exhibited noticeably elevated dose rates during the second quarter of 2004. The 200-East Area location was at the A Tank Farm (a group of underground waste-storage tanks) and the 200-West Area location was at the S Tank Farm. These elevated dose rate levels appeared to be directly correlated with waste retrieval activities in both tank farms during 2004. By the end of the year, dose rates at both locations returned to typical site background levels. The overall effect, primarily from these two elevated-dose rate locations, was that average dose rates measured in the 200-East and 200-West Areas in 2004 were $69 \%$ and 112\% higher, respectively, than the 2003 average dose rates (Figure 8.13.1.)

Average dose rates measured in 2004 at the Environmental Restoration Disposal Facility (located near the 200-West Area) were similar to 2003 levels, with only a slight increase of approximately $1 \%$.

200-North Area. One thermoluminescent dosimeter monitoring site, located in the 200-North Area at the contaminated 212-R Railroad Car Disposition Area, 


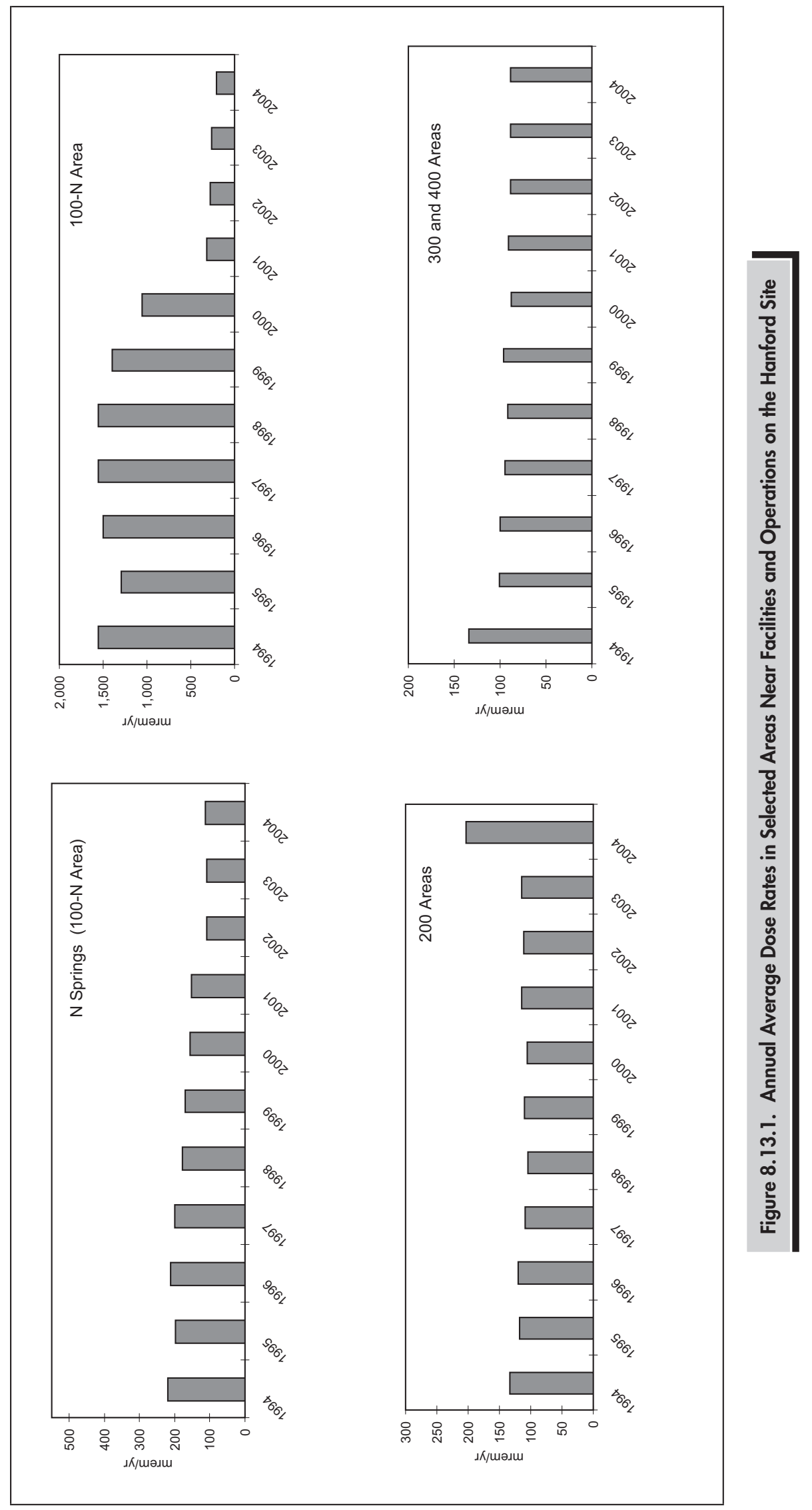


showed a decrease in the annual average dose rate of $4 \%$ in 2004 compared to 2003. This thermoluminescent dosimeter location was established in 2000 to monitor expected high radiation levels emitted from contaminated railroad cars staged in the immediate vicinity.

300 and 400 Areas. The average dose rates in the 300 Area and at the 300 Area Treated Effluent Disposal Facility in 2004 were virtually unchanged from their 2003 levels, and dose rate levels observed in the 400 Area were only 3\% higher than dose rates measured in 2003 (Figure 8.13.1).

Thermoluminescent dosimeters were installed during the second quarter of 2004 to monitor activities at the 300-FF-2 remedial action site in the 300 Area. Dose rate levels measured at these six locations were comparable to typical levels observed in the older established locations in the 300 and 400 Areas (i.e., approximately $85 \mathrm{mrem} / \mathrm{yr}$ ).

\subsubsection{Radiological Surveys at Active and Inactive Waste Disposal Sites}

\section{S. M. McKinney and R. M. Mitchell}

During 2004, 524 environmental radiological surveys were conducted at active and inactive waste disposal sites and the terrain surrounding them to detect and characterize radioactive surface contamination. Vehicles equipped with radiation detection devices and global positioning systems were used to accurately measure the extent of the contamination. Area measurements were entered into the Hanford Geographical Information System, a computer database maintained by Fluor Hanford, Inc. Routine radiological survey locations included former waste disposal cribs and trenches, retention basin perimeters, ditch banks, solid waste disposal sites (e.g., burial grounds), unplanned release sites, tank farm perimeters, stabilized waste disposal sites, roads, and firebreaks in and around the site operational areas. These sites were posted as underground radioactive materials areas, contamination areas, and soil contamination areas. It was estimated that the external dose rate at $80 \%$ of the outdoor contaminated areas was less than $1 \mathrm{mrem} / \mathrm{hr}(0.01 \mathrm{mSv} / \mathrm{hr})$, though direct dose rate readings from isolated radioactive specks could have been higher.
Underground radioactive materials areas are areas where radioactive materials occur below the soil surface. These areas are typically stabilized cribs, burial grounds, covered ponds, trenches, and ditches. Barriers over the contamination sources are used to inhibit radionuclide transport to the surface. These areas are surveyed at least annually to assess the effectiveness of the barriers.

Contamination areas and soil contamination areas may or may not be associated with an underground structure containing radioactive material. A breach in the surface barrier of a contaminated underground area may result in the growth of contaminated vegetation. Insects or animals may burrow into the soil and bring contamination to the surface. Vent pipes or risers from an underground structure may be a source of speck contamination (particles with a diameter less than 0.6 centimeter $[0.25 \mathrm{inch}]$ ). Areas of contamination not related to subsurface structures can include sites contaminated with fallout from effluent stacks or with materials from unplanned releases (e.g., contaminated tumbleweeds, and animal feces).

All contaminated areas may be susceptible to contamination migration and are surveyed at least annually to assess their current radiological status (locations of posted contamination areas are illustrated in PNNL-15222, APP. 2). In addition, onsite roadways are surveyed annually and the intersections along the Environmental Restoration Disposal Facility haul routes are surveyed quarterly.

During 2004, the Hanford Site had approximately 3,628 hectares $(8,965$ acres $)$ of outdoor contaminated areas of all types and approximately 637 hectares (1,575 acres) that contained underground radioactive materials not including active facilities. A listing of the contaminated areas, underground radioactive materials areas, their status, and their general locations is provided in Table 8.13.2. No new areas of significant size were discovered during 2004, and approximately 33 hectares (82 acres) of previously posted contamination and/or underground radioactive materials areas were remediated and released from posting during the year. Table 8.13.3 summarizes the change in status of outdoor contamination areas during 2004. 


\begin{tabular}{|c|c|c|c|c|c|c|}
\hline \multirow[b]{2}{*}{ Area } & \multicolumn{5}{|c|}{$\begin{array}{c}\text { Table 8.13.2. Status of Outdoor Contamination Areas } \\
\text { at Hanford, } 2004\end{array}$} & \multirow[b]{2}{*}{$\begin{array}{l}\text { d Out, } \\
\text { cres) }\end{array}$} \\
\hline & \multicolumn{2}{|c|}{$\begin{array}{c}\text { Contamination } \\
\text { Areas, }{ }^{\text {(a) }} \text { ha (acres) }\end{array}$} & \multicolumn{2}{|c|}{$\begin{array}{c}\text { Underground } \\
\text { Radioactive Materials } \\
\text { Areas, }^{\text {(b) }} \text { ha (acres) } \\
\end{array}$} & $\begin{array}{l}\text { Clos } \\
\text { ha }\end{array}$ & \\
\hline $100-B / C$ & 8 & $(20)$ & 39 & (96) & 0 & $(0)$ \\
\hline $100-\mathrm{D} / \mathrm{DR}$ & 0 & $(0)$ & 29 & $(72)$ & 0 & $(0)$ \\
\hline $100-\mathrm{F}$ & 1 & (2) & 31 & (77) & 3 & (7) \\
\hline $100-\mathrm{H}$ & 0 & $(0)$ & 10 & $(25)$ & 4 & $(10)$ \\
\hline $100-K$ & 8 & (20) & 53 & (131) & 9 & (22) \\
\hline $100-\mathrm{N}$ & 25 & $(62)$ & 12 & $(30)$ & 4 & $(10)$ \\
\hline 200-East ${ }^{(\mathrm{c})}$ & 72 & (178) & 141 & (348) & 0 & $(0)$ \\
\hline 200-West ${ }^{(c)}$ & 27 & (67) & 225 & (556) & 0 & (0) \\
\hline 300 & 9 & (22) & 42 & (104) & 13 & (32) \\
\hline 400 & 0 & $(0)$ & 0 & $(0)$ & 0 & $(0)$ \\
\hline $600^{(d)}$ & 3,478 & $(8,594)$ & 55 & (136) & 0 & (0) \\
\hline Totals & 3,628 & $(8,965)$ & 637 & $(1,575)$ & 33 & $(82)$ \\
\hline \multicolumn{7}{|c|}{$\begin{array}{l}\text { (a) Includes areas posted as contamination/soil contamination or as radiologically } \\
\text { controlled and areas that had both underground radioactive material and } \\
\text { contamination/soil contamination. } \\
\text { (b) Includes areas with only underground contamination. } \\
\text { (c) Includes tank farms. } \\
\text { (d) Includes BC crib controlled area, Environmental Restoration Disposal } \\
\text { Facility, and waste disposal facilities outside the 200-East and 200-West Areas } \\
\text { boundaries. }\end{array}$} \\
\hline
\end{tabular}

in surrounding communities including 2 at distant locations (Figure 8.13.3), and 28 locations along the Columbia River shoreline from the Vernita Bridge to downstream of Bateman Island at the mouth of the Yakima River (Figure 8.13.4). Measurements were made using thermoluminescent dosimeters and pressurized ionization chambers. Annual results for 2004 are compared to results obtained during the previous 5 years in Tables 8.13.4 through 8.13.6. External radiation and surface contamination surveys at specified locations were performed with portable radiation survey instruments.

All community and most of the onsite and perimeter thermoluminescent dosimeter locations were collocated with air-monitoring stations. The onsite and perimeter locations were selected based on determinations of the high potential for public exposure to radiation resulting from remediation activities (i.e., access areas and downwind population centers) and from past and current Hanford Site

\begin{tabular}{|c|c|c|c|}
\hline \multicolumn{4}{|c|}{$\begin{array}{l}\text { Table 8.13.3. Change in Status of Outdoor } \\
\text { Contamination Areas at Hanford, } 2004\end{array}$} \\
\hline$\underline{\text { Areas }}$ & Changes & \multicolumn{2}{|c|}{ Area, ha (acres) } \\
\hline 100 & CA/URM to None ${ }^{(a)}$ & 20 & $(50)$ \\
\hline 200-East & None to report & 0 & $(0)$ \\
\hline 200-West & None to report & 0 & (0) \\
\hline 300 & CA/URM to None ${ }^{(a)}$ & 13 & (32) \\
\hline 400 & None to report & 0 & $(0)$ \\
\hline 600 & None to report & 0 & $(0)$ \\
\hline \multicolumn{4}{|c|}{$\begin{array}{l}\text { (a) Changes due to remediation activities. } \\
\text { CA = Contamination/soil contamination area. } \\
\text { URM = Underground radioactive material area. }\end{array}$} \\
\hline
\end{tabular}

\subsubsection{External Radiation Monitoring at Site-Wide and Offsite Locations}

\section{E. J. Antonio}

During 2004, external radiation levels were measured at 33 site-wide locations on the Hanford Site (Figure 8.13.2), 11 locations around the perimeter of the site, 9 locations operations. The two background stations in Yakima and Toppenish were chosen because they are generally upwind and distant from the site.

Ground contamination surveys were conducted quarterly at 13 shoreline locations. One new shoreline location, Coyote Rapids (location 7 in Figure 8.13.4), was added in 2004 because shoreline survey results at that location indicated possible elevated radiation levels. These surveys were conducted using Geiger-Mueller meters (also called Geiger or GM counters) and Bicron ${ }^{\circledR}$ Microrem meters. Readings were in counts per minute and microrem per hour, respectively. Geiger counter measurements were made within 2.54 centimeters (1 inch) of the ground and covered a 1-square-meter (10-square-foot) area. The Bicron ${ }^{\circledR}$ measurements were taken 1 meter ( 3.3 feet) above the ground surface and at least 10 meters (33 feet) away from devices or structures, which may have contributed to the ambient radiation levels.

Pressurized ionization chambers were situated at four community-operated monitoring stations (Section 8.13.2.5). These instruments measured ambient exposure rates near and downwind of the site and at locations distant and upwind of the site. Continuous 


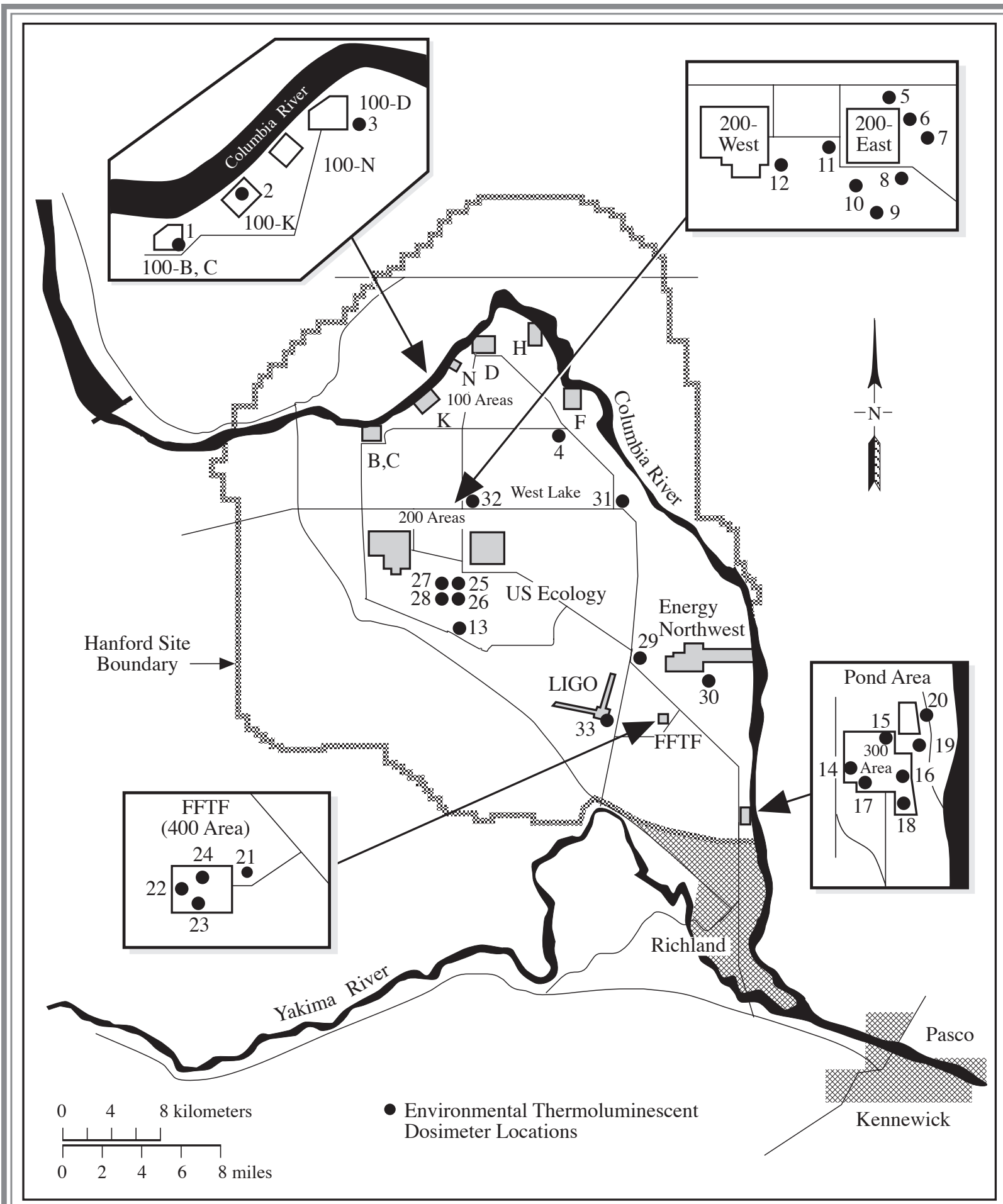

G04030025.18

Figure 8.13.2. Surface Environmental Surveillance Project Thermoluminescent Dosimeter Locations (and Station Numbers) on the Hanford Site, 2004 (see Appendix C, Table C.10 for station names) 


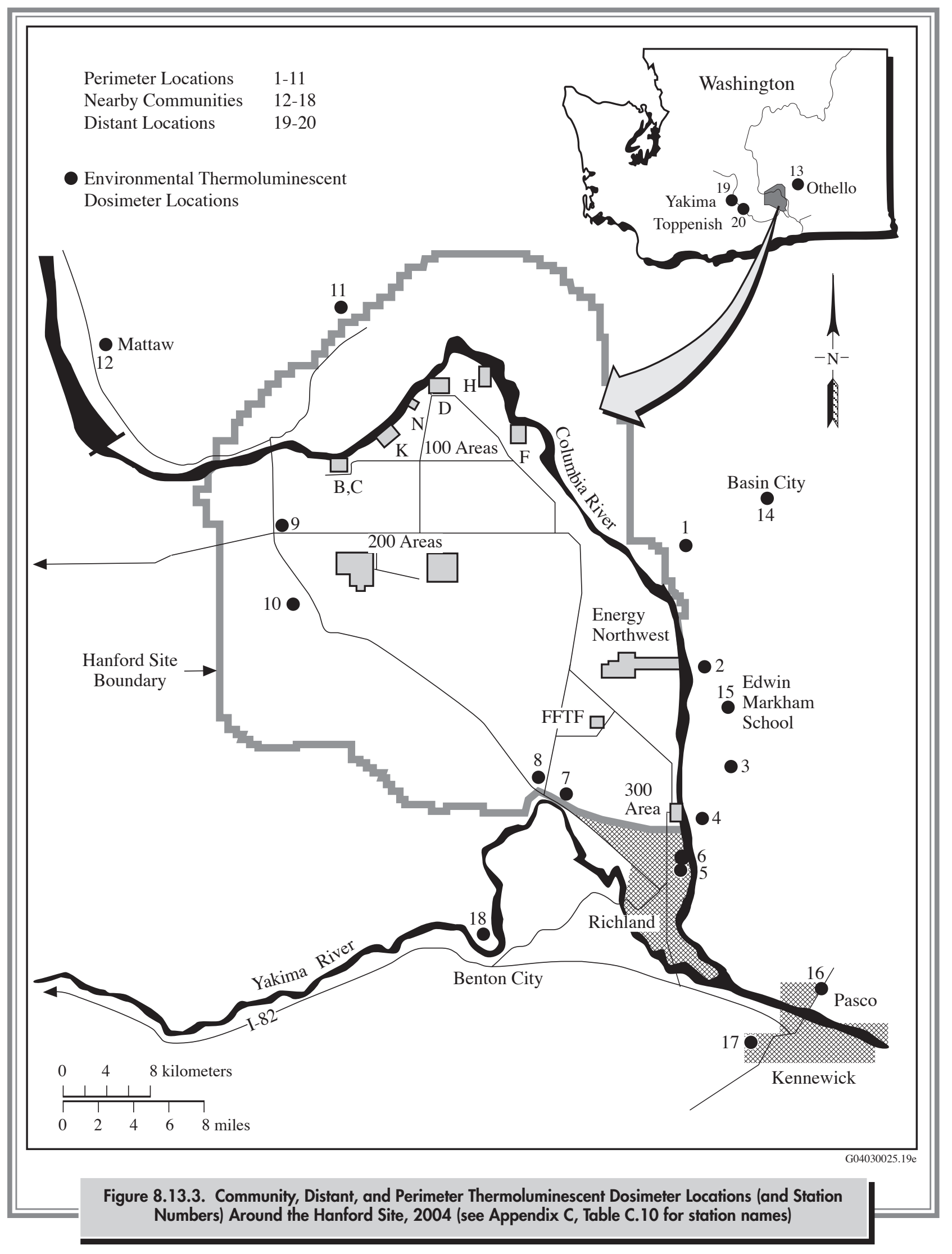




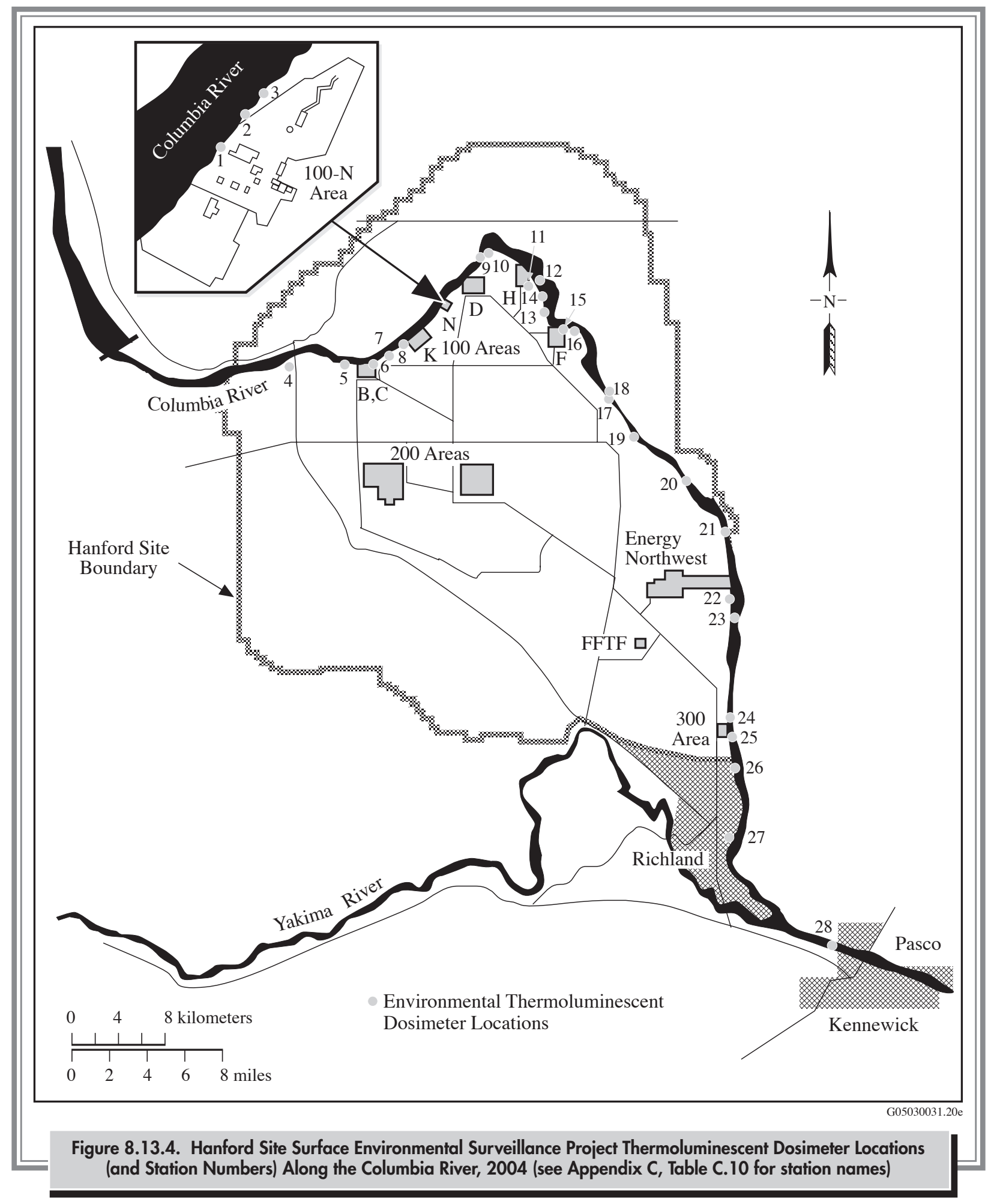




\begin{tabular}{|c|c|c|c|c|c|c|c|}
\hline \multicolumn{7}{|c|}{$\begin{array}{l}\text { Table 8.13.4. Dose Rates (mrem/yr[a]) Measured by Thermoluminescent Dosimeters at } \\
\text { Site-Wide Locations on the Hanford Site, } 2004 \text { Compared to Previous } 5 \text { Years }\end{array}$} & \\
\hline \multirow{2}{*}{\multicolumn{2}{|c|}{ Location }} & \multirow[b]{2}{*}{$\begin{array}{l}\text { Map } \\
\text { Location }^{(\mathbf{b})}\end{array}$} & \multicolumn{2}{|c|}{2004} & \multicolumn{3}{|c|}{$1999-2003$} \\
\hline & & & $\underline{\text { Maximum }}^{(\mathrm{c})}$ & $\underline{\operatorname{Mean}}^{(\mathrm{d})}$ & $\begin{array}{l}\text { No. of } \\
\text { Samples }\end{array}$ & $\underline{\operatorname{Maximum}}^{(\mathrm{c})}$ & $\underline{\text { Mean }}^{(\mathrm{d})}$ \\
\hline 100 & Areas & $1-4$ & $88 \pm 6$ & $82 \pm 5$ & 17 & $88 \pm 4$ & $82 \pm 3$ \\
\hline 200 & Areas & $5-13$ & $95 \pm 9$ & $87 \pm 3$ & 44 & $98 \pm 6$ & $88 \pm 1$ \\
\hline 300 & Area & $14-20$ & $91 \pm 7$ & $84 \pm 3$ & 32 & $107 \pm 6$ & $84 \pm 2$ \\
\hline 400 & Area & $21-24$ & $84 \pm 7$ & $83 \pm 1$ & 20 & $89 \pm 7$ & $83 \pm 1$ \\
\hline 600 & Area & $25-33$ & $96 \pm 9$ & $86 \pm 3$ & 40 & $128 \pm 22$ & $88 \pm 3$ \\
\hline Con & hbined site-wide & $1-33$ & $96 \pm 9$ & $85 \pm 2$ & 153 & $128 \pm 22$ & $86 \pm 1$ \\
\hline \multicolumn{8}{|c|}{$\begin{array}{l}\text { (a) Multiply by } 10 \text { to convert to } \mu \mathrm{Sv} / \mathrm{yr} \text {. } \\
\text { (b) All station locations are shown on Figure } 8.13 .2 \text { and are described in Appendix C, Table C.10. } \\
\text { (c) Maximum annual average dose rate for all locations within a given distance classification ( } \pm 2 \text { standard deviations). } \\
\text { (d) Means computed by averaging annual means for each location within a given distance classification ( } \pm 2 \text { standard } \\
\text { error of the mean). }\end{array}$} \\
\hline
\end{tabular}

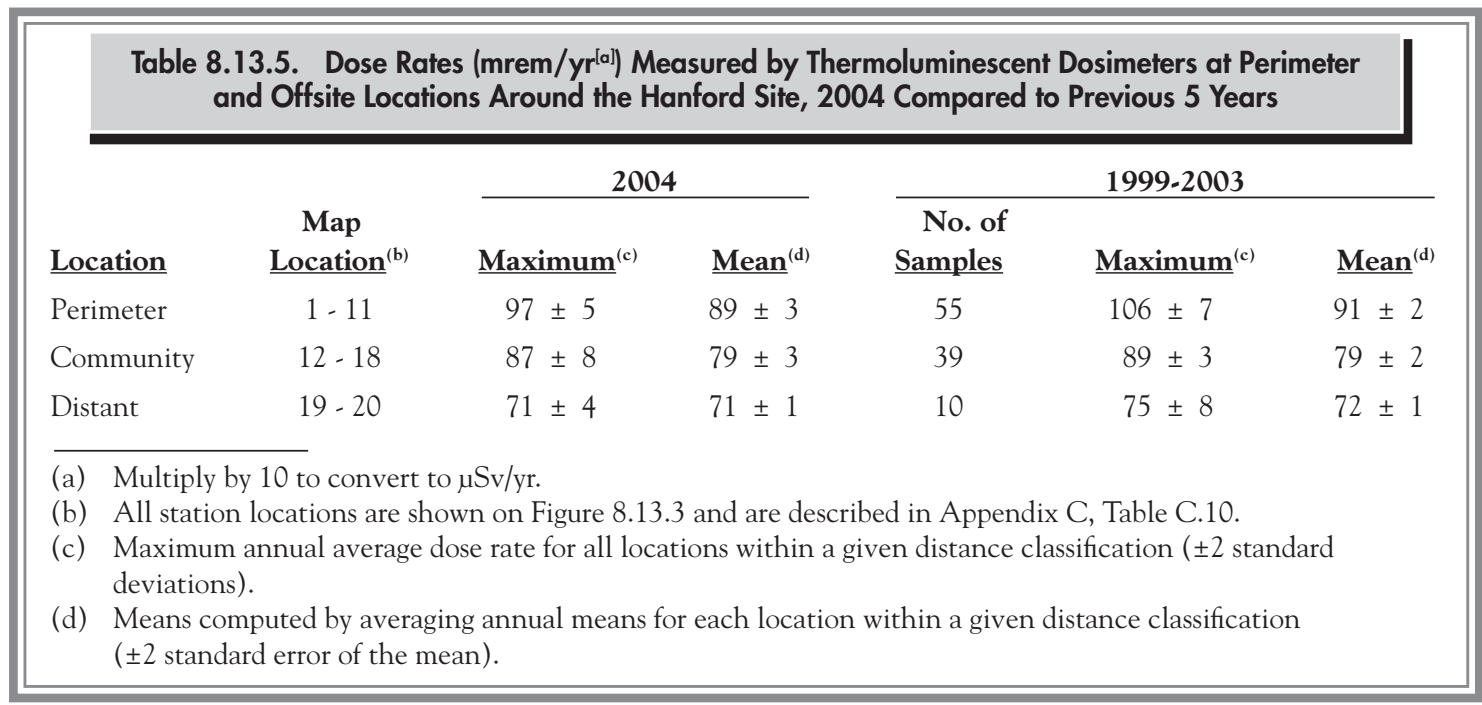

exposure-rate data were displayed at each station to provide information to the public and to serve as an educational tool for the teachers who manage the stations.

\subsubsection{External Radiation Measurements at Site-Wide Locations}

The average dose rates near all operational areas (Table 8.13.4) were higher than average dose rates measured at distant locations (Table 8.13.5). The highest annual average dose rate measured at site-wide locations during $2004(96 \pm 9$ mrem $[0.96 \pm 0.09 \mathrm{mSv}])$ was detected at the southwest corner of the US Ecology waste burial site (location 28 in Figure 8.13.2). The 5-year maximum annual average site-wide dose rate $(128 \pm 22 \mathrm{mrem}$ $[1.28 \pm 0.22 \mathrm{mSv}])$ was measured during 1999 at the same location.

\subsubsection{External Radiation Measurements at Perimeter and Offsite Locations}

The average perimeter dose rate was $89 \pm 3$ mrem $(0.89 \pm$ $0.03 \mathrm{mSv})$ in 2004; the maximum was $97 \pm 5 \mathrm{mrem}(0.97 \pm$ $0.05 \mathrm{mSv}$ ) (Table 8.13.1). The 5 -year (1999 through 2003) 


\begin{tabular}{|c|c|c|c|c|c|c|}
\hline \multicolumn{7}{|c|}{$\begin{array}{l}\text { Table 8.13.6. Dose Rates (mrem/yr }{ }^{[a]} \text { ) Measured by Thermoluminescent Dosimeters Along the } \\
\text { Shoreline of the Hanford Reach of the Columbia River, } 2004 \text { Compared to Previous } 5 \text { Years }\end{array}$} \\
\hline \multirow[b]{2}{*}{ Location } & \multirow[b]{2}{*}{$\begin{array}{l}\text { Map } \\
\text { Location }^{(\mathbf{b})}\end{array}$} & \multicolumn{2}{|c|}{2004} & \multicolumn{3}{|c|}{$1999-2003$} \\
\hline & & $\underline{\text { Maximum }}^{(\mathrm{c})}$ & $\underline{\text { Mean }}^{(\mathrm{d})}$ & $\begin{array}{l}\text { No. of } \\
\text { Samples }\end{array}$ & $\underline{\text { Maximum }}^{(\mathrm{c})}$ & $\underline{\text { Mean }}^{(\mathrm{d})}$ \\
\hline 100-N Area shoreline & $1-3$ & $103 \pm 7$ & $92 \pm 9$ & 15 & $143 \pm 9$ & $112 \pm 9$ \\
\hline Typical shoreline & $4-27$ & $100 \pm 15$ & $86 \pm 3$ & 112 & $101 \pm 16$ & $87 \pm 1$ \\
\hline All shoreline & $1-27$ & $103 \pm 7$ & $86 \pm 3$ & 127 & $143 \pm 9$ & $90 \pm 2$ \\
\hline \multicolumn{7}{|c|}{$\begin{array}{l}\text { (a) Multiply by } 10 \text { to convert to } \mu \mathrm{Sv} / \mathrm{yr} \text {. } \\
\text { (b) All station locations are shown on Figure } 8.13 .4 \text { and are described in Appendix C, Table C. } 10 \text {. } \\
\text { (c) Maximum annual average dose rate for all locations within a given distance classification }( \pm 2 \text { standard } \\
\text { deviations). } \\
\text { (d) Means computed by averaging annual means for each location within a given distance classification }( \pm 2 \text { standard } \\
\text { error of the mean). }\end{array}$} \\
\hline
\end{tabular}

perimeter annual average dose rate was $91 \pm 2$ mrem $(0.90 \pm 0.02 \mathrm{mSv})$ and the 5-year maximum annual average dose rate was $106 \pm 7 \mathrm{mrem}(1.06 \pm 0.07 \mathrm{mSv})$. The location of the 2004 maximum perimeter dose was Byers Landing (location number 4 on Figure 8.13.3). The variation in dose rates may be partially attributed to changes in natural background radiation that can occur as a result of changes in annual cosmic radiation (up to $10 \%$ ) and terrestrial radiation (15\% to $25 \%$ ) (National Council on Radiation Protection and Measurements 1987). Other factors possibly affecting the annual dose rates reported here have been described in PNL-7124, The Determination of the Penetrating Radiation Dose at Hanford.

The average background dose rate (measured in distant communities $)$ in 2004 was $71 \pm 1 \mathrm{mrem}(0.71 \pm 0.01 \mathrm{mSv})$ per year, which was almost equal to the average for 2003 (PNNL-14687) and the 5-year annual average of $72 \pm$ 1 mrem (0.72 $\pm 0.01 \mathrm{mSv}$ ) (Table 8.13.1). Site-wide and perimeter average dose rates in 2004 were 13 mrem $(0.13 \mathrm{mSv})$ and $18 \mathrm{mrem}(0.18 \mathrm{mSv})$ per year higher, respectively, than average dose rates measured at distant locations (Figure 8.13.5).

\subsubsection{External Radiation Measurements at Columbia River Shoreline Locations}

During 2004, average dose rates along the Columbia River shoreline near the $100-\mathrm{N}$ Area were approximately 6 mrem $(0.06 \mathrm{mSv})$ per year higher than the average of all other shoreline dose rates (Table 8.13.6). Higher dose rates historically measured along the $100-\mathrm{N}$ Area shoreline were attributed to waste management practices in that area (PNL-3127). The shoreline location of the highest average thermoluminescent dosimeter reading was along the 100-N Area shoreline. The 2004 maximum annual $100-\mathrm{N}$ Area shoreline dose rate of $103 \pm 7$ mrem $(1.03 \pm 0.07 \mathrm{mSv})$ is about the same as the maximum annual dose rate of $99 \pm 7$ mrem $(0.99 \pm 0.07 \mathrm{mSv})$ measured at that location in 2003 (PNNL-14687), but is significantly different (i.e., the 95\% confidence intervals

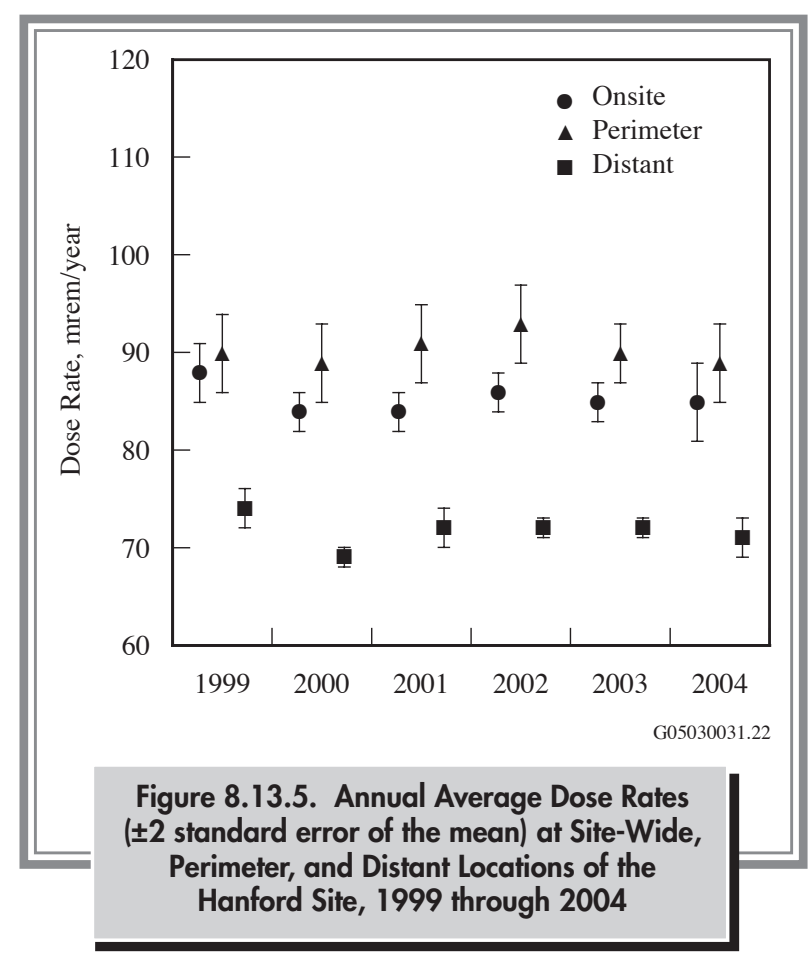


associated with the two measurements do not overlap) than the 5-year maximum annual average of $143 \pm$ 9 mrem $(1.43 \pm 0.9 \mathrm{mSv})$ measured during 1999. Over the past 5 years, the maximum dose rates along the $100-\mathrm{N}$ Area shoreline have decreased as a result of cleanup efforts in the 100-N Area (Figure 8.13.6). The general public is not permitted access to the $100-\mathrm{N}$ Area shore above the high water line but does have boat access to the Columbia River. The dose implications associated with using the Columbia River near the 100-N Area are discussed in Section 8.14 and in DOH 320-032, 2003 External Radiation Survey Along the Columbia River Shoreline of the Hanford Site's 100 Area.

\subsubsection{Columbia River Shoreline Radiological Survey Results}

During 2004, Bicron ${ }^{\circledR}$ Microrem meters and Geiger counters were used to perform radiological surveys at selected Columbia River shoreline locations. These surveys provided a coarse screening for external radiation fields. The highest dose rate measured with the Bicron ${ }^{\circledR}$ Microrem meter $(9 \mu \mathrm{rem}[0.09 \mu \mathrm{Sv}]$ per hour, approximately 78 mrem per year) was measured along the $100-\mathrm{N}$ Area shoreline; the lowest dose rate measured with the Bicron ${ }^{\circledR}$ Microrem meter was $4 \mu$ rem $(0.04 \mu \mathrm{Sv})$ per hour

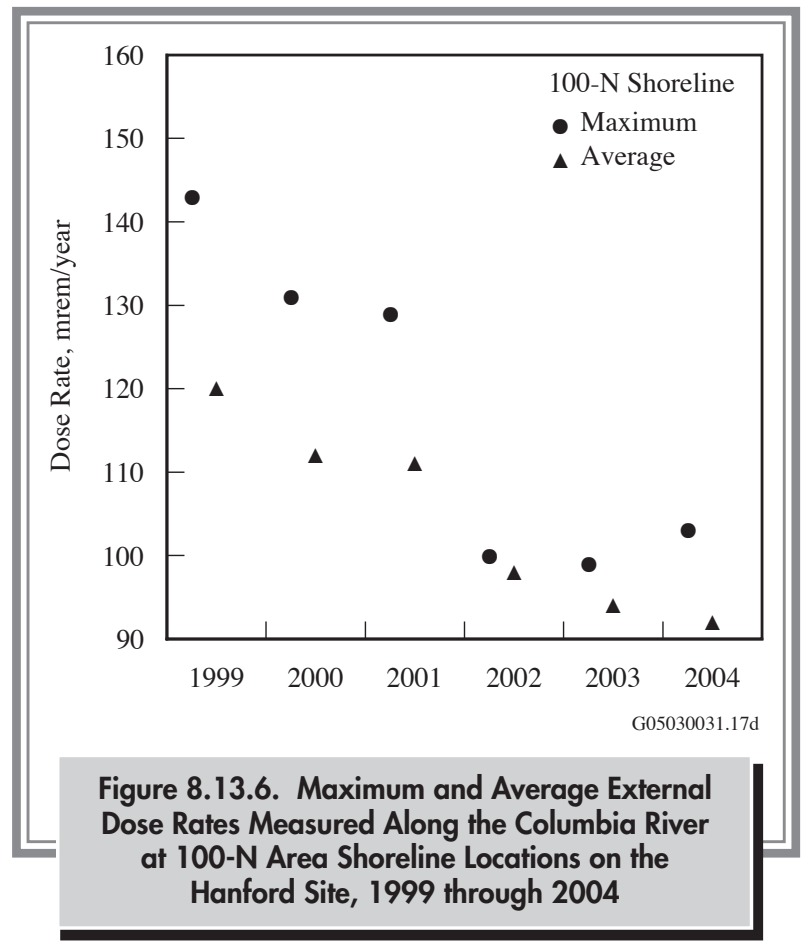

2004 Annual Environmental Report and was recorded at various locations along the Hanford Reach shoreline. The highest reported count rate measured with the Geiger counter in ground level surveys (100 counts per minute) was measured at various locations and in multiple yearly quarters. The lowest ground level count rate (50 counts per minute) was recorded at several locations throughout the year.

\subsubsection{Pressurized Ionization Chamber Results at Four Offsite Locations}

Gamma radiation levels were monitored with pressurized ionization chambers at four community-operated airmonitoring stations during 2004 (Section 8.17). These stations were located in Leslie Groves Park in Richland, at Edwin Markham Elementary School in north Franklin County, at Basin City Elementary School in Basin City, and at Heritage University near Toppenish (locations 36, 40, 35, and 44, respectively, on Figure 8.2.2). Measurements were collected to determine ambient gamma radiation levels near and downwind of the site and upwind and distant from the site, to display near-continuous exposure rate information to the public living near the stations, and for educational information for the teachers who manage the stations.

Data collection systems consisted of computers, data loggers, and radiotelemetry instruments. Data from all stations were transmitted by radiotelemetry to a computer at the Hanford Meteorology Station near the 200-West Area. These data were summarized and posted on the Internet (http://hms.pnl.gov) at 15-minute intervals.

Readings at the Leslie Groves Park and Heritage University stations were collected every 5 seconds with a ReuterStokes Model RSS-121 pressurized ionization chamber and an average reading was recorded every hour. Data at Basin City and Edwin Markham Elementary Schools were collected every second with a Reuter-Stokes Model RSS-131 pressurized ionization chamber and averaged every 15 minutes. The 15 -minute averages were then used to generate a 60 -minute average.

Average maximum hourly exposure rates ranged from 16.1 microRoentgen $(\mu \mathrm{R})$ per hour at Edwin Markham Elementary School during January to $7.9 \mu \mathrm{R}$ per hour at Heritage University in July (Table 8.13.7). Monthly mean 
Table 8.13.7. Exposure Rates ${ }^{(a)}$ Measured by Pressurized lonization Chambers at Four Locations Around the Hanford Site, ${ }^{(b)} 2004$

Exposure Rate, $\mu \mathrm{R} / \mathrm{h}$ (number of hourly averages)

\begin{tabular}{|c|c|c|c|c|c|c|c|c|c|}
\hline \multirow{2}{*}{\multicolumn{2}{|c|}{$\underline{\text { Month }}$}} & \multirow{2}{*}{\multicolumn{2}{|c|}{$\underline{\text { Leslie Groves Park }}^{(\mathrm{c})}$}} & & & & & & \\
\hline & & & & \multicolumn{2}{|c|}{$\underline{\text { Basin City }}^{(\mathrm{d})}$} & \multicolumn{2}{|c|}{$\underline{\text { Edwin Markham }}^{(\mathrm{d})}$} & \multicolumn{2}{|c|}{$\underline{\text { Toppenish }}^{(\mathrm{c})}$} \\
\hline \multirow[t]{3}{*}{ January } & Mean & 8.2 & $(740)$ & 7.4 & $(630)$ & 7.0 & $(165)$ & 7.5 & $(740)$ \\
\hline & Maximum & 12.6 & & 14.1 & & 16.1 & & 13.2 & \\
\hline & Minimum & 4.9 & & 6.8 & & 7.0 & & 7.0 & \\
\hline \multirow[t]{3}{*}{ February } & Mean & 8.8 & $(696)$ & 7.8 & $(562)$ & $\mathrm{ND}$ & & 7.9 & $(695)$ \\
\hline & Maximum & 9.8 & & 8.9 & & ND & & 10.3 & \\
\hline & Minimum & 5.9 & & 7.4 & & $\mathrm{ND}$ & & 7.3 & \\
\hline \multirow[t]{3}{*}{ March } & Mean & 8.6 & $(744)$ & 7.8 & $(730)$ & 7.5 & $(541)$ & 7.7 & $(744)$ \\
\hline & Maximum & 9.3 & & 8.6 & & 8.5 & & 9.1 & \\
\hline & Minimum & 6.4 & & 7.5 & & 6.8 & & 7.2 & \\
\hline \multirow[t]{3}{*}{ April } & Mean & 8.7 & $(719)$ & 7.7 & $(279)$ & 7.5 & $(586)$ & 7.8 & $(727)$ \\
\hline & Maximum & 9.6 & & 14.5 & & 8.9 & & 9.0 & \\
\hline & Minimum & 4.9 & & 7.4 & & 6.6 & & 7.4 & \\
\hline \multirow[t]{3}{*}{ May } & Mean & 8.5 & $(744)$ & 7.7 & $(734)$ & 7.5 & $(736)$ & 7.8 & $(747)$ \\
\hline & Maximum & 9.9 & & 8.8 & & 9.6 & & 10.5 & \\
\hline & Minimum & 3.8 & & 7.5 & & 6.4 & & 7.5 & \\
\hline \multirow[t]{3}{*}{ June } & Mean & 8.5 & $(720)$ & 7.8 & $(448)$ & 7.5 & $(444)$ & 7.7 & $(60)$ \\
\hline & Maximum & 10.3 & & 8.2 & & 8.6 & & 8.0 & \\
\hline & Minimum & 6.0 & & 7.5 & & 6.4 & & 7.5 & \\
\hline \multirow[t]{3}{*}{ July } & Mean & 8.5 & $(744)$ & 7.9 & $(584)$ & 7.5 & $(571)$ & 7.6 & $(281)$ \\
\hline & Maximum & 9.0 & & 8.9 & & 9.8 & & 7.9 & \\
\hline & Minimum & 7.8 & & 7.5 & & 7.0 & & 7.4 & \\
\hline \multirow[t]{3}{*}{ August } & Mean & 8.5 & $(744)$ & 7.9 & $(640)$ & 7.5 & $(645)$ & 7.8 & $(742)$ \\
\hline & Maximum & 9.2 & & 9.0 & & 9.5 & & 9.9 & \\
\hline & Minimum & 3.7 & & 7.5 & & 6.9 & & 7.3 & \\
\hline \multirow[t]{3}{*}{ September } & Mean & 8.7 & $(697)$ & 7.8 & $(579)$ & 7.5 & $(523)$ & 8.1 & $(710)$ \\
\hline & Maximum & 9.4 & & 8.6 & & 8.5 & & 9.5 & \\
\hline & Minimum & 8.2 & & 7.3 & & 6.5 & & 7.6 & \\
\hline \multirow[t]{3}{*}{ October } & Mean & 8.8 & $(597)$ & 7.9 & $(512)$ & 7.6 & $(533)$ & 8.9 & $(229)$ \\
\hline & Maximum & 9.6 & & 9.2 & & 8.9 & & 10.6 & \\
\hline & Minimum & 8.4 & & 7.3 & & 7.1 & & 8.1 & \\
\hline \multirow[t]{3}{*}{ November } & Mean & 9.0 & $(715)$ & 8.0 & $(717)$ & 7.7 & $(707)$ & 8.9 & $(654)$ \\
\hline & Maximum & 10.0 & & 8.8 & & 8.4 & & 10.0 & \\
\hline & Minimum & 8.4 & & 7.5 & & 7.1 & & 8.0 & \\
\hline \multirow[t]{3}{*}{ December } & Mean & 9.1 & $(736)$ & 8.3 & $(713)$ & 7.7 & $(662)$ & 8.7 & $(546)$ \\
\hline & Maximum & 12.8 & & 15.3 & & 13.3 & & 11.8 & \\
\hline & Minimum & 8.5 & & 6.9 & & 2.0 & & 7.7 & \\
\hline
\end{tabular}

(a) Maximum and minimum values are hourly averages. Means are monthly means.

(b) Measurement locations are illustrated in Figure 8.2.2.

(c) Readings are stored every 60 minutes. Each 60-minute reading is an average of measurements collected at 5-second intervals.

(d) Readings were collected every second and averaged every 15 minutes. Fifteen-minute averages were used to compute 60-minute averages (as many as 3,600 individual measurements per hour).

ND $=$ No data collected. 
readings were consistently between 7.0 and $9.1 \mu \mathrm{R}$ per hour at the stations near Hanford and ranged between 7.5 and $8.9 \mu \mathrm{R}$ per hour at the distant station (Heritage University). These average exposure rates were similar to exposure rates measured at these locations in past years and by thermoluminescent dosimeters located at or near these locations in 2004 (Table 8.13.8). One $\mu R$ per hour is approximately equal to 1 microrem per hour.

\begin{tabular}{|c|c|c|c|c|c|}
\hline & \multicolumn{5}{|c|}{$\begin{array}{l}\text { Table 8.13.8. Quarterly Average Exposure Rates }\left(\mu R / h^{[a]}\right) \text { Measured by Thermoluminescent } \\
\text { Dosimeters at Four Locations Around the Hanford Site, }{ }^{(b)} 2004\end{array}$} \\
\hline & & $\underline{\text { Leslie Groves Park }}^{(\mathrm{c})}$ & Basin City & Edwin Markham & Toppenish \\
\hline \multicolumn{6}{|c|}{ Quarter Ending } \\
\hline \multicolumn{2}{|c|}{ March } & $8.29 \pm 0.46$ & $8.58 \pm 0.08$ & $8.08 \pm 0.50$ & $7.54 \pm 0.08$ \\
\hline \multicolumn{2}{|c|}{ June } & $9.04 \pm 0.08$ & (d) & $8.88 \pm 0.08$ & $8.54 \pm 0.21$ \\
\hline \multicolumn{2}{|c|}{ September } & $8.75 \pm 0.63$ & (d) & $8.25 \pm 0.00$ & $8.33 \pm 0.13$ \\
\hline \multicolumn{2}{|c|}{ December } & $9.50 \pm 0.00$ & $8.92 \pm 0.13$ & $8.79 \pm 0.00$ & $8.13 \pm 0.08$ \\
\hline \multicolumn{6}{|c|}{$\overline{\text { (a) } \pm \text { counting error. }}$} \\
\hline (b) & \multicolumn{5}{|c|}{ Sampling locations shown on Figure 8.2.2. } \\
\hline \multicolumn{6}{|c|}{$\begin{array}{l}\text { (c) Thermoluminescent dosimeter located } \sim 1 \\
\text { Figure 8.13.4. }\end{array}$} \\
\hline
\end{tabular}




\subsection{Potential}

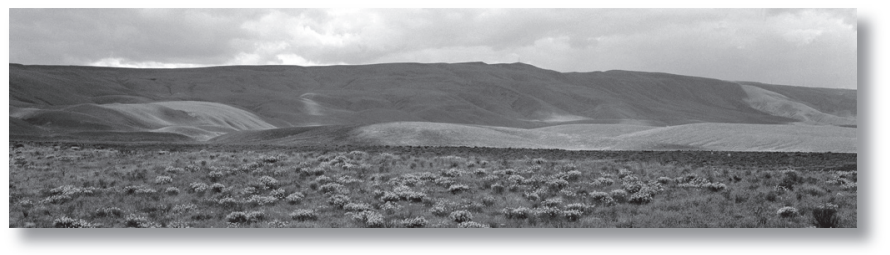

\section{Radiological Doses from 2004 Hanford Site Operations}

\section{E. J. Antonio and K. Rhoads}

During 2004, potential radiological doses to the public and biota from Hanford Site operations were evaluated in detail to determine compliance with pertinent regulations and limits. The potential sources of radionuclide contamination included gaseous emissions from stacks and ventilation exhausts, liquid effluent from operating wastewater treatment facilities, contaminated groundwater seeping into the Columbia River, and fugitive emissions from contaminated soil areas and facilities. The methods used to calculate the potential doses are detailed in Appendix E.

The radiological impact of 2004 Hanford Site operations was assessed in terms of the:

- dose to a hypothetical, maximally exposed individual at an offsite location using a multimedia pathway assessment (DOE Order 5400.5; Section 8.14.1)

- collective dose to the population residing within 80 kilometers (50 miles) of Hanford Site operating areas (Section 8.14.2)

- dose for air pathways, using EPA methods, for comparison to the Clean Air Act standards in 40 CFR 61, Subpart H, National Emission Standards for Hazardous Air Pollutants (Section 8.14.3)

- maximum dose rate from external radiation at a publicly accessible location at or just within the site boundary (Section 8.14.4.1)

- dose to a worker consuming drinking water on the site (Section 8.14.4.3)

- inhalation dose associated with measured radionuclide concentrations in air (Section 8.14.4.4)

- doses from non-DOE industrial sources on and near Hanford (Section 8.14.5)
- absorbed dose received by animals exposed to radionuclide releases to the Columbia River and to radionuclides in onsite surface water bodies (Section 8.14.6).

It is generally accepted that radiological dose assessments should be based on direct measurements of radiation dose rates and radionuclide concentrations. However, the amounts of most radioactive materials released during 2004 from Hanford Site sources were, generally, too small to be measured directly once it was dispersed in the offsite environment. For many of the radionuclides present in measurable amounts, they were difficult to separate the contributions from Hanford sources from the contributions from fallout and from naturally occurring uranium and its decay products. Therefore, in nearly all instances, offsite doses were estimated using GENII - The Hanford Environmental Radiation Dosimetry Software System, Version 1.485 (PNL-6584) and the Hanford Site-specific parameters listed in Appendix E and in PNNL-15222, APP. 1.

Radiological doses from the water pathway were calculated based on the differences in radionuclide concentrations between upstream and downstream sampling points on the Columbia River. During 2004, tritium, iodine-129, two uranium isotopes, and plutonium-239/240 were found in the Columbia River downstream of Hanford at greater levels than predicted based on direct discharges from the 100-K Area (Section 8.4 and Appendix C). All other radionuclide concentrations were lower than those predicted from known releases. Riverbank spring water, containing radionuclides, is known to enter the Columbia River along the portion of the Hanford shoreline extending from the $100-\mathrm{B} / \mathrm{C}$ Area downstream to the 300 Area 
(Sections 8.5 and 8.7). No direct discharge of radioactive materials from the 300 Area to the Columbia River was reported during 2004.

\subsubsection{Maximally Exposed Individual Dose (Offsite Resident)}

The maximally exposed individual is a hypothetical person who lives at a particular location and has a lifestyle that makes it unlikely that any other member of the public would have received a higher radiological dose from Hanford releases during 2004. This individual's exposure pathways were chosen to maximize the combined doses from all reasonable environmental routes of exposure to radionuclides in Hanford Site effluent and emissions using a multimedia pathway assessment (DOE Order 5400.5). In reality, such a combination of maximized parameters is highly unlikely to apply to any single individual.

The location of the hypothetical, maximally exposed individual varies from year to year, depending on the relative contributions of the several sources of radioactive emissions released to the air and liquid effluent released to the Columbia River from Hanford facilities (Figure 8.14.1). During 2004, the dose assessment determined that the maximally exposed individual was located across the Columbia River (east of the Hanford Site) at Sagemoor (Figure 8.14.1). For the calculation, it was assumed that this individual:

- inhaled and was submersed in airborne radionuclides

- received external exposure to radionuclides deposited on the ground

- ingested locally grown food products that had been irrigated with water withdrawn from the Columbia River downstream from the Hanford Site

- used the Columbia River near the Hanford Site for recreational purposes, resulting in direct exposure from radionuclides in water and radionuclides deposited on the shoreline

- ingested locally caught Columbia River fish.

Doses were calculated using Hanford Site air emissions and effluent data (Tables 8.1.1 and 8.3.2) and the calculated quantities of radionuclides assumed to be present in the Columbia River from riverbank spring discharges along the Hanford Site shoreline. The estimated contaminant releases to the river from these sources were derived from the difference between the upstream and downstream radionuclide concentrations in Columbia River water. These radionuclides were assumed to originate from historical releases of contaminants to the ground in the 100 and 200 Areas and to have entered the river through shoreline groundwater springs between the 100-B/C Area and the 300 Area.

Historically at Hanford, there has been one primary expression of radiological risk to an offsite individual - this is the maximally exposed individual dose. However, the maximally exposed individual dose is currently calculated by two different methods in response to two different requirements. One maximally exposed individual dose computation is required by DOE Order 5400.5 and is calculated using the GENII computer code. This calculation considers all reasonable environmental pathways (e.g., air, water, and food) that maximize a hypothetical individual's offsite exposure to Hanford's radiological effluent and emissions. A second estimate of maximally exposed individual dose is required by the Clean Air Act and is calculated using an EPA dose modeling computer code (CAP-88) or other methods accepted by EPA for estimating offsite exposure. This offsite dose is based solely on an airborne radionuclide emissions pathway and considers Hanford's stack emissions and emissions from diffuse and unmonitored sources (e.g., windblown dust).

Because the DOE and EPA computer codes use different input parameters, the location and predicted dose of each agency's maximally exposed individual may be different. However, the estimated doses from both methods have historically been significantly lower than health-based exposure criteria.

Recently, DOE has allowed private businesses to locate their activities and personnel on the Hanford Site. This has created the need to calculate a maximum onsite occupational dose for an individual who is employed by a non-DOE business and works within the boundary of the Hanford Site. This dose is based on a mix of air emission modeling data, the individual's exposure at an onsite work location, and the individual's potential offsite exposure.

Another way to estimate risk is to calculate the collective dose. This dose is based on exposure to Hanford radiological contaminants through the food, water, and air pathways and is calculated for the population residing within 80 kilometers (50 miles) of the Hanford Site operating areas. The collective dose is reported in units of person-rem (person-sievert), which is the average estimated individual dose multiplied by the total number of people in the population. 


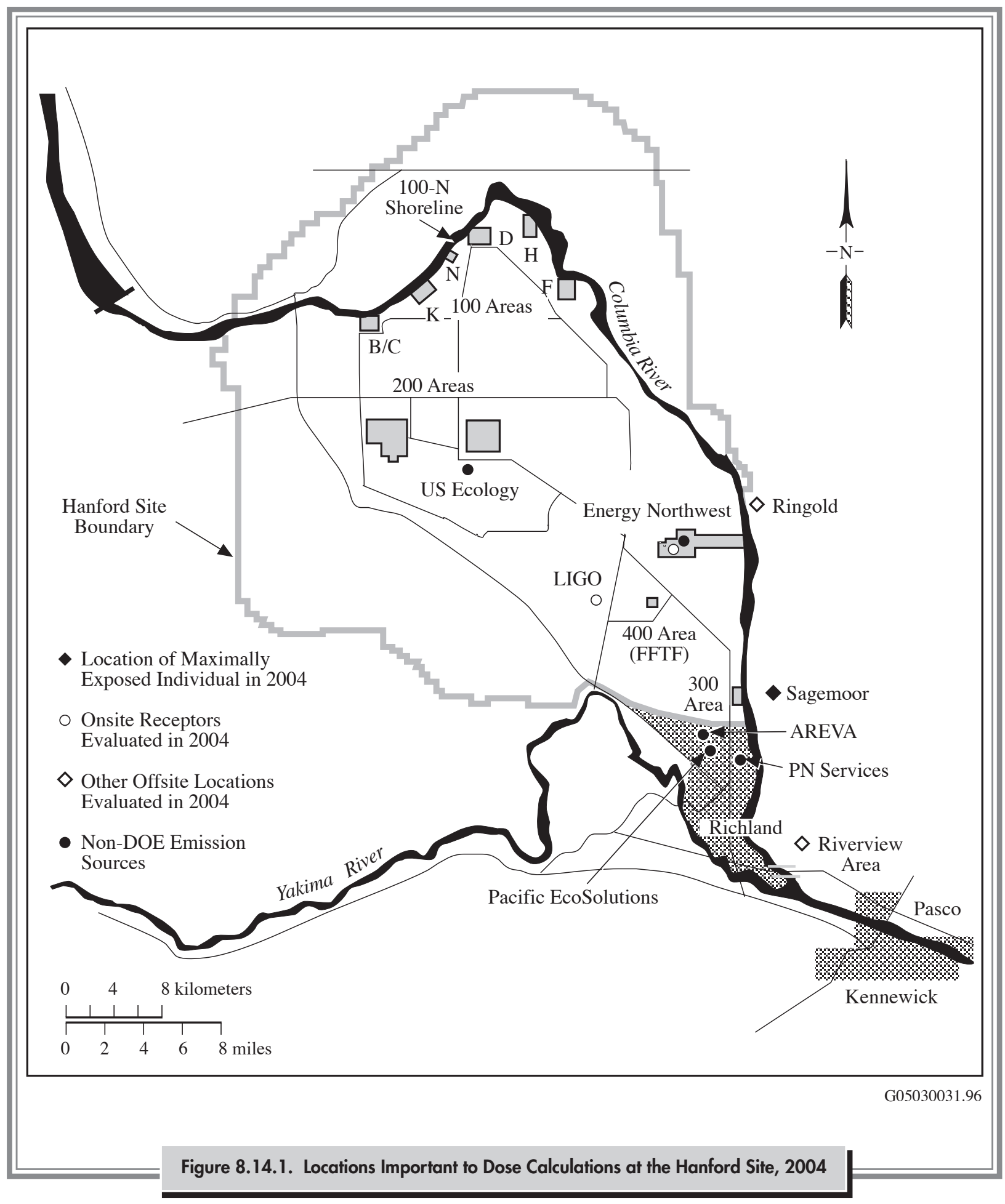




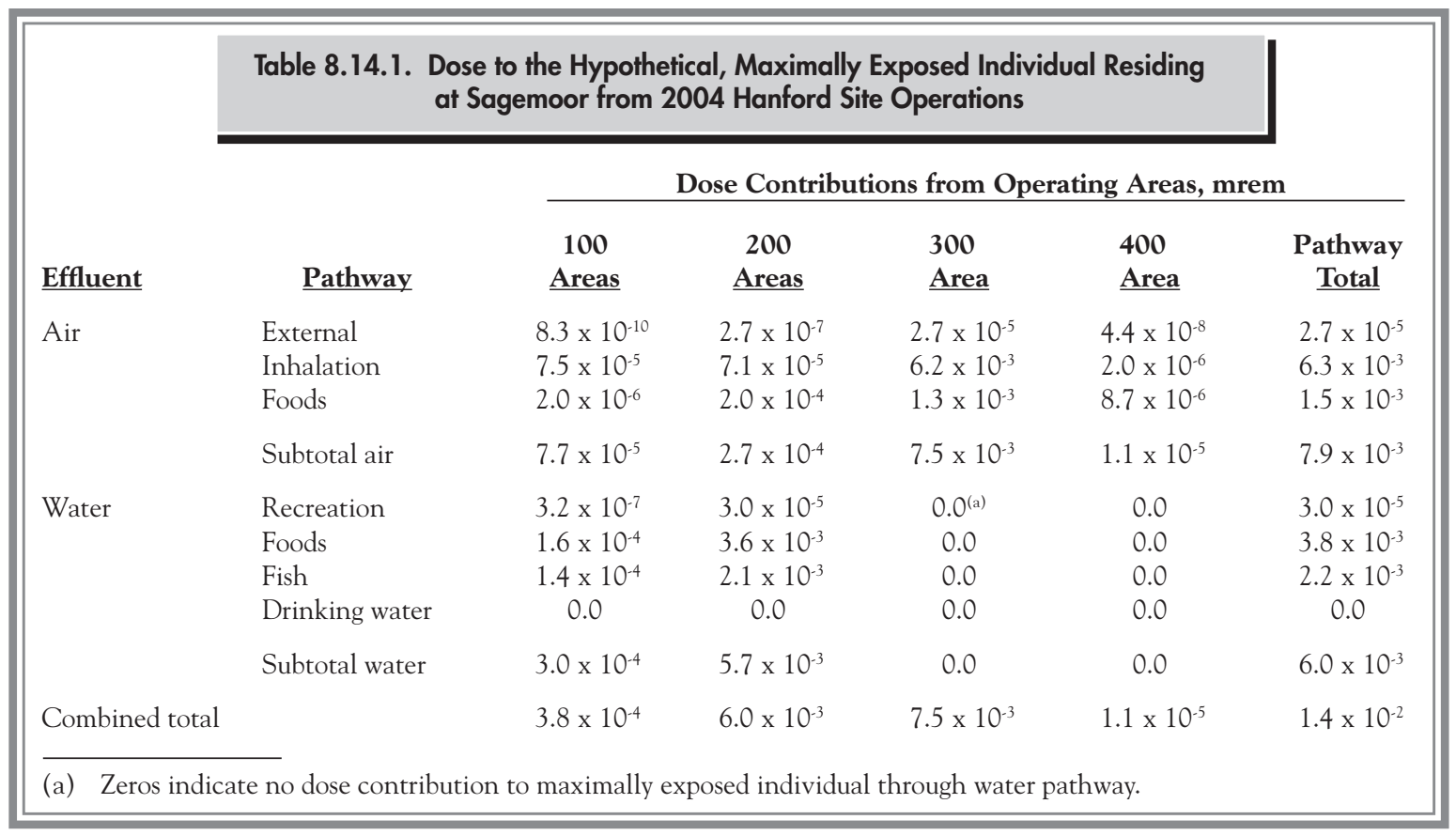

During 2004, the total dose to the maximally exposed individual at Sagemoor (Figure 8.14.1) was calculated to be 0.014 mrem $(0.14 \mu \mathrm{Sv})$ per year (Table 8.14.1). This dose was $0.014 \%$ of the DOE limit of $100 \mathrm{mrem}(1 \mathrm{mSv})$ per year specified in DOE Order 5400.5 (Figure 8.14.2.). The primary pathways (Appendix E, Tables E.1, E.2, and E.4) contributing to this dose (and the percentage of all pathways) were:

- the inhalation of air downwind of Hanford (45\%) and the consumption of food products grown downwind of Hanford (approximately 11\%), resulting in exposure to airborne releases of radon and tritium from the 300 Area

- the consumption of foods irrigated with Columbia River water withdrawn downstream of Hanford $(27 \%)$ and the consumption of fish from the Columbia River (16\%), resulting in exposure to tritium and uranium isotopes in the river.

\subsubsection{Collective Dose}

Collective dose is defined as the sum of doses to all individual members of the public within 80 kilometers (50 miles) of the operating areas at Hanford. The regional collective dose from 2004 Hanford Site operations was estimated by calculating the radiological dose to the population residing within an 80-kilometer (50-mile) radius of the onsite operating areas. During 2004, the collective dose calculated for the population was 0.32 person-rem (0.0032 person-Sv) per year (Table 8.14.2; Figure 8.14.3), which is just over half of the 2003 collective dose (0.5 person-rem [0.005 person-Sv]) per year (Appendix E, Tables E.5 to E.10).

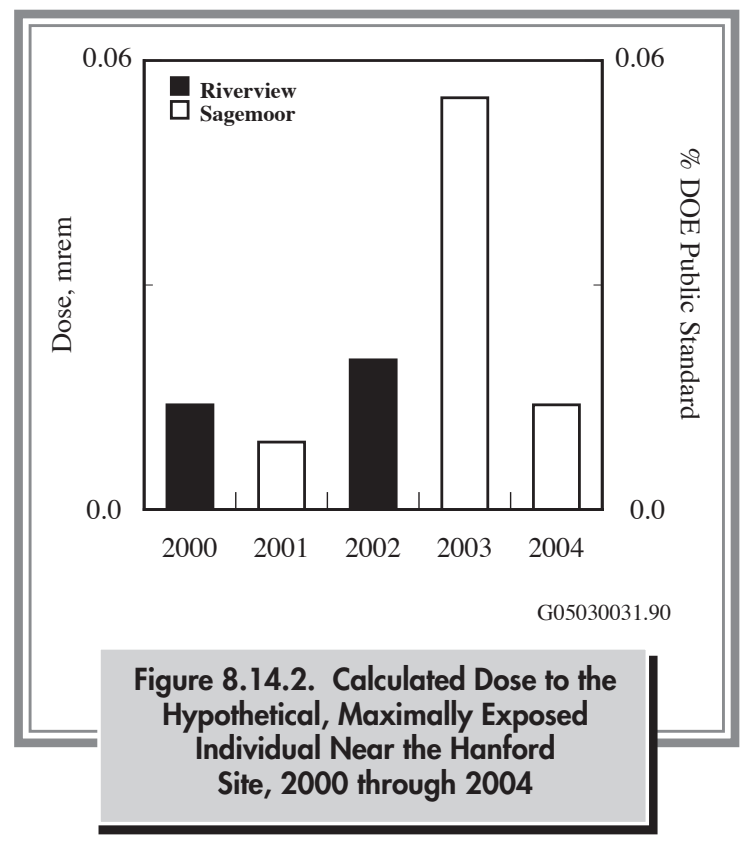


Table 8.14.2. Collective Dose to the Population from 2004 Hanford Site Operations

Dose Contributions from Operating Areas, person-rem

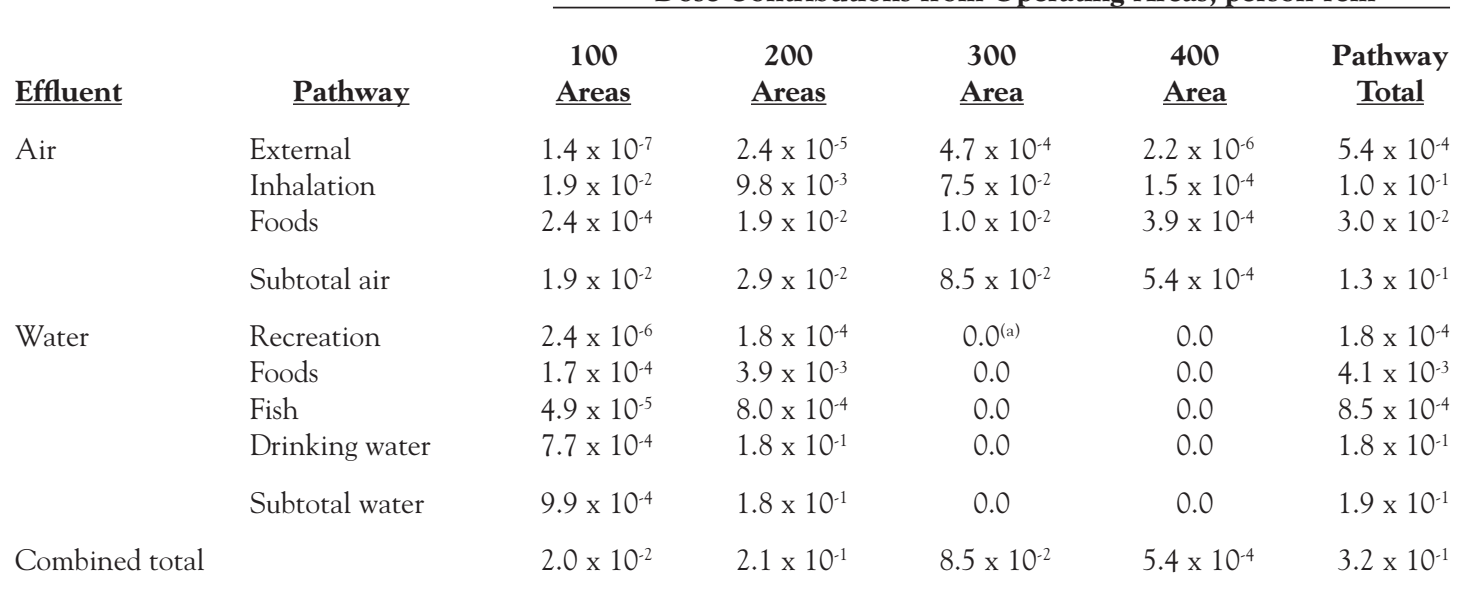

(a) Zeros indicate no dose contribution to the population through the water pathway.

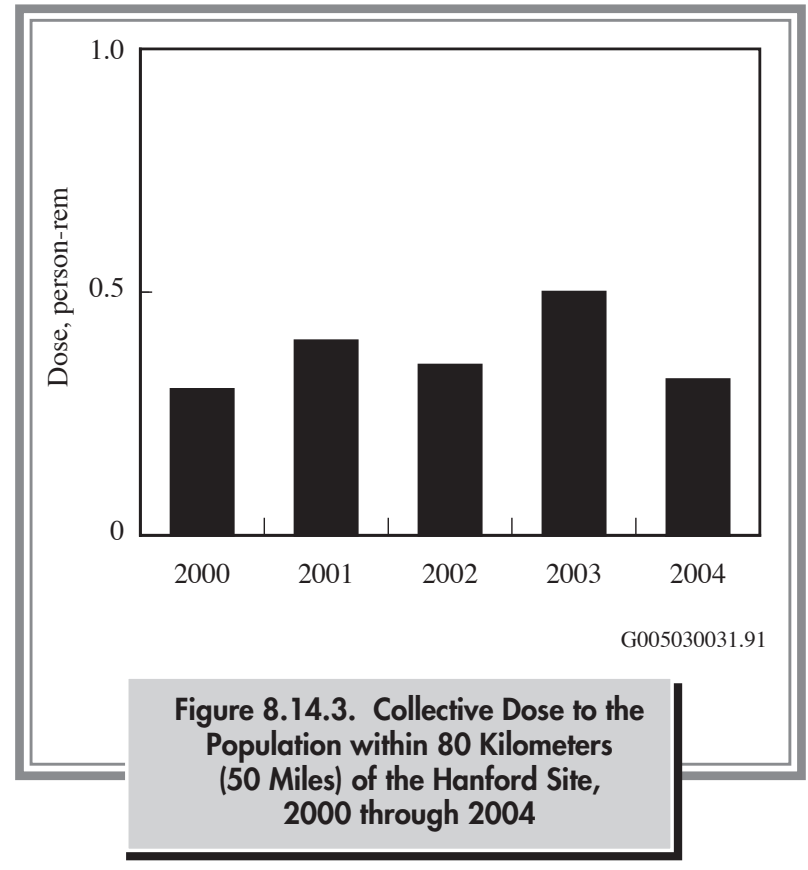

Primary pathways contributing to the 2004 collective dose (and the percentage of all pathways) included:

- inhalation of radionuclides that were released to the air, principally radon from the 300 Area and iodine- 129 from the 200 Areas (31\%), and consumption of food grown downwind of Hanford (approximately 9\%)

- the consumption of water withdrawn from the Columbia River downstream of Hanford (56\%) and foods irrigated with water withdrawn from the Columbia
River downstream of Hanford (approximately 1\%) containing principally tritium, uranium-234, and uranium-238.

Collective doses reported for 2004 are based on population data from the 2000 census. The collective dose is reported in units of person-rem (person-sievert), which is the average estimated individual dose multiplied by the total number of people in the population. Between 1990 and 2000 , the population within 80 kilometers (50 miles) of the major operating areas on the Hanford Site increased by $24 \%$ to $29 \%$.

The average individual dose from 2004 Hanford Site operations based on a population of 486,000 within 80 kilometers $(50$ miles) of the site was 0.0007 mrem $(0.007 \mu \mathrm{Sv})$ per year. To place this estimated dose into perspective, it may be compared with doses received from other routinely encountered sources of radiation such as natural terrestrial and cosmic background radiation, medical treatment and $\mathrm{x}$-rays, natural radionuclides in the body, and inhalation of naturally occurring radon (Figure 8.14.4). The estimated annual average individual dose to members of the public from Hanford Site sources during 2004 was approximately $0.0002 \%$ of the estimated annual individual dose received from natural background sources (300 mrem). The calculated radiological doses from Hanford Site operations in 2004 were a small percentage of the federal standards and of doses from natural background sources (Table 8.14.3). 


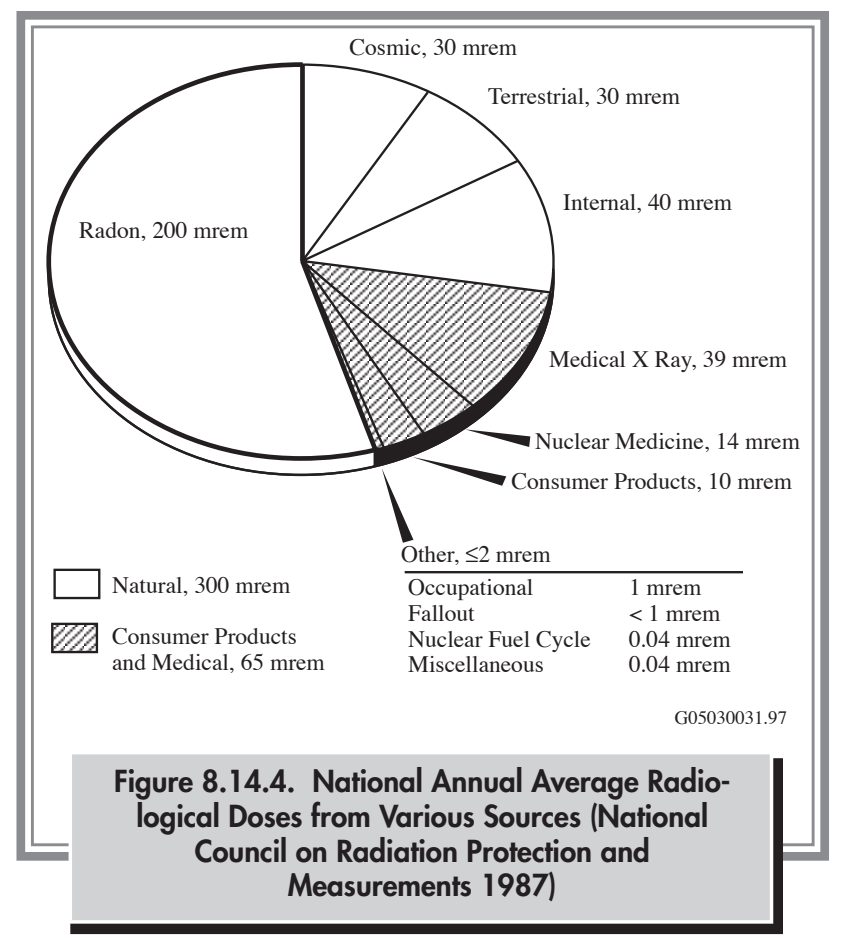

\subsubsection{Compliance with Clean Air Act Standards}

In addition to complying with the all-pathways dose limits established by DOE Order 5400.5, DOE facilities are required to demonstrate that they comply with standards established by EPA for airborne radionuclide emissions under the Clean Air Act in 40 CFR 61, Subpart H. This regulation specifies that no member of the public shall receive a dose greater than 10 mrem $(0.1 \mathrm{mSv})$ per year from exposure to airborne radionuclide emissions, other than radon, released at DOE facilities. Whereas DOE uses the GENII computer code at Hanford to determine dose to the all-pathways maximally exposed individual, EPA requires the use of the CAP- 88 computer code (EPA 402-R-00-004) or other EPA-approved computer models to demonstrate compliance with the requirements in 40 CFR 61, Subpart H. The assumptions embodied in the CAP- 88 computer code differ slightly from standard assumptions used with the GENII computer code. Therefore, air pathway doses calculated by the two codes may differ somewhat. In addition, the maximally exposed individual for air pathways may be evaluated at a different location from the all-pathways maximally exposed individual because of the relative contributions from each exposure pathway (Section 8.14.1).

The EPA regulation also requires that each DOE facility submit an annual report to EPA that supplies information about atmospheric emissions for the preceding year and their potential offsite dose. For more detailed information

\begin{tabular}{|c|c|c|}
\hline \multicolumn{3}{|c|}{$\begin{array}{l}\text { Table 8.14.3. Comparison of } 2004 \text { Doses to the Public from Hanford Site Effluent } \\
\text { and Emissions to Federal Standards and Natural Background Levels }\end{array}$} \\
\hline Federal Standard & $\underline{\text { Hanford Dose }}^{(\mathrm{a})}$ & $\begin{array}{l}\text { Percent of Standard } \\
\text { or of Background Dose }\end{array}$ \\
\hline $\begin{array}{l}\mathrm{DOE}-100 \mathrm{mrem} / \mathrm{yr} \\
\text { all pathways } \mathrm{MEI}^{(\mathrm{b})}\end{array}$ & $0.014 \mathrm{mrem} / \mathrm{yr}$ & 0.014 \\
\hline $\begin{array}{l}\mathrm{EPA}-10 \mathrm{mrem} / \mathrm{yr} \\
\text { air pathway } \mathrm{MEI}^{(\mathrm{c})}\end{array}$ & $0.0022 \mathrm{mrem} / \mathrm{yr}$ & 0.23 \\
\hline \multicolumn{3}{|l|}{ Background Dose } \\
\hline $\begin{array}{l}300 \mathrm{mrem} / \mathrm{yr} \text { average } \\
\text { U.S. individual }{ }^{(\mathrm{d})}\end{array}$ & $0.0007 \mathrm{mrem} / \mathrm{yr}$ & 0.0002 \\
\hline \multicolumn{3}{|l|}{$\begin{array}{l}145,800 \text { person-rem/yr } \\
\text { to population within }\end{array}$} \\
\hline \multicolumn{3}{|c|}{$\begin{array}{l}\text { (a) To convert the dose values to mSv or person-Sv, divide by } 100 . \\
\text { (b) DOE Order } 5400.5 \text {. } \\
\text { (c) } 40 \text { CFR } 61 . \\
\text { (d) National Council on Radiation Protection and Measurements (1987). } \\
\text { MEI = Maximally exposed individual. }\end{array}$} \\
\hline
\end{tabular}


about 2004 air emissions on the Hanford Site, refer to DOE's report to the EPA, Radionuclide Air Emissions Report for the Hanford Site, Calendar Year 2004 (DOE/RL-2005-06).

\subsubsection{Dose to an Offsite Maximally Exposed Individual}

During 2004, the maximally exposed offsite individual for air pathways using EPA-specified methods was determined to be at a location in the Ringold area of Franklin County, approximately 13 kilometers (8 miles) directly north of the 300 Area, across the Columbia River (Figure 8.14.1). The potential air pathway dose from stack emissions to a maximally exposed individual at that location calculated using the CAP-88 computer code was determined to be $0.0022 \mathrm{mrem}(0.000022 \mathrm{mSv})$ per year, which represented less than $0.4 \%$ of the EPA standard. This is similar to the offsite individual doses calculated for EPA in previous years and to the air pathway doses for stack emissions in Table 8.14.1.

\subsubsection{Maximum Dose to Non- DOE Workers on the Site}

The DOE Richland Operations Office received guidance from EPA's Region 10 office and the Washington State Department of Health that, in demonstrating compliance with the 40 CFR 61 standards, it should evaluate potential doses to non-DOE employees who work on the Hanford Site but who are not under direct DOE control. Accordingly, the doses to members of the public employed at non-DOE facilities that were outside access-controlled areas on the Hanford Site (those requiring DOE access authorization for entry) were evaluated for the 2004 EPA air emissions report (DOE/RL-2005-06). These locations included the Columbia Generating Station operated by Energy Northwest and the Laser Interferometer Gravitational Wave Observatory (LIGO) operated by the University of California (Figure 8.14.1). Of those locations, an employee at the LIGO facility received the highest dose for non-DOE employees who worked on the Hanford Site. The dose from stack emissions calculated using the CAP-88 computer code was $0.0019 \mathrm{mrem}(0.000019 \mathrm{mSv})$ per year, assuming full-time occupancy.

EPA guidance does not currently allow for adjustment of doses calculated using the CAP- 88 computer code to account for less than full-time occupancy at locations within the site boundary. However, if a selected occupancy period of 2,000 hours per year were assumed for workers at onsite non-DOE facilities, the doses to individuals at any of the locations evaluated would be lower than the dose reported for LIGO. In 2004, the estimated doses to non-DOE onsite workers were lower than the doses to offsite individuals for all locations.

\subsubsection{Dose from Diffuse and Fugitive Radionuclide Emissions}

The December 15, 1989, revisions to the Clean Air Act (40 CFR 61, Subpart H) required DOE facilities to estimate the dose to a member of the public for radionuclides released from all potential sources of airborne radionuclides. DOE and EPA interpreted the regulation to include diffuse (widespread) and fugitive (unintended) emissions as well as emissions from monitored point sources (i.e., stacks). EPA has not specified or approved standardized methods to estimate diffuse air emissions because of the wide variety of sources at DOE sites. The method developed at Hanford to estimate potential diffuse emissions is based on environmental monitoring measurements of airborne radionuclides at the site perimeter (DOE/RL-2005-06). During 2004, the estimated dose from diffuse emissions to a maximally exposed individual at a location in the Ringold area was calculated using the CAP-88 computer code to be $0.031 \mathrm{mrem}(0.00031 \mathrm{mSv})$ per year. This is consistent with results for recent years, where the dose from diffuse emissions has been greater than the dose from stack emissions because radionuclide emissions from operating Hanford facilities are currently very low. The dose to an onsite non-DOE worker from diffuse and fugitive emissions would be similar to, or lower than, the dose at the site perimeter. Therefore, the potential combined dose from stack emissions and diffuse emissions during 2004 was well below the EPA $10 \mathrm{mrem}(0.1 \mathrm{mSv})$ per year standard for either onsite or offsite members of the public.

\subsubsection{Special Case Dose Estimates}

The parameters used to calculate the dose to the maximally exposed individual were selected to provide a scenario yielding a reasonable upper (or bounding) estimate of the 
dose. However, such a scenario may not have necessarily resulted in the highest conceivable radiological dose. Other low-probability exposure scenarios existed that could have resulted in somewhat higher doses. Four scenarios that could have potentially led to larger doses included (1) an individual who spent time at the site boundary location with the maximum external radiological dose rate, (2) a sportsman who consumed contaminated wildlife that migrated from the site, (3) a person who drank water at the Fast Flux Test Facility in the 400 Area, and (4) individuals at various locations who breathed the measured radionuclide concentrations in air for an entire year. The potential doses resulting from these scenarios are examined in the following sections.

\subsubsection{Maximum Boundary Dose Rate}

The boundary radiological dose rate is the external radiological dose rate measured at publicly accessible locations at or near the Hanford Site boundary. The maximum boundary dose rate was determined from radiation exposure measurements using thermoluminescent dosimeters where elevated dose rates might be expected at site-wide locations and at representative locations offsite. These boundary dose rates were not used to calculate annual doses to the general public because no one could actually reside at any of these boundary locations. However, these rates were used to determine the dose to a specific individual who might have spent some time at that location.

External radiological dose rates measurements during 2004 were made along the $100-\mathrm{N}$ Area shoreline (Figure 8.13.1) (Section 8.13). The measurements were consistently above background levels and represented the highest measured boundary dose rates. The Columbia River allows public access to within approximately 100 meters (330 feet) of the N Reactor and supporting facilities at this location.

The highest dose rate along the $100-\mathrm{N}$ Area shoreline during 2004 was about $0.012 \mathrm{mrem}(0.12 \mu \mathrm{Sv})$ per hour, or approximately $20 \%$ higher than the average dose rate of $0.01 \mathrm{mrem}(0.1 \mu \mathrm{Sv})$ per hour normally observed at other shoreline locations. Therefore, for every hour someone spent near the 100-N Area shoreline during 2004, the external radiological dose received from Hanford operations was approximately 0.002 mrem $(0.02 \mu \mathrm{Sv})$ above the average shoreline dose rate. If an individual had spent 7 hours at that location, he or she would have received a dose comparable to the annual dose calculated for the hypothetical, maximally exposed individual at Sagemoor. Members of the public could reach the 100-N Area shoreline by boat and could have legally occupied the shoreline area below the high water line. However, the topography of the shoreline below the high water line near the $\mathrm{N}$ Reactor is very rocky and visitors are not likely to remain on shore for extended periods.

\subsubsection{Sportsman Dose}

Wildlife have access to areas of the Hanford Site that are contaminated with radioactive materials. Wildlife have the potential to acquire radioactive contamination and migrate off the site. Wildlife sampling was conducted on the site to estimate the maximum contamination levels that might have existed in animals from Hanford that were hunted off the site. Because this scenario had a relatively low probability of occurrence, this pathway was not considered in the maximally exposed individual calculation.

The only radionuclides detected in wildlife samples collected in 2004 were potassium-40, a primordial radioisotope not of Hanford origin; strontium-90, which was only detected in bone samples; and technetium-99, detected in a composite sample of deer mouse carcasses taken from the Vernita Bridge area and in other composite samples of sculpin carcasses collected from the Columbia River near the Vernita Bridge and near shoreline springs at the $100-\mathrm{K}$ Area, 100-H Area, 100-F Area, Hanford town site, and the 300 Area. Because concentrations of Hanford contaminants in edible wildlife tissues were below detection limits in 2004, the dose to a sportsman who might consume the game animals was not calculated.

\subsubsection{Onsite Drinking Water}

During 2004, groundwater from wells in the 400 Area was used as drinking water by workers in the Fast Flux Test Facility. Columbia River water was used for drinking water in the 100 and 200 Areas. Drinking water was sampled and analyzed throughout the year in accordance with applicable regulations (40 CFR 141). All annual average radionuclide concentrations measured during 2004 were below applicable drinking water standards. However, tritium in 
the Fast Flux Test Facility groundwater wells was detected at levels greater than typical background values and radium isotopes were identified in the $100-\mathrm{K}$ Area drinking water (Section 8.6).

Based on the measured concentrations, the potential annual dose to onsite workers (an estimate derived by assuming a consumption of 1 liter [0.26 gallon] per day for 240 working days) would be approximately 0.49 mrem $(4.9 \mu \mathrm{Sv})$. This dose is well below the drinking water dose limit of 4 mrem $(40 \mu \mathrm{Sv})$ per year for public drinking water supplies.

\subsubsection{Inhalation Doses for Entire Year}

A nominal inhalation rate of 23 cubic meters $(812$ cubic feet) per day of air and an exposure period of 8,766 hours (365 days) were assumed for all offsite calculations. For onsite locations, the exposure period was reduced to 2,000 hours (250, 8-hour workdays) to simulate a typical work year, and the breathing rate was increased to 28.8 cubic meters ( 1,017 cubic feet) per day to account for light duty work.

Radiological inhalation doses to hypothetical offsite individuals modeled to be in the same location for the entire year and to onsite individuals located near site-wide air monitoring stations during their workday are presented in Table 8.14.4. The average radionuclide concentrations measured at the air monitoring stations were used in the calculations (Table 8.2.4) and assumed to be constant for the year-long evaluation period. Inhalation doses calculated using this method ranged from 0.017 mrem $(0.00017 \mathrm{mSv})$ at distant locations to $0.06 \mathrm{mrem}$ $(0.0006 \mathrm{mSv})$ at the site perimeter. These were comparable to doses calculated using the CAP- 88 computer code and reported for various air pathways (Section 8.14.3).

\subsubsection{Doses from Non- DOE Sources}

DOE Order 5400.5, Chapter II, paragraph 7, has a reporting requirement for a combined dose due to DOE and other manmade sources that exceeds $100 \mathrm{mrem}(1 \mathrm{mSv})$ per year. During 2004, various non-DOE industrial sources of public radiation exposure existed on or near the

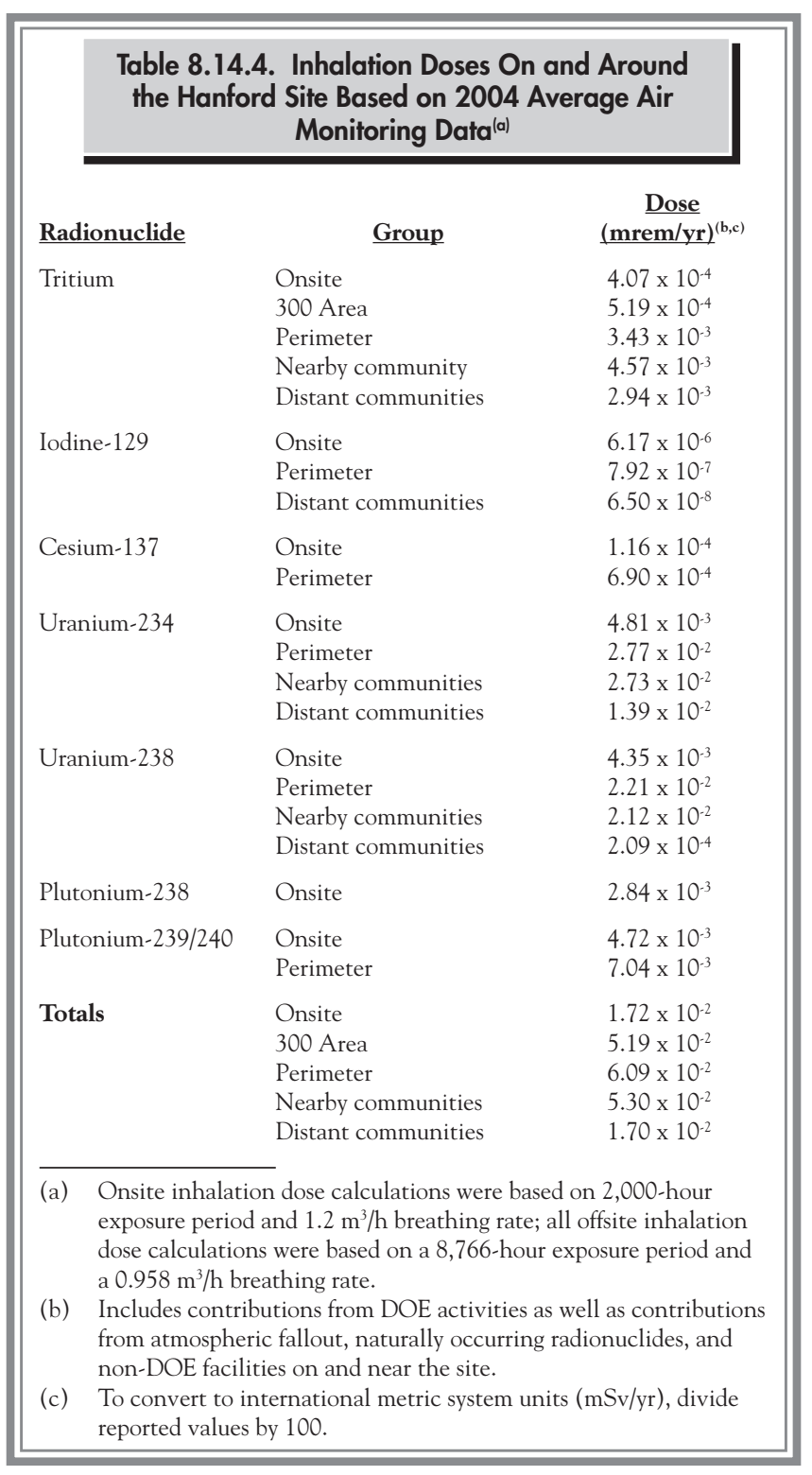

Hanford Site. These included a commercial, low-level, radioactive waste burial ground at Hanford operated by US Ecology; a nuclear power-generating station at Hanford operated by Energy Northwest; a nuclear-fuel production plant operated near the site by AREVA; a commercial, low-level, radioactive waste treatment facility operated near the site by Pacific EcoSolutions (formerly Allied Technology Group Corporation); and a commercial decontamination facility operated near the site by PN Services (Figure 8.14.1).

DOE maintains an awareness of these other sources of radiation, which, if combined with the DOE sources, might have the potential to cause a dose exceeding $10 \mathrm{mrem}$ $(0.1 \mathrm{mSv})$ per year to any member of the public. With 
information gathered from these companies via personal communication and annual reporting, it was conservatively estimated that the total 2004 individual dose from their combined activities was on the order of $0.067 \mathrm{mrem}$ $(0.00067 \mathrm{mSv})$ per year. Therefore, the combined annual dose from Hanford area non-DOE and DOE sources to a member of the public for 2004 was well below any regulatory dose limit.

\subsubsection{Dose Rates to Animals}

Upper estimates have been made of the radiological dose to aquatic organisms in accordance with the DOE Order 5400.5 interim requirement for management and control of liquid discharges. The current dose limit for native aquatic biota is $1 \mathrm{rad}(10 \mathrm{mGy})$ per day. The proposed limit for terrestrial biota is $0.1 \mathrm{rad}(1 \mathrm{mGy})$ per day.

Concentration guides for assessing doses to biota are very different from the DOE derived concentration guides that are used to assess radiological doses to humans. A screening method is used to estimate radiological doses to aquatic and terrestrial biota. This method uses the RESRADBIOTA computer code (DOE/EH-0676; DOE/STD-11532002) to compare radionuclide concentrations measured by routine monitoring programs to a set of conservative biota concentration guides (e.g., $1 \mathrm{rad}$ [10 mGy] per day for aquatic biota). For samples containing multiple radionuclides, a sum of fractions is calculated to account for the contribution to dose from each radionuclide relative to the dose guideline. If the sum of fractions exceeds 1.0, then the dose guideline has been exceeded. If the initial estimated screening value (Tier 1 [Table 8.14.5]) exceeds the guideline (sum of fractions $>1.0$ ), another screening calculation is performed (Tier 2 [Table 8.14.5]) to more accurately evaluate exposure of the biota to the radionuclides. The process may culminate in a site-specific assessment requiring additional sampling and study of exposure. During 2004, biota dose screening assessments were conducted on and off the site (Table 8.14.5).

Maximum concentrations of radionuclides measured in soil, Columbia River sediment, onsite pond water and sediment, and Columbia River riverbank spring water were evaluated using the RESRAD-BIOTA computer code. Riverbank springs carry groundwater contaminants into the Columbia River at greater concentrations than observed in river water and provide another level of conservatism in the biota dose assessment process. The results of the screening calculations indicated that the concentrations in all but one of the samples (West Lake) passed the Tier 1 screen, indicating that the calculated doses were below the dose limits and guidelines (sum of fractions $<1.0$ ). The West Lake sample was evaluated by further screening calculations (Tier 2) and its calculated dose was also below the dose limits and guidelines (sum of fractions $<1.0$ ) (Table 8.14.5).

\subsubsection{Radiological Dose in Perspective}

Scientific studies (National Research Council 1980, 1990; United Nations Science Committee on the Effects of Atomic Radiation 1988) have been performed to estimate the possible risk from exposure to low levels of radiation. These studies provided information to government and scientific organizations and are used to recommend radiological dose limits and standards for public and occupational safety.

Although no increase in the incidence of health effects from low doses of radiation has actually been confirmed by the scientific community, regulatory agencies cautiously assume that the probability of these types of health effects occurring due to exposure to low doses (down to zero dose) is the same per unit dose as the health effects observed after an exposure to much higher doses (e.g., in atomic bomb survivors, individuals receiving medical exposure, or radium-dial painters). This concept is known as the linear no threshold hypothesis. Under these assumptions, even natural background radiation, which is hundreds of times greater than radiation from current Hanford Site releases, increases each person's probability or chance of developing a detrimental health effect.

Scientists do not agree on how to translate the available data on health effects into the numerical probability (risk) of detrimental effects from low radiological doses. Some scientific studies have indicated that low radiological doses result in beneficial effects (Sagan 1987). Because cancer and hereditary diseases in the general population are caused by many sources (e.g., genetic defects, sunlight, chemicals, and background radiation), some scientists doubt that the risk from low-level radiation exposure can ever be proven conclusively. In developing Clean Air 


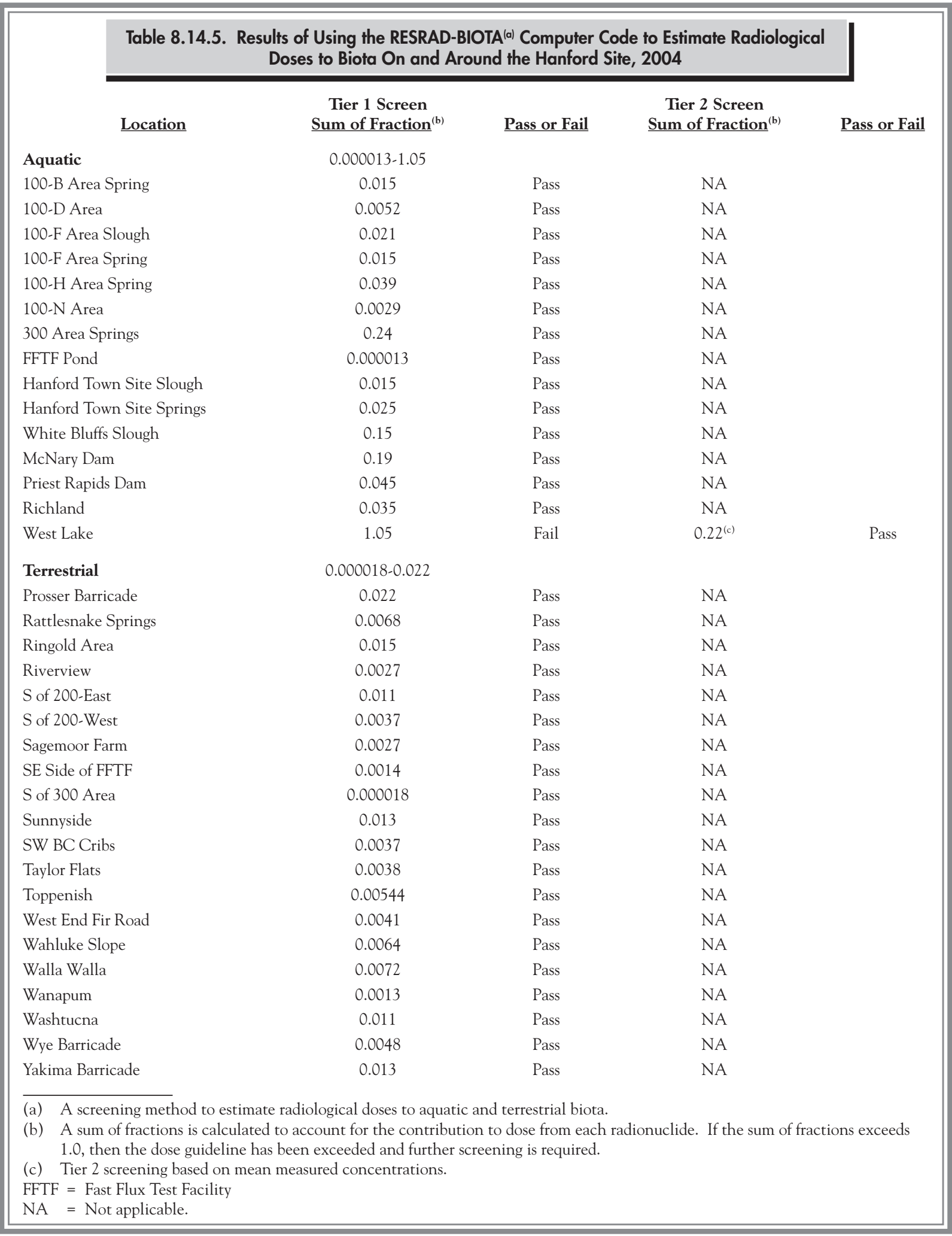


Act regulations, EPA used a probability value of approximately 4 per 10 million (0.0004) for the risk of developing a fatal cancer after receiving a dose of $1 \mathrm{mrem}(0.01 \mathrm{mSv})$ (EPA 520/1-89-005). Additional data (National Research Council 1990) support the reduction of even this small risk value, possibly to zero, for certain types of radiation when the dose is spread over an extended time.

Government agencies are trying to determine what level of exposure is safe for members of the public exposed to pollutants from industrial operations (e.g., DOE facilities, nuclear power plants, chemical plants, and hazardous waste sites). All of these industries are considered beneficial to people in some way such as providing electricity, national defense, waste disposal, and consumer products. Government agencies have a complex task to establish environmental regulations that control levels of risk to the public without unnecessarily reducing needed benefits from industry.

One perspective on risks from industry is to compare them to risks involved in other typical activities. For instance, two risks that an individual experiences when flying on an airplane are added radiological dose (from a stronger cosmic radiation field that exists at higher altitudes) and the possibility of being in an aircraft accident. The estimated risks from various radiological doses are compared to the risks of some activities encountered in everyday life in Table 8.14.6. Some activities are considered approximately equal in risk to that from the dose received by the maximally exposed individual from monitored Hanford effluent during 2004 (Table 8.14.7).

\begin{tabular}{|c|c|c|}
\hline \multicolumn{3}{|c|}{ Table 8.14.6. Estimated Risk from Various Activities and Exposure ${ }^{(a)}$} \\
\hline & Activity or Exposure Per Year & Risk of Fatality \\
\hline \multicolumn{2}{|r|}{ Smoking 1 pack of cigarettes per day (lung/heart/other diseases) } & $3,600 \times 10^{-6}$ \\
\hline \multicolumn{2}{|r|}{ Home accidents } & $100 \times 10^{-6(\mathrm{~b})}$ \\
\hline \multicolumn{2}{|c|}{ Taking contraceptive pills (side effects) } & $20 \times 10^{-6}$ \\
\hline \multicolumn{2}{|r|}{ Drinking 1 can of beer or $0.12 \mathrm{~L}(4 \mathrm{oz})$ of wine per day (liver cancer/cirrhosis) } & $10 \times 10^{-6}$ \\
\hline \multicolumn{2}{|r|}{ Firearms, sporting (accidents) } & $10 \times 10^{-6(b)}$ \\
\hline \multicolumn{2}{|r|}{ Flying as an airline passenger (cross-country roundtrip - accidents) } & $8 \times 10^{-6(b)}$ \\
\hline \multicolumn{2}{|r|}{ Eating $\sim 54 \mathrm{~g}$ ( $4 \mathrm{Tbsp}$ ) of peanut butter per day (liver cancer) } & $8 \times 10^{-6}$ \\
\hline \multicolumn{2}{|c|}{ Pleasure boating (accidents) } & $6 \times 10^{-6(b)}$ \\
\hline \multicolumn{2}{|r|}{ Drinking chlorinated tap water (trace chloroform - cancer) } & $3 \times 10^{-6}$ \\
\hline \multicolumn{2}{|r|}{ Riding or driving in a passenger vehicle $(483 \mathrm{~km}[300 \mathrm{mi}])$} & $2 \times 10^{-6(b)}$ \\
\hline \multicolumn{2}{|r|}{ Eating $41 \mathrm{~kg}(90 \mathrm{lb})$ of charcoal-broiled steaks (gastrointestinal tract cancer) } & $1 \times 10^{-6}$ \\
\hline \multicolumn{2}{|r|}{ Natural background radiological dose $(300 \mathrm{mrem}[3 \mathrm{mSv}])$} & 0 to $120 \times 10^{-6}$ \\
\hline \multicolumn{2}{|r|}{ Flying as an airline passenger (cross-country roundtrip - radiation) } & 0 to $5 \times 10^{-6}$ \\
\hline \multicolumn{2}{|r|}{ Dose of $1 \mathrm{mrem}(0.01 \mathrm{mSv})$ for $70 \mathrm{yr}$} & 0 to $0.4 \times 10^{-6}$ \\
\hline \multicolumn{2}{|r|}{ Dose to the maximally exposed individual living near Hanford } & 0 to $0.02 \times 10^{-6}$ \\
\hline \multicolumn{3}{|c|}{$\begin{array}{l}\text { (a) These values are generally accepted approximations with varying levels of uncertainty; there can be significant } \\
\text { variation as a result of differences in individual lifestyle and biological factors (Atallah 1980; Dinman 1980; Ames } \\
\text { et al. 1987; Wilson and Crouch 1987; Travis and Hester 1990). } \\
\text { (b) Real actuarial values. Other values are predicted from statistical models. For radiological dose, the values are } \\
\text { reported in a possible range from the least conservative (0) to the currently accepted most conservative value. }\end{array}$} \\
\hline
\end{tabular}

Table 8.14.7. Activities Comparable in Risk to the 0.014-mrem (0.0014-mSv) Dose Calculated for the Hanford Site's 2004 Maximally Exposed Individual

Driving or riding in a car $1.4 \mathrm{~km}(0.84 \mathrm{mi})$

Smoking less than $1 / 100$ of a cigarette

Flying $\sim 7.6 \mathrm{~km}(4.7 \mathrm{mi})$ on a commercial airliner

Eating $\sim 1$ Tbsp of peanut butter

Eating one $0.227-\mathrm{kg}(\sim 8-\mathrm{oz})$ charcoal-broiled steak

Drinking 1.4 L ( $0.37 \mathrm{gal})$ of chlorinated tap water

Being exposed to natural background radiation for $25 \mathrm{~min}$ in a typical terrestrial location

Drinking $~ 0.02 \mathrm{~L}(0.82 \mathrm{oz})$ of wine or $0.07 \mathrm{~L}(2.5 \mathrm{oz})$ of beer 


\subsection{Cultural Resources Monitoring}

D. W. Harvey

DOE established a cultural resources program in 1987 to identify, preserve, and protect cultural and historic resources. The Pacific Northwest National Laboratory; Bechtel Hanford, Inc.; and Columbia River Exhibition of History, Science, and Technology (CREHST) Museum provided support to DOE for the cultural resources program on the Hanford Site throughout 2004. The U.S. Fish and Wildlife Service has managed cultural resources for DOE on Hanford Reach National Monument lands since October 1999.

To comply with the federal laws and regulations (see Section 5.5.2), DOE maintains the Hanford Cultural and Historic Resource Program. This program is described in detail in the 2003 revision of the Hanford Cultural Resources Management Plan (DOE/RL-98-10; http://www. hanford.gov/doe/history/?history=rmp). The primary compliance components of this program are to:

- review Hanford project activities to assure that important cultural resources are not inadvertently affected

- monitor resources of cultural and scientific importance to detect problems and address them if possible

- identify and evaluate new cultural resources so that they can be managed appropriately

- confer with tribes and stakeholders to gather input on the identification, documentation, and management of cultural resources important to them

- manage data and collections for long-term preservation.

\subsubsection{Cultural Resources Reviews}

Reviews are conducted of all activities with the potential to affect cultural resources at Hanford to comply with
National Historic Preservation Act Section 106 and the National Environmental Policy Act. Cultural resources reviews must be conducted before a federally funded, federally assisted, or federally licensed ground disturbance, building alteration, or demolition project can take place. Because the Hanford Site is a federal facility, cultural resource reviews are required to identify properties within a proposed project area that may be eligible for, or listed in, the National Register of Historic Places (National Register) and evaluate the project's potential to affect those properties.

During 2004, 166 cultural resource review requests were received across the Hanford Site, mostly for projects in the 200 Areas (Figure 8.15.1). Bechtel Hanford Inc., the environmental restoration contractor, received 16 review requests in 2004 and completed all 16 reviews during the year. Of the 150 review requests received by the Pacific Northwest National Laboratory, 146 reviews were completed in 2004 and 4 were not completed. Of those completed reviews, it was determined that 120 activities would have no effect on historic properties; 20 activities were exempted by the Programmatic Agreement Among the U.S. Department of Energy, Richland Operations Office, the Advisory Council on Historic Preservation, and the Washington State Historic Preservation Office for the Maintenance, Deactivation, Alteration, and Demolition of the Built Environment on the Hanford Site, Washington (DOE/RL-96-77). The programmatic agreement exempts undertakings that involve routine maintenance, energy conservation measures, or replacements that matched the original materials used in the structure in terms of dimensions, detail, and color. Six reviews required walk-throughs of historic buildings to assess their contents to identify artifacts, which may have interpretive or educational value as potential museum exhibits. 


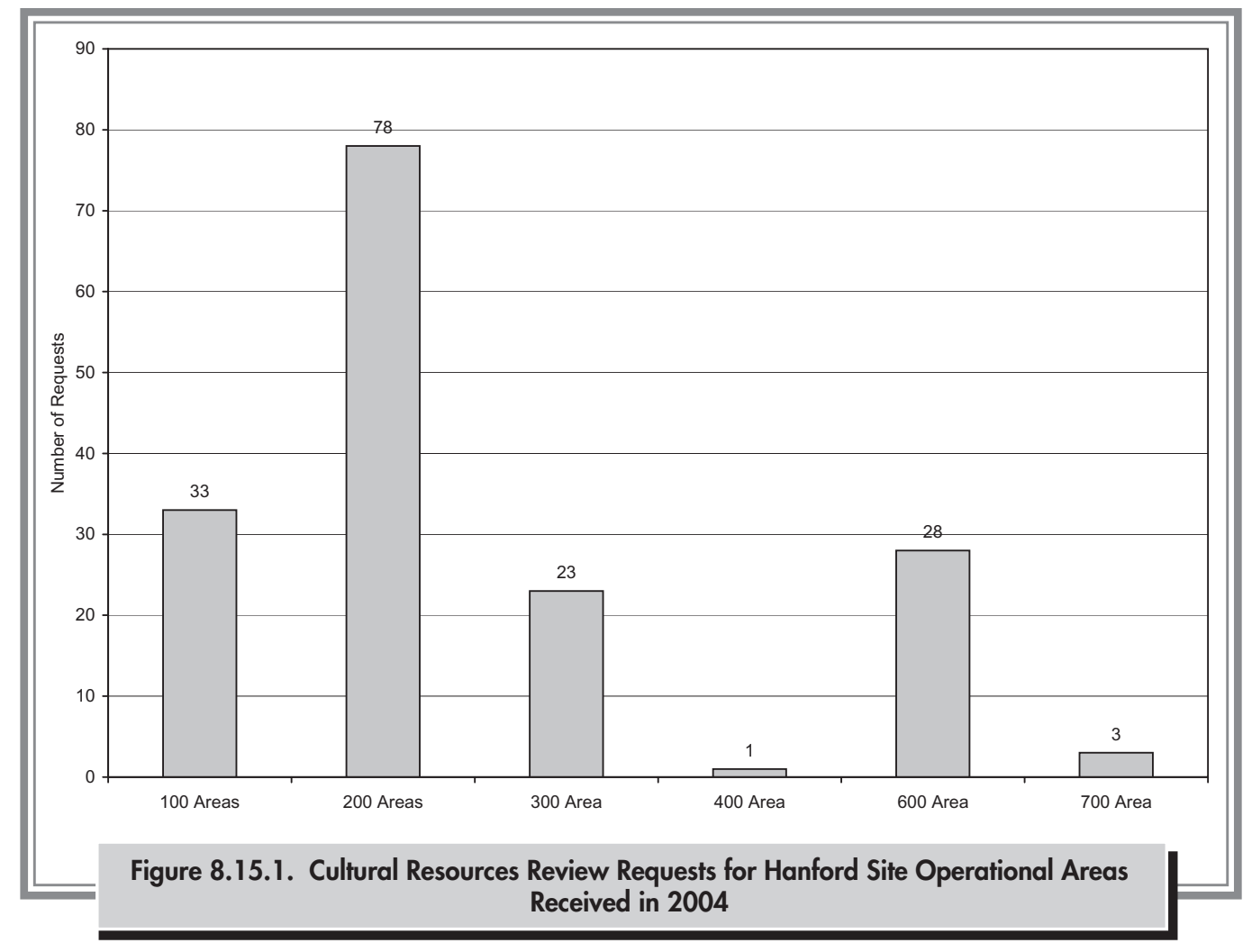

As occurred in 2003, the increase in the number of review requests per week, particularly those termed "Not the type of activity with the potential to cause effects to historic properties," or "No Potential to Effect," continued this year. The "No Potential to Effect" class designation continued to be used in cases where an undertaking was determined to not be the type of activity with potential to affect historic properties. To make this determination, an assessment of the undertaking's effect on cultural resources and existing ground disturbance is made. DOE tends to use this classification cautiously because it is often difficult to confirm whether or not there is existing ground disturbance. The cultural resources program is developing a programmatic agreement to exempt these types of activities from cultural resources reviews. At this date, this programmatic agreement has not been completed.

Major cultural resource reviews conducted by Pacific Northwest National Laboratory in 2004 are summarized in Table 8.15.1. Two of these project reviews were initiated in 2003 and are still in the mitigation process and have not been completed (U.S. Bureau of Land Management [BLM] Survey of the Fitzner/Eberhardt Arid Lands Ecology [ALE] Reserve Unit Boundary and the DOE Ownership Transfer of Hanford Reach National Monument to the U.S. Fish and Wildlife Service).
Bechtel Hanford, Inc. conducted four major cultural resource reviews for DOE in 2004.

- A review was conducted of the proposed characterization of waste sites 128-F-2 and 1607-F-5 in the 100-F Area. Archaeological testing was conducted at both locations and results were reported (BHI-01743).

- A review was conducted of the proposed characterization of waste sites $128-\mathrm{B}-2$ and $128-\mathrm{B}-3$ in the $100-\mathrm{B} / \mathrm{C}$ Area. Archaeological testing was conducted at both locations and results were reported (BHI-01742). In addition, a determination of National Register eligibility was prepared for a historic site (45BN722) located northeast of the $100-\mathrm{B} / \mathrm{C}$ Area near the Columbia River. It was recommended to DOE as not eligible. Also, subsurface prehistoric materials were discovered during remediation activities of waste sites 128-B-2 and 128-B-3. These resources will be collected in 2005.

- A review was conducted for the proposed removal of debris at waste sites 600-129 and 600-191 in the 600 Area near the White Bluffs town site. A determination of National Register eligibility was prepared for a historic archaeological site (HT-95-006) near the waste sites and it was recommended to DOE as not eligible. 
Table 8.15.1. Major Cultural Resources Reviews Conducted by Pacific Northwest National Laboratory in 2004

\author{
Project Name \\ Well Drilling/Groundwater Protection \\ Bonneville Power Administration Wood Pole \\ Replacement Program Along 13-Mile Stretch of the \\ Midway-Benton \#1 Transmission Line in the 600 Area \\ of the Hanford Site
}

DOE Ownership Transfer of Hanford Reach National Monument to the U.S. Fish and Wildlife Service

U.S. Bureau of Land Management (BLM) Survey of the Fitzner/Eberhardt Arid Lands Ecology (ALE) Reserve Unit Boundary

Remediation of the 618-10 and 618-11 Solid Waste Burial Sites in the 600 Area of the Hanford Site

Transfer of the 748 Building Emergency Decontamination Facility from DOE to Kadlec Medical Center, Richland

\section{Finding}

A review was conducted of the 100-KR-4 pump-and-treat well drilling site. Archaeological testing of the site consisted of the excavation of a $1 \times 1$ meter $(3 \times 3$ feet $)$ test unit. No cultural resources were identified that would be affected by the proposed drilling.

A cultural resources survey was conducted of the Bonneville Power Administration right-of-way and the proposed replacement of wooden power poles along the $\# 1$ transmission line. A historic archaeological site (HT-2004-001) was recorded outside the area to be affected by the wooden pole replacement project. It was determined that the replacement of the wooden poles would have no adverse effect to the archaeological site and the National Register eligible Bonneville Power Administration Midway-Benton \#1 115-kV transmission line.

A programmatic agreement is being developed by the U.S. Fish and Wildlife Service, Tribes, Washington State Historic Preservation Officer, DOE, and Federal Advisory Council on Historic Preservation for the protection and management of significant cultural resources in the Hanford Reach National Monument lands to be transferred.

During this survey, no historic properties were identified that would be adversely affected by the BLM survey of the Fitzner/Eberhardt ALE Reserve Unit boundary. Intermittent monitoring of BLM Fitzner/ Eberhardt ALE Reserve Unit survey activities will continue through 2006.

A cultural resources survey was conducted of the 618-10 and 618-11 solid waste burial sites located in the 600 Area of the Hanford Site near Energy Northwest. No historic properties were identified or will be affected by the proposed remediation of the waste sites.

During the review, four historic artifacts were identified for preservation in the 748 Building:

1. A chair used by Harold McCluskey (a contaminated patient).

2. Patient bed/shielded body wash tank, made of stainless steel and lead.

3. Hanging lead mask/shield (used to protect medical personnel during surgical procedures on contaminated patients).

4. Suspension gurney located in emergency patient wash tank.

Several of the artifacts were transferred to the CREHST Museum in Richland to be curated into Hanford's artifact collection.

CREHST $=$ Columbia River Exhibition of History, Science, and Technology.

DOE = U.S. Department of Energy.

- A review was conducted for an expansion of the Environmental Restoration and Disposal Facility. No significant cultural resources were identified.

A complete listing of all reviews conducted can be found on the Hanford Cultural and Historic Resources website (http://www.hanford.gov/doe/history).

In addition to Hanford projects, the Bonneville Power Administration has also been conducting activities onsite and consulting with DOE to assure that significant resources are not affected.

\subsubsection{Cultural Resources Protection}

Activities to assure protection of cultural resource sites across the Hanford Site are conducted to comply with 
National Historic Preservation Act Section 110, the Native American Graves Protection and Repatriation Act, and the Archaeological Resources Protection Act. The Hanford Site has had a monitoring program since 1987 to assess the effects of weathering and erosion or unauthorized excavation and collection upon the site's significant cultural resources. Activities include onsite inspections of important sites to monitor site conditions, assess the impact observed, and respond with protective measures when the impact observed is significant.

\subsubsection{Monitoring Cultural Sites for Natural and Visitor Impact}

Monitoring efforts included surveillances of important cultural and scientific sites. Monitoring cultural sites for natural and visitor impact began during 1989 and continued during 2004. In 2004, 127 sites, which fit into the following categories (some sites are included in more than one category) were visited:

- places that were either listed or determined eligible for listing in the National Register of Historic Places
- Native American cemeteries or places where human remains were observed

- archaeological sites identified as "high risk" because of a history of impacts, and because they were at risk from human disturbance or natural degradation

- pre-1943 buildings

- eroding cut banks in sensitive areas

- traditional cultural property sites (any site included, or eligible for inclusion, in the National Register of Historic Places because of its association with cultural practices or beliefs of a living community that are rooted in the community's history and are important in maintaining the continuing cultural history of the community).

Site visits typically were conducted in cooperation with tribal cultural resource staff. Site conditions were documented on monitoring forms; if significant damage was observed, the DOE Hanford Cultural and Historical Resources Program Manager was contacted. Types of impact that have been observed during the history of the monitoring program are illustrated in Figure 8.15.2.

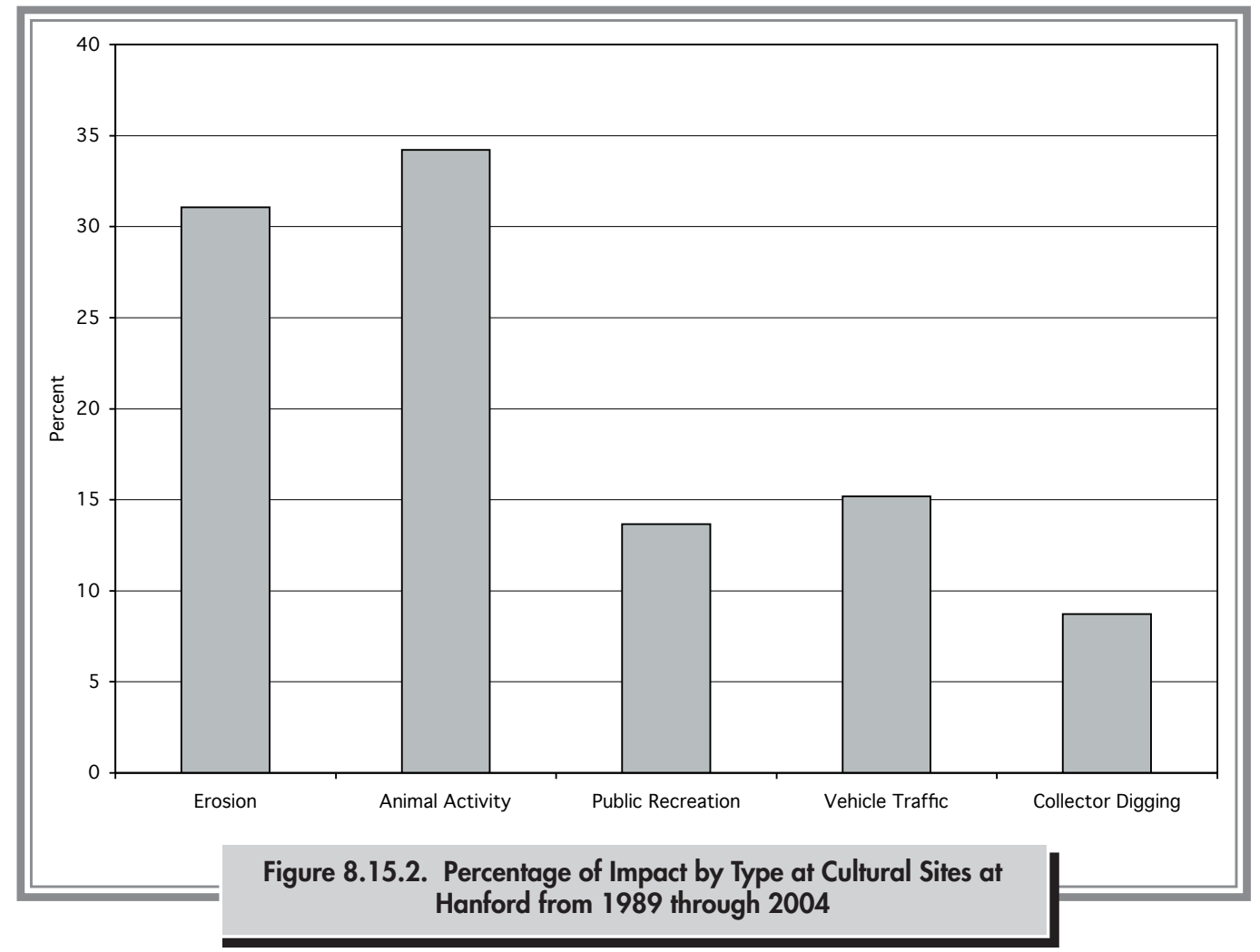




\subsubsection{Assessing Natural and Visitor Impact}

Natural and visitor impact is assessed following site visits and at the end of the year to determine if any protective measures need to be put in place. No impact requiring protective measures was observed in 2004. Erosion along the Hanford Reach of the Columbia River continues to occur. For example, Locke Island has been affected by river erosion, particularly during the mid-1990s. As illustrated in Figure 8.15.3, since 1998 the rate of erosion has slowed considerably. DOE continues to visit Locke Island to measure erosion so that protective measures can be taken if erosion rates begin to increase. Measurements taken at other sites and cut banks also support this finding (Sharpe 2004). Impact from collector digging and recreational activities has also been of concern over the years (Figures 8.15.4 and 8.15.5).

\subsubsection{Responding to Impact with Protective Measures}

DOE has responded in various ways to significant problems identified in impact assessments. For example, at one location, recreationalists had continued to affect the area by creating new roads and dumping trash. As a protective measure, the access road to the location was blocked in 2003, and observations made in 2004 indicated that no new impact had occurred.

At another location, wind erosion had unearthed human remains in 2002. In 2003 and 2004, joint efforts conducted with tribes temporarily stabilized the site, and evaluations of different options for long-term stabilization were made. Currently, it appears as if the site is naturally revegetating. DOE will continue to monitor onsite conditions to confirm that no additional efforts are needed.

The historic First Bank of White Bluffs building continues to deteriorate. In 2003, DOE granted a lease to the U.S. Fish and Wildlife Service to facilitate their volunteer efforts for stabilization. Stabilization and planning for the rehabilitation of the bank building continued in 2004. The polyvinyl tarp that had been placed over the roof in 2003 to hold the rafters in place and protect the walls from further water intrusion had to be removed. It had been damaged by extremely high winds during the winter. The wooden support braces constructed on both the inside and outside of the west wall to stabilize it remain in place.

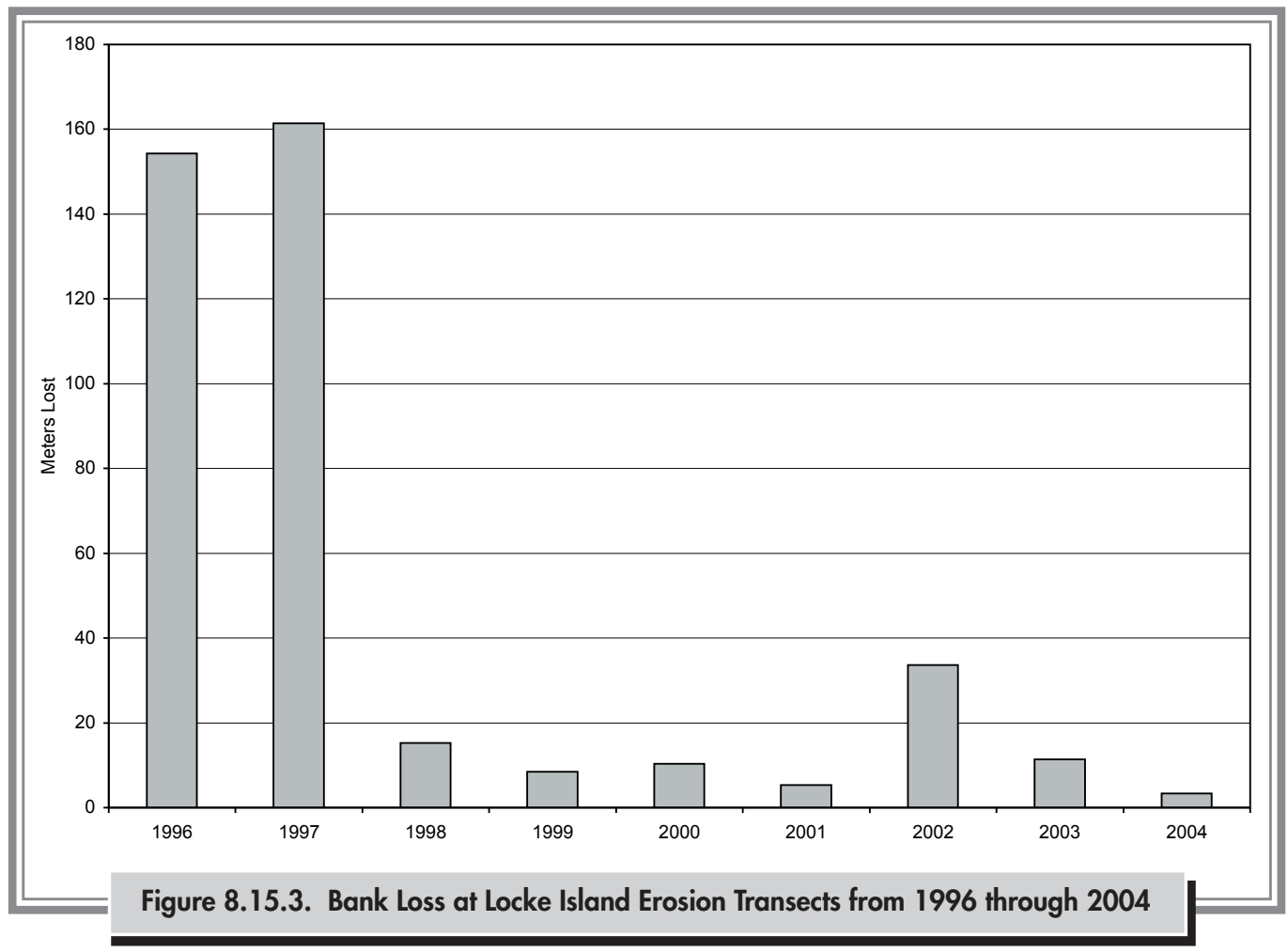



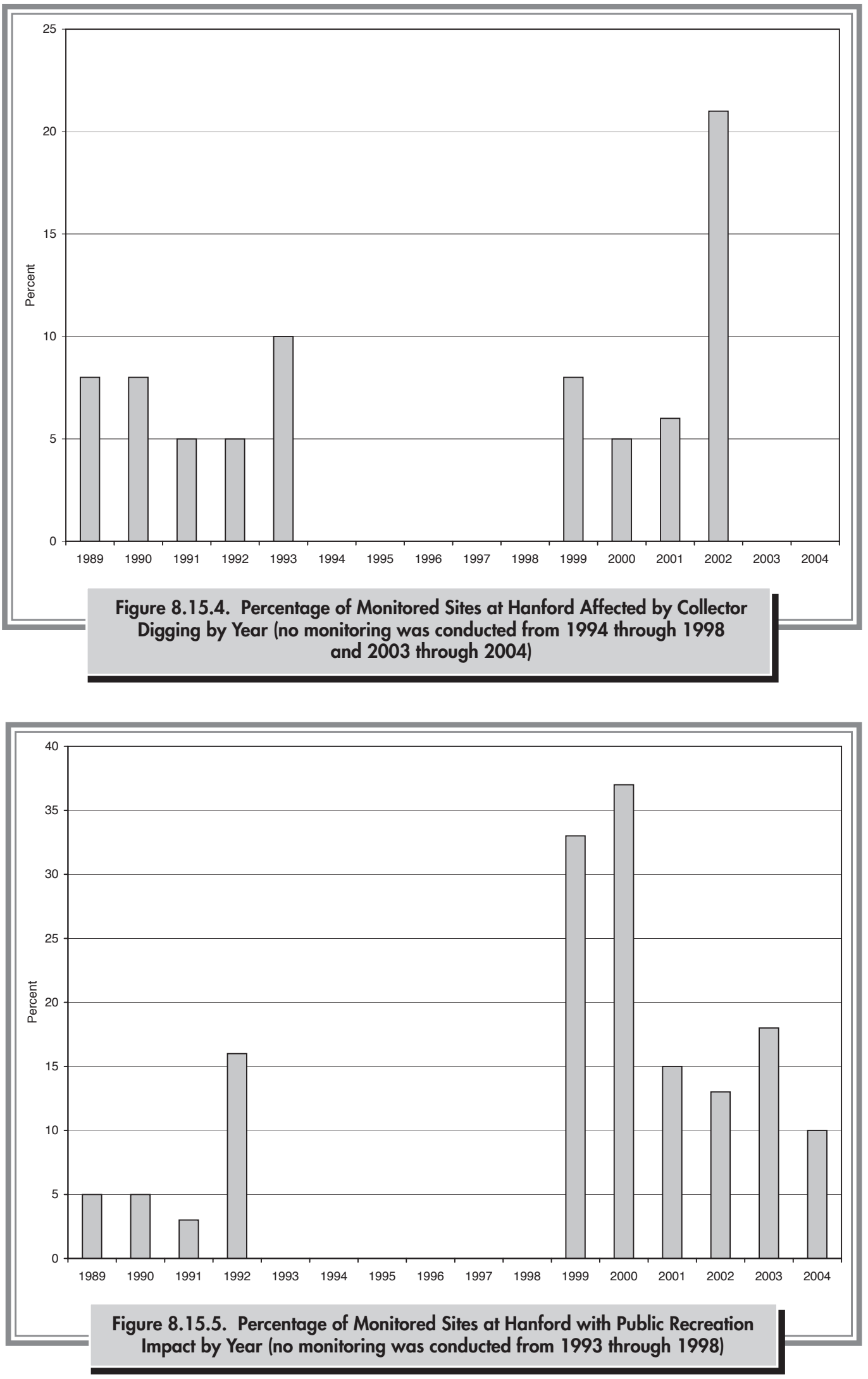
Plans for the rehabilitation of the bank building are moving forward. In 2004, measurements were taken of the building, including the dimensions of the different types of concrete blocks that will be reproduced, and will form the basis of a reconstruction work plan. The plan will also outline steps for the replacement of the roof, restoration of the wood frame windows and interior walls, and construction of a new wood floor. Fifty to sixty percent of current walls will need to be reconstructed with new blocks.

DOE will continue to assist the U.S. Fish and Wildlife Service in future stabilization and rehabilitation efforts.

\subsubsection{Identification and Evaluation Activities}

Identification and evaluation activities are performed to comply with National Historic Preservation Act Section 106 and Section 110. In 2004, approximately 1,335 hectares (3,300 acres) were surveyed. Twenty-one historic period archaeological sites and 32 isolated finds, 25 of which date to the prehistoric period, were recorded in 2004.

Evaluation efforts in 2004 focused on generating information about the Hanford Site's pre-1943 agricultural landscape and White Bluffs town site in order for DOE to make its determination on the eligibility of these resources for listing in the National Register. DOE will make a final determination on their eligibility in 2005.

Two Bonneville Power Administration cultural resource reviews resulted in two resources being determined eligible for listing in the National Register of Historic Places (National Register) during 2004. The Midway-Benton\#1 $115-\mathrm{kV}$ transmission line, which traverses a portion of the Hanford Site was determined to be a contributing feature of Bonneville Power Administration Master Grid District, significant because of its continuous use since 1941 as a distribution line for electricity from the National Register-eligible Midway Substation. This line was one of the first distribution lines built by the Bonneville Power Administration, which delivered power to lower Columbia Basin and Walla Walla valley communities. Archaeological site 45BN135 was also determined to be National Register-eligible for its potential to provide valuable information to understand the prehistoric past of the Columbia Plateau and the Hanford Reach. Recent subsurface testing and excavation suggest use of this area as long as 6,300 years ago.

\subsubsection{Management of Artifact and Data Collections}

The Hanford Cultural Resources Project manages archaeological and historical collections, DOE cultural resource records, a reference library, and an assortment of supporting documentations required to facilitate compliance efforts. Over 1,400 site files and curated archaeological collections from over 80 sites are stored in the archive room. During 2004, the database and geographic information system underwent improvements with new data sets being added. A digital archive was employed, using the Total Records Information Management database for efficient retrieval of representative site photos, site monitoring photos, and historic photos. The Total Records Information Management database was also used for archival of all electronic documents produced by project activities. In 2004, data management procedures and release agreements were developed and implemented to improve data quality and address security issues. Data sharing continued with the Washington State Historic Preservation Officer, DOE, Bechtel Hanford, Inc., U.S. Fish and Wildlife Service, Yakama Nation, Confederated Tribes of the Umatilla Indian Reservation, Nez Perce Tribe, and Wanapum Band.

The application of the curation strategy for artifacts and records associated with the Hanford Site Manhattan Project and Cold War Era Historic District continued during 2004. The strategy is stipulated in the Programmatic Agreement for the Built Environment (DOE/RL-96-77), which directs DOE to assess the contents of Hanford's historic buildings and structures prior to the commencement of deactivation, decontamination, or decommissioning activities. The purpose of DOE's assessments of the contents of Hanford's historic buildings is to identify and preserve any artifacts (e.g., control panels, signs, scale models, and machinery) that may have interpretive or educational value as exhibits within national, state, or local museums. The assessments are accomplished by conducting walk-throughs of the contributing properties within the historic district by teams of cultural resource specialists, historians, archivists and curators, and facility experts. Twenty walk-throughs were conducted during 2004, in four buildings in the 300 Area, seven buildings in the 200 Area, two facilities in the 700 Area (downtown Richland), and seven buildings in the 100-N Area. 
One reassessment of all identified artifacts in the $100-\mathrm{K}$ Area was also conducted. The reassessment was for the purpose of relocating all the tagged artifacts in the $100-\mathrm{K}$ Area facilities for final disposition and curation into the Hanford collection. During 2004, a number of the smaller tagged artifacts from the 100-K Area were collected and transferred to DOE's Hanford collection managed and curated by the Columbia River Exhibition of History, Science and Technology Museum located in Richland. Artifacts that are too heavy and/or large to be removed immediately will be removed to a secure facility in the 100-K Area for temporary storage.

During 2004, staff from the Pacific Northwest National Laboratory; Columbia River Exhibition of History, Science and Technology Museum; and Bechtel Hanford, Inc. continued to review the status of important Manhattan Project and Cold War era artifacts and the applicability of the criteria used to identify artifacts for the Hanford collection. Duplicate artifacts were removed from the collection. In selected 100 and 300 Areas buildings, staff monitored the condition of artifacts tagged for preservation; artifact tags were replaced with newer, more identifiable ones; and a number of artifacts from buildings proposed for demolition were transferred to the Hanford collection storage facility.
After the artifact review was completed, important Manhattan Project and Cold War era artifacts were documented with photographs and narratives in a booklet format. This initial or pilot effort focused on significant artifacts that could not be curated into the Hanford collection because they were too large for long-term storage and/or exhibit purposes or were radiologically contaminated. During this effort, additional tagged artifacts were identified that could not be curated into the Hanford collection; it was recommended that during 2005 they be photo-documented and included in the booklet.

Finally, to complete the mitigation of the proposed demolition of the National Register-eligible Emergency Decontamination Facility (Building 748) and loss of important artifacts that could not be curated into DOE's Manhattan Project and Cold War era artifact collection because of potential contamination concerns, a video was produced in 2004 that documented the historic significance of the Emergency Decontamination Facility and its contents. Special attention was paid to the important medical artifacts. 


\subsection{Climate and Meteorology}

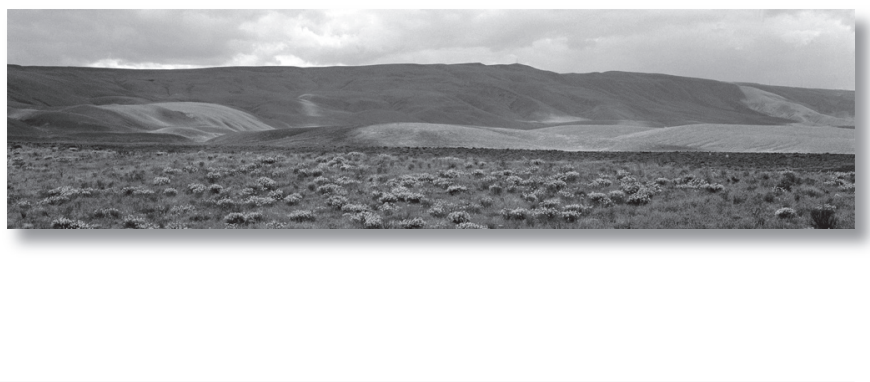

D. J. Hoitink

Meteorological measurements are taken to support Hanford Site emergency preparedness and response, operations, and atmospheric dispersion calculations for dose assessments (Appendix E, Tables E.5, E.7, and E.10). Support is provided through weather forecasting and maintaining and distributing climatological data. Forecasting is provided to help manage weather-dependent operations. Climatological data are provided to help plan weatherdependent activities and are used as a resource to assess the environmental effects of site operations.

The Hanford Meteorology Station relies on data provided by the Hanford Meteorological Monitoring Network. This network consists of 30 remote monitoring stations that transmit data to the Hanford Meteorology Station via radio telemetry every 15 minutes. There are twenty-seven 9-meter (30-foot) towers and three 61-meter (200-foot) towers. Meteorological information collected at these stations includes wind speed, wind direction, temperature, precipitation, atmospheric pressure, and relative humidity; however, not all of these data are collected at all stations.

Regional temperatures, precipitation, and winds are affected by the presence of mountain barriers. The Cascade Range, beyond Yakima to the west, greatly influences the climate of the Hanford Site because of its rain shadow effect. The Rocky Mountains and ranges in southern British Columbia protect the inland basin from severe, cold polar air masses moving southward across Canada and winter storms associated with them.

Real-time and historical data from the Hanford Meteorology Station can be obtained at http://hms.pnl. gov. Data on this web site include hourly weather observations, 15-minute data from the Hanford Meteorological Monitoring Network, monthly climatological summaries, and historical data.
The Hanford Meteorology Station is located on the Hanford Site's Central Plateau, where the prevailing wind direction is from the northwest during all months of the year. The secondary wind direction is from the southwest. Summaries of wind directions indicate that winds from the northwestern quadrant occur most often during winter and summer. During spring and fall, the frequency of southwesterly winds increases, with a corresponding decrease in the northwesterly flow. Monthly average wind speeds are lowest during winter months, averaging about 3 meters per second ( 6 to 7 miles per hour), and highest during summer, averaging about 4 meters per second ( 8 to 9 miles per hour). Wind speeds that are well above average are usually associated with southwesterly winds. However, summertime drainage winds are generally northwesterly and frequently exceed 13 meters per second ( 30 miles per hour). These winds are most prevalent over the northern portion of the site. Figure 8.16.1 shows the 2004 wind roses (i.e., diagrams showing direction and frequencies of wind) measured at a height of 9 meters ( 30 feet) for the 30 meteorological monitoring stations on and around the Hanford Site.

Atmospheric dispersion is a function of wind speed, wind duration and direction, atmospheric stability, and mixing depth. Dispersion conditions are generally good if winds are moderate to strong, the atmosphere is of neutral or unstable stratification, and there is a deep mixing layer. Good dispersion conditions associated with neutral and unstable stratification exist approximately $57 \%$ of the time during summer. Less favorable conditions may occur when wind speed is light and the mixing layer is shallow. These conditions are most common during winter, when moderate to extremely stable stratification exists approximately $66 \%$ of the time. Occasionally, there are extended periods of poor dispersion conditions, primarily during winter, that are associated with stagnant air in stationary high-pressure systems. 


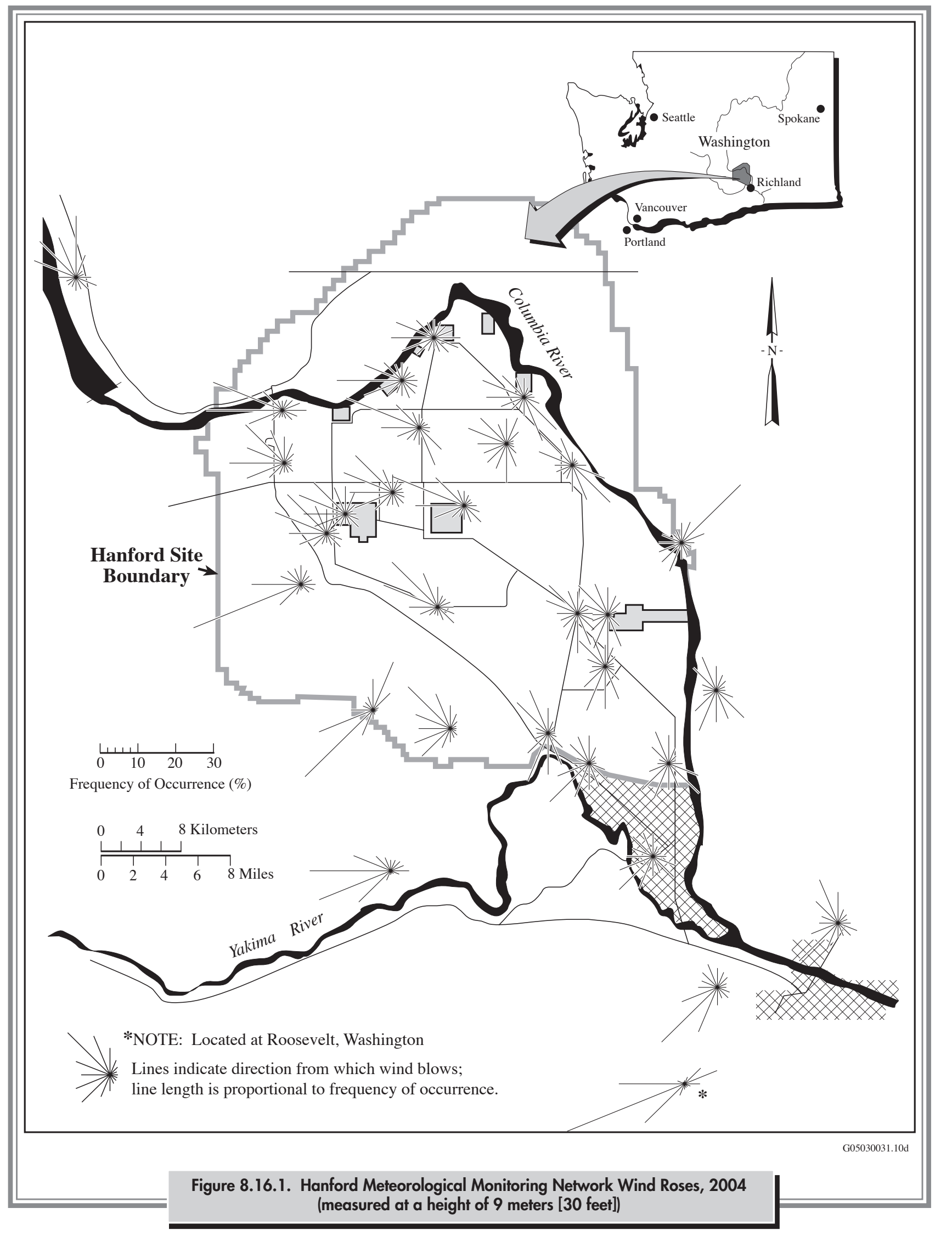




\subsubsection{Historical Climatological Information}

Daily and monthly averages and extremes of temperature, dew point temperature, and relative humidity for 1945 through 2004 are reported in PNNL-15160. From 1945 through 2004, the record maximum temperature was $45^{\circ} \mathrm{C}$ $\left(113.0^{\circ} \mathrm{F}\right)$ recorded during August 1961 and July 2002, and the record minimum temperature was $-30.6^{\circ} \mathrm{C}\left(-23.1^{\circ} \mathrm{F}\right)$ in February 1950. Normal monthly average temperatures ranged from a low of $-0.2^{\circ} \mathrm{C}\left(31.7^{\circ} \mathrm{F}\right)$ in December to a high of $24.6^{\circ} \mathrm{C}\left(76.3^{\circ} \mathrm{F}\right)$ in July. During winter, the highest monthly average temperature at the Hanford Meteorology Station was $6.9^{\circ} \mathrm{C}\left(44.5^{\circ} \mathrm{F}\right)$ in February 1991, and the record lowest was $-11.1^{\circ} \mathrm{C}\left(12.1^{\circ} \mathrm{F}\right)$ in January 1950. During summer, the record maximum monthly average temperature was $27.9^{\circ} \mathrm{C}\left(82.2^{\circ} \mathrm{F}\right)$ in July 1985 , and the record minimum was $17.2^{\circ} \mathrm{C}\left(63.0^{\circ} \mathrm{F}\right)$ in June 1953. The normal annual relative humidity at the Hanford Meteorology Station is 54\%. Humidity is highest during winter, averaging approximately $76 \%$, and lowest during summer, averaging approximately 36\%. Normal annual precipitation at the Hanford Meteorology Station is 17.7 centimeters (6.98 inches). The wettest year on record, 1995, received 31 centimeters (12.31 inches) of precipitation; the driest, 1976, received 8 centimeters (2.99 inches). Most precipitation occurs during late autumn and winter, with more than half of the annual amount occurring from November through February. The snowiest winter on record, 1992-1993, received 142.5 centimeters ( 56.1 inches) of snow.

\subsubsection{Results of 2004 Monitoring}

Calendar year 2004 was slightly warmer than normal and precipitation was above normal.

The average temperature for 2004 was $12.6^{\circ} \mathrm{C}\left(54.6^{\circ} \mathrm{F}\right)$, which was $0.6^{\circ} \mathrm{C}\left(1.0^{\circ} \mathrm{F}\right)$ above normal $\left(12.0^{\circ} \mathrm{C}\left[53.6^{\circ} \mathrm{F}\right]\right)$. Seven months during 2004 were warmer than normal; five months were cooler than normal. December had the greatest positive departure, $2.3^{\circ} \mathrm{C}\left(4.2^{\circ} \mathrm{F}\right)$; January, at $1.4^{\circ} \mathrm{C}\left(2.6^{\circ} \mathrm{F}\right)$ below normal, had the greatest negative departure.

Precipitation during 2004 totaled 20.2 centimeters (7.96 inches), which is $114 \%$ of normal ( 17.7 centimeters [6.98 inches]). Snowfall for 2004 totaled 58.2 centimeters (22.9 inches), compared to an annual normal snowfall of 39.1 centimeters (15.4 inches).

The average wind speed during 2004 was 3.1 meters per second ( 7.0 miles per hour), which was 0.3 meter per second (0.6 mile per hour) below normal. The peak gust for the year was 28.2 meters per second (63 miles per hour) on January 30.

No dust storms were recorded at the Hanford Meteorology Station during 2004. There has been an average of five dust storms per year at the Hanford Meteorology Station during the entire period of record (1945-2004).

Table 8.16.1 provides monthly and annual climatological data collected at the Hanford Meteorology Station during 2004. 


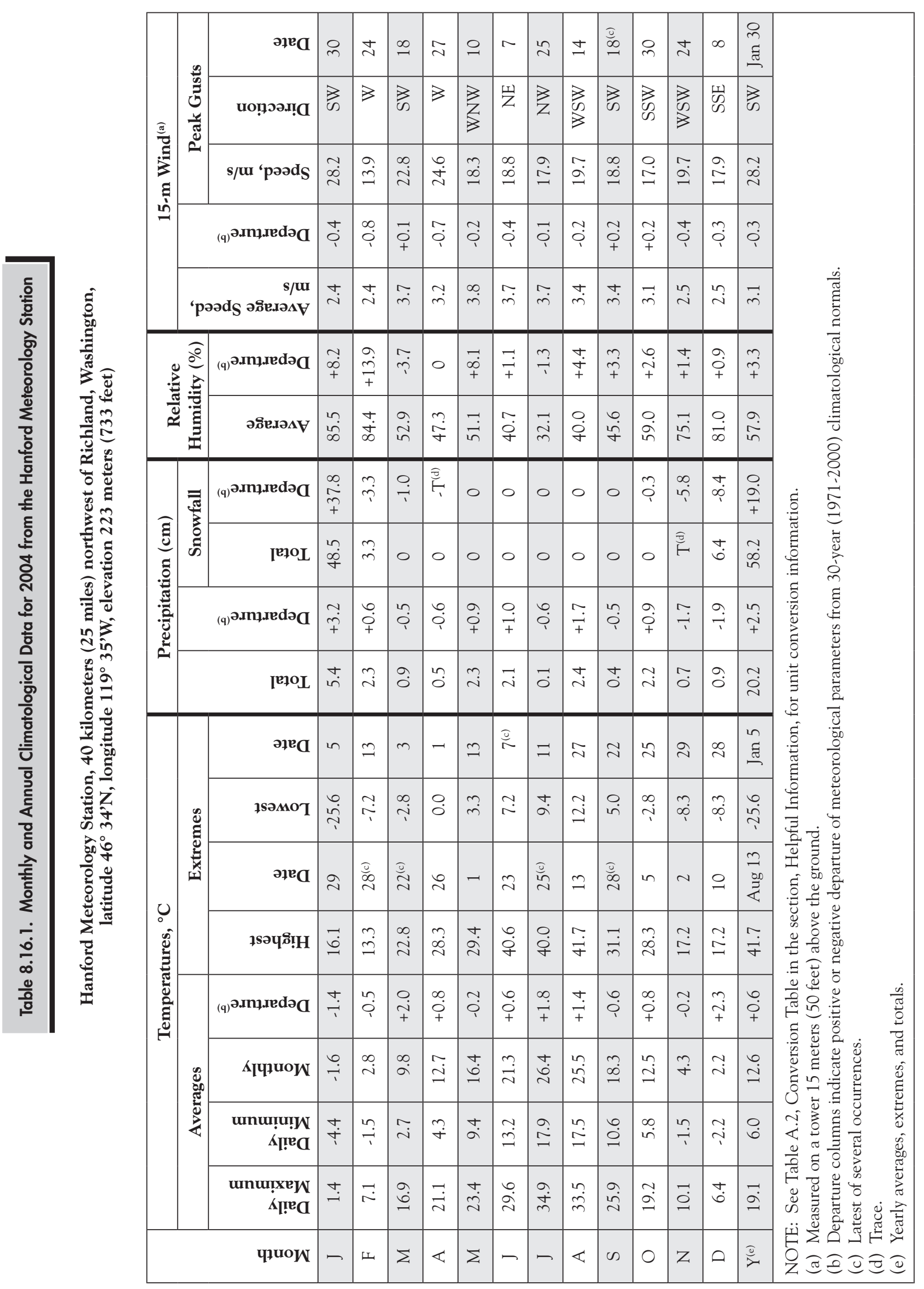




\subsection{Community Involvement in Environmental Surveillance}

R. W. Hanf

During 2004, four teacher-operated radiological air sampling stations operated near the Hanford Site. These stations were located in Basin City, Richland, and Toppenish, Washington, and in north Franklin County at Edwin Markham Elementary School. Each of the stations has a large, lighted display that provides real-time weather and background radiation information to the public as well as general information on station equipment, sample types, and analyses (Figure 8.17.1).

Two teachers from nearby schools manage each station. Station equipment includes air samplers to collect airborne dust and atmospheric moisture for radiological analysis, a variety of weather monitors, and detectors to monitor ambient radiation levels. The teachers are

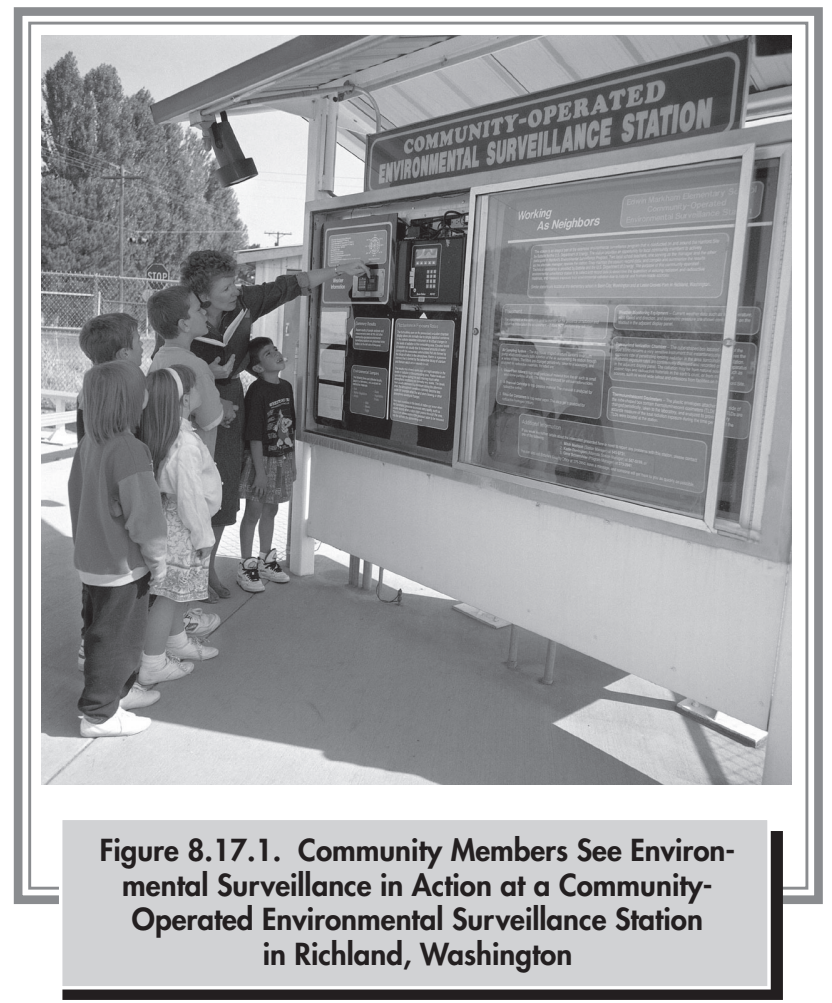

responsible for collecting samples, preparing samples and collection records for submission to the analytical laboratory, monitoring the performance of station equipment, performing minor station maintenance, and participating in scheduled training. They also serve as points of contact for local citizens. The station managers' names and telephone numbers are provided on the displays for anyone desiring additional information about the purpose of the station, station equipment, or analytical data. Pacific Northwest National Laboratory personnel work closely with the teachers to provide training, maintain station equipment and displays, and coordinate sampling and analytical efforts with other Hanford Site environmental surveillance personnel. Computerized data collection systems at each station collect and display weather and background radiation information. The data are transmitted by radiotelemetry to the Hanford Meteorology Station computer where they are posted on the Internet every 15 minutes (http://hms.pnl.gov/stamap.htm). Analytical results for the radiological air samples collected at these stations during 2004 are discussed in this report in Section 8.2. Results of gamma radiation measurements obtained at the stations during 2004 are discussed in Section 8.13.2.5 of this report. 


\subsection{Quality Assurance}

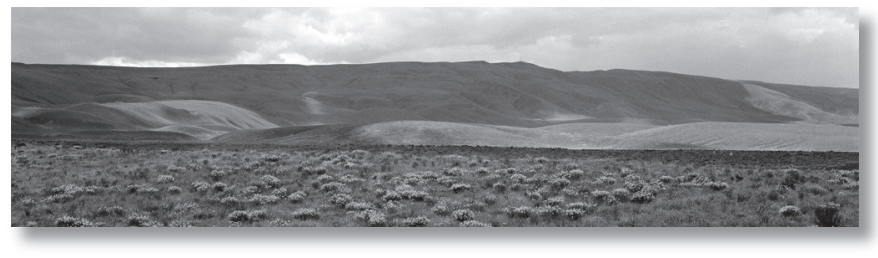

\section{E. A. Lepel, L. P. Diediker, and D. L. Dyekman}

Quality assurance and quality control practices encompass all aspects of Hanford Site environmental monitoring programs. This section discusses specific measures taken in 2004 to ensure quality in project management, sample collection, and analytical results.

Samples were collected and analyzed according to documented standard analytical procedures. Analytical data quality was verified by a continuing program of internal laboratory quality control, participation in interlaboratory crosschecks, replicate sampling and analysis, submittal of blind standard samples and blanks, and splitting samples with other laboratories.

Quality assurance and quality control for the Hanford Site environmental monitoring programs also included procedures and protocols to:

- document instrument calibrations

- conduct program-specific activities in the field

- maintain groundwater wells to ensure representative samples were collected

- avoid cross-contamination by using dedicated well sampling pumps.

\subsubsection{Site-Wide and Offsite Environmental Monitoring and Groundwater Monitoring}

During 2004, comprehensive quality assurance programs, including various quality control practices, were maintained to assure the quality of data collected through Pacific Northwest National Laboratory's Surface Environmental Surveillance Project and Groundwater Performance Assessment Project. Quality assurance plans were maintained for all project activities and defined the appropriate controls and documentation required by EPA and DOE.

\subsubsection{Project Management Quality Assurance}

Site environmental monitoring, groundwater monitoring, and related activities such as processing thermoluminescent dosimeters and performing dose calculations were subject to an overall quality assurance program. This program implemented the requirements of DOE Order 414.1B, Quality Assurance. Quality assurance plans are maintained by each monitoring project; these plans describe the specific quality assurance elements that apply to each project. These plans were approved by a quality assurance organization that monitored compliance with the plans. Work performed through contracts, such as sample analyses, must meet the same quality assurance requirements. Potential equipment and service suppliers are audited before service contracts or material purchases that could have a significant impact on quality within the projects are approved and awarded.

\subsubsection{Sample Collection Quality Assurance and Quality Control}

Surface Environmental Surveillance Project samples were collected by staff trained to conduct sampling according to approved and documented procedures (PNL-MA-580). Continuity of all sampling location identities was maintained through careful documentation. Field replicates were collected for water, soil, and biota samples (Table 8.18.1). Eighty-two percent of the 2004 field replicate results were acceptable. A result was acceptable 


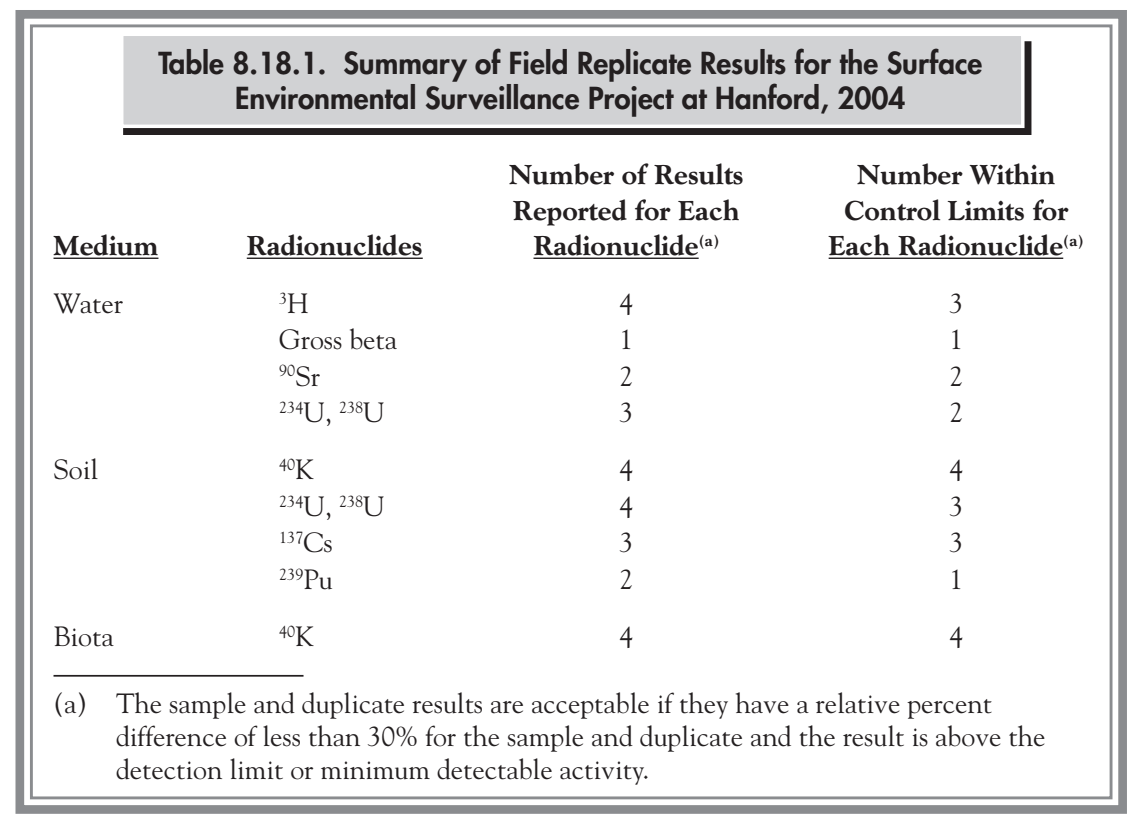

Relative percent difference (RPD) - A measure of the precision of the measurement of a sample $(\mathrm{S})$ and its duplicate (D). The formula is

$$
R P D=\left(\frac{|S-D|}{\frac{(S+D)}{2}}\right) \times 100
$$

if it was greater than the minimum detectable activity and the relative percent difference was less than $30 \%$ for the sample and duplicate.

Samples for the Groundwater Performance Assessment Project were collected by trained staff according to approved and documented procedures (PNNL-15070, Appendix C). Chain-of-custody procedures were followed in Test Methods for Evaluating Solid Waste: Physicall Chemical Methods, SW-846, Third Edition (EPA 1986). Samples representing field blanks and field duplicates were obtained during field operations. Summaries of the 2004 groundwater field quality control sample results are provided in Appendix C of PNNL-15070. The percentage of acceptable field blank and duplicate results during fiscal year 2004 was 97\% for field blanks and 99\% for field duplicates. For field blanks, a result was acceptable if it was less than two times the method detection limit for nonradiological data or less than two times the total propagated analytical uncertainty. An acceptable result indicates that there was not a contamination problem found with the sample. For a field duplicate, the result was acceptable if the measured precision was within 20\%, as measured by the relative percent difference, and the result was greater than five times the minimum detectable activity or method detection limit.

\subsubsection{Analytical Results Quality Assurance and Quality Control}

Routine chemical analyses of water samples were performed under contract primarily by Severn Trent Laboratories, Inc., St. Louis, Missouri, for the environmental surveillance and groundwater monitoring projects. Some routine analyses of hazardous and non-hazardous chemicals for the CERCLA groundwater program also were performed under contract by Lionville Laboratory, Inc., Lionville, Pennsylvania. Each laboratory participated in the EPAsanctioned Water Pollution and Water Supply Performance Evaluation Studies conducted by Environmental Resource Associates. Each laboratory maintained an internal quality control program that met the requirements in EPA (1986); each program was audited and reviewed internally by Pacific Northwest National Laboratory, which submitted additional quality control double-blind spiked samples to these laboratories for analysis.

Routine inorganic metals analyses were also performed by Battelle Marine Sciences Laboratory. The laboratory participated in the NSI Laboratory Proficiency Testing Program. NSI Solutions, Inc. supplied spiked soil and water samples that were analyzed by Pacific Northwest National Laboratory. Analytical results were provided to NSI Solutions, Inc. and compared to the known concentrations of the spikes. Water sample results from seven studies in 2004 were reported. The criteria of being acceptable were met by $90 \%$ of the results from the water

Double-blind spiked sample - A sample of known activity and/or concentration prepared to look like a typical sample submitted to the analytical service laboratory. 
samples. There were also results reported from two soil studies in 2004; $98 \%$ of these results were acceptable. The results are summarized in Table 8.18.2.

Routine radiochemical analyses of samples for the environmental surveillance and groundwater monitoring projects were performed primarily by Severn Trent Laboratories, Inc., Richland, Washington. Severn Trent Laboratories, Inc., Richland, participated in DOE's Quality Assessment Program at the Environmental Measurements Laboratory in New York, and the InterLab RadChem Proficiency Testing Program conducted by Environmental Resource Associates. Environmental Resource Associates prepared and distributed proficiency standard samples according to EPA requirements. A quality control blind spiked sample program also was conducted for each project by Pacific Northwest National Laboratory. The laboratory maintains an internal quality control program, which was audited and reviewed internally. Additional information on these quality control efforts is provided in the following sections.

\subsubsection{DOE and EPA Comparison Studies}

Blind water samples (containing activities and concentrations unknown to the analytical laboratory) were distributed to participating laboratories as part of the EPA performance evaluation program. These blind samples contained specific organic and inorganic analytes that had concentrations unknown to the analyzing laboratories. After analysis, the results were submitted to Environmental Resource Associates, the EPA performance evaluation program sponsor, for comparison with known values and results from other participating laboratories. Summaries of the results for 2004 groundwater samples are provided in PNNL-15070, Appendix C, for the primary laboratory, Severn Trent Laboratories, Inc., St. Louis.

The DOE Quality Assessment Program and the Environmental Resource Associates Proficiency Testing Program provided standard samples of environmental media (e.g., water, air filters, soil, and vegetation) that contained specific amounts of one or more radionuclides that were unknown by the participating laboratory. After analysis, the results were forwarded to the DOE Quality Assessment Program or Environmental Resource Associates for comparison with known values and results from other laboratories. Both the DOE Quality Assessment Program and Environmental Resource Associates had established criteria for evaluating the accuracy of results (NERLCi-0045; EML-621). Summaries of the 2004 results are provided in Tables 8.18.3 and 8.18.4. The DOE Quality Assessment Program ended in 2004 after one set of samples was analyzed. The laboratory that provided this service,

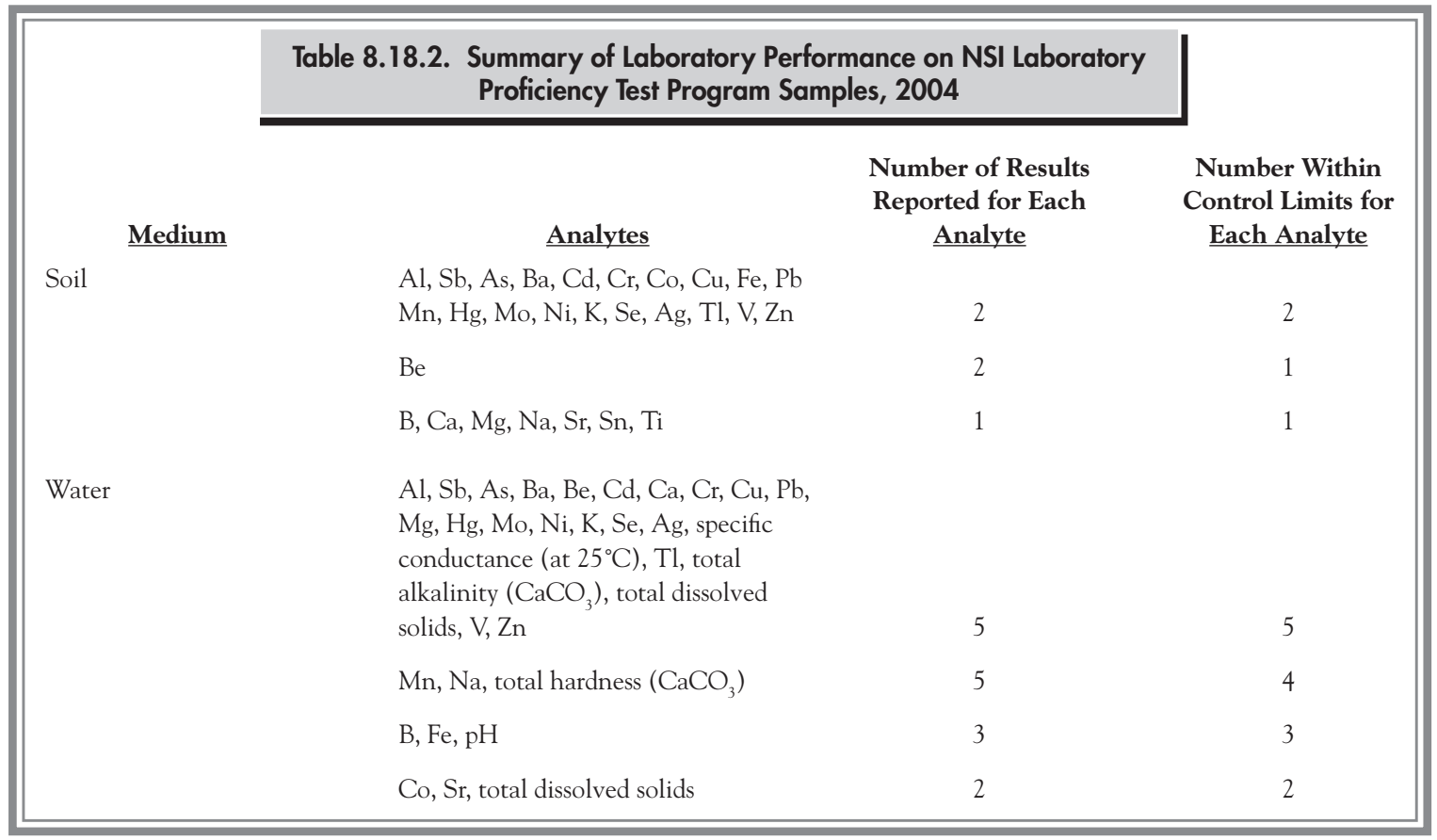


Table 8.18.3. Summary of Laboratory Performance on Hanford Site Surface Environmental Surveillance Project Samples by the DOE Quality Assessment Program, 2004

Medium

Radionuclides
Number of Results

Reported for Each

Radionuclide
Number of Results Within Acceptable Control Limits for Each Radionuclide $^{(\mathrm{a})}$

Severn Trent Laboratories, Richland, Washington

Air filter particulate

Gross alpha, gross beta, ${ }^{60} \mathrm{Co},{ }^{90} \mathrm{Sr},{ }^{134} \mathrm{Cs}$,

${ }^{137} \mathrm{Cs},{ }^{234} \mathrm{U},{ }^{238} \mathrm{U},{ }^{238} \mathrm{Pu},{ }^{239} \mathrm{Pu},{ }^{241} \mathrm{Am}$,

total uranium

1

1

Soil

${ }^{40} \mathrm{~K},{ }^{90} \mathrm{Sr},{ }^{137} \mathrm{Cs},{ }^{212} \mathrm{Bi},{ }^{212} \mathrm{~Pb},{ }^{214} \mathrm{Bi},{ }^{214} \mathrm{~Pb}$,

${ }^{228} \mathrm{Ac},{ }^{234} \mathrm{Th},{ }^{234} \mathrm{U},{ }^{238} \mathrm{U},{ }^{238} \mathrm{Pu},{ }^{239} \mathrm{Pu}$,

${ }^{241} \mathrm{Am}$, total uranium

1

1

Vegetation

${ }^{40} \mathrm{~K},{ }^{60} \mathrm{Co},{ }^{90} \mathrm{Sr},{ }^{137} \mathrm{Cs},{ }^{238} \mathrm{Pu},{ }^{239} \mathrm{Pu},{ }^{241} \mathrm{Am}$,

${ }^{244} \mathrm{Cm}$

$1-1$

Water

${ }^{3} \mathrm{H},{ }^{60} \mathrm{Co},{ }^{90} \mathrm{Sr},{ }^{137} \mathrm{Cs},{ }^{234} \mathrm{U},{ }^{238} \mathrm{U},{ }^{238} \mathrm{Pu}$,

${ }^{239} \mathrm{Pu},{ }^{241} \mathrm{Am}$, total uranium

$1-1$

Gross alpha, gross beta

1

0

(a) Control limits are from EML-621.

Table 8.18.4. Summary of Laboratory Performance on Hanford Site Surface Environmental Surveillance Project Samples by the Environmental Resource Associates Proficiency Testing Program, 2004

\begin{tabular}{|c|c|c|c|}
\hline$\underline{\text { Medium }}$ & $\underline{\text { Radionuclides }}$ & $\begin{array}{c}\text { Number of Results } \\
\text { Reported for Each } \\
\text { Radionuclide }\end{array}$ & $\begin{array}{c}\text { Number Within } \\
\text { Control Limits for } \\
\text { Each Radionuclide }^{(\mathrm{a})}\end{array}$ \\
\hline \multicolumn{4}{|c|}{ Severn Trent Laboratories, Richland, Washington } \\
\hline \multirow[t]{5}{*}{ Water } & Gross alpha & 6 & 6 \\
\hline & $\begin{array}{l}{ }^{60} \mathrm{Co},{ }^{134} \mathrm{Cs},{ }^{137} \mathrm{Cs},{ }^{226} \mathrm{Ra},{ }^{228} \mathrm{Ra} \text {, } \\
\text { total uranium }\end{array}$ & 5 & 5 \\
\hline & ${ }^{89} \mathrm{Sr},{ }^{90} \mathrm{Sr}$ & 5 & 4 \\
\hline & ${ }^{65} \mathrm{Zn},{ }^{133} \mathrm{Ba}$ & 4 & 4 \\
\hline & ${ }^{3} \mathrm{H},{ }^{131} \mathrm{I}$ & 3 & 3 \\
\hline
\end{tabular}

Environmental Measurements Laboratory, was transitioned from a DOE facility to a Department of Homeland Security laboratory. Hence, its mission changed and, as a result, only one set of samples were provided in 2004. Severn Trent Laboratories, Inc., St Louis, analyzed and reported on that one set. Acceptable control limits as defined by the DOE Quality Assessment Program were met by $96 \%$ of the DOE quality assessment sample results. The acceptable control limit range as defined by the National
Standards for Water Proficiency Testing Studies, Criteria Document (NERL-Ci-0045) was met by $97 \%$ of the Environmental Resource Associates samples.

\subsubsection{Pacific Northwest National Laboratory Evaluations}

In addition to the DOE and EPA interlaboratory quality control programs, Pacific Northwest National Laboratory 
Blind spiked sample - A sample of known activity and/or concentration submitted to the analytical laboratory but not necessarily in the same physical geometry as the typical samples submitted.

maintained a quality control program to evaluate analytical contractor precision and accuracy and to conduct special intercomparisons. This program included the use of both radiological and non-radiological blind spiked samples. Blind spiked quality control samples and blanks were prepared and submitted to check the accuracy and precision of analyses at Severn Trent Laboratories, Inc., Richland. In 2004, 221 blind spiked samples were submitted for the Groundwater Performance Assessment Project (PNNL-15070, Appendix C) and 8 samples were submitted for the Surface Environmental Surveillance Project. The samples included air filters, soil, water, and vegetation (Table 8.18.5). The results of all water sample non-radiochemistry blind spiked determinations are discussed in Appendix C of PNNL-15070 and indicated an acceptable performance by the laboratory.

For all media, 98\% of Severn Trent Laboratories, Inc., Richland, radiochemistry blind spiked determinations were within the control limits $( \pm 30 \%$ of the known value), which indicated acceptable results. One result for cobalt-60 in vegetation by gamma spectroscopy was slightly outside the acceptable range $( \pm 31 \%)$.

\subsubsection{Laboratory Internal Quality Assurance Programs}

The analytical laboratories were required to maintain an internal quality assurance and control program. Periodically, the laboratories were audited for compliance to the quality assurance and control programs. At Severn Trent Laboratories, Inc., St. Louis, the quality control program met the quality assurance and control criteria in EPA (1986). The laboratories also were required to maintain a system to review and analyze the results of the quality control samples to detect problems that may have arisen from contamination, inadequate calibrations, calculation errors, or improper procedure performance. Detection levels for each analytical method were determined at least annually.

The internal quality control program at Severn Trent Laboratories, Inc., Richland, involved routine calibrations of counting instruments, yield determinations of radiochemical procedures, frequent radiation check sources and background counts, replicate and spiked sample analyses, matrix and reagent blanks, and maintenance of control charts to indicate analytical deficiencies. Available calibration standards traceable to the National Institute of Standards and Technology were used for radiochemical calibrations. Calculation of minimum detectable concentrations involved the use of factors such as the average counting efficiencies and background for detection instruments, length of time for background and sample counts,

\begin{tabular}{|c|c|c|c|c|}
\hline \multirow[b]{2}{*}{$\underline{\text { Medium }}$} & \multicolumn{3}{|c|}{$\begin{array}{l}\text { Table 8.18.5. Summary of Hanford Site Surface Environmental Surveillance } \\
\text { Project Blind Spiked Determinations, } 2004\end{array}$} & \\
\hline & $\underline{\text { Radionuclides }}$ & $\begin{array}{l}\text { Number of Results } \\
\text { Reported for Each } \\
\text { Radionuclide }\end{array}$ & $\begin{array}{r}\text { Nun } \\
\text { Withi } \\
\text { for Eac } \\
\end{array}$ & $\begin{array}{l}\text { ber of Results } \\
\text { Control Limits } \\
\text { Radionuclide }^{(a)}\end{array}$ \\
\hline \multicolumn{5}{|c|}{ Severn Trent Laboratories, Richland, Washington } \\
\hline \multirow[t]{2}{*}{ Air Filters } & ${ }^{60} \mathrm{Co},{ }^{90} \mathrm{Sr},{ }^{137} \mathrm{Cs},{ }^{234} \mathrm{U},{ }^{238} \mathrm{U}$ & 2 & & 2 \\
\hline & ${ }^{238} \mathrm{Pu}$ & 1 & & 1 \\
\hline Soil & ${ }^{40} \mathrm{~K},{ }^{90} \mathrm{Sr},{ }^{137} \mathrm{Cs},{ }^{234} \mathrm{U},{ }^{238} \mathrm{U},{ }^{238} \mathrm{Pu},{ }^{239 / 240} \mathrm{Pu}$ & 2 & & 2 \\
\hline Vegetation & ${ }^{40} \mathrm{~K},{ }^{60} \mathrm{Co},{ }^{90} \mathrm{Sr},{ }^{137} \mathrm{Cs},{ }^{238} \mathrm{Pu},{ }^{239 / 240} \mathrm{Pu}$ & 2 & & 2 \\
\hline Surface Water & ${ }^{3} \mathrm{H},{ }^{60} \mathrm{Co},{ }^{137} \mathrm{Cs},{ }^{238} \mathrm{Pu},{ }^{239} / 240 \mathrm{Pu},{ }^{234} \mathrm{U},{ }^{238} \mathrm{U}$ & 2 & & 2 \\
\hline
\end{tabular}


sample volumes, radiochemical yields, and a pre-designated uncertainty multiplier (EPA 520/1-80-012).

Periodically, inspections of services were performed and conformance with the contractual requirements of the analytical facility was documented. This procedure provided the framework to identify and resolve potential performance problems. Responses to assessment and inspection findings were documented by written communication, and corrective actions were verified by follow-up audits and inspections.

In 2004, six audits of the commercial laboratories supporting the Groundwater Performance Assessment Project were performed. Three audits were performed by the DOE Consolidated Assessment Program, one audit by a joint team from Bechtel Hanford, Inc. and Pacific Northwest National Laboratory, and two audits by Bechtel Hanford, Inc. only. The DOE Consolidated Assessment Program audit evaluated Severn Trent Laboratories, Inc., St. Louis, on March 30 and April 1, 2004, Lionville Laboratory on May 4 to 6, 2004, and Severn Trent Laboratories, Inc., Richland, on August 3 to 5, 2004. The scope of the DOE Consolidated Assessment Program audits included the following specific functional areas: (1) quality assurance management systems and general laboratory practices, (2) data quality for organic analyses, (3) data quality for inorganic and wet chemistry analyses, (4) data quality for radiochemistry analyses, (5) hazardous and radioactive materials management, and (6) verification of correctiveaction implementation from previous audit findings.

The purpose of the joint Bechtel Hanford, Inc. and Pacific Northwest National Laboratory audit conducted on August 10 to 12, 2004, was to evaluate the continued support of analytical services to Hanford Site contractors as specified in the statement of work between Fluor Hanford, Inc. and Severn Trent Laboratories, Inc. The audit was based on the analytical and quality assurance requirements for both groundwater and multimedia samples as specified in the statement of work. The primary areas of focus were personnel training, procedure compliance, sample receipt and tracking, instrument operation and calibration, equipment maintenance, instrumentation records and logbooks, implementation of Severn Trent Laboratories, Inc.'s quality assurance management plan in accordance with Hanford Analytical Services Quality Assurance Requirements Document (DOE/RL-96-68,
Volumes 1 and 4), and implementation of corrective actions for deficiencies identified in previous audits.

A total of 22 findings and 33 observations were noted for the three DOE Consolidated Assessment Program audits, 11 findings and 6 observations were identified in the joint Bechtel Hanford, Inc. and Pacific Northwest National Laboratory audit, and 5 findings and 19 observations were identified by Bechtel Hanford, Inc. only audits. Results of these audits are summarized in Appendix C of PNNL-15070. Corrective actions were accepted for all the audits and verification of the corrective actions will be performed in future audits. All laboratories have been qualified to continue to provide analytical services for samples generated at DOE sites.

Internal laboratory quality control program data were reported with the analytical results. Scientists at Pacific Northwest National Laboratory summarized the results quarterly. The Surface Environmental Surveillance Project and the Groundwater Performance Assessment Project indicated that each laboratory met the contractspecified requirements for each quarter of calendar year 2004 (for the Surface Environmental Surveillance Project) and fiscal year 2004 (for the Groundwater Performance Assessment Project).

\subsubsection{Media Audits and Comparisons}

Additional audits and comparisons were conducted on several specific types of samples. The Washington State Department of Health routinely co-sampled various environmental media and measured external radiation levels at multiple locations during 2004. Media that were co-sampled and analyzed for radionuclides included irrigation water, water from 19 locations along and across the Columbia River, water from 5 Columbia River shoreline springs, water from 1 onsite drinking water location, soil from 13 locations on and off the site, and sediment from 6 Columbia River sites from Priest Rapids Dam (upriver from the site) to McNary Dam (downriver from the site). Also co-sampled and analyzed for radionuclides were samples of carp as well as upwind and downwind samples of quail, mule deer (muscle and bone), concord grapes, potato tubers, asparagus, alfalfa, cow milk, and red and white wines. 
The U.S. Food and Drug Administration (FDA) also received co-samples from downwind sampling locations and analyzed leafy vegetables, potato tubers, and concord grapes for radionuclides (Table 8.18.6). The FDA determined that concord grapes from the Riverview area had positive results for strontium-90. However, these values were below the strontium-90 detection limit determined by Pacific Northwest National Laboratory for the same sample. All other results from the FDA were below detection limits.

Quality control for environmental thermoluminescent dosimeters included audits that exposed three environmental thermoluminescent dosimeters per quarter to known values of radiation (between 17 and 29 milliroentgen). For the twelve measurements, the lowest ratio of determined/known exposure was 0.99; the highest determined/known exposure ratio was 1.09 , with an average of $1.05 \pm 0.03$ (Table 8.18.7).

\subsubsection{Effluent Monitoring and Environmental Monitoring Near Facilities and Operations}

The Effluent Monitoring and Near-Facility Environmental Monitoring Programs were subject to the quality assurance requirements specified in DOE/RL-96-68. These quality assurance programs complied with DOE Order 414.1B, using standards from the American Society of Mechanical Engineers (ASME NQA-1 1997 Edition) as their basis. The program also adhered to the guidelines and objectives in Requirements for Quality Assurance Project Plans for Environmental Data Operations (EPA QA/R-5).

The monitoring programs each have a quality assurance project plan describing applicable quality assurance elements. These plans were approved by contractor quality

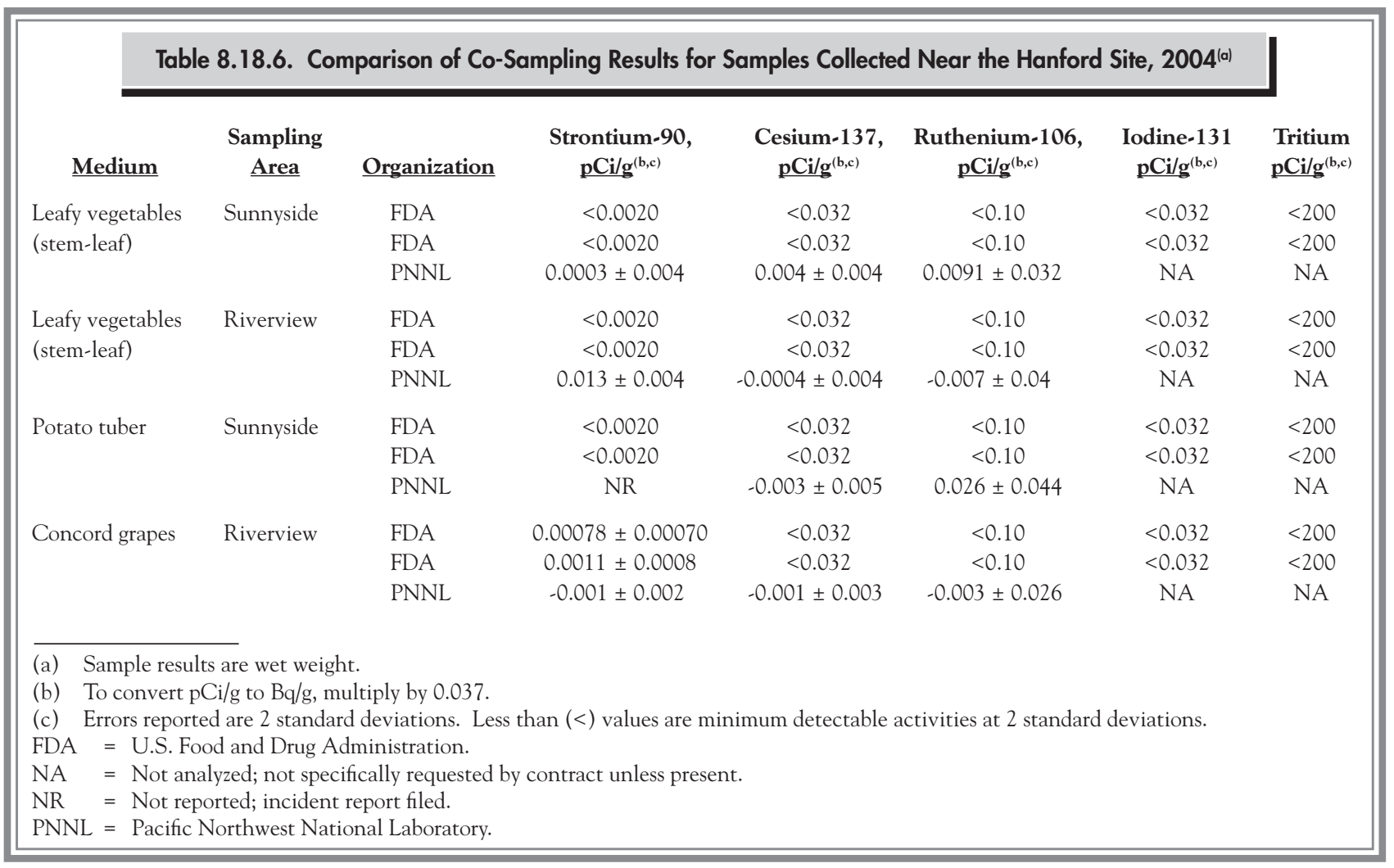




\begin{tabular}{|c|c|c|c|c|}
\hline \multirow[b]{2}{*}{ Quarter } & \multicolumn{4}{|c|}{$\begin{array}{l}\text { Table 8.18.7. Comparison of Pacific Northwest National Laboratory Thermoluminescent Dosimeter } \\
\text { Results with Known Exposure, } 2004\end{array}$} \\
\hline & Exposure Date & $\begin{array}{l}\text { Known Exposure, }{ }^{(a)} \\
\text { milliroentgen }(\mathbf{m R})\end{array}$ & $\begin{array}{c}\text { Determined Exposure, }{ }^{(a)} \\
\text { milliroentgen }(\mathrm{mR})\end{array}$ & $\begin{array}{c}\text { Ratio of } \\
\text { Determined/ } \\
\text { Known Exposure }\end{array}$ \\
\hline 1 st & February 12, 2004 & $\begin{array}{l}29 \pm 1.08 \\
18 \pm 0.67 \\
26 \pm 0.97\end{array}$ & $\begin{array}{l}30.98 \pm 1.03 \\
18.68 \pm 0.36 \\
25.81 \pm 1.19\end{array}$ & $\begin{array}{l}1.07 \\
1.04 \\
0.99\end{array}$ \\
\hline $2 \mathrm{nd}$ & May 14, 2004 & $\begin{array}{l}27 \pm 1.00 \\
23 \pm 0.86 \\
17 \pm 0.63\end{array}$ & $\begin{array}{l}27.86 \pm 0.61 \\
23.33 \pm 0.33 \\
17.76 \pm 0.18\end{array}$ & $\begin{array}{l}1.03 \\
1.01 \\
1.04\end{array}$ \\
\hline $3 \mathrm{rd}$ & August 13, 2004 & $\begin{array}{l}22 \pm 0.82 \\
19 \pm 0.71 \\
28 \pm 1.04\end{array}$ & $\begin{array}{l}22.06 \pm 0.72 \\
20.48 \pm 0.42 \\
29.92 \pm 0.80\end{array}$ & $\begin{array}{l}1.00 \\
1.08 \\
1.07\end{array}$ \\
\hline 4th & November 16, 2004 & $\begin{array}{l}20 \pm 074 \\
25 \pm 0.93 \\
18 \pm 0.67\end{array}$ & $\begin{array}{l}21.77 \pm 0.85 \\
27.07 \pm 0.04 \\
19.21 \pm 0.12\end{array}$ & $\begin{array}{l}1.09 \\
1.08 \\
1.07\end{array}$ \\
\hline
\end{tabular}

assurance groups, who monitored compliance with the plans. Work such as sample analyses performed through contracts had to meet the requirements of these plans. Suppliers were audited before the contract selection was made for equipment and services that may have significantly affected the quality of a project.

\subsubsection{Sample Collection Quality Assurance}

Samples for the Effluent Monitoring and Near-Facility Environmental Monitoring Programs were collected by staff trained in accordance with approved procedures. Established sampling locations were accurately identified and documented to assure continuity of data for those sites and are described in DOE/RL-91-50.

\subsubsection{Analytical Results Quality Assurance}

Samples for the Effluent Monitoring and Near-Facility Environmental Monitoring Programs were analyzed by up to three different analytical laboratories. The use of these laboratories was dependent on the Hanford contractor collecting the samples and the contract(s) established between the contractor and the analytical laboratory(s). Table 8.18.8 provides a summary of the Hanford Site's analytical laboratories used for effluent monitoring and near-facility monitoring samples in 2004.

The quality of the analytical data was assured by several means. For instance, counting room instruments were kept within calibration limits through daily checks, the results of which were stored in computer databases. Radiochemical standards used in analyses were regularly measured and the results were reported and tracked. Formal, written laboratory procedures were used to analyze samples. Analytical procedural control was assured through administrative procedures. Chemical technologists at the laboratories were qualified to perform analyses through formal classroom and on-the-job training.

The participation of the Hanford Site analytical laboratories in EPA and DOE laboratory performance evaluation programs also served to assure the quality of the data produced. The Waste Sampling and Characterization Facility performance was evaluated in four different laboratory performance studies for 2004. For the EPA Water Pollution Studies 108 and 114, Soil Studies 45 and 47, and Soil Study 48 for inorganic and organic analyses, 360 different analytes and compounds were submitted to the Waste Sampling and Characterization Facility for analysis. Of the 360 reported analytes, 341 results were acceptable while 19 were unacceptable for a total acceptable rate of $95 \%$. In the DOE Mixed Analyte Performance 
Table 8.18.8. Hanford Site Laboratories Used by Site Contractors and Types of Effluent Monitoring and Near-Facility Monitoring Samples Analyzed, 2004

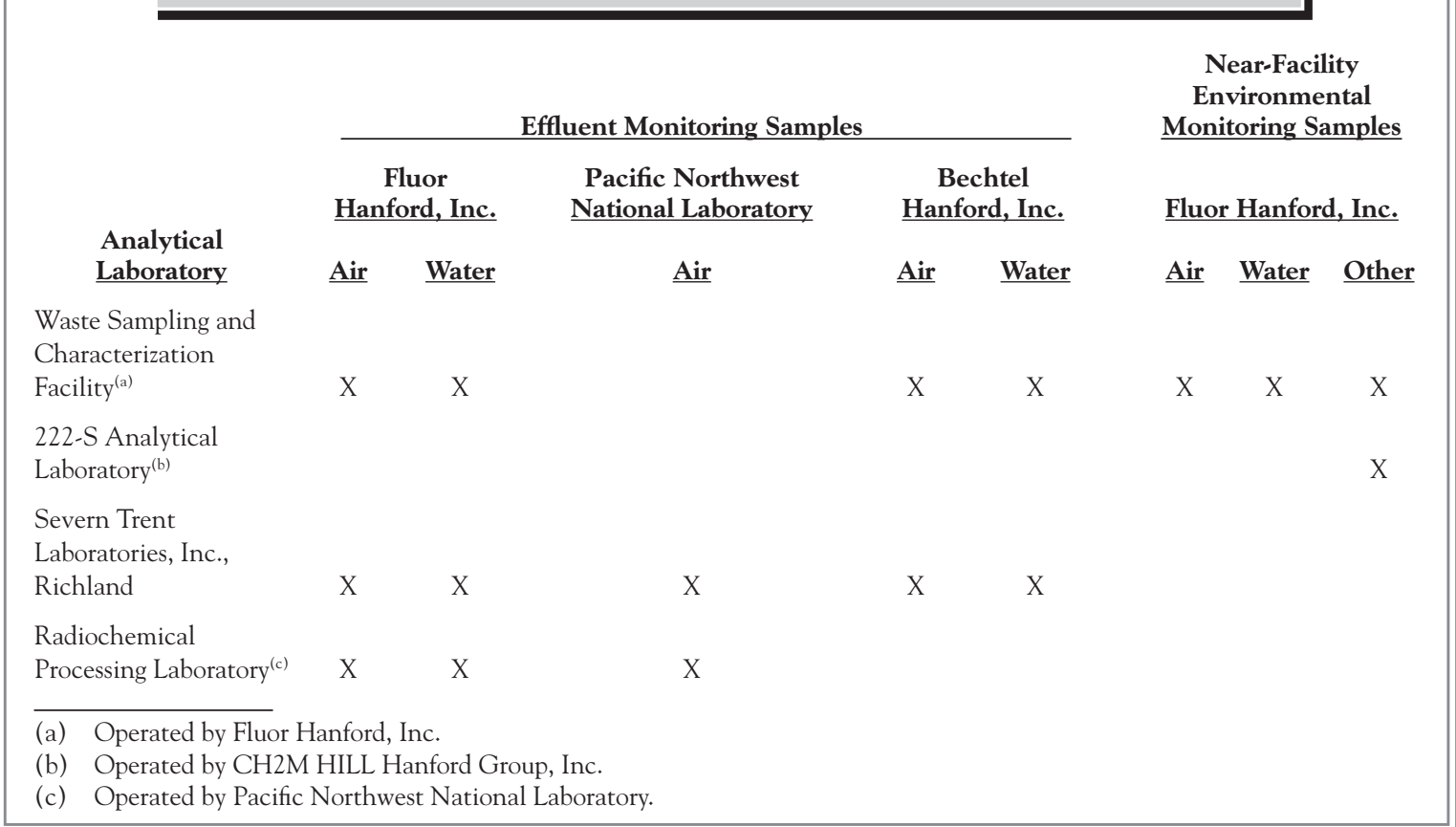

Evaluation Program studies (MAPEP-03-W11 and MAPEP-04-MaS12), 122 different radionuclides and analytes were submitted to the Waste Sampling and Characterization Facility for analysis. Of the 122 reported radionuclide analytes, 116 results were acceptable while 6 were unacceptable for a total acceptable rate of $95 \%$. In the National Institute of Standards and Technology Radiochemistry Intercomparison Program study, four different radionuclides (strontium-90, plutonium-238, uranium-238, and americium-241) in filters and soils were submitted to the Waste Sampling and Characterization Facility for 40 different analyses. All radionuclide results for both filters and soils were acceptable for a total acceptable rate of $100 \%$. In the DOE Quality Assessment Program, 36 different radionuclides were submitted to the Waste Sampling and Characterization Facility for analysis, and 17 different radionuclides were submitted to the 222-S Analytical Laboratory. Of the 36 reported radionuclides for the Waste Sampling and Characterization
Facility, 36 results were acceptable for a total acceptable rate of $100 \%$. Of the 17 reported radionuclides for the 222-S Analytical Laboratory, all 17 results were acceptable for a total acceptable rate of $100 \%$. The $222-\mathrm{S}$ Analytical Laboratory also participated in the 2004 study of DOE's Mixed Analyte Performance Evaluation Program. Of the 33 reported radionuclides, 32 were found to be acceptable for an acceptable rate of $97 \%$. Performance results for the DOE Quality Assessment Program and others are presented in Tables 8.18.9 through 8.18.11.

The DOE Quality Assessment Program was discontinued in June 2004 and replaced by the DOE Mixed Analyte Performance Evaluation Program. The new program expanded the performance evaluation sample matrices to include filters (started in July 2004) and vegetation (started in January 2005). 
Table 8.18.9. The Hanford Site's Waste Sampling and Characterization Facility(a) Performance on DOE Quality Assessment Program Samples and on DOE Mixed Analyte Performance Evaluation Program Samples, 2004

\begin{tabular}{|c|c|}
\hline Medium & Radionuclide \\
\hline Air filters & $\begin{array}{l}{ }^{54} \mathrm{Mn},{ }^{57} \mathrm{Co},{ }^{60} \mathrm{Co},{ }^{65} \mathrm{Zn},{ }^{90} \mathrm{Sr},{ }^{134} \mathrm{Cs},{ }^{137} \mathrm{Cs}, \\
{ }^{234} \mathrm{U},{ }^{238} \mathrm{Pu},{ }^{238} \mathrm{U},{ }^{239 / 240} \mathrm{Pu},{ }^{241} \mathrm{Am} \text {, gross } \\
\text { alpha, gross beta }\end{array}$ \\
\hline Soil & 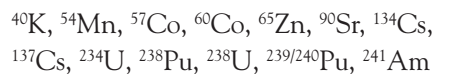 \\
\hline
\end{tabular}

Vegetation

Water
Number of Results Reported

19

23
Number of Results Within Control Limits

24

( ${ }^{90} \mathrm{Sr}$ failed once)

17

${ }^{234} \mathrm{U}$ and ${ }^{238} \mathrm{U}$ failed; only naturally occurring uranium was present in the $\mathrm{MAPEP}^{(\mathrm{b})}$ soil sample)

(a) Onsite laboratory operated by Fluor Hanford, Inc.

(b) Mixed Analyte Performance Evaluation Program.

\begin{tabular}{|c|c|c|c|}
\hline \multirow[b]{2}{*}{$\underline{\text { Medium }}$} & \multicolumn{3}{|c|}{$\begin{array}{l}\text { Table 8.18.10. The Hanford Site's 222-S Analytical Laboratory(a) Performance on } \\
\text { DOE Quality Assessment Program Samples, } 2004\end{array}$} \\
\hline & $\underline{\text { Radionuclide }}$ & $\begin{array}{c}\text { Number of Results } \\
\text { Reported }\end{array}$ & $\begin{array}{c}\text { Number of Results } \\
\text { Within Acceptable Limits }\end{array}$ \\
\hline Air filters & $\begin{array}{l}{ }^{60} \mathrm{Co},{ }^{134} \mathrm{Cs},{ }^{137} \mathrm{Cs} \text {, gross alpha, } \\
\text { gross beta }\end{array}$ & 5 & 5 \\
\hline Soil & ${ }^{137} \mathrm{Cs}$, total uranium & 2 & 2 \\
\hline Vegetation & ${ }^{137} \mathrm{Cs}$ & 1 & 1 \\
\hline Water & $\begin{array}{l}{ }^{3} \mathrm{H},{ }^{60} \mathrm{Co},{ }^{90} \mathrm{Sr},{ }^{137} \mathrm{Cs},{ }^{238} \mathrm{Pu},{ }^{239 / 240} \mathrm{Pu}, \\
\text { gross alpha, gross beta, total uranium }\end{array}$ & 9 & 9 \\
\hline $\begin{array}{l}\text { (a) Onsite } \\
\text { sample }\end{array}$ & $\begin{array}{l}\text { h-level radiological laboratory operated by } \\
\text { e low-level environmental activity sample }\end{array}$ & CH2M HILL Hanford ( & p, Inc. (Note: These \\
\hline
\end{tabular}

Table 8.18.11. The Hanford Site's 222-S Analytical Laboratory (a) Performance on EPA Laboratory Water Pollution Inorganic and Organic Studies, 2004

\begin{tabular}{|c|c|c|}
\hline Laboratory & $\begin{array}{l}\text { Water Pollution Study } 111 \\
\text { June } 2004 \\
\text { \% Acceptable }\end{array}$ & $\begin{array}{l}\text { Water Pollution Study } 117 \\
\text { December } 2004 \\
\text { \% Acceptable }\end{array}$ \\
\hline 2-S Analytical Laboratory & $99^{(\mathrm{b})}$ & $99^{(\mathrm{c})}$ \\
\hline \multicolumn{3}{|c|}{$\begin{array}{l}\text { Onsite high-level radiological laboratory operated by CH2M HILL Hanford Group, Inc. } \\
\text { Of } 163 \text { analytes, } 161 \text { were evaluated as acceptable. } \\
\text { Of } 170 \text { analytes, } 169 \text { were evaluated as acceptable. }\end{array}$} \\
\hline
\end{tabular}




\subsection{References}

10 CFR 820. "Procedural Rules for DOE Nuclear Activities." Code of Federal Regulations, U.S. Department of Energy.

10 CFR 830. "Nuclear Safety Management." Code of Federal Regulations, U.S. Department of Energy.

10 CFR 835. "Occupational Radiation Protection." Code of Federal Regulations, U.S. Department of Energy.

10 CFR 1021. "Compliance with the National Environmental Policy Act." Code of Federal Regulations, U.S. Department of Energy.

29 CFR 1910, Subpart Z. "Toxic and Hazardous Substances." Code of Federal Regulations, U.S. Department of Labor.

29 CFR 1910.1200(c). "Hazard Communication." Code of Federal Regulations, U.S. Department of Labor.

40 CFR 50. "National Primary and Secondary Ambient Air Quality Standards." Code of Federal Regulations, U.S. Environmental Protection Agency.

40 CFR 61. "National Emission Standards for Hazardous Air Pollutants." Code of Federal Regulations, U.S. Environmental Protection Agency.

40 CFR 61.92. "Standards." Code of Federal Regulations, U.S. Environmental Protection Agency.

40 CFR 61, Subpart H. "National Emission Standards for Emissions of Radionuclides Other Than Radon from Department of Energy Facilities." Code of Federal Regulations, U.S. Environmental Protection Agency.

40 CFR 61, Subpart M. "National Emission Standard for Asbestos." Code of Federal Regulations, U.S. Environmental Protection Agency.

40 CFR 122. "EPA Administered Permit Programs: The National Pollutant Discharge Elimination System." Code of Federal Regulations, U.S. Environmental Protection Agency.
40 CFR 141. "National Primary Drinking Water Regulations; Radionuclides; Proposed Rule." Code of Federal Regulations, U.S. Environmental Protection Agency.

40 CFR 265.93(b) and (d). "Interim Status Standards for Owners and Operators of Hazardous Waste Treatment, Storage, and Disposal Facilities; Preparation, Evaluation, and Response." Code of Federal Regulations, U.S. Environmental Protection Agency.

40 CFR 300. "National Oil and Hazardous Substances Pollution Contingency Plan." Code of Federal Regulations, U.S. Environmental Protection Agency.

40 CFR 302. "Designation, Reportable Quantities and Notification.” Code of Federal Regulations, U.S. Environmental Protection Agency.

40 CFR 355. "Emergency Planning and Notification." Code of Federal Regulations, U.S. Environmental Protection Agency.

40 CFR 761. "Polychlorinated Biphenyls (PCBs) Manufacturing, Processing, Distribution in Commerce, and Use Prohibitions." Code of Federal Regulations, U.S. Environmental Protection Agency.

40 CFR 761.60(j). "Disposal Requirements." Code of Federal Regulations. U.S. Environmental Protection Agency.

40 CFR 761.180. "General Records and Reports." Code of Federal Regulations, U.S. Environmental Protection Agency.

40 CFR 1500-1508. "Regulations for Implementing the Procedural Provisions of the National Environmental Policy Act." Code of Federal Regulations, Council on Environmental Quality.

50 CFR 17. "Endangered and Threatened Wildlife and Plants." Code of Federal Regulations, U.S. Department of Interior. 
50 CFR 17, Subpart B. "Lists." Code of Federal Regulations, U.S. Department of Interior.

36 FR 8921, May 13, 1971. Executive Order 11593, "Protection and Enhancement of the Cultural Environment." Federal Register.

52 FR 2923, January 29, 1987. Executive Order 12580, "Superfund Implementation." Federal Register.

55 FR 8666. "National Oil and Hazardous Substances Pollution Contingency Plan." Federal Register.

65 FR 114. June 13, 2000. Presidential Proclamation 7319, "Establishment of the Hanford Reach National Monument." Federal Register.

65 FR 24595, April 26, 2000. Executive Order 13148, "Greening the Government Through Leadership in Environmental Management." Federal Register.

65 FR 37253. 2000. "Establishment of the Hanford Reach National Monument." Proclamation 7319 of June 9, 2000, by the President of the United States of America. Federal Register.

68 FR 10635, March 3, 2003. Executive Order 13287, "Preserve America." Federal Register.

69 FR 39449, June 30, 2004. "Waste Management Program: Treatment and Storage of Transuranic Waste." Federal Register.

American Indian Religious Freedom Act. 1978. Public Law 95-341, as amended, 42 USC 1996, 1996 note.

Ames BN, R Magaw, and LS Gold. 1987. "Ranking Possible Carcinogenic Hazards.” Science 236:271-280.

ANL-EAD-4. 2002. Users Manual for RESRAD Version 6.21. C Yu, AJ Zielen, JJ Cheng, DJ LePoire, E Gnanapgragasam, S Kamboj, J Arnish, A Wallo III, WA Williams, and H Peterson, Argonne National Laboratory, Argonne, Illinois.

Antiquities Act. 1906. 34 Stat. 225, 16 USC 431-433.

AP-42. 1995. Compilation of Air Pollutant Emission Factors, Volume I: Stationary Point and Area Sources, Fifth Edition. Office of Air Quality Planning and Standards, Office of Air and Radiation, U.S. Environmental Protection Agency, Research Triangle Park, North Carolina.
Archaeological and Historic Preservation Act. 1974. Public Law 93-291, as amended, 16 USC 469-469c-2.

Archaeological Resources Protection Act. 1979. Public Law 96-95, as amended, 16 USC 470-470ii.

ARH-CD-775. 1976. Geohydrologic Study of the West Lake Basin. RE Gephart, PA Eddy, RC Arnett, and GA Robinson, Atlantic Richfield Hanford Company, Richland, Washington.

ASME NQA-1-1997 Edition. 1997. Quality Assurance Requirements for Nuclear Facility Applications. American Society of Mechanical Engineers, New York.

Atomic Energy Act. 1954. Chapter 1073, 68 Stat. 919, 42 USC 2011 et seq.

Atallah S. 1980. "Assessing and Managing Industrial Risk.” Chemical Engineering 9/8/80:94-103.

Bald and Golden Eagle Protection Act. 1992. Public Law 87-884, as amended, 76 Stat. 1246, 16 USC 688 et seq.

Beasley TM, LA Ball, and JE Andrews III. 1981. "Hanford-Derived Plutonium in Columbia River Sediments." Science 214(20):913-915.

BHI-00778. 1996. Chromium in River Substrate Pore Water and Adjacent Groundwater: 100-D/DR Area, Hanford Site, Washington. Bechtel Hanford Inc., Richland, Washington.

BHI-01742. 2004. Archaeological Subsurface Testing Report: Remediation of Waste Sites 128-B-2 and 128-B-3 on the Hanford Site, Benton County, Washington. JJ Sharpe, TE Marceau, KR Fecht, and G Cruz, Bechtel Hanford, Inc., Richland, Washington.

BHI-01743. 2004. Archaeological Subsurface Testing Report: Remediation of Waste Sites 128-F-2 and 1607-F-5 on the Hanford Site, Benton County, Washington. JJ Sharpe, TE Marceau, KR Fecht, and G Cruz, Bechtel Hanford, Inc., Richland, Washington.

BNWL-1979. 1976. Environmental Surveillance at Hanford for CY-1975. DR Speer, JJ Fix, and PJ Blumer, Pacific Northwest Laboratory, Richland, Washington.

BNWL-2305. 1977. Association of Hanford Origin Radionuclides with Columbia River Sediment. DE Robertson and JJ Fix, Pacific Northwest Laboratory, Richland, Washington. 
Clean Air Act. 1986. Public Law 88-206, as amended, 42 USC 7401 et seq.

Clean Water Act. 1977. Public Law 95-217, as amended, 91 Stat. 1566 and Public Law 96-148, as amended.

Comprehensive Environmental Response, Compensation, and Liability Act. 1980. Public Law 96-150, as amended, 94 Stat. 2767, 42 USC 9601 et seq.

Corkran CC and C Thoms. 1996. Amphibians of Oregon, Washington, and British Columbia. Lone Pine Publishing, Renton, Washington, 175 pp.

Cox SE, PR Bell, JS Lowther, and PC VanMetre. 2004. Vertical Distribution of Trace Element Concentrations and Occurrence of Metallurgical Slag Particles in Accumulated Bed Sediments of Lake Roosevelt, Washington, September 2002. Scientific Investigations Report 2004-2005, U.S. Geological Survey.

CP-13514. 2003. 200-PW-1 Operable Unit Report on Step I Sampling and Analysis of the Dispersed Carbon Tetrachloride Vadose Zone Plume. Fluor Hanford, Inc., Richland, Washington.

CP-14592, Rev. 0. 2003. 618-10 and 618-11 Waste Burial Grounds Basis for Interim Operations. LC Hulstrom and C Farwick, Fluor Hanford, Inc., Richland, Washington.

CP-16244, Revision 0. 2003. Data Quality Objectives Summary Report for the U Plant Closure Area Waste Sites. Fluor Hanford, Inc., Richland, Washington.

CP-22319. 2004. Plan for Central Plateau Closure. Fluor Hanford Inc., Richland, Washington.

Cushing CE, DG Watson, AJ Scott, and JM Gurtisen. 1981. "Decrease of Radionuclides in Columbia River Biota Following Closure of the Hanford Reactors." Health Physics 41:59-67.

D\&D-23840. 2004. Radiological Survey Records for the 618-10 and 618-11 Burial Grounds (1953 through 1967). Fluor Hanford, Inc., Richland, Washington.

Dauble DD and DG Watson. 1997. "Status of Fall Chinook Salmon Populations in the Mid-Columbia River: 1948-1992." North American Journal of Fisheries Management 17:283-300.
Defense Nuclear Facilities Safety Board. 1994. Recommendation 94-2, Conformance with Safety Standards at DOE Low-Level Nuclear Waste and Disposal Sites. Washington, D.C. Available URL: http://www.deprep.org/archive/ rec/94-2.asp.

Defense Nuclear Facilities Safety Board. 2002. Recommendation 2002-1, Quality Assurance for Safety Software at Department of Energy Defense Nuclear Facilities. Washington, D.C. Available URL: http://www.deprep. org/archive/rec/2002-1.asp.

DeWitt TH, RC Swartz, DJ Hansen, D McGovern, and WJ Berry. 1996. "Bioavailability and Chronic Toxicity of Cadmium in Sediment to the Estuarine Amphipod Leptocheirus plumulosus." Environmental Toxicology and Chemistry 15(12):2095-2101.

Dinman BD. 1980. "The Reality and Acceptance of Risk." Journal of the American Medical Association (JAMA) (11):1226-1228.

DOE. 2000. American Indian and Alaska Native Tribal Government Policy. U.S. Department of Energy, Washington, D.C.

DOE. 2002. Toxic Substances Control Act, Polychlorinated Biphenyl Hanford Users Guide. U.S. Department of Energy, Richland, Washington.

DOE/EH-0173T. 1991. Environmental Regulatory Guide for Radiological Effluent Monitoring and Environmental Surveillance. U.S. Department of Energy, Washington, D.C.

DOE/EH-0676. 2004. User's Guide, Version 1. RESRADBIOTA: A Tool for Implementing a Graded Approach to Biota Dose Evaluation. Interagency Steering Committee on Radiation Standards Technical Report 2004-02, U.S. Department of Energy, Washington, D.C.

DOE/EIS-0113. 1987. Final Environmental Impact Statement, Disposal of Hanford Defense High-Level, Transuranic, and Tank Wastes, Hanford Site, Richland, Washington. U.S. Department of Energy, Washington, D.C.

DOE/EIS-0113-SA4. 2004. Supplement Analysis. Waste Retrieval from the 218-W-4C, 218-E-12B, 218-W-3A, and 218-W-4B Low-Level Burial Grounds, 200 Areas, Richland, Washington. U.S. Department of Energy, Richland, Washington. 
DOE/EIS-0222-F. 1999. Final Hanford Comprehensive Land-Use Plan Environmental Impact Statement. U.S. Department of Energy, Washington, D.C. Available URL: http://www.hanford.gov/eis/hraeis/hraeis.htm.

DOE/EIS-0286F. 2004. Final Hanford Site Solid (Radioactive and Hazardous) Waste Program Environmental Impact Statement, Richland, Washington. U.S. Department of Energy, Richland Operations Office, Richland, Washington.

DOE/IG-0514. 2001. Administrative Control of the Hanford Reach National Monument. U.S. Department of Energy, Washington, D.C.

DOE Manual 231.1-1A. "Environment, Safety, and Health Reporting Manual."

DOE Order 231.1A. "Environment, Safety, and Health Reporting.

DOE Order 414.1B. "Quality Assurance."

DOE Order 435.1. "Radioactive Waste Management."

DOE Order 450.1. "Environmental Protection Program."

DOE Order 451.1B, Change 1. "National Environmental Policy Act Compliance Program - Change 1."

DOE Order 5400.1. "General Environmental Protection Program."

DOE Order 5400.5. "Radiation Protection of the Public and the Environment."

DOE Order 5820.2A. "Radioactive Waste Management."

DOE P 450.4. 1996. Safety Management System Policy. U.S. Department of Energy, The Office of Environment, Safety and Health, Washington, D.C.

DOE/RL-91-28, Rev. 4. 1998. Hanford Facility Dangerous Waste Permit Application, General Information Portion. U.S. Department of Energy, Richland, Washington.

DOE/RL-91-50, Rev. 3. 2000. Environmental Monitoring Plan, United States Department of Energy Richland Operations Office. U.S. Department of Energy, Richland, Washington.

DOE/RL-92-12, Rev. 1. 1992. Sampling and Analysis of 100 Area Springs. U.S. Department of Energy, Richland, Washington.
DOE/RL-92-67, Draft B. 1992. Final Remedial Investigation/ Feasibility Study - Environmental Assessment Report for the 1100-EM-1 Operable Unit, Hanford. U.S. Department of Energy, Richland, Washington.

DOE/RL-94-102, Rev. 1. 1995. Proposed Plan for Interim Remedial Measure at the 100-HR-3 Operable Unit. Prepared by CH2M HILL Hanford, Inc. for Bechtel Hanford, Inc. for U.S. Department of Energy, Richland, Washington.

DOE/RL-94-113, Rev. 1. 1995. Proposed Plan for Interim Remedial Measure at the 100-KR-4 Operable Unit. Prepared by CH2M HILL Hanford, Inc. for Bechtel Hanford, Inc. for U.S. Department of Energy, Richland, Washington.

DOE/RL-94-150, Rev. 0. 1994. Bald Eagle Site Management Plan for the Hanford Site, South-Central Washington. RE Fitzner and SG Weiss, Pacific Northwest Laboratory and CH2M HILL Hanford, Inc. for U.S. Department of Energy, Richland, Washington.

DOE/RL-96-32, Rev. 0. 2000. Hanford Site Biological Resources Management Plan. U.S. Department of Energy, Richland, Washington.

DOE/RL-96-68, Rev 2. 1996. Hanford Analytical Services Quality Assurance Requirements Document. U.S. Department of Energy, Richland, Washington.

DOE/RL-96-77, Rev 0. 1996. Programmatic Agreement Among the U.S. Department of Energy, Richland Operations Office, the Advisory Council on Historic Preservation, and the Washington State Historic Preservation Office for the Maintenance, Deactivation, Alteration, and Demolition of the Built Environment on the Hanford Site, Washington. U.S. Department of Energy, Richland, Washington.

DOE/RL-96-88, Rev. 0. 2003. Hanford Site Biological Resources Mitigation Strategy. U.S. Department of Energy, Richland, Washington. Available URL: http://www.pnl. gov/ecomon/Docs/BRMiS.pdf.

DOE/RL-98-10, Rev. 0. 2003. Hanford Cultural Resources Management Plan. U.S. Department of Energy, Richland Operations Office, Richland, Washington.

DOE/RL-98-28, Rev. 0. 1999. 200 Areas Remedial Investigation/Feasibility Study Implementation Plan - Environmental Restoration Program. U.S. Department of Energy, Richland, Washington. 
DOE/RL-98-77, Rev. 0. 1998. Control of the Spread of Radioactive Contamination Due to Biological Transport On the Hanford Site. U.S. Department of Energy, Richland, Washington.

DOE/RL-99-44, Rev. 0. 2000. 200-CS-1 Operable Unit RI/FS Work Plan and RCRA TSD Unit Sampling Plan. U.S. Department of Energy, Richland, Washington.

DOE/RL-99-66, Rev. 0. 2000. 200-CW-5 U-Pond/ Z-Ditches Cooling Water Group Operable Unit RI/FS Work Plan. U.S. Department of Energy, Richland, Washington.

DOE/RL-2000-38, Rev. 0. 2001. 200-TW-1 Scavenged Waste Group Operable Unit and 200-TW-2 Tank Waste Group Operable Unit RI/FS Work Plan. U.S. Department of Energy, Richland, Washington.

DOE/RL-2000-60, Draft A. 2000. 200-PW-2 UraniumRich Process Waste Group Operable Unit RI/FS Work Plan and RCRA TSD Unit Sampling Plan. U.S. Department of Energy, Richland, Washington.

DOE/RL-2001-01, Draft A. 2001. 200-PW-1 Plutonium/ Organic-Rich Process Condensate/Process Waste Group Operable Unit RI/FS Work Plan. U.S. Department of Energy, Richland, Washington.

DOE/RL-2001-01, Rev. 0. 2004. Plutonium/OrganicRich Process Waste Group Operable Unit RI/FS Work Plan: Includes the 200-PW-1, 200-PW-3, and 200-PW-6 Operable Units. U.S. Department of Energy, Richland, Washington.

DOE/RL-2001-11, Rev. 0. 2001. Final Feasibility Study for the Canyon Disposition Initiative (221-U Facility). U.S. Department of Energy, Richland Operations Office, Richland, Washington.

DOE/RL-2001-29, Rev. 0. 2004. Proposed Plan for Remediation of the 221-U Facility (Canyon Disposition Initiative). U.S. Department of Energy, Richland, Washington.

DOE/RL-2001-41, Rev 0. 2002. Sitewide Institutional Controls Plan for Hanford CERCLA Response Actions. U.S. Department of Energy, Richland, Washington.

DOE/RL-2001-65, Rev. 0. 2002. 200-MW-1 Miscellaneous Waste Group Operable Unit RI/FS Work Plan. U.S. Department of Energy, Richland, Washington.
DOE/RL-2001-66, Rev. 0. 2002. Chemical Laboratory Waste Group Operable Unit RI/FS Work Plan -- Includes: 200-LW-1 and 200-LW-2 Operable Units. U.S. Department of Energy, Richland, Washington.

DOE/RL-2002-14, Rev. 1A. 2002. Tanks/Lines/Pits/Boxes/ Septic Tank and Drain Fields Waste Group Operable Unit RI/FS Work Plan and RCRA TSD Unit Sampling Plan Includes: 200-IS-1 and 200-ST-1 Operable Units. U.S. Department of Energy, Richland, Washington.

DOE/RL-2002-38, Rev. 0. 2002. Hanford Site Air Operating Permit Semiannual Report for the Period January 1, 2002 through June 30, 2002. U.S. Department of Energy, Richland, Washington.

DOE/RL-2002-42, Rev. 0. 2003. Remedial Investigation Report for the 200-TW-1 and 200-TW-2 Operable Units. U.S. Department of Energy, Richland, Washington.

DOE/RL-2002-47, Rev D. 2002. Performance Management Plan for the Accelerated Cleanup of the Hanford Site. U.S. Department of Energy, Richland, Washington. Available URL: http:///www.hanford.gov/docs/hpmp.

DOE/RL-2002-68, Rev 0. 2003. Hanford's Groundwater Plan: Accelerated Cleanup and Protection. U.S. Department of Energy, Richland, Washington.

DOE/RL-2003-11, Rev. 0. 2004. Remedial Investigation Report for the 200-CW-5 U Pond/Z-Ditches Cooling Water Group, the 200-CW-2 S Pond and Cooling Water Group, the 200-CW-4 T Pond and Ditches Cooling Water Group, and the 200-SC-1 Steam Condensate Group Operable Units. U.S. Department of Energy, Richland, Washington.

DOE/RL-2003-12, Rev. 0. 2003. Hanford Facility Dangerous Waste Permit Application, Integrated Disposal Facility. U.S. Department of Energy, Richland, Washington.

DOE/RL-2003-23, Draft A. 2003. Focused Feasibility Study for the U Plant Closure Area Waste Sites. U.S. Department of Energy, Richland, Washington.

DOE/RL-2003-24, Draft A. 2003. Proposed Plan for the U Plant Closure Area Waste Sites. U.S. Department of Energy, Richland, Washington. 
DOE/RL-2003-44, Rev. 0. 2003. BC Cribs and Trenches 200-TW-1 Operable Unit Borehole Sampling and Analysis Plan. U.S. Department of Energy, Richland, Washington.

DOE/RL-2003-51, Draft A. 2003. Sampling and Analysis Plan for the U Plant Closure Area Waste Sites. Fluor Hanford, Inc., Richland, Washington.

DOE/RL-2003-64, Draft A. 2003. Feasibility Study for 200-TW-1 Scavenged Waste Group, the 200-TW-2 Tank Waste Group, and the 200-PW-5 Fission-Product-Rich Waste Group Operable Units. U.S. Department of Energy, Richland, Washington.

DOE/RL-2004-10, Draft A. 2004. Proposed Plan for the 200-TW-1 Scavenged Waste Group, the 200-TW-2 Tank Waste Group, and the 200-PW-5 Fission-Product-Rich Waste Group Operable Units. U.S. Department of Energy, Richland, Washington.

DOE/RL-2004-17, Rev. 0. 2004. Remedial Investigation for the 200-CS-1 Chemical Sewer Group Operable Unit. U.S. Department of Energy, Richland, Washington.

DOE/RL-2004-23, Rev 0. 2004. Hanford Facility Annual Dangerous Waste Report, Calendar Year 2003. U.S. Department of Energy, Richland, Washington.

DOE/RL-2004-24, Draft A. 2004. Feasibility Study for the 200-CW-2 (S Pond/Ditches), 200-CW-4 (T Pond/Ditches) Cooling Water Group, and 200-SC-1 Steam Condensate Group Operable Units. U.S. Department of Energy, Richland, Washington.

DOE/RL-2004-25, Draft A. 2004. Remedial Investigation for the 200-PW-2 Uranium-Rich Process Waste Group and 200-PW-4 General Process Condensate Group Operable Units. U.S. Department of Energy, Richland, Washington.

DOE/RL-2004-39, Draft A. 2004. 200-UR-1 Unplanned Release Waste Group Operable Unit Remedial Investigation/ Feasibility Study Work Plan. U.S. Department of Energy, Richland, Washington.

DOE/RL-2004-51. 2004. 2003 Polychlorinated Biphenyl Annual Document Log - Report for the Hanford Site. U.S. Department of Energy, Richland, Washington.

DOE/RL-2004-52. 2004. 2003 Polychlorinated Biphenyl Annual Report - For the Hanford Site. U.S. Department of Energy, Richland, Washington.
DOE/RL-2004-56, Rev. 0. 2004. 2004 Site Wide Institutional Controls Annual Assessment Report for Hanford CERCLA Response Actions. U.S. Department of Energy, Richland, Washington.

DOE/RL-2004-57. 2004. Hanford Site Pollution Prevention and Waste Minimization Plan. U.S. Department of Energy, Richland, Washington.

DOE/RL-2004-60, Draft A. 2004. 200-SW-1 Nonradioactive Landfills and Dumps Group Operable Unit and 200-SW-2 Radioactive Landfills and Dumps Group Operable Unit Remedial Investigation/Feasibility Study Work Plan. U.S. Department of Energy, Richland, Washington.

DOE/RL-2005-06, Rev 0. 2005. Radionuclide Air Emissions Report for the Hanford Site, Calendar Year 2004. Prepared by DJ Rokkan, DL Dyekman, and NA Homan (Fluor Hanford, Inc.), and K Rhoads and LH Staven (Pacific Northwest National Laboratory) for the U.S. Department of Energy, Richland, Washington.

DOE/RL-2005-11, Rev. 0. 2005. 2004 Hanford Site Tier Two Emergency and Hazardous Chemical Inventory. Emergency Planning and Community Right-To-Know Act Section 312. U.S. Department of Energy, Richland, Washington.

DOE/RL-2005-12, Rev. 0. 2004. Hanford Site Toxic Chemical Release Inventory. Emergency Planning and Community Right-To-Know Act Section 313. U.S. Department of Energy, Richland, Washington.

DOE/RL-2005-22, Rev. 0. 2005. 100-NR-2 Study Area Ecological Risk Assessment Sampling and Analysis Plan. U.S. Department of Energy, Richland, Washington.

DOE-STD-1153-2002. 2002. A Graded Approach for Evaluating Radiation Doses to Aquatic and Terrestrial Biota. U.S. Department of Energy, Washington, D.C.

DOH 320-031. 2004. Final Environmental Impact Statement. Washington State Department of Health, Olympia, Washington.

DOH 320-032. 2004. 2003 External Radiation Survey Along the Columbia River Shoreline of the Hanford Site's 100 Area. Washington State Department of Health, Olympia, Washington. 
DOH 320-034. 2005. Survey of Potential Hanford Site Contaminants in the Upper Sediment for the Reservoirs at McNary, John Day, The Dalles, and Bonneville Dams, 2003. Washington State Department of Health, Olympia, Washington.

DTS-OEM-001. 2003. Operational Environmental Monitoring. SM McKinney, Duratek Technical Services, Northwest Operations, Richland, Washington.

Duenas C, MC Fernandez, J Carretero, E Liger, and S Canete. 2003. "7Be and 210Pb Concentrations in Air in Malaga (Spain)." Journal of Radioanalytical and Nuclear Chemistry 257:249-253.

Ecology - Washington State Department of Ecology, U.S. Environmental Protection Agency, and U.S. Department of Energy. 1989. Hanford Federal Facility Agreement and Consent Order. Document No. 89-10, as amended (The Tri-Party Agreement), Olympia, Washington.

Ecology. 1994. Dangerous Waste Portion of the Resource Conservation and Recovery Act Permit for the Treatment, Storage, and Disposal of Dangerous Waste. Permit Number WA 7890008967, as amended. Washington State Department of Ecology, Olympia, Washington.

Eisenbud M. 1987. Environmental Radioactivity from Natural, Industrial, and Military Sources. Third Edition, Chapter 5, Academic Press, Inc., New York.

Emergency Planning and Community Right-To-Know Act. 1986. Public Law 99-499, as amended, 100 Stat. 1728, 42 USC 11001 et seq.

EML-621. June 2003. Semi-Annual Report of the Department of Energy, Office of Environmental Management, Quality Assessment Program. PD Greenlaw and A Berne, Environmental Measurements Laboratory, U.S. Department of Energy, New York.

Endangered Species Act. 1973. Public Laws 93-205 through 100-707, as amended, 87 Stat. 884, 16 USC 1531 et seq.

Environmental News Network. 2000. Bullfrog's Serenade Signals Trouble in Canada. Available URL: http://www.cnn. com/2000/NATURE/08/21/bullfrog.enn.
EPA. 1986. Test Methods for Evaluating Solid Waste: Physical/Chemical Methods, SW-846, Third Edition. Office of Solid Waste and Emergency Response, U.S. Environmental Protection Agency, Washington, D.C.

EPA. 1994. Federal Facility Compliance Agreement for Radionuclides NESHAP, for the U.S. Department of Energy, Richland Operations Office, Richland, Washington. U.S. Environmental Protection Agency, Region 10, Seattle, Washington.

EPA. 1996a. Records of Decision for the 100-HR-3 and 100-KR-4 Operable Units. U.S. Environmental Protection Agency, Washington, D.C.

EPA. 1996b. Record of Decision for the 300-FF-1 and 300-FF-5 Operable Units. U.S. Environmental Protection Agency, Region 10, Seattle, Washington.

EPA. 2001. Declaration of the Record of Decision for the 300-FF-2 Operable Unit. Washington State Department of Ecology, U.S. Environmental Protection Agency, and U.S. Department of Energy, Richland Operations Office, Richland, Washington.

EPA 402-R-00-004. 2000. Updated User's Guide for CAP88-PC, Version 2.0. Office of Radiation and Indoor Air, U.S. Environmental Protection Agency, Washington, D.C.

EPA 520/1-80-012. 1980. Upgrading Environmental Radiation Data: Health Physics Society Committee Report HPSR-1 (1980). U.S. Environmental Protection Agency, Washington, D.C.

EPA 520/1-89-005. 1989. Risk Assessment Methodology: Draft Environmental Impact Statement for Proposed NESHAPS for Radionuclides, Vol. 1, Background Information Document. U.S. Environmental Protection Agency, Washington, D.C.

EPA-570/9-76-003. 1976. National Interim Primary Drinking Water Regulations. U.S. Environmental Protection Agency, Office of Water Supply, Washington, D.C.

EPA 822-R-96-001. 1996. Drinking Water Regulations and Health Advisories. U.S. Environmental Protection Agency, Office of Water, Washington, D.C. 
EPA QA/R-5. 1994. Requirements for Quality Assurance Project Plans for Environmental Data Operations. U.S. Environmental Protection Agency, Washington, D.C.

Federal Advisory Committee Act. 1972. Public Law 92-463, as amended, 86 Stat. 770.

Federal Insecticide, Fungicide, and Rodenticide Act. 1975. Public Laws 94-51 through 94-140, as amended, 7 USC 136 et seq.

Frest TJ and EJ Johannes. 1995. Interior Columbia Basin Mollusk Species of Special Concern. Report to the Interior Columbia Basin Ecosystem Management Project, Walla Walla, Washington.

Hansen DJ, WJ Berry, JD Mahoney, WS Boothman, DM DiToro, DL Robson, GT Ankley, D Ma, Q Yan, and CE Pesch. 1996. "Predicting the Toxicity of Metal-Contaminated Field Sediments Using Interstitial Concentration of Metals and Acid-Volatile Sulfide Normalizations." Environmental Toxicology and Chemistry 15(12):2080-2094.

Hazardous and Solid Waste Amendments. 1984. Public Law 98-616, as amended, 42 USC 6926.

Historic Sites, Buildings and Antiquities Act. 1935. Chapter 593, as amended, 16 USC 461-467.

HNF-EP-0125-16. 2004. Summary of Radioactive Solid Waste Received in the 200 Areas During Calendar Year 2003. DL Hagel, Waste Management Federal Services of Hanford, Inc., Richland, Washington.

HNF-EP-0527-14. 2005. Environmental Releases for Calendar Year 2004. DL Dyekman and DJ Rokkan, Fluor Hanford, Inc., Richland, Washington.

Ho ECY and DF Measday. 2005. "A Simple Model for Describing the Concentration of $212 \mathrm{~Pb}$ in the Atmosphere." Journal of Environmental Radioactivity 78:289-309.

HW-73672. 1962. Dispersion of 300 Area Liquid Effluent in the Columbia River. GE Backman, Hanford Atomic Products Operation, General Electric Company, Richland, Washington.

ISO 14001. 1996. Environmental Management SystemsSpecifications with Guidance for Use. American Society for Testing and Materials, West Conshohocken, Pennsylvania.
Jenkins OP. 1922. Underground Water Supply of the Region About White Bluffs and Hanford. State of Washington Department of Conservation and Development, Olympia, Washington.

Johnson A, D Norton, B Yake, and S Twiss. 1990. "Transboundary Metal Pollution of the Columbia River (Franklin D. Roosevelt Lake).” Bull Environ Contam Toxicol 45:703-710.

MAPEP-03-W11. 2003. Water Sample MAPEP-03-W11 Performance Report. U.S. Department of Energy, Mixed Analyte Performance Evaluation Program, Radiological and Environmental Sciences Laboratory, Idaho Falls, Idaho.

MAPEP-04-MaS12. 2004. Soil Sample MAPEP-04-Study 12 Performance Report. U.S. Department of Energy, Mixed Analyte Performance Evaluation Program, Radiological and Environmental Sciences Laboratory, Idaho Falls, Idaho.

Marcazzan GM, E Caprioli, G Valli, and R Vecchi. 2003. "Temporal Variation of $212 \mathrm{~Pb}$ Concentration in Outdoor Air of Milian and a Comparison with 214Bi." Journal of Environmental Radioactivity 65:77-90.

Memorandum of Agreement. 1996. Memorandum of Agreement Among the United States Department of Energy, United States Department of the Interior, Nez Perce Tribe, State of Oregon, Confederated Tribes of the Umatilla Indian Reservation, State of Washington (including the Departments of Ecology and Fish and Wildlife), and the Confederated Tribes and Bands of the Yakama Indian Nation. U.S. Department of Energy, Richland Operations Office, Richland, Washington.

Migratory Bird Treaty Act. 1918. Chapter 128, as amended, 40 Stat. 755, 16 USC 703-712.

Morgan G, S Corbett, and J Wlodarczyk. 1998. “Air Pollution and Hospital Admissions in Sydney, Australia, 1990 to 1994.” Am. J Public Health 88:1761-1766.

National Council on Radiation Protection and Measurements. 1975. Natural Background Radiation in the United States. NCRP Report No. 45, Washington, D.C. 
National Council on Radiation Protection and Measurements. 1987. Ionizing Radiation Exposure of the Population of the United States. NCRP Report No. 93, Bethesda, Maryland.

National Environmental Policy Act. 1969. Public Law 91-190, as amended, 42 USC 4321 et seq.

National Historic Preservation Act. 1966. Public Law 89-665, as amended, 16 USC 470 et seq.

National Oceanic and Atmospheric Administration (NOAA) Fisheries. 2005. Endangered Species Act Status Pages. Available URL: http://www.nwr.noaa.gov/1salmon/ salmesa/specprof.htm.

National Research Council. 1980. The Effects on Populations of Exposure to Low Levels of Ionizing Radiation: 1980. Committee on the Biological Effects of Ionizing Radiations, National Academy Press, Washington, D.C.

National Research Council. 1990. Health Effects of Exposure to Low Levels of Ionizing Radiation. Committee on the Biological Effects of Ionizing Radiations, National Academy Press, Washington, D.C.

Native American Graves Protection and Repatriation Act. 1990. Public Law 101-601, as amended, 25 USC 3001 et seq.

NAVD88. 1988. North American Vertical Datum of 1988.

NERL-Ci-0045. December 30, 1998. National Standards for Water Proficiency Testing Studies, Criteria Document. U.S. Environmental Protection Agency, Washington, D.C.

Nuclear Waste Policy Act. Public Law 97-425, as amended, 42 USC 10101 et seq.

Nussbaum RA, ED Broadie Jr., and RM Storm. 1983. Amphibians and Reptiles of the Pacific Northwest. University of Idaho Press, Moscow, Idaho. 332 pp.

OHD. 1994. Environmental Radiological Surveillance Report on Oregon Surface Waters 1961-1993. Oregon Health Division, Radiation Protection Services, Portland, Oregon. Available URL: http://www.ohd.hr.state.or.us/rps/docs/ 6293new9.pdf.
Ostro BD, S Hurley, and MJ Lipsett. 1999. "Air Pollution and Daily Mortality in the Coachella Valley, California: A Study of PM10 Dominated by Coarse Particles." Environmental Research 81:231-238.

Patton GW, AT Cooper, and MR Tinker. 1997. "Ambient Air Sampling for Tritium - Determination of Breakthrough Volumes and Collection Efficiencies for Silica Gel Absorbent." Health Physics 72:397-407.

PNL-3127. 1980. Radiological Survey of Exposed Shorelines and Islands of the Columbia River Between Vernita and the Snake River Confluence. MJ Sula, Pacific Northwest Laboratory, Richland, Washington.

PNL-5289. 1984. Investigation of Ground-Water Seepage from the Hanford Shoreline of the Columbia River. WD McCormack and JMV Carlile, Pacific Northwest Laboratory, Richland, Washington.

PNL-6584 (3 vols). 1988. GENII - The Hanford Environmental Radiation Dosimetry Software System. BA Napier, RA Peloquin, DL Strenge, and JV Ramsdell, Pacific Northwest Laboratory, Richland, Washington.

PNL-7124. 1989. The Determination of the Penetrating Radiation Dose at Hanford. LA Rathbun, Pacific Northwest Laboratory, Richland, Washington.

PNL-7500. 1990. 1988 Hanford Riverbank Springs Characterization Report. RL Dirkes, Pacific Northwest Laboratory, Richland, Washington.

PNL-7662. 1991. An Evaluation of the Chemical, Radiological, and Ecological Conditions of West Lake on the Hanford Site. TM Poston, KR Price, and DR Newcomer, Pacific Northwest Laboratory, Richland, Washington.

PNL-8073. 1992. Hanford Site Ground-Water Monitoring for 1990. JC Evans, RW Bryce, and DJ Bates, Pacific Northwest Laboratory, Richland, Washington.

PNL-8148. 1992. Hanford Site Environmental Report for Calendar Year 1991. RK Woodruff, RW Hanf, and RE Lundgren (eds.), Pacific Northwest Laboratory, Richland, Washington.

PNL-8531. 1993. Columbia River Monitoring: Distribution of Tritium in Columbia River Water at the Richland Pumphouse. RL Dirkes, Pacific Northwest Laboratory, Richland, Washington. 
PNL-8580. 1993. Water Level Measurements for Modeling Hydraulic Properties in the 300-FF-5 and 100 Aggregate Area Operable Units. MD Campbell, WJ McMahon, and KR Simpson, Pacific Northwest Laboratory, Richland, Washington.

PNL-8654. 1993. Columbia River Monitoring: Summary of Chemical Monitoring Along Cross Sections at Vernita Bridge and Richland. RL Dirkes, GW Patton, and BL Tiller, Pacific Northwest Laboratory, Richland, Washington.

PNL-8817. 1993. Contribution of Hanford Liquid Effluents to Strontium-90 Levels in Offsite Soils. RE Jaquish, Pacific Northwest Laboratory, Richland, Washington.

PNL-8942. 1993. Habitat Types on the Hanford Site: Wildlife and Plant Species of Concern. JL Downs, WH Rickard, CA Brandt, LL Cadwell, CE Cushing, DR Geist, RM Mazaika, DA Neitzel, LE Rogers, MR Sackschewsky, and JJ Nugent, Pacific Northwest Laboratory, Richland, Washington.

PNL-9394. 1994. Ecotoxicity Literature Review of Selected Hanford Site Contaminants. CJ Driver, Pacific Northwest Laboratory, Richland, Washington.

PNL-10174. 1994. A Qualitative Evaluation of Radionuclide Concentrations in Hanford Site Wildlife, 1983 through 1992. TM Poston and AT Cooper, Pacific Northwest Laboratory, Richland, Washington.

PNL-10400. 1995. Identification of Contaminants of Concern, Columbia River Comprehensive Impact AssessmentDraft. BA Napier, NC Batishko, DA Heise-Craff, MF Jarvis, and SF Snyder, Pacific Northwest Laboratory, Richland, Washington.

PNL-10535. 1995. Environmental Monitoring of Columbia River Sediments: Grain-Size Distribution and Containment Association. ML Blanton, WW Gardiner, and RL Dirkes, Pacific Northwest Laboratory, Richland, Washington.

PNL-10698. 1995. Hanford Site Ground-Water Monitoring for 1994. PE Dresel, PD Thorne, SP Luttrell, BM Gillespie, WD Webber, JK Merz, JT Rieger, MA Chamness, SK Wurstner, and BE Optiz, Pacific Northwest Laboratory, Richland, Washington.
PNL-MA-580, Rev. 4. 2004. Surface Environmental Surveillance Procedures Manual. RW Hanf and TM Poston (eds.), Pacific Northwest National Laboratory, Richland, Washington.

PNNL-6415, Rev. 16. 2004. Hanford Site National Environmental Policy Act (NEPA) Characterization Report. DA Neitzel, AL Bunn, SD Cannon, JP Duncan, RA Fowler, BG Fritz, DW Harvey, PL Hendrickson, DJ Hoitink, DG Horton, GV Last, TM Poston, EL Prendergast-Kennedy, SP Reidel, AC Rohay, MJ Scott, and PD Thorne, Pacific Northwest National Laboratory, Richland, Washington.

PNNL-11472. 1997. Hanford Site Environmental Report for Calendar Year 1996. RL Dirkes and RW Hanf (eds.), Pacific Northwest National Laboratory, Richland, Washington.

PNNL-11518. 1997. Investigation of Anatomical Anomalies in the Hanford Site Mule Deer. BL Tiller, GE Dagle, LL Cadwell, TM Poston, and A Oganesian, Pacific Northwest National Laboratory, Richland, Washington.

PNNL-11795, APP. 1. 1998. Hanford Site Environmental Surveillance Data Report for Calendar Year 1997. LE Bisping, Pacific Northwest National Laboratory, Richland, Washington.

PNNL-11800. 1998. Composite Analysis of Low-Level Waste Disposal in the 200-Area Plateau of the Hanford Site. CT Kincaid, MP Bergeron, CR Cole, MD Freshley, NL Hassig, VG Johnson, DI Kaplan, RJ Serne, GP Streile, DL Strenge, PD Thorne, LW Vail, GA Whyatt, and SK Wurstner, Pacific Northwest National Laboratory, Richland, Washington.

PNNL-11933. 1998. Survey of Radiological Contaminants in the Near Shore Environment at the Hanford Site 100-N Reactor Area. SP Van Verst, CL Albin, GW Patton, ML Blanton, TM Poston, AT Cooper, and EJ Antonio, Pacific Northwest National Laboratory, Richland, Washington.

PNNL-12088. 1999. Hanford Site Environmental Report for Calendar Year 1998. RL Dirkes, RW Hanf, and TM Poston (eds.), Pacific Northwest National Laboratory, Richland, Washington. 
PNNL-13230. 2000. Hanford Site Environmental Report for Calendar Year 1999. TM Poston, RW Hanf, and RL Dirkes (eds.), Pacific Northwest National Laboratory, Richland, Washington.

PNNL-13417. 2001. Simultaneously-Extracted Metals/ Acid-Volatile-Sulfide and Total Metals in Surface Sediment from the Hanford Reach of the Columbia River and the Lower Snake River. GW Patton and EA Crecelius, Pacific Northwest National Laboratory, Richland, Washington.

PNNL-13487. 2001. Hanford Site Environmental Report for Calendar Year 2000. TM Poston, RW Hanf, RL Dirkes, and LF Morasch (eds.), Pacific Northwest National Laboratory, Richland, Washington.

PNNL-13688. 2001. Vascular Plants of the Hanford Site. MR Sackschewsky and JL Downs, Pacific Northwest National Laboratory, Richland, Washington.

PNNL-13692. 2002. Survey of Radiological and Chemical Contaminants in the Near-Shore Environment at the Hanford Site 300 Area. GW Patton, SP Van Verst, BL Tiller, EJ Antonio, and TM Poston, Pacific Northwest National Laboratory, Richland, Washington.

PNNL-13910. 2002. Hanford Site Environmental Report for Calendar Year 2001. TM Poston, RW Hanf, RL Dirkes, and LF Morasch (eds.), Pacific Northwest National Laboratory, Richland, Washington.

PNNL-13989. 2003. Historical Site Assessment: Select Hanford Reach National Monument Lands - Fitzner/ Eberhardt Arid Lands Ecology Reserve (ALE), McGee Ranch/ Riverlands, and North Slope Units. BG Fritz, RL Dirkes, TM Poston, and RW Hanf, Jr., Pacific Northwest National Laboratory, Richland, Washington.

PNNL-14027. 2002. An Initial Assessment of Hanford Impact Performed with the System Assessment Capability. RW Bryce, CT Kincaid, PW Eslinger, and LF Morasch (eds.), Pacific Northwest National Laboratory, Richland, Washington.

PNNL-14184. 2003. Hanford Site Environmental Surveillance Master Sampling Schedule. LE Bisping, Pacific Northwest National Laboratory, Richland, Washington.
PNNL-14295. 2003. Hanford Site Environmental Report for Calendar Year 2002. TM Poston, RW Hanf, RL Dirkes, and LF Morasch (eds.), Pacific Northwest National Laboratory, Richland, Washington.

PNNL-14295, APP. 1. 2003. Hanford Site Environmental Surveillance Data Report for Calendar Year 2002. LE Bisping, Pacific Northwest National Laboratory, Richland, Washington.

PNNL-14372. 2004. Technical Scope and Approach for the 2004 Composite Analysis of Low-Level Waste Disposal at the Hanford Site. CT Kincaid, RW Bryce, and JW Buck, Pacific Northwest National Laboratory, Richland, Washington.

PNNL-14444. 2003. Aquifer Sampling Tube Results for Fiscal Year 2003. MJ Hartman and RE Peterson, Pacific Northwest National Laboratory, Richland, Washington.

PNNL-14531. 2004. Technical Basis for the Derivation of Authorized Limits for Units of the Hanford Reach National Monument. BA Napier, WE Kennedy, Jr., TA Ikenberry, MM Hunacek, and AM Kennedy, Pacific Northwest National Laboratory.

PNNL-14548. 2004. Hanford Site Groundwater Monitoring for Fiscal Year 2003. MJ Hartman, LF Morasch, and WD Webber, Pacific Northwest National Laboratory, Richland, Washington.

PNNL-14553. 2004. Hanford Site Surveillance Master Sampling Schedule for Calendar Year 2004. LE Bisping, Pacific Northwest National Laboratory, Richland, Washington.

PNNL-14622. 2004. Authorized Limits Request: Radiological Clearance of Select Hanford Reach National Monument Lands. BA Napier, Pacific Northwest National Laboratory, Richland, Washington.

PNNL-14633. 2004. Fitzner/Eberhardt Arid Lands Ecology (ALE) Reserve Soil Sampling and Analysis Plan. BG Fritz, TM Poston, and RL Dirkes, Pacific Northwest National Laboratory, Richland, Washington.

PNNL-14687. 2004. Hanford Site Environmental Report for Calendar Year 2003. TM Poston, RW Hanf, RL Dirkes, and LF Morasch (eds.), Pacific Northwest National Laboratory, Richland, Washington. 
PNNL-14937. 2005. ALE Soil Sampling for Establishing Compliance with Authorized Limits. BG Fritz, TM Poston, and RL Dirkes, Pacific Northwest National Laboratory, Richland, Washington.

PNNL-14950. 2004. Soil Sampling and Analysis Plan for the McGee Ranch-Riverlands and North Slope Units of the Hanford Reach National Monument. BG Fritz and RL Dirkes, Pacific Northwest National Laboratory, Richland, Washington.

PNNL-15070. 2005. Hanford Site Groundwater Monitoring Report for Fiscal Year 2004. MJ Hartman, LF Morasch, and WD Webber (eds.), Pacific Northwest National Laboratory, Richland, Washington.

PNNL-15089. 2005. Site Specific Seismic Site Response Model for the Waste Treatment Plant, Hanford, Washington. AC Rohay and SP Reidel, Pacific Northwest National Laboratory, Richland, Washington.

PNNL-15094. 2005. Environmental Solutions, A Summary of Contributions for FY04: PNNL Contributions to CH2M HILL Hanford Group, Inc. TM Brouns, Pacific Northwest National Laboratory, Richland, Washington.

PNNL-15160. 2005. Hanford Site Climatological Data Summary 2004 with Historical Data. DJ Hoitink, JV Ramsdell Jr., KW Burk, and WJ Shaw, Pacific Northwest National Laboratory, Richland, Washington.

PNNL-15222, APP. 1. 2005. Hanford Site Environmental Surveillance Data Report for Calendar Year 2004. LE Bisping, Pacific Northwest National Laboratory, Richland, Washington.

PNNL-15222, APP. 2. 2005. Hanford Site Near-Facility Environmental Monitoring Data Report for Calendar Year 2004. CJ Perkins, RM Mitchell, RT Coffman, SM McKinney, and RC Roos, Duratek Technical Services for Pacific Northwest National Laboratory, Richland, Washington.

PNNL-15222-SUM. 2005. Summary of the Hanford Site Environmental Report for Calendar Year 2004. RW Hanf, LF Morasch, TM Poston, and RL Dirkes, Pacific Northwest National Laboratory, Richland, Washington.
RCW 15.58. Washington Pesticide Control Act. Revised Code of Washington.

RCW 17.21. Washington Pesticide Application Act. Revised Code of Washington.

RCW 43.21C. Washington State Environmental Policy Act. Revised Code of Washington.

RCW 70.94. Washington Clean Air Act. Revised Code of Washington.

RCW 70.105E. Mixed Hazardous Waste Management. Revised Code of Washington.

Record of Decision. 1995. Declaration of the Record of Decision for the USDOE Hanford Environmental Restoration Disposal Facility. State of Washington Department of Ecology, U. S. Environmental Protection Agency, and U.S. Department of Energy, Richland Operations Office, Richland, Washington.

Resource Conservation and Recovery Act. 1976. Public Law 94-580, as amended, 90 Stat. 2795, 42 USC 6901 et seq.

RL/RIM-2002-01, Rev. 4. 2004. Functions, Responsibilities, and Authorities Manual. U.S. Department of Energy, Richland, Washington.

RPP-10757. 2002. Technetium-99 in Groundwater at Hanford Well 299-W23-19: Options, Analysis and Recommended Action Report. CH2M HILL Hanford Group, Inc., Richland, Washington.

Safe Drinking Water Act. 1974. Public Law 93-523, as amended, 88 Stat. 1660, 42 USC 300 f et seq.

Safe Drinking Water Act Amendments. 1986. Public Laws 99-339 and 104-182, as amended, Stat. 666 and 1613, 42 USC 300 f et seq.

Sagan LA. 1987. Health Physics Society Official Journal: Special Issue on Radiation Hormesis 52(5).

Schwartz J. 1994. "PM 10 , Ozone, and Hospital Admissions for the Elderly in Minneapolis-St. Paul, Minnesota." Archives of Environmental Health 49(5):366-373.

Sharpe JJ. 2004. Cutbank Investigation along the Right Bank and Islands of the Columbia River of the Hanford Site. Prepared for Pacific Northwest National Laboratory by Bechtel Hanford, Inc., Richland, Washington. 
Soll J, JA Hall, R Pabst, and C Soper (eds.). 1999. Biodiversity Inventory and Analysis of the Hanford Site Final Report 1994-1999. The Nature Conservancy of Washington, Seattle, Washington.

Superfund Amendments and Reauthorization Act. 1986. Public Law 99-499, as amended, 100 Stat. 1613, 42 USC 11001 et seq.

Tiller BL and TM Poston. 2000. "Mule Deer Antlers as Biomonitors of Sr-90 on the Hanford Site." J of Env. Radioactivity 47:29-44.

Tiller BL, GE Dagle, and LL Cadwell. 1997. "Testicular Atrophy in a Mule Deer Population." J. Wildl. Manage. 33:420-429.

Toxic Substances Control Act. 1976. Public Law 94-469, as amended, 90 Stat. 2003, 15 USC 2601 et seq.

Travis CC and ST Hester. 1990. "Background Exposure to Chemicals: What Is the Risk?" Risk Analysis 10(4).

Tri-Party Agreement Agencies. 2002. Hanford Site TriParty Agreement Public Involvement Community Relations Plan. U.S. Department of Energy, Richland Operations Office, Richland, Washington.

United Nations Science Committee on the Effects of Atomic Radiation. 1988. Sources, Effects and Risks of Ionizing Radiation. Report E.88.1X.7, United Nations, New York.

U.S. Geological Survey. 1995. Nitrate Concentrations in Ground Water of the Central Columbia Plateau. Open File Report 95-445, U.S. Geological Survey, Tacoma, Washington.

U.S. Geological Survey Circular 1144. 1998. "Water Quality in the Central Columbia Plateau, Washington and Idaho, 1992-95.” AK Williamson, MD Munn, SJ Ryker, RJ Wagner, JC Ebbert, and AM Vanderpool, U.S. Geological Survey, Tacoma, Washington. Available URL: http://water.usgs.gov/pubs/circ/circ1144.

WA-94-1. 1995. Water Resources Data, Washington Water Year 1994. WD Wiggins, GP Ruppert, RR Smith, LL Reed, LE Hubard, and ML Courts, U.S. Geological Survey, Tacoma, Washington.
WA-99-1. 2000. Water Resources Data, Washington Water Year 1999. TJ Zembrzuski, Jr., WD Wiggins, RR Smith, SM Knowles, and VF Renslow, U.S. Department of Interior, Washington, D.C.

WAC 16-228. "Pesticide Regulations." Washington Administrative Code, Olympia, Washington.

WAC 173-201A. "Water Quality Standards for Surface Waters of the State of Washington." Washington Administrative Code, Olympia, Washington.

WAC 173-201A-040. "Toxic Substances." Washington Administrative Code, Olympia, Washington.

WAC 173-216. "State Waste Discharge Program.” Washington Administrative Code, Olympia, Washington.

WAC 173-240. "Submission of Plans and Reports for Construction of Wastewater Facilities." Washington Administrative Code, Olympia, Washington.

WAC 173-303. "Dangerous Waste Regulations." Washington Administrative Code, Olympia, Washington.

WAC 173-303-040. "Definitions." Washington Administrative Code, Olympia, Washington.

WAC 173-303-145. "Spills and Discharges into the Environment." Washington Administrative Code, Olympia, Washington.

WAC 173-303-400. "Dangerous Waste Regulations; Interim Status Facility Standards." Washington Administrative Code, Olympia, Washington.

WAC 173-303-645. "Dangerous Waste Regulations; Releases from Regulated Units." Washington Administrative Code, Olympia, Washington.

WAC 173-303-645(11)(g). "Dangerous Waste Regulations; Releases from Regulated Units." Washington Administrative Code, Olympia, Washington.

WAC 173-303-806(6). "Final Facility Permits." Washington Administrative Code, Olympia, Washington.

WAC 173-303-840(1)(b). "Procedures for Decision Making." Washington Administrative Code, Olympia, Washington. 
WAC 173-304. "Minimum Functional Standards for Solid Waste Handling." Washington Administrative Code, Olympia, Washington.

WAC 173-400. "General Regulations for Air Pollution Sources." Washington Administrative Code, Olympia, Washington.

WAC 173-425. “Open Burning." Washington Administrative Code, Olympia, Washington.

WAC 246-247. "Radiation Protection-Air Emissions." Washington Administrative Code, Olympia, Washington.

WAC 246-247-080(8) and (10). "Inspections, Reporting, and Recordkeeping." Washington Administrative Code, Olympia, Washington.

WAC 246-290. "Public Water Supplies." Washington Administrative Code, Olympia, Washington.

Washington Department of Fish and Wildlife. 2005. Species of Concern in Washington State. Olympia, Washington. Available URL: http://www.wdfw.wa.gov/wlm/ diversity/soc/soc.htm.

Washington Department of Fish and Wildlife. 2001. Game Status and Trend Report. Olympia, Washington.

Washington State GAP Analysis Project. 1997. Washington Cooperative Fish and Wildlife Research Unit. University of Washington, Seattle, Washington. Available URL: http://www.fish.washington.edu/naturemapping/ wagap/public_html/herps.

Washington Herp Atlas. 2002. Washington Natural Heritage Program, Washington Department of Fish and Wildlife and U.S.D.I. Bureau of Land Management. Available URL: http://www.dnr.wa.gov/nhp/refdesk/herp.

Washington Natural Heritage Program. 1997. Rare Plant Species County List. Washington State Department of Natural Resources, Olympia, Washington. Available URL: http://www.dnr.wa.gov/nhp/refdesk/plants.html.

Washington Natural Heritage Program. 2005. Rare Plant Species. Washington State Department of Natural Resources, Olympia, Washington. Available URL: http://www.dnr.wa.gov/nhp/refdesk/plants.html.
Wells D. 1994. Radioactivity in Columbia River Sediments and Their Health Effects. Washington State Department of Health, Olympia, Washington.

WHC-MR-0418. 1994. Historical Records of Radioactive Contamination in Biota at the 200 Areas of the Hanford Site. AR Johnson, BM Markes, JW Schmidt, AN Shah, SG Weiss, and KJ Wilson, Westinghouse Hanford Company, Richland, Washington.

WHC-SD-EN-TI-006. 1992. Hydrologic and Geologic Data Available for the Region North of Gable Mountain, Hanford Site, Washington. RE Peterson, Westinghouse Hanford Company, Richland, Washington.

WHC-SD-EN-TI-070. 1992. Soil Concentration Limits for Accessible and Inaccessible Areas. PD Rittman, Westinghouse Hanford Company, Richland, Washington.

WHC-SD-W236A-TI-002, Rev. 1. 1996. Probabilistic Seismic Hazard Analysis, DOE Hanford Site, Washington. Westinghouse Hanford Company, Richland, Washington.

Wilson R and ESC Crouch. 1987. "Risk Assessment and Comparisons: An Introduction.” Science 236(4799):267-270.

Winkler R, F Ruckerbauer, M Trautmannschimer, J Tschiersch, and E Karg. 2001. "Diurnal and Seasonal Variation of the Equilibrium State Between Short-Lived Radon Decay Products and Radon Gas in Ground-Level Air." Radiation and Environmental Biophysics 40:115-123.

WMP-18061. 2003. Optimization Strategy for Central Plateau Closure. Fluor Hanford, Inc., Richland, Washington.

WMP-19920. 2005. Data Quality Objectives Summary Report for 200-UR-1 Operable Unit Unplanned Releases Waste Group. Fluor Hanford, Inc., Richland, Washington.

WMP-20394. 2004. Design Basis/Design Criteria Report, 618-10 and 618-11 Burial Grounds Remedial Action Project. Fluor Hanford, Inc., Richland, Washington.

WMP-21465. 2004. Update to Geophysical Investigations of the 618-10 and 618-11 Burial Grounds, 300-FF-2 Operable Unit. Fluor Hanford, Inc., Richland, Washington.

Yokel J and DA Delistraty. 2003. "Arsenic, Lead, and Other Trace Elements in Soils Contaminated with Pesticide Residues at the Hanford Site (USA).” Environmental Toxicology 18(2):104-114. 


\section{Appendix A Helpful Information}

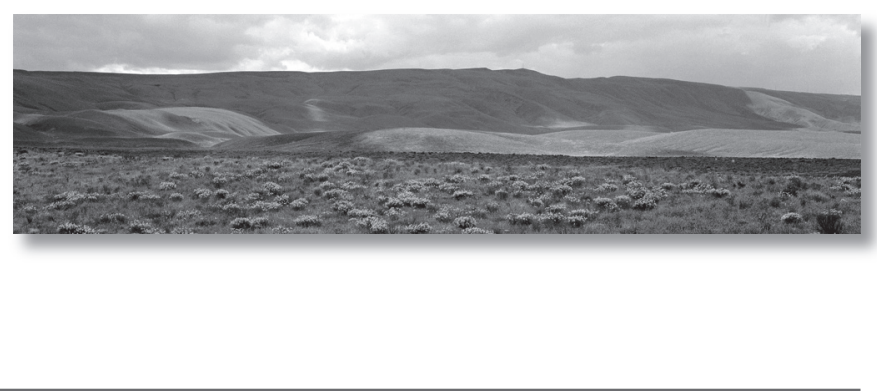

R. W. Hanf

The following information is provided to assist the reader in understanding this report. Included here is information on scientific notation, units of measure, radioactivity units, radiological dose units, chemical and elemental nomenclature, understanding data tables and data uncertainty, understanding graphs, and greater than or less than symbols. Definitions of technical terms can be found in Appendix B.

\section{Scientific Notation}

Scientific notation is used to express very large or very small numbers. For example, the number 1 billion could be written as $1,000,000,000$ or, by using scientific or $\mathrm{E}$ notation, written as $1 \times 10^{9}$ or $1.0 \mathrm{E}+09$. Translating from scientific notation to a more traditional number requires moving the decimal point either left or right from its current location. If the value given is $2.0 \times 10^{3}$ (or $2.0 \mathrm{E}+03$ ), the decimal point should be moved three places to the right so that the number would then read 2,000. If the value given is $2.0 \times 10^{-5}$ (or 2.0E-05), the decimal point should be moved five places to the left so that the result would be 0.00002 .

\section{Units of Measure}

The primary units of measure used in this report follow the International System of Units (SI) and are metric. Table A.1 summarizes and defines the terms and corresponding symbols (metric and non-metric). A conversion table is also provided in Table A.2.

\section{Radioactivity Units}

Much of this report deals with levels of activity (also known as radioactivity) in various environmental media.
Activity in this report is usually discussed in units of curies $(\mathbf{C} \mathbf{i})$, with conversions to becquerels $(\mathbf{B q})$, the SI unit, provided (Table A.3). The curie is the basic unit used to describe the amount of activity present, and activities are generally expressed in terms of curies per mass or volume (e.g., picocuries per liter). One curie is equivalent to 37 billion disintegrations per second or is a quantity of any radionuclide that decays at the rate of 37 billion disintegrations per second. One becquerel is equivalent to one disintegration per second. Nuclear disintegrations produce spontaneous emissions of alpha or beta particles, gamma radiation, or combinations of these. Table A.4 includes selected conversions from curies to becquerels.

\section{Radiological Dose Units}

Radiological dose in this report is usually written in terms of effective dose equivalent and reported numerically in units of millirems (mrem), with the metric units millisieverts $(\mathrm{mSv})$ following in parenthesis or footnoted.

Millirem (millisievert) is a term that relates a given amount of absorbed radiation energy to its biological effectiveness or risk (to humans). For perspective, a dose of 0.01 millirem ( 1 millisievert) would have a biological effect roughly the same as received from 1 day's exposure to natural background radiation. An acute (short-term) dose to the whole body of 100 rem (1 sievert) would likely cause temporary radiation sickness in some exposed individuals. An acute dose of over 500 rem (5 sieverts) would soon result in death in approximately $50 \%$ of those exposed. Exposure to lower amounts of radiation (10 mrem [100 $\mu \mathrm{Sv}]$ or less) produces no immediate observable effects, but long-term (delayed) effects are possible. The average person in the United States receives an annual dose from exposure to naturally produced 


\begin{tabular}{|c|c|c|c|}
\hline & \multicolumn{3}{|c|}{ Table A.1. Names and Symbols for Units of Measure } \\
\hline $\begin{array}{l}\text { Symbol } \\
\text { Temperature } \\
{ }^{\circ} \mathrm{C} \\
{ }^{\circ} \mathrm{F} \\
\text { Time } \\
\mathrm{d} \\
\mathrm{h} \\
\mathrm{min} \\
\mathrm{s} \\
\mathrm{yr} \\
\text { Rate } \\
\mathrm{cfs}\left(\mathrm{or} \mathrm{ft}^{3} / \mathrm{s}\right) \\
\mathrm{cpm} \\
\mathrm{gpm} \\
\mathrm{mph} \\
\mathrm{mR} / \mathrm{hr} \\
\mathrm{mrem} / \mathrm{yr} \\
\text { Volume } \\
\mathrm{cm}^{3} \\
\mathrm{ft}^{3} \\
\mathrm{gal}^{\mathrm{L}} \\
\mathrm{m}^{3} \\
\mathrm{~mL}^{3} \\
\mathrm{yd}^{3}\end{array}$ & $\begin{array}{l}\quad \text { Name } \\
\text { degree Celsius } \\
\text { degree Fahrenheit } \\
\text { day } \\
\text { hour } \\
\text { minute } \\
\text { second } \\
\text { year } \\
\text { cubic foot per second } \\
\text { counts per minute } \\
\text { gallon per minute } \\
\text { mile per hour } \\
\text { milliroentgen per hour } \\
\text { millirem per year } \\
\text { cubic centimeter } \\
\text { cubic foot } \\
\text { gallon } \\
\text { liter } \\
\text { cubic meter } \\
\text { milliliter }\left(1 \times 10^{-3} \mathrm{~L}\right) \\
\text { cubic yard }\end{array}$ & $\begin{array}{l}\text { Symbol } \\
\text { Concentration } \\
\text { ppb } \\
\text { ppm } \\
\text { ppmv } \\
\text { Length } \\
\mathrm{cm} \\
\mathrm{ft} \\
\mathrm{in} . \\
\mathrm{km} \\
\mathrm{m} \\
\mathrm{mi} \\
\mathrm{mm} \\
\mu \mathrm{m} \\
\text { Area } \\
\mathrm{ha} \\
\mathrm{km} \mathrm{m}^{2} \\
\mathrm{mi}{ }^{2} \\
\mathrm{ft}^{2} \\
\text { Mass } \\
\mathrm{g} \\
\mathrm{kg} \\
\mathrm{mg} \\
\mu \mathrm{g} \\
\mathrm{lb}\end{array}$ & $\begin{array}{l}\quad \text { Name } \\
\text { parts per billion } \\
\text { parts per million } \\
\text { parts per million by volume } \\
\text { centimeter }\left(1 \times 10^{-2} \mathrm{~m}\right) \\
\text { foot } \\
\text { inch } \\
\text { kilometer }\left(1 \times 10^{3} \mathrm{~m}\right) \\
\text { meter } \\
\text { mile } \\
\text { millimeter }\left(1 \times 10^{-3} \mathrm{~m}\right) \\
\text { micrometer }\left(1 \times 10^{-6} \mathrm{~m}\right) \\
\text { hectare }\left(1 \times 10^{4} \mathrm{~m}^{2}\right) \\
\text { square kilometer } \\
\text { square mile } \\
\text { square foot } \\
\text { gram } \\
\text { kilogram }\left(1 \times 10^{3} \mathrm{~g}\right) \\
\text { milligram }\left(1 \times 10^{-3} \mathrm{~g}\right) \\
\text { microgram }\left(1 \times 10^{-6} \mathrm{~g}\right) \\
\text { pound }\end{array}$ \\
\hline
\end{tabular}

\begin{tabular}{|c|c|c|c|c|c|}
\hline \multirow[b]{2}{*}{ Multiply } & \multirow[b]{2}{*}{$\underline{\text { By }}$} & \multicolumn{2}{|c|}{ Table A.2. Conversion Table } & \multirow[b]{2}{*}{$\underline{\text { By }}$} & \multirow[b]{2}{*}{ To Obtain } \\
\hline & & To Obtain & Multiply & & \\
\hline $\mathrm{cm}$ & 0.394 & in. & in. & 2.54 & $\mathrm{~cm}$ \\
\hline $\mathrm{m}$ & 3.28 & $\mathrm{ft}$ & $\mathrm{ft}$ & 0.305 & $\mathrm{~m}$ \\
\hline $\mathrm{km}$ & 0.621 & $\mathrm{mi}$ & $\mathrm{mi}$ & 1.61 & $\mathrm{~km}$ \\
\hline $\mathrm{kg}$ & 2.205 & $\mathrm{lb}$ & $\mathrm{lb}$ & 0.454 & $\mathrm{~kg}$ \\
\hline $\mathrm{L}$ & 0.2642 & gal & gal & 3.785 & $\mathrm{~L}$ \\
\hline $\mathrm{m}^{2}$ & 10.76 & $\mathrm{ft}^{2}$ & $\mathrm{ft}^{2}$ & 0.093 & $\mathrm{~m}^{2}$ \\
\hline ha & 2.47 & acres & acre & 0.405 & ha \\
\hline $\mathrm{km}^{2}$ & 0.386 & $\mathrm{mi}^{2}$ & $\mathrm{mi}^{2}$ & 2.59 & $\mathrm{~km}^{2}$ \\
\hline $\mathrm{m}^{3}$ & 35.31 & $\mathrm{ft}^{3}$ & $\mathrm{ft}^{3}$ & 0.0283 & $\mathrm{~m}^{3}$ \\
\hline $\mathrm{m}^{3}$ & 1.308 & $y d^{3}$ & $y d^{3}$ & 0.7646 & $\mathrm{~m}^{3}$ \\
\hline $\mathrm{pCi}$ & 1,000 & $\mathrm{nCi}$ & $\mathrm{nCi}$ & 0.001 & $\mathrm{pCi}$ \\
\hline$\mu \mathrm{Ci} / \mathrm{mL}$ & $10^{9}$ & $\mathrm{pCi} / \mathrm{L}$ & $\mathrm{pCi} / \mathrm{L}$ & $10^{-9}$ & $\mu \mathrm{Ci} / \mathrm{mL}$ \\
\hline $\mathrm{Ci} / \mathrm{m}^{3}$ & $10^{12}$ & $\mathrm{pCi} / \mathrm{m}^{3}$ & $\mathrm{pCi} / \mathrm{m}^{3}$ & $10^{-12}$ & $\mathrm{Ci} / \mathrm{m}^{3}$ \\
\hline $\mathrm{mCi} / \mathrm{cm}^{3}$ & $10^{15}$ & $\mathrm{pCi} / \mathrm{m}^{3}$ & $\mathrm{pCi} / \mathrm{m}^{3}$ & $10^{-15}$ & $\mathrm{mCi} / \mathrm{cm}^{3}$ \\
\hline $\mathrm{nCi} / \mathrm{m}^{2}$ & 1.0 & $\mathrm{mCi} / \mathrm{km}^{2}$ & $\mathrm{mCi} / \mathrm{km}^{2}$ & 1.0 & $\mathrm{nCi} / \mathrm{m}^{2}$ \\
\hline $\mathrm{Ci}$ & $3.7 \times 10^{10}$ & $\mathrm{~Bq}$ & $\mathrm{~Bq}$ & $2.7 \times 10^{-11}$ & $\mathrm{Ci}$ \\
\hline $\mathrm{pCi}$ & 0.037 & $\mathrm{~Bq}$ & $\mathrm{~Bq}$ & 27 & $\mathrm{pCi}$ \\
\hline $\mathrm{rad}$ & 0.01 & Gy & Gy & 100 & $\mathrm{rad}$ \\
\hline rem & 0.01 & $\mathrm{~Sv}$ & $\mathrm{~Sv}$ & 100 & rem \\
\hline ppm & 1,000 & $\mathrm{ppb}$ & $\mathrm{ppb}$ & 0.001 & ppm \\
\hline${ }^{\circ} \mathrm{C}$ & $\left({ }^{\circ} \mathrm{C} \times 9 / 5\right)+32$ & ${ }^{\circ} \mathrm{F}$ & ${ }^{\circ} \mathrm{F}$ & $\left({ }^{\circ} \mathrm{F}-32\right) \div 9 / 5$ & ${ }^{\circ} \mathrm{C}$ \\
\hline $\mathrm{Oz}$ & 28.349 & g & g & 0.035 & $\mathrm{oz}$ \\
\hline ton & 0.9078 & tonne & tonne & 1.1 & ton \\
\hline
\end{tabular}




\begin{tabular}{|c|c|c|c|}
\hline \multirow[b]{2}{*}{ Symbol } & \multicolumn{2}{|c|}{ Table A.3. Names and Symbols for Units of Radioactivity } & activity \\
\hline & Name & Symbol & Name \\
\hline $\mathrm{Ci}$ & curie & $\mathrm{Bq}$ & becquerel $\left(2.7 \times 10^{-11} \mathrm{Ci}\right)$ \\
\hline $\mathrm{mCi}$ & millicurie $\left(1 \times 10^{-3} \mathrm{Ci}\right)$ & $\mathrm{kBq}$ & kilobecquerel $\left(1 \times 10^{3} \mathrm{~Bq}\right)$ \\
\hline$\mu \mathrm{Ci}$ & microcurie $\left(1 \times 10^{-6} \mathrm{Ci}\right)$ & $\mathrm{MBq}$ & megabecquerel $\left(1 \times 10^{6} \mathrm{~Bq}\right)$ \\
\hline $\mathrm{nCi}$ & nanocurie $\left(1 \times 10^{-9} \mathrm{Ci}\right)$ & $\mathrm{mBq}$ & millibecquerel $\left(1 \times 10^{-3} \mathrm{~Bq}\right)$ \\
\hline $\mathrm{pCi}$ & picocurie $\left(1 \times 10^{-12} \mathrm{Ci}\right)$ & $\mathrm{GBq}$ & gigabecquerel $\left(1 \times 10^{9} \mathrm{~Bq}\right)$ \\
\hline $\mathrm{fCi}$ & femtocurie $\left(1 \times 10^{-15} \mathrm{Ci}\right)$ & $\mathrm{TBq}$ & terabecquerel $\left(1 \times 10^{12} \mathrm{~Bq}\right)$ \\
\hline $\mathrm{aCi}$ & attocurie $\left(1 \times 10^{-18} \mathrm{Ci}\right)$ & & \\
\hline
\end{tabular}

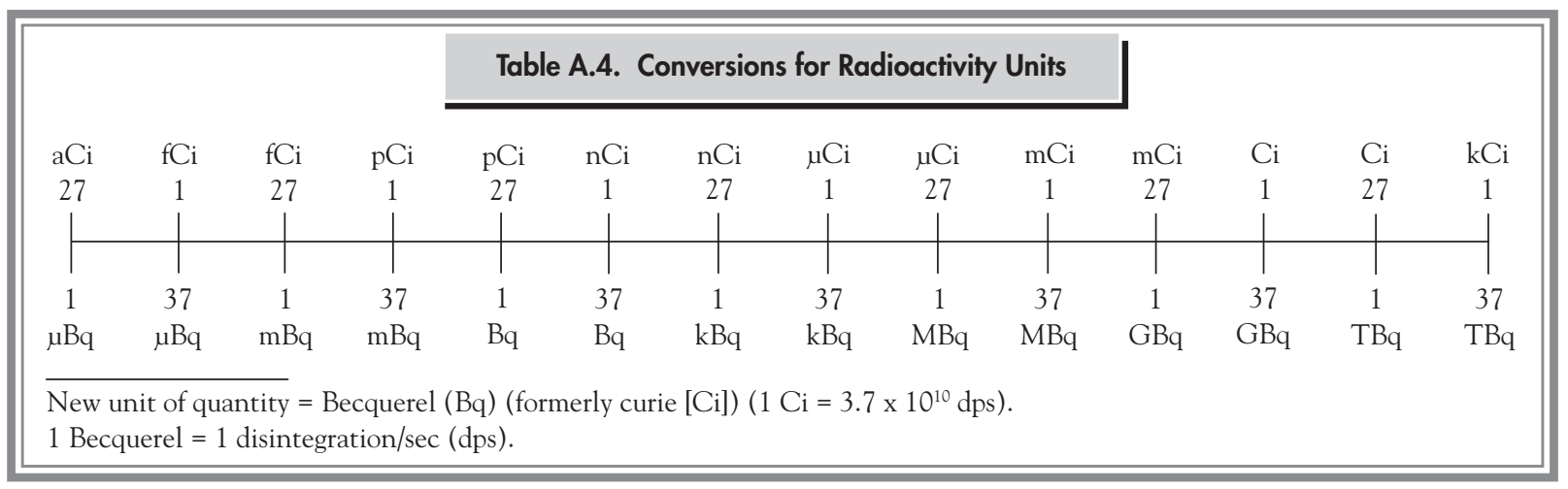

radiation of approximately $300 \mathrm{mrem}(3 \mathrm{mSv})$. Medical and dental $\mathrm{x}$-rays and air travel add to this total. Table A.5 includes selected conversions from rems to sieverts.

Also used in this report is the rad, with the corresponding unit gray $(\mathbf{G y})$ in parenthesis or footnoted. The rad (gray) is a measure of the energy absorbed by any material, whereas a rem relates to both the amount of radiation energy absorbed by humans and its consequence. The gray can be converted to rad

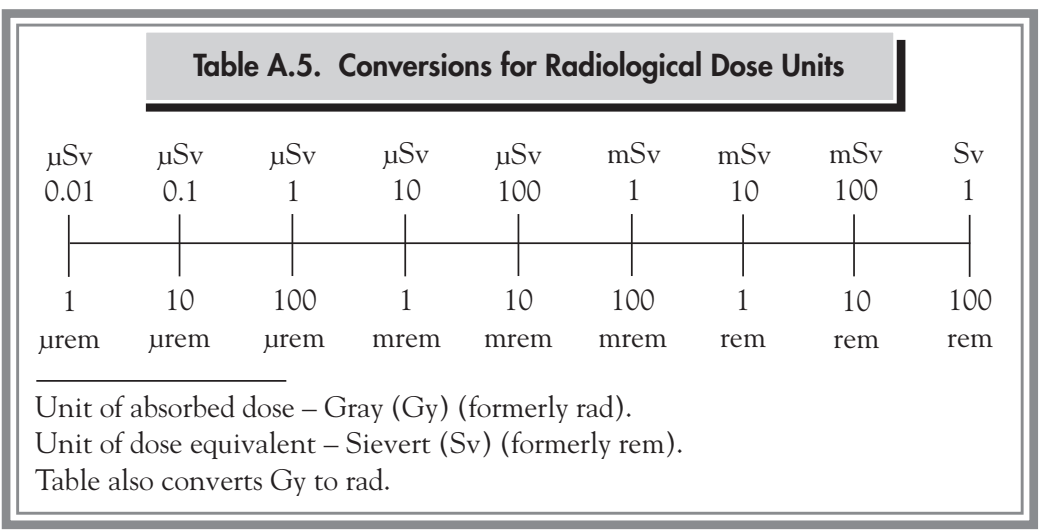
by multiplying by 100 . The conversions in Table A.5 can also be used to convert grays to rads.

A roentgen $(\mathbf{R})$ is a measure of exposure to electromagnetic radiation (i.e., gamma and $\mathrm{x}$-radiation) with no SI equivalent. One roentgen is equivalent to a charge release of 258 microcoulombs per kilogram of air.

The names and symbols for units of radiation dose used in this report are listed in Table A.6

Additional information on radiation and dose terminology can be found in Appendix B. A list of the radionuclides discussed in this report, their symbols, and their half-lives are included in Table A.7.

\begin{tabular}{|ll|}
\hline $\begin{array}{c}\text { Table A.6. Names and Symbols for Units } \\
\text { of Radiation Dose or Exposure }\end{array}$ \\
\hline$\underline{\text { Symbol }}$ & $\underline{\text { Name }}$ \\
mrad & millirad $\left(1 \times 10^{-3} \mathrm{rad}\right)$ \\
$\mathrm{mrem}$ & millirem $\left(1 \times 10^{-3} \mathrm{rem}\right)$ \\
$\mu \mathrm{rem}$ & microrem $\left(1 \times 10^{-6} \mathrm{rem}\right)$ \\
$\mathrm{Sv}$ & sievert $(100 \mathrm{rem})$ \\
$\mathrm{mSv}$ & millisievert $\left(1 \times 10^{-3} \mathrm{~Sv}\right)$ \\
$\mu \mathrm{Sv}$ & microsievert $\left(1 \times 10^{-6} \mathrm{~Sv}\right)$ \\
$\mathrm{R}$ & roentgen \\
$\mathrm{mR}$ & milliroentgen $\left(1 \times 10^{-3} \mathrm{R}\right)$ \\
$\mu \mathrm{R}$ & microroentgen $\left(1 \times 10^{-6} \mathrm{R}\right)$ \\
$\mathrm{Gy}$ & gray $(100 \mathrm{rad})$ \\
$\mathrm{mGy}$ & milligray $\left(1 \times 10^{-3} \mathrm{rad}\right)$ \\
\hline
\end{tabular}




\section{Chemical and Elemental Nomenclature}

Many of the chemical contaminants discussed in this report are listed in Table A.8 along with their chemical (or elemental) names and their corresponding symbols.

\section{Understanding the Data Tables}

Some degree of variability, or uncertainty, is associated with all analytical measurements. This uncertainty is the consequence of random or systematic inaccuracies related to collecting, preparing, and analyzing the samples. These inaccuracies could include errors associated with reading or recording the result, handling or processing the sample, calibrating the counting instrument, and numerical rounding. With radionuclides, inaccuracies can also result from the randomness of radioactive decay. In this report, the uncertainties used include standard deviation, total propagated analytical uncertainty, and standard error of the mean.

\section{Standard Deviation}

The standard deviation (SD) of sample data relates to the variation around the mean of a set of individual sample results. If differences in analytical results occur among samples, then two times the standard deviation (or $\pm 2 \mathrm{SD}$ ) implies that $95 \%$ of the time, a re-count or re-analysis of the same sample would give a value somewhere between the mean result minus two times the standard deviation and the mean result plus two times the standard deviation.

\begin{tabular}{|c|c|c|c|c|c|}
\hline \multirow[b]{2}{*}{ Symbol } & \multirow[b]{2}{*}{$\underline{\text { Radionuclide }}$} & \multicolumn{3}{|c|}{ Table A.7. Radionuclides and Their Half-Lives ${ }^{(a)}$} & \multirow[b]{2}{*}{ Half-Life } \\
\hline & & $\underline{\text { Half-Life }}$ & Symbol & $\underline{\text { Radionuclide }}$ & \\
\hline${ }^{3} \mathrm{H}$ & tritium & $12.35 \mathrm{yr}$ & ${ }^{137 m} \mathrm{Ba}$ & barium-137m & $2.552 \mathrm{~min}$ \\
\hline${ }^{7} \mathrm{Be}$ & beryllium-7 & $53.44 \mathrm{~d}$ & ${ }^{152} \mathrm{Eu}$ & europium-152 & $13.3 \mathrm{yr}$ \\
\hline${ }^{14} \mathrm{C}$ & carbon-14 & $5,730 \mathrm{yr}$ & ${ }^{154} \mathrm{Eu}$ & europium-154 & $8.8 \mathrm{yr}$ \\
\hline${ }^{40} \mathrm{~K}$ & potassium-40 & $1.3 \times 10^{8} \mathrm{yr}$ & ${ }^{155} \mathrm{Eu}$ & europium-155 & $5 \mathrm{yr}$ \\
\hline${ }^{51} \mathrm{Cr}$ & chromium-51 & $27.7 \mathrm{~d}$ & ${ }^{212} \mathrm{~Pb}$ & lead-212 & $10.6 \mathrm{~h}$ \\
\hline${ }^{54} \mathrm{Mn}$ & manganese-54 & $312.7 \mathrm{~d}$ & ${ }^{220} \mathrm{Rn}$ & radon-220 & $56 s$ \\
\hline${ }^{55} \mathrm{Fe}$ & iron-55 & $2.7 \mathrm{yr}$ & ${ }^{222} \mathrm{Rn}$ & radon- 222 & $3.8 \mathrm{~d}$ \\
\hline${ }^{59} \mathrm{Fe}$ & iron-59 & $44.63 \mathrm{~d}$ & ${ }^{232} \mathrm{Th}$ & thorium-232 & $1.4 \times 10^{10} \mathrm{yr}$ \\
\hline${ }^{59} \mathrm{Ni}$ & nickel-59 & $75,000 \mathrm{yr}$ & $\mathrm{U}$ or uranium & natural uranium & $\sim 4.5 \times 10^{9(\mathrm{~b})}$ \\
\hline${ }^{60} \mathrm{Co}$ & cobalt -60 & $5.3 \mathrm{yr}$ & ${ }^{233} \mathrm{U}$ & uranium-233 & $1.59 \times 10^{5} \mathrm{yr}$ \\
\hline${ }^{63} \mathrm{Ni}$ & nickel-63 & $100.1 \mathrm{yr}$ & ${ }^{234} \mathrm{U}$ & uranium-234 & $2.4 \times 10^{5} \mathrm{yr}$ \\
\hline${ }^{65} \mathrm{Zn}$ & zinc-65 & $243.9 \mathrm{~d}$ & ${ }^{235} \mathrm{U}$ & uranium-235 & $7 \times 10^{8} \mathrm{yr}$ \\
\hline${ }^{85} \mathrm{Kr}$ & krypton-85 & $10.7 \mathrm{yr}$ & ${ }^{237} \mathrm{~Np}$ & neptunium-237 & $2.14 \times 10^{6} \mathrm{yr}$ \\
\hline${ }^{90} \mathrm{Sr}$ & strontium-90 & $29.1 \mathrm{yr}$ & ${ }^{238} \mathrm{U}$ & uranium-238 & $4.5 \times 10^{9} \mathrm{yr}$ \\
\hline${ }^{90} \mathrm{Y}$ & yttrium-90 & $64.1 \mathrm{~h}$ & ${ }^{238} \mathrm{Pu}$ & plutonium-238 & $87.7 \mathrm{yr}$ \\
\hline${ }^{95} \mathrm{Zr}$ & zirconium-95 & $63.98 \mathrm{~d}$ & ${ }^{239} \mathrm{Pu}$ & plutonium-239 & $2.4 \times 10^{4} \mathrm{yr}$ \\
\hline${ }^{99} \mathrm{Tc}$ & technetium-99 & $2.1 \times 10^{5} \mathrm{yr}$ & ${ }^{240} \mathrm{Pu}$ & plutonium-240 & $6.5 \times 10^{3} \mathrm{yr}$ \\
\hline${ }^{103} \mathrm{Ru}$ & ruthenium-103 & $39.3 \mathrm{~d}$ & ${ }^{241} \mathrm{Pu}$ & plutonium-241 & $14.4 \mathrm{yr}$ \\
\hline${ }^{106} \mathrm{Ru}$ & ruthenium-106 & $368.2 \mathrm{~d}$ & ${ }^{242} \mathrm{Pu}$ & plutonium-242 & $3.76 \times 10^{5} \mathrm{yr}$ \\
\hline${ }^{113} \mathrm{Sn}$ & $\operatorname{tin}-113$ & $115 \mathrm{~d}$ & ${ }^{241} \mathrm{Am}$ & americium-241 & $432.2 \mathrm{yr}$ \\
\hline${ }^{125} \mathrm{Sb}$ & antimony-125 & $2.8 \mathrm{yr}$ & ${ }^{243} \mathrm{Am}$ & americium-243 & $7,380 \mathrm{yr}$ \\
\hline${ }^{129} \mathrm{I}$ & iodine-129 & $1.6 \times 10^{7} \mathrm{yr}$ & ${ }^{243} \mathrm{Cm}$ & curium-243 & $28.5 \mathrm{yr}$ \\
\hline${ }^{131} \mathrm{I}$ & iodine-131 & $8 \mathrm{~d}$ & ${ }^{244} \mathrm{Cm}$ & curium-244 & $18.11 \mathrm{yr}$ \\
\hline${ }^{134} \mathrm{Cs}$ & cesium-134 & $2.1 \mathrm{yr}$ & ${ }^{245} \mathrm{Cm}$ & curium-245 & $8,500 \mathrm{yr}$ \\
\hline${ }^{137} \mathrm{Cs}$ & cesium-137 & $30 \mathrm{yr}$ & & & \\
\hline \multicolumn{6}{|c|}{ (a) From Shleien (1992). } \\
\hline \multicolumn{6}{|c|}{ (b) Natural uranium is a mixture dominated by ${ }^{238} \mathrm{U}$, thus the half-life is $\sim 4.5 \times 10^{9}$ years. } \\
\hline
\end{tabular}


Table A.8. Elemental and Chemical Constituent Nomenclature

\begin{tabular}{|c|c|c|c|}
\hline \multirow[b]{2}{*}{ Symbol } & \multicolumn{3}{|c|}{ Table A.8. Elemental and Chemical Constituent Nomenclature } \\
\hline & Constituent & Symbol & Constituent \\
\hline $\mathrm{Ag}$ & silver & $\mathrm{K}$ & potassium \\
\hline $\mathrm{Al}$ & aluminum & $\mathrm{LiF}$ & lithium fluoride \\
\hline As & arsenic & $\mathrm{Mg}$ & magnesium \\
\hline B & boron & $\mathrm{Mn}$ & manganese \\
\hline $\mathrm{Ba}$ & barium & Mo & molybdenum \\
\hline $\mathrm{Be}$ & beryllium & $\mathrm{NH}_{3}$ & ammonia \\
\hline $\mathrm{Br}$ & bromine & $\mathrm{NH}_{4}^{+}$ & ammonium \\
\hline $\mathrm{C}$ & carbon & $\mathrm{N}^{4}$ & nitrogen \\
\hline $\mathrm{Ca}$ & calcium & $\mathrm{Na}$ & sodium \\
\hline $\mathrm{CaF}_{2}$ & calcium fluoride & $\mathrm{Ni}$ & nickel \\
\hline $\mathrm{CCl}_{4}^{2}$ & carbon tetrachloride & $\mathrm{NO}_{2}^{-}$ & nitrite \\
\hline $\mathrm{Cd}^{4}$ & cadmium & $\mathrm{NO}_{3}^{2}$ & nitrate \\
\hline $\mathrm{CHCl}_{3}$ & trichloromethane & $\mathrm{Pb}$ & lead \\
\hline $\mathrm{Cl}^{-}$ & chloride & $\mathrm{PO}_{4}^{-3}$ & phosphate \\
\hline $\mathrm{CN}^{-}$ & cyanide & $\mathrm{P}^{4}$ & phosphorus \\
\hline $\mathrm{Cr}^{+6}$ & chromium (hexavalent) & $\mathrm{Sb}$ & antimony \\
\hline $\mathrm{Cr}$ & chromium (total) & $\mathrm{Se}$ & selenium \\
\hline $\mathrm{CO}_{3}^{-2}$ & carbonate & $\mathrm{Si}$ & silicon \\
\hline $\mathrm{Co}$ & cobalt & $\mathrm{Sr}$ & strontium \\
\hline $\mathrm{Cu}$ & copper & $\mathrm{SO}_{4}^{-2}$ & sulfate \\
\hline $\mathrm{F}^{-}$ & fluoride & $\mathrm{Ti}$ & titanium \\
\hline $\mathrm{Fe}$ & iron & $\mathrm{Tl}$ & thallium \\
\hline $\mathrm{HCO}_{3}^{-}$ & bicarbonate & $\mathrm{V}$ & vanadium \\
\hline $\mathrm{Hg}$ & mercury & & \\
\hline
\end{tabular}

\section{Total Propagated Analytical Uncertainty}

For samples that are prepared or manipulated in the laboratory prior to counting (counting the rate of radioactive emissions from a sample), the total propagated analytical uncertainty includes both the counting uncertainty and the uncertainty associated with sample preparation and chemical separations. For samples that are not manipulated (e.g., ashed, dried, or chemically treated) in the laboratory before counting, the total propagated analytical uncertainty only accounts for the uncertainty associated with counting the sample. The uncertainty associated with samples that are analyzed but not counted includes only the analytical process uncertainty. In this situation, the total propagated analytical uncertainty is assumed to be the nominal detection limit.

\section{Standard Error of the Mean}

Just as individual values are accompanied by counting uncertainties, the mean of mean values (averages) is accompanied by \pm 2 times the standard error of the calculated mean (or \pm 2 SEM). Two times the standard error of the mean implies that approximately $95 \%$ of the time the next calculated mean will fall somewhere between the reported value minus two times the standard error and the reported value plus two times the standard error.

\section{Median, Maximum, and Minimum Values}

Median, maximum, and minimum values are reported in some sections of this report. A median value is the middle value of an odd numbered set and the average of the two central values in an even numbered set. For example, the median value in the odd numbered series of numbers - 1 , $2,3,3,4,5,5,5,6$ is 4 . The maximum value would be 6 and the minimum value would be 1 . Median, maximum, and minimum values are reported when there are too few analytical results to accurately determine the average with a \pm statistical uncertainty or when the data do not follow a bell-shape (i.e., normal) distribution. Figure A.1 provides a graphical representation of median, maximum, 


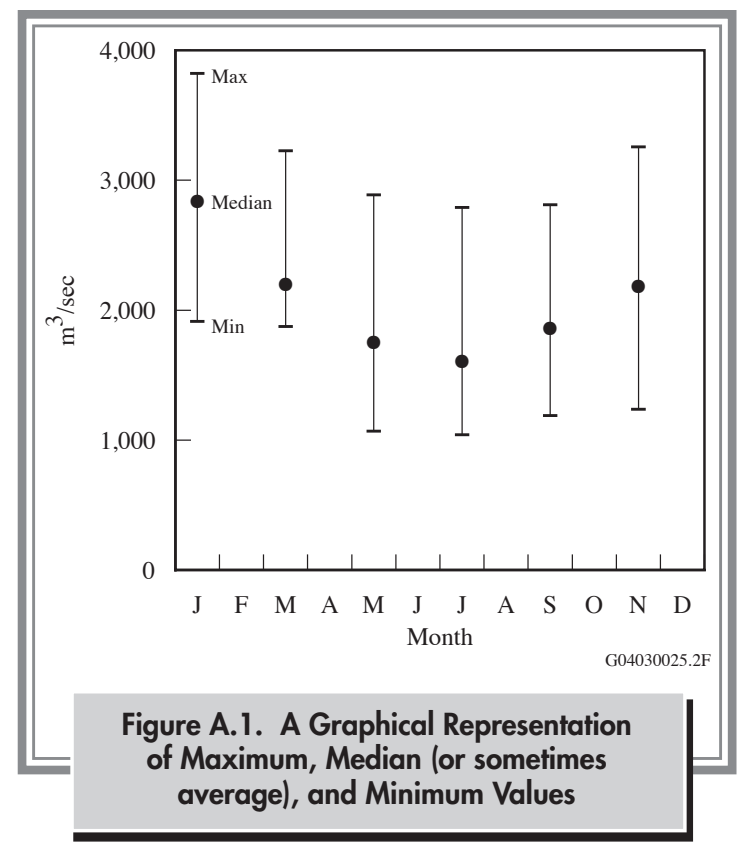

and minimum values. The upper line is the maximum value, the center dot is the median value, and the lower line is the minimum value.

\section{Negative Concentrations}

Instruments used in the laboratory to measure radioactivity in Hanford Site environmental samples are sensitive enough to measure natural, or background, radiation along with any contaminant radiation in a sample. To obtain a true measure of the contaminant level in a sample, the background radiation level must be subtracted from the total amount of radioactivity measured by an instrument. Because of the randomness of radioactive emissions, the very low activities of some contaminants, or the presence of undesirable materials, it is possible to obtain a background measurement that is larger than the actual contaminant measurement. When the larger background measurement is subtracted from the smaller contaminant measurement, a negative result is generated. The negative results are reported because they are essential when conducting statistical evaluations of the data.

\section{Understanding Graphs}

Graphs are useful when comparing numbers collected at several locations or at one location over time. Graphs often make it easy to visualize differences in data where they exist. However, careful consideration should be given to the scale (linear or logarithmic) and units.

Some of the data graphed in this report are plotted using logarithmic, or compressed, scales. Logarithmic scales are useful when plotting two or more numbers that differ greatly in size or are very close together. For example, a sample with a concentration of 5 grams per liter would get lost at the bottom of the graph if plotted on a linear scale with a sample having a concentration of 1,000 grams per liter (Figure A.2). A logarithmic plot of these same two numbers allows the reader to see both data points clearly (Figure A.3).
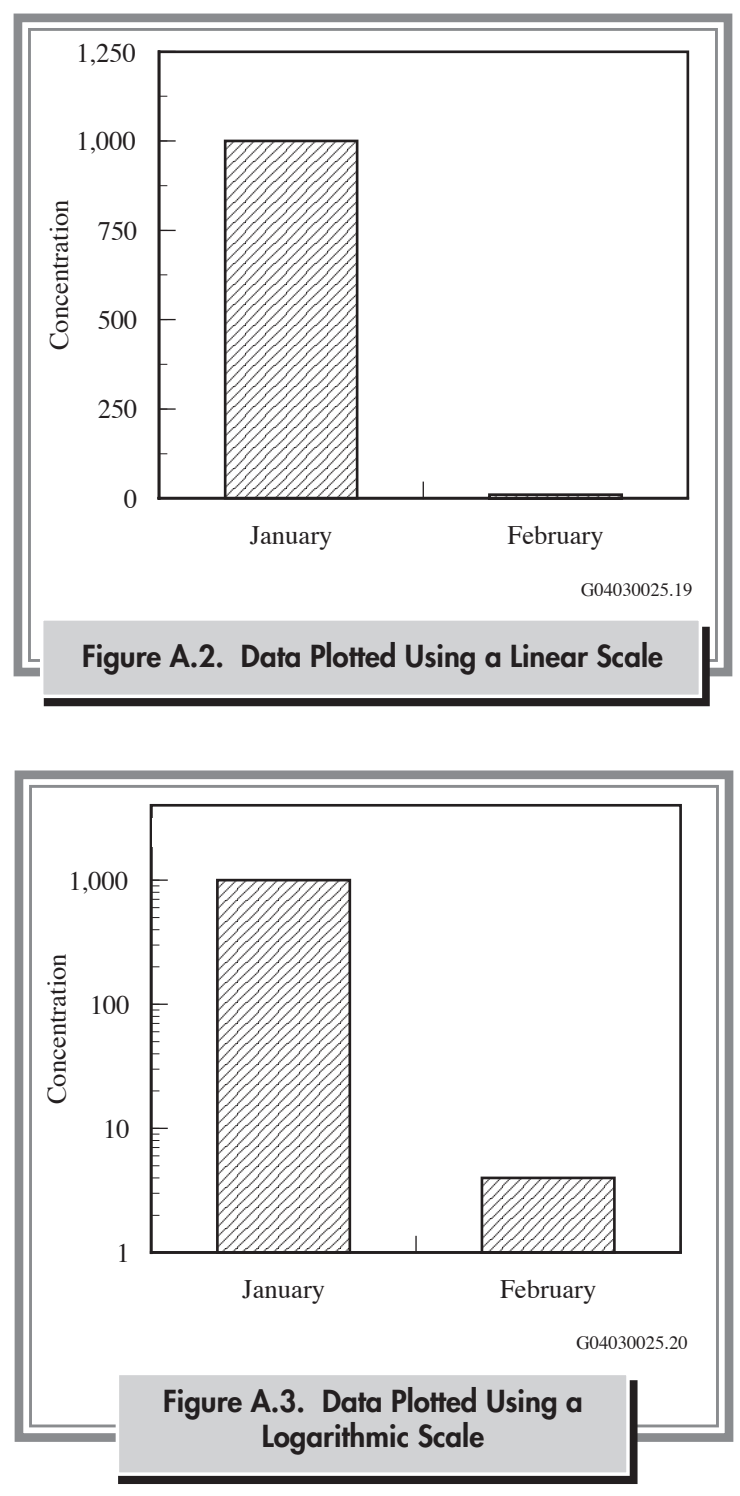
The mean (average) and median (defined earlier) values graphed in this report have vertical lines extending above and below the data point. When used with a value, these lines (called error bars) indicate the amount of uncertainty (standard deviation, total propagated analytical uncertainty, or two standard error of the mean) in the reported value. The error bars in this report represent a $95 \%$ chance that the value is between the upper and lower ends of the error bar and a $5 \%$ chance that the true value is either lower or higher than the error bar. ${ }^{(a)}$ For example, in Figure A.4, the first plotted value is $2.0 \pm 1.1$, so there is a $95 \%$ chance that the true value is between 0.9 and 3.1, a $2.5 \%$ chance that it is less than 0.9 , and a $2.5 \%$ chance that it is greater than 3.1. Error bars are computed statistically, employing all of the information used to generate the value. These bars provide a quick, visual indication that one value may be statistically similar to or different from another value. If the error bars of two or more

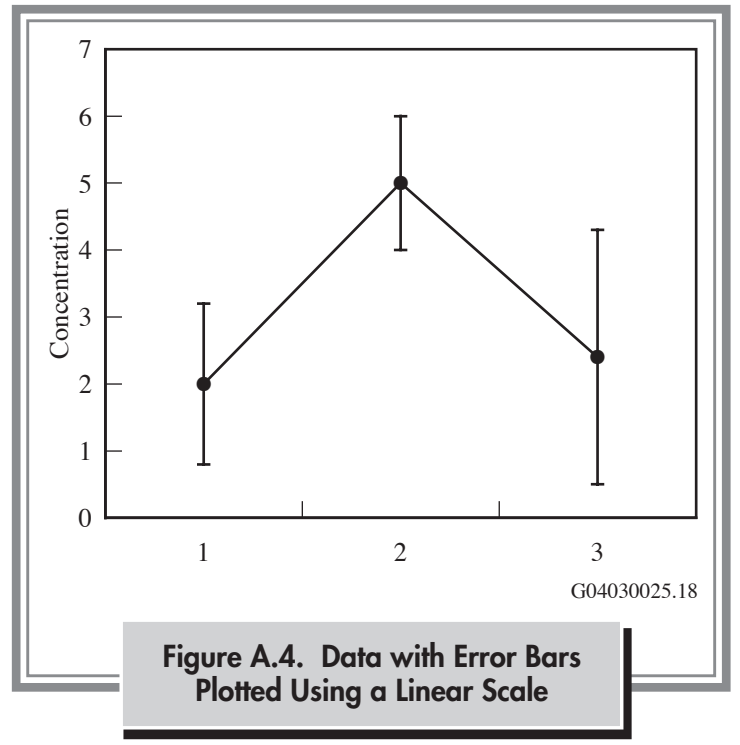

values overlap, as is the case with values 1 and 3 and values 2 and 3 , the values may be statistically similar. If the error bars do not overlap (values 1 and 2), the values may be statistically different. Values that appear to be very different visually (values 2 and 3) may actually be quite similar when compared statistically.

When vertical lines are used with median values, the lower end of each bar represents the minimum concentration measured; the upper end of each bar represents the maximum concentration measured (Figure A.1).

\section{Greater Than ( $>$ ) or Less Than (<) Symbols}

Greater than $(>)$ or less than $(<)$ symbols are used to indicate that the actual value may either be larger than the number given or smaller than the number given. For example, $>0.09$ would indicate that the actual value is greater than 0.09. A symbol pointed in the opposite direction $(<0.09)$ would indicate that the number is less than the value presented. A symbol used with an underscore ( $\leq$ or $\geq$ ) indicates that the actual value is less than or equal to or greater than or equal to the number given, respectively.

\section{Reference}

Shleien, B. 1992. The Health Physics and Radiological Health Handbook, Revised Edition. Scinta, Inc., Silver Spring, Maryland.

(a) Assuming the data are normally distributed. 


\section{Appendix B Glossary}

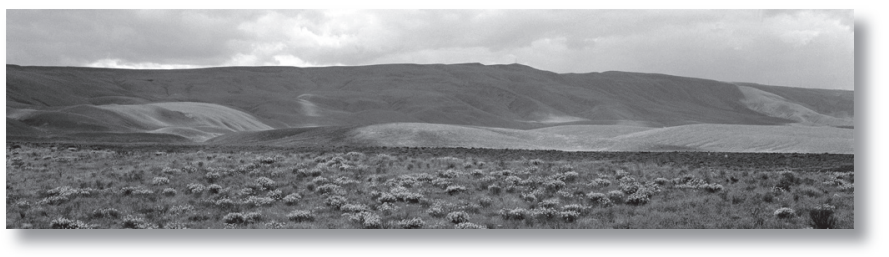

This glossary contains selected words and phrases used within the context of this report that may not be familiar to the reader. Words appearing in italic within a definition are also defined in this glossary.

absorbed dose - Energy absorbed per unit mass from any kind of ionizing radiation in any kind of matter. Units: rad, which is equal to the absorption of 100 ergs per gram of material irradiated, or gray, which is the International System of Units (SI) equivalent.

activation product - Material made radioactive by exposure to radiation, principally by neutron radiation as in metals in a nuclear reactor, e.g., cobalt-60 from cobalt -59 in stainless steel.

adsorption - The accumulation of gases, liquids, or solutes on the surface of a solid or liquid.

alpha particle - A positively charged particle composed of two protons and two neutrons ejected spontaneously from the nuclei of some radionuclides. It has low penetrating power and short range. The most energetic alpha will generally fail to penetrate the skin. Alpha particles are hazardous when an alpha-emitting isotope is introduced into the body.

anion - A negatively charged ion.

aquifer - Underground sediment or rock that stores and/or transmits water.

background radiation - Radiation in the natural environment, including cosmic rays from space and radiation from naturally occurring radioactive elements in the air, in the earth, and in our bodies. It also includes radiation from global fallout from historical atmospheric nuclear weapons testing. In the United States, the average person receives approximately 300 millirem of background radiation per year. bank storage - Hydrologic term that describes river water that flows into and is retained in permeable stream banks during periods of high river stage. Flow is reversed during periods of low river stage.

becquerel (Bq) - Unit of activity or amount of a radioactive substance (also radioactivity) equal to one nuclear transformation per second $(1 \mathrm{~Bq}=1$ disintegration per second). Another unit of radioactivity, the curie, is related to the becquerel: $1 \mathrm{Ci}=3.7 \times 10^{10} \mathrm{~Bq}$.

beta particle - A negatively charged particle (essentially an electron) emitted from a nucleus during radioactive decay. Large amounts of beta particles may cause skin burns and are harmful if they enter the body. Beta particles are easily stopped by a thin sheet of metal or plastic.

cation - A positively charged ion.

clean closed - A facility is classified as "clean closed" under Resource Conservation and Recovery Act regulations when all dangerous waste has been removed and groundwater monitoring is no longer required.

collective total effective dose equivalent - Sum of the total effective dose equivalents for individuals composing a defined population. The units for this are person-rem or person-sievert.

committed dose equivalent - The dose equivalent to organs or tissues that will be received from an intake of radioactive material by an individual during the 50 -year period following intake.

committed effective dose equivalent - The sum of the committed dose equivalent to various tissues in the body, each multiplied by the appropriate weighting factor. 
composite sample - Sample formed by mixing discrete samples taken at different times or from different locations.

confined aquifer - An aquifer bounded above and below by less-permeable layers. Groundwater in the confined aquifer is under a pressure greater than atmospheric pressure.

continuous sample - Sample formed by the continuous collection of the medium or contaminants within the medium during the entire sample period.

cosmic radiation - High-energy subatomic particles and electromagnetic radiation from outer space that bombard the earth. Cosmic radiation is part of natural background radiation.

crib - An underground structure designed to receive liquid waste that percolates into the soil directly or percolates into the soil after having traveled through a connected tile field. These structures are no longer used at Hanford.

curie (Ci) - A unit of radioactivity equal to 37 billion $\left(3.7 \times 10^{10}\right)$ nuclear transformations per second (becquerels).

decay - The decrease in the amount of any radioactive material (disintegration) with the passage of time. See radioactivity.

decay product - The atomic nucleus or nuclei that are left after radioactive transformation of a radioactive material. Decay products may be radioactive or non-radioactive (stable). Informally referred to as daughter products. See radioactivity.

deep-dose equivalent - The dose equivalent at a tissue depth of 1 centimeter from radiation originating outside of the body.

derived concentration guide (DCG) - Concentrations of radionuclides in air and water that an individual could continuously consume, inhale, or be immersed in at average annual rates, and not receive an effective dose equivalent of greater than 100 millirem per year.

detection level (or limit) - Minimum amount of a substance that can be measured with a specified or implied confidence that the analytical result is greater than a specific value (e.g., zero). dispersion - Process whereby effluent or emissions are spread or mixed when they are transported by groundwater, surface water, or air.

dose equivalent - Product of the absorbed dose, a quality factor, and any other modifying factors. The dose equivalent is a quantity for comparing the biological effectiveness of different kinds of radiation on a common scale. The unit of dose equivalent is the rem.

dose rate - The rate at which a dose is delivered over time, e.g., dose equivalent rate in millirem per hour $(\mathrm{mrem} / \mathrm{h})$.

dosimeter - Portable device for measuring the accumulated exposure or absorbed dose from specific types or energies of ionizing radiation fields.

effective dose - See effective dose equivalent.

effective dose equivalent - The sum of products of dose equivalent to selected tissues of the body and appropriate tissue weighting factors. The tissue weighting factors put doses to various tissues and organs on an equal basis in terms of health risk.

effluent - Liquid waste material released from a facility.

effluent monitoring - Sampling or measuring specific liquid effluent streams for the presence of pollutants.

emission - Gaseous waste streams released from a facility.

exposure - The interaction of an organism with a physical agent (e.g., radiation) or a chemical agent (e.g., arsenic) of interest. Also used as a term for quantifying $\mathrm{x}$ - and gamma radiation fields. See roentgen.

external radiation - Radiation originating from a source outside the body.

fallout - Typically refers to radioactive materials that are released into the earth's atmosphere following a nuclear explosion or atmospheric release and that eventually fall to earth.

fission - The splitting or breaking apart of a nucleus into at least two other nuclei, accompanied with a release of a relatively large amount of energy.

fission products - Nuclides formed from fissioning. Many fission products are radioactive. 
fully institutionalized - To incorporate into a formalized, structured system and be implemented and fully functional.

gamma radiation - High-energy electromagnetic radiation (photons) originating in the nucleus of decaying radionuclides. Gamma radiation is substantially more penetrating than alpha or beta particles.

grab sample - A short duration sample (e.g., air, water, and soil) that is grabbed from the collection site.

grand mean - A mean of means or an overall mean where there is some subdivision of the data where means were already provided for each subdivision.

groundwater - Subsurface water that is in the pores of sand and gravel or in the cracks of fractured rock.

gray $(\mathbf{G y})$ - Unit of absorbed dose in the International System of Units (SI) equal to the absorption of 1 joule per kilogram. The common unit of absorbed dose, the rad, is equal to $0.01 \mathrm{~Gy}$.

half-life - Length of time in which a radioactive substance will lose one half of its radioactivity by decay. Half-lives range from a fraction of a second to billions of years, and each radionuclide has a unique half-life.

high-activity waste - See high-level waste.

high-level waste - Highly radioactive waste material resulting from the reprocessing of spent nuclear fuel, including liquid waste produced directly in reprocessing and any solid material derived from such liquid waste that contains fission products and other radioisotopes in sufficient concentrations to require permanent isolation.

institutional controls - Long-term actions or restrictions including monitoring, periodic sampling, access controls, and land use restrictions designed to mitigate any risks posed by contamination following remediation. Institutional controls alone may be sufficient to reduce risks posed by low levels of contamination.

internal radiation - Radiation from radioactive material inside the body.

ion exchange - The reversible exchange of one species of ion for a different species of ion within a medium. irradiation - Exposure to radiation.

isotopes - Nuclides of the same chemical element with the same number of protons but a differing number of neutrons.

isotopic plutonium - Any of two or more atoms of the chemical element plutonium with the same atomic number and position in the periodic table and nearly identical chemical behavior but with differing atomic mass number and different physical properties. Plutonium-239 is produced by neutron irradiation of uranium-238

isotopic uranium - Any of two or more atoms of the chemical element uranium with the same atomic number and position in the periodic table and nearly identical chemical behavior but with differing atomic mass number and different physical properties. Uranium exists naturally as a mixture of three isotopes of mass 234,235 , and 238 in the proportions of $0.006 \%, 0.71 \%$, and $99.27 \%$, respectively.

legacy waste - Waste that was generated prior to termination of Hanford's nuclear materials production mission.

low-activity waste - See low-level waste.

low-level waste - Radioactive waste that is not high-level radioactive waste, spent nuclear fuel, transuranic waste, byproduct material, or naturally occurring radioactive material.

maximally exposed individual - A hypothetical member of the public residing near the Hanford Site who, by virtue of location and living habits, would reasonably receive the highest possible radiation dose from materials originating from Hanford.

mean (or average) - Average value of a series of measurements. The mean is computed as:

$$
\text { mean }=\frac{\sum \mathrm{x}}{\mathrm{n}}
$$

where $\mathrm{n}$ is the number of measurements and $\sum_{\mathrm{x}}$ is the sum of all measurements.

median - Middle value in an odd numbered set of results when the data are ranked in increasing or decreasing order or the average of two central values in an even number set of results. 
millirem - A unit of radiation dose equivalent that is equal to one one-thousandth (1/1000) of a rem.

minimum detectable amount or concentration Smallest amount or concentration of a chemical or radioactive material that can be reliably detected in a sample.

mitigation - Prevention or reduction of expected risks to workers, the public, or the environment.

mixed waste - A U.S. Environmental Protection Agency or state designated dangerous, extremely hazardous, or acutely hazardous waste that contains both a nonradioactive hazardous component and a radioactive component.

monitoring - As defined in DOE Order 5400.5, the collection and analysis of samples or measurements of liquid effluent and gaseous emissions for purposes of characterizing and quantifying contaminants, assessing radiation exposure to the public, and demonstrating compliance with regulatory standards.

noble gas - Any of a group of chemically and biologically inert gases that includes argon, krypton, and xenon. These gases are not retained in the body following inhalation. The principal exposure pathway for radioactive noble gases is direct external dose from the surrounding air.

nuclide - A particular combination of neutrons and protons. A radionuclide is a radioactive nuclide.

offsite locations - Sampling and measurement locations outside the Hanford Site boundary.

onsite locations - Sampling and measurement locations within the Hanford Site boundary.

operable unit - A discrete area for which an incremental step can be taken toward comprehensively addressing site problems. The cleanup of a site can be divided into a number of operable units, depending on the complexity of the problems associated with the site.

outfall - End of a drain or pipe that carries wastewater or other effluent into a ditch, pond, or river.

person-rem or person-sievert (person-Sv) - Unit of collective total effective dose equivalent. 1 person-Sv = 100 person-rem. photon - A quantum of radiant energy. Gamma radiation and $\mathrm{x}$-radiation ( $\mathrm{x}$-rays) are both composed of photons of varying energy.

plume - The cloud of a pollutant in air, surface water, or groundwater formed after the pollutant is released from a source.

plutonium - A heavy, radioactive, metallic element consisting of several isotopes. One important isotope is ${ }^{239} \mathrm{Pu}$, which is produced by the irradiation of ${ }^{238} \mathrm{U}$. Routine analysis cannot distinguish between the ${ }^{239} \mathrm{Pu}$ and ${ }^{240} \mathrm{Pu}$ isotopes; hence, the term ${ }^{239 / 240} \mathrm{Pu}$ as used in this report is symbolic of the presence of one or both of these isotopes in the analytical results.

primordial radionuclide - A radioactive material in the earth's crust that has a very long half-life and has existed since the beginning of the planet.

quality assurance - Actions that provide confidence that an item or process meets or exceeds that user's requirements and expectations.

quality control - Comprises all those actions necessary to control and verify the features and characteristics of a material, process, product, or service to specified requirements. Quality control is an element of quality assurance.

rad - The unit of absorbed dose. $1 \mathrm{rad}=0.01 \operatorname{gray}(\mathrm{Gy})$.

radiation - The energy emitted in the form of photons or particles (e.g., alpha and beta particles) such as that from transforming radionuclides. For this report, radiation refers to ionizing types of radiation; not radiowaves, microwaves, radiant light, or other types of non-ionizing radiation.

radioactivity - Property possessed by radioisotopes emitting radiation (such as alpha or beta particles, or high-energy photons) spontaneously in their decay process also, the radiation emitted.

radioisotope - An unstable isotope of an element that decays or disintegrates spontaneously, emitting radiation (Shleien 1992).

radiologically controlled area - An area to which access is controlled to protect individuals from exposure to radiation or radioactive materials. 
radionuclide - A species of atoms having a particular number of protons $(\mathrm{Z})$, a particular number of neutrons (A), and a particular atomic weight $(\mathrm{N}=\mathrm{Z}+\mathrm{A})$ that happens to emit radiation. Carbon- 14 is a radionuclide but carbon-12, which is not radioactive, is referred to simply as a nuclide.

recruitment - Survival from one life form or stage to the next or from one age class to the next.

redox - A chemical reaction involving oxidation and reduction.

rem - A unit of dose equivalent and effective dose equivalent.

remediation - Reduction of known risks to the public and environment to an agreed-upon level.

risk - The probability that a detrimental health effect will occur.

risk-based disposal approval - A written application to the U.S. Environmental Protection Agency intended for the management and disposal of Toxic Substances Control Act-regulated polychlorinated biphenyl waste not addressed suitably within the regulations. The risk-based disposal approval process is applicable to any person wishing to sample, clean up, or dispose of waste in a manner other than as prescribed in 40 CFR 761. For polychlorinated biphenyl remediation waste, the requirements for a risk-based disposal approval are specified in 40 CFR 761.61(c). A written approval from the U.S. Environmental Protection Agency is required before waste management activities are performed.

roentgen $(\mathbf{R})$ - The unit of $\mathrm{x}$-ray or gamma photon exposure as measured in air, historically used to describe external radiation levels. An exposure of 1 roentgen typically causes an effective dose of $1 \mathrm{rem}$.

sievert (Sv) - The unit of dose equivalent and its variants in the International System of Units (SI). The common unit for dose equivalent and its variants, the rem, is equal to $0.01 \mathrm{~Sv}$.

special case waste - Waste for which there is an undetermined disposal path because of high levels of radioactivity and difficulties in characterization, classification, and packaging. specific retention facilities - Historical structures consisting of cribs, ditches, trenches, or holes in the ground that received relatively small volumes of high concentration liquid radioactive waste. The small volume of liquid waste was designed to prevent flushing of the contaminants through the soil column to the groundwater.

spent fuel - Uranium metal or oxide and its metal container that have been used to power a nuclear reactor and for one reason or another has reached the end of its useful life. It is highly radioactive and typically contains fission products, plutonium, and residual uranium.

standard error of the mean - A measure of the precision of a mean of observed values; that is, an estimate of how close a mean of observed values is expected to be to the true mean.

surveillance - As defined in DOE Order 5400.5, the collection and analysis of samples of air, water, soil, foodstuffs, biota, and other media, and the measurement of external radiation for purposes of demonstrating compliance with applicable standards, assessing exposures to the public, and assessing effects, if any, on the local environment.

tank farm - A group of underground waste storage tanks.

transuranic element - An element with an atomic number greater than 92 (92 is the atomic number of uranium).

transuranic waste - Waste containing more than 100 nanocuries (10-9 curies) per gram of alpha-emitting transuranic isotopes (half-lives greater than 20 years).

thermoluminescent dosimeter - A device containing a material that, after being exposed to beta and/or gamma radiation, emits light when heated. The amount of light emitted is proportional to the absorbed dose to the thermoluminescent dosimeter.

total effective dose equivalent - The sum of committed effective dose equivalent from intakes of radioactive material and dose equivalent from external radiation. Unit: rem or sievert.

unconfined aquifer - An aquifer containing groundwater that is not confined above by relatively impermeable rocks. The pressure at the top of the unconfined aquifer is equal to that of the atmosphere. At Hanford, the unconfined aquifer is the uppermost aquifer and is most susceptible to contamination from site operations. 
vadose zone - Underground area from the surface to the top of the water table or aquifer.

volatile organic compounds - Lightweight organic compounds that vaporize easily; used in solvents and degreasing compounds as raw materials.

water table - The top of the unconfined aquifer.

wind rose - A diagram showing how often winds of various speeds blow from different directions, usually based on yearly averages.

\section{References}

40 CFR 761. U.S. Environmental Protection Agency. "Polychlorinated Biphenyls (PCBs) Manufacturing, Processing, Distribution in Commerce, and Use Prohibitions." Code of Federal Regulations.
40 CFR 761.61(c). U.S. Environmental Protection Agency. "PCB Remediation Waste." Code of Federal Regulations.

DOE Order 5400.5. "Radiation Protection of the Public and the Environment."

Shleien, B. (ed.). 1992. The Health Physics and Radiological Health Handbook, Revised Edition. Scinta, Inc., Silver Spring, Maryland.

Resource Conservation and Recovery Act. 1976. Public Law 94-580, as amended, 90 Stat. 2795, 42 USC 6901 et seq.

Toxic Substances Control Act. 1976. Public Law 94-469, as amended, 90 Stat. 2003, 15 USC 2601 et seq. 


\section{Appendix C Additional Monitoring Results for 2004}

G. W. Patton, E. J. Antonio, and J. A. Stegen

This appendix contains additional information on 2004 monitoring results, supplementing the data summarized in the main body of the report. More detailed information is available in Hanford Site Environmental Surveillance Data Report for Calendar Year 2004 (PNNL-15222, APP. 1). 


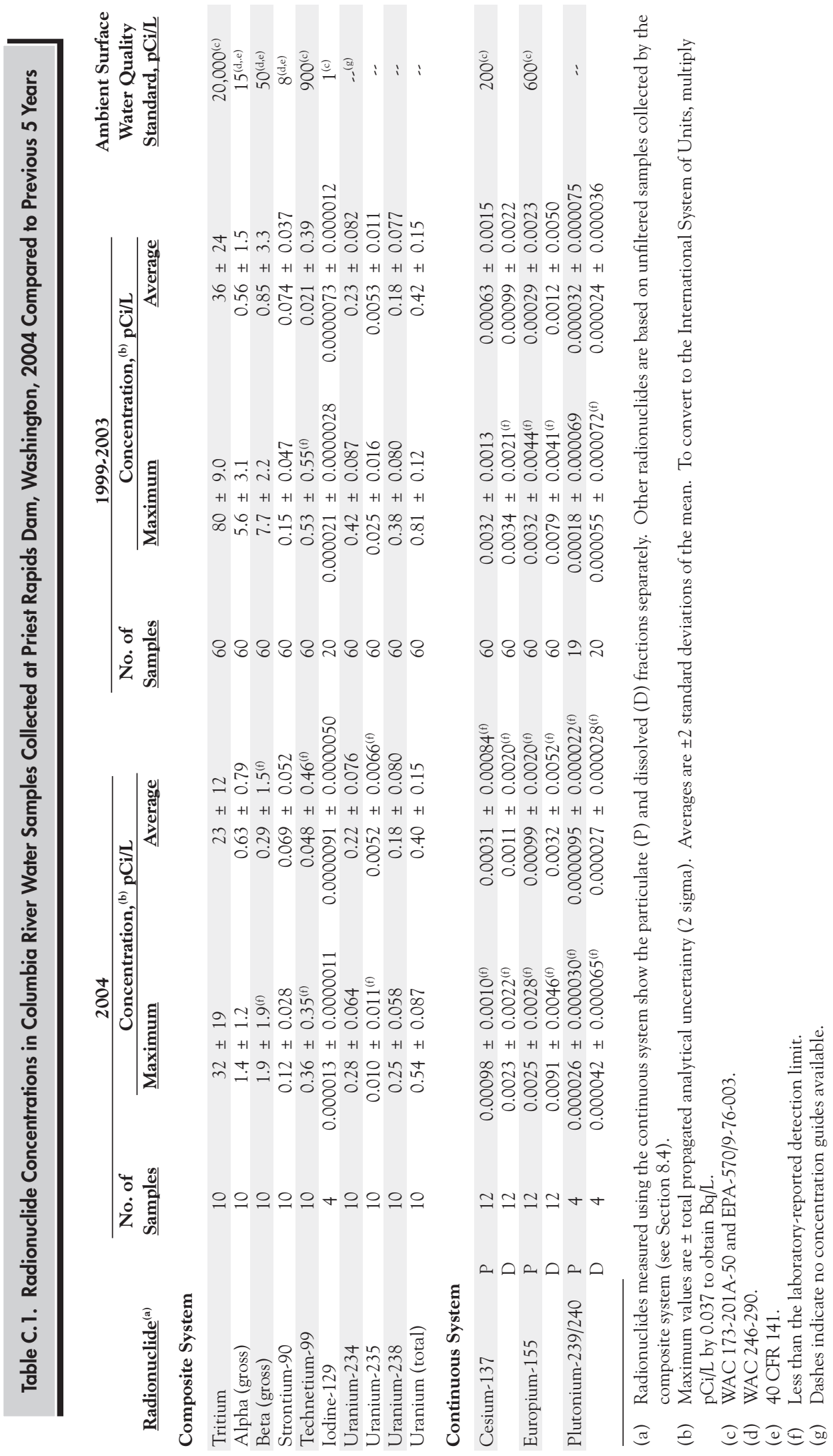




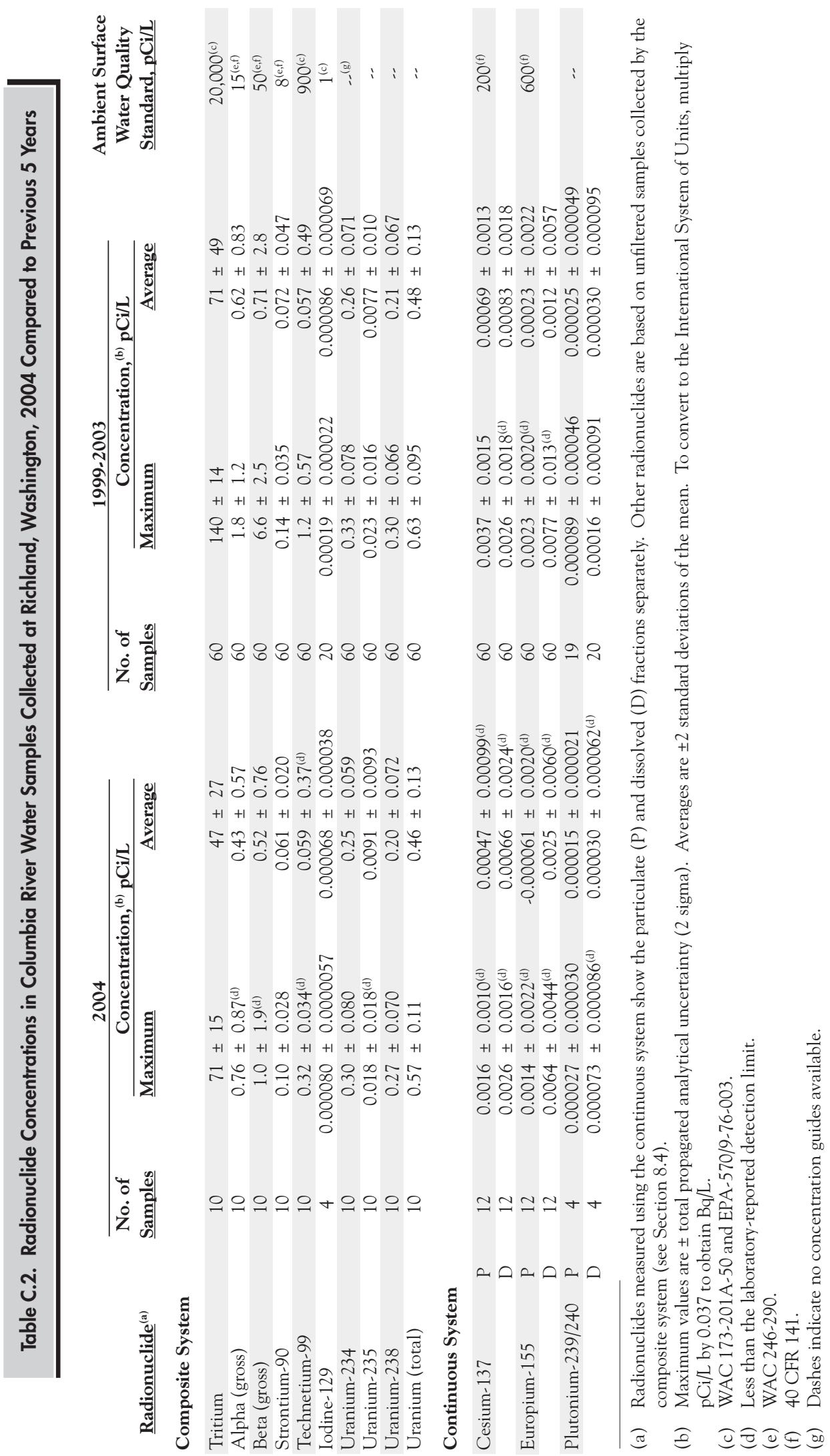

C. 3 


\begin{tabular}{|c|c|c|c|}
\hline \multicolumn{4}{|c|}{$\begin{array}{l}\text { Table C.3. Radionuclide Concentrations Measured in Columbia River Water } \\
\text { Samples Collected Along Transects of the Hanford Reach, } 2004\end{array}$} \\
\hline \multirow[b]{2}{*}{ Transect/Radionuclide } & \multirow{2}{*}{$\begin{array}{l}\text { No. of } \\
\text { Samples }\end{array}$} & \multicolumn{2}{|c|}{ Concentration, ${ }^{(a)} \mathrm{pCi} / \mathrm{L}$} \\
\hline & & $\underline{\text { Maximum }}$ & $\underline{\text { Minimum }}$ \\
\hline \multicolumn{4}{|c|}{ Vernita Bridge (HRM 0.3) } \\
\hline Tritium & 16 & $47 \pm 10$ & $17 \pm 5.5$ \\
\hline Strontium-90 & 16 & $0.11 \pm 0.035$ & $0.030 \pm 0.041^{(b)}$ \\
\hline Uranium (total) & 16 & $0.66 \pm 0.15$ & $0.33 \pm 0.14$ \\
\hline \multicolumn{4}{|l|}{ 100-N Area (HRM 9.5) } \\
\hline Tritium & 7 & $57 \pm 6.8$ & $20 \pm 6.2$ \\
\hline Strontium-90 & 7 & $0.083 \pm 0.051$ & $0.033 \pm 0.052^{(\mathrm{b})}$ \\
\hline Uranium (total) & 7 & $0.53 \pm 0.16$ & $0.30 \pm 0.15$ \\
\hline \multicolumn{4}{|l|}{ 100-F Area (HRM 19) } \\
\hline Tritium & 6 & $24 \pm 4.5$ & $17 \pm 4.1$ \\
\hline Strontium-90 & 6 & $0.089 \pm 0.050$ & $0.028 \pm 0.059^{(\mathrm{b})}$ \\
\hline Uranium (total) & 5 & $0.58 \pm 0.16$ & $0.35 \pm 0.14$ \\
\hline \multicolumn{4}{|l|}{$\begin{array}{l}\text { Hanford Town Site } \\
\text { (HRM 28.7) }\end{array}$} \\
\hline Tritium & 6 & $660 \pm 56$ & $18 \pm 4.1$ \\
\hline Strontium-90 & 6 & $0.049 \pm 0.041$ & $0.018 \pm 0.033^{(\mathrm{b})}$ \\
\hline Uranium (total) & 5 & $0.40 \pm 0.14$ & $0.29 \pm 0.15$ \\
\hline \multicolumn{4}{|l|}{300 Area (HRM 43.1) } \\
\hline Tritium & 6 & $120 \pm 11$ & $26 \pm 6.8$ \\
\hline Strontium-90 & 6 & $0.045 \pm 0.042$ & $0.0072 \pm 0.034^{(\mathrm{b})}$ \\
\hline Uranium (total) & 6 & $1.8 \pm 0.26$ & $0.37 \pm 0.14$ \\
\hline \multicolumn{4}{|l|}{ Richland (HRM 46.4) } \\
\hline Tritium & 26 & $93 \pm 18$ & $21 \pm 6.6$ \\
\hline Strontium-90 & 26 & $0.10 \pm 0.039$ & $0.022 \pm 0.040^{(\mathrm{b})}$ \\
\hline Uranium (total) & 26 & $1.0 \pm 0.14$ & $0.37 \pm 0.066$ \\
\hline \multicolumn{4}{|c|}{$\begin{array}{l}\text { (a) Maximum and minimum values are } \pm \text { total propagated analytical uncertainty ( } 2 \text { sigma). To } \\
\text { convert to the International System of Units, multiply } \mathrm{pCi} / \mathrm{L} \text { by } 0.037 \text { to obtain } \mathrm{Bq} / \mathrm{L} \text {. } \\
\text { (b) Less than the laboratory-reported detection limit. } \\
\text { HRM = Hanford river marker. }\end{array}$} \\
\hline
\end{tabular}


Table C.4. Radionuclide Concentrations Measured in Columbia River Water Samples Collected at Near-Shore Locations in the Hanford Reach, 2004

\begin{tabular}{|c|c|c|c|}
\hline \multirow[b]{2}{*}{ Near-Shore/Radionuclide } & \multirow{2}{*}{$\begin{array}{l}\text { No. of } \\
\text { Samples }\end{array}$} & \multicolumn{2}{|c|}{ Concentration, ${ }^{(a)} \mathrm{pCi} / \mathrm{L}$} \\
\hline & & Maximum & Minimum \\
\hline \multicolumn{4}{|l|}{ Vernita Bridge (HRM 0.3) } \\
\hline Tritium & 4 & $22 \pm 4.0$ & $17 \pm 5.5$ \\
\hline Strontium-90 & 4 & $0.11 \pm 0.035$ & $0.039 \pm 0.039^{(b)}$ \\
\hline Uranium (total) & 4 & $0.43 \pm 0.071$ & $0.33 \pm 0.14$ \\
\hline \multicolumn{4}{|c|}{ 100-N Area (HRM 8.4 to 9.8 ) } \\
\hline Tritium & 6 & $57 \pm 6.8$ & $24 \pm 4.3$ \\
\hline Strontium-90 & 6 & $0.083 \pm 0.051$ & $0.033 \pm 0.052^{(b)}$ \\
\hline Uranium (total) & 6 & $0.42 \pm 0.15$ & $0.36 \pm 0.14$ \\
\hline \multicolumn{4}{|l|}{ 100-F Area (HRM 18 to 23) } \\
\hline Tritium & 4 & $26 \pm 4.6$ & $17 \pm 4.2$ \\
\hline Strontium-90 & 4 & $0.067 \pm 0.042$ & $0.035 \pm 0.039^{(b)}$ \\
\hline Uranium (total) & 3 & $0.42 \pm 0.14$ & $0.35 \pm 0.14$ \\
\hline \multicolumn{4}{|l|}{$\begin{array}{l}\text { Hanford Town Site } \\
\text { (HRM } 26 \text { to 30) }\end{array}$} \\
\hline Tritium & 4 & $1,600 \pm 140$ & $18 \pm 4.0$ \\
\hline Strontium-90 & 4 & $0.056 \pm 0.040$ & $0.0091 \pm 0.050^{(\mathrm{b})}$ \\
\hline Uranium (total) & 4 & $0.46 \pm 0.15$ & $0.32 \pm 0.14$ \\
\hline \multicolumn{4}{|c|}{300 Area (HRM 41.5 to 43.1$)$} \\
\hline Tritium & 5 & $400 \pm 35$ & $120 \pm 11$ \\
\hline Strontium-90 & 5 & $0.054 \pm 0.041$ & $0.0072 \pm 0.034^{(\mathrm{b})}$ \\
\hline Uranium (total) & 5 & $0.67 \pm 0.16$ & $0.44 \pm 0.15$ \\
\hline \multicolumn{4}{|c|}{ Richland (HRM 43.5 to 46.4 ) } \\
\hline Tritium & 22 & $110 \pm 20$ & $24 \pm 4.5$ \\
\hline Strontium-90 & 22 & $0.092 \pm 0.033$ & $0.033 \pm 0.040^{(b)}$ \\
\hline Uranium (total) & 22 & $0.81 \pm 0.11$ & $0.22 \pm 0.13$ \\
\hline
\end{tabular}

(a) Maximum and minimum values are \pm total propagated analytical uncertainty ( 2 sigma). To convert to the International System of Units, multiply $\mathrm{pCi} / \mathrm{L}$ by 0.037 to obtain $\mathrm{Bq} / \mathrm{L}$.

(b) Less than the laboratory-reported detection limit.

HRM = Hanford river marker. 


\begin{tabular}{|c|c|c|c|c|c|c|}
\hline \multirow[b]{2}{*}{ Location } & \multicolumn{5}{|c|}{$\begin{array}{l}\text { Table C.5. Concentrations ( } \mu \mathrm{g} / \mathrm{L} \text { ) of Dissolved Metals in Columbia River Transect } \\
\text { and Near-Shore Water Samples Collected Near the Hanford Site, } 2004\end{array}$} & \multirow[b]{2}{*}{ \pm 2 SD } \\
\hline & $\underline{\text { Metal }}$ & $\begin{array}{l}\text { No. of } \\
\text { Samples }\end{array}$ & $\underline{\text { Maximum }}$ & $\underline{\text { Minimum }}$ & $\underline{\text { Average }}$ & \\
\hline Vernita Bridge & $\begin{array}{l}\text { Aluminum } \\
\text { Antimony } \\
\text { Arsenic } \\
\text { Barium } \\
\text { Beryllium } \\
\text { Cadmium } \\
\text { Chromium } \\
\text { Copper } \\
\text { Lead } \\
\text { Manganese } \\
\text { Nickel } \\
\text { Selenium } \\
\text { Silver } \\
\text { Thallium } \\
\text { Thorium } \\
\text { Uranium } \\
\text { Zinc }\end{array}$ & $\begin{array}{l}3 \\
7 \\
7 \\
3 \\
7 \\
7 \\
7 \\
7 \\
7 \\
3 \\
7 \\
7 \\
7 \\
7 \\
3 \\
3 \\
7\end{array}$ & $\begin{array}{l}1.4 \\
0.26 \\
0.65 \\
25.3 \\
0.030 \\
0.022 \\
0.13 \\
0.56 \\
0.032 \\
0.90 \\
0.93 \\
0.21 \\
0.003 \\
0.017 \\
0.003 \\
0.61 \\
2.7\end{array}$ & $\begin{array}{l}1.0 \\
0.15 \\
0.44 \\
25.0 \\
0.011 \\
0.010 \\
0.054 \\
0.49 \\
0.013 \\
0.76 \\
0.80 \\
0.098 \\
0.002 \\
0.015 \\
0.003 \\
0.56 \\
0.91\end{array}$ & $\begin{array}{l}1.2 \\
0.21 \\
0.55 \\
25.2 \\
0.019 \\
0.016 \\
0.091 \\
0.53 \\
0.022 \\
0.81 \\
0.86 \\
0.15 \\
0.002 \\
0.016 \\
0.003 \\
0.58 \\
1.6\end{array}$ & $\begin{array}{l}0.40 \\
0.092 \\
0.19 \\
0.346 \\
0.020 \\
0.010 \\
0.045 \\
0.049 \\
0.014 \\
0.16 \\
0.097 \\
0.086 \\
0.001 \\
0.001 \\
0.00 \\
0.051 \\
1.5\end{array}$ \\
\hline 100-N Area & $\begin{array}{l}\text { Antimony } \\
\text { Arsenic } \\
\text { Beryllium } \\
\text { Cadmium } \\
\text { Chromium } \\
\text { Copper } \\
\text { Lead } \\
\text { Nickel } \\
\text { Selenium } \\
\text { Silver } \\
\text { Thallium } \\
\text { Zinc }\end{array}$ & $\begin{array}{l}10 \\
10 \\
10 \\
10 \\
10 \\
10 \\
10 \\
10 \\
10 \\
10 \\
10 \\
10\end{array}$ & $\begin{array}{l}0.38 \\
0.68 \\
0.011 \\
0.015 \\
0.15 \\
0.56 \\
0.019 \\
1.2 \\
0.28 \\
0.002 \\
0.017 \\
2.1\end{array}$ & $\begin{array}{l}0.21 \\
0.62 \\
0.011 \\
0.011 \\
0.023 \\
0.47 \\
0.013 \\
0.72 \\
0.10 \\
0.002 \\
0.015 \\
0.97\end{array}$ & $\begin{array}{l}0.26 \\
0.65 \\
0.011 \\
0.013 \\
0.081 \\
0.52 \\
0.015 \\
0.91 \\
0.17 \\
0.002 \\
0.016 \\
1.2\end{array}$ & $\begin{array}{l}0.10 \\
0.036 \\
0.00 \\
0.003 \\
0.095 \\
0.054 \\
0.005 \\
0.30 \\
0.11 \\
0.00 \\
0.001 \\
0.69\end{array}$ \\
\hline 100-F Area & $\begin{array}{l}\text { Antimony } \\
\text { Arsenic } \\
\text { Beryllium } \\
\text { Cadmium } \\
\text { Chromium } \\
\text { Copper } \\
\text { Lead } \\
\text { Nickel } \\
\text { Selenium } \\
\text { Silver } \\
\text { Thallium } \\
\text { Zinc }\end{array}$ & $\begin{array}{l}9 \\
9 \\
9 \\
9 \\
9 \\
9 \\
9 \\
9 \\
9 \\
9 \\
9 \\
9\end{array}$ & $\begin{array}{l}0.38 \\
0.81 \\
0.011 \\
0.015 \\
0.11 \\
0.68 \\
0.042 \\
1.0 \\
0.36 \\
0.004 \\
0.016 \\
1.2\end{array}$ & $\begin{array}{l}0.23 \\
0.60 \\
0.011 \\
0.009 \\
0.018 \\
0.47 \\
0.010 \\
0.65 \\
0.10 \\
0.002 \\
0.013 \\
0.73\end{array}$ & $\begin{array}{l}0.29 \\
0.67 \\
0.011 \\
0.012 \\
0.074 \\
0.54 \\
0.018 \\
0.79 \\
0.16 \\
0.002 \\
0.015 \\
0.93\end{array}$ & $\begin{array}{l}0.096 \\
0.12 \\
0.00 \\
0.004 \\
0.068 \\
0.12 \\
0.020 \\
0.24 \\
0.16 \\
0.002 \\
0.002 \\
0.36\end{array}$ \\
\hline $\begin{array}{l}\text { Hanford Town } \\
\text { Site }\end{array}$ & $\begin{array}{l}\text { Antimony } \\
\text { Arsenic } \\
\text { Beryllium } \\
\text { Cadmium } \\
\text { Chromium } \\
\text { Copper } \\
\text { Lead } \\
\text { Nickel } \\
\text { Selenium } \\
\text { Silver } \\
\text { Thallium } \\
\text { Zinc }\end{array}$ & $\begin{array}{l}10 \\
10 \\
10 \\
10 \\
10 \\
10 \\
10 \\
10 \\
10 \\
10 \\
10 \\
10\end{array}$ & $\begin{array}{l}0.34 \\
0.69 \\
0.011 \\
0.012 \\
0.12 \\
0.51 \\
0.031 \\
0.74 \\
0.20 \\
0.002 \\
0.018 \\
1.6\end{array}$ & $\begin{array}{l}0.24 \\
0.60 \\
0.011 \\
0.007 \\
0.018 \\
0.48 \\
0.014 \\
0.65 \\
0.10 \\
0.002 \\
0.015 \\
0.76\end{array}$ & $\begin{array}{l}0.27 \\
0.63 \\
0.011 \\
0.010 \\
0.050 \\
0.50 \\
0.019 \\
0.69 \\
0.13 \\
0.002 \\
0.017 \\
1.0\end{array}$ & $\begin{array}{l}0.064 \\
0.053 \\
0.00 \\
0.003 \\
0.067 \\
0.019 \\
0.012 \\
0.056 \\
0.061 \\
0.00 \\
0.002 \\
0.49\end{array}$ \\
\hline
\end{tabular}




\begin{tabular}{|c|c|c|c|c|c|c|}
\hline \multirow[b]{2}{*}{ Location } & \multirow[b]{2}{*}{$\underline{\text { Metal }}$} & \multicolumn{2}{|c|}{ Table C.5. (contd) } & \multirow[b]{2}{*}{$\underline{\text { Minimum }}$} & \multirow[b]{2}{*}{ Average } & \multirow[b]{2}{*}{ $\pm 2 \mathrm{SD}$} \\
\hline & & $\begin{array}{c}\text { No. of } \\
\text { Samples }\end{array}$ & $\underline{\text { Maximum }}$ & & & \\
\hline \multirow[t]{12}{*}{300 Area } & Antimony & 12 & 0.31 & 0.16 & 0.25 & 0.080 \\
\hline & Arsenic & 12 & 3.0 & 0.68 & 1.1 & 1.7 \\
\hline & Beryllium & 12 & 0.011 & 0.011 & 0.011 & 0.00 \\
\hline & Cadmium & 12 & 0.016 & 0.009 & 0.011 & 0.004 \\
\hline & Chromium & 12 & 2.0 & 0.024 & 0.38 & 1.5 \\
\hline & Copper & 12 & 0.91 & 0.54 & 0.61 & 0.19 \\
\hline & Lead & 12 & 0.029 & 0.012 & 0.017 & 0.011 \\
\hline & Nickel & 12 & 1.4 & 0.66 & 0.81 & 0.42 \\
\hline & Selenium & 12 & 1.3 & 0.13 & 0.43 & 0.79 \\
\hline & Silver & 12 & 0.003 & 0.002 & 0.002 & 0.001 \\
\hline & Thallium & 12 & 0.019 & 0.007 & 0.016 & 0.008 \\
\hline & Zinc & 12 & 1.0 & 0.69 & 0.83 & 0.23 \\
\hline \multirow[t]{12}{*}{ Richland } & Antimony & 10 & 0.30 & 0.25 & 0.27 & 0.032 \\
\hline & Arsenic & 10 & 1.1 & 0.62 & 0.74 & 0.30 \\
\hline & Beryllium & 10 & 0.011 & 0.011 & 0.011 & 0.00 \\
\hline & Cadmium & 10 & 0.014 & 0.009 & 0.011 & 0.003 \\
\hline & Chromium & 10 & 0.18 & 0.018 & 0.080 & 0.12 \\
\hline & Copper & 10 & 0.78 & 0.50 & 0.58 & 0.19 \\
\hline & Lead & 10 & 0.032 & 0.014 & 0.020 & 0.011 \\
\hline & Nickel & 10 & 0.92 & 0.70 & 0.78 & 0.12 \\
\hline & Selenium & 10 & 0.27 & 0.10 & 0.18 & 0.12 \\
\hline & Silver & 10 & 0.002 & 0.002 & 0.002 & 0.00 \\
\hline & Thallium & 10 & 0.018 & 0.015 & 0.017 & 0.002 \\
\hline & Zinc & 10 & 1.4 & 0.88 & 1.1 & 0.32 \\
\hline
\end{tabular}




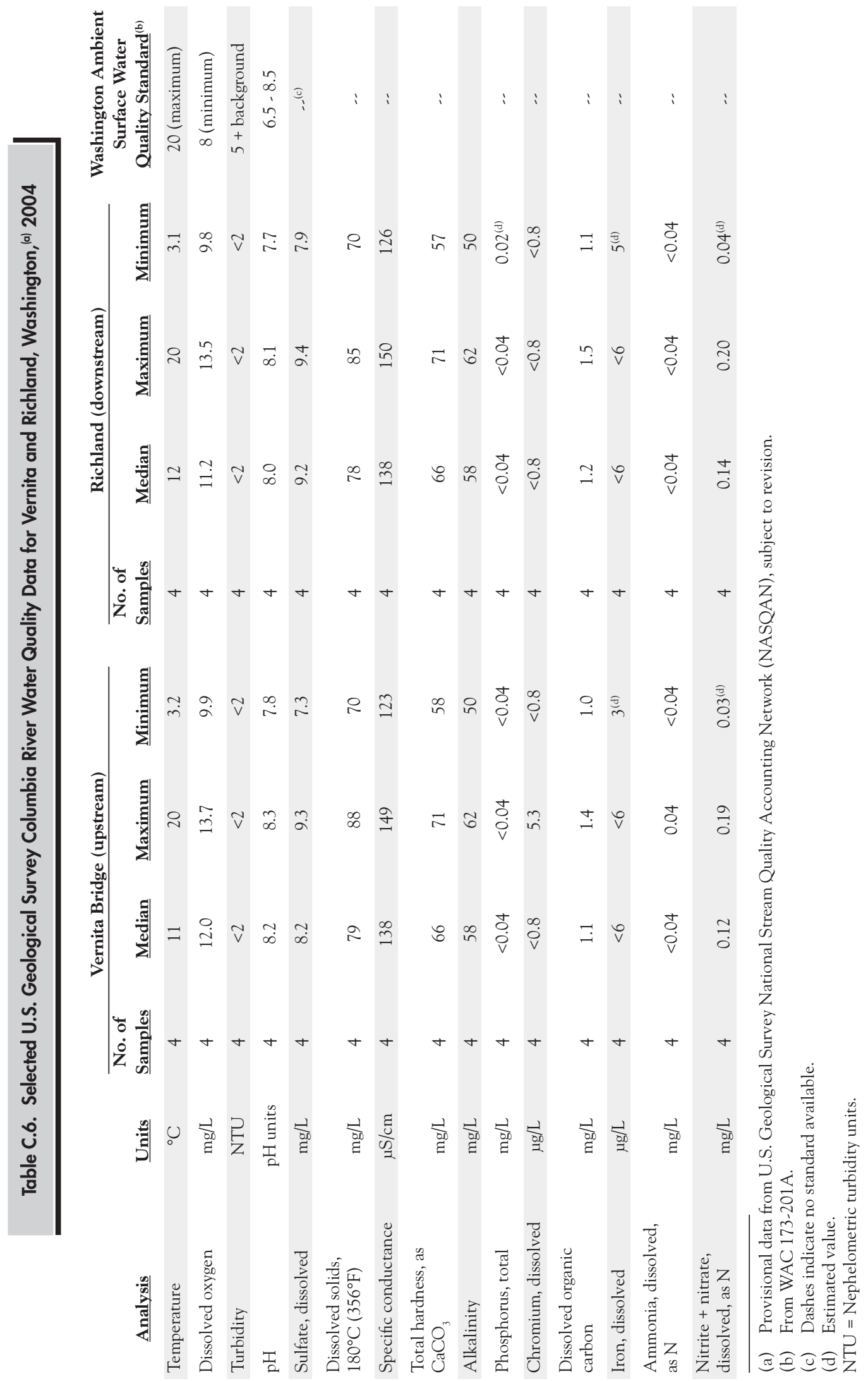




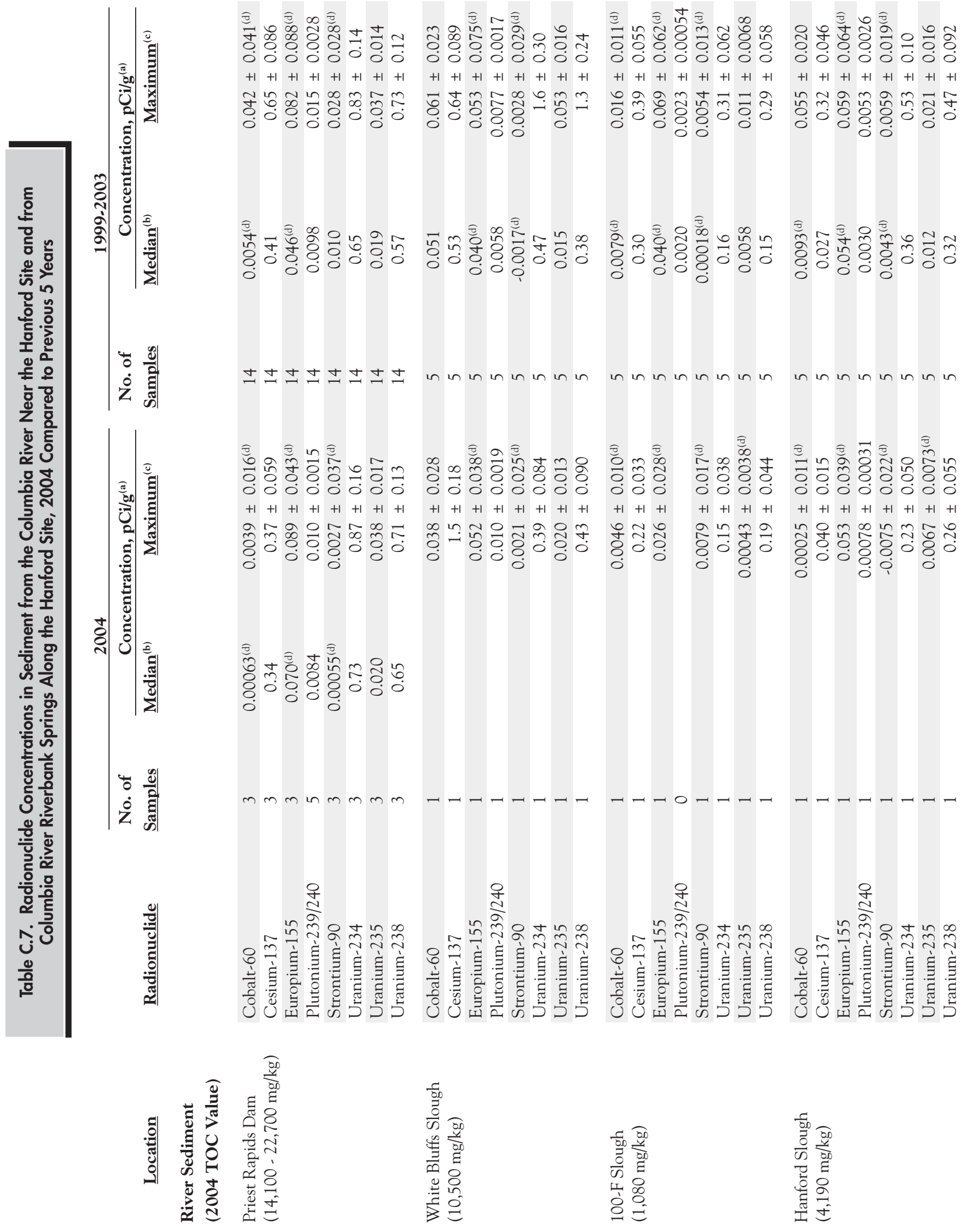



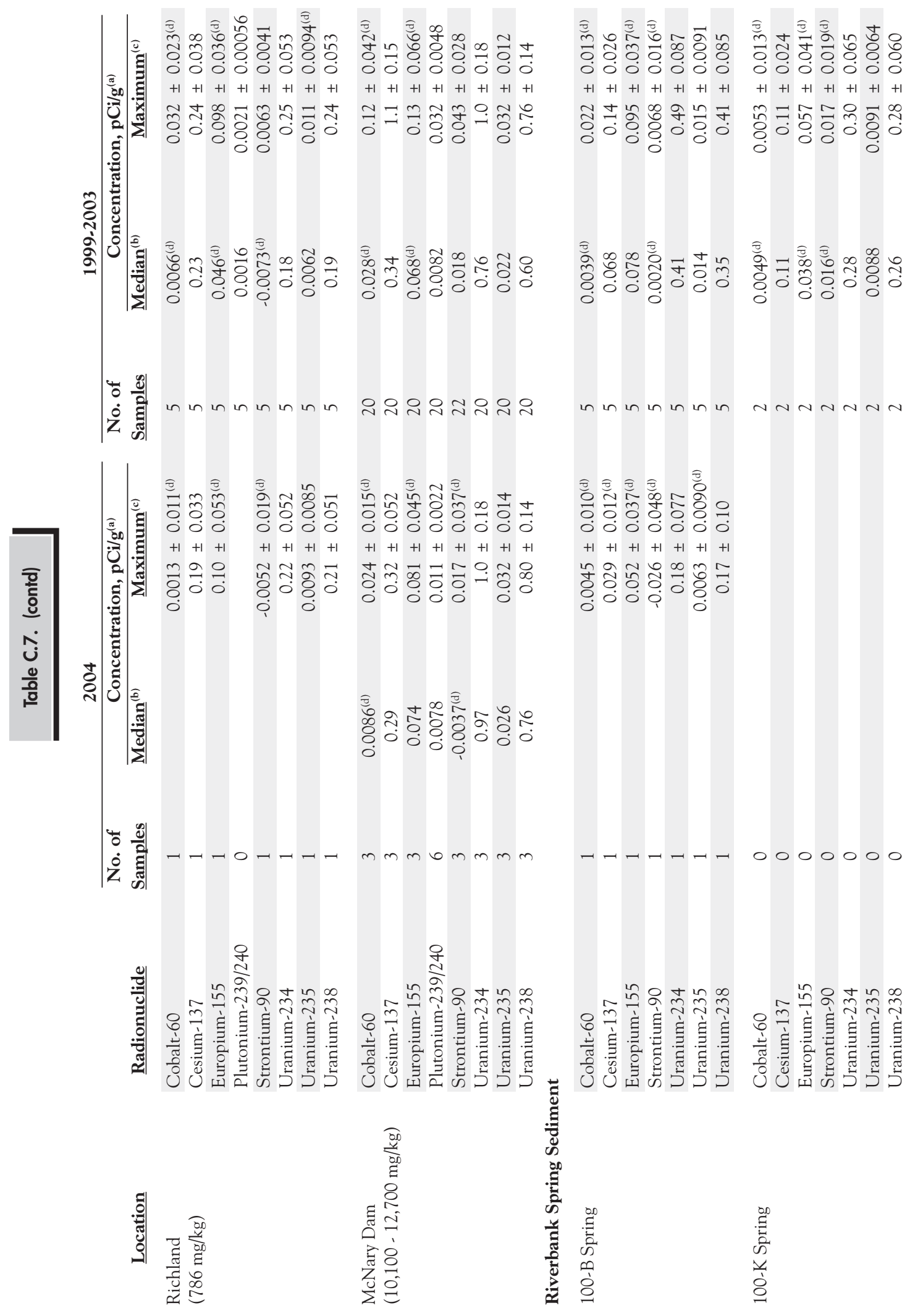

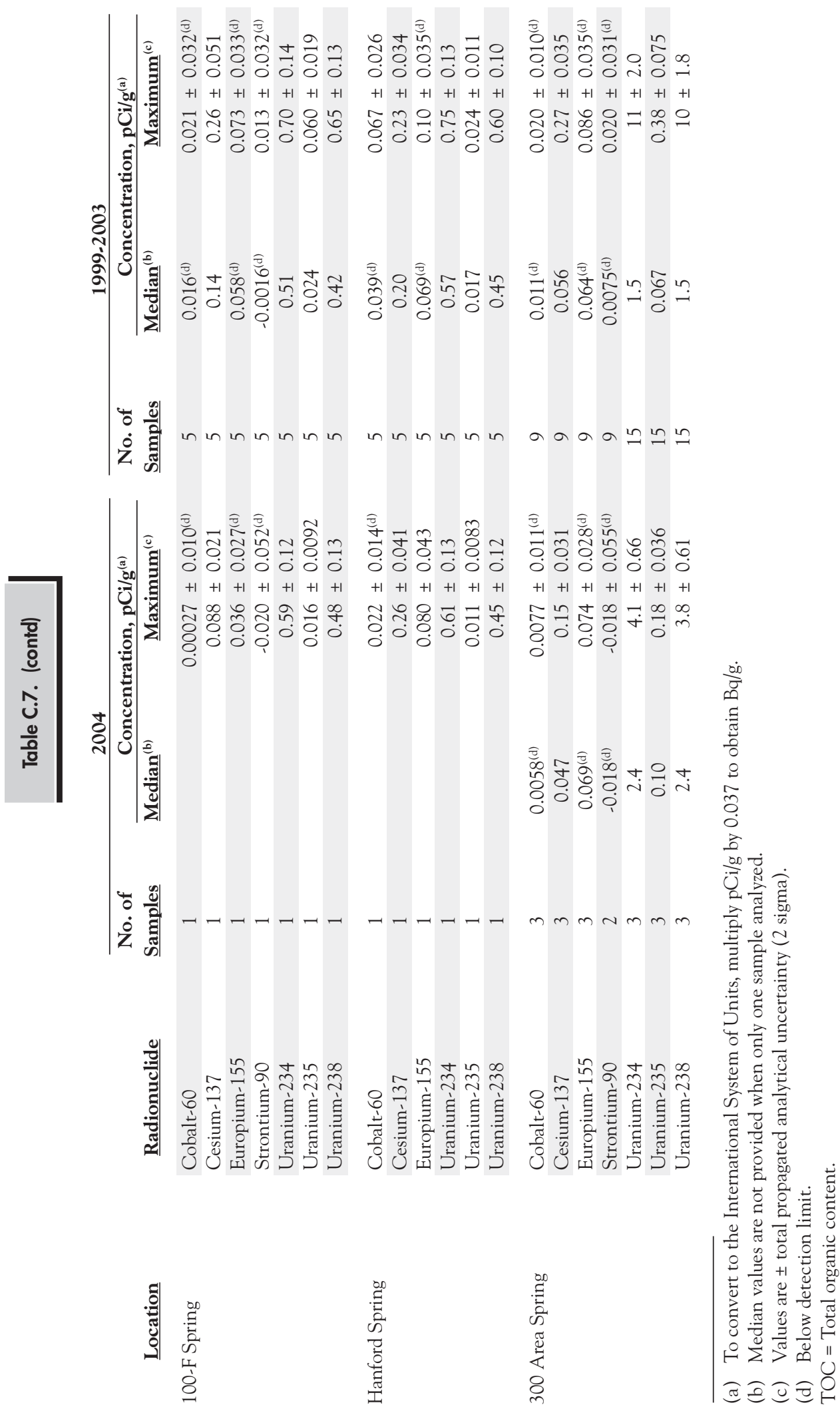


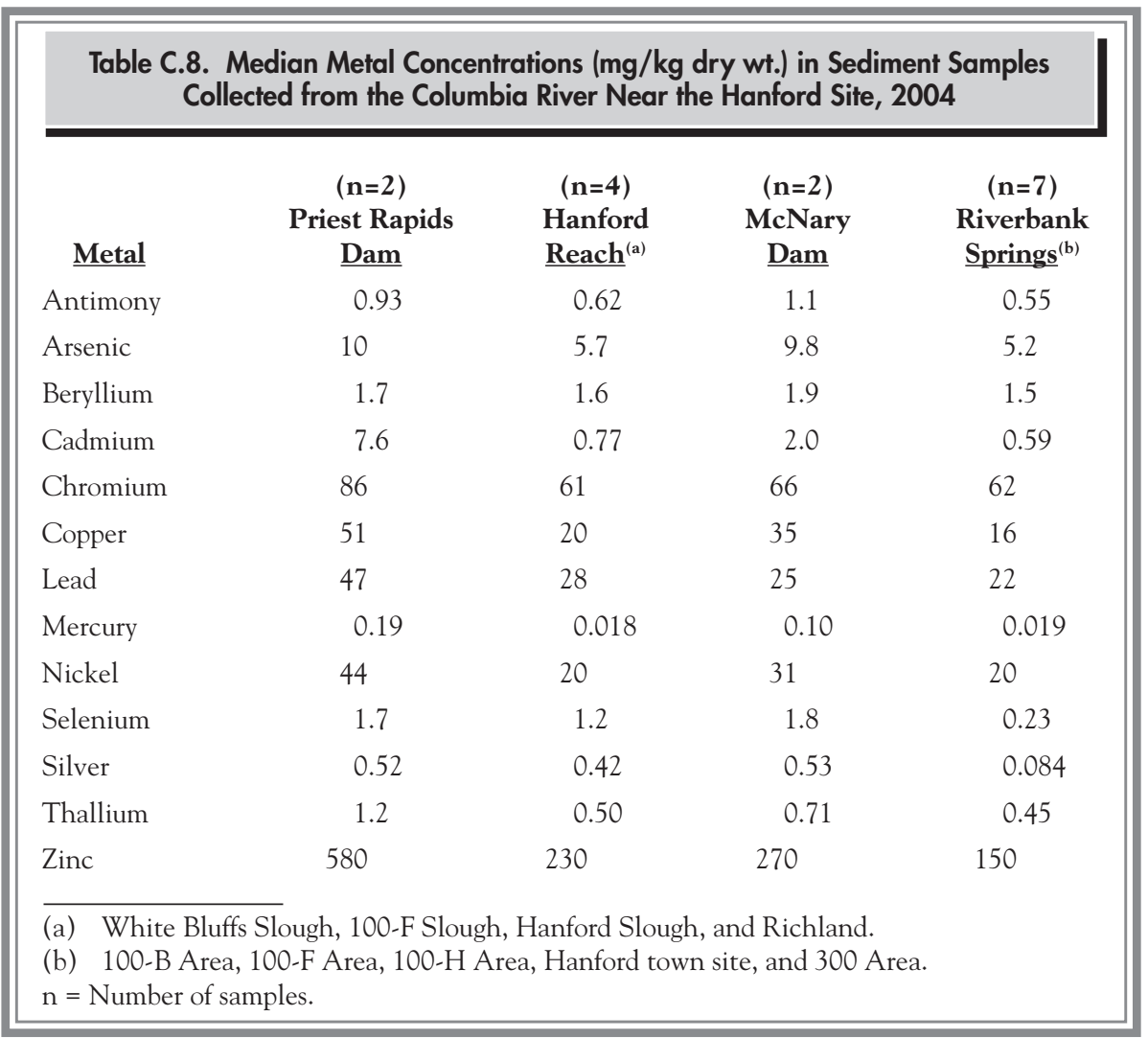




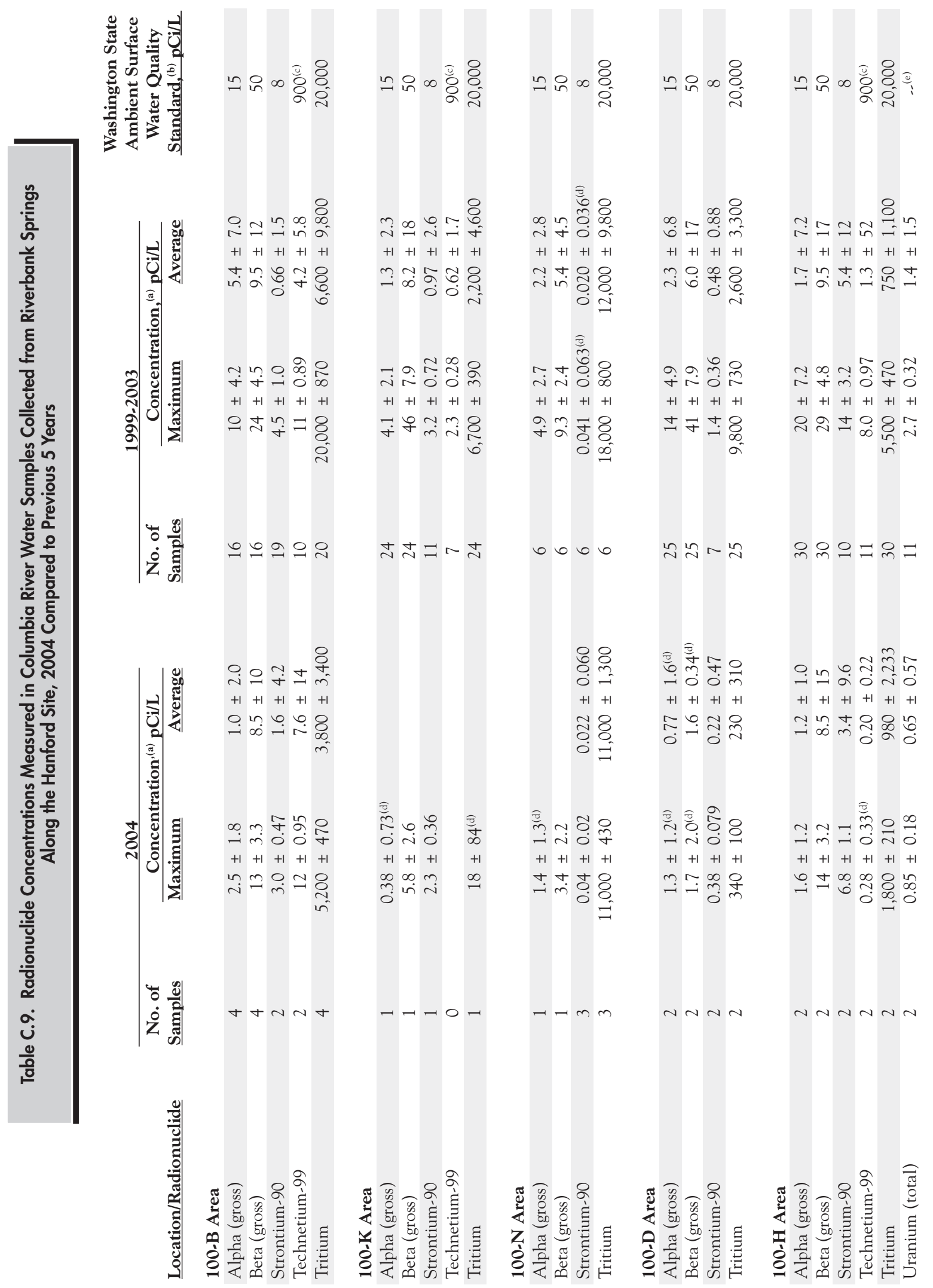




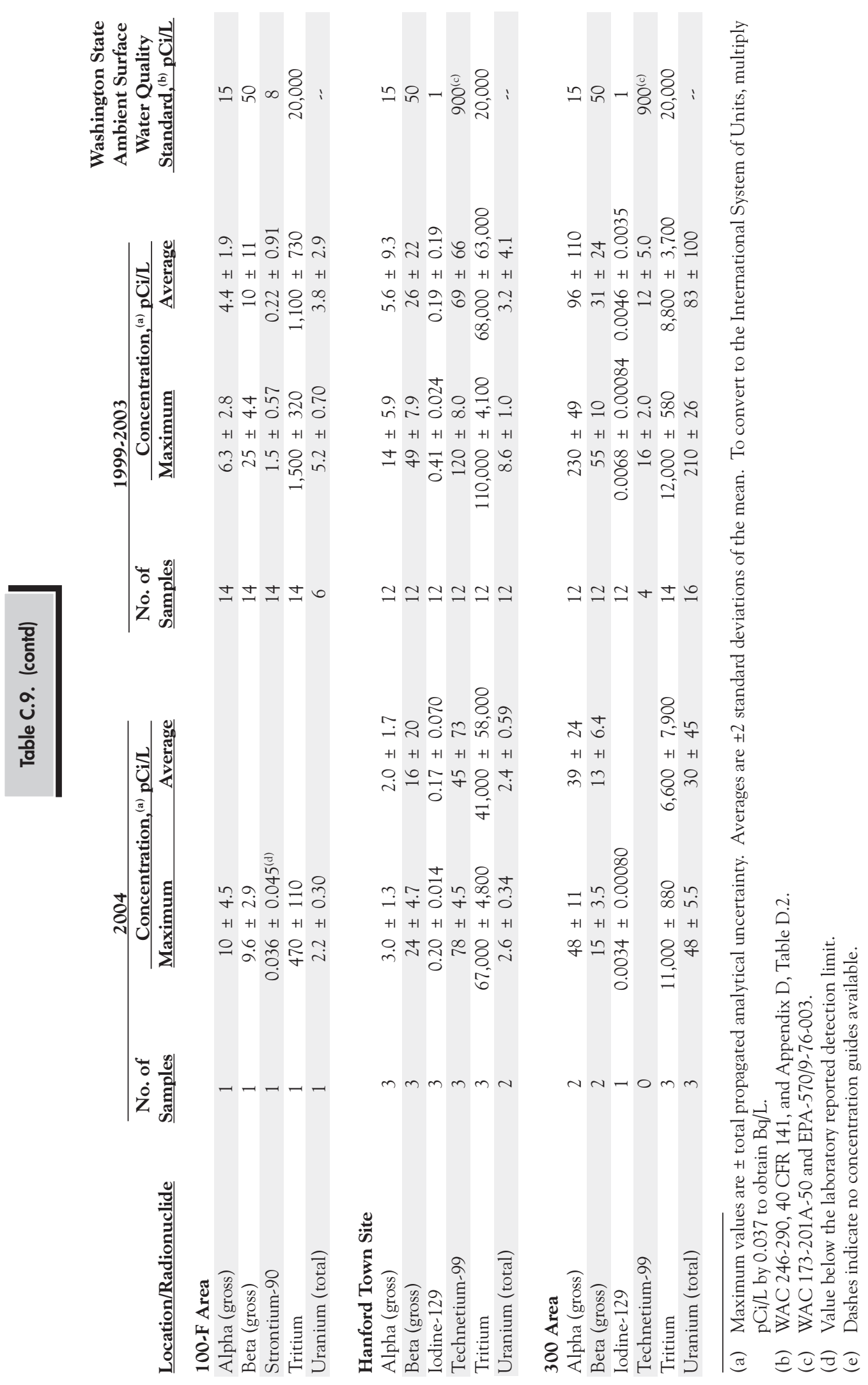


Table C.10. Annual Average Dose Rates Measured at Site-Wide and Offsite Locations in 2004

\begin{tabular}{|c|c|c|c|c|c|}
\hline Location & $\begin{array}{l}\text { Location } \\
\text { Number }\end{array}$ & $\begin{array}{l}\text { Annual Average } \\
{\underline{(\mathbf{m r e m} / \mathbf{y r})^{(\mathbf{a})}}}\end{array}$ & Location & $\begin{array}{l}\text { Location } \\
\text { Number }\end{array}$ & $\begin{array}{c}\text { Annual Average } \\
{\underline{(\mathrm{mrem} / \mathrm{yr})^{(\mathrm{a})}}}\end{array}$ \\
\hline \multicolumn{3}{|l|}{ Onsite $^{(\mathrm{b})}$} & \multicolumn{3}{|l|}{ Community $^{(c)}$} \\
\hline 100 B Reactor Museum & 1 & $84 \pm 8$ & Mattawa & 12 & $79 \pm 4$ \\
\hline $100 \mathrm{~K}$ Area & 2 & $74 \pm 3$ & Othello & 13 & $73 \pm 5$ \\
\hline 100 D Area & 3 & $88 \pm 6$ & Basin City School ${ }^{(\mathrm{d})}$ & 14 & $77 \pm 4$ \\
\hline 100 F Met Tower & 4 & $81 \pm 6$ & Edwin Markham School & 15 & $74 \pm 7$ \\
\hline $\mathrm{N}$ of $200 \mathrm{E}$ & 5 & $94 \pm 12$ & Pasco & 16 & $87 \pm 8$ \\
\hline B Pond & 6 & $82 \pm 4$ & Kennewick - Ely Street & 17 & $80 \pm 16$ \\
\hline E of $200 \mathrm{E}$ & 7 & $87 \pm 4$ & Benton City & 18 & $80 \pm 4$ \\
\hline 200 ESE & 8 & $86 \pm 8$ & \multirow{2}{*}{\multicolumn{3}{|c|}{ Distant $^{(\mathrm{c})}$}} \\
\hline S of $200 \mathrm{E}$ & 9 & $95 \pm 9$ & & & \\
\hline 200 Tel. Exchange & 10 & $82 \pm 2$ & Yakima & 19 & $71 \pm 4$ \\
\hline SW of B/C Cribs & 11 & $86 \pm 11$ & Toppenish & 20 & $71 \pm 8$ \\
\hline $200 \mathrm{~W}$ SE & 12 & $82 \pm 6$ & \multicolumn{3}{|l|}{ Columbia River Shoreline ${ }^{(\mathrm{e})}$} \\
\hline Army Loop Camp & 13 & $86 \pm 9$ & Below 100N Outfall & 1 & $86 \pm 15$ \\
\hline 3705 Bldg. 300 Area & 14 & $82 \pm 6$ & Above Tip 100N Berm & 2 & $86 \pm 7$ \\
\hline 313 Bldg. & 15 & $91 \pm 7$ & 100 N Trench Spring & 3 & $103 \pm 7$ \\
\hline 300 Water Intake & 16 & $78 \pm 3$ & S End Vernita Bridge & 4 & $78 \pm 5$ \\
\hline 300 Southwest Gate & 17 & $82 \pm 12$ & Above 100 B Area & 5 & $86 \pm 6$ \\
\hline 300 South Gate & 18 & $82 \pm 4$ & Below 100B Retention Basin & 6 & $97 \pm 15$ \\
\hline 300 Trench & 19 & $86 \pm 9$ & Coyote Rapids ${ }^{(f)}$ & 7 & $71 \pm 22$ \\
\hline $300 \mathrm{NE}$ & 20 & $88 \pm 11$ & Above $1 \mathrm{~K}$ Boat Ramp & 8 & $83 \pm 6$ \\
\hline $400 \mathrm{E}$ & 21 & $80 \pm 2$ & Below 100 D Area & 9 & $72 \pm 4$ \\
\hline $400 \mathrm{~W}$ & 22 & $84 \pm 7$ & 100-D Island & 10 & $78 \pm 5$ \\
\hline $400 \mathrm{~S}$ & 23 & $83 \pm 7$ & $100 \mathrm{H}$ Area & 11 & $85 \pm 4$ \\
\hline $400 \mathrm{~N}$ & 24 & $83 \pm 11$ & Lower End Locke Island & 12 & $90 \pm 4$ \\
\hline US Ecology NE Corner & 25 & $86 \pm 9$ & White Bluffs Ferry Landing & 13 & $82 \pm 3$ \\
\hline US Ecology SE Corner & 26 & $86 \pm 7$ & White Bluffs Slough $^{(f)}$ & 14 & $100 \pm 15$ \\
\hline US Ecology NW Corner & 27 & $86 \pm 8$ & Below $100 \mathrm{~F}$ & 15 & $79 \pm 6$ \\
\hline US Ecology SW Corner & 28 & $96 \pm 9$ & 100 F Flood Plain & 16 & $85 \pm 10$ \\
\hline Wye Barricade & 29 & $87 \pm 4$ & Hanford Slough & 17 & $95 \pm 9$ \\
\hline WPPSS 1 ; $S$ of WNP 2 & 30 & $85 \pm 6$ & Hanford Powerline Crossing & 18 & $93 \pm 10$ \\
\hline Hanford Townsite & 31 & $82 \pm 6$ & Hanford Railroad Track ${ }^{(f)}$ & 19 & $91 \pm 16$ \\
\hline West Lake & 32 & $90 \pm 5$ & Savage Island Slough ${ }^{(f)}$ & 20 & $82 \pm 10$ \\
\hline \multirow{2}{*}{ LIGO } & \multirow[t]{2}{*}{33} & \multirow[t]{2}{*}{$77 \pm 4$} & Ringold Island & 21 & $82 \pm 4$ \\
\hline & & & Powerline Crossing & 22 & $84 \pm 6$ \\
\hline \multicolumn{3}{|l|}{ Perimeter $^{(\mathrm{c})}$} & S End Wooded Island & 23 & $94 \pm 5$ \\
\hline Ringold Met Tower & 1 & $92 \pm 1$ & Island Above 300 Area $^{(f)}$ & 24 & $93 \pm 12$ \\
\hline W End of Fir Road & 2 & $93 \pm 11$ & Island Near 300 Area & 25 & $91 \pm 4$ \\
\hline Dogwood Met Tower & 3 & $91 \pm 4$ & Port of Benton-River & 26 & $85 \pm 6$ \\
\hline Byers Landing & 4 & $97 \pm 5$ & N. Richland & 27 & $78 \pm 9$ \\
\hline Battelle Complex & 5 & $82 \pm 5$ & \multirow{7}{*}{$\begin{array}{l}\text { Island Downstream } \\
\text { Bateman Island }^{(\mathrm{d})}\end{array}$} & & \\
\hline WPPSS 4; WPS Warehse & 6 & $77 \pm 7$ & & 28 & $92 \pm 4$ \\
\hline Horn Rapids Substation ${ }^{(f)}$ & 7 & $84 \pm 10$ & & & \\
\hline Prosser Barricade & 8 & $89 \pm 10$ & & & \\
\hline Yakima Barricade & 9 & $96 \pm 14$ & & & \\
\hline Rattlesnake Springs & 10 & $89 \pm 10$ & & & \\
\hline Wahluke Slope & 11 & $92 \pm 8$ & & & \\
\hline \multicolumn{6}{|c|}{$\begin{array}{l}\text { (a) Average for four quarterly measurements } \pm 2 \text { sta } \\
\text { (b) All locations are shown on Figure 8.13.2. } \\
\text { (c) All locations are shown on Figure 8.13.3. } \\
\text { (d) Measurements for two calendar quarters only. } \\
\text { (e) All locations are shown on Figure 8.13.4. } \\
\text { (f) Measurements for three calendar quarters only. }\end{array}$} \\
\hline
\end{tabular}




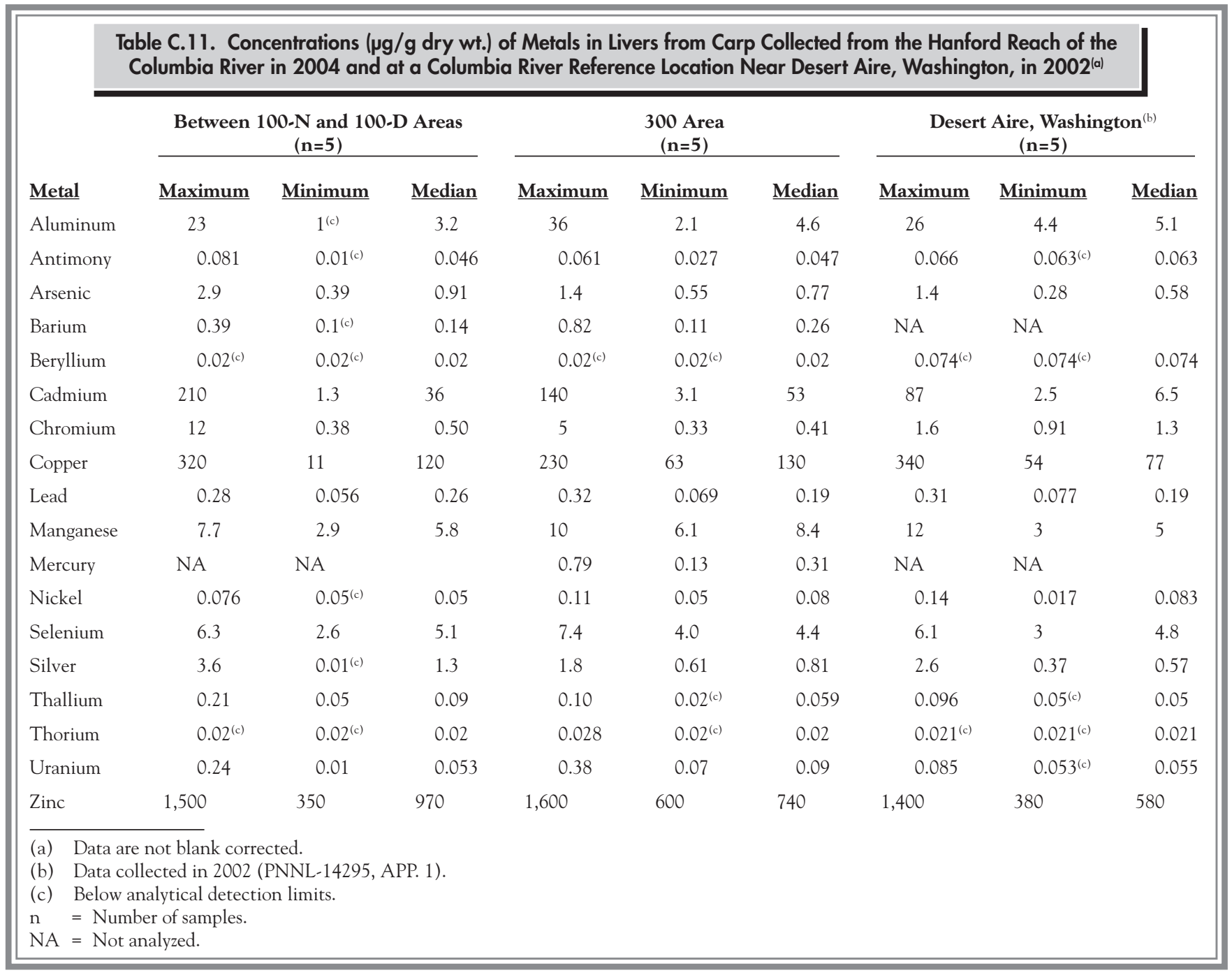




\begin{tabular}{|c|c|c|c|c|c|c|c|c|c|}
\hline \multirow[b]{3}{*}{ Metal } & \multicolumn{8}{|c|}{$\begin{array}{l}\text { Table C.12. Concentrations ( } \mu \mathrm{g} / \mathrm{g} \text { dry wt.) of Metals in Livers from Quail Collected on the Hanford Site and } \\
\text { at a Reference Location Near Grandview, Washington, in 2004(a) }\end{array}$} & \\
\hline & \multicolumn{3}{|c|}{$\begin{array}{l}\text { Between 100-D and 100-H Areas } \\
(n=4)\end{array}$} & \multicolumn{3}{|c|}{$\begin{array}{l}\text { Between the } 100-\mathrm{H} \text { and } 100-\mathrm{F} \text { Areas } \\
(\mathrm{n}=3)\end{array}$} & \multicolumn{3}{|c|}{$\begin{array}{l}\text { Grandview, Washington } \\
(\mathbf{n}=5)\end{array}$} \\
\hline & Maximum & $\underline{\text { Minimum }}$ & Median & $\underline{\text { Maximum }}$ & Minimum & Median & Maximum & Minimum & $\underline{\text { Median }}$ \\
\hline Aluminum & 5.6 & 1.5 & 3.3 & 9.5 & 0.79 & 0.85 & 1.5 & 1.0 & 1.3 \\
\hline Antimony & $0.01^{(\mathrm{b})}$ & $0.01^{(\mathrm{b})}$ & $0.01^{(\mathrm{b})}$ & $0.01^{(\mathrm{b})}$ & $0.01^{(\mathrm{b})}$ & $0.01^{(\mathrm{b})}$ & 0.017 & $0.01^{(\mathrm{b})}$ & 0.011 \\
\hline Arsenic & 1.2 & 0.1 & 0.71 & 1.1 & 0.1 & 0.87 & 0.77 & 0.46 & 0.61 \\
\hline Barium & $0.23^{(c)}$ & $0.23^{(\mathrm{c})}$ & 0.23 & $0.20^{(d)}$ & & & NA & NA & \\
\hline Beryllium & $0.02^{(\mathrm{b})}$ & $0.02^{(\mathrm{b})}$ & $0.02^{(\mathrm{b})}$ & $0.02^{(\mathrm{b})}$ & $0.02^{(\mathrm{b})}$ & $0.02^{(\mathrm{b})}$ & $0.02^{(\mathrm{b})}$ & $0.02^{(\mathrm{b})}$ & $0.02^{(\mathrm{b})}$ \\
\hline Cadmium & 5.1 & 0.44 & 2.3 & 0.94 & 0.43 & 0.55 & 1.03 & 0.28 & 0.39 \\
\hline Chromium & 1.4 & 0.33 & 0.65 & 0.87 & 0.32 & 0.34 & 0.66 & 0.36 & 0.40 \\
\hline Copper & 28 & 16 & 17 & 17 & 15 & 16 & 7 & 14 & 14 \\
\hline Lead & 0.29 & 0.042 & 0.048 & 0.12 & 0.035 & 0.06 & 1.1 & 0.03 & 0.10 \\
\hline Manganese & 19 & 13 & 18 & 22 & 19 & 19 & 2 & 8.8 & 11 \\
\hline Mercury & $0.05^{(\mathrm{d})}$ & & & $0.060^{(\mathrm{d})}$ & & & NA & NA & \\
\hline Nickel & 0.086 & 0.05 & 0.052 & $0.05^{(\mathrm{b})}$ & $0.05^{(\mathrm{b})}$ & $0.05^{(\mathrm{b})}$ & $0.05^{(\mathrm{b})}$ & $0.05^{(\mathrm{b})}$ & $0.05^{(\mathrm{b})}$ \\
\hline Selenium & 6.8 & 1.8 & 4.3 & 3.3 & 2.1 & 2.1 & 2.3 & 1.4 & 1.6 \\
\hline Silver & 0.016 & 0.009 & 0.01 & 0.01 & 0.009 & 0.009 & $0.01^{(\mathrm{b})}$ & $0.01^{(\mathrm{b})}$ & $0.01^{(b)}$ \\
\hline Thallium & 0.023 & 0.005 & 0.022 & 0.022 & 0.009 & 0.011 & 0.01 & 0.002 & 0.004 \\
\hline Thorium & $0.02^{(\mathrm{b})}$ & $0.02^{(\mathrm{b})}$ & $0.02^{(\mathrm{b})}$ & $0.02^{(b, d)}$ & & & $0.02^{(\mathrm{b})}$ & $0.02^{(\mathrm{b})}$ & $0.02^{(b)}$ \\
\hline Uranium & $0.01^{(\mathrm{b})}$ & $0.009^{(b)}$ & $0.0095^{(\mathrm{b})}$ & $0.01^{(\mathrm{b})}$ & $0.009^{(b)}$ & $0.009^{(b)}$ & $0.01^{(\mathrm{b})}$ & $0.01^{(\mathrm{b})}$ & $0.01^{(b)}$ \\
\hline Zinc & 100 & 90 & 94 & 100 & 94 & 100 & 110 & 85 & 92 \\
\hline \multicolumn{10}{|c|}{$\begin{array}{l}\text { (a) Data are not blank corrected. } \\
\text { (b) Below detection limit. } \\
\text { (c) Only two samples analyzed. } \\
\text { (d) Only one sample analyzed. } \\
\text { n }=\text { Number of samples. } \\
\text { NA }=\text { Not analyzed. }\end{array}$} \\
\hline
\end{tabular}




\begin{tabular}{|c|c|c|c|c|c|c|c|}
\hline \multirow[b]{3}{*}{ Metal } & \multicolumn{7}{|c|}{$\begin{array}{l}\text { ble C. 13. Concentrations ( } \mu \mathrm{g} / \mathrm{g} \text { dry wt.) of Metals in Livers from Deer Collected on the Hanford Site in } 2004 \\
\text { and at Reference Locations Near Olympia, Washington, in } 2004 \text { and Boardman, Oregon, in } 1994\end{array}$} \\
\hline & \multicolumn{3}{|c|}{$\begin{array}{l}\text { 100-N Area } \\
(\mathrm{n}=2)\end{array}$} & \multirow{2}{*}{$\begin{array}{c}\begin{array}{c}\text { Olympia, Washington }^{(a)} \\
(\mathbf{n}=1)\end{array} \\
\underline{\text { Maximum }}\end{array}$} & \multicolumn{3}{|c|}{$\begin{array}{l}\text { Boardman, Oregon }^{(\mathrm{b})} \\
(\mathrm{n}=4)\end{array}$} \\
\hline & Maximum & $\underline{\text { Minimum }}$ & $\underline{\text { Median }}$ & & $\underline{\text { Maximum }}$ & Minimum & Median \\
\hline Aluminum & 1.3 & $0.6^{(\mathrm{c})}$ & 0.93 & 1.2 & NA & NA & \\
\hline Antimony & $0.01^{(\mathrm{c})}$ & $0.01^{(\mathrm{c})}$ & $0.01^{(c)}$ & $0.01^{(\mathrm{c})}$ & $0.02^{(\mathrm{c})}$ & $0.02^{(\mathrm{c})}$ & $0.02^{(\mathrm{c})}$ \\
\hline Arsenic & 2.3 & 2.0 & 2.1 & $0.1^{(\mathrm{c})}$ & 0.081 & $0.037^{(\mathrm{c})}$ & 0.050 \\
\hline Barium & $\mathrm{NA}$ & NA & & 0.25 & NA & NA & \\
\hline Beryllium & $0.02^{(\mathrm{c})}$ & $0.02^{(\mathrm{c})}$ & $0.02^{(c)}$ & $0.004^{(\mathrm{c})}$ & $0.15^{(\mathrm{c})}$ & $0.02^{(\mathrm{c})}$ & $0.15^{(\mathrm{c})}$ \\
\hline Cadmium & 0.77 & 0.56 & 0.66 & 0.12 & 0.39 & 0.21 & 0.38 \\
\hline Chromium & 0.36 & 0.35 & 0.35 & 0.52 & 0.11 & 0.07 & 0.07 \\
\hline Copper & 76 & 24 & 50 & 22 & 160 & 120 & 150 \\
\hline Lead & 0.04 & 0.038 & 0.039 & $0.03^{(\mathrm{c})}$ & 0.26 & 0.007 & 0.032 \\
\hline Manganese & 13 & 12 & 13 & 20 & NA & NA & \\
\hline Mercury & NA & NA & & $0.004^{(\mathrm{c})}$ & 0.016 & 0.011 & 0.015 \\
\hline Nickel & $0.05^{(\mathrm{c})}$ & $0.05^{(\mathrm{c})}$ & $0.05^{(c)}$ & $0.02^{(c)}$ & $0.056^{(c)}$ & $0.056^{(\mathrm{c})}$ & $0.056^{(c)}$ \\
\hline Selenium & 1.2 & 0.71 & 0.93 & $0.2^{(\mathrm{c})}$ & 0.97 & 0.59 & 0.74 \\
\hline Silver & 0.039 & $0.009^{(\mathrm{c})}$ & 0.024 & 0.022 & 0.18 & 0.11 & 0.14 \\
\hline Thallium & 0.016 & 0.005 & 0.011 & $0.004^{(c)}$ & $0.034^{(\mathrm{c})}$ & $0.001^{(\mathrm{c})}$ & $0.034^{(\mathrm{c})}$ \\
\hline Thorium & $0.005^{\text {(c) }}$ & $0.005^{\text {(c) }}$ & $0.005^{(c)}$ & $0.005^{(c)}$ & NA & NA & \\
\hline Uranium & $0.009^{\text {(c) }}$ & $0.009^{\text {(c) }}$ & $0.009^{(\mathrm{c})}$ & $0.003^{(\mathrm{c})}$ & NA & $\mathrm{NA}$ & \\
\hline Zinc & 110 & 90 & 99 & 150 & 160 & 110 & 140 \\
\hline \multicolumn{8}{|c|}{$\begin{array}{l}\text { (a) Data not blank corrected. } \\
\text { (b) Data blank corrected; originally presented in PNNL-11518. } \\
\text { (c) Below analytical detection limit. } \\
\mathrm{n} \quad=\text { Number of samples. } \\
\mathrm{NA}=\text { Not analyzed. }\end{array}$} \\
\hline
\end{tabular}




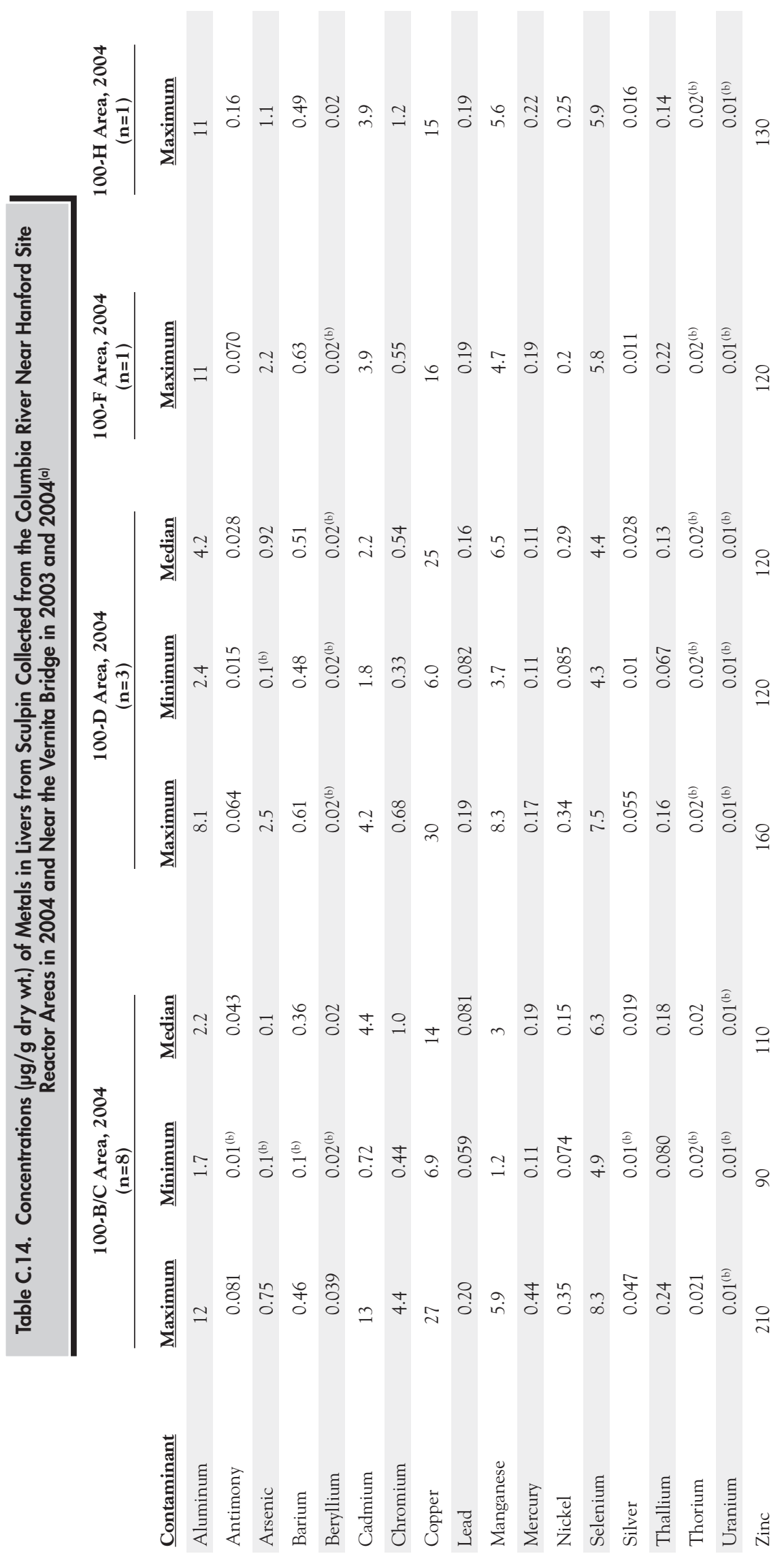



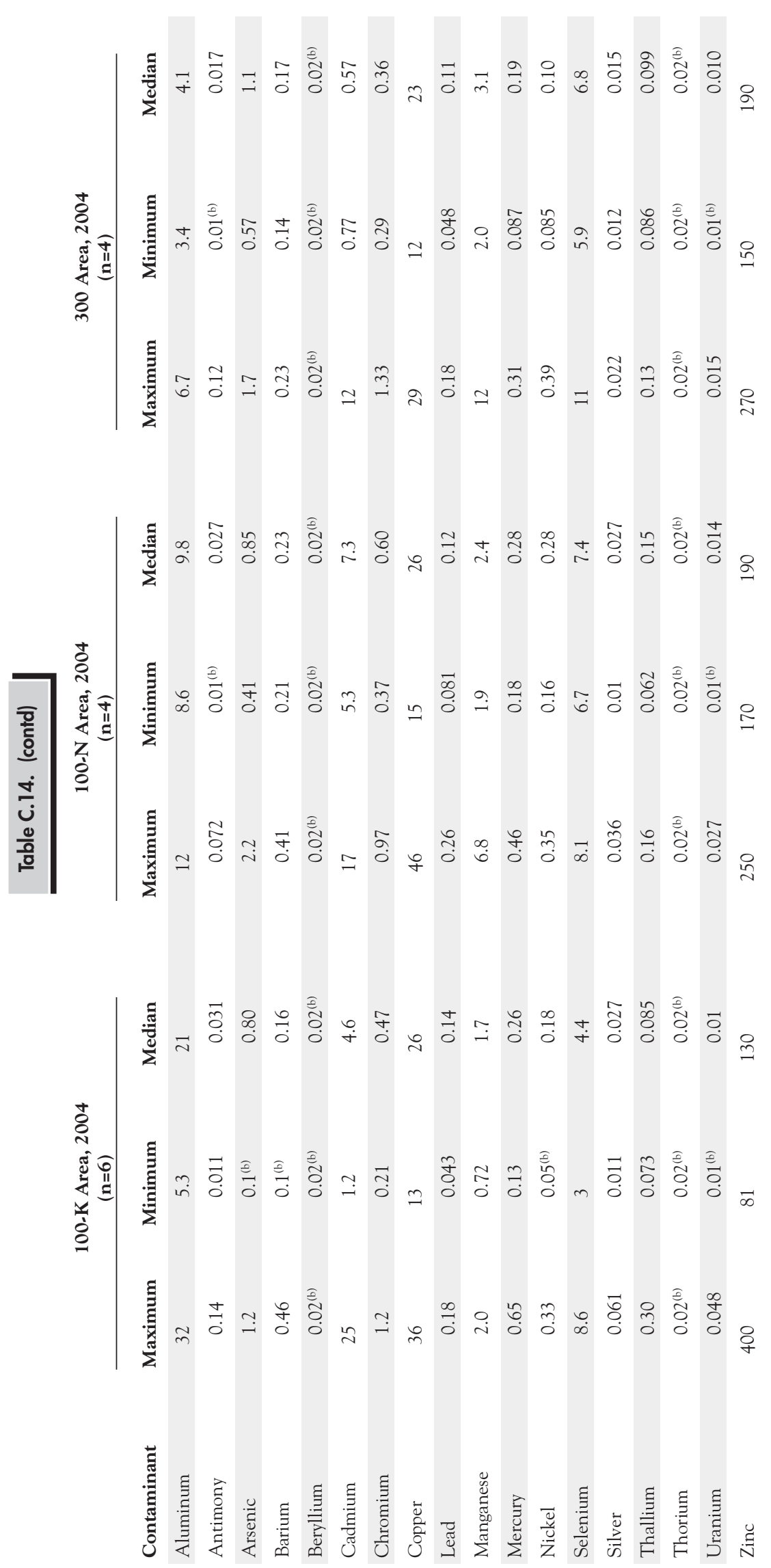

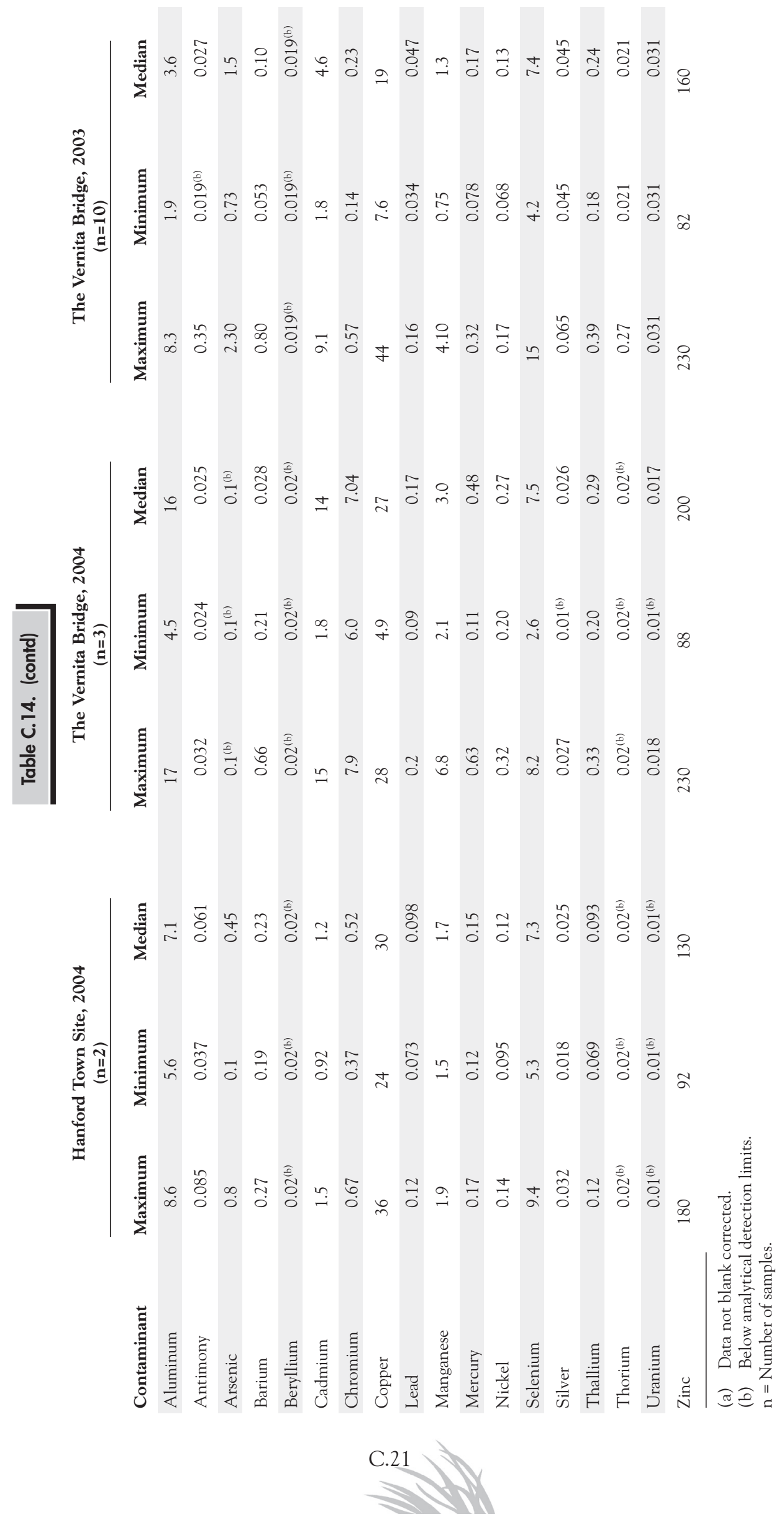


\section{References}

40 CFR 141. U.S. Environmental Protection Agency. "National Primary Drinking Water Regulations; Radionuclides; Proposed Rule." Code of Federal Regulations.

EPA-570/9-76-003. 1976. National Interim Primary Drinking Water Regulations. Office of Water Supply, U.S. Environmental Protection Agency, Washington, D.C.

PNNL-11518. 1997. Investigation of Anatomical Anomalies in the Hanford Site Mule Deer. BL Tiller, GE Dagle, LL Cadwell, TM Poston, and A Oganesian, Pacific Northwest National Laboratory, Richland, Washington.

PNNL-14295, APP. 1. 2003. Hanford Site Environmental Surveillance Data Report for Calendar Year 2002. LE Bisping, Pacific Northwest National Laboratory, Richland, Washington.
PNNL-15222, APP. 1. 2005. Hanford Site Environmental Surveillance Data Report for Calendar Year 2004. LE Bisping, Pacific Northwest National Laboratory, Richland, Washington.

WAC 173-201A. "Water Quality Standards for Surface Waters of the State of Washington." Washington Administrative Code, Olympia, Washington.

WAC 173-201A-50. "Radioactive Substances." Washington Administrative Code, Olympia, Washington.

WAC 246-290. "Public Water Systems." Washington Administrative Code, Olympia, Washington. 


\section{Appendix D Standards and Permits}

R. W. Hanf

Operations at the Hanford Site must conform to a variety of government standards and permits designed to assure the biological and physical quality of the environment for public health, ecological, or aesthetic considerations. The primary environmental quality standards and permits applicable to Hanford Site operations in 2004 are listed in the following tables. The state of Washington has water quality standards for the Columbia River, defined in Washington Administrative Code (WAC) 173-201A, Water Quality Standards for Surface Waters of the State of Washington. The Hanford Reach of the Columbia River has been designated as Class A (Excellent). This designation requires that the water be usable for substantially all needs, including drinking water, recreation, and wildlife. In 2003, the Washington State Department of Ecology revised the surface-water quality standards and submitted them to the U.S. Environmental Protection Agency (EPA) for approval. As the new standards are approved, the Class A (Excellent) designation uses are being replaced by other use designations. Four use designations have been identified for water bodies in the state: (1) Aquatic Life Uses, (2) Recreational Uses, (3) Water Supply Uses, and (4) Miscellaneous Uses. Within each designation are categories that apply to specific bodies of water. For the Hanford Reach of the Columbia River, the category for Aquatic Life Uses is noncore salmon and trout; for the protection of spawning, noncore rearing, and migration of salmon and trout, and other associated aquatic life. The category for Recreational Uses is primary contact recreation, which refers to the allowable amount of fecal coliform organisms. Designated water supply uses and miscellaneous uses include domestic water, industrial water, agricultural water, stock water, wildlife habitat, harvesting, commerce and navigation, boating, and aesthetics. Some of the new use designations and their criteria have been approved and some have not. For those not yet approved, the old criteria are still in effect. A summary of currently applicable
Hanford Reach water criteria is provided in Table D.1. Table D.2 summarizes drinking water standards from EPA in Title 40, Code of Federal Regulations, Part 141 (40 CFR 141) and WAC 246-290, Public Water Systems. Select surface freshwater quality criteria for toxic pollutants are included in Table D.3.

Environmental radiation protection standards are published in U.S. Department of Energy (DOE) Order 5400.5, Radiation Protection of the Public and the Environment. The Order establishes limits for public radiation dose and gives guidance to keep radiation exposure to members of the public as low as reasonably achievable. These standards are based on guidelines recommended by authoritative organizations such as the International Commission on Radiological Protection and the National Council on Radiation Protection and Measurements. DOE initiated a policy to create and implement public radiation protection standards that are generally consistent with the standards used by the U.S. Nuclear Regulatory Commission to regulate and license non-DOE nuclear facilities, such as nuclear power plants. Table D. 4 shows the radiation standards from DOE Order 5400.5, National Emission Standards for Hazardous Air Pollutants (40 CFR 61), and National Primary Drinking Water Regulations (40 CFR 141). These standards govern allowable public exposure to ionizing radiation from DOE operations.

DOE Order 5400.5 established derived concentration guides that reflect the concentrations of radionuclides in water and air that an individual could continuously consume, inhale, or be immersed in at average annual levels without exceeding an effective dose equivalent of $100 \mathrm{mrem}$ $(1 \mathrm{mSv})$ per year. Derived concentration guides are not exposure limits but are simply reference values that are provided to allow for comparisons of radionuclide concentrations in environmental media. Table D.5 lists selected DOE derived concentration guides for radionuclides of 
particular interest at the Hanford Site. The guides are useful reference values but do not generally represent concentrations in the environment that assure compliance with DOE, Clean Air Act, or drinking water dose standards.

Permits required for regulated releases to water and air have been issued by the EPA under the National Pollutant Discharge Elimination System of the Clean Water Act and the "Prevention of Significant Deterioration" requirements of the Clean Air Act. Also, under authority granted by the Clean Air Act, the Washington State Department of Health issued a permit for Hanford Site radioactive air emissions. Permits to collect wildlife for environmental sampling are issued by the Washington Department of Fish and Wildlife and the U.S. Fish and Wildlife Service. Current permits are discussed in Table D.6.

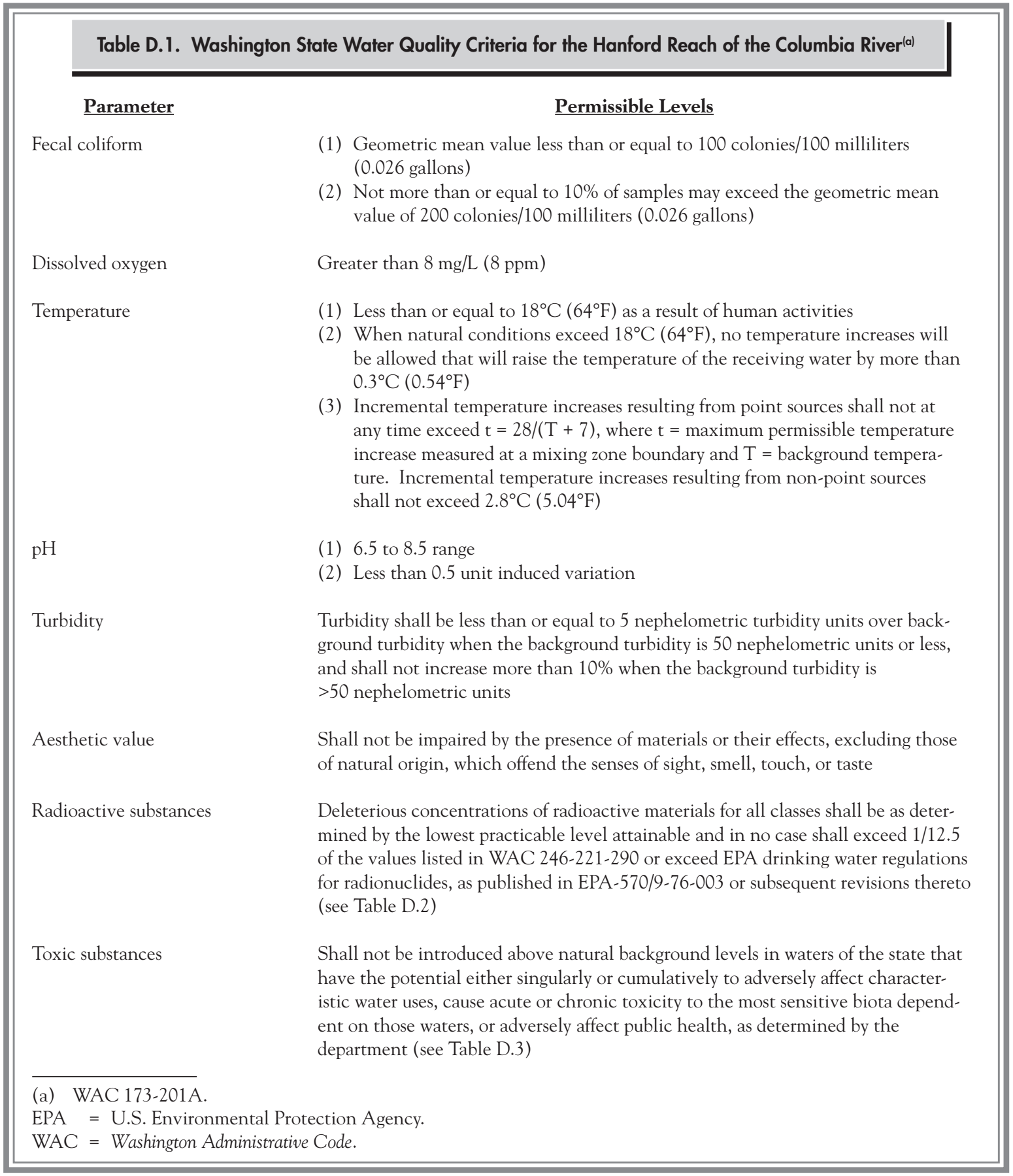




\begin{tabular}{|c|c|c|c|c|}
\hline \multirow[b]{2}{*}{$\underline{\text { Radiological Constituent }}$} & \multicolumn{2}{|c|}{ Table D.2. Selected Drinking Water Standards } & \multirow[b]{2}{*}{$\underline{\text { Agency }}$} & \multirow[b]{2}{*}{$\underline{\text { Status }}$} \\
\hline & $\begin{array}{l}\text { Primary Maximum } \\
\text { Contaminant Level }\end{array}$ & $\begin{array}{l}\text { Interim Drinking } \\
\text { Water Standard }\end{array}$ & & \\
\hline Gross alpha ${ }^{(a)}$ & \multicolumn{2}{|l|}{15 pCi $/ \mathrm{L}(0.56 \mathrm{~Bq} / \mathrm{L})$} & $\mathrm{DOH}^{(\mathrm{b})} \mathrm{EPA}^{(\mathrm{c})}$ & Final \\
\hline Beta particle and photon activity & \multicolumn{2}{|l|}{$4 \mathrm{mrem} / \mathrm{yr}(40 \mu \mathrm{Sv} / \mathrm{yr})^{(\mathrm{d})}$} & $\mathrm{DOH}^{(\mathrm{b})} \mathrm{EPA}^{(\mathrm{c})}$ & Final \\
\hline Tritium & \multicolumn{2}{|l|}{$20,000^{(\mathrm{e})} \mathrm{pCi} / \mathrm{L}(740 \mathrm{~Bq} / \mathrm{L})$} & $\mathrm{DOH}^{(\mathrm{b})} \mathrm{EPA}^{(\mathrm{c})}$ & Final \\
\hline Beryllium-7 & & $6,000^{(e)} \mathrm{pCi} / \mathrm{L}(222 \mathrm{~Bq} / \mathrm{L})$ & $\mathrm{EPA}^{(f)}$ & Interim \\
\hline Cobalt-60 & & $100^{(\mathrm{e})} \mathrm{pCi} / \mathrm{L}(3.7 \mathrm{~Bq} / \mathrm{L})$ & $\operatorname{EPA}^{(f)}$ & Interim \\
\hline Strontium-90 & \multicolumn{2}{|l|}{$8^{(\mathrm{e})} \mathrm{pCi} / \mathrm{L}(0.296 \mathrm{~Bq} / \mathrm{L})$} & $\mathrm{DOH},{ }^{(b)} \mathrm{EPA}^{(\mathrm{c})}$ & Final \\
\hline Technetium-99 & & $900^{(\mathrm{e})} \mathrm{pCi} / \mathrm{L}(33.3 \mathrm{~Bq} / \mathrm{L})$ & $\mathrm{EPA}^{(\mathrm{f})}$ & Interim \\
\hline Ruthenium-106 & & $30^{(\mathrm{e})} \mathrm{pCi} / \mathrm{L}(1.11 \mathrm{~Bq} / \mathrm{L})$ & $\mathrm{EPA}^{(f)}$ & Interim \\
\hline Antimony-125 & & $300^{(\mathrm{e})} \mathrm{pCi} / \mathrm{L}(11.1 \mathrm{~Bq} / \mathrm{L})$ & $\mathrm{EPA}^{(\mathrm{f})}$ & Interim \\
\hline Iodine-129 & & $1^{(\mathrm{e})} \mathrm{pCi} / \mathrm{L}(0.037 \mathrm{~Bq} / \mathrm{L})$ & $\mathrm{EPA}^{(f)}$ & Interim \\
\hline Iodine-131 & & $3^{(\mathrm{e})} \mathrm{pCi} / \mathrm{L}(0.111 \mathrm{~Bq} / \mathrm{L})$ & $\mathrm{EPA}^{(\mathrm{f})}$ & Interim \\
\hline Cesium-134 & & $20,000^{(\mathrm{e})} \mathrm{pCi} / \mathrm{L}(740 \mathrm{~Bq} / \mathrm{L})$ & $\mathrm{EPA}^{(\mathrm{f})}$ & Interim \\
\hline Cesium-137 & & $200^{(\mathrm{e})} \mathrm{pCi} / \mathrm{L}(7.4 \mathrm{~Bq} / \mathrm{L})$ & $\mathrm{EPA}^{(f)}$ & Interim \\
\hline Europium-154 & & $200^{(\mathrm{e})} \mathrm{pCi} / \mathrm{L}(7.4 \mathrm{~Bq} / \mathrm{L})$ & $\mathrm{EPA}^{(f)}$ & Interim \\
\hline Europium-155 & & $600^{(\mathrm{e})} \mathrm{pCi} / \mathrm{L}(22.2 \mathrm{~Bq} / \mathrm{L})$ & $\mathrm{EPA}^{(\mathrm{f})}$ & Interim \\
\hline Uranium & \multicolumn{2}{|l|}{$30 \mu \mathrm{g} / \mathrm{L}(0.03 \mathrm{ppm})^{(\mathrm{g})}$} & $\mathrm{EPA}^{(\mathrm{e})}$ & Final $^{(\mathrm{h})}$ \\
\hline Radium-226 & \multicolumn{2}{|l|}{$20 \mathrm{pCi} / \mathrm{L}(0.74 \mathrm{~Bq} / \mathrm{L})^{(\mathrm{c})}$} & DOH, EPA & Final \\
\hline Radium-226 and -228 & \multicolumn{2}{|l|}{$5 \mathrm{pCi} / \mathrm{L}(0.185 \mathrm{~Bq} / \mathrm{L})$} & EPA & Final \\
\hline Fluoride & \multicolumn{2}{|l|}{$4 \mathrm{mg} / \mathrm{L}(4 \mathrm{ppm})$} & $\mathrm{DOH},{ }^{(\mathrm{b})} \mathrm{EPA}^{(\mathrm{c}, \mathrm{i})}$ & Final/under review \\
\hline Nitrate, as $\mathrm{NO}_{3}$ & \multicolumn{2}{|l|}{$45 \mathrm{mg} / \mathrm{L}(45 \mathrm{ppm})$} & $\mathrm{DOH},{ }^{(\mathrm{b})} \mathrm{EPA}^{(\mathrm{c}, \mathrm{i})}$ & Final \\
\hline Chromium & \multicolumn{2}{|l|}{$100 \mu \mathrm{g} / \mathrm{L}(0.1 \mathrm{ppm})$} & $\mathrm{DOH},{ }^{(\mathrm{b})} \mathrm{EPA}^{(\mathrm{c}, \mathrm{i})}$ & Final \\
\hline Cyanide & \multicolumn{2}{|l|}{$200 \mu \mathrm{g} / \mathrm{L}(0.2 \mathrm{ppm})$} & $\mathrm{EPA}^{(\mathrm{b}, \mathrm{c}, \mathrm{i})}$ & Final \\
\hline Trichloroethene & \multicolumn{2}{|l|}{$5 \mu \mathrm{g} / \mathrm{L}(0.005 \mathrm{ppm})$} & $\mathrm{DOH},{ }^{(\mathrm{b})} \mathrm{EPA}^{(\mathrm{c}, \mathrm{i})}$ & Final \\
\hline Tetrachloroethene & \multicolumn{2}{|l|}{$5 \mu \mathrm{g} / \mathrm{L}(0.005 \mathrm{ppm})$} & $\mathrm{DOH}^{\left({ }^{(b)}\right.} \mathrm{EPA}^{(\mathrm{c}, \mathrm{i})}$ & Final \\
\hline Carbon tetrachloride & \multicolumn{2}{|l|}{$5 \mu \mathrm{g} / \mathrm{L}(0.005$ ppm) } & $\mathrm{DOH},{ }^{(\mathrm{b})} \mathrm{EPA}^{(\mathrm{c}, \mathrm{i})}$ & Final \\
\hline Chloroform $(\text { THM })^{(j)}$ & \multicolumn{2}{|l|}{$100 \mu \mathrm{g} / \mathrm{L}(0.1 \mathrm{ppm})$} & $\mathrm{DOH},{ }^{(\mathrm{b})} \mathrm{EPA}^{(\mathrm{i})}$ & Final \\
\hline cis-1,2-Dichloroethene & \multicolumn{2}{|l|}{$0.07 \mathrm{mg} / \mathrm{L}(0.07 \mathrm{ppm})$} & $\mathrm{EPA}^{(\mathrm{i})}$ & Final \\
\hline \multicolumn{5}{|c|}{ 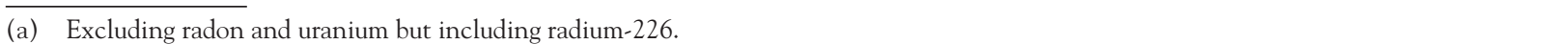 } \\
\hline \multirow{2}{*}{\multicolumn{5}{|c|}{ (b) WAC 246-290. }} \\
\hline & & & & \\
\hline \multicolumn{5}{|c|}{ (d) Beta and photon radioactivity from manmade radionuclides. Annual average activity shall not exceed an effective dose equivalent of } \\
\hline \multicolumn{5}{|c|}{ (e) Activity assumed to yield an annual dose of 4 mrem per year. } \\
\hline \multicolumn{5}{|l|}{ (f) $\quad$ EPA-570/9-76-003. } \\
\hline \multicolumn{5}{|c|}{ (g) Equivalent to $27 \mathrm{pCi} / \mathrm{L}$ (assuming typical uranium natural abundance in rock). } \\
\hline (h) 40 CFR Parts 9,141 , and 14 & Final rule promulgated Decer & ber 7, 2000 (65 FR 76708). & & \\
\hline (i) EPA 822-R-96-001. & & & & \\
\hline (j) Standard is for total trihalon & hanes (THM). & & & \\
\hline $\mathrm{DOH}=$ Washington State Depar & ent of Health. & & & \\
\hline $\mathrm{EPA}=$ U.S. Environmental Pro & tion Agency. & & & \\
\hline
\end{tabular}




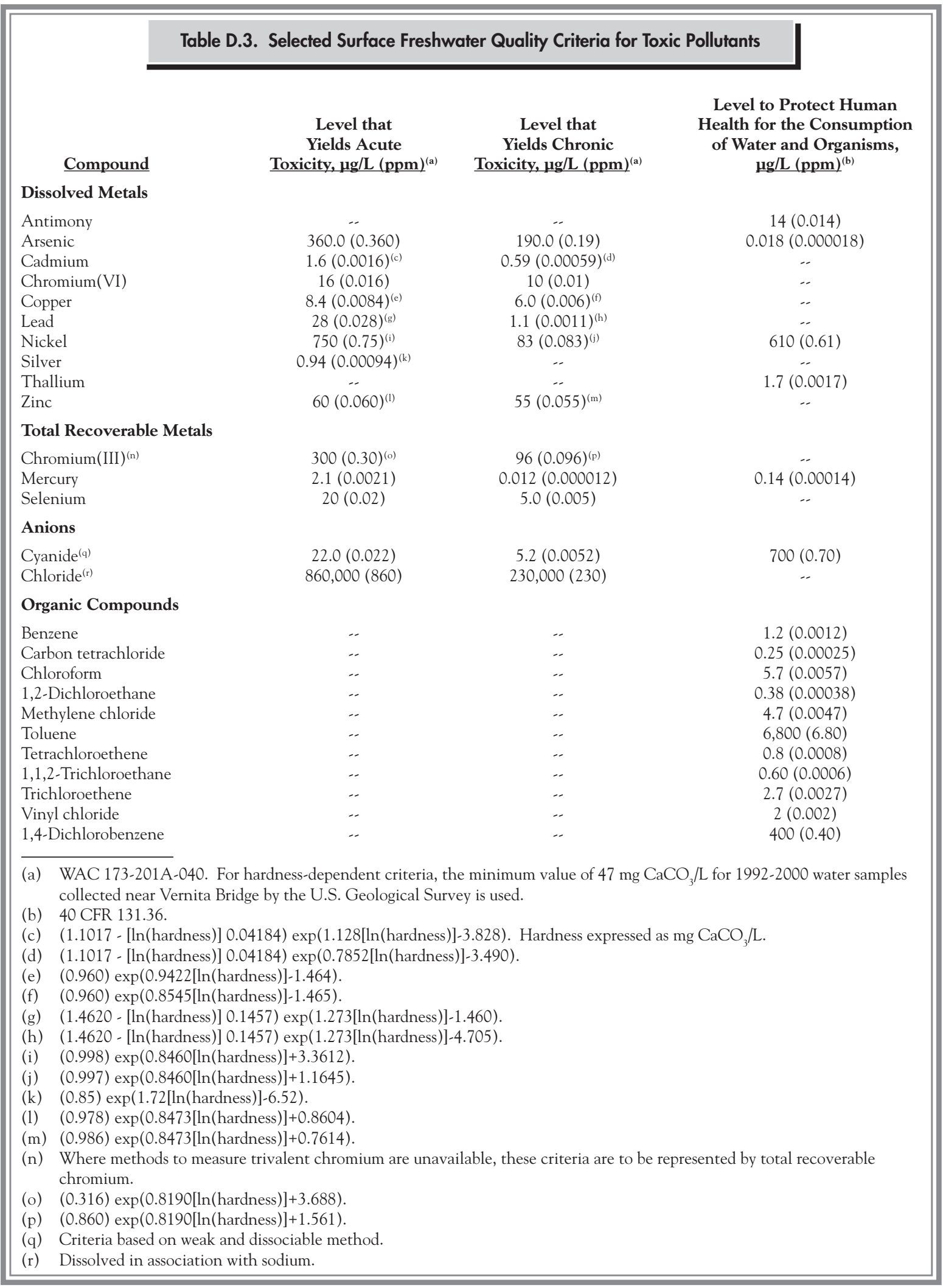


Table D.4. Radiation Standards (dose limits ${ }^{[a])}$ for Protection of the Public from all Routine DOE Concentrations

All Pathways (limits from DOE Order 5400.5)

The effective dose equivalent for any member of the public from all routine DOE operations ${ }^{(b)}$ shall not exceed the values given below.

Routine public dose

Potential authorized temporary public dose $\mathrm{e}^{(\mathrm{d})}$
Effective Dose Equivalent
$\underline{\mathrm{mrem} / \mathrm{yr}}$
$\underline{\mathrm{mSv} / \mathrm{yr}}$

100

500
1

5

Dose to Native Aquatic Animal Organisms from Liquid Discharges (interim limits from DOE Order 5400.5)

Radioactive material in liquid waste discharged to natural waterways shall not cause an absorbed dose ${ }^{(e)}$ to native aquatic animal organisms that exceeds $1 \mathrm{rad}(10 \mathrm{mGy})$ per day.

Drinking Water Pathway Only (limits from 40 CFR Parts 9, 141, and 142; WAC 246-290; and DOE Order 5400.5)

Radionuclide concentrations in DOE-operated public drinking water supplies shall not cause persons consuming the water to receive an effective dose equivalent greater than $4 \mathrm{mrem}(0.04 \mathrm{mSv})$ per year. DOE operations shall not cause private or public drinking water systems downstream of the facility discharge to exceed the radiological drinking water limits in 40 CFR Parts 9, 141, and 142 (see Table D.2).

Air Pathways Only (limits from 40 CFR 61)

$$
\begin{aligned}
& \underline{\text { Effective Dose Equivalent }}{ }^{(\mathrm{c})} \\
& \underline{\mathrm{mrem} / \mathrm{yr}} \underline{\mathrm{mSv} / \mathrm{yr}}
\end{aligned}
$$

Public dose limit at location of maximum annual air concentration as a consequence of routine DOE operations ${ }^{(b)}$
10

0.1

(a) Radiation doses received from natural background, residual weapons testing and nuclear accident fallout, medical exposure, and consumer products are excluded from the implementation of these dose limits.

(b) "Routine DOE operations" implies normal, planned activities and does not include actual or potential accidental or unplanned releases.

(c) Effective dose equivalent is expressed in rem (or millirem) and sievert (or millisievert).

(d) Authorized temporary annual dose limits may be greater than 100 mrem (1 mSv) per year (but cannot exceed 500 mrem [5 mSv]) per year if unusual circumstances exist that make avoidance of doses greater than 100 mrem $(1 \mathrm{mSv})$ per year to the public impracticable. DOE Richland Operations Office is required to request and receive specific authorization from DOE Headquarters for an increase from the routine public dose limit to a temporary annual dose limit.

(e) Absorbed dose is expressed in rad (or millirad) with the corresponding value in gray (or milligray) in parentheses. 


\begin{tabular}{|c|c|c|c|c|c|}
\hline \multirow{2}{*}{\multicolumn{2}{|c|}{$\underline{\text { Radionuclide }}$}} & \multicolumn{3}{|c|}{ Table D.5. Selected DOE Derived Concentration Guides ${ }^{(a, b, c)}$} & \multirow{2}{*}{ 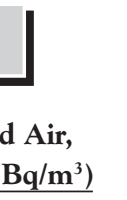 } \\
\hline & & \multicolumn{2}{|c|}{$\begin{array}{l}\text { Ingested Water, } \\
\underline{\mathrm{pCi} / \mathrm{L}(\mathrm{Bq} / \mathrm{L})}\end{array}$} & $\begin{array}{c}\text { Inhaled Air, } \\
\text { pCi// } \mathbf{m}^{3}\left(\mathrm{~Bq} / \mathbf{m}^{3}\right)\end{array}$ & \\
\hline \multicolumn{2}{|c|}{ Tritium } & $2,000,000$ & $(74,000)$ & 100,000 & $(3,700)$ \\
\hline \multicolumn{2}{|c|}{ Carbon-14 } & 70,000 & $(2,590)$ & 500,000 & $(18,500)$ \\
\hline \multicolumn{2}{|c|}{ Chromium-51 } & $1,000,000$ & $(37,000)$ & 60,000 & $(2,220)$ \\
\hline \multicolumn{2}{|c|}{ Cobalt- 60} & 5,000 & $(185)$ & 80 & $(2.96)$ \\
\hline \multicolumn{2}{|c|}{ Strontium-90 } & 1,000 & (37) & 9 & $(0.333)$ \\
\hline \multicolumn{2}{|c|}{ Technetium-99 } & 100,000 & $(3,700)$ & 2,000 & (74) \\
\hline \multicolumn{2}{|c|}{ Ruthenium-103 } & 50,000 & $(1,850)$ & 2,000 & (74) \\
\hline \multicolumn{2}{|c|}{ Ruthenium-106 } & 6,000 & $(222)$ & 30 & (1.11) \\
\hline \multicolumn{2}{|c|}{ Iodine-129 } & 500 & $(18.5)$ & 70 & $(2.59)$ \\
\hline \multicolumn{2}{|c|}{ Iodine-131 } & 3,000 & $(111)$ & 400 & (14.8) \\
\hline \multicolumn{2}{|c|}{ Cesium-137 } & 3,000 & (111) & 400 & (14.8) \\
\hline \multicolumn{2}{|c|}{ Uranium-234 } & 500 & $(18.5)$ & 0.09 & $(0.00333)$ \\
\hline \multicolumn{2}{|c|}{ Uranium-235 } & 600 & $(22.2)$ & 0.1 & $(0.0037)$ \\
\hline \multicolumn{2}{|c|}{ Uranium-238 } & 600 & $(22.2)$ & 0.1 & $(0.0037)$ \\
\hline \multicolumn{2}{|c|}{ Plutonium-238 } & 40 & $(1.48)$ & 0.03 & $(0.00111)$ \\
\hline \multicolumn{2}{|c|}{ Plutonium-239 } & 30 & (1.11) & 0.02 & $(0.00074)$ \\
\hline \multicolumn{2}{|c|}{ Plutonium-240 } & 30 & (1.11) & 0.02 & $(0.00074)$ \\
\hline \multicolumn{2}{|c|}{ Americium-241 } & 30 & $(1.11)$ & 0.02 & $(0.00074)$ \\
\hline \multicolumn{6}{|c|}{$\begin{array}{l}\text { (a) Concentration of a specific radionuclide in water or air that could be continuously } \\
\text { consumed or inhaled at average annual rates and not exceed an effective dose } \\
\text { equivalent of } 100 \text { mrem ( } 1 \mathrm{mSv}) \text { per year. } \\
\text { (b) Values in this table represent the lowest, most-conservative, derived concentration } \\
\text { guides considered potentially applicable to Hanford Site operations and may be } \\
\text { adjusted upward (larger) if accurate solubility information is available. } \\
\text { (c) From DOE Order } 5400.5 \text {. }\end{array}$} \\
\hline
\end{tabular}




\section{Clean Air Act Permits}

Prevention of Significant Deterioration Permit No. PSD-X80-14, issued to DOE Richland Operations Office by EPA Region 10; covers emission of $\mathrm{NO}_{\mathrm{x}}$ to the atmosphere from the Plutonium-Uranium Extraction Plant and the Uranium-TriOxide Plant. No expiration date.

Hanford Site Air Operating Permit 00-05-006 covers operations on the Hanford Site having a potential to emit airborne emissions. Effective July 2, 2001, expires July 1, 2006. The permit is intended to provide a compilation of applicable Clean Air Act requirements both for radioactive and non-radioactive emissions at the Hanford Site. It will be implemented through federal and state programs.

State License FF-01 was incorporated into the Hanford Site air operating permit.

\section{Clean Water Act - National Pollutant Discharge Elimination System Permits}

Permit WA-002591-7 (governing effluent discharges to the Columbia River) includes the outfall for the 300 Area Treated Effluent Disposal Facility and two outfalls in the 100-K Area.

Permit WAR05A57F, issued May 30, 2001, governs storm water discharges.

Permit CR-IU005 allows wastewater from the Environmental and Molecular Sciences Laboratory to be discharged to the city of Richland's wastewater treatment facility.

\section{Washington State Department of Ecology - State Wastewater Permits}

Permit ST 4500 allows treated wastewater from the Effluent Treatment Facility to be discharged to the State-Approved Land Disposal Site. Expires August 1, 2005.

Permit ST 4501 allows for the discharge of cooling water and other primarily uncontaminated wastewater from 400 Area facilities to two ponds located north-northeast of the 400 Area perimeter fence. Expired July 31, 2001. A renewal application has been submitted. A new permit was issued on September 10, 2003, and was effective on October 1, 2003.

Permit ST 4502 allows treated effluent from the 200-East and 200-West Areas to be discharged to the 200 Area Treated Effluent Disposal Facility. Expires May 2005.

Permit ST 4507 allows domestic wastewater to be discharged to the 100-N Area sewage lagoon. Permit expired in May 2002. A renewal application has been submitted. Still operating on an extension of the old permit, which will be in effect until a new permit is issued. The Washington State Department of Ecology hopes to issue a new permit in late 2005.

Permit ST 4511 is a consolidation of permits ST 4508, ST 4509, and ST 4510. This Categorical State Waste Discharge Permit authorizes the discharge of wastewater from maintenance, construction, and hydrotesting activities and allows for cooling water, condensate, and industrial stormwater discharges at the Hanford Site. Issued February 16, 2005; expires February 16, 2010.

Permit WAG-50-5180 (General Sand and Gravel) for the Concrete Batch Plant in the 200-East Area.

Permit WAG-50-5181 for Gravel Pit 30 in the 200-East Area.

Permit ST 9240 is a one time limited duration discharge permit (per request) in support of higher volume Waste Treatment Plant construction discharges.

\section{Wildlife Sampling Permits}

Scientific Collection Permit 04-020, issued by Washington Department of Fish and Wildlife to Pacific Northwest National Laboratory for 2004; covered the collection of food fish, shellfish, and wildlife, including game fish, for research purposes. Renewed annually.

Federal Fish and Wildlife Permit No. MB671877-0, issued by the U.S. Fish and Wildlife Service to Pacific Northwest National Laboratory; covers the collection of migratory wildlife. Expires March 31, 2006.

Copies of the regulations concerning these permits may be obtained from the following organizations:

State of Washington

Department of Ecology

P.O. Box 47600

Olympia, WA 92504-7600
U.S. Environmental Protection Agency

Region 10

1200 Sixth Avenue

Seattle, WA 98101
U.S. Department of Energy Richland Operations Office 825 Jadwin Avenue Richland, WA 99352 


\section{References}

40 CFR 61. U.S. Environmental Protection Agency. "National Emission Standards for Hazardous Air Pollutants." Code of Federal Regulations.

40 CFR 131.36. U.S. Environmental Protection Agency. "Toxics Criteria for Those States not Complying with the Clean Water Act Section 303(c)(2)(B)." Code of Federal Regulations.

40 CFR 141. U.S. Environmental Protection Agency. "National Primary Drinking Water Regulations." Code of Federal Regulations.

40 CFR Parts 9, 141, and 142. U.S. Environmental Protection Agency. "National Primary Drinking Water Regulations; Radionuclides; Final Rule.” Code of Federal Regulations. 65 FR 76708, December 7, 2000.

Clean Air Act. 1986. Public Law 88-206, as amended, 42 USC 7401 et seq.

Clean Water Act. 1977. Public Law 95-217, as amended, 91 Stat. 1566 and Public Law 96-148, as amended.
DOE Order 5400.5. "Radiation Protection of the Public and the Environment."

EPA-570/9-76-003. 1976. National Interim Primary Drinking Water Regulations. Office of Water Supply, U.S. Environmental Protection Agency, Washington, D.C.

EPA 822-R-96-001. 1996. Drinking Water Regulations and Health Advisories. Office of Water, U.S. Environmental Protection Agency, Washington, D.C.

WAC 173-201A. "Water Quality Standards for Surface Waters of the State of Washington." Washington Administrative Code, Olympia, Washington.

WAC 173-201A-040. "Toxic Substances." Washington Administrative Code, Olympia, Washington.

WAC 246-221-290. "Appendix A - Annual Limits on Intake (ALI) and Derived Air Concentrations (DAC) of Radionuclides for Occupational Exposure; Effluent Concentrations; Concentrations for Release to Sanitary Sewerage." Washington Administrative Code, Olympia, Washington.

WAC 246-290. "Public Water Systems." Washington Administrative Code, Olympia, Washington. 


\section{Appendix E Dose Calculations}

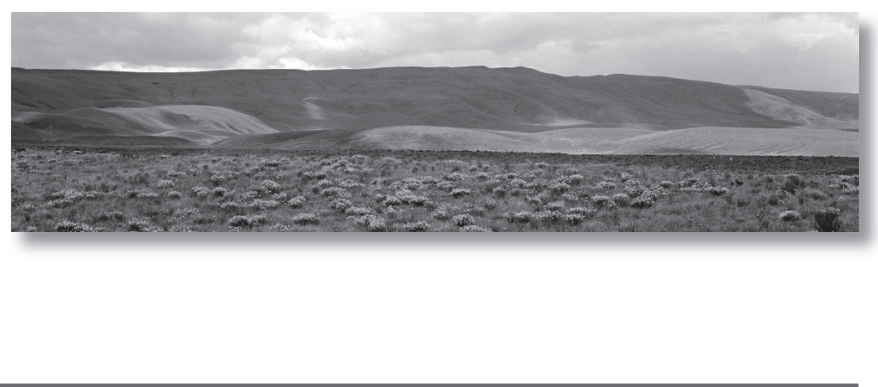

E. J. Antonio

\section{Measurements}

The interaction of radiation with matter results in energy being deposited in that matter. This is why your hand feels warm when it is exposed to a light source (e.g., sunlight or a flame). Ionizing radiation energy deposited in a mass of material is called radiation absorbed dose. A special unit of measurement, called the rad, was introduced for this concept during the early 1950s. The rad is equal to 100 ergs of ionizing energy deposited in 1 gram of material. The International System of Units introduced the gray, which is defined as follows: 1 gray $=1$ Joule per kilogram and is numerically equivalent to $100 \mathrm{rad}$ (American Society for Testing and Materials 1993).

One device to measure radiation absorbed dose is the thermoluminescent dosimeter (TLD). This device absorbs and stores the energy of ionizing radiation within its crystal lattice. By heating the dosimeter material under controlled laboratory conditions, the stored energy is released in the form of light, which is measured and related to the amount of ionizing radiation energy stored in the material. Thermoluminescence, or light output exhibited by dosimeters when heated, is proportional to the energy absorbed, which by convention is related to the amount of radiation exposure $(\mathrm{X})$, which is measured in units of roentgen $(\mathrm{R})$. The exposure is multiplied by a factor of 0.98 to convert to a dose (D), in rad, to soft tissue (Shleien 1992). This conversion factor relating $R$ to rad is, however, assumed to be unity (1) throughout this report for consistency with past reports. This dose is further modified by a quality factor, $Q=1$, for beta and gamma radiation and the product of all other modifying factors $(\mathrm{N})$. $\mathrm{N}$ is assumed to be unity to obtain dose equivalence $(\mathrm{H})$ measured in rem. The international unit, the sievert $(\mathrm{Sv})$, is equivalent to 100 rem.

$$
\begin{aligned}
& \mathrm{D}(\mathrm{rad})=\mathrm{X}(\mathrm{R}) * 1.0 \\
& \mathrm{H}(\mathrm{rem})=\mathrm{D} * \mathrm{~N} * \mathrm{Q}
\end{aligned}
$$

\section{Calculations}

The radiological dose that the public could have received in 2004 from Hanford Site cleanup operations was calculated in terms of the total effective dose equivalent. The total effective dose equivalent is the sum of the effective dose equivalent from external sources and the committed effective dose equivalent for internal exposure. Effective dose equivalent is a weighted sum of doses to organs and tissues that accounts for the sensitivity of the tissue and the nature of the radiation causing the dose. It is calculated in units rem or, more typically, the sub-unit millirem (millisievert) ${ }^{(a)}$ for individuals and in units of person-rem for the collective dose received by the total population within an 80-kilometer (50-mile) radius of the site operations areas. This appendix describes how the doses in this report were calculated.

The calculation of the effective dose equivalent takes into account the long-term (50 years) internal exposure from radionuclides taken into the body during the current year. The effective dose equivalent is the sum of individual committed ( 50 years) organ doses multiplied by weighting factors that represent the proportion of the total health effect risk that each organ would receive from uniform irradiation of the whole body. Internal organs may also be

(a) 1 rem $(0.01 \mathrm{~Sv})=1,000 \mathrm{mrem}(10 \mathrm{mSv})$. 
irradiated from external sources of radiation. The external exposure received during the current year is added to the committed internal dose to obtain the total effective dose equivalent. In this report, the effective dose equivalent is expressed in millirem with the corresponding value in sievert (or millisievert) in parentheses. The transfer factors used for pathway and dose calculations are documented in GENII - The Hanford Environmental Radiation Dosimetry Software System, Version 1.485 (PNL-6584) and in Recommended Environmental Dose Calculation Methods and Hanford-Specific Parameters (PNL-3777).

Releases of radionuclides from Hanford Site facilities are usually too small to be measured in offsite air, drinking water, and food crops. Therefore, the air dose calculations were based on measurements made at the point of release (stacks and vents). The water pathway dose calculations were based on measurements of releases to the Columbia River (from the 100 Areas) or the difference in detectable radionuclide concentrations measured upstream and downstream of the site. Environmental radionuclide concentrations were estimated from the effluent measurements by using environmental transport models.

The transport of radionuclides in the environment to the point of exposure is predicted by empirically derived models of exposure pathways. These models calculate radionuclide levels in air, water, and foods. Radionuclides taken into the body by inhalation or ingestion may be distributed among different organs and retained for various times. In addition, long-lived radionuclides deposited on the ground become possible sources for long-term external exposure and uptake by agricultural products. Dietary and exposure parameters were applied to calculate radionuclide intakes and radiological doses to the public. Standardized computer programs were used to perform the calculations. These programs contain internally consistent mathematical models that use site-specific dispersion and uptake parameters. These programs are incorporated in a master code (PNL-6584), which employs the dosimetry methodology described in International Commission on Radiological Protection reports (1979a, 1979b, 1980, 1981a, 1981b, 1982a, 1982b, 1988). The assumptions and data used in these calculations are described below.

The RESRAD-BIOTA computer code (DOE/EH-0676) was used to screen the 2004 radionuclide concentrations in environmental media (water and sediment) to see if they exceeded established biota concentration guides (e.g., soil, sediment, or water concentrations that result in a dose rate of $1 \mathrm{rad}$ per day for aquatic biota or $0.1 \mathrm{rad}$ per day for terrestrial organisms). Both internal and external doses to aquatic, riparian, and terrestrial animals as well as to terrestrial plants are included in the screening process. For analyses with multiple media and multiple radionuclides, a sum of fractions is calculated to account for the contribution to dose from each radionuclide relative to its corresponding biota concentration guide. In the initial screening assessment, the maximum measured concentration is compared to the biota concentration guide. If the sum of fraction does not exceed 1.0, no further analysis is required. However, if the sum of fractions does exceed 1.0, a second analysis is performed using average concentrations. The screening process is further described in A Graded Approach for Evaluating Radiation Doses to Aquatic and Terrestrial Biota (DOE-STD-1153-2002).

The computer program, CAP88-PC (EPA 402-R-00-004), was used to calculate an air pathway dose to a maximally exposed individual, as required by the U.S. Environmental Protection Agency (EPA) through the National Emission Standards for Hazardous Air Pollutants (Title 40, Code of Federal Regulations, Part 61 [40 CFR 61], Subpart H), from airborne radionuclide effluent (other than radon) released at U.S. Department of Energy (DOE) facilities. Technical details of the CAP88-PC calculations are provided in Radionuclide Air Emissions Report for the Hanford Site, Calendar Year 2004 (DOE/RL-2004-10).

\section{Types of Dose Calculations Performed}

Calculations of radiological doses to the public from radionuclides released into the environment are performed to demonstrate compliance with applicable standards and regulations.

DOE Order 5400.5, Radiation Protection of the Public and the Environment, requires the following:

- effective dose equivalent must be used in estimating public doses

- calculations of doses to the public from exposures resulting from both routine and unplanned activities 
must be performed using EPA or DOE dose conversion factors or analytical models prescribed in regulations applicable to DOE operations

- doses to the public must be calculated using facility effluent data when environmental concentrations are too low to measure accurately.

The following types of radiological doses were estimated.

Boundary Dose Rate (mrem/h and $\mathbf{m r e m} / \mathbf{y r})$. The external radiological dose rates during the year in areas accessible by the general public were determined from measurements obtained near Hanford Site facilities.

Maximally Exposed Individual Dose (mrem). The maximally exposed individual is a hypothetical member of the public who lives at a location and has a lifestyle that makes it unlikely that other members of the public would receive higher doses. All potentially significant exposure pathways to this hypothetical individual were considered, including:

- inhalation of airborne radionuclides

- submersion in airborne radionuclides

- ingestion of foodstuffs contaminated by radionuclides deposited on vegetation and the ground by both airborne deposition and irrigation water drawn from the Columbia River downstream of N Reactor

- exposure to ground contaminated by both airborne deposition and irrigation water

- ingestion of fish taken from the Hanford Reach of the Columbia River

- recreation along the Hanford Reach of the Columbia River, including boating, swimming, and shoreline activities.

\section{Determination of the Location of Maximally Exposed} Individual. The location of the hypothetical maximally exposed individual can vary from year to year, depending on the relative contributions of the several sources of radioactive emissions released to the air and effluent released to the Columbia River from Hanford facilities. Based on experience since 1990, three separate locations (Figure 8.14.1) have been used to assess the dose to the maximally exposed individual: (1) the Ringold area, along the east shoreline of the Columbia River 26 kilometers (16 miles) east of separations facilities in the 200 Areas; (2) the Sagemoor area, across the Columbia River from the 300 Area; and (3) the Riverview area across the river from Richland. Although the Ringold area is closer than the Riverview area to Hanford facilities that historically released airborne emissions, at Riverview the maximally exposed individual receives a higher dose rate from radionuclides in the Columbia River than a Ringold resident. The applicable exposure pathways for Ringold and Sagemoor are described in the following paragraphs. In 1990, the maximally exposed individual was located in the Ringold area. In 1991, 1992, 2000, and again in 2002, the maximally exposed individual resided in the Riverview area. However, from 1993 through 1999, 2001, 2003, and again in 2004, the hypothetical, maximally exposed individual was located across the Columbia River from the 300 Area in the Sagemoor area (Figure 8.14.1).

Ringold Maximally Exposed Individual. Because of its location, an individual in the Ringold area has the potential to receive the maximum exposure to airborne emissions from the 200 Areas, including direct exposure to a contaminated plume, inhalation, external exposure to radionuclides that deposit on the ground, and ingestion of contaminated locally grown food products. In addition, it is assumed that individuals in the Ringold area irrigate their crops with water taken from the Columbia River downstream of where groundwater enters the river from the 100 and 200-East Areas. This results in additional exposure from ingestion of irrigated food products and external irradiation from radionuclides deposited on the ground by irrigation. Recreational use of the Columbia River also is considered for this individual, resulting in direct exposure from water and radionuclides deposited on the shoreline and doses from ingestion of locally caught fish.

Riverview Maximally Exposed Individual. Because of its location, an individual in the Riverview area has the potential to receive the maximum exposure to waterborne effluent from Hanford facilities. For the calculation, it was assumed that the Riverview area maximally exposed individual obtained domestic water from a local water treatment system that pumped from the Columbia River just downstream of the Hanford Site. In addition, it was assumed that individuals in the Riverview area irrigate their crops with water taken from the Columbia River. This results in additional exposure from ingestion of irrigated food products and external irradiation from radionuclides deposited on the ground by irrigation. 
Recreational use of the Columbia River was also considered, resulting in direct exposure from water and radionuclides deposited on the shoreline and doses from ingestion of locally caught fish. This individual also receives exposure via the air pathways, including direct exposure to a contaminated plume, inhalation, external exposure to radionuclides that deposit on the ground, and ingestion of locally grown food products contaminated by air deposition.

Sagemoor Maximally Exposed Individual. Because of the shift in site operations from nuclear weapons production to the current mission of managing waste products, cleaning up the site, and researching new ideas and technologies for waste disposal and cleanup, the significance of air emissions from production facilities in the 200 Areas has decreased compared to emissions from research facilities in the 300 Area.

An individual in the Sagemoor area, located approximately 1.4 kilometers $(0.87$ mile) directly across the Columbia River from the 300 Area, receives the maximum exposure to airborne emissions from the 300 Area. However, domestic water at this location comes from wells rather than from the river, and wells in this region are not directly contaminated by radionuclides of Hanford origin (EPS-87-367A). Because the farms located across from the 300 Area obtain irrigation water from the Columbia River upstream of the Hanford Site, the conservative assumption was made that the diet of an individual from the Sagemoor area consisted totally of foods purchased from the Riverview area, which could contain radionuclides present in both the liquid effluent and air emissions pathways. The added contribution of radionuclides in the Riverview area irrigation water maximizes the calculated dose from the air and water pathways combined.

80-kilometer (50-mile) Collective Population Doses (person-rem). Regulatory limits have not been established for population doses. However, evaluation of the collective population doses to all residents within an 80-kilometer (50-mile) radius of Hanford Site operations is required by DOE Order 5400.5 . The radiological dose to the collective population within 80 kilometers (50 miles) of the site operations areas was calculated to confirm adherence to DOE environmental protection policies, and provide information to the public. The 80 -kilometer (50-mile) collective dose is the sum of doses to all individual members of the public within 80 kilometers (50 miles) of the site operations areas.

Pathways similar to those used for the maximally exposed individual were used to calculate doses to the offsite population. In calculating the effective dose, an estimate was made of the fraction of the offsite population expected to be affected by each pathway. The exposure pathways for the population are as follows:

- Drinking water - The cities of Richland and Pasco obtain their municipal water directly and Kennewick indirectly from the Columbia River downstream from the Hanford Site. Approximately 130,000 people in the three cities are assumed to obtain all their drinking water directly from the Columbia River or from wells adjacent to the river.

- Irrigated food - Columbia River water is withdrawn for irrigation of small vegetable gardens and farms in the Riverview district of Pasco in Franklin County. Enough food is grown in this district to feed an estimated 2,000 people. Commercial crops are also irrigated by Columbia River water in the Horn Rapids area of Benton County. These crops are widely distributed.

- River recreation - These activities include swimming, boating, and shoreline recreation. Specific pathways include external exposure from radionuclides in the water or on the shoreline and ingestion of river water while swimming. An estimated 125,000 people who reside within 80 kilometers $(50$ miles) of the Hanford Site operations areas are assumed to be affected by these pathways.

- Fish consumption - Population doses from the consumption of fish obtained locally from the Columbia River were calculated from an estimated total annual catch of 15,000 kilograms (33,075 pounds) per year without reference to a specified human group of consumers.

\section{Data}

The data that are needed to perform dose calculations are based on either measured upstream and downstream differences or measured effluent releases and include information on initial transport through the atmosphere or river, transfer or accumulation in terrestrial and aquatic 
pathways, and public exposure. By comparison, radiological dose calculations based on measured activities of radionuclides in food require data describing only dietary and recreational activities and exposure times. These data are discussed below.

\section{Population Distribution and Atmospheric Dispersion}

Geographic distributions of the population residing within an 80-kilometer (50-mile) radius of the Hanford Site operating areas are shown in the Hanford Site Environmental Surveillance Data Report for Calendar Year 2004 (PNNL-15222, APP. 1). These distributions are based on 2000 Bureau of the Census data (PNNL-14428). These data influence the population dose by providing estimates of the number of people exposed to radioactive effluent and their proximity to the points of release.

Atmospheric dispersion data are also shown in PNNL-15222, APP. 1. These data describe the transport and dilution of airborne radioactive material, which influence the amounts of radionuclides being transported through the air to specific locations.

\section{Terrestrial and Aquatic Pathways}

Important parameters affecting the movement of radionuclides within exposure pathways such as irrigation rates, growing periods, and holdup periods are listed in Table E.1. Certain parameters are specific to the lifestyles of either maximally exposed individuals or individuals for whom average parameter values were used.

\section{Public Exposure}

The offsite radiological dose is related to the extent of external exposure to or intake of radionuclides released from Hanford Site operations. Tables E.2 through E.4 give the parameters describing the diet, residency, and river recreation parameters assumed for maximally exposed and average individuals.

\section{Dose Calculation Documentation}

DOE established the Hanford Dose Overview Panel to promote consistency and defensibility of environmental dose calculations at Hanford. The panel was responsible

\begin{tabular}{|c|c|c|c|c|c|c|c|}
\hline \multirow{4}{*}{$\frac{\text { Medium }}{\text { Leafy vegetables }}$} & \multicolumn{6}{|c|}{ Table E.1. Food Pathway Parameters Used in Hanford Site Dose Calculations, 2004} & \\
\hline & \multicolumn{2}{|c|}{ Holdup (days) ${ }^{(a)}$} & \multirow[b]{2}{*}{$\begin{array}{c}\text { Growing } \\
\text { Period (days) }\end{array}$} & \multirow{2}{*}{\multicolumn{2}{|c|}{$\begin{array}{c}\text { Yield, } \\
\mathrm{kg} / \mathrm{m}^{2}\left(\mathrm{lb} / \mathrm{yd}^{2}\right)\end{array}$}} & \multirow{2}{*}{\multicolumn{2}{|c|}{$\begin{array}{c}\text { Irrigation Rate, } \\
\mathrm{L} / \mathrm{m}^{2} / \mathrm{mo}\left(\mathrm{gal} / \mathrm{yd}^{2} / \mathrm{mo}\right)\end{array}$}} \\
\hline & $\begin{array}{l}\text { Maximally Exposed } \\
\text { Individual }\end{array}$ & $\begin{array}{c}\text { Average } \\
\text { Individual }\end{array}$ & & & & & \\
\hline & 1 & 14 & 90 & 1.5 & $(3.3)$ & 150 & $(40)$ \\
\hline Other vegetables & 5 & 14 & 90 & 4 & $(8.2)$ & 170 & (45) \\
\hline Fruit & 5 & 14 & 90 & 2 & $(4.41)$ & 150 & $(40)$ \\
\hline Cereal & 180 & 180 & 90 & 0.8 & $(1.76)$ & 0 & \\
\hline Eggs & 1 & 18 & 90 & 0.8 & $(1.76)$ & 0 & \\
\hline Milk & 1 & 4 & .. & .. & & .. & \\
\hline Hay & $(100)^{(b)}$ & $(100)$ & 45 & 2 & $(4.41)$ & 200 & $(53)$ \\
\hline Pasture & (0) & $(0)$ & 30 & 1.5 & $(3.3)$ & 200 & (53) \\
\hline Red meat & 15 & 34 & .- & .- & & .. & \\
\hline Hay & $(100)$ & $(100)$ & 45 & 2 & $(4.41)$ & 200 & (53) \\
\hline Grain & $(180)$ & $(180)$ & 90 & 0.8 & $(1.76)$ & 0 & \\
\hline Poultry & 1 & 34 & 90 & 0.8 & $(1.76)$ & 0 & \\
\hline Fish & 1 & 1 & .. & .. & & .. & \\
\hline Drinking water & 1 & 1 & .- & .. & & -. & \\
\hline
\end{tabular}


Table E.2. Dietary Parameters Used in Hanford Site Dose Calculations, 2004

\begin{tabular}{|c|c|c|c|c|}
\hline \multirow{3}{*}{$\frac{\underline{\text { Medium }}}{\text { Leafy vegetables }}$} & \multicolumn{4}{|c|}{ Consumption } \\
\hline & \multicolumn{2}{|c|}{$\begin{array}{l}\text { Maximally Exposed } \\
\text { Individual }\end{array}$} & \multicolumn{2}{|c|}{$\begin{array}{c}\text { Average } \\
\text { Individual }\end{array}$} \\
\hline & $30 \mathrm{~kg} / \mathrm{yr}$ & $(66 \mathrm{lb} / \mathrm{yr})$ & $15 \mathrm{~kg} / \mathrm{yr}$ & $(33 \mathrm{lb} / \mathrm{yr})$ \\
\hline Other vegetables & $220 \mathrm{~kg} / \mathrm{yr}$ & (485 lb/yr) & $140 \mathrm{~kg} / \mathrm{yr}$ & $(310 \mathrm{lb} / \mathrm{yr})$ \\
\hline Fruit & $330 \mathrm{~kg} / \mathrm{yr}$ & (728 lb/yr) & $64 \mathrm{~kg} / \mathrm{yr}$ & $(140 \mathrm{lb} / \mathrm{yr})$ \\
\hline Grain & 80 kg/yr & $(180 \mathrm{lb} / \mathrm{yr})$ & $72 \mathrm{~kg} / \mathrm{yr}$ & $(160 \mathrm{lb} / \mathrm{yr})$ \\
\hline Eggs & 30 kg/yr & $(66 \mathrm{lb} / \mathrm{yr})$ & $20 \mathrm{~kg} / \mathrm{yr}$ & $(44 \mathrm{lb} / \mathrm{yr})$ \\
\hline Milk & $270 \mathrm{~L} / \mathrm{yr}$ & $(71 \mathrm{gal} / \mathrm{yr})$ & $230 \mathrm{~L} / \mathrm{yr}$ & $(61 \mathrm{gal} / \mathrm{yr})$ \\
\hline Red meat & $80 \mathrm{~kg} / \mathrm{yr}$ & $(180 \mathrm{lb} / \mathrm{yr})$ & $70 \mathrm{~kg} / \mathrm{yr}$ & $(150 \mathrm{lb} / \mathrm{yr})$ \\
\hline Poultry & $18 \mathrm{~kg} / \mathrm{yr}$ & $(40 \mathrm{lb} / \mathrm{yr})$ & $8.5 \mathrm{~kg} / \mathrm{yr}$ & $(19 \mathrm{lb} / \mathrm{yr})$ \\
\hline Fish & $40 \mathrm{~kg} / \mathrm{yr}$ & (88 lb/yr) & -. (a) & \\
\hline Drinking water & $730 \mathrm{~L} / \mathrm{yr}$ & $(193 \mathrm{gal} / \mathrm{yr})$ & $440 \mathrm{~L} / \mathrm{yr}$ & $(116 \mathrm{gal} / \mathrm{yr})$ \\
\hline
\end{tabular}

(a) Average individual consumption not identified; radiation doses were calculated based on estimated total annual catch of $15,000 \mathrm{~kg}(33,075 \mathrm{lb})$.

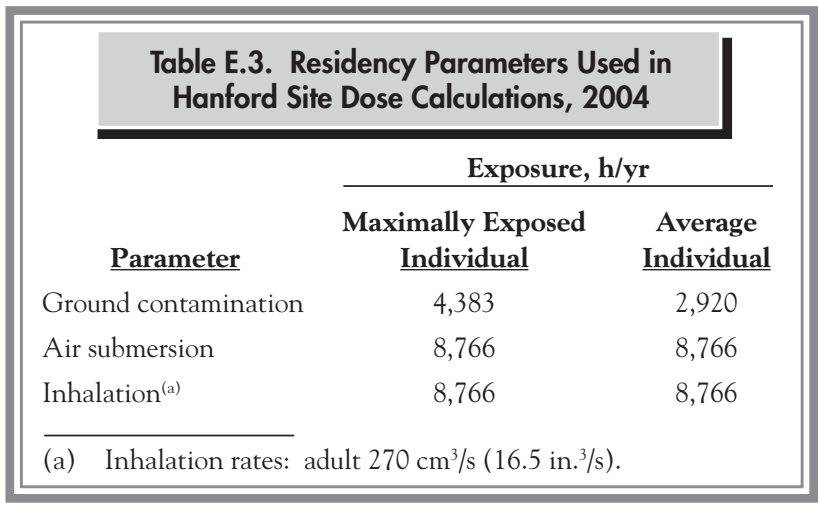

for defining standard, documented computer codes and input parameters used for radiological dose calculations for the public in the vicinity of the Hanford Site. This panel is no longer functional. Only those procedures, models, and parameters previously defined by the panel were used to calculate the radiological doses (PNL-3777). The calculations were then reviewed by a former panel member. Summaries of dose calculation technical details for this report are shown in Tables E.5 through E.10 and in PNNL-15222, APP. 1.

\section{Area Drinking Water}

Drinking water at the Fast Flux Test Facility contained slightly elevated levels of tritium. The potential doses to 400 Area workers consuming this water in 2004 are given in Table E.11.

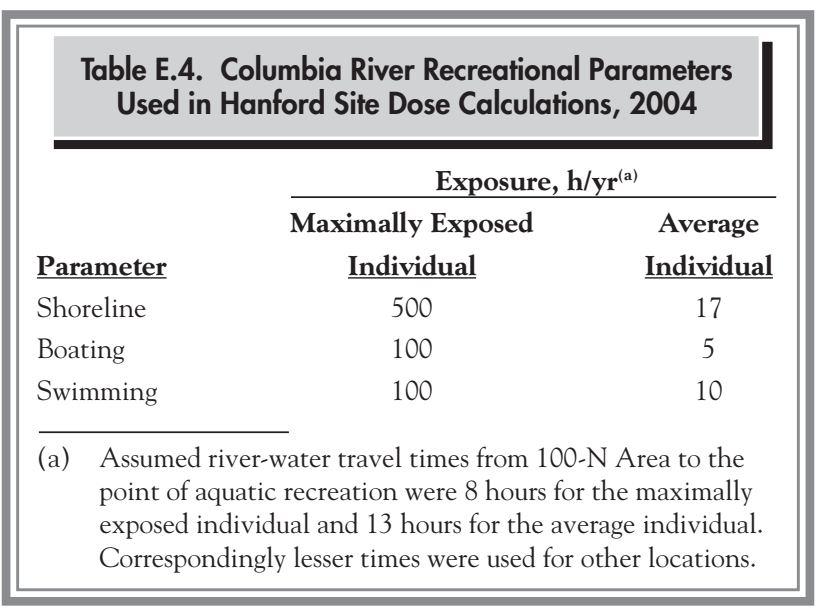

\section{Ambient-Air Inhalation Doses}

Radionuclide concentrations measured in ambient air at locations on or near the Hanford Site were used to calculate radiological doses from breathing contaminated air. Inhalation rates were taken from International Commission on Radiological Protection (1994). Occupancy times ranged from $100 \%$ at offsite locations to $33 \%$ for onsite locations. 
Table E.5. Technical Details of Airborne Release Dose Calculations for the 100-K Area of the Hanford Site, 2004

Facility name

Releases $(\mathrm{Ci}[\mathrm{Bq}])$

Meteorological conditions

$\overline{\mathrm{X}} / \mathrm{Q}$ ' dispersion factors

Release height

Population distribution

Computer code

Doses calculated

Pathways considered

Files used by GENII,

Version 1.485 in dose

calculations
100-K Area

${ }^{90} \mathrm{Sr}\left(2.3 \times 10^{-5}\left[8.5 \times 10^{5}\right]\right),{ }^{137} \mathrm{Cs}\left(4.7 \times 10^{-3}\left[1.7 \times 10^{3}\right]\right),{ }^{238} \mathrm{Pu}\left(2.8 \times 10^{-6}\left[1.0 \times 10^{5}\right]\right)$,

${ }^{239} \mathrm{Pu}\left(1.9 \times 10^{-5}\left[7.0 \times 10^{5}\right]\right),{ }^{241} \mathrm{Pu}\left(1.5 \times 10^{-4}\left[5.6 \times 10^{6}\right]\right),{ }^{241} \mathrm{Am}\left(1.5 \times 10^{-5}\left[5.6 \times 10^{5}\right]\right)$

2004 annual average, calculated from data collected at the 100-K Area and the Hanford Meteorology Station from January through December 2004

Maximally exposed individual, $2.0 \times 10^{-8} \mathrm{~s} / \mathrm{m}^{3}$ at $41 \mathrm{~km}(25 \mathrm{mi}) \mathrm{SE} ; 80-\mathrm{km}(50-\mathrm{mi})$ population, $5.0 \times 10^{-3} \mathrm{~s} / \mathrm{m}^{3}$ person- $\mathrm{s} / \mathrm{m}^{3}$

10-m (33-ft) effective stack height

$\sim 482,000$ (PNNL-14428)

GENII, Version 1.485, December 3, 1990 (PNL-6584)

Chronic, 1 -yr exposure, 50-yr committed internal dose equivalent, and annual effective dose equivalent to individual and population

External exposure to plume and ground deposits Inhalation

Ingestion of foods produced locally at Riverview

Radionuclide Library, Rev. 7-1-92

Food Transfer Library, Rev. 8-29-88

External Dose Factor Library, Rev. 5-9-88

Internal Dose Factor Library, Rev. 12-3-90

Table E.6. Technical Details of Liquid Release Dose Calculations for the 100-N Area of the Hanford Site, 2004

Facility name

Releases (Ci $[\mathrm{Bq}])$

Mean river flow

Shoreline-width factor

Population distribution

Computer code

Doses calculated

Pathways considered

Files used by GENII, Version 1.485 in dose calculations
100-N Area

${ }^{3} \mathrm{H}\left(4.5 \times 10^{-3}\left[1.7 \times 10^{8}\right]\right),{ }^{90} \mathrm{Sr}\left(4.8 \times 10^{-2}\left[1.8 \times 10^{9}\right]\right),{ }^{239} \mathrm{Pu}\left(5.5 \times 10^{-6}\left[2.0 \times 10^{5}\right]\right)$

$2,830 \mathrm{~m}^{3} / \mathrm{s}\left(99,893 \mathrm{ft}^{3} / \mathrm{s}\right)$

0.2

130,000 for drinking water pathway 125,000 for aquatic recreation 2,000 for consumption of irrigated foodstuffs $15,000 \mathrm{~kg} / \mathrm{yr}(33,075 \mathrm{lb} / \mathrm{yr})$ total harvest of Columbia River fish

GENII, Version 1.485, December 3, 1990 (PNL-6584)

Chronic, 1-yr exposure, 50-yr committed internal dose equivalent, and annual effective dose equivalent to individual and population

External exposure to irrigated soil, to river water, and to shoreline sediments Ingestion of aquatic foods and irrigated farm products

Radionuclide Library, Rev. 7-1-92

Food Transfer Library, Rev. 8-29-88

External Dose Factor Library, Rev. 5-9-88

Internal Dose Factor Library, Rev. 12-3-90 


\begin{tabular}{|c|c|}
\hline Facility name & 200 Areas \\
\hline \multirow[t]{4}{*}{ Releases (Ci [Bq]) } & 200-East Area \\
\hline & $\begin{array}{l}{ }^{90} \mathrm{Sr}\left(4.8 \times 10^{-5}\left[1.8 \times 10^{6}\right]\right),{ }^{137} \mathrm{Cs}\left(2.0 \times 10^{-5}\left[7.4 \times 10^{5}\right]\right),{ }^{239} \mathrm{Pu}\left(1.7 \times 10^{-6}\left[6.3 \times 10^{4}\right]\right), \\
{ }^{241} \mathrm{Am}\left(1.3 \times 10^{-6}\left[4.8 \times 10^{4}\right]\right)\end{array}$ \\
\hline & 200-West Area \\
\hline & $\begin{array}{l}{ }^{90} \mathrm{Sr}\left(6.3 \times 10^{-5}\left[2.3 \times 10^{6}\right]\right),{ }^{137} \mathrm{Cs}\left(4.3 \times 10^{-6}\left[1.6 \times 10^{5}\right]\right),{ }^{238} \mathrm{Pu}\left(1.2 \times 10^{-6}\left[4.4 \times 10^{4}\right]\right), \\
{ }^{239} \mathrm{Pu}\left(6.7 \times 10^{-5}\left[2.5 \times 10^{6}\right]\right),{ }^{241} \mathrm{Pu}\left(5.3 \times 10^{-5}\left[2.0 \times 10^{6}\right]\right)\end{array}$ \\
\hline Meteorological conditions & $\begin{array}{l}2004 \text { annual average, calculated from data collected at the Hanford Meteorology Station from } \\
\text { January through December } 2004\end{array}$ \\
\hline$\overline{\mathrm{X}} / \mathrm{Q}^{\prime}$ dispersion factors & $\begin{array}{l}\text { Maximally exposed individual, } 9.9 \times 10^{-9} \mathrm{~s} / \mathrm{m}^{3} \text { at } 28 \mathrm{~km}(17 \mathrm{mi}) \mathrm{SE} ; 80-\mathrm{km}(50-\mathrm{mi}) \text { population, } \\
1.3 \times 10^{-3} \text { person-s } / \mathrm{m}^{3}\end{array}$ \\
\hline Release height & 89-m (292-ft) effective stack height \\
\hline Population distribution & $\sim 486,000($ PNNL-14428) \\
\hline Computer code & GENII, Version 1.485, December 3, 1990 (PNL-6584) \\
\hline Doses calculated & $\begin{array}{l}\text { Chronic, } 1 \text {-yr exposure, } 50 \text {-yr committed internal dose equivalent, and annual effective dose } \\
\text { equivalent to individual and population }\end{array}$ \\
\hline Pathways considered & $\begin{array}{l}\text { External exposure to plume and ground deposits } \\
\text { Inhalation } \\
\text { Ingestion of foods produced locally at Riverview }\end{array}$ \\
\hline $\begin{array}{l}\text { Files used by GENII, } \\
\text { Version } 1.485 \text { in dose } \\
\text { calculations }\end{array}$ & $\begin{array}{l}\text { Radionuclide Library, Rev. 7-1-92 } \\
\text { Food Transfer Library, Rev. 8-29-88 } \\
\text { External Dose Factor Library, Rev. 5-9-88 } \\
\text { Internal Dose Factor Library, Rev. 12-3-90 }\end{array}$ \\
\hline
\end{tabular}




\begin{tabular}{|c|c|}
\hline Facility name & 200 Areas \\
\hline Releases (Ci [Bq]) & $\begin{array}{l}{ }^{3} \mathrm{H}\left(3.5 \times 10^{3}\left[1.3 \times 10^{14}\right]\right),{ }^{129} \mathrm{I}\left(6.0 \times 10^{-3}\left[2.2 \times 10^{8}\right]\right),{ }^{234} \mathrm{U}\left(1.8 \times 10^{0}\left[6.6 \times 10^{10}\right]\right),{ }^{238} \mathrm{U}\left(1.8 \times 10^{0}\right. \\
\left.\left[6.6 \times 10^{10}\right]\right),{ }^{239} \mathrm{Pu}\left(8.9 \times 10^{-5}\left[3.3 \times 10^{6}\right]\right)\end{array}$ \\
\hline Mean river flow & $2,830 \mathrm{~m}^{3} / \mathrm{s}\left(99,893 \mathrm{ft}^{3} / \mathrm{s}\right)$ \\
\hline Shoreline-width factor & 0.2 \\
\hline Population distribution & $\begin{array}{l}130,000 \text { for drinking water pathway } \\
125,000 \text { for aquatic recreation } \\
2,000 \text { for consumption of irrigated foodstuffs } \\
15,000 \mathrm{~kg} / \mathrm{yr}(33,075 \mathrm{lb} / \mathrm{yr}) \text { total harvest of Columbia River fish }\end{array}$ \\
\hline Computer code & GENII, Version 1.485, December 3, 1990 (PNL-6584) \\
\hline Doses calculated & $\begin{array}{l}\text { Chronic, } 1 \text {-yr exposure, } 50 \text {-yr committed internal dose equivalent, and annual effective dose } \\
\text { equivalent to individual and population }\end{array}$ \\
\hline Pathways considered & $\begin{array}{l}\text { External exposure to irrigated soil, to river water, and to shoreline sediments, ingestion of } \\
\text { aquatic foods and irrigated farm products }\end{array}$ \\
\hline $\begin{array}{l}\text { Files used by GENII, } \\
\text { Version } 1.485 \text { in dose } \\
\text { calculations }\end{array}$ & $\begin{array}{l}\text { Radionuclide Library, Rev. 7-1-92 } \\
\text { Food Transfer Library, Rev. 8-29-88 } \\
\text { External Dose Factor Library, Rev. 5-9-88 } \\
\text { Internal Dose Factor Library, Rev. 12-3-90 }\end{array}$ \\
\hline
\end{tabular}




\begin{tabular}{|c|c|}
\hline Facility name & 300 Area \\
\hline Releases (Ci [Bq]) & $\begin{array}{l}{ }^{3} \mathrm{H}(\text { as HT })^{(\text {a) }}\left(1.8 \times 10^{0}\left[6.6 \times 10^{10}\right]\right),{ }^{3} \mathrm{H}(\text { as HTO })^{(a)}\left(6.0 \times 10^{0}\left[2.2 \times 10^{11}\right]\right),{ }^{85} \mathrm{Kr}\left(2.0 \times 10^{-4}\right. \\
{\left[7.4 \times 10^{6}\right),{ }^{90} \mathrm{Sr}\left(1.6 \times 10^{-6}\left[5.8 \times 10^{4}\right]\right),{ }^{137} \mathrm{Cs}\left(3.0 \times 10^{-6}\left[1.1 \times 10^{5}\right]\right),{ }^{220} \mathrm{Rn}\left(8.9 \times 10^{1}\left[3.3 \times 10^{12}\right]\right),} \\
{ }^{222} \mathrm{Rn}\left(5.8 \times 10^{0}\left[2.2 \times 10^{11}\right]\right),{ }^{238} \mathrm{Pu}\left(1.1 \times 10^{-8}\left[4.1 \times 10^{2}\right]\right),{ }^{239} \mathrm{Pu}\left(2.7 \times 10^{-7}\left[1.0 \times 10^{4}\right]\right), \\
{ }^{241} \mathrm{Am}\left(5.0 \times 10^{-8}\left[1.9 \times 10^{3}\right]\right),{ }^{243} \mathrm{Am}\left(9.0 \times 10^{-10}\left[3.3 \times 10^{1}\right]\right)\end{array}$ \\
\hline Meteorological conditions & $\begin{array}{l}2004 \text { annual average, calculated from data collected at the } 300 \text { Area and the Hanford Meteorol- } \\
\text { ogy Station from January through December } 2004\end{array}$ \\
\hline$\overline{\mathrm{X}} / \mathrm{Q}^{\prime}$ dispersion factors & $\begin{array}{l}\text { Maximally exposed individual at residence, } 9.4 \times 10^{-7} \mathrm{~s} / \mathrm{m}^{3} \text { at } 1.4 \mathrm{~km}(0.87 \mathrm{mi}) \mathrm{E} ; 80-\mathrm{km}(50-\mathrm{mi}) \\
\text { population, } 1.2 \times 10^{-2} \text { person-s } / \mathrm{m}^{3}\end{array}$ \\
\hline Release height & $10 \mathrm{~m}(33 \mathrm{ft})$ \\
\hline Population distribution & $\sim 349,000($ PNNL-14428) \\
\hline Computer code & GENII, Version 1.485, December 3, 1990 (PNL-6584) \\
\hline Doses calculated & $\begin{array}{l}\text { Chronic, } 1 \text {-yr exposure, } 50 \text {-yr committed internal dose equivalent, and annual effective dose } \\
\text { equivalent to individual and population }\end{array}$ \\
\hline Pathways considered & $\begin{array}{l}\text { External exposure to plume and ground deposits } \\
\text { Inhalation } \\
\text { Ingestion of foods produced locally at Riverview }\end{array}$ \\
\hline $\begin{array}{l}\text { Files used by GENII, } \\
\text { Version } 1.485 \text { in dose } \\
\text { calculations }\end{array}$ & $\begin{array}{l}\text { Radionuclide Library, Rev 7-1-92 } \\
\text { Food Transfer Library, Rev. 8-29-88 } \\
\text { External Dose Factor Library, Rev. 5-9-88 } \\
\text { Internal Dose Factor Library, Rev. 12-3-90 }\end{array}$ \\
\hline
\end{tabular}


Table E.10. Technical Details of Airborne Release Dose Calculations for the 400 Area of the Hanford Site, 2004

Facility name

Releases (Ci $[\mathrm{Bq}])$

Meteorological conditions

$\overline{\mathrm{X}} / \mathrm{Q}^{\prime}$ dispersion factors

Release height

Population distribution

Computer code

Doses calculated

Pathways considered

Files used by GENII, Version 1.485 in dose calculations
400 Area

${ }^{3} \mathrm{H}\left(3.6 \times 10^{-1}\left[1.3 \times 10^{10}\right]\right),{ }^{137} \mathrm{Cs}\left(1.2 \times 10^{-5}\left[4.4 \times 10^{5}\right]\right),{ }^{239} \mathrm{Pu}\left(1.4 \times 10^{-7}\left[5.2 \times 10^{3}\right]\right)$

2004 annual average, calculated from data collected at the 400 Area and the Hanford Meteorology Station from January through December 2004

Maximally exposed individual at residence, $9.0 \times 10^{-8} \mathrm{~s} / \mathrm{m}^{3}$ at $11 \mathrm{~km}(7 \mathrm{mi}) \mathrm{SE} ; 80-\mathrm{km}(50-\mathrm{mi})$ population, $6.7 \times 10^{-3}$ person-s $/ \mathrm{m}^{3}$

$10 \mathrm{~m}(33 \mathrm{ft})$

$\sim 354,000$ (PNNL-14428)

GENII, Version 1.485, December 3, 1990 (PNL-6584)

Chronic, 1-yr exposure, 50-yr committed internal dose equivalent, and annual effective dose equivalent to individual and population

External exposure to plume and ground deposits

Inhalation

Ingestion of foods produced locally at Riverview

Radionuclide Library, Rev. 7-1-92

Food Transfer Library, Rev. 8-29-88

External Dose Factor Library, Rev. 5-9-88

Internal Dose Factor Library, Rev. 12-3-90

Table E.11. Annual Dose to Workers in the 100-K Area of the Hanford Site from Ingestion of Drinking Water Obtained from the Columbia River and to Workers in the 400 Area from Ingestion of Drinking Water Obtained from Groundwater Wells, 2004

\begin{tabular}{|c|c|c|c|c|}
\hline$\underline{\text { Radionuclide }}$ & $\begin{array}{l}\text { Average Drinking Water } \\
\text { Activity, pCi/L }\end{array}$ & $\begin{array}{l}\text { Intake, } \\
\mathrm{pCi} / \mathrm{yr}\end{array}$ & $\begin{array}{l}\text { Ingestion Dose } \\
\text { Factor, rem/pCi }\end{array}$ & $\begin{array}{c}\text { Ingestion Dose, } \\
\underline{\mathrm{rem} / \mathrm{yr}}\end{array}$ \\
\hline \multicolumn{5}{|l|}{ 100-K Area } \\
\hline${ }^{226} \mathrm{Ra}$ & 0.057075 & 13.698 & $1.1 \times 10^{-6}$ & $1.5 \times 10^{-5}$ \\
\hline${ }^{228} \mathrm{Ra}$ & 1.64 & 394 & $1.2 \times 10^{-6}$ & $4.73 \times 10^{-4}$ \\
\hline${ }^{90} \mathrm{Sr}$ & 0.0659 & 15.8 & $1.30 \times 10^{-7}$ & $2.06 \times 10^{-6}$ \\
\hline Total & & & & $4.90 \times 10^{-4}$ \\
\hline \multicolumn{5}{|l|}{400 Area } \\
\hline Gross beta & 6.86 & 1,650 & $5.00 \times 10^{-8}$ & $8.23 \times 10^{-5}$ \\
\hline${ }^{226} \mathrm{Ra}$ & 0.081225 & 19.5 & $1.10 \times 10^{-6}$ & $2.14 \times 10^{-5}$ \\
\hline${ }^{228} \mathrm{Ra}$ & 0.531 & 127 & $1.20 \times 10^{-6}$ & $1.53 \times 10^{-4}$ \\
\hline${ }^{90} \mathrm{Sr}$ & 0.0112 & 2.69 & $1.30 \times 10^{-7}$ & $3.49 \times 10^{-7}$ \\
\hline Tritium & 3,225 & 774,000 & $6.30 \times 10^{-11}$ & $4.88 \times 10^{-5}$ \\
\hline${ }^{129} \mathrm{I}$ & 0.0104 & 2.50 & $2.80 \times 10^{-7}$ & $6.99 \times 10^{-7}$ \\
\hline Total & & & & $3.07 \times 10^{-4}$ \\
\hline
\end{tabular}




\section{References}

40 CFR 61, Subpart H. U.S. Environmental Protection Agency. "National Emission Standards for Hazardous Air Pollutants." Code of Federal Regulations.

American Society for Testing and Materials. 1993. "E 380-93 Standard Practice for Use of the International System of Units (SI) (the Modernized Metric System)." Annual Book of ASTM Standards. Philadelphia, Pennsylvania.

DOE/EH-0676. 2004. RESRAD-BIOTA: A Tool for Implementing a Graded Approach to Biota Dose Evaluation. Interagency Steering Committee on Radiation Standards Technical Report 2004-02, U.S. Department of Energy, Washington, D.C.

DOE Order 5400.5. "Radiation Protection of the Public and the Environment."

DOE/RL-2004-10. 2005. Radionuclide Air Emissions Report for the Hanford Site, Calendar Year 2004. DJ Rokkan, K Rhoads, and LH Staven, U.S. Department of Energy, Richland, Washington.

DOE-STD-1153-2002. 2002. A Graded Approach for Evaluating Radiation Doses to Aquatic and Terrestrial Biota. Final Technical Standard, Office of Environmental Policy and Guidance, Washington, D.C.

EPA 402-R-00-004. 2000. Updated User's Guide for CAP88-PC, Version 2.0. Office of Radiation and Indoor Air, U.S. Environmental Protection Agency, Washington, D.C.

EPS-87-367A. 1988. Environmental Radiation Program, 26th Annual Report, January Through December 1987. Washington State Department of Health, Olympia, Washington.

International Commission on Radiological Protection. 1979a. "ICRP Publication 30, Part 1, Limits for Intakes of Radionuclides by Workers." Annals of the ICRP 2:3/4, Pergamon Press, Elmsford, New York.

International Commission on Radiological Protection. 1979b. "ICRP Publication 30, Supplement to Part 1, Limits for Intakes of Radionuclides by Workers." Annals of the ICRP 3:1 4, Pergamon Press, Elmsford, New York.
International Commission on Radiological Protection. 1980. "ICRP Publication 30, Part 2, Limits for Intakes of Radionuclides by Workers." Annals of the ICRP 4:3/4, Pergamon Press, Elmsford, New York.

International Commission on Radiological Protection. 1981a. "ICRP Publication 30, Supplement to Part 2, Limits for Intakes of Radionuclides by Workers." Annals of the ICRP 5:1-6, Pergamon Press, Elmsford, New York.

International Commission on Radiological Protection. 1981b. "ICRP Publication 30, Part 3 Including Addendum to Parts 1 and 2, Limits for Intakes of Radionuclides by Workers." Annals of the ICRP 6:2/3, Pergamon Press, Elmsford, New York.

International Commission on Radiological Protection. 1982a. "ICRP Publication 30, Supplement A to Part 3, Limits for Intakes of Radionuclides by Workers." Annals of the ICRP 7:1-3, Pergamon Press, Elmsford, New York.

International Commission on Radiological Protection. 1982b. "ICRP Publication 30, Supplement B to Part 3 Including Addendum to Supplements to Parts 1 and 2, Limits for Intakes of Radionuclides by Workers." Annals of the ICRP 8:1-3, Pergamon Press, Elmsford, New York.

International Commission on Radiological Protection. 1988. "ICRP Publication 30, Part 4, Limits for Intakes of Radionuclides by Workers: an Addendum." Annals of the ICRP 19:4, Pergamon Press, Elmsford, New York.

International Commission on Radiological Protection. 1994. "ICRP Publication 66, Human Respiratory Tract Model for Radiological Protection." Annals of the ICRP 24:1-3. Pergamon Press, Elmsford, New York.

PNL-3777, Rev. 2. 1993. Recommended Environmental Dose Calculation Methods and Hanford-Specific Parameters. RG Schreckhise, K Rhoads, JS Davis, BA Napier, and JV Ramsdell, Pacific Northwest Laboratory, Richland, Washington.

PNL-6584. 1988. GENII - The Hanford Environmental Radiation Dosimetry Software System, 3 vols. BA Napier, RA Peloquin, DL Strenge, and JV Ramsdell, Pacific Northwest Laboratory, Richland, Washington. 
PNNL-14428. 2004. Hanford Area 2000 Population. DB Elliott, MJ Scott, EJ Antonio, and K Rhoads, Pacific Northwest National Laboratory, Richland, Washington.

PNNL-15222, APP. 1. 2005. Hanford Site Environmental Surveillance Data for Calendar Year 2004. LE Bisping, Pacific Northwest National Laboratory, Richland, Washington.
Shleien B. 1992. The Health Physics and Radiological Health Handbook, Revised Edition. Scinta, Inc., Silver Spring, Maryland. 


\section{Appendix F \\ Radionuclides Measured by Gamma Spectroscopy (Gamma Scan)}

E. J. Antonio

Gamma rays are a form of high energy electromagnetic radiation that originate from the nucleus of an atom. They have very short wavelengths and can easily penetrate all but the most dense materials. Gamma-emitting radionuclides may be natural in origin, result from Hanford Site operations, or be related to fallout from historic nuclear weapons testing.
Gamma rays can be detected and quantified by inorganic scintillators, which convert energy into visible light. Scintillators may include thallium-activated sodium iodide crystals $(\mathrm{NaI}[\mathrm{Tl}])$ or germanium semiconductor detectors and their associated electronics (gamma spectroscopy). A partial list of radionuclides whose activity is measurable using gamma spectroscopy is provided in Table F.1.

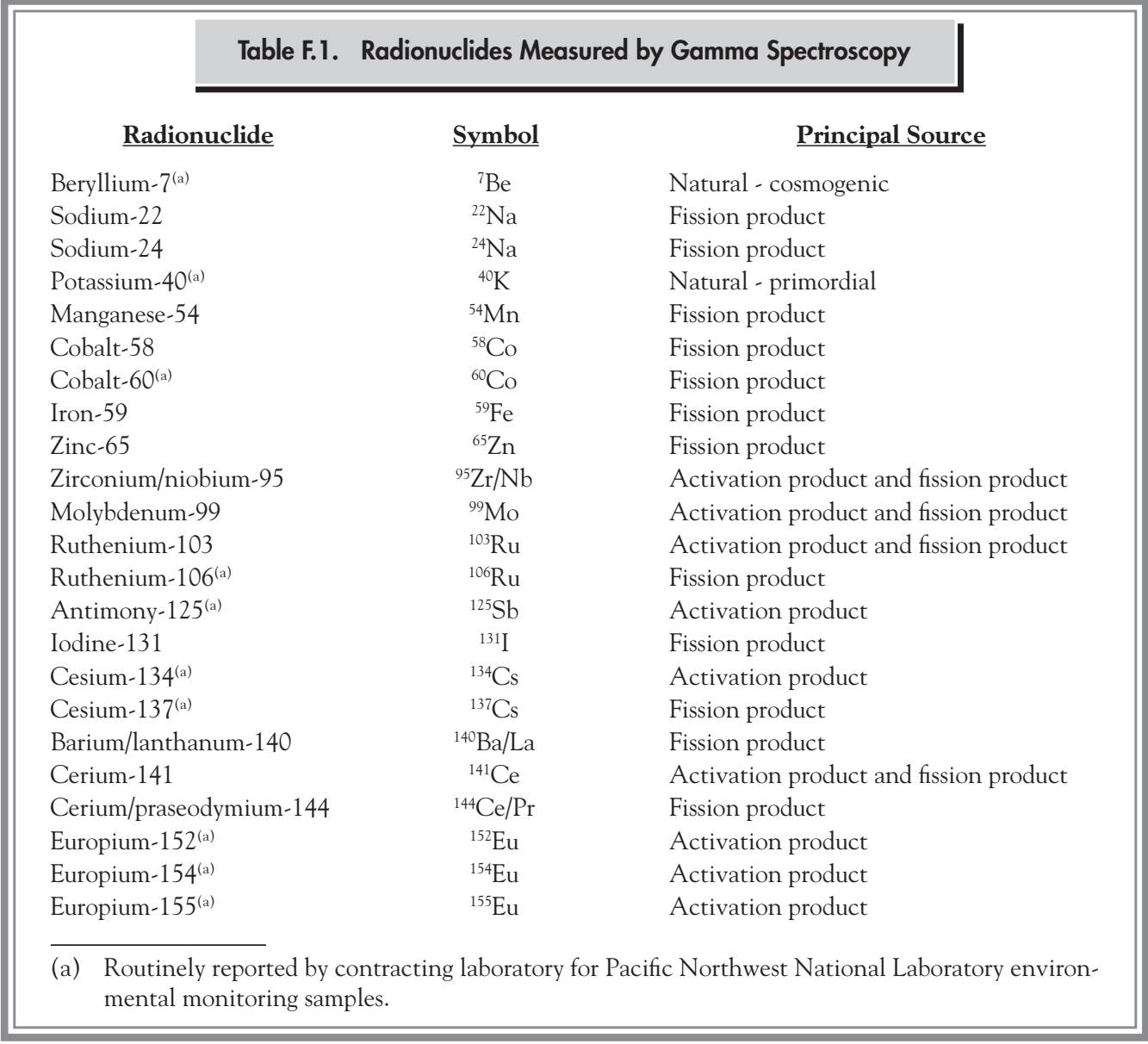




\section{Distribution List}

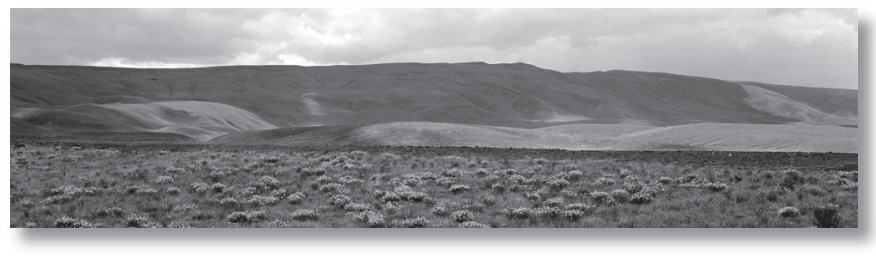

No. of

Copies

OFFSITE

CD Mary T. Adams, MS-8F42

U.S. Nuclear Regulatory Commission

Washington, DC 20555

P Lynn Albin

Division of Radiation Protection

Washington State Department of Health

P.O. Box 47890, MS 7827

Olympia, WA 98504-7890

CD Bradley D. Andersen

Idaho National Laboratory

P.O. Box 1625

Idaho Falls, ID 83415-4110

P/S Candace Andrews

Public Information Office

P.O. Box 190

Richland, WA 99352

CD Margaret W. Arnett

Westinghouse Savannah River Company

Building 730-2B

Savannah River Site

Aiken, SC 29802

CD Mike R. Ault

US Ecology, Inc.

1777 Terminal Drive

Richland, WA 99352

P Mary C. Baker

Hanford Natural Resource Trustee Council 7600 Sand Point Way N.E.

Seattle, WA 98115
No. of

Copies

CD/S Gary Ballew

Economic Development Coordinator

Benton County Commissioners

P.O. Box 190

Prosser, WA 99350

CD Mary M. Baranek

Environmental Quality Management Division

Savannah River Site

Building 730-B

Aiken, SC 29802

CD John Bargar, MS-69

Stanford Synchrotron Radiology Laboratory

ESRD Molecular Environmental Science

P.O. Box 4349

Stanford, CA 94025

P/CD/S Basin City Branch of Mid-Columbia Library 50-A N. Canal Boulevard

Basin City, WA 99343

$\mathrm{CD} / \mathrm{S}$ James Beaver, Mayor

City of Kennewick

2311 S. Benton Place

Kennewick, WA 99336

CD/S Nina Bell

Northwest Environmental Advocates

P.O. Box 12187

Portland, OR 97212-0187

CD/S Max Benitz, Jr.

Benton County Commissioner, District 2

Benton County Courthouse

P.O. Box 190

Prosser, WA 99350

$\mathrm{P} / \mathrm{CD} / \mathrm{S}$ Benton City Branch of the Mid-Columbia Library

P.O. Box 369

Benton City, WA 99320

CD Benton Clean Air Authority

114 Columbia Point Drive, Suite C

Richland, WA 99352
$\mathrm{CD}=\mathrm{CD}-\mathrm{ROM}$

$\mathrm{P}=$ Paper Copy

$\mathrm{S}=$ Summary Booklet 
CD Gabriel Bohnee, Environmental Specialist Nez Perce Tribe ERWM

P.O. Box 365

Lapwai, ID 83540

2P Carol M. Borgstrom, Director

Office of NEPA Policy and Compliance

U.S. Department of Energy, EH-42

1000 Independence Avenue S.W.

Washington, DC 20585

CD/S Leo Bowman, Chairman

Benton County Commissioner, District 1

Benton County Courthouse

620 Market Street

Prosser, WA 99350

$\mathrm{CD} / \mathrm{S}$ Frank H. Brock

Franklin County Commissioner, District 3

1016 N. 4th Avenue

Pasco, WA 99301

CD Lisa Brown

Washington State Department of Ecology

Eastern Regional Office

N. 4601 Monroe

Spokane, WA 99205-1295

CD Russell A. Brown

162 East 22nd Street

Idaho Falls, ID 83404

P/CD/S Burbank Community Library

130 Lake Road

Burbank, WA 99323

CD Bureau of Land Management

Spokane District Office

1103 N. Fancher

Spokane, WA 99212-1275

P/CD Norm Buske, Director

The RadioActivist Campaign

7312 N.E. North Shore Road

Belfair, WA 98528

P/CD Paula Call

U.S. Fish and Wildlife Service

3250 Port of Benton Boulevard

Richland, WA 99354

P/S Senator Maria Cantwell

717 Hart Senate Office Building

Washington, DC 20510
P Nicholas Ceto

U.S. Environmental Protection Agency,

Region 10, Hanford Project Office

712 Swift Boulevard, Suite 5, MS B1-46

Richland, WA 99352

CD/S Representative Bruce Chandler

15th Legislative District

P.O. Box 40600

Olympia, WA 98504-0600

$\mathrm{P} / \mathrm{CD} / \mathrm{S}$ Columbia Basin College Library

2600 N. 20th Avenue

Pasco, WA 99301

CD Columbia National Wildlife Refuge

U.S. Fish and Wildlife Service

735 E. Main Street

P.O. Drawer F

Othello, WA 99344-0227

CD Columbia Riverkeeper

P.O. Box 912

Bingen, WA 98605

$\mathrm{CD} / \mathrm{S}$ The Columbian

P.O. Box 180

Vancouver, WA 98666-0180

P Al W. Conklin

Division of Radiation Protection

Washington State Department of Health

P.O. Box 47890, MS 7827

Olympia, WA 98504-7890

$\mathrm{P} / \mathrm{CD} / \mathrm{S}$ Connell Branch of the Mid-Columbia Library

118 N. Columbia

Connell, WA 99326

CD/S Neva Corkrum

Franklin County Commissioner, District 1

1016 N. 4th Avenue

Pasco, WA 99301

CD John Cox

CTUIR

750 Swift Boulevard, Suite 14

Richland, WA 99352

P/CD/S CREHST Museum

95 Lee Boulevard

Richland, WA 99352 
No. of

Copies

CD/S Al Danielson

Office of Radiation Protection

Washington State Department of Health

309 Bradley Boulevard, Suite 201

Richland, WA 99352

CD/S John C. Darrington

Richland City Manager

City Hall

505 Swift Boulevard

Richland, WA 99352

P Damon Delistraty

Washington State Department of Ecology

N. 4601 Monroe

Spokane, WA 99205-1295

CD/S Senator Jerome Delvin

8th Legislative District

201 Irv Newhouse Building

P.O. Box 40408

Olympia, WA 98504-0408

P Stephen L. Domotor

U.S. Department of Energy, EH-41

Office of Air, Water and Radiation

1000 Independence Avenue S.W.

Washington, DC 20585

CD Dirk Dunning

Oregon Office of Energy

625 Marion Street, NE

Salem, OR 97301-3737

CD Craig F. Eberhart

Meteorology and Air Quality Group

Los Alamos National Laboratory

P.O. Box 1663

Los Alamos, NM 87545

P William A. Eckroade

U.S. Department of Energy, OA-20

19901 Germantown Road

Germantown, MD 20874

P Earl Edris

U.S. Army Corps of Engineers

Engineer Research and Development Center

3909 Halls Ferry Road

Vicksburg, MS 39810
No. of

$\underline{\text { Copies }}$

P David Einan

Hanford Project Office

U.S. Environmental Protection Agency

Region 10

712 Swift Boulevard, Suite 5, MS B1-46

Richland, WA 99352

P/CD/S Energy Northwest Library

P.O. Box 968

Richland, WA 99352

P John L. Erickson

Special Assistant

Public Health Emergency Preparedness and

Response

Washington State Department of Health

P.O. Box 47890, MS 7890

Olympia, WA 98504-7890

P Michael Farrow

Confederated Tribes of the Umatilla Indian

Reservation

Department of Natural Resources

P.O. Box 638

Pendleton, OR 97801

CD Federal Emergency Management Agency

Region X

130 228th Street S.W.

Bothell, WA 98021-9796

CD/S Holly Ferguson, Ph.D.

COESP Alternate Manager

WSU Irrigated Agriculture Research \&

Extension Center

514 Konnowac Pass Road

Moxee, WA 98936

CD Charles H. Fink

Sandia National Laboratories, New Mexico

P.O. Box 5800

Albuquerque, NM 87185-1042

CD Virginia L. Finley

MS01 C-Site Mod. 6

Plasma Physics Laboratory

P.O. Box 451

Princeton, NJ 08543-0451

P Pete Fledderman

Westinghouse Savannah River Company

Building 735-B

Savannah River Site

Aiken, SC 29802 


\begin{tabular}{|c|c|}
\hline $\begin{array}{r}2 \mathrm{P} / \\
2 \mathrm{CD}\end{array}$ & $\begin{array}{l}\text { Mike Fox } \\
348 \text { Broadmoor } \\
\text { Richland, WA } 99352\end{array}$ \\
\hline $\mathrm{D} / \mathrm{S}$ & $\begin{array}{l}\text { Mike Garrison, Mayor } \\
\text { City of Pasco } \\
909 \text { N. 26th } \\
\text { Pasco, WA } 99301\end{array}$ \\
\hline $\mathrm{CD} / \mathrm{S}$ & $\begin{array}{l}\text { Norbert W. Golchert } \\
\text { Argonne National Laboratory - East } \\
9700 \text { S. Cass Avenue } \\
\text { Argonne, IL } 60439\end{array}$ \\
\hline $\mathrm{P}$ & $\begin{array}{l}\text { Larry Goldstein } \\
\text { Hanford Natural Resource Trustee Council } \\
\text { Washington State Department of Ecology } \\
\text { P.O. Box } 47600 \\
\text { Olympia, WA } 98504\end{array}$ \\
\hline $\mathrm{CD}$ & $\begin{array}{l}\text { Dibakar Goswami } \\
\text { Washington State Department of Ecology } \\
\text { Richland Field Office } \\
3100 \text { Port of Benton Boulevard } \\
\text { Richland, WA } 99354\end{array}$ \\
\hline $\mathrm{CD}$ & $\begin{array}{l}\text { Government Accountability Project } \\
1511 \text { Third Avenue, Suite } 321 \\
\text { Seattle, WA } 98101\end{array}$ \\
\hline $\mathrm{P} / \mathrm{S}$ & $\begin{array}{l}\text { Representative Bill Grant } \\
\text { 16th Legislative District } \\
\text { 434B Legislative Building } \\
\text { P.O. Box 40600 } \\
\text { Olympia, WA 98504-0600 }\end{array}$ \\
\hline $\mathrm{P} / \mathrm{S}$ & $\begin{array}{l}\text { Governor Christine Gregoire } \\
\text { Office of the Governor } \\
\text { P.O. Box } 40002 \\
\text { Olympia, WA 98504-0002 }\end{array}$ \\
\hline $\mathrm{CD}$ & $\begin{array}{l}\text { David M. Hamby, Professor } \\
\text { Department of Nuclear Engineering and } \\
\text { Radiation Health Physics } \\
\text { 130 Radiation Center } \\
\text { Oregon State University } \\
\text { Corvallis, OR 97331-5902 }\end{array}$ \\
\hline $\mathrm{CD}$ & $\begin{array}{l}\text { Hanford Watch } \\
4549 \text { N.E. 39th Avenue } \\
\text { Portland, OR } 97221\end{array}$ \\
\hline
\end{tabular}


No. of

Copies

CD Senator Jim Honeyford

15th Legislative District

204 Irving R. Newhouse Building

P.O. Box 40415

Olympia, WA 98504-0415

CD Balwan Hooda

Environmental Services Division

Brookhaven National Laboratory

Building 120

Upton, NY 11973-5000

P Bill Hoppes

Lawrence Livermore National Laboratory

P.O. Box 808

Livermore, CA 94551-0808

CD Lynda Horst

Oregon Department of Energy

625 Marion Street N.E.

Salem, OR 97301-3737

CD Joel M. Hubbell

Idaho National Laboratory

P.O. Box 1625

Idaho Falls, ID 83415-2107

CD Greg Hughes

U.S. Fish and Wildlife Service

3250 Port of Benton Boulevard

Richland, WA 99354-1670

P Joan F. Hughes

Oak Ridge National Laboratory

P.O. Box 2008

Oak Ridge, TN 37831-2008

P Susan Coburn Hughs

Hanford Natural Resource Trustee Council

State of Oregon Department of Energy

625 Marion Street NE

Salem, OR 97301-3737

CD Mickey Hunacek

Dade Moeller \& Associates

1835 Terminal Drive, Suite 200

Richland, WA 99352

CD Tracy A. Ikenberry

Dade Moeller \& Associates

1835 Terminal Drive, Suite 200

Richland, WA 99352
No. of

Copies

P Jake Jakabosky

Hanford Natural Resource Trustee Council

Bureau of Land Management

Spokane District Office

1103 N. Fancher

Spokane, WA 99212-1275

CD G. Tim Jannik

Environmental Dosimetry Department

Westinghouse Savannah River Company

Savannah River Technology Center

Building 773-42A

Aiken, SC 29802

$\mathrm{P} / \mathrm{CD} \quad$ Richard E. Jaquish

Washington State Department of Health

1232 Vintage Avenue

Richland, WA 99352

P/CD Russell Jim, Manager

Environmental Restoration and Waste

Management Program

The Confederated Tribes and Bands of the

Yakama Nation

2808 Main Street

Union Gap, WA 98903

CD Matthew P. Johansen

Los Alamos National Laboratory

P.O. Box 1663

Los Alamos, NM 87545

CD/S Dale R. Johns

COESP Alternate Manager

59406 E. Main PR, SE

Benton City, WA 99320

P Betsy S. Jonker

DOE Idaho Operations Office

Environmental Technical Support Division 850 Energy Drive, MS 1216

Idaho Falls, ID 83402

$\mathrm{P} / \mathrm{CD} / \mathrm{S}$ Kahlotus Branch of the Mid-Columbia Library

E. 255 Weston

Kahlotus, WA 99335

P Richard R. Kauffman

Senior Regional Representative

Agency for Toxic Substances and Disease

Registry, Region 10

1200 Sixth Avenue, Room 1930

Seattle, WA 98101 
P/CD/S Keewaydin Park Branch of the Mid-Columbia Library

405 S. Dayton

Kennewick, WA 99336

$\mathrm{P} / \mathrm{CD} / \mathrm{S}$ Kennewick Branch of the Mid-Columbia Library

1620 S. Union Street

Kennewick, WA 99338

CD Paul M. Kesich

FERMI National Accelerator Laboratory

ES\&H Environmental Protection Group

P.O. Box 500 - MS 119

Batavia, IL 60510-0500

CD/S Robert Koch

Franklin County Commissioner, District 2

1016 N. 4th Avenue

Pasco, WA 99301

CD Kay Koontz, Executive Director

Clark County Health Department

P.O. Box 9825

Vancouver, WA 98666-8825

P/CD/S Knight Library

University of Oregon

1501 Kincaid

Eugene, OR 97403-1299

CD Ron Kreizenbeck, Acting Regional Administrator U.S. Environmental Protection Agency,

Region 10

1200 Sixth Avenue, MS RA-140

Seattle, WA 98101

CD Dan Landeen

Hanford Natural Resource Trustee Council

$\mathrm{Nez}$ Perce Tribe

P.O. Box 365

Lapwai, ID 83540

CD/S Ryan A. Landvoy

COESP Manager

950 Songbird Way

Yakima, WA 98908

CD Barbara L. Larsen

Sandia National Laboratories, California

P.O. Box 969

Livermore, CA 94551-9221
P/CD/S Andrew C. Lawrence

Deputy Assistant Secretary for Environment

Office of Environment, Safety, and Health

U.S. Department of Energy, EH-4

1000 Independence Avenue S.E.

Washington, DC 20585

CD Robert Lorenz, Manager

Environmental Sampling and Reporting

Westinghouse Savannah River Company

Savannah River Site

Building 730-4B

Aiken, SC 29808

CD/S Mitch P. Madison

COESP Manager

1715 N. 18th Avenue

Pasco, WA 99301

CD Ron W. Malanowski

Westinghouse Savannah River Company

Building 730-2B

Aiken, SC 29808

CD Albert R. Mamatey

Westinghouse Savannah River Company

Savannah River Site

Building 742-A

Aiken, SC 29808

CD/S Terry A. Marden

Benton County Planning Department

P.O. Box 910

Prosser, WA 99350

P/CD Debra McBaugh

Division of Radiation Protection

Washington State Department of Health

P.O. Box 47890, MS 7827

Olympia, WA 98504-7890

P Jay McConnaughey

Hanford Natural Resource Trustee Council

The Confederated Tribes and Bands of the Yakama Nation

P.O. Box 6066

Kennewick, WA 99336-0066

CD/S Kathy McEachen

COESP Alternate Manager

160 Basin Drive

Mesa, WA 99343 
No. of

$\underline{\text { Copies }}$

CD

Wayne McMahon

Y-12 National Security Complex

BWXT Y-12, L.L.C.

Oak Ridge, TN 37831-8169

CD Jennifer Meisel

U.S. Fish and Wildlife Service

3250 Port of Benton Boulevard

Richland, WA 99354

P/CD/S Merrill's Corner Branch of the Mid-Columbia Library

5240 Eltopia West

Eltopia, WA 99330

P Maria Miles

Idaho National Laboratory

P.O. Box 1625

Idaho Falls, ID 83415-2504

P Caryle B. Miller

Laboratory Infrastructure Division

U.S. Department of Energy, SC-31.2

19901 Germantown Road

Germantown, MD 20874-1290

CD Mike Mills

Energy Facility Site Evaluation Council

Compliance Manager

P.O. Box 43172

Olympia, WA 98504-3172

CD/S Antone Minthorn, Chairman

Confederated Tribes of the Umatilla Indian

Reservation

P.O. Box 638

Pendleton, OR 97801

P Beth A. Moore

U.S. Department of Energy, EM-22

1000 Independence Avenue S.W.

Washington, DC 20585

CD/S Senator Joyce Mulliken

109A Newhouse Building

P.O. Box 40413

Olympia, WA 98504-0413

P/S Senator Patty Murray

United States Senate

173 Russell Senate Office Building

Washington, DC 20510
No. of

Copies

3P/ Rosario L. Natoli

3CD/ Office of Air, Water, and Radiation

3S U.S. Department of Energy, EH-41

1000 Independence Avenue S.W.

Washington, DC 20585

CD The News Tribune

1950 S. State Street

Tacoma, WA 98405

CD Heidi Newsome

U.S. Fish and Wildlife Service

3250 Port of Benton Boulevard

Richland, WA 99354

P Nez Perce Tribe

P.O. Box 365

Lapwai, ID 83540

CD Ken Niles, Administrator

Nuclear Safety Division

Oregon Department of Energy

625 Marion Street, NE, Suite 1

Salem, OR 97301-3742

P Craig O'Connor

Hanford Natural Resource Trustee Council

7600 Sand Point Way, N.E.

Seattle, WA 98115

$\mathrm{CD} / \mathrm{S} \quad$ Claude Oliver

Benton County Commissioner, District 3

Benton County Courthouse

620 Market Street

Prosser, WA 99350

CD The Oregonian

ATTN: Editor

1320 SW Broadway

Portland, OR 97201

$\mathrm{P} / \mathrm{CD} / \mathrm{S}$ Othello Branch of the Mid-Columbia Library

101 East Main

Othello, WA 99344

CD Pacific EcoSolutions

2025 Battelle Boulevard

Richland, WA 99352

CD Carroll Palmer

The Confederated Tribes and Bands of the

Yakama Nation

Department of Natural Resources

P.O. Box 151

Toppenish, WA 98948 
No. of

$\underline{\text { Copies }}$

P Douglas Paquette

Brookhaven National Laboratory

Building 120

Upton, NY 11973-5000

$\mathrm{P} / \mathrm{CD} / \mathrm{S}$ Pasco Branch of the Mid-Columbia Library 1320 W. Hopkins

Pasco, WA 99301

P Aristides A. Patrinos, Associate Director

Office of Biological and Environmental

Research

U.S. Department of Energy, SC-23

19901 Germantown Road

Germantown, MD 20874

CD/S Jerry Peltier, Mayor

City of West Richland

3801 W. Van Giesen

West Richland, WA 99353

P Esteban D. Picazo

c/o WVNSCO

10282 Rock Springs Road

West Valley, NY 14171

CD John Pierce

Chief Scientist, Washington Department of

Fish and Wildlife

600 Capital Way North

Olympia, WA 98504

CD Camille Pleasants

Confederated Tribes of the Colville

Reservation

P.O. Box 150

Nespelem, WA 99155

CD Gerald M. Pollet, Executive Director

Heart of America Northwest

1305 Fourth Avenue, Suite 208

Seattle, WA 98101

CD Mike Priddy

Washington State Department of Health

309 Bradley Boulevard

Richland, WA 99352

P/CD/S Prosser Branch of the Mid-Columbia Library 902 7th Street

Prosser, WA 99350
No. of

$\underline{\text { Copies }}$

P Stan Pynch, Director

Washington State Senate Committee

Services

P.O. Box 40466

Olympia, WA 98504-0466

P Karen Ratel

Brookhaven National Laboratory

Building 120

Upton, NY 11973-5000

CD Regulatory Compliance

US Ecology, Inc.

1777 Terminal Drive, Suite A

Richland, WA 99352

P/CD/S Richland Public Library

955 Northgate Drive

Richland, WA 99352

CD Wade Riggsbee

Confederated Tribes and Bands of the Yakama Nation

1216 W. Kennewick Avenue

Kennewick, WA 99336

CD Mike Ritter

U.S. Fish and Wildlife Service

3250 Port of Benton Boulevard

Richland, WA 99354

3P Gary L. Robertson, Director, MS-7827

Division of Radiation Protection

Washington State Department of Health

P. O. Box 47890

Olympia, WA 98504-7890

P Douglas Robison

Hanford Natural Resource Trustee Council

8702 N. Division Street

Spokane, WA 99203

CD Michael Ruggieri

Environmental Services Group

Ernest Orlando Lawrence Berkeley National Laboratory

One Cyclotron Road, MS 90-1140

Berkeley, CA 94720

CD Robert E. Safay

Agency for Toxic Substances and Disease Registry

Atlanta Federal Center

61 Forsyth Street, SW

Atlanta, GA 30303 
No. of

Copies

$\mathrm{CD}$

C. Sawyer

SAIC

20201 Century Building, 3rd Floor

Germantown, MD 20874

CD John W. Schmidt

Office of Radiation Protection

Washington State Department of Health

309 Bradley Boulevard, Suite 201

Richland, WA 99352

CD Dr. Gene Schreckhise, Associate Dean

Washington State University Tri-Cities

2710 University Drive

Richland, WA 99352

CD Seattle Post-Intelligencer Newsroom

101 Elliott Avenue West

Seattle, WA 98119-4220

CD Seattle Times

P.O. Box 70

Seattle, WA 98111

CD Lenora Seelatsee

Wanapum Band

P.O. Box 878

Ephrata, WA 98823

P Paul Shaffer

Oregon Department of Energy

Nuclear Safety Division

625 Marion Street, N. E.

Salem, OR 97301-3742

CD Rob Sheneman

MS 01 C-Site Mod VI 123

Plasma Physics Laboratory

P.O. Box 451

Princeton, NJ 08543-0451

CD Patrick Sobotta, Director

ERWM

Nez Perce Tribe

P.O. Box 365

Lapwai, ID 83540

CD Spokesman Review

W. 999 Riverside Avenue

Spokane, WA 99201
No. of

Copies

CD M. D. Squeochs

Department of Natural Resources

Environmental Program

Yakama Nation

P.O. Box 151

Toppenish, WA 98948

P Don Steffeck

Hanford Natural Resource Trustee Council

U.S. Fish and Wildlife Service

Portland Eastside Federal Complex

911 NE 11th Avenue

Portland, OR 97232-4181

CD Ernest Stensgar, Chairman

Coeur d'Alene Tribal Council

P.O. Box 408

Plummer, ID 83851-9704

CD/S Cliff L. Stevenson

COESP Manager

70 Canal Drive

Mesa, WA 99343

P Tom Stoops

Hanford Natural Resource Trustee Council 625 Marion Street, N. E.

Salem, OR 97301-3737

P Leah V. Street

Idaho National Laboratory

P.O. Box 1625

Idaho Falls, ID 83415-4110

CD Lisa Stiffler

Seattle Post-Intelligencer

101 Elliott Avenue West

Seattle, WA 98119-4220

CD Ronald Suppah, Council Chairman

Confederated Tribes of the Warm Springs

Reservation

P.O. Box 1299

Warm Springs, OR 97761

2CD Tim Takaro

University of Washington

Clinical Assistant Professor

Medicine and Environmental Health

4225 Roosevelt Way NE, Suite 100

Seattle, WA 98105 
No. of

Copies

P Jeff Tayer

Washington Department of Fish and Wildlife 1701 S. 24th Avenue

Yakima, WA 98902-5720

CD/S Karen A. Thomas

COESP Alternate Manager

6521 W. Argent

Pasco, WA 99301

P Priscilla Thompson

BWXT-Pantex

Building 12-132

P.O. Box 30021

Amarillo, TX 79120

CD Brett L. Tiller

609 Lynnwood Court

Richland, WA 99352

P Lisa C. Treichel

U.S. Department of Energy, EM-23

Cloverleaf Building

19901 Germantown Road

Germantown, MD 20874-1290

CD/S Tri-City Herald

333 W. Canal Drive

Kennewick, WA 99336-3811

$\mathrm{P} / \mathrm{CD} / \mathrm{S}$ University of Washington

Government Publications

Suzzallo Library

Box 352900

Seattle, WA 98195-2900

CD U.S. Army Corps of Engineers

Rural Route 6, Box 693

Pasco, WA 99301

CD U.S. Fish and Wildlife Service

McNary National Wildlife Refuge

2805 St. Andrews Loop, Building 3, Suite C

Pasco, WA 99302

CD U.S. Geological Survey

Water Science Center Office

1201 Pacific Avenue, Suite 520

Tacoma, WA 98402

P/CD/S U.S. Geological Survey Library

950 National Center, Room 1D100

12201 Sunrise Valley Drive

Reston, VA 20192
No. of

$\underline{\text { Copies }}$

P Francine S. Vigil

Sandia National Laboratories, New Mexico

P.O. Box 5800

Albuquerque, NM 87185-1120

P Lauri Vigue

Hanford Natural Resource Trustee Council

Department of Fish and Wildlife

600 Capitol Way North

Olympia, WA 98501-1091

CD/S Chuck A. Wagner

COESP Manager

354 Molokai Street

Richland, WA 99352

P/CD/S Walla Walla College

Peterson Memorial Library

204 S. College Avenue

College Place, WA 99324-2295

$\mathrm{P} / \mathrm{CD} / \mathrm{S}$ Andrew Wallo, III

Air, Water, and Radiation Division

U.S. Department of Energy, EH-41

1000 Independence Avenue S.W.

Washington, DC 20585

P/S Representative Maureen Walsh

16th Legislative District

319 John L. O'Brien Building

P.O. Box 40600

Olympia, WA 98504-0600

$\mathrm{P} / \mathrm{CD} / \mathrm{S}$ Washington State Department of Ecology Library

P.O. Box 47600

Olympia, WA 98504-7600

P/CD/S Washington State Department of Health

Environmental Section Library

Division of Radiation Protection

P.O. Box 47827

Olympia, WA 98504-7827

P Jim Watts

Hanford Reach National Monument

Federal Planning Advisory Committee

c/o U.S. Fish and Wildlife Service

3250 Port of Benton Boulevard

Richland, WA 99354

CD/S Rob Welch, Mayor

City of Richland

P.O. Box 190

Richland, WA 99352 
No. of

$\underline{\text { Copies }}$

$\mathrm{P} / \mathrm{CD} / \mathrm{S}$ West Richland Branch of the Mid-Columbia Library

3803 W. Van Giesen

West Richland, WA 99353

P Gail R. Whitney

Savannah River Operations Office

Building 730-B, Road 1A

Aiken, SC 29801

P Mike Wilson, Manager

Nuclear Waste Program

Washington Sate Department of Ecology

3100 Port of Benton Boulevard, MS HO-57

Richland, WA 99354

P Allen H. Wrigley

U.S. Department of Energy

Princeton Area Office

Environmental, Safety \& Health

US Route 1, Forrestal Campus C Site

Room B274 LSB

Princeton, NJ 08542

CD Yakama Agency

Bureau of Indian Affairs

P.O. Box 632

Toppenish, WA 98948

CD Yakima Herald-Republic

114 N. 4th Street

Yakima, WA 98901

P Jerel W. Yokel

Washington State Department of Ecology

Hanford Project Office

3100 Port of Benton Boulevard

Richland, WA 99354

\section{ONSITE}

Rosanne L. Aaberg (CD)

K3-54

Kelle M. Airhart (CD)

Terri L. Aldridge (CD)

Tom Ambalam (CD)

Tom V. Anderson (2P/2CD/2S)

Al R. Ankrum (CD)

Ernest J. Antonio (P)

John G. April (CD)

Stuart G. Arnold (CD)

Edward S. Aromi, Jr. (P)

John F. Bagley (2P/4CD)

D. Brent Barnett (CD)

J. Matthew Barnett (CD)
No. of

Copies

Brett M. Barnes (CD) T3-28

Robert C. Barr (P) H6-60

John A. Bates (CD) H8-12

Steven R. Baum (CD) P7-22

James M. Becker (CD) K6-85

Ronald D. Belden (CD) X3-40

Mark W. Benecke (CD) E6-35

Marcel P. Bergeron (CD) K9-36

Clark P. Beus (CD) J2-56

Richard L. Biggerstaff (CD) E6-35

Gordon R. Bilyard (CD) K6-50

Jerry M. Bishop (CD) L1-08

Lynn E. Bisping (P) K6-75

Bruce N. Bjornstad (P) K6-81

Dale G. Black (CD) T4-03

L. Ty Blackford (CD) R1-51

Douglas L. Bowers (CD) X3-40

Elizabeth M. Bowers (CD) A4-70

Roger C. Bowman (CD) H8-12

Allen B. Bowser (CD) G3-40

Harlan C. Boynton (CD) T4-52

Charles A. Brandt (CD) K6-85

C. Roger Briggs (CD) K8-50

Peter K. Brockman (CD) R2-50

Thomas M. Brouns (P) K9-69

Ronald C. Brunke (CD) H8-40

Robert W. Bryce (CD) E6-35

Dana C. Bryson (CD) H6-60

John W. Buck (CD) K6-52

Mark A. Buckmaster (CD) X3-16

Amoret L. Bunn (CD) K6-85

Mary E. Burandt (CD) H6-60

Jennifer S. Carr (CD) K6-96

Donald J. Carrell (CD) R1-51

Mike A. Casbon (CD) T2-05

Joe G. Caudill (CD) L4-19

Christopher S. Cearlock (CD) H0-23

Steven E. Chalk (CD) A7-75

Douglas H. Chapin (CD) A3-04

Briant L. Charboneau (CD) A6-33

Yi-Ju Chien (CD) K6-81

Charissa J. Chou (P) K6-75

Jennifer R. Christensen (CD) J2-44

Steven W. Clark (CD) H9-01

Suzanne S. Clark (CD) A6-39

Kevin V. Clarke (P) A7-75

Suzanne E. Clarke (CD) A6-33

Ray E. Clayton (CD) P7-22

Joe G. Coenenberg (CD) H8-13

Alan J. Colburn (CD) A5-17

Scott F. Conley (CD) K6-75 
No. of

Rhonda R. Connolly (CD)

Gloria D. Cummins (CD)

Barry L. Curn (P)

Norman R. Dahl (CD)

James L. Daily (P)

Dennis D. Dauble (P/CD)

Jerry D. Davis (CD)

Ronald A. Del Mar (CD)

Larry P. Diediker (2P/13CD)

Linda A. Dietz (CD)

Roger L. Dirkes (P)

Lorna M. Dittmer (P/CD)

Brian J. Dixon (CD)

Richard L. Donahoe (CD)

Jack W. Donnelly (CD)

John J. Dorian (P)

John D. Doughty (CD)

Janelle L. Downs (CD)

P. Evan Dresel (CD)

James G. Droppo, Jr. (CD)

Corey A. Duberstein (CD)

Joanne P. Duncan (P/CD)

Paul F. Dunigan, Jr. (P/CD)

Robin E. Durham (CD)

Dale L. Dyekman (CD)

Richard M. Ecker (CD)

Robert S. Edrington (CD)

Donald B. Engelman (P)

Richard H. Engelmann (2P/11CD)

David B. Erb (CD)

Leif Erickson (P/CD)

John C. Evans, Jr. (CD)

Jon D. Fancher (CD)

Orville T. Farmer, III (CD)

William T. Farris (CD)

Linda L. Fassbender (CD)

J. Mike Faurote (CD)

Michael J. Fayer (CD)

Karl R. Fecht (P)

Thomas W. Ferns (2P/18CD)

Carrie M. Fetto (CD)

Jack J. Fix (CD)

Thomas W. Fogwell (CD)

Bryan L. Foley (CD)

Bruce H. Ford (CD)

Eugene J. Freeman (CD)

Mark D. Freshley (P)

Brad G. Fritz (P)

Jonathan S. Fruchter (CD)

Robert W. Fulton (P)

Larry E. Gadbois (P)

T4-09
H8-12
H4-02
N2-57
A3-04
K6-84
E6-35
P7-28
H8-13
H0-23
K6-75
H9-02
R3-32
X0-17
X0-17
H1-11
H6-03
K6-85
K6-96
K9-30
K6-85
K6-85
A5-15
K6-85
H8-13
Sequim
E6-35
H5-25
H8-12
E6-35
A3-04
K6-96
X5-57
P8-08
K9-04
K6-50
H6-62
K9-33
H9-01
A5-15
H6-60
K3-55
E6-35
A6-38
E6-35
K9-36
K9-33
K6-75
K6-96
K6-75

Ronald G. Gallagher (P)

H5-20

Ken A. Gano (CD)

$\mathrm{HO}-23$

Stephen W. Gajewski (CD)

K9-18

Doug A. Gantt (CD)

N2-51

David R. Geist (CD)

Keith N. Geiszler (CD)

Roy E. Gephart (CD)

Michele S. Gerber (CD)

Tyler J Gilmore (CD)

Clifford S. Glantz (CD)

Wayne M. Glines (CD)

Glenn I. Goldberg (CD)

Jim W. Golden, Jr. (CD)

Eric M. Greager (CD)

Jeff M. Grover (P)

Rudolph F. Guercia (CD)

Richard H. Gurske (P)

Chris R. Haas (CD)

Darlene L. Hagel (CD)

Sheila M. Hahn (CD)

John B. Hall (CD)

Kristine D. Hand (CD)

Jonathan W. Handy (CD)

K6-85

P7-22

K8-88

B3-30

K6-96

K9-30

A5-17

A6-35

X5-50

T4-10

$\mathrm{H} 9-02$

A3-04

H8-12

H8-40

H8-40

A4-70

A3-04

K6-85

H5-26

K6-75

K6-96

K6-75

A3-04

S5-31

X5-50

A5-15

B7-50

H9-02

HO- 12

K6-50

K6-75

B2-62

A6-38

P7-01

K9-30

K6-75

H0-04

E6-35

H7 -22

X5-50

H8-40

H6-03

H6-18

H5-26

H9-01

K6-96

E6-35 
No. of

$\underline{\text { Copies }}$

Janet L. Julya (CD)

Jim D. Kautzky (CD)

Lynn M. Kelly (CD)

George G. Kelty (CD)

Charles T. Kincaid (CD)

Deanna L. Klages (CD)

Keith A. Klein (P/CD/S)

Greg L. Koller (P/CD/S)

Steve E. Kos (CD)

Randall N. Krekel (P)

Paul W. Kruger (P)

Igor V. Kutnyakov (CD)

Roger J. Landon (CD)

David C. Lanigan (CD)

George V. Last (CD)

Greg J. LeBaron (CD)

Elwood A. Lepel (CD)

Jeffrey A. Lerch (CD)

Robert D. Lichfield (CD)

Deborah L. Liddell (CD)

Jon W. Lindberg (CD)

Michael J. Lindberg (CD)

Clark W. Lindenmeier (CD)

Jenifer K. Linville (CD)

Robert W. Lober (CD)

Thomas E. Logan (P)

Steven S. Lowe (CD)

John D. Ludowise (CD)

Stuart P. Luttrell (CD)

Charles K. MacLeod (30S)

Fred M. Mann (CD)

Tom E. Marceau (CD)

Marla K. Marvin (P/CD/S)

Brian W. Mathis (CD)

Rick G. McCain (CD)

Matthew S. McCormick (P)

John P. McDonald (CD)

Steve M. McKinney (CD)

William J. Millsap (CD)

Brian F. Miller (CD)

David L. Mitchell (CD)

Ron M. Mitchell (CD)

Thomas W. Moon (P)

Launa F. Morasch (P/CD/S)

Ron D. Morrison (CD)

John G. Morse (P)

Robert P. Mueller (CD)

Ellyn M. Murphy (CD)

Christopher J. Murray (CD)

David A. Myers (CD)

Bruce A. Napier (CD)
No. of

$\underline{\text { Copies }}$

K6-75

Susan M. Narbutovskih (CD)

K6-96

A5-16

S4-21

E6-35

K9-33

H8-40

A7-50

K1-36

B2-62

A3-04

K8-50

P7-22

H9-03

K6-75

K6-81

S2-42

P8-01

L6-06

HO- 15

G3-51

K6-75

P7-22

P7-22

Ho-23

H6-60

HO-30

T4-52

H9-02

K6-96

B3-64

E6-35

HO-23

A $4-52$

B2-62

B2-62

A5-11

K6-96

H1-11

T4-10

K6-85

H8-44

H1-11

J2-25

K6-86

A4-25

A6-38

K6-85

K9-18

K6-81

E6-35

K3-54

Thomas G. Naymik (CD) K6-96

Gay M. Neath (CD) H6-60

Kathy R. Neiderhiser (P) K6-90

Duane A. Neitzel (P/CD/S) K6-85

Iral C. Nelson (P/CD) K3-54

Britta B. Nelson-Maki (CD) R3-32

Dean E. Nester (CD) T4-05

Darrell R. Newcomer (CD) K6-96

Karin L. Nickola (CD) G5-51

Robert R. Nielson (CD) X5-50

Steve M. O'Toole (CD) S7-90

Erik Olds (P) H6-60

Shirley J. Olinger $(\mathrm{P}) \quad$ H6-60

Jennifer F. Ollero (P) H9-03

Khris B. Olsen (CD) K6-96

Brian E. Opitz (P) K6-75

Robert D. Orr (CD) K6-81

D. J. Ortiz (CD) A3-04

Kent E. Parker (CD) P7-22

Gregory W. Patton (P) K6-75

Alan W. Pearson (CD) B2-62

Craig J. Perkins (CD) H1-11

Jon K. Perry (CD) H8-40

Len K. Peters (P/CD) K1-46

Scott W. Petersen (CD) E6-35

Kirk A. Peterson (CD) H8-12

Robert E. Peterson (CD) K6-75

Jeanie L. Polehn (P) H6-60

Ted M. Poston (P/4CD/S) K6-75

John B. Price (CD) H0-57

Keith R. Price (P) K6-75

Andrea L. Prignano (CD) H8-40

Kathleen M. Probasco (CD) K2-31

Kathryn H. Pryor (CD) J2-40

Eddie L. Radford (P) K6-75

Van Ramsdell (CD) K3-54

Raja Ranade (CD) H8-12

David E. Rasmussen (CD) L1-08

Jim E. Rasmussen (P/CD/S) H6-60

Bruce A. Rathbone (CD) P7-01

Stephen P. Reidel (CD) K6-75

Kathleen Rhoads (P) K3-54

William H. Rickard (P) K6-85

Julie R. Robertson (CD) H8-46

Annabelle L. Rodriguez (P/S) A5-15

Juan M. Rodriguez (CD) L4-19

Virginia J. Rohay (CD) E6-35

Donald J. Rokkan (P/CD) H8-13

Richard C. Roos (CD) L4-19

Fred A. Ruck, III (CD) H8-40 
No. of

Copies

R. Woody Russell (CD)

Michael R. Sackschewsky (CD)

John P. Sands (P)

Stuart B. Saslow (CD)

Dan G. Saueressig (CD)

Herbert T. Schaef (CD)

Roy J. Schepens (P/CD/S)

R. A. Schieffer (CD)

Andrew J. Schmidt (CD)

Walter B. Scott (CD)

R. Jeffrey Serne (CD)

Yvonne T. Sherman (P/CD/S)

Ana R. Sherwood (CD)

Mary Ann Showalter (CD)

Fen M. Simmons (CD)

Mary Ann Simmons (CD)

Gregory L. Sinton (CD)

Jerome O. Skolrud (CD)

Annie K. Smet (CD)

Ronald M. Smith (CD)

Ronald L. Smithwick (CD)

Kelvin L. Soldat (P)

Chris Sorensen (P)

Paul M. Srubek (CD)

Paul S. Stansbury (CD)

Darby C. Stapp (CD)

William E. Starkey (CD)

Amanda Stegen (CD)

Robert D. Stenner (CD)

Christopher E. Strickland (CD)

Daniel J. Strom (CD)

S. D. Stubblebine (CD)

Monte J. Sula (CD)

L. Craig Swanson (CD)

Mark D. Sweeney (CD)

Darci D. Teel (CD)

Alex E. Teimouri (CD)

K. Mike Thompson (P/CD)

Suzette A. Thompson (CD)

Jill E. Thomson (CD)

Paul D. Thorne (CD)

Edward C. Thornton (CD)

Harold T. Tilden II (CD)

Wayne E. Toebe (CD)
No. of

Copies

H6-60

K6-85

A3-04

K9-08

T4-04

K6-81

H6-60

$\mathrm{T} 1-27$

K2-12

H6-60

P7-22

A6-35

H8-40

K9-13

H8-40

K6-85

A6-38

H8-13

X0-17

K6-96

A0-20

K3-53

H6-60

T5-09

K3-54

K6-75

N2-34

K6-85

K3-54

K9-36

K3-56

H6-60

Sequim

E6-35

K6-75

$\mathrm{HO}-23$

A3-04

A6-38

H8- 12

Ho-23

K9-33

K6-96

K3-75

H8-12
Arlene C. Tortoso (P) A6-38

Gary D. Trump (CD) A0-20

Wooyong Um (CD) P7-22

Michelle M. Valenta (CD) P7-22

Barry L. Vedder (CD) H9-03

Tanya S. Vickerman (CD) P7-22

Jeffry A. Voogd (CD) S5-23

Terry L. Walton (P) K9-46

Dana C. Ward (30P/50CD/50S) A2-17

G. Jay Warwick (CD) S3-30

Kriss E. Weeks (CD) T4-55

Regan S. Weeks (CD) K3-75

Michael J. Weis (P) A7-50

Stephen G. Weiss (CD) H0-23

Debra J. Wilcox (CD) A4-52

Dick T. Wilde (CD) H8-44

Bruce A. Williams (CD) K6-75

Janice D. Williams (CD) H8-68

Barbara D. Williamson (CD) A4-52

John A. Winterhalder (CD) E6-35

Barbara K. Wise (CD) B3-30

Steven H. Wisness (P/CD/S) A3-04

Curtis D. Wittreich (P) H6-62

Marcus I. Wood (CD) H8-44

Thomas W. Wood (CD) K6-50

Robin K. Woodford (CD) S8-04

Rodger K. Woodruff (CD) J2-25

Joan G. Woolard (CD) H9-03

Christopher S. Wright (CD) E6-35

Signe K. Wurstner (CD) K9-36

Donna M. Yasek (CD) L1-07

Robert M. Yasek (CD) H6-60

John M. Zachara (CD) K8-96

Diane E. Zaloudek (CD) H8-13

Jamie H. Zeisloft (P) A3-04

Martin E. Zizzi (P) G3-70

Rhett K. Zufelt (CD) K6-85

DOE Public Reading Room (2P/2CD/2S) H2-53

Hanford Site Administrative

Record $(2 \mathrm{P} / 2 \mathrm{CD} / 2 \mathrm{~S}) \quad$ H6-08

Hanford Technical Library $(2 \mathrm{P} / 2 \mathrm{CD} / 2 \mathrm{~S}) \quad \mathrm{P} 8-55$

Historical File-Ted M. Poston (P/CD/S) K6-75

LMSI Central Files (P/CD/S) B1-07 